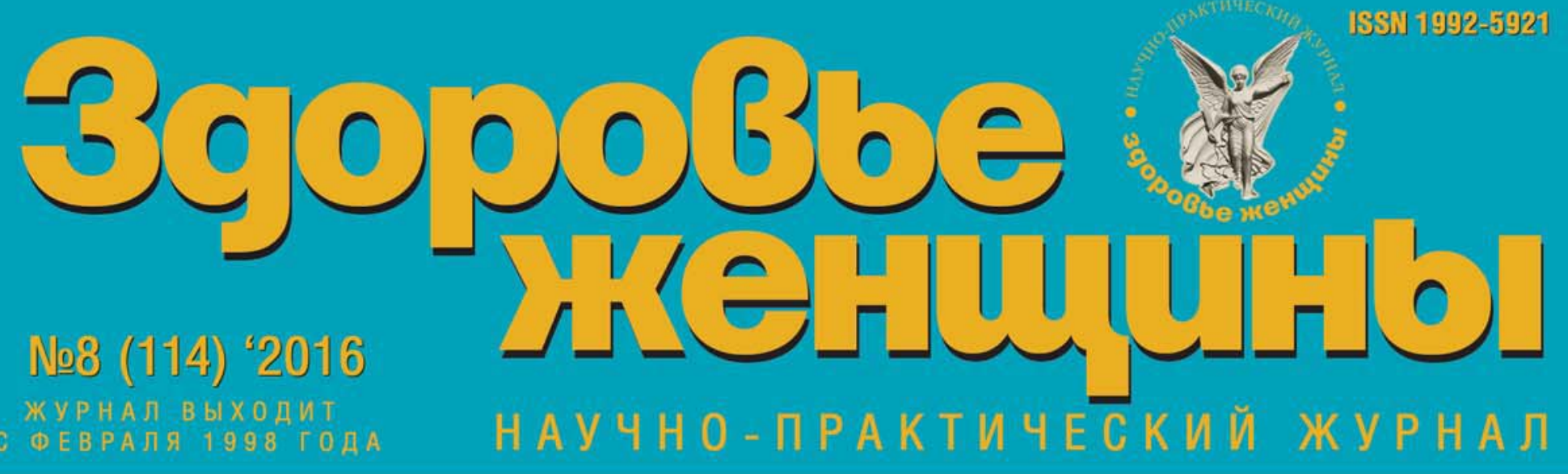

ДИСТАНЦИОННОЕ ОБУЧЕНИЕ

10

СОСТОЯНИЕ ПСИХОЭМОЦИОНАЛЬНОГО И ВЕГЕТАТИВНОГО СТАТУСА У ЖЕНЩИН С ПОВТОРНОЙ ПЛАЦЕНТАРНОЙ ДИСФУНКЦИЕЙ

\title{
ОБЕСПЕЧЕНИЕ ЭССЕНЦИАЛЬНЫМИ
} МИКРОЭЛЕМЕНТАМИ БЕРЕМЕННЫХ РАЗНОГО РЕПРОДУКТИВНОГО ВОЗРАСТА, РОЖАЮЩИХ ВПЕРВЫЕ

МОРФОЛОГИЧЕСКИЕ ОСОБЕННОСТИ СОСТОЯНИЯ ФЕТОПЛАЦЕНТАРНОГО КОМПЛЕКСА У ЖЕНЩИН С РАННИМИ ПРЕЖДЕВРЕМЕННЫМИ РОДАМИ ПОСЛЕ ПРИМЕНЕНИЯ ВРТ

СРАВНИТЕЛЬНАЯ ОЦЕНКА ПОКАЗАТЕЛЕЙ КАЧЕСТВА ЖИЗНИ У ПАЦИЕНТОК ПОСЛЕ ОПЕРАТИВНОГО ЛЕЧЕНИЯ ПО ПОВОДУ МИОМЫ МАТКИ

ОПТИМИЗАЦИЯ НЕПРЕРЫВНОГО ПРОФЕССИОНАЛЬНОГО

РАЗВИТИЯ ВРАЧА

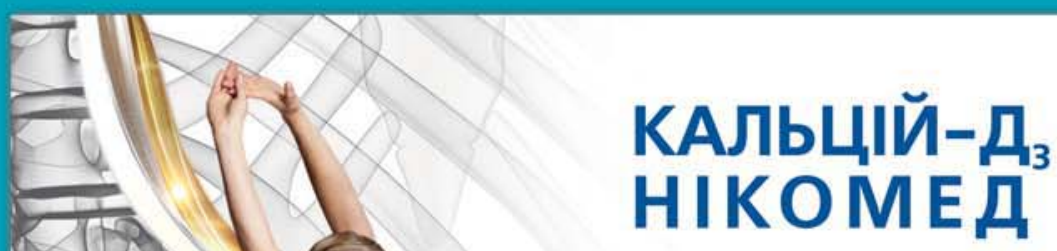

\section{ТАКТИКА ВСПОМОГАТЕЛЬНЫХ} РЕПРОДУКТИВНЫХ ТЕХНОЛОГИЙ ПОСЛЕ ОПЕРАТИВНОГО ЛЕЧЕНИЯ ЖЕНЩИН С ЭНДОМЕТРИОМАМИ яичников

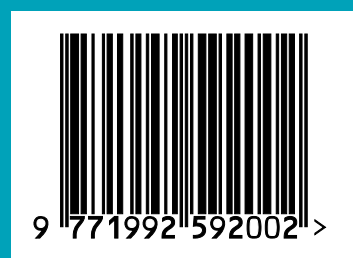

\section{Незламна сила для кісток!}

- Збільшує мінеральну щільність кісток ${ }^{1}$

- Покращує опорно-рухову функцію2 ${ }^{*}$

- Поповнює добову потребу кальцію та вітаміну Д $3^{3}$
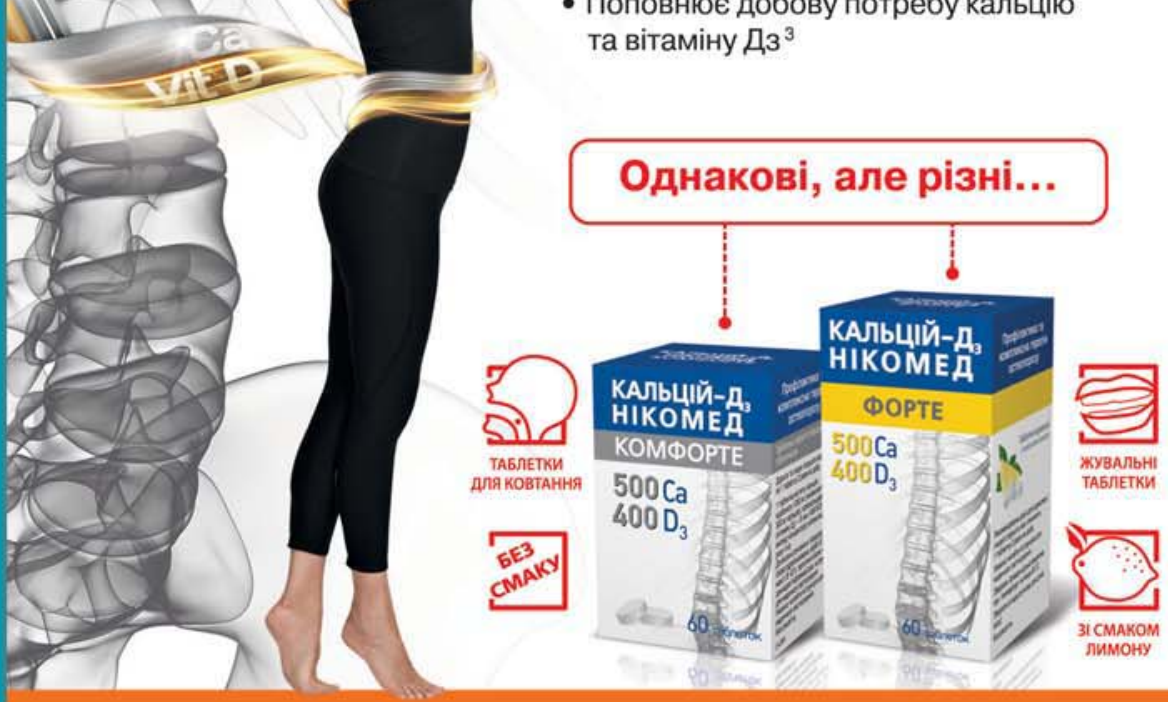

"для xitok 45+ poxiB. 1. G. Grimnes \& F. Joakimsen \& Y. Figenschau The effect of high-dose vitamin D on bone mineral densily and bone tumover markers in

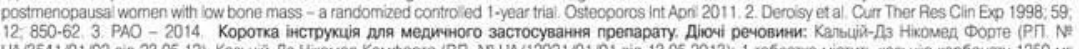

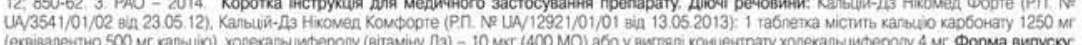

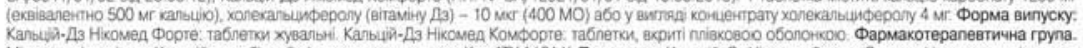

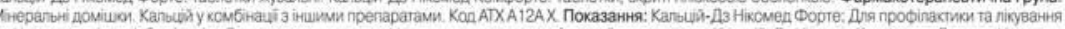

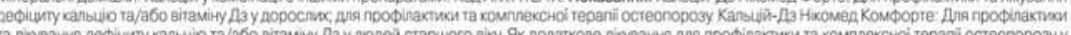

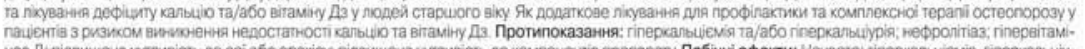

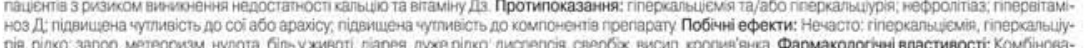

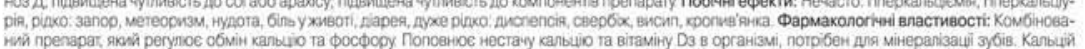

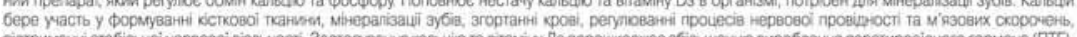

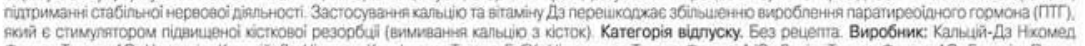

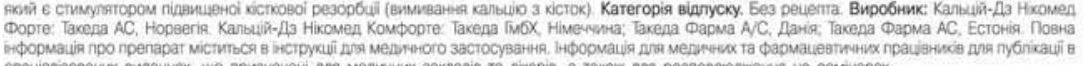

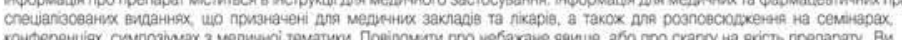

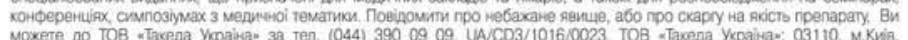

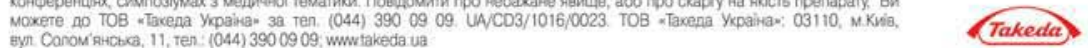




\section{ВИБУРКОЛ}

Комплексный биорегуляционный ${ }^{1,2}$

препарат в практике врача акушера-гинеколога

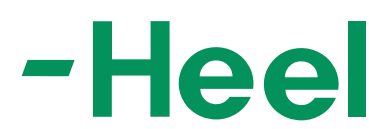

Healthcare designed by nature

Может применяться у беременных

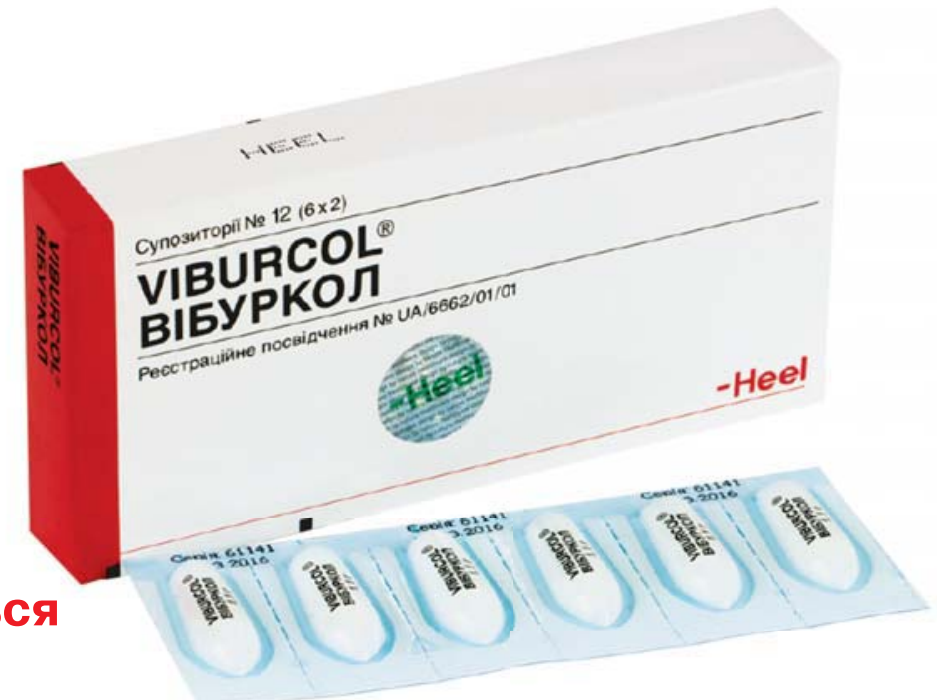

и кормящих женщин

\section{Показания:}

угроза прерывания беременности*3-5 дородовая подготовка (при угрозе развития аномалий родовой деятельности) 6

профилактика аномалий родовой деятельности ${ }^{6-8}$

обезболивание родов ${ }^{9}$

воспалительные процессы в органах малого таза у женщин

* Вибуркол противопоказан при угрозе прерывания беременности, обусловленной истмико-цервикальной недостаточностью (до наложения швов на шейку матки $)^{5}$

\section{Клинические эффекты:}

оказывает спазмолитический эффект без угнетения тономоторной функции матки 6 уменьшает болевой синдром при воспалительных процессах и лихорадочных состояниях ${ }^{10}$ снижает повышенную рефлекторную возбудимость ${ }^{10}$

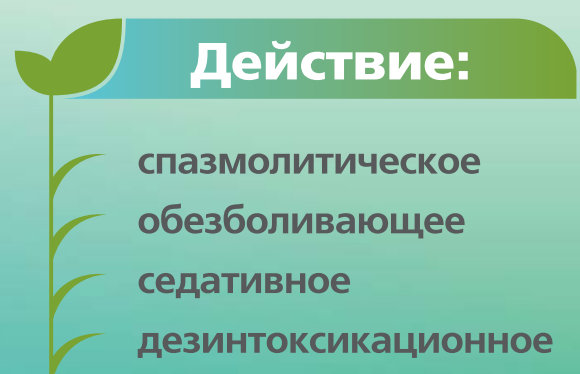

1. Клименко В.Г.: Основные положения патогенетического биорегуляционного подхода в общей терапевтической практике //Б.Т.-№1.-2013.-С.8-11. 2. Хайне Хартмут.: Значение антигомотоксической терапии в регуляторной медицине // Б.М.-№2.-2004.-С.4-9.

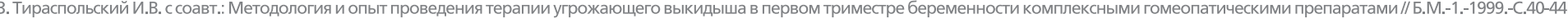
4. Манухин И.Б. с соавт.: Применение гомеопатического метода в акушерстве // МР МЗ России, 1998.

5. Тираспольский И.В.: Антигомотоксическая терапия в практике акушера-гинеколога. Издание второе, дополненное. М.: Арнебия. 2015.-192 с., 55илл., 2 табл.

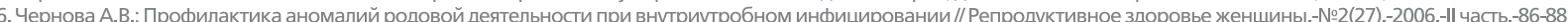

7. Крамарский В.А. ссоавт.: Антигомотоксическая терапия в профилактике дискоординации родовой деятельности // Б.М.-№2.-2008.-С.23-24.

8. Вдовиченко ЮЛ. ссоавт: Профилактика аномалий родовой деятельности сиспользованием антигомотоксическихпрепаратов // Б.Т.-№4-2002-С 30-33.

9. Тираспольский И.В. с соавт.: Эффективность гомеопатических свечей Вибуркол при обезболивании родов // Биологическая медицина.-№1.-1998.- С.35-38.

10. Шамугия Б.К.; Тимошков Б.К.: Биорегуляционный подход к лечению боли//Therapia.-№2(77).-2013.-С.75-78.

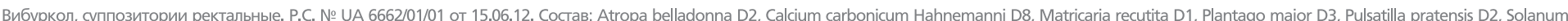
dulcamara D4. Побочные действия: в очень редких случаях возможны аллергические реакции, включая кожные высыпания, зуд. Производитель. Биологише Хайльмиттель Хеель ГмбХ, Германия.

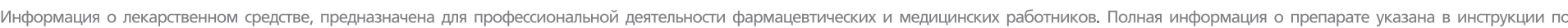
медицинскому применению. 


\section{ФУЦИС}

\section{(фЛуконазол)}

таблетки 50 мг, 100 мг, 150 мг, 200 мг

дисперговані таблетки ДТ 50 мг

гель 5 мг/г

\section{Лідер в Україні \\ серед препаратів флуконазолу ${ }^{1}$}

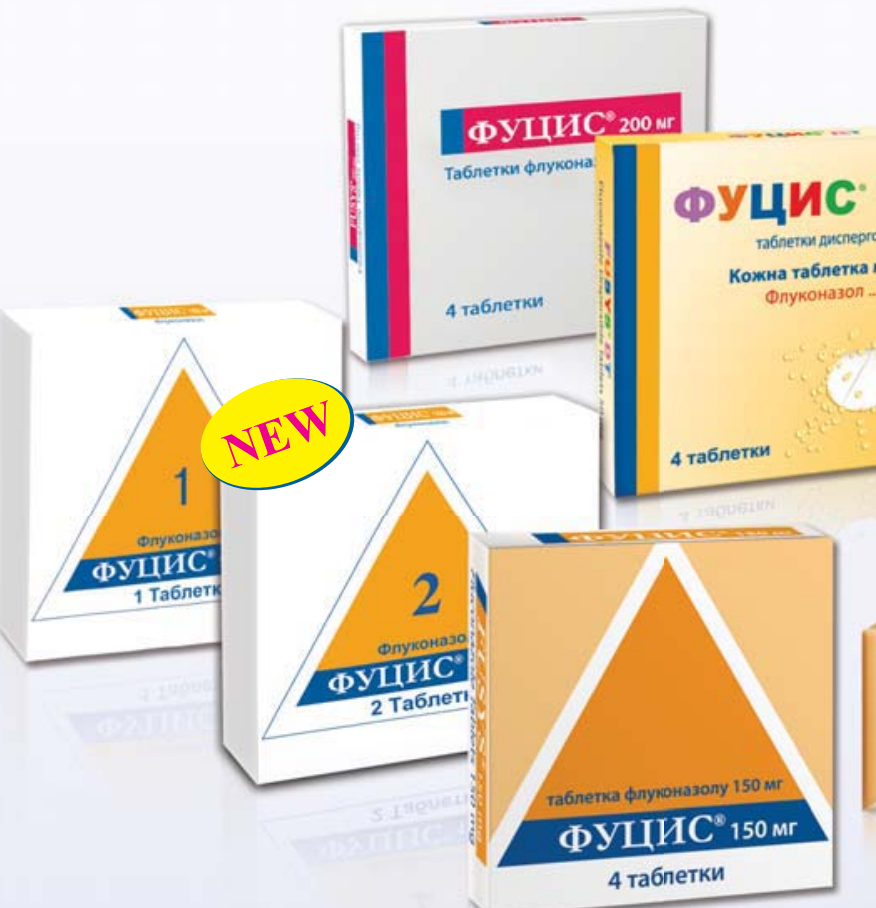

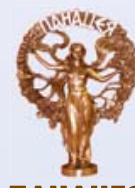

ПAHALEЯ ПPEПAPAT
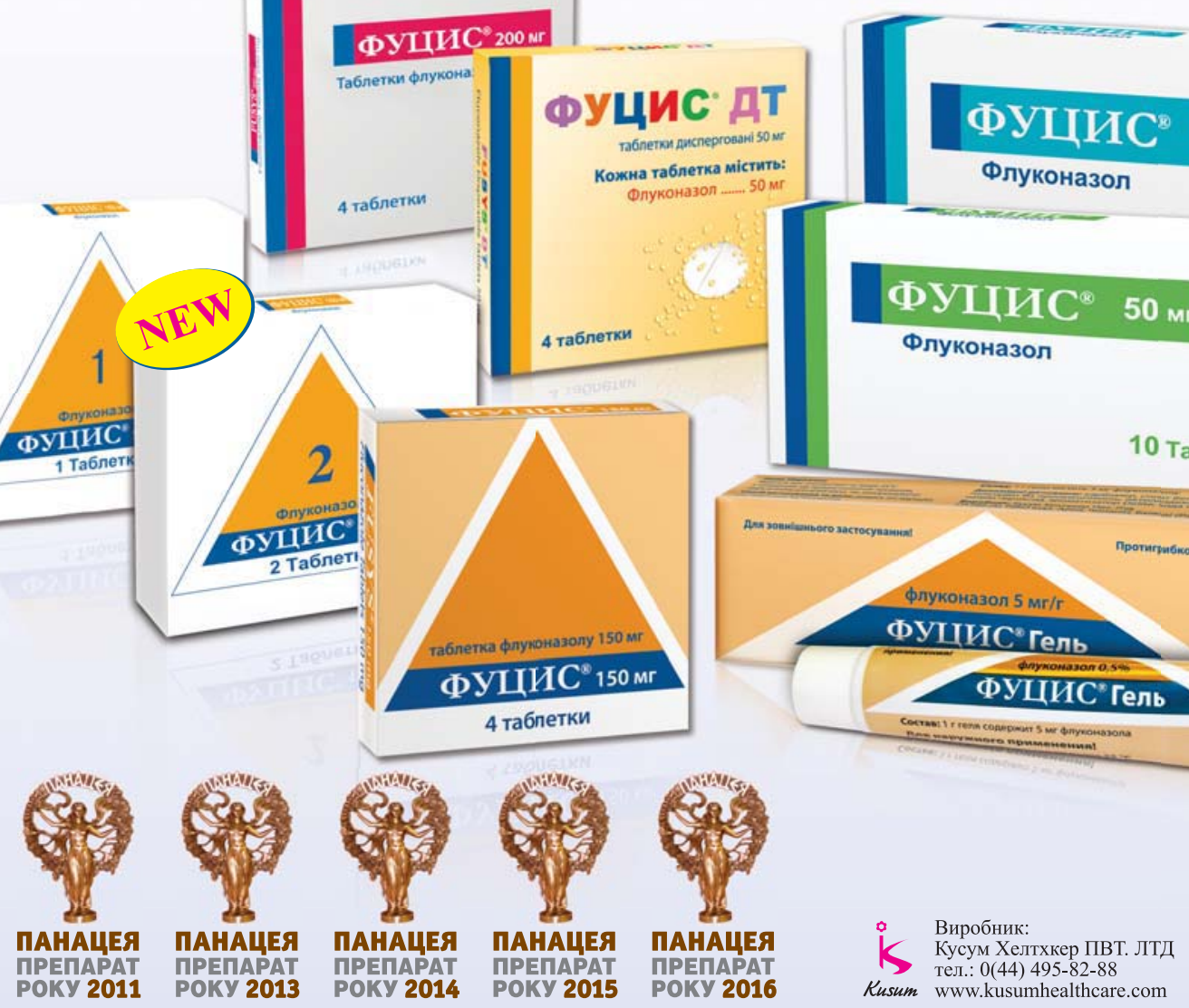

ФУЦИС 100 мг

\section{Флуконазол}

Інформація для професійної діяльності медичних та фармацевтичних працівників.

ФУЦИС 150 мг № 1. Р.П. МОЗ України № UA/7617/01/03. Склад. 1 таблетка містить флуконазолу 150 мг. ФУЦИС® Р.П. МО3 України № UA/7617/01/01, № UA/7617/01/02, № UA/7617/01/03, № UA/7617/01/04. Склад. 1 таблетка містить флуконазолу 50 мг, 100 мг, 150 мг або 200 мг. ФУЦИС ${ }^{\circledast T}$ Д.П. МОЗ України № UA/7617/02/01. Склад. 1 таблетка містить флуконазолу 50 мг. ФУЦИС гель Р.П. МОЗ України № UA/7617/03/01.Склад. 1 г гелю містить 5 мг флуконазолу. Назва і місцезнаходження виробника. КУСУМ ХЕЛТХКЕР ПВТ. ЛТД. СП 289 (А), РІІКО Індл. Ареа, Чопанкі, Бхіваді (Радж.), Індія. Фармакотерапевтична група. Протигрибкові засоби. Код АТС Ј02А С01. Показання для застосування. Фуцис 150 мг: вагінальні кандидози. Фуцис 50 мг, 100 мг, 200 мг: вагінальний кандидоз (гострий або рецидивуючий), профілактика рецидивів вагінального кандидозу (при частоті виникнення 3 рази і більше на рік), а також кандидозного баланіту; Фуцис ${ }^{\circledR}$ ДТ: вагінальний кандидоз (гострий або рецидивуючий), кандидозний баланіт. Фуцис ${ }^{\circledR}$ гель: пахові епідермофітії; інфекції, спричинені Candida. Протипоказання. Фуциє ${ }^{\circledR} 0$ мг, 100 мг, 150 мг, 200 мг, Фуциє ${ }^{\circledast}$ ДТ: не слід призначати при індивідуальній підвищеній чутливості до флуконазолу або до інших речовин, подібних за своєю хімічною структурою до азольних сполук. Одночасне призначення терфенадину, цизаприду, астемізолу, пімозиду, хінідину та еритроміцину протипоказане хворим, які застосовують Фуцис ${ }^{\circledR}$. Фуцис ${ }^{\circledR}$ гель: підвищена

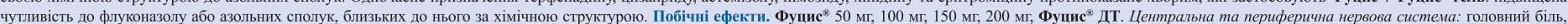
запаморочення. Травна система: біль у животі, діарея, диспепсія, нудота, блювання. Печінка/жовчовидільна система: підвищення рівня аланінамінотрансферази (АЛТ), аспартатамінотрансферази (АСТ). Імунна система: анафілаксія, набряк обличчя та свербіж шкіри, кропив'янка. Шкіра та ї̈ придатки: висипання, свербіж, медикаментозний дерматит, кропив'янка. Фуцис ${ }^{\star 2}$ гель: можливе подразнення шкіри.

Повна інформація про лікарський засіб міститься в інструкції для медичного застосування. 


\section{ЗАОРОВЬЕ ЖЕНШННЫ $8(114) / 2016$}

\section{УЧРЕДИТЕЛИ}

МИНИСТЕРСТВО ЗДРАВООХРАНЕНИЯ УКРАИНЫ

НАЦИОНАЛЬНАЯ МЕДИЦИНСКАЯ АКАДЕМИЯ ПОСЛЕДИПЛОМНОГО ОБРАЗОВАНИЯ им. П.Л. Шупика (НМАПО) ГУ «ИНСТИТУТ ПЕДИАТРИИ, АКУШЕРСТВА И ГИНЕКОЛОГИИ НАМН УКРАИНЫ»

ГУ «УКРАИНСКИЙ ИНСТИТУТ СТРАТЕГИЧЕСКИХ ИССЛЕДОВАНИЙ МЗ УКРАИНЫ»

ЩЕРБИНСКАЯ Е.С.

БАХТИЯРОВА Д.О.

\section{АДРЕС ДЛЯ КОРРЕСПОНДЕНЦИИ}

И ТЕЛЕФОНЫ РЕДАКЦИИ И ИЗДАТЕЛЕЙ

Украина, 03039, Киев, а/я 36

Тел.: +38(044) 220-15-41, 220-15-43, 498-08-80,

+38(067) 233-75-91

E-mail: office@zdr.kiev.ua

НАШ ПОДПИСНОЙ ИНДЕКС: 74598

По вопросам подписки или приобретения обращаться в почтовые отделения связи, в редакцию или на сайт: www.medexpert.org.ua

Тираж - 5500 экз.

Периодичность издания - 10 номеров в год. Журнал зарегистрирован в Государственном комитете информационной политики, телевидения и радиовещания Украины. Свидетельство о регистрации КВ №20930-10730ПР от 29.08.2014 г.

Приказом МОН Украины № 241 от 09.03.2016 журнал «ЗДоровъе женшины» включен в перечень спечиализированных научных изданий Украины в области медицинских наук. В издании могут быть опубликованы основные результать диссертационных работ.

Журнал «Здоровве женщины» реферируется Институтом проблем регистрации информации НАН Украины

Журнал «Здоровье женщины» включен в международные наукометрические базы, а таже в реферативную базу данны $х$ «крайніка наукова»

\section{РЕКОМЕНДОВАНО}

Ученым советом Национальной медицинской академии последипломного образования им. П.Л. Шупика. Протокол № 9 от 12.10.2016 г.

Подписано к печати 31.10.2016 г.

Статьи, публикуемые в журнале

«ЗДОРОВЬЕ ЖЕНЩИНЫ», - рецензированы.

Ответственность за достоверность фактов

и прочих сведений в публикациях несут авторы.

Ответственность за содержание рекламы, а также за

соответствие приводимых в рекламе сведений требованиям

законодательства несут рекламодатели.

Редакция и издатели не несут ответственности

за достоверность информации, опубликованной

в рекламных материалах.

Мнение редакции может не совпадать с мнением авторов публикации.

Перепечатка материалов только с письменного разрешения редакции. При перепечатке ссылка на журнал

«ЗДОРОВЬЕ ЖЕНЩИНЫ» обязательна.

Фотовывод и печать

Типография «Аврора-принт»,

г. Киев, ул. Причальная, 5, тел. (044) 550-52-44

() Министерство здравоохранения Украины, 2016

(c) Национальная медицинская академия

последипломного образования им. П.Л. Шупика, 2016

(c) ГУ «Институт педиатрии, акушерства и гинекологии НАМН Украины», 2016

(C) Щербинская Е.C.

(с) Бахтиярова Д.О.

НАЦИОНАЛЬНАЯ АКАДЕМИЯ МЕДИЦИНСКИХ НАУК УКРАИНЫ МИНИСТЕРСТВО ЗДРАВООХРАНЕНИЯ УКРАИНЫ

ГУ «ИНСТИТУТ ПЕДИАТРИИ, АКУШЕРСТВА И ГИНЕКОЛОГИИ НАМН УКРАИНЫ»

НАЦИОНАЛЬНАЯ МЕДИЦИНСКАЯ АКАДЕМИЯ ПОСЛЕДИПЛОМНОГО ОБРАЗОВАНИЯ им. П.Л. ШУПИКа МЗ УКРАИНЫ

ГУ «УКРАИНСКИЙ ИНСТИТУТ СТРАТЕГИЧЕСКИХ ИССЛЕДОВАНИЙ МЗ УКРАИНЫ»

\section{ЗДОРОВЬЕ ЖЕНЩИНЫ ЗДОРОВ'Я ЖІНКИ HEALTH OF WOMAN}

Всеукраинский научно-практический журнал ИЗДАЕТСЯ ПРИ ПОДДЕРЖКЕ НАЦИОНАЛЬНОЙ АКАДЕМИИ МЕДИЦИНСКИХ НАУК УКРАИНЫ,

АССОЩИАЦИИ АКУШЕРОВ-ГИНЕКОЛОГОВ УКРАИНЫ, АССОЦИАЦИИ ПЕРИНАТОЛОГОВ УКРАИНЫ, УКРАИНСКОГО ИНСТИТУТА СЕКСОЛОГИИ И АНДРОЛОГИИ

\section{ГЛАВНЫЙ НАУЧНЫЙ КОНСУЛЬТАНТ}

\section{Ю. Г. Антипкин}

академик НАМН Украины,д-р мед. наук, профессор, директор ГУ «Институт ПАГ НАМН Украины»

\section{ГЛАВНЫЕ РЕДАКТОРЫ}

\section{Ю. П. ВДОвиченко}

член-корр. НАМН Украины,

д-р мед. наук, профессор,

Первый проректор НМАПО

им. П.Л. Шупика,

зав. кафедрой акушерства, гинекологии и перинатологии №1 НМАПО, Президент

Ассоциации перинатологов Украины

\section{P. А. Моисеенко}

д-р мед. наук, профессор, проректор по научно-педагогической и лечебной работе НМАПО им. Шупика

\section{ЗАМ. ГЛАВНОГО РЕДАКТОРА \\ Д.О. Бахтиярова \\ Е.C. Щербинская, \\ канд. мед. наук}

ЭКСПЕРТНАЯ ГРУППА РЕЦЕНЗЕНТОВ

Н.Г. Гойда, д-р мед. наук, профессор о.в. Грищенко, д-р мед. наук, профессор С.И. Жук, д-р мед. наук, профессор А.Г. Корнацкая, д-р мед. наук, профессор В.И. Медведь, член-корр. НАМН Украины, д-р мед. наук, профессор

В.И. Пирогова, д-р мед. наук, профессор

\section{НАУЧНЫЕ КОНСУЛЬТАНТЫ}

Б. М. Венцковский, член-корр. НАМН Украины, д-р мед. наук, профессор И. И. Горпинченко, д-р мед. наук, профессор - консультант рубрики “Женская сексология»

В.В. Подольский, д-р мед. наук, профессор Научный редактор A. Е. Дубчак, д-р мед. наук, профессор

\section{ДИРЕКТОР ПО РЕКЛАМЕ}

И.Н. Лукавенко

ОТВЕТСТВЕННЫЙ СЕКРЕТАРЬ

А.А. Попильнюк

РЕКЛАМА

И.В. Арестович

Е.О. Панова

\section{ЛИТЕРАТУРНЫЙ РЕДАКТОР}

Н.К. Багдасарян

КОРРЕКТОР

Л. В. Тищенко

ДИЗАЙН И ВЕРСТКА

С.О. Обедникова
Председатель редакционной коллегии

В. В. Каминский

\section{Редакционная коллегия}

T.В. Авраменко

B.А. Бенюк

В.В. Бережной

О. А. Берестовой

В.И. Бойко

Р. Г. Ботчоришвили (Франция)

Г.И. Брехман (Израиль)

Б.М. Венцковский

И.Б. Венцковская

И.Б. Вовк

Ю.В. Вороненко

В.А. Владимиров

Н.И. Генык

И.З. Гладчук

Е.П. Гнатко

О.В. Горбунова

3.М. Дубоссарская

Т.Д. Задорожная

B.Н. Запорожан

C.О. Иванюта

Т.В. Лещева

И.С. Лукьянова

Л.Г. Назаренко

Л.И. Омельченко

С. П. Писарева

B.A. Потапов

А. Г. Резников

Т. Г. Романенко

O.В. Ромащенко

Н. Н. Рожковская

А. Я. Сенчук

А. И. Соловьев

А.А. Суханова

T. Ф. Татарчук

P.А. Ткаченко

В. А. Товстановская

Л. Е. Туманова

А. Г. Цыпкун

л. И. Чернышова

и. и. Хаща

3. А. Шкиряк-Нижник

E. Е. Шунько

А. М. Юзько

C. Н. Янюта

H.Е. Яроцкий 


\section{HEALTH OF WOMAn 8 (114)/2016}

\section{FOUNDERS}

MINISTRY OF HEALTH OF UKRAINE

NATIONAL MEDICAL ACADEMY

OF POSTGRADUATE EDUCATION NAMED

AFTER PL SHUPYK (NMAPE)

SI «INSTITUTE OF PEDIATRICS, OBSTETRICS

AND GYNECOLOGY NAMS OF UKRAINE»

SI «INSTITUTE OF STRATEGIC RESEARCH MOH

UKRAINE»

SHCHERBINSKAYA E.S.

BAKHTIYAROVA D.O.

EDITORIAL OFFICES ADDRESS AND

TELEPHONE OF PUBLISHERS

Ukraine, 03039, Kyiv, p/b 36

Tel.: +38(044) 220-15-41, 220-15-43, 498-08-80,

$+38(067) 233-75-91$

E-mail: office@zdr.kiev.ua

\section{OUR SUBSCRIPTION INDEX: 74598}

To subscribe or purchase contact the post offices, editori or site: www.medexpert.org.ua

\section{Circulation -5500 copies.}

Periodicity - 10 issues per year. The journal is registered by the State Committee of Information Policy, Television and Radio Broadcasting. Certificate of registration of КВ №20930-10730ПР от 29.08.2014 г.

The command of the Ministry of education and science of Ukraine № 241 from 09.03.2016 Journal «Health of rooman» is included in the list of specialized scientific publications in Ukraine in the field of medical sciences. In the publication can be published key results of dissertations.

Journal «Health of Woman» is reviewed by the Institute of Information Recording of NAS of Ukraine

Journal «Health of Woman» included in the international scientometric bases: eLIBRARY.RU (РИНЦ, Science index), Google Scholar, and in the abstracts database «Ukrainika naukova»

\section{RECOMMENDED BY}

Academic Council National Medical Academy of Postgraduate EducationNamed after PL Shupyk Protocol № 9 from 12.10.2016.

\section{Passed for printing 31.10.2016}

Articles published in the journal

«Health of Woman» - reviewed. Authors are responsible for accuracy of the facts and other information in the publication. Advertisers are responsible for the content of advertising, as well as those appearing in the advertisement information requirements of the law. The editors and publishers are not responsible for the accuracy of the information publishedin promotional materials. Editorial opinion may not coincide with the opinion of the authors of the publication.

Reprinting material only with the written permission of the publisher.

When reprinting reference to the journal

«Health of Woman» is obligatory.

Imagesetter and Printing

«Aurora-print»,

Kyiv, Prichalna str, 5, tel. (044) 550-52-44

(c) Ministry of Health of Ukraine, 2016

(C) National Medical Academy of Postgraduate

EducationNamed after PL Shupyk, 2016

(C) SI «Institute of Pediatrics, Obstetrics

and Gynecology NAMS of Ukraine», 2016

(C) Institute of Strategic Research MoH Ukraine, 2016

(C) E.S.Shcherbinskaya, 2016

(C) D.O.Bakhtiyarova, 2016

NATIONAL ACADEMY OF MEDICAL SCIENCES OF UKRAINE MINISTRY OF HEALTH OF UKRAINE

SI «INSTITUTE OF PEDIATRICS, OBSTETRICS AND GYNECOLOGY NAMS OF UKRAINE»

NATIONAL MEDICAL ACADEMY OF POSTGRADUATE EDUCATION NAMED AFTER PL SHUPYK MOH UKRAINE

INSTITUTE OF STRATEGIC RESEARCH MOH UKRAINE ASSOCIATION OF PERINATOLOGISTS OF UKRAINE

\section{HEALTH OF WOMAN ЗДОРОВ'Я ЖІНКИ ЗДОРОВЬЕ ЖЕНЩИНЫ}

Ukrainian scientific-practical journal

PUBLISHED WITH THE SUPPORT OF THE NATIONAL ACADEMY OF MEDICAL SCIENCES, ASSOCIATION OF OBSTETRICIANS AND GYNECOLOGISTS OF UKRAINE UKRAINIAN INSTITUTE OF SEXOLOGY AND ANDROLOGY

Chief Scientific Adviser Yu.G.Antipkin, academician of NAMS of Ukraine,

Dr. med., sciences, professor, director of the «Institute of PAG NAMS of Ukraine»

\section{CHIEF EDITORS}

Yu.P..Vdovychenko, corresponding member of NAMS of Ukraine, Dr. med., Sciences, professor, First Vice rector of NMAPE named after $P L$ Shupyk, Head of the Department of Obstetrics, Gynecology and Perinatology No1 NMAPE, President of the Ukraine Perinatology Association

R.A.Moiseenko, Dr. med., Sciences, professor, Vice-Rector for Clinical Work of NMAPE named after PL Shupyk

\section{DEPUTY of CHIEF EDITOR \\ D.O.Bakhtiyarova \\ E.S.Shcherbinskaya, $P h D$.}

EXPERT GROUP Of REVIEWERS

N.G.Goyda, Dr. med., Sciences, professor

O.V.Grishchenko, Dr. med., Sciences, professor S.I.Zhuk, Dr. med., Sciences, professor A.G.Kornatskay, Dr. med., Sciences, professor V.I.Medved, a corresponding member of NAMS of Ukraine, Dr. med., Sciences, professor V.I.Pyrogova, Dr. med., Sciences, professor

\section{SCIENTIFIC CONSULTANTS}

B.M.Ventskovskiy, corresponding member of NAMS of Ukraine, Dr. med., Sciences, professor I.I.Gorpynchenko, Dr. med., Science, Professor - Consultant of «Women's sexology» rubric V.V.Podolskiy, Dr. med., Sciences, professor A.E.Dubchak, Dr. med., Sciences, professor

\section{ADVERTISING DIRECTOR}

I.Lukavenko

RESPONSIBLE SECRETARY

A.Popilnyuk

ADVERTISEMENT

I. Arestovich

E. Panova

LITERARY EDITOR

N. Bagdasarian

CORRECTION

L. Suhih

DESIGN AND IMPOSITION

S. Obednikova
Chairman of Editorial Board V.V.Kaminskiy

\section{Editorial board}

T.V. Avramenko

V.A. Beniuk

V.V. Berezhnoy

O.A. Berestovoy

V.I. Boiko

R.G. Botchorishvili (France)

G.I. Brekhman (Israel)

B.M. Ventskovskiy

I.B. Ventskovskaya

I.B. Vovk

Yu.V. Voronenko

V.A. Vladimirov

N.I. Genyk

I.Z. Gladchuk

E.P. Gnatko

O.V. Gorbunova

Z.M. Dubossary

T.D. Zadorozhnaya

V.N. Zaporozhan

S.O. Ivanyuta

T.V. Leshcheva

I.S. Lukyanova

L.G. Nazarenko

L.I. Omelchenko

C. P. Pisareva

V.A. Potapov

A.G. Reznikov

T.G. Romanenko

O.V. Romashchenko

N.N. Rozhkovskaya

A.Y. Senchuk

A.I. Soloviev

A.A. Suhanova

T.F. Tatarchuk

R.A. Tkachenko

V.A. Tovstanovskaya

L.E. Tumanova

A.G. Tsypkun

L.I. Chernyshova

I.I. Hascha

Z.A. Shkiryak-Nizhnik

E.E. Shunko

A.M. Yuzko

S.N. Yanyuta

N.E. Yarotskiy 


\section{СОДЕР ЖКАНИЕ 8 (114)/2016}

\section{ДИСТАНЦИОННОЕ ОБУЧЕНИЕ}

Соматичні та акушерські аспекти дефіциту магнію

(Клінічна лекція)

С.О. Шурпяк

\section{АКТУАЛЬНЫЕ ТЕМЫ}

Fast track: хирургические протоколы ускоренной реабилитации в гинекологии

К.В. Пучков, В.В. Коренная, Н.М. Подзолкова ................20

Ранні предиктори плацентарної дисфункції

Ю.М. Мельник, А.О. Шляхтіна

\section{В ПОМОЩЬ ПРАКТИЧЕСКОМУ ВРАЧУ}

Оптимизация терапии диспластических

ВПЧ-ассоциированных процессов

В.В. Бобрицкая

Місце топічних глюкокортикоїдів у лікуванні дерматитів різної етіології

Л.Д. Калюжна

\section{АКУШЕРСТВО}

Инновационные подходы к коррекции микронутриентного статуса беременных и кормящих женщин

С.И. Жук, К.К. Бондаренко .37

Биорегуляционные возможности препаратов Вибуркол и Лимфомиозот в акушерстве и гинекологии

О.И. Остапенко
Важность и значение полиморфизма генов при преэклампсии

П.Н. Веропотвелян, И.С. Цехмистренко,

Н.П. Веропотвелян, Н.С. Русак, П.С. Горук

Стан психоемоційного та вегетативного статусу у жінок з повторною плацентарною дисфункцією

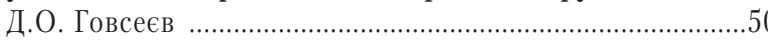

Морфофункціональні зміни в плаценті у вагітних при затримці росту плода

О.В. Басистий

Забезпеченість есенціальними мікроелементами вагітних різного репродуктивного віку, що народжують уперше В.В. Маркевич

Морфологическая классификация повреждений плаценты

Н.П. Веропотвелян, П.Н. Веропотвелян,

И.С. Цехмистренко, А.А. Бондаренко, Т.В. Усенко

Особливості формування судинного компонента хоріона при невиношуванні вагітності у I триместрі гестації

О.В. Кравченко .72

Виявлення та характеристика антитіл проти Hsp60 людини у вагітних

М.В. Макаренко, Д.А. Говсєєв, Р.М. Ворона,

А.М. Цісаренко, О.Я. Васильчук, О.В. Павлюк,

Л.Ф. Яковенко, І.В. Крупська, А.П. Погрібна,

Л.Л. Сидорик

\section{Хурнал «Здоровье женщины» индексируется и/или представлен здесь:}

• «Библиометрика украинской науки»

• «Научная периодика Украины» (Национальной библиотеки

Украины имени В.И. Вернадского)

- Google Scholar

- Copernicus International

- Science Index (eLIBRARY.RU)

- CrossRef (статьям журнала присваиется цифровой идентифрикатор объекта (DOI)
- INFOBASEINDEX

- ReaserchBib

- SIS

- Directory of Research Journals Indexing (DRJI)

- Open Academic Journals Index (OAJI)

- Bielefeld Academic Search Engine (BASE)

- International Innovative Journal Impact Factor (IIJIF)

- Hinari
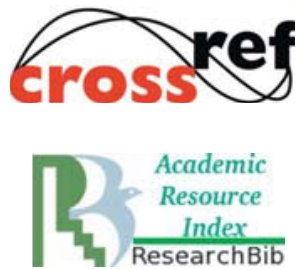

INDEX COPERNICUS

I $\mathrm{N} T \mathrm{~T}$ E $\mathrm{N}$ A T I O N A L

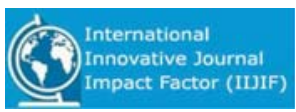

Open Academic Journals Index

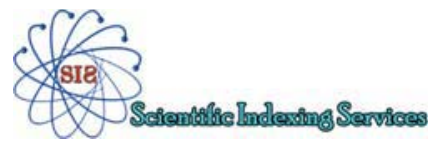

INFOBASE INDEX .net
НАУЧНАЯ ЭЛЕКТРОННАЯ

БИБЛИОТЕКА

LLIBRARY.RU

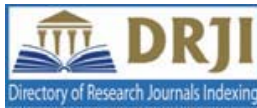
РОССИЙСКИЙ ИНДЕКС
НАУЧНОГО ЦИТИРОВАНИЯ Science Index

BASE Bielefelic Academic Search Enoine

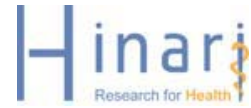




\section{флєбодіа Дві проблеми- б00мгдісмин}
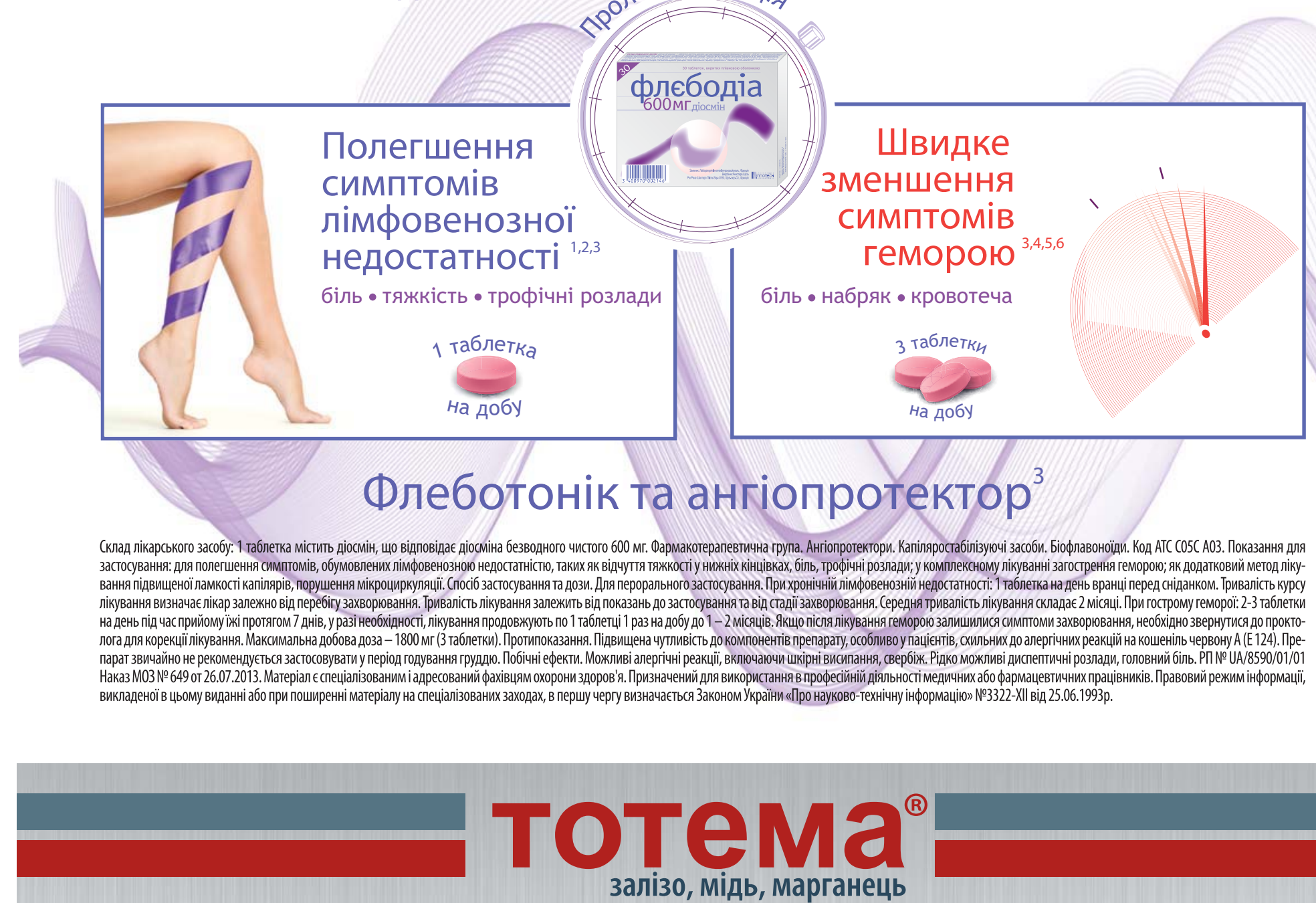

\section{ФРАНЦУЗЬКА ЯКІСТЬ - ЗАЛІЗНИЙ РЕЗУЛЬТАТ!}
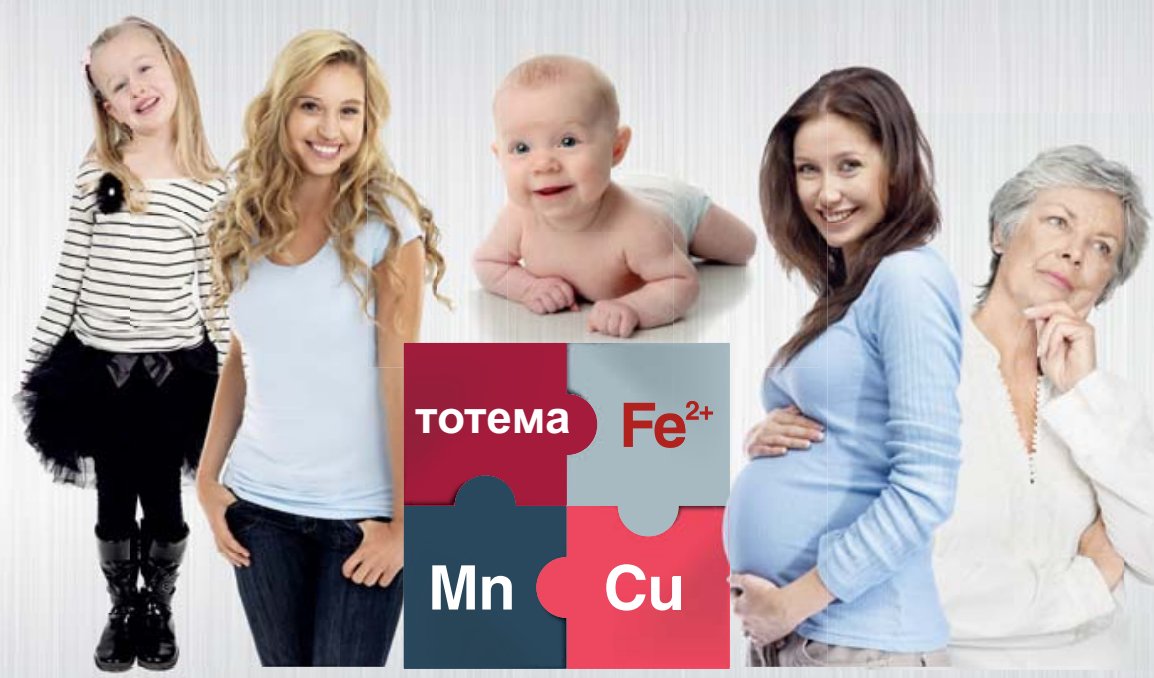

- Швидка гематологічна відповідь ${ }^{1}$

- Органічні солі заліза, міді та марганцю²

- Можливе застосування під час вагітності

- Дозволено дітям 3 1-го місяця²

- Відповідає рекомендаціям В003³

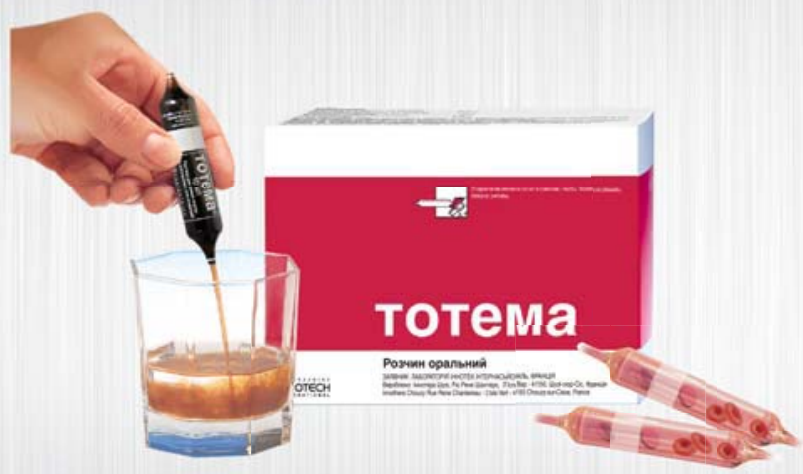

С.В. Семочиин Клиническая эффективность применения препарага Тотема в печении желез

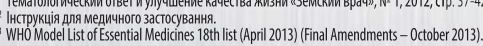

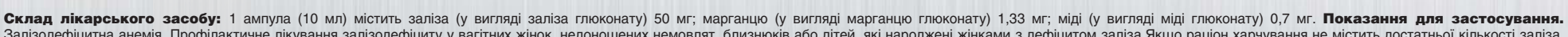

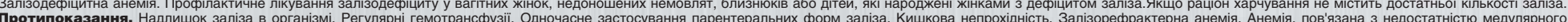

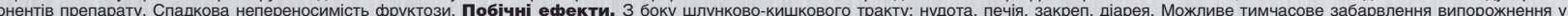

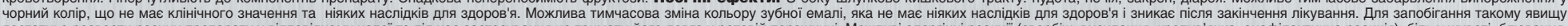

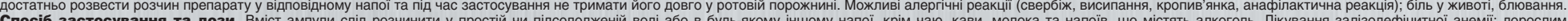

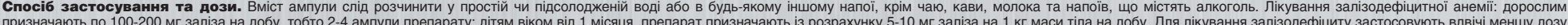

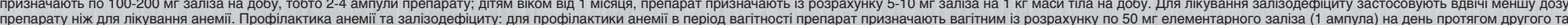




\section{СОДЕР ЖКАНИЕ 8 (114)/2016}

Морфологічні особливості стану фетоплацентарного комплексу у жінок з ранніми передчасними пологами після застосування допоміжних репродуктивних технологій А.С. Мандрикова .79

Оптимізація тактики ведення жінок з рубцем на матці з використанням родинно орієнтованих технологій та партнерських пологів

І.П. Нецкар . .82

\section{ГИНЕКОЛОГИЯ}

Клинико-сонологические особенности эндометриоидных образований яичников у женщин в репродуктивный период

О. С. Шаповал . .85

Оцінювання ефективності терапії хронічного тазового болю у жінок з варикозним розширенням вен малого таза

C.О. Остафійчук, Н.I. Геник, Н.В. Дрогомирецька,

П.Р. Волосовський

Порівняльне оцінювання показників якості життя у пацієнток після оперативного лікування 3 приводу міоми матки

О.М. Макарчук, Г.М. Гаврилюк.

Роль медико-социальных и психологических факторов в отягощенном репродуктивном анамнезе

А.А. Довгань

\section{ЗАРУБЕЖНЫЕ ИССЛЕДОВАНИЯ}

Лапароскопическая хирургия в лечении тубоовариальных образований в I триместре беременности Lucas Minig, Lucas Otaco, Pilar Cruz, Marнa Guadalupe Patrono, Cecilia Botazzi, Ignacio Zapardiel .......................103

Laparoscopic surgery for treating adnexal masses during the first trimester of pregnancy

Lucas Minig, Lucas Otaco, Pilar Cruz, Marнa Guadalupe Patrono, Cecilia Botazzi, Ignacio Zapardiel ........................107

\section{ДЕТСКАЯ И ПОДРОСТКОВАЯ ГИНЕКОЛОГИЯ}

Роль гиперпролактинемии в генезе преждевременного телархе и ее коррекция у девочек первых пяти лет жизни О.И. Мальцева

\section{ЛАБОРАТОРНЫЕ ИССЛЕДОВАНИЯ}

Субклинический гипертиреоз: диагностические критерии и принципы лечения

(Обзор руководства европейской тиреоидной ассоциации 2015 года «Diagnosis and Treatment of endogenous subclinical hyperthyroidism»)

В.В. Галицкая

\section{НЕПРЕРЫВНОЕ ПРОФЕССИОНАЛЬНОЕ} ОБРАЗОВАНИЕ ВРАЧЕЙ В УКРАИНЕ

Шляхи оптимізації безперервного професійного розвитку лікаря

О.С. Щербінська

\section{МЕЖДУНАРОДНЫЕ ПРОТОКОЛЫ}

Рекомендации международного общества по менопаузе в отношении здоровья женщин зрелого возраста и менопаузальной гормональной терапии (2016)

\section{БЕСПЛОДИЕ И ПЛАНИРОВАНИЕ СЕМЬИ}

Тактика проведення допоміжних репродуктивних технологій у пацієнток із супутнім ожирінням та метаболічним синдромом

В.О. Петропавловська

Рівні інтерлейкіну-4 та інтерлейкіну-17 (IL-4, IL-17) крові у пацієнток зі звичним невиношуванням вагітності, яка настала у циклі екстракорпорального запліднення

К.П. Головатюк

Анамнестичні фактори, які формують репродуктивне здоров'я жінок із неодноразовими невдалими спробами запліднення in vitro

Н.В. Коцабин, О.М. Макарчук

Тактика допоміжних репродуктивних технологій після оперативного лікування жінок з ендометріомами яєчників

Ю.В. Страховецька 


\section{Bionorica $^{\circ}$}

\section{Порушення менструального циклу?}

\section{ЦиклодИнон ${ }^{\circledR}$}

7 нормалізує менструальний цикл ${ }^{1}$

в. відновлює гормональну рівновагу²

\%е містить гормонів ${ }^{3}$

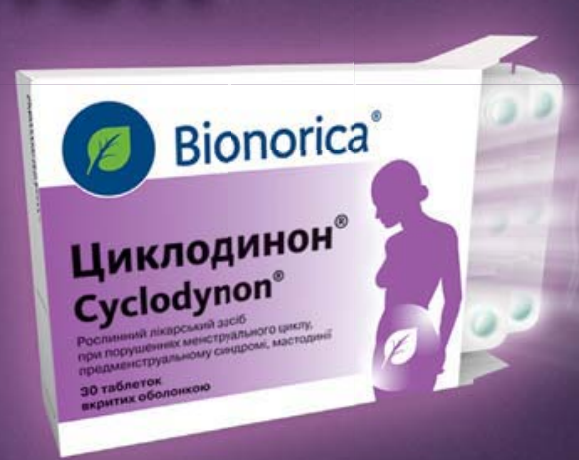

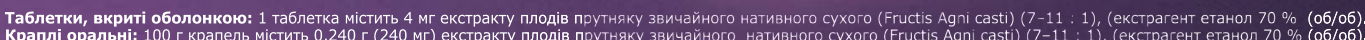
Показання. Порушення менструального циклу i/aбо безпліддя пов'язане з недостатністю жовтого тіла. Застосування. Препарат приймають по 1 таблетці 1 раз на день. Лікування триває протягом 3 місяців без перерви на час менструації. Протипоказання. Не можна застосовувати у випадку підвищено чутливості до плодів прутняку звичайнго або

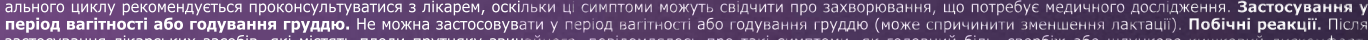
застосування лікарських засобів, які містять плоди прутняку звичайного, повідомлялось про такі симптоми, як головний біль, свербіж або шлунково-кишковий дискомффор 1. В.П. Сметник, Л.Б. Бутарева Науковий центр акушерства, гінекології та перинатології РАМн, Москва. Журнал «Проблемы репродукции», том 11, 5/2005, стр. 50-54

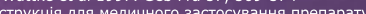

\section{розкриваючи силу рослин}

Запалення нирок? Цистит?

\section{RaHeqpor ${ }^{\circledR}$ H}

(2. німецька якість фітопрепарату

з значний досвід призначень різним віковим групам та категоріям пацієнтів ${ }^{1-3}$

п) потенціювання

протизапальної терапії

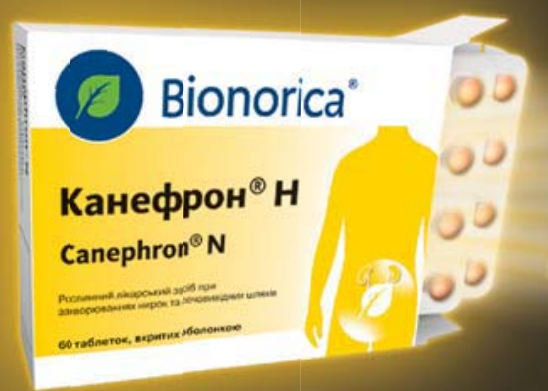

Канефронष Н. Таблетки, вкриті оболонкою: 1 таблетка містить порошок висушених лікарських рослин: трави золототисячнику 18 мг, кореня любистку 18 мг, листя розмарину 18 мг.
Краплі оральні: 100 г крапель містять 29 г годно-спиртового екстракту (1:16) з лікарських рослин: трави золототисячнику 0,6г, кореня любистку 0,6г, листя розмарину 0,6г. Показання. Базисна терапія, а також як компонент комплексної терапії при гострих та хронічних інфекціях сечового міхура і нирок; хронічні неінфекційні захворювання нирок; профілактика

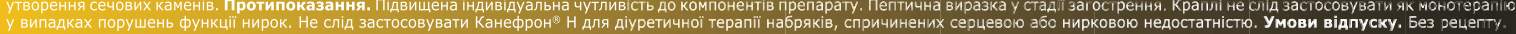
Джерело: 1 - Медведь В.И., Исламова Е.В. (2009) Безопасность Канефрона Н во время беременности: от клинического опыта к доказательствам. Мед. аспекты здоровья женщины, 3(20): 2-5. Кравченко Н.Ф. 2 - Мурашко Л.Е. (2008) Использование препарата Канефрон Н для профилактики и лечения гестоза при патологии мочевыделительной системы. Репрод. здоровье женщины,

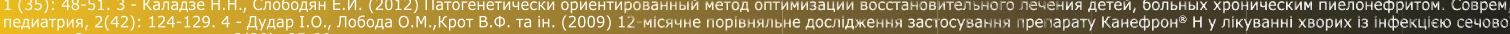




\section{TABLE OF CONTENTS №8 (114)/2016}

\section{DISTANCE LEARNING}

Somatic and obstetrical aspects of magnesium deficiency (Clinical lecture)

S.A. Shurpyak

\section{TOPICAL ISSUES}

Fast track: surgical protocols of accelerated rehabilitation in gynecology

K.V. Puchkov, V.V. Korennaya, N.M. Podzolkova ..........................20

Early predictors of placental dysfunction

J. M. Melnik, A. A. Shlyahtina ........................................................25

\section{FOR PRACTICING PHYSICIANS}

Therapy optimization dysplastic HPV-associated processes

V.V. Bobrytska

Place of topical corticosteroids in the treatment of dermatitis of various etiologies

L.D. Kaluzhna .....

\section{OBSTETRICS}

Innovative approaches to the correction of chronotrope status of pregnant and lactating women

S.I. Zhuk, K.K. Bondarenko

Bioregulatory opportunities of Viburkol and Limphomiozot medicines in obstetries and gynecology

The importance and significance of gene polymorphisms in preeclampsia

P.N. Veropotvelyan, I.S. Tsehmistrenko, N.P. Veropotvelyan,

N.S. Rusak, M.S. Pivnev

Condition of the psychoemotional and vegetative status at women with a repeated placental dysfuction

D.A. Govseev

Morphofunctional changes in the placenta of pregnant with Intrauterine growth retardation

O.V. Basystyi ..... $\ldots . .55$

Provision of essential microelements of pregnant women of all reproductive age give birth first time

V.V. Markevich .....59

Morphological classification of lesions of the placenta

N.P. Veropotvelyan, P.N. Veropotvelyan, I.S. Tsehmistrenko,

A.A. Bondarenko, T.V. Usenko .................................................... 63

Formational features of the vascular component of the chorion in miscarriage in the first trimester of gestation

E. V. Kravchenko

Identification and characterization of antibodies against human Hsp60 at pregnancy

M. Makarenko, D. Govsieiev, R. Vorona, A. Tsisarenko, O. Vasil'tchuk, O. Pavlyuk, L. Yakovenko, I. Kroupska, A. Pogribna, L. Sidorik .......75

Morphological features of the state of fetoplacental complex in women with early preterm birth after assisted reproductive technologies

A.S. Mandrykova .79

Optimization of tactics of maintaining women with the cicatrix on a uterus with use family focused technologies and partner labors I.P. Netskar
GYNECOLOGY

Clinical and sonological features in endometriomas in women of reproductive age

O. Shapoval

Evaluation of treatment of chronic pelvic pain in women with pelvic varicose veins

S.O. Ostafiychuk, N.I. Henyk, N.V. Drohomyretska,

P.R. Volosovsky

Comparison of indicators quality of life in women

after operative rehabilitation on uterine fibroids

O. Makarchuk, G. Gavrilyuk

Role of medical-social and psychological factors in the burdened reproductive anamnesis

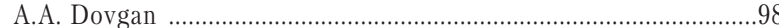

\section{FOREIGN STUDIES}

Laparoscopic surgery for treating adnexal masses during the first trimester of pregnancy

Lucas Minig, Lucas Otaco, Pilar Cruz, Marнa Guadalupe Patrono,

Cecilia Botazzi, Ignacio Zapardiel...................................................103

\section{PEDIATRIC AND ADOLESCENT GYNECOLOGY}

Role of hyperprolactinemia in the genesis of the premature telarhe and its correction in girls during the first five years of life

O. I. Maltseva .....

\section{LABORATORY TESTS}

Subclinical hyperthyroidism: diagnostic criteria and principles of treatment (Review of European Thyroid Association guidelines «Diagnosis and Treatment of endogenous subclinical hyperthyroidism», 2015)

V.V. Galitskaya

\section{CONTINUING PROFESSIONAL EDUCATION}

OF DOCTORS IN UKRAINE

Optimisation for physicians continuous professional development

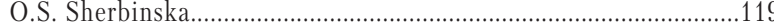

\section{INTERNATIONAL PROTOCOLS}

Recommendations of the International menopause society in the health of women of mature age and menopausal hormone therapy (2016)

\section{INFERTILITY AND FAMILY PLANNING}

Tactics of carrying out of auxiliary reproductive technologies at patients with accompanying adiposity and metabolic syndrome V.O. Petropavlovskay

Levels interleukine-4 and interleukin-17 (IL-4, IL-17)

of blood in patients with habitual recurrent pregnancy loss, which occurred in a loop in vitro fertilization

K.P. Golovatyuk

Anamnestic factors that shape reproductive health of women with repeated unsuccessful popygamy in vitro fertilization N.V. Cotsabin, O.M. Makarchuk

Tactics of auxiliary genesial technologies after expeditious treatment of women with endometriome of ovaries Yu.V. Strakhovetskaya. 


\section{Журнал «Здоровье Женщины» \\ является официальным изданием Ассоциации перинатологов Украины, \\ которая входит в состав Ассоциации \\ акушеров-гинекологов Украины}

Хурнал сертифицирован для проведения непрерывного профессионального последипломного обучения врачей

Согласно Приказу № 484 от 07.07.2009 Министерства здравоохранения Украины «Про затвердження Змін до Положення про проведення іспитів на передатестаційних циклах» с 2012 года

\section{в журнале введена новая форма дистанционного обучения врачей: обучающие лекции, в конце которых будут опубликованы вопросы к ним}

Ответы на вопросы следует присылать в редакцию по почте или на электронный адрес.

Эл. адрес: alexandra@zdr.kiev.ua

Почтовый адрес: 03039, г. Киев, а/я 36.

Необходимый минимум - 90\% правильных ответов.

Врачам, приславшим 90\% и более правильных ответов, будут высланы сертификаты

Национальной медицинской академии последипломного образования им. П.Л. Шупика.

\section{Фамилии докторов, получивших сертификаты}

За правильные ответы на тесты к статье:

«Анти-D-імунопрофілактика у світогляді лікаря акушерагінеколога (Клінічна лекція)" (Л.Г. Назаренко) Важненко Т.C.

За правильные ответы на тесты к статье: «Гиперплазия эндометрия (Клиническая лекция)"

(И.Б. Вовк, Н.Е. Горбань, О.Ю. Борисюк)

Горин И.М.

Горин Т.И.

Манылова И.И.

Николишин 3.В.

Палош А.Д.

Фендак Т.М.
За правильные ответы на тесты к статье:

“Синдром хронічного тазового болю у гінекологічній практиці (Оглядова стаття)" (С.О. Шурпяк)

$$
\begin{aligned}
& \text { Горин И.М. } \\
& \text { Горин Т.И. } \\
& \text { Горин Т.М. } \\
& \text { Дорожко О.м. } \\
& \text { Илюк Т.А. } \\
& \text { Палош А.Д. }
\end{aligned}
$$

За правильные ответы на тесты к статье:

«Нестероїдні протизапальні препарати: окремі аспекти

застосування в акушерсько-гінекологічній клініці» (Л.Г. Назаренко)

$$
\text { Марынова О.В. }
$$

Получение данных сертификатов необходимо для прохождения аттестации, подтверждения врачебной категории и сертификата врача-специалиста, что дает право продолжать врачебную деятельность. 


\title{
Соматичні та акушерські аспекти дефіциту магнію (Клінічна лекція)
}

\author{
C.O. Шурпяк \\ Львівський національний медичний університет імені Данила Галицького
}

\begin{abstract}
Гомеостаз магнію в організмі є обов'язковою умовою здоров'я людини. Як необхідний макроелемент для клітин і тканин, магній бере участь у багатьох фізіологічних процесах, що забезпечують нормальну життєдіяльність організму. У той самий час, низкою масштабних досліджень встановлено значну поширеність дефіциту магнію, який у загальній популяції становить $14,5 \%$, а субоптимальний рівень спостерігається у $33,7 \%$. У резолюції Міжнародної Експертної Ради з питань дефіциту магнію в акушерстві та гінекологіі відзначено актуальність проблеми і важливість корекції дефіциту магнію у вагітних і гінекологічних пацієнток. У лекції висвітлені різні аспекти дефіциту магнію, розглянуті патофізіологічні механізми порушення магнієвого гомеостазу організму, принципи застосування препаратів магнію 3 профілактичною та лікувальною метою.
\end{abstract}

Ключові слова: дефіцит магнію, клінічні симптоми гіпомагніємї, вагітність.

- лементний склад організму людини на 99\% складається з 12 Е основних хімічних елементів, серед яких магній посідає четверте місце після калію, кальцію і натрію. Зміна вмісту магнію часто зумовлюється екологічними, географічними, професійними особливостями і веде до розвитку цілої низки патологічних станів. Сучасний ритм життя, підвищений рівень гострого і особливо хронічного стресу, дієта з переважним вмістом штучних продуктів харчування і напоїв, гіподинамія створюють проблему хронічного дефіциту магнію в організмі [3, 35, 38, 54]. У сучасному світі брак магнію в організмі є одним з найбільш поширених дефіцитних станів людини. Концентрація магнію в організмі знижується під впливом різних чинників: умови життя і харчування, вік, фізичні навантаження, фізіологічні (вагітність, лактація) і патологічні стани (захворювання серцево-судинної, сечовидільної систем, органів травлення, ендокринних залоз). На сьогодні для позначення порушень обміну магнію використовують два терміни: «магнієвий дефіцит»зниження загального вмісту магнію в організмі і «гіпомагніємія» - зниження концентрації магнію у сироватці крові менше 0,8-1,2 ммоль/л. Про помірну недостатність магнію в організмі свідчать його рівні у сироватці крові 0,5-0,7 ммоль/л, про виражену (що загрожує життю) - нижче 0,5 ммоль/л [46, 52, 61].

У сучасному світі брак магнію в організмі є одним 3 найбільш поширених дефіцитних станів людини. За даними дослідження, проведеного в Німеччині, поширеність дефіциту магнію в загальній популяції становить 14,5\%, а субоптимальний рівень спостерігається у 33,7\% [55]. За іншими даними, в стаціонарах загального профілю 40\% хворих мають клінічні ознаки гіпомагніємії, у блоках інтенсивної терапії - 70\%, у хворих з гострим коронарним синдромом дефіцит магнію має місце у $90 \%$ випадків [7, 33, 59], а за даними інших досліджень, частота дефіциту магнію у популяції сягає 46\% [54]. За даними дослідників зі США, ризик розвитку гіпомагніємії становить $2 \%$ у всій популяції, $10-20 \%$ - у госпіталізованих пацієнтів, 50-60\% - у пацієнтів відділень інтенсивної терапії, 30-80\% - в алкоголіків, 25\% - у пацієнтів з цукровим діабетом, а за клінічними симптомами - притаманний 72\% пацієнтів [44, 54].
За Міжнародною класифікацією хвороб (МКХ-10) діагноз «недостатність магнію» кодується як Е61.2.

В останні роки в світі підвищується частота виявлення магнієдефіцитних станів серед осіб з різними патологічними захворюваннями і станами, що доводить його зв'язок з широким спектром захворювань і патологічних станів, які асоціюються з ендотеліальною дисфункцією, порушенням апоптозу, метаболічним і гіпертензивним синдромами, патологією сполучної тканини, вагітністю, передменструальним і клімактеричним синдромом, проблемами імунітету $[8,15,25$, $27,32,36,39,41,50,51]$

Діагностика дефіциту магнію в організмі переважно грунтується на клінічних симптомах, тим більше що відомі стани і захворювання, за яких магнієвий дефіцит виявляють часто. Однак унаслідок неспецифічності клінічних проявів дефіциту магнію виникають труднощі у діагностиці і своєчасності лікування. У практичній діяльності акушеру-гінекологу важливо знати причини гіпомагніємії, клінічні симптоми магнієвого дефіциту, принципи профілактики і лікування порушень магнієвого балансу.

\section{Патофізіологія гомеостазу магнію в організмі}

Гомеостаз магнію регулюється за допомогою білків підродини Transient Receptor Potential (TRP) - TRPM6 - на рівні організму і TRPM7 - на клітинному рівні. TRPM6 експресується переважно в нирках, кишечнику, легенях, TRPM7 - у всіх органах і тканинах. Зниження надходження магнію в організм з їжею стимулює експресію гена TRPM6 у нирках, що в свою чергу підвищує реабсорбцію магнію у висхідному коліні петлі Генле. Спадкові дефекти TRPM6 є причиною первинної гіпомагніємії. TRPM7 регулює трансмембранний тік $\mathrm{Mg}^{2+}$ і $\mathrm{Ca}^{2+}$ у клітину залежно від її активності. Активність TRPM7 визначається внутрішньоклітинним рівнем $\mathrm{Mg}^{2+}$, Mg-АТФ. Відомо, що TRPM7 бере участь у регуляції багатьох процесів, включаючи клітинну адгезію, ріст і проліферацію клітин тощо. Крім того, білки TRPM 6/7 відповідальні за виникнення дефіциту магнію на тлі стресу $[21,41,46]$.

Потреба у магнії зростає в середньому на 150 мг на добу при фізичних навантаженнях, стресі, в період вагітності і лактації, при зловживанні алкоголем, незбалансованих обмежувальних дієтах і синдромі хронічної втоми $[47,60]$. Гомеостаз $\mathrm{Mg}^{2+}$ також залежить від віку (літні люди схильні до гіпомагніємії, а у молодих середньодобова потреба на 150 мг більше) і стану кишкової абсорбції (наприклад, рівень магнію різко знижений при синдромі мальабсорбції і діареї) у дванадцятипалій кишці і проксимальному відділі порожньої кишки.

Знижують всмоктування магнію залізо, кальцій, фосфор, оксалатна кислота, танін, що містяться в міцно завареному чаї, а для підвищення засвоюваності магнію необхідне надходження в організм у достатній кількості кофакторів: оротової, лактатної, аспарагінової кислот і вітаміну $\mathrm{B}_{6}[46,58]$. Брак магнію відповідно зумовлює дефіцит цинку, міді, кальцію, калію, кремнію і подальше їхнє заміщення токсичними важкими металами: свинцем, кадмієм, алюмінієм. 


\section{ДИСТАНЦИОННОЕ ОБУЧЕНИЕ}

Загальна кількість магнію в організмі людини становить близько 24 г, причому $40 \%$ розподілено внутрішньоклітинно. Близько 60\% магнію знаходиться у кістковій і близько $20 \%$ у м'язовій тканинах. Приблизно 40\% від загальної кількості міститься у клітинах головного мозку, серця, нирок, з них $20-30 \%$ може бути швидко мобілізовано в умовах його підвищеного споживання. Магній не синтезується в організмі людини, у вигляді іона $\mathrm{Mg}^{2+}$ він надходить з їжею, водою і сіллю. Збалансована дієта містить 300-350 мг магнію на добу, у разі збідненої магнієм їжі всмоктується до 70\% магнію, при збагаченій - 25\%. Після надходження у кров макроелемента, що всмоктався у травному тракті, з'єднання магнію розподіляються в організмі: близько 60\% депонується у кістках (зокрема, обмінна фракція - 30\%, яка використовується як резервна для стабілізації концентрації магнію у сироватці), близько $20 \%$ - у скелетних м'язах, 19\% - в інших м'яких тканинах менше $1 \%$ становить позаклітинна фракція. В іонізованому стані знаходиться близько $60 \%$ сироваткового магнію, інша частина зв'язана з протеїнами, фосфатами, цитратами. Менше 1\% від загальної кількості магнію міститься у плазмі крові та еритроцитах [29, 49, 53].

Найбільше магнію міститься у рослинній їжі: горіхах, фруктах, овочах і зелені, бобових, насінні соняшника, соєвих продуктах, деяких сортах морської риби і морепродуктах. Джерелом магнію також є вода: чим вона жорсткіше, тим вище в ній вміст магнію. Вітамін D і його метаболіти підвищують абсорбцію магнію. Виводиться магній з організму в основному з сечею (50-120 мг) і потом (5-15 мг).

Позаклітинний магній безперервно поповнюється запасами 3 кісткової і м'язової тканин, у разі виникнення внутрішньоклітинного дефіциту $20-30 \%$ депонованого елемента негайно переміщується в клітини, при цьому концентрація внутрішньоклітинного магнію є вищою в клітинах, які швидко діляться. Це свідчить, що клітинний транспорт магнію пов'язаний з метаболічною активністю клітини [52].

Магнієвий баланс в організмі залежить від динамічної взаємодії між всмоктуванням у кишечнику, обміном з кістковою тканиною і нирковою екскрецією [34]. Діагностують дефіцит магнію за клінічними симптомами і вмістом його в біологічних рідинах. Нормальна концентрація магнію становить у сироватці крові у віці 20-60 років 0,66-1,07 ммоль/л, у 60-90 років - 0,70-0,99 ммоль/л; в еритроцитах 1,65-2,65 ммоль/л; у добовій порції сечі - 3-50 ммоль/л; у спинномозковій рідині - 1,1-1,5 ммоль/л [61].

Рівень магнію у сироватці крові $0,5-0,7$ ммоль/л відповідає помірній недостатності, нижче 0,5 ммоль/л - вираженій недостатності [34]. Вміст магнію можна визначати у лімфоцитах, макрофагах, тромбоцитах, конденсаті повітря, що видихається, у слині, волоссі, нігтях, зубах, скелетних м'язах. Про дефіцит магнію свідчить зниження концентрації $\mathrm{Mg}^{2+}$ в еритроциті - менше 1,6 ммоль/л. Разом з тим, відсутня кореляція між сироватковим і внутрішньотканинним вмістом магнію, що утруднює лабораторну діагностику магнієвого дефіциту [34]. У плазмі крові концентрація іонів магнію невисока, і вона рідко змінюється під впливом фізіологічних і патологічних чинників. На сьогодні не існує доступних швидких точних тестів для оцінювання магнієвого гомеостазу [59]

Найбілыш важливі причини дефіциту магнію [5, 14, 16, 17, 26, 33, 35]:

Знижене споживання магнію: Знижений вміст у «цивілізованій їжі», дієтичні курси, алкоголізм, парентеральне харчування з низьким вмістом магнію.

Знижена киикова резорбщія: тривала діарея, синдром порушення всмоктування, запальні ентеропатії, стан після резекції кишечнику, знижена резорбція через високе споживання кальцію, великої кількості алкоголю, їжі, багатої на білки та жири.
Підвищена потреба у магнї: вагітність і годування груддю, підвищена фізична активність (потовиділення), період зростання, період одужання, стрес.

Підвищене виведення магнію: шлунково-кишкові розлади блювання, тривала діарея, зловживання проносними засобами; ниркові захворювання - нефротичний синдром, синдром Бартера, ренальна втрата солей, нирковий ацидоз; хронічний алкоголізм, цукровий діабет, діуретична і цитостатична терапія, протитуберкульозні препарати.

Ендокринні порушення: гіпертиреоїдизм, гиперпаратиреоїдизм.

\section{Первинна гіпомагніємія}

Дефіцит магнію може бути первинний (генетично зумовлений) і вторинний (аліментарний, ятрогенний). У хворих з гіпомагніємією діагностують генетичні дефекти 602014, 9g22.2, HOMG, HSH, HMGX.p [32]. До причин первинного дефіциту магнію і гіпомагніємії належать спадкові моно- і гетерогенні захворювання, для яких характерними є порушення всмоктування в кишечнику, зміни транспорту, підвищене виведення, недостатня абсорбція і реабсорбція в ниркових канальцях магнію, калію та інших електролітів $[21,41,44,56]$.

Дефіцит магнію описують серед причин розвитку спадкових порушень сполучної тканини - гетерогенної групи захворювань, зумовлених мутаціями генів білків позаклітинного матриксу або генів білків, що беруть участь у морфогенезі сполучної тканини. Налічують більше 250 синдромів і захворювань з ознаками спадкових порушень сполучної тканини, у числі яких - моногенні захворювання, представлені синдромами з відомими діагностичними критеріями (синдром Марфана, Луїса-Дітца, Елерса-Данло тощо) і синдромами з фенотипами полігенного мультифакторного генезу - дисплазії сполучної тканини, у групі яких розглядають стани, що часто іксують: синдром пролапсу мітрального клапана, синдром гіпермобільності суглобів, марфаноподібний фенотип, марфаноподібна зовнішність, елерсоподібний фенотип, змішаний фенотип [21, 34, 45].

\section{Вторинна гіпомагніємія}

Вторинний дефіцит магнію розвивається у результаті однієї або поєднання декількох причин: зниження споживання, перерозподіл в організмі, зниження всмоктування в кишечнику, підвищене виділення магнію через травний тракт і/або сечовидільну систему.

До зниження споживання магнію призводять незбалансована дієта; хронічний алкоголізм; фізіологічні умови, що вимагають підвищених витрат (висока фізична активність, період зростання, стрес, вагітність і лактація, реконвалесценція, літній і старечий вік) $[52,54]$. Перерозподіл магнію в організмі спостерігається у разі переміщення магнію з кісткового депо або позаклітинної рідини при метаболічному ацидозі, паратиреоїдектомії, гострих захворюваннях з некрозом тканини, дифузній остеобластомі, при хірургічних втручаннях на серці, застійній серцевій недостатності, цукровому діабеті [40, 42]. Дефіцит магнію з'являється у разі порушення всмоктування у товстому кишечнику або підвищеного виділення іонів магнію через травний тракт при синдромі мальабсорбції (целіакія, діарея), хворобі Крона, неспецифічному виразковому коліті, радіаційному ураженні кишечнику, при інших хронічних захворюваннях кишечнику, після резекції кишечнику, новоутвореннях, зловживанні послаблювальними засобами [47, 57]. Порушення канальцевої реабсорбції магнію при захворюваннях нирок є поширеним чинником дефіциту магнію: тубулопатії, пієлонефрит, гломерулонефрит, трансплантація нирок, хронічна або гостра ниркова недостатність у фазі поліурії [59]. Магнієвий дефіцит виявляють при ендокринній патології - гіпертиреозі, гіперпаратиреозі, первинному гіперальдостеронізмі, цукровому діабеті. До порушень магнієвого гомеостазу призводять осмо- 


\section{ДИСТ АНЦИОННОЕ ОБУЧЕНИЕ}

тичні ниркові втрати іона у зв'язку з глюкозурією, зниженим всмоктуванням магнію в кишечнику, а також перерозподіл магнію у клітини з депо і плазми через нестачу внутріклітинного магнію у зв'язку з дефіцитом інсуліну [35, 36, 59].

Застосування лікарських засобів часто призводить до порушень магнієвого балансу в організмі, при цьому група препаратів, застосування яких спричинює дефіцит магнію, достатньо значуща. Основним класом препаратів, що зумовлюють порушення обміну магнію, є діуретики, які впливають на проксимальні відділи нефрона і підвищують екскрецію іонів калію і магнію. Короткочасне використання тіазидових діуретиків, що діють на дистальні ниркові канальці, де всмоктується менше 5\% магнію, не призводить до дефіциту [59]. Цитотоксична терапія (цисплатин) зумовлює дозозалежне пошкодження нирок з порушенням екскреції магнію майже у 100\% пацієнтів. Гіпомагніємія розвивається через 3 тиж після хіміотерапії і зберігається протягом декількох місяців, іноді - протягом декількох років, після завершення лікування [29, 48].

Антибіотики і деякі протитуберкульозні препарати також можуть спричиняти гіпомагніємію, яка швидко наростає. Так, аміноглікозиди (гентаміцин, тобраміцин, амікацин) у здорових людей приводять до збільшення екскреції магнію. При споживанні магнієвмісних продуктів або вживанні препаратів магнію одночасно з фторхінолонами і тетрацикліном зниження абсорбції магнію розвивається як наслідок утворення важкорозчинних з'єднань, що не всмоктуються у кишечнику. Гіпомагніємія розвивається при тривалому лікуванні серцевими глікозидами, вживанні естрогенвмісних (КОК), кофеїнвмісних препаратів (нікотин, кокаїн, морфін, героїн, амфетамін), терапії імунодепресантами (циклоспорин, такролімус), інгібіторами протонної помпи, препаратами для лікування обструктивного синдрому ( $\beta_{2}$-агоністи, сальбутамол).Теофілін у високих дозах призводить до збільшення екскреції магнію, при тривалому вживанні терапевтичних доз препаратів підвищується ризик розвитку гіпомагніємії, а також з'являються інші метаболічні порушення (гіпокаліємія, гіпонатріємія, гіпофосфатемія, гіперглікемія) [37, 57].

\section{Клінічні синдроми дефіциту магнію}

Клінічні прояви вторинних порушень магнієвого балансу залежать від темпів розвитку дефіциту магнію. У разі тривалого перебігу первинного патологічного процесу його симптоми довгий час можуть маскувати ознаки порушень магнієвого гомеостазу.

На сьогодні магній вважають одним з основних регуляторів обмінних процесів, і його фізіологічні ефекти в організмі людини добре вивчені. Магній впливає на енергетичний обмін, окисне фосфорилювання, синтез білка, ліпідів, нуклеїнових кислот. Біологічна роль магнію багатогранна, оскільки він є найважливішим елементом багатьох біохімічних процесів, таких, як стабілізація ДНК у процесах мітозу і мейозу, активізація білыш 300 ферментів: креатинінкінази, аденілатциклази, фосфофруктокінази, К-, Na-АТФази, ферментів білкового синтезу, гліколізу, трансмембранного транспорту іонів. Магній бере активну участь у процесі нервово-м'язової збудливості і впливає на процеси терморегуляції організму. Магній незамінний у вуглеводному, білковому і ліпідному обмінах, синтезі нуклеїнових кислот, в організмі людини існує не менше 500 магнієзалежних білків. Магній бере участь у підтриманні нормальної функції нервової та серцево-судинної систем, особлива роль відведена магнію у процесах мембранного транспорту іонів кальцію і натрію, а його дефіцит призводить до дестабілізації мембран. Вплив магнію на серцево-судинну систему є подвійним, він бере участь у процесі згортання крові як антитромботичний фактор і здійснює безпосередній вплив на серцевий м'яз, оскільки є потужним вазодилататором, стабілізатором роботи кальцієвих каналів і ритму скорочень міокарда [38, 50, 59].
Магній є фізіологічним антагоністом кальцію, конкурує 3 ним на клітинній мембрані і бере участь у розслабленні м'язових волокон. Відома роль магнію в остеогенезі, оскільки він підтримує нормальний рівень кальцію у кістках, сприяє оновленню кальцію в них, перешкоджає втратам кальцію і вкрай необхідний для стабілізації енергетичних процесів у кістковій тканині.

Дефічит магнію може мати різні клінічні прояви [59], а саме:

- серцево-судинні (кардіалгії, серцебиття, коливання артеріального тиску (АT), подовження інтервалу QT);

- психосоматичні (погіршення когнітивних функцій, зниження працездатності, збільшення тривожності, дратівливості, вегетативний дисбаланс, схильність до депресії, інсомнічні розлади, запаморочення);

- бронхолегеневі (бронхоспазм і ларингоспазм);

- гастроентерологічні (закреп або діарея, пілороспазм, нудота, блювання, біль у животі);

- неврологічні (парестезії, спазми гладком'язових тканин).

Найбільш ранніми проявами дефіциту магнію є порушення з боку нервово-м'язової системи і психоемоційного стану. Можуть спостерігатися мозаїчні м'язові посмикування, судоми, гіперрефлексія, тремор, атаксія або м'язова слабкість, ларингоспазм, бронхоспазм, приєднуються астенія, неспокій, агресивність, знижується стресостійкість, підвищується схильність до інфекційних ускладнень [34].

Дефіцит магнію виявляють при синдромі хронічної втоми, соматоформній вегетативній дисфункції, деменції, іпохондричному і депресивному синдромах.

Пацієнти часто відзначають запаморочення, головний біль за типом мігрені, парестезії, зниження концентрації уваги, дезорієнтацію. До вісцеральних проявів дефіциту магнію належать виникнення абдомінального болю, гіперкінетичних проносів, раннє старіння, поява набряків.

Серцево-судинні симптоми, характерні для порушень магнієвого балансу, включають лабільність судинного тонусу, ангіоспазми, регіонарні порушення кровообігу, аритмії серця, збільшення тривалості або дисперсії інтервалу QT, підвищення агрегації тромбоцитів, прогресування атеросклерозу [34]. Тривалий дефіцит магнію в організмі знижує антиоксидантний захист, спричинює гемореологічні порушення 3 підвищенням ризику тромбоутворення. Магній діє як м'який антикоагулянт, інгібує плазмові чинники згортання, знижує спонтанну і індуковану агрегацію тромбоцитів, потенціює дезагрегаційні властивості ацетилсаліцилової кислоти, пентоксифіліну. Гальмування тромбоутворення є дозозалежним ефектом, інгібуюча дія спостерігається у разі застосування препаратів магнію в ефективних клінічних дозах.

Соматоформна вегетативна дисфункція, що виникає у разі дефіциту магнію, характеризується різноманітними клінічними симптомами і емоційними розладами у вигляді порушень вегетативної регуляції внутрішніх органів, роботи залоз внутрішньої секреції, серцево-судинної системи, травного тракту, респіраторної системи.

Окрім того, доведено важливу роль дефіциту магнію у виникненні метаболічного синдрому, а високий вміст магнію в дієті істотно знижує ризик його розвитку [34]. Основним механізмом є активація каскаду запальних реакцій, що призводять до зниження чутливості до інсуліну, виникнення ендотеліальної дисфункції, розвитку оксидативного стресу. Недостатня концентрація магнію зумовлює зниження чутливості рецепторів клітини до інсуліну і розвитку інсулінорезистентності - патофізіологічного механізму метаболічного синдрому. Дослідження вмісту магнію в осіб з метаболічним синдромом встановили, що в 40-50\% випадків виявляють внутрішньоклітинний (внутрішньоеритроцитарний) дефіцит магнію. Автори відзначили зниження концентрації магнію в 


\section{ДИСТАНЦИОННОЕ ОБУЧЕНИЕ}

еритроцитах на $26,8 \%$, а також виражену інсулінорезистентність і компенсаторну гіперфункцію підшлункової залози (підвищення концентрації імунореактивного інсуліну у 5 разів і С-пептиду у 2 рази) у порівнянні з хворими без дефіциту магнію. На більш ранніх етапах формування цих порушень у пацієнтів часто формується астенія, що посилює вже наявні метаболічні порушення [12, 27].

В останні роки встановлено, що симптоми клімактеричного синдрому схожі з симптомами магнієвої недостатності: приливи і нічна пітливість, відчуття тиску в голові і тілі, м'язовий і суглобовий біль, парестезії, головний біль, запаморочення і непритомність, утруднення дихання, втрата чутливості в стопах і в кистях рук [18, 21].

Між естрогенами, з одного боку, і магнієм і піридоксином - з іншого, є відносини фізіологічного антагонізму: естрогени зумовлюють зниження забезпеченості організму цими двома нутрієнтами. Рівень магнію достовірно знижується під час фолікулярної фази менструального циклу і є обернено пропорційним рівню естрогену у сироватці [6].

Підвищений рівень естрогену в плазмі крові також зумовлює виведення 3 організму вітаміну $\mathrm{B}_{6}$ [16]. Природний, фізіологічний антагонізм між естрогенами, магнієм і піридоксином істотно збільшується при пероральному вживанні естрогенвмісних препаратів. Мета-аналіз подвійних плацебоконтрольованих досліджень засвідчив, що вживання оральних контрацептивів призводить до різкого зниження концентрації рівня вітаміну $\mathrm{B}_{6}$ (піридоксину), який є основним «носієм» магнію в організмі, вже через 1-3 міс вживання [7, 19].

\section{Роль магнію під час вагітності}

Магній модулює низку біохімічних реакцій, що відіграють роль у патогенезі різних захворювань. Нормалізація процесів синтезу оксиду азоту сприяє запобіганню розвитку дисфункції ендотелію і її наслідків - прееклампсії, плацентарної недостатності, передчасних пологів, а нормалізація процесів гліколізу сприяє профілактиці розвитку гестаційного цукрового діабету.

Під час вагітності гіпомагніємія зумовлена необхідністю забезпечення повноцінного росту і розвитку плода, а також посиленим виділенням магнію нирками. Суттєву роль у розвитку гіпомагніємії відіграють блювання у ранні терміни вагітності і захворювання органів травлення. Гіпомагніємія часто супроводжується відносною гіперестрогенією, внаслідок якої посилюється продукція печінкою ангіотензину, підвищується рівень альдостерону і артеріального тиску, що спричинює розвиток ускладнень вагітності $[1,5,6,16]$. Під час вагітності та лактації потреба у магнії підвищується на 20-30\% [6].

Достатня забезпеченість організму матері цим важливим елементом створює основу для повноцінного виношування плода та народження здорової дитини [5]. Хоча магній і визначається у високих концентраціях у порівнянні з іншими органами і тканинами, у мозку, матці, міокарді, м'язах, та найбільший його вміст - у плаценті [6, 9, 24]. Плацента характеризується одним з найвищих рівнів вмісту магнію, вона синтезує більше 150 білків і гормонів, у тому числі 70\% магнієзалежних. Потреба організму вагітної у магнії нерідко перевищує його надходження, і ця обставина дозволяє розглядати вагітність як фізіологічну модель гіпомагніємії [17, $23,25]$. Вагітність супроводжується прогресивним зниженням рівня магнію як у сироватці крові, так і в тканинах внаслідок посиленого його залучення у пластичні та енергетичні процеси і підвищенням ренальної екскреції майже на $25 \%$. Такий «фізіологічний» дефіцит магнію під час вагітності за відсутності адекватної нутрієнтної дотації може підвищувати ризик порушення імплантації ембріона, ранніх і пізніх викиднів, кальцинозу плаценти (наслідок порушення обміну кальцію в умовах дефіциту магнію), передчасних по- логів, прееклампсії, затримки внутрішньоутробного росту плода, ембріональних набряків, вад розвитку плода, дискоординації пологової діяльності, народження дітей з низькою масою тіла, виникнення симфізіопатій і симфізиту $[6,19]$.

До найбільш поширених проявів дефіциту магнію під час вагітності належать судоми литкових м'язів, тремор, посмикування дрібних груп м'язів, підвищений тонус матки, артеріальна гіпертензія $[8,12,20]$.

Наявність загальних проявів дефіциту магнію, які нерідко мають місце під час вагітності, підтверджує зниження еластичності суглобів і зв'язкового апарату, руйнування кісток, у тому числі остеомаляції як наслідку порушення процесів депонування кальцію тощо. Іншими проявами дефіциту магнію у вагітних можуть бути: каменеутворення у жовчних шляхах і нирках; формування інсулінорезистентності; гіпертензія; гіперкоагуляція; порушення моторики травного тракту (проноси, закрепи); дифузний біль у животі, ларингоспазм.

Під час вагітності нормалізація вмісту магнію призводить до зниження тонусу матки, вазодилатації, поліпшення кровотоку в судинах плаценти, зниження агрегації тромбоцитів, підвищення активності простациклінів і зниження активності тромбоксанів А2. Магній підвищує стійкість тканин плода до гіпоксії, у тому числі під час пологів. Магній блокує кальцієві канали на мембранах клітин, що створює і підтримує в клітині потенціал спокою, необхідний для спазмолітичної дії, зниження підвищеного тонусу матки. Магній також реалізує антитромботичний ефект за рахунок активації синтезу простацикліну, стабілізації фібринолізу і пригнічення викиду катехоламінів з депо. В останні роки з'явилися нові дані про внутрішньоутробний нейропротекторний вплив сульфату магнію. Так, магній здатний зменшувати індуковані ішемією пошкодження клітин мозку плода. Клінічне дослідження «випадок-контроль» новонароджених з низькою масою тіла при народженні встановило значно меншу ймовірність розвитку дитячого церебрального паралічу на тлі застосування сульфату магнію. Потенційний нейропротекторний вплив включає антиоксидантну дію, зменшення продукції прозапальних цитокінів, стабілізацію мембран, збільшення мозкового кровотоку і запобігання значних коливань артеріального тиску. При цьому найбільш виражена протекторна дія спостерігається у гестаційному терміні 24-32 тиж [11, 13, 43, 51]. Для превентивного поповнення магнієвого дефіциту показано застосування магнію, якому притаманна багатофакторна дія на різні ланки патогенезу захворювань жіночої репродуктивної системи.

\section{Корекиія дефіииту магнію}

Проблема дефіциту магнію в акушерстві та гінекології вкрай актуальна. У резолюції, прийнятій в кінці 2013 р. Міжнародною Експертною Радою з питань дефіциту магнію в акушерстві та гінекології, засвідчена актуальність проблеми і важливість корекції дефіциту магнію у вагітних і гінекологічних пацієнток, наведені критерії сучасних магнієвмісних препаратів і дані щодо достатньої доказової бази впливу магнію на перебіг та наслідки вагітності [16].

Міжнародна Експертна Рада з питань дефіциту магнію в акушерстві та гінекології рекомендувала оцінювати магнієвий статус пацієнток, які звертаються по акушерськогінекологічну допомогу, будь-яким доступним способом (стандартизовані опитувальники, біохімічний аналіз вмісту магнію у сироватці крові, інші методи), а як референсні значення нормального вмісту магнію у сироватці крові використовувати значення від 0,80 до 0,85 ммоль/л [16, 24].

Хронічний дефіцит магнію може і повинен бути компенсований пероральним вживанням препаратів магнію. Застосування пероральних препаратів магнію коригує дефіцит магнію у вагітних, знижує ймовірність загрози переривання 


\section{ДИСТАНЦИОННОЕ ОБУЧЕНИЕ}

вагітності та еклампсії, запобігає розвитку гестаційного цукрового діабету та ожиріння. Препарати магнію також необхідно включати у комплекс лікувальних заходів у пацієнток 3 метаболічним синдромом, синдромом полікістозних яєчників, дисплазією сполучної тканини, передменструальним і клімактеричним синдромами.

Препарати магнію рекомендовані до призначення у комплексі прегравідарної підготовки до вагітності, у терапії прееклампсії, для профілактики і терапії загрози переривання вагітності, плацентарної недостатності $[3,4,11,13,30]$.

У дітей від народження до пубертатного періоду потреба в магнії становить 10-30 мг/кг маси тіла на добу. Інтенсивне зростання зі збільшенням м'язової маси, кісткової тканини інтеграції нервової системи підвищує потребу в магнії, що бере участь у синтезі білків, жирних кислот і ліпідів, а також у синтезі і розпаді нуклеїнових кислот.

У маленьких дітей дефіцит магнію розвивається внаслідок незбалансованого харчування і проявляється судомними нападами, занепокоєнням, плаксивістю, частими відрижками після годування; у дітей старшого віку характерними ознаками дефіциту магнію є дратівливість, збудливість підвищена рухова активність, тривожність, відставання у зрості і розумовому розвитку, синдром дефіциту уваги з гіперактивністю (attention deficit hyperactivity disorder).

3 метою досягнення максимальної ефективності необхідно призначати препарат магнію з урахуванням його фармакологічних властивостей.

Виділяють чотири покоління препаратів, що містять солі магнію:

- препарати I покоління - неорганічні сполуки: окис магнію, сірчанокисла магнезія, карбонат магнію;

- препарати II покоління - органічні сполуки магнію: лактат, цитрат, підолат, оротат, аспаргінат;

- препарати III покоління - комплекси з біологічними лігандами природного (рослинного і тваринного) походження: лактат магнію у комплексі з піридоксином, амінокислотами;

- nрепарати IV покоління - комплекси з екзолігандами, повними аналогами ендогенних лігандів, у тому числі рекомбінантні форми, комплекси з нейропептидами, амінокислотами, ферментами, полісахаридами, ліпідами - Mg-креатинінкінази.

Визначення оптимальних шляхів корекції дефіциту магнію і активної профілактики ускладнень магнієдефіцитних станів залишається важливим завданням акушерства і гінекології.

Препарати магнію в акушерстві застосовують понад 100 років. Магнію сульфат, пригнічуючи процеси збудження в корі великих півкуль, гіпоталамічній області, судинному і дихальному центрі, нервово-м'язову збудливість, виявляє седативну, спазмолітичну, гіпотензивну і протисудомну дію. Магнію сульфат зменшує дисбаланс між синтезом простацикліну судинною стінкою і тромбоксаном, знижує синтез і вивільнення з депо катехоламінів, тим самим покращуючи перфузію тканин. Однак ефекти парентерально введеного сульфату магнію короткочасні і зникають після завершення інфузії або через 3-4 год після внутрішньом'язового введення [3, 31].

Неорганічні сполуки залежно від способу введення в організм зумовлюють неоднакові ефекти. Сульфат магнію при парентеральному введенні виявляе протисудомну, судинорозширювальну, седативну, гіпотензивну, токолітичну дію. У разі вживання всередину - погано всмоктується (20\% і менше), підвищує осмотичний тиск у травному тракті, спричинюе затримку рідини і іï дифузію у просвіт кишечнику, стимулюе перистальтику. До того ж сульфат магнію зумовлює виділення холецистокініну, що посилює відділення жовчі.

Доведено, що препарати I покоління солей магнію мало впливають на метаболізм і зумовлюють небажані реакції у вигляді присмаку металу у роті, нудоти і блювання, що обмежує їхне застосування. Неорганічні солі магнію (оксид, карбонат, діоксид, фосфат) мають антацидні властивості, і для корекції дефіциту магнію їх не використовують.

Препарати II покоління (органічні солі магнію) відрізняє висока абсорбція у травному тракті: у цитрату і аспаргінату - $30-37 \%$, оротату і лактату $-38-40 \%$, підолату $-43 \%$.

Препаратами вибору для корекції дефіциту магнію і довготривалої профілактики ускладнень вагітності є органічні солі магнію для перорального вживання, які краще засвоюються, легше переносяться і дають менше небажаних реакцій з боку травного тракту $[1,4,5,16,18,23]$.

3 профілактичною метою препарати магнію застосовують в осіб груп ризику розвитку дефіциту магнію, до яких належать діти і підлітки в період інтенсивного зростання; вагітні і жінки, які годують, особи, що займаються інтенсивною працею; спортсмени; люди, що дотримуються дієти 3 незбалансованим вмістом макро- і мікроелементів; літні і люди старечого віку, що часто хворіють.

Ефективність магнію зростає при використанні його з так званими магнієфіксаторами. Оротова кислота у зарубіжній літературі класифікується як «Mg-fixing agent» i сприяє транспорту іонів $\mathrm{Mg}^{2+}$ всередину клітини. Одним з препаратів, що застосовують у лікуванні і профілактиці дефіциту магнію, є препарат органічної солі магнію, до складу якого входить 32,8 мг елементарного магнію або 500 мг оротату магнію. Оротова кислота, яка входить до складу препарату, є посередником у біосинтезі піримідинів, синтезі глікогену і аденозинтрифосфату. Оротат магнію призначають по 2 таблетки 3 рази на день протягом 7 днів, потім - по 1 таблетці 2-3 рази на день. Тривалість курсу - не менше 4-6 тиж [30].

Поява комбінованих препаратів, що містять магній i вітамін $\mathrm{B}_{6}$ (піридоксин), значно поліпшила фармакологічні властивості солей магнію. Піридоксин бере участь в обміні білків, вуглеводів, жирних кислот, синтезі нейромедіаторів і багатьох ферментів, виявляє нейро-, кардіо-, гепатотропний, гемопоетичний вплив, сприяє поповненню енергетичних ресурсів. Висока активність комбінованого препарату, що містить магній і вітамін $\mathrm{B}_{6}$ (піридоксин), зумовлена синергізмом дії компонентів: піридоксин збільшує концентрацію магнію у плазмі та еритроцитах і знижує кількість магнію, що виводиться з організму; покращує всмоктування магнію у травному тракті, його проникнення і фіксацію в клітинах. Магній, у свою чергу, активізує процес трансформації в печінці піридоксину в його активний метаболіт піридоксаль-5-фосфат [4, 7, 22, 23]. Окрім того, піридоксин покращує всмоктування магнію у травному тракті.

Вживання препарату, що містить солі магнію і вітамін $\mathrm{B}_{6}$, значно зменшує такі прояви передменструального синдрому, як дратівливість, депресія, агресивність, плаксивість, відчуття втоми. Жінки, що вживають у другій половині менструального циклу магній і вітамін $\mathrm{B}_{6}$, рідше скаржаться на болючість грудних залоз, метеоризм, набряки, задишку і спрагу $[2,10]$.

Цитрат магнію є одним з оптимальних препаратів для корекції дефіциту магнію. Цитрат магнію - одна 3 органічних солей, які використовують у якості активної діючої речовини у сучасних пероральних магнієвмісних препаратах. Цитрат магнію має низку суттєвих переваг у порівнянні як з неорганічними солями магнію (оксид магнію, сульфат магнію, хлорид магнію), так і з лактатом магнію. Цитрат магнію характеризується одним з найвищих показників розчинності серед органічних і неорганічних солей магнію. 3 іншого боку, цитрат є центральною ланкою у циклі Кребса і необхідний для синтезу АТФ і енергетичного обміну в мітохондріях (інша назва циклу Кребса - цитратний цикл). При цьому метаболізм цитрату передбачає утилізацію у вуглекислий газ і воду, що робить його ідеальним переносником 


\section{ДИС ТАНЦИОННОЕ ОБУЧЕ ИЕ}

магнію всередину клітин. Цитрат магнію вживають перорально по 1 таблетці 3 рази на день [12].

У корекції дефіциту магнію з успіхом використовують препарат магнію оксиду легкого, що містить добову кількість $\mathrm{Mg}^{2++}$ яка за рахунок найменшої молекули легко і швидко всмоктується. Цей препарат показаний при дратівливості, порушеннях сну, головному болю, стресі, клімаксі, передменструальному синдромі, дисменореї, спазмах у животі, закрепах, судомах ніг, а також при інших станах, які можуть бути зумовлені дефіцитом магнію. Його вживання рекомендоване при інтенсивних фізичних навантаженнях, заняттях спортом, зловживанні алкоголем, дотриманні дієт, нерегулярному харчуванні, вживанні деяких лікарських препаратів (сечогінних, КОК тощо).

Препарати магнію і вітаміну $\mathrm{B}_{6}$ включають у комплексну терапію депресій, судомних станів, порушень сну. Препарати магнію і вітаміну $\mathrm{B}_{6}$ успішно застосовують при вегетативних розладах у людей різних вікових груп. Ферменти та іони магнію забезпечують фазу спокою під час проведення нервовом'язових імпульсів, регулюють нейрохімічні процеси, зокрема синтез нейропептидів у головному мозку, синтез і деградацію катехоламінів і ацетилхоліну. Застосування препаратів магнію з вітаміном $\mathrm{B}_{6}$ або оротовою кислотою приводить до зниження частоти симптомів вегетативної дисфункції, розладів настрою, судинних порушень у молодих людей з пролапсом мітрального клапана. Пролапс мітрального клапана і вегетативна дисфункція часто розвиваються при дисплазії сполучної тканини, яка характеризується порушенням будови і метаболізму колагену, еластичних волокон, міжклітинної речовини. Препарати магнію, включені у комплексну терапію дисплазії сполучної тканини, покращують цитоархітектоніку колагенових волокон, стимулюють колагеноутворення і знижують ступінь вираженості функціональних розладів сполучної тканини.

\section{Соматические и акушерские аспекты дефицита магния (Клиническая лекция) C.А. Шурпяк}

Гомеостаз магния в организме является обязательным условием здоровья человека. Как необходимый макроэлемент для клеток и тканей, магний участвует во многих физиологических процессах, обеспечивающих нормальную жизнедеятельность организма. В то же время, рядом масштабных исследований установлена значительная распространенность дефицита магния, который в общей популяции составляет 14,5\%, а субоптимальный уровень наблюдается у $33,7 \%$. В резолюции Международного Экспертного Совета по вопросам дефицита магния в акушерстве и гинекологии отмечена актуальность проблемы и важность коррекции дефицита магния у беременных и гинекологических пациенток. В лекции освещены различные аспекты дефицита магния, рассмотрены патофизиологические механизмь нарушения магниевого гомеостаза организма, принципы применения препаратов магния с профилактической и лечебной целью.

Ключевые слова: дефииит магния, клинические симптомы гипомагниемии, беременность.
Препарати магнію рекомендуються для широкого застосування у терапії передменструального синдрому з переважанням психоемоційного напруження (депресія, дратівливість, набряки, болючість і відчуття нагрубання грудних залоз) $[2,6,13,14,53]$. Тривалість терапії повинна становити не менше 2-3 менструальних циклів і може бути продовжена протягом значно більшого часу. Включення препаратів магнію у комплекс лікувальних заходів патогенетично показано пацієнткам з пролапсом статевих органів, особливо у профілактиці рецидивів після оперативного втручання.

У резолюції, яка прийнята Міжнародною Експертною Радою, «Дефіцит магнію в акушерстві та гінекології (2013) наведені критерії, яким повинні відповідати сучасні препарати магнію, що використовуються в акушерській практиці $[16,24]$ :

1. Препаратами вибору є органічні солі магнію - магнію цитрат, магнію підолат і магнію лактат, що мають високу засвоюваність.

2. Точність дозування елементного магнію $\left(\mathrm{Mg}^{2++}\right)$ (при призначенні препарату магнію лікар повинен розуміти, скільки магнію у підсумку отримає пацієнт (50 або 100 мг).

3. Наявність у препараті магнієфіксаторів «Mg-fixing agent».

4. Зручна форма застосування, можливість вибору форми застосування для поліпшення комплаєнтності.

5. Оригінальна якість, виробництво з дотриманням правил належної виробничої практики (GMP - good manufacture practice).

6. Наявність клінічних досліджень, що підтверджують ефективність і безпеку застосування препарату в акушерстві та гінекології.

\section{Somatic and obstetrical aspects of magnesium deficiency (Clinical lecture) S.A. Shurpyak}

Homeostasis of magnesium in the body is a prerequisite for human health. As required macrocell for cells and tissues, magnesium is involved in many physiological processes, to ensure the normal functioning of the organism. At the same time a number of large-scale studies established a significant prevalence of magnesium deficiency, which is in the general population is $14,5 \%$, and the suboptimal level observed in $33,7 \%$. The resolution of the International Advisory Council for magnesium deficiency in obstetrics and gynecology noted urgency of the problem and the importance of correction of magnesium deficiency in pregnant and gynecological patients. The lecture covered various aspects of magnesium deficiency are considered violations of the pathophysiological mechanisms of magnesium homeostasis, Principles on the Use of magnesium products with preventive and curative purposes.

Key words: magnesium deficiency, clinical symptoms of hypomagnesemia, pregnancy.

\section{Сведения об авторе}

Шурпяк Сергей Александрович - Львовский национальный медицинский университет имени Данила Галицкого, 79010, г. Львов, ул. Пекарская, 69. E-mail: shurpyak_serhiy@yahoo.com

\section{СПИСОК ЛІТЕРАТУРИ}

1. Буданов П.В. Актуальные проблемы невынашивания беременности на фоне дефицита магния // Гинекология. $-2010 .-5$ (1): 28-32.

2. Буданов П.В. Лечение предменструального синдрома: современные представления и перспективы // Трудный пациент. - 2012. - № 10, № 2-3. - C. 34-37.
3. Бурчинский С.Г. Проблема дефицита магния в организме: методы фармакологической коррекции. www.health-ua.com/articles/983.

4. Городецкий В.В., Талибов О.Б. Препараты магния в медицинской практике. Малая энциклопедия магния. - М.: ИД Медпрактика-М, 2007. 5. Громова О.А. Витамины и микро- элементы при беременности и у кормящих матерей. Клиническая фармакология. Обучающие программы ЮНЕСКО. Под ред. В.М. Сидельниковой. - М., 2006. - 58 с.

6. Громова О.А., Серов В.Н., Торшин И.Ю. Магний в акушерстве и гинекологии: история применения и современные взгляды // Трудный паци- ент. - 2008. - № 8. - С. 10-15.

7. Громова О.А. Магний и пиридоксин: Основа знаний. - М.: ПротоТип, 2006. $-230 \mathrm{c}$

8. Дадак К. Дефицит магния в акушерстве и гинекологии // Акушерство, гинекология и репродукция. 2013; 2: 6-14.

9. Кошелева Н.Г., Аржанова О.Н., 


\section{ДИСТАНЦИОННОЕ ОБУЧЕНИЕ}

Плужникова Т.А. Невынашивание беременности: этиопатогенез, диагностика, клиника и лечение. - СПб, 2003. $-70 \mathrm{c}$.

10. Межевитинова Е.А., Прилепская В.Н., Назарова Н.М. Роль магния в развитии предменструального синдрома // Гинекология. - 2003. № 2. - C. 23-33.

11. Мелліна І.М., Павловська Т.Л., Владимиров О.А., Тофан Н.І. Досвід використання Магне-В6 в акушерській практиці // Педіатрія, акушерство та гінекологія. - 2002. № 2. - C. 119-123.

12. Мубаракшина О.А. Особенности применения препаратов магния беременными женщинами // Фарматека. - 2013. - № 18. - С. 2-5.

13. Мубаракшина О.А. Современные подходы к применению препаратов магния у беременных женщин // Акушерство и гинекология. - 2012. № 5. - С. 109-112.

14. Недогода С.В. Роль препаратов магния в ведении пациентов терапевтического профиля // Лечащий Врач. - 2009. - № 6. - С. 16-19.

15. Роль гипомагниемии в акушерской патологии. Применение препаратов магния / под ред. Н.Г. Кошелевой. - СПб., 2007.

16. Роль дефицита магния в акушерстве и гинекологии (позиция экспертов). Коллектив авторов // Акушерство и гинекология. 2014; 1.

17. Серов В.Н., Блинов Д.В., Зимовина У.В., Джобава Э.М. Результаты исследования распространенности дефицита магния у беременных // Акушерство и гинекология. 2014; 6 33-39.

18. Серов В.Н., Керимкулова Н.В., Торшин И.Ю., Громова О.А. Зарубежный и российский опыт применения магния в акушерстве и гинекологии. Доказательные исследования // Вопросы гинекологии, акушерства и перинатологии. - 2012; 11 (4): 62-72.

19. Спасов А. А. Магний в медицинской практике. - Волгоград, 2000. - 272 с. 20. Тетруашвили Н.К., Сидельникова В.М. Восполнение дефицита магния в комплексной терапии пациенток с угрозой прерывания беременности // Трудный пациент. - 2005. T. 3, № 2. - C. 20-23.

21. Торшин И.Ю., Громова О.А. Дисплазия соединительной ткани, клеточная биология и молекулярные механизмы воздействия магния // РМЖ. - 2008. - T. 16, № 4. C. $230-238$
22. Торшин И.Ю., Громова О.А. Механизмы антистрессового и антидепрессивного действия магния и пиридоксина // Журнал неврологии и психиатрии им. С.С. Корсакова. - 2009 109 (11): 107-111.

23. Торшин И.Ю., Рудаков К.В., Тетруашвили Н.К. и др. Магний, пиридоксин и тромбофилия беременных: молекулярные механизмы и доказательная медицина // Российский вестник акушера-гинеколога. - 2010.

- № 4. - С. 67-71.

24. Фофанова И.Ю. Дефицит магния и его связь с акушерской патологией // Медицинский совет. - 2013. № 5. - С. 34-41.

25. Цаллагова Е.В. Магний: перспек тивы женского и детского здоровья // Фарматека. - 2013. - № 18. C. 6-8.

26. Чушков Ю.В. Современные воз можности коррекции дефицита магния в акушерстве // РМЖ. - 2012. № 17. - С. 867-873.

27. Шилов А.М., Авшалумов А.Ш., Синицина Е.Н. и др. Метаболический синдром и «дефицит магния»: особенности течения и лечения. - 2008 - www.vrach.ru.

28. Barbagallo M., Belvedere M. Dominguez L.J. Magnesium homeostasis and aging // Magnes. Res. - 2009. - Vol. 22, № 4. - P. 235-246.

29. Bussiere F.I., Mazur A. Fauquert J.L. et al. High magnesium concentration in vitro decreases human leukocyte activation // Magnes Res. 2002; 15: 43-48.

30. Classen H.G. Magnesium orotateexperimental and clinical evidence // Rom. J. Intern. Med. - 2004. - Vol. 42 (3). - P. 491-501.

31. Coudray C., Rambeau M., Feillecct-Coudray C. et al. Study of magnesium bioavailability from ten organic and inorganic $\mathrm{Mg}$ salts in $\mathrm{Mg}$ depleted rats using a stable isotope approach // Magnes. Res. - 2005. Vol. 18 (4). - P. 215-223.

32. Durlach J., Pages N., Bac P. et al. Magnesium deficit and sudden infant death syndrome (SIDS): SIDS due to magnesium deficiency and SIDS due to various forms of magnesium depletion: possible importance of the chronopathological form // Magnes. Res. - 2002. - Vol. 15 (3-4). P. 269-278.

33. Fausto de Silva \& Willams PJ. Biological chemisrty 0 felements. Cambrige, 2003: 678.

34. Fox C., Ramsoomair D., Carter C. Magnesium: its proven and potentia clinical significance. South Med J 2001:94:1195-1201.

35. Guerrero-Romero F., RodriguezMoran M. Hypomagnesemia, oxidative stress, inflammation, and metabolic syndrome // Diabetes Metab. Res. Rev. - 2006. - Vol. 22 (6). - P. 471-476. 36. Gunther T. The biochemical function of $\mathrm{Mg} \mathrm{2+}$ in insulin secretion, insulin signal transduction and insulin resistance // Magnes. Res. - 2010. № 23 (1). - P. 5-18.

37. Huang C.L., Kuo E. Mechanism of Hypokalemia in Magnesium Deficiency. J Am Soc Nephrol 2007;18(10):2649-2652.

38. Kenji Ueshima. Magnesium and ischemic heart disease: a review of epidemiological, experimental, and clinical evidences // Magnes. Res. - 2005. № 18 (4). - P. 275-284.

39. Killilea D.W., Maier J.A.M. A connection between magnesium deficiency and aging: new insights from cellular studies // Magnesium Research. 2008. - № 21 (2). - P. 77-82.

40. King D.E. Inflammation and elevation of C-reactive protein: does magnesium play a key role? // Magnes. Res. - 2009. - № 22 (2). - P. 57-59.

41. Konrad M., Weber S. Recent advances in molecular genetics of hereditary magnesium-losing disorders. J Am Soc Nephrol 2003;14:249-260.

42. Mazur A., Maier J.A., Rock E. et al. Magnesium and the inflammatory response: potential physiopathological implications // Arch Biochem Biophys. - 2007; 458 (1): 48-56.

43. Mittendorf R., Dammann 0. Lee K.S. Brain lesions in newborns exposed to high-dose magnesium sulfate during preterm labor // J. Perinatol. - 2006. - Vol. 26 (1). P. 57-63.

44. Naderi A.S.A., Reilly R. F.Jr. Hereditary etiologies of hypomagnesemia. Nature Clinical Practice Nephrology 2008;4:80-89.

45. National guidelines for hereditary disorders of connective tissue. Kapдиоваскулярная терапия и профилактика 2009; 8(6) Приложение 5: $1-24$.

46. Navarro J.F., Mora-Fernandez C. (2007) in: New perspectives in magnesium research: nutrition and health $(Y$ Nishizawa, H. Morii, J. Durlach, eds.)Springer-Verlag, London, pp. 303-315

47. Okuno S., Inaba M. (2007) in: New perspectives in magnesium research: nutrition and health (Y. Nishizawa,
H. Morii, J. Durlach, eds.) SpringerVerlag, London,pp. 316-329.

48. Rayssiguier Y., Mazur A. Magnesium and inflammation: lessons from animal models // Clin Calcium. 2005; 15 (2): 245-248.

49. Rodriguez-Moran M., GuerreroRomero F. Serum magnesium and Creactive protein levels // Arch Dis Child. 2008; 93 (8): 676-680.

50. Rosanoff A. Magnesium and hypertension // Clin. Calcium. - 2005. № 15. - P. 255-260.

51. Rouse D.J., Hirtz D.G., Thom E., Varne M.W. et al. Eunice Kennedy Shriver NICHD Maternal-Fetal Medicine Units Network. A randomized, controlled trial of agnesium sulfate for the prevention of cerebral palsy. N. Engl. J. Med. - 2008; 359 (9): 895-905.

52. Rude R.K. Magnesium metabolism and deficiency. Endocrinol Metab Clin North Am 1993; 22: 377-395.

53. Ryan M.F., Barbour H. Magnesium measurement in routine clinical practice. Ann Clin Biochem 1998;35:449-459.

54. Saris N.E., Mervaala E., Karppanen H., Khawaja J.A., Lewenstam A. Magnesium. An update on physiological, clinical and analytical aspects. Clin Chim Acta 2000; 294:1-26;

55. Schimatschek H.F., Rempis R. Prevalence of hypomagnesemia in an unselected German population of 16,000 individuals // Magnes Res. 2001; 14: 283-290.

56. Schlingmann K.P., Konrad M., Seyberth H.W. Genetics of hereditary disorders of magnesium homeostasis. Pediatr Nephrol 2004;19:13-25.

57. Sheen E., Triadafilopoulos G. Adverse effects of long-term proton pump inhibitor therapy. Digestive diseases and sciences 2011;56(4):931-950.

58. Song Y., Ridker P.M., Manson J.E. et al. Magnesium intake, C-reactive protein, and the prevalence of metabolic syndrome in middle-aged and older U. S. women // Diabetes Care. 2005; 28: $1438-1444$.

59. Swaminathan R. Magnesium Metabolism and its Disorders. Clin Biochem Rev 2003;24 (2):47-66. 60. Tam M., Gomez S., GonzalezGross M. et al. Possible roles of magnesium on the immune system // Europ J Clin Nut. 2003; 57: 1193-1197.

61. Wu A. Tietz Clinical Guide to Laboratory Tests. 4th Ed. St. Louis, MO: Saunders Elsevier; 2006. 


\section{ДИС ТАНЦИОН НОЕ ОБУЧЕНИЕ}

\section{ТЕСТОВІ ЗАПИТАННЯ}

\section{(один або декілька правильних варіантів відповідей на кожне запитання)}

1. За Міжнародною класифікацією хвороб (МКХ-10) діагноз «недостатність магнію» кодується як:
E64.2
E61.2
E61.0

E64.1

2. Про помірну недостатність магнію в організмі свідчить його рівень у сироватці крові:
$0,5-0,7$ ммоль $/ л$
口 $0,2-0,3$ ммоль/л
0,8-0,9 ммоль/л
口 1,0-1,1 ммоль/л.

3. Під час вагітності і лактації, фізичних навантаженнях потреба в магнії на добу зростає в середньому на:

$\square 150 \mathrm{Mr}$

口 $200 \mathrm{Mг}$

口 $250 \mathrm{Mг}$

○ $300 \mathrm{Mг}$

4. Дефіцит магнію в організмі відповідно зумовлюе дефіцит:
- Заліза
- Вітаміну C
口 Цинку
Натрію.

5. Про дефіцит магнію свідчить зниження його концентрації в еритроциті менше:
2 ммоль/л
1,9 ммоль/л
1,6 ммоль/л
У Усе наведене невірно.
6. До найбілыш поширених причин дефіциту магнію належать:

口 Генетичні чинники

口 Знижене споживання магнію

๑ Знижена кишкова резорбція
口 Підвищене виведення магнію

$\checkmark$ Усе наведене вірно.

9. Яка ендокринна патологія супроводжується дефіцитом магнію?

๑ Гіпертиреоз

口 Гіпотиреоз

口 Недостатність лютеїнової фази

口 Синдром Іценко-Кушинга.

10. Магній є фізіологічним антагоністом:

๑ Заліза

๑ Цинку

口 Кальцію

$\square$ Натрію.

11. Які з наведених лікарських засобів можуть спричиняти гіпомагніємію?

$\square$ Гентаміцин

$\square$ КОК

- Сальбутамол

У Усе наведене невірно

$\checkmark$ Усе наведене вірно

12. До препаратів магнію I покоління належить:

口 Сульфат магнію

口 Лактат магнію

口 Магнію аспарагінат

口 Усе наведене вірно.

12. До магнієфіксаторів належить:

- Оротова кислота

口 Піридоксин

口 Оксалатна кислота

口 Усе наведене невірно.

13. Одним з ранніх проявів дефіциту магнію у вагітних є: 口 Глосит

口 Артеріальна гіпотонія

口 Судоми литкових м'язів

口 $\mathrm{B}_{12}$-дефіцитна анемія. 


\title{
но вос ти. Со Бы тия
}

\author{
НАЦІОНАЛЬНА АКАДЕМІЯ ДЕРЖАВНОГО УПРАВЛІННЯ ПРИ ПРЕЗИДЕНТОВІ УКРАЇНИ \\ НАЦІОНАЛЬНА МЕДИЧНА АКАДЕМІЯ ПІСЛЯДИПЛОМНОЇ ОСВІТИ ІМЕНІ П.Л. ШУПИКА \\ ВГО «АСОЦІАЦІЯ АДВОКАТІВ УКРАЇНИ» \\ ВГО «УКРАЇНСЬКА ЛІГА РОЗВИТКУ ПАЛІАТИВНОЇ ТА ХОСПІСНОЇ ДОПОМОГИ» \\ НАВЧАЛЬНО-НАУКОВИЙ ЦЕНТР МЕДИЧНОГО ПРАВА ЮРИДИЧНОГО ФАКУЛЬТЕТУ КИЇВСЬКОГО \\ НАЦІОНАЛЬНОГО УНІВЕРСИТЕТУ ІМЕНІ ТАРАСА ШЕВЧЕНКА
}

Інформачійні партнери: Міжнародний медичний форум;

Міжнародний журнал «Реабілітація та паліативна медицина»; Журнал «Довідник головної медичної сестри»

\section{ІНФОРМАЦЙНИЙ ЛИСТ № 2}

Шановні колеги!

Повідомляємо Вам, що 11 листопада 2016 року у Національній академії державного управління при Президентові України відбудеться Науково-практична конференція з міжнародною участю

\section{«ПРАВОВІ ТА ОРГАНІЗАЦІЙНІ ЗАСАДИ ПАЛІАТИВНОї ДОПОМОГИ В УКРАЇН|»}

\author{
Місце проведення: м. Київ, вул. Пугачова, 12/2, Конференц-зала. \\ Початок о 10:00. Реєстрація з 9:00
}

НАУКОВА ТЕМАТИКА КОНФЕРЕНЦІї:

Організаційно-функціональна модель системи надання паліативної допомоги в Україні та її нормативно-правове забезпечення

Моделі фінансування надання паліативної допомоги: світовий досвід для України

Нормативно-правове забезпечення надання паліативної допомоги на первинному рівні

Клінічні і нормативно-правові критерії визначення статусу паліативного пацієнта

Міжнародний досвід надання паліативної допомоги Надання паліативної допомоги у психіатрії

- виступ із доповіддю;

Форми участі у конференції:

- публікація статті або тез доповіді;

- участь без доповіді.

Під час роботи конференції відбудуться:

- пленарне засідання;

- секційні засідання.

Тривалість доповіді на пленарному засіданні до 15 хв, на секційних засіданнях - до 10 хв.

Виступи в обговоренні - до 5 хв.

Робочі мови конференції: українська, російська, англійська.

Для участі у конференції необхідно до 24 жовтня 2016 р. надіслати на адресу Оргкомітету електронною поштою (atsarenko@gmail.com) заявку (у додатку), статтю або тези для публікації в Міжнародному журналі «Реабілітація та паліативна медицина» відповідно до вимог публікації наукових матеріалів у журналі (у додатку).

Оргкомітет розподіляє та відбирає заявочні матеріали учасників для доповідей на пленарному та секційних засіданнях і залишає за собою право наукового та літературного редагування статей та тез доповідей. Оргкомітет відбере найкращі статті та тези для наступної публікації у Міжнародному журналі «Реабілітація та паліативна медицина».

З питань, пов'язаних з організацією і проведенням конференції, звертатися:

кафедра управління охороною суспільного здоров'я Національної академії державного управління при Прези- дентові України, м. Київ, вул. С. Перовської, 5, кім. 400 (ГГТ № 1).

тел.: (044) 455-62-92; e-mail: schoolha@ukr.net; http://ligalife.com.ua

СКЛАД ОРГАНІЗАЦІЙНОГО КОМІТЕТУ КОНФЕРЕНЦІЇ

1. Князевич Василь Михайлович - голова Оргкомітету завідувач кафредри управління охороною суспільного здоров'я Національної академії державного управління при Президентові України, доктор медичних наук

2. Вороненко Юрій Васильович - співголова Оргкомітету - ректор Національної медичної академії післядипломної освіти імені П.Л. Шупика, доктор медичних наук, профессор, академік НАМН України

3. Рачук Олег Олександрович - співголова Оргкомітету - президент ВГО «Асоціація адвокатів України»

4. Царенко Анатолій Володимирович - секретар Оргкомітету - заступник Голови правління ВГО «Українська ліга розвитку паліативної та хоспісної допомоги", доцент кафедри паліативної та хоспісної медицини Національної медичної академії післядипломної освіти імені П.Л. Шупика, кандидат медичних наук, доцент

5. Юнгер Віталій Іванович - секретар Оргкомітету - доцент кафедри управління охороною суспільного здоров'я Національної академії державного управління при Президентові України, кандидат медичних наук

\section{ЧЛЕНИ ОРГАНІЗАЦІЙНОГО КОМІТЕТУ}

1. Бронова Владислава Михайлівна - радник Голови Правління ГО «Українська ліга розвитку паліативної та хоспісної допомоги»

2. Гревцова Радміла Юріївна - адвокат, кандидат юридичних наук, доцент, директор Навчально-наукового центру медичного права юридичного фракультету

3. Матюха Лариса Федорівна - завідувач кафедри сімейної медицини Національної медичної академії післядипломної освіти імені П.Л. Шупика, професор, доктор медичних наук

4. Моісеєнко Раїса Олександрівна - співголова Оргкомітету - проректор з науково-педагогічної та лікувальної роботи Національної медичної академії післядипломної освіти імені П.Л. Шупика, доктор медичних наук, профеесор

5. Пінчук Ірина Яківна - директор Українського науководослідного інституту соціальної і судової психіатрії та наркології МОЗ України 


\section{но В О С Т И. СО Бы Тия}

6. Радиш Ярослав Федорович - професор кафедри управління охороною суспільного здоров'я Національної академії державного управління при Президентові України, доктор наук з державного управління, професор

7. Шекера Олег Григорович - директор Інституту сімейної медицини Національної медичної академії післядипломної освіти імені П.Л. Шупика, доктор медичних наук, профессор

8. Децик Орина Зенонівна - завідувач кафедри соціальної медицини, організації охорони здоров'я і медичного пра- вознавства Івано-Франківського національного медичного університету, доктор медичних наук, професор

9. Чайковська Віра Володимирівна - керівник лабораторії соціальної геронтології ДУ «Інститут геронтології імені Д.Ф. Чеботарьова НАМН України", доктор медичних наук;

10. Чайківська Дзвенислава Романівна - МБФ «Карітас України"

11. Яковенко Ігор Валентинович - директор Інституту суспільства Київського університету імені Бориса Грінченка, кандидат економічних наук, доцент.

ДОДАТОК 1

ДО ІНФОРМАЦІЙНОГО ЛИСТА № 2

РЕССТРАЦІЙНА ФОРМА

учасника науково-практичної конференції

«ПРАВОВІ ТА ОРГАНІЗАЦІЙНІ ЗАСАДИ ПАЛІАТИВНОЇ ДОПОМОГИ В УКРАЇНІ»

11 листопада 2016 року, м. Київ

Національна академія державного управління при Президентові України

\begin{tabular}{|c|c|}
\hline Прізвище, ім`я, по-батькові доповідача/учасника & \\
\hline Форма участі в роботі Конференції & $\begin{array}{c}\text { 1. Усна доповідь і публікація тез у збірнику матеріалів Конференції } \\
\text { 2. Участь в роботі Конференції без публікації в збірнику матеріалів Конференції }\end{array}$ \\
\hline Країна, місто & \\
\hline Місце роботи, посада & \\
\hline Вчений ступінь, наукове та почесне звання & \\
\hline Назва доповіді \\
\hline Поштова адреса, Е-таіІ, мобільний телефон & \\
\hline
\end{tabular}

\section{Правила подання матеріалу для публікації у Міжнародному журналі «Реабілітація та паліативна медицина»}

Структура матеріалу: вступ (стан проблеми за даними літератури не більше 5-7-річної давності); мета, основні завдання та методи дослідження; основна частина (висвітлення статистично оброблених результатів дослідження); висновки; перспективи подальшого розвитку в даному напрямку; список літератури, реферати російською, українською та англійською мовами.

На останній сторінці статті повинні бути власні підписи всіх авторів, прізвища, ім'я та по батькові (повністю), поштова адреса установи, номери телефонів (службовий), ступінь, звання, посада. Обов'язково контактний телефон автора/ів, з яким/и редакція може спілкуватися у разі виникнення питань.

Авторський текстовий оригінал повинен складатися з двох екземплярів українською, англійською або російською мовами:

- тексту (обсяг оригінальних статей, у тому числі рисунків, літератури, рефератів не більше 8 сторінок, оглядів літератури, лекцій, проблемних статей - не більше 12 сторінок, коротких повідомлень, рецензій - не більше 7 сторінок);

- списку літератури (якщо у статті є посилання, не більше 20 літературних джерел, в оглядах - не більше 50);

- таблиць;

- рисунків (не більше 4) та підписів до них.

До статті надаються реферати українською, російською та англійською мовами з обов'язковим зазначенням прізвищ та ініціалів авторів, а також назви установи на цих мовах. Обсяг резюме не повинен перевищувати 200-250 слів. Обов'язково надаються «ключові слова» (від 3 до 8 слів) у порядку значущості, що сприятиме індексуванню статті в інформаційно-пошукових системах. Резюме є незалежним від статті джерелом інформації. Воно буде надруковано окремо від основного тексту статті і має бути зрозумілим без посилання на саму публікацію. Резюме є коротким і послідовним викладенням матеріалу публікації за основними розділами та повинно відображати основний зміст статті, виходити з логіки викладення матеріалу та опису результатів у статті з наведенням конкретних даних.
Резюме до оригінальної статті повинно бути структурованим:

а) мета дослідження;

б) матеріали та методи;

в) результати;

г) висновки.

Усі розділи в резюме повинні бути виділені в тексті жирним шрифтом. Для інших статей (огляд, лекція, обмін досвідом тощо) резюме повинно включати короткий виклад основної концепції статті та ключові слова.

Статті друкують на комп'ютері у програмі Word і подають роздрукованими та на електронному носії. Текст реферату слід набирати шрифтом Times New Roman, 12 пт з міжстроковим інтервалом 1,5. Текст друкують, дотримуючись таких розмірів полів: верхнє і нижнє - 20 мм, ліве - 25 мм, праве - 10 мм. Ілюстрації (діаграми, графіки, схеми) слід виконувати у програмах Word або Excel у вигляді окремих файлів і разом з текстовим файлом подавати в електронному вигляді.

На першій сторінці зазначаються: індекс УДК зліва, назва статті, ініціали та прізвища авторів, назва установи, де працюють автори, місто у дужках.

Список літератури подається після тексту. Джерела літератури розташовують за алфавітом за вимогами ВАК до наукових робіт. Усі джерела повинні бути пронумерованими та мати не більше 5-7-річну давність.

Відповідальність за достовірність і оригінальність наданих матеріалів (фактів, цитат, прізвищ, імен, результатів досліджень тощо) покладається на авторів.

Статті, оформлені без дотримання правил, не розглядаються та не повертаються авторам.

Редакція забезпечує рецензування статей, виконує наукове та літературне редагування. 


\title{
Fast track: хирургические протоколы ускоренной реабилитации в гинекологии
}

\author{
К.В. Пучков ${ }^{1,2,3}$, В.В. Коренная ${ }^{4}$, Н.М. Подзолкова ${ }^{4}$
}

${ }^{1}$ ГБОУ ВПО Рязанский государственный медицинский университет имени академика И.П. Павлова Минздрава России ${ }^{2}$ Швейцарская университетская клиника, г. Москва, Россия ${ }^{3}$ Центр клинической и экспериментальной хирургии, г. Москва, Россия ${ }^{4}$ ГБОУ ДПО Российская медицинская академия последипломного образования Минздрава России, г. Москва Гинекология. 2015; 17 (3): 40-45

Fast track (FT)-хирургия (от англ. fast track - быстрый путь) - программы комплексного лечения, включающие подготовку на предоперационном этапе, использование минимально инвазивных техник выполнения оперативного вмешательства и активное ведение послеоперационного периода с целью уменьшения сроков стационарного лечения, времени реабилитации и максимально быстрого возвращения пациентов к обычной жизни.

Впервые принципы программ FT были сформулированы в конце XX в. Henrik Kehlet и изначально внедрены в кардиохирургии, колопроктологии и онкологии, но постепенно стали завоевывать признание и в других хирургических направлениях.

Собственный опыт применения FT-протоколов у гинекологических больных показал, что они позволяют улучшить течение раннего послеоперационного периода, не оказывают негативного влияния на отдаленные исходы и частоту повторных госпитализаций, позволяют значительно сократить сроки восстановления после операции и повысить удовлетворенность пациенток проведенным лечением.

Ключевые слова: fast track, послеоперачионная реабилитачия.

Среди синонимов fast track (FT)-хирургии в англоязыч- ной литературе часто можно встретить также термин «программы ускоренной послеоперационной реабилитации» - ERAS или RRSP (Enhanced Recovery after Surgery или Rapid Recovery after Surgery programs). Сторонники применения этих программ под «ускорением» понимают не только сокращение времени нахождения в стационаре, но и потенцирование всех составляющих лечебного процесса для быстрой нормализации жизненных функций организма, возвращения пациента к обычной жизни, минимизации последствий хирургической травмы $[2,3]$.

FT-хирургия основывается на данных доказательной медицины, а не привычках хирурга и установках хирургической школы, и является профильной. На заре своего становления ведение больных в рамках программ ускоренной реабилитации было единым, однако со временем была сформулирована необходимость создания стандартизированных протоколов для каждого вида операций с учетом исходного состояния больного и особенностей проведения вмешательства.

Также FT-хирургия является мультидисциплинарной и комплексной, так как при ее применении задействованы хирург, анестезиолог, средний медперсонал и она должна включать не менее 6-8 компонентов из 18 рекомендованных.

Компоненты FT-хирургии:

1. Информирование пациента.

2. Отказ от использования механической очистки толстого кишечника.

3. Отказ от премедикации опиодными аналгетиками.

4. Назначение пробиотиков перед операцией.

5. Отказ от предоперационного голодания.

6. Назначение пищевых углеводных смесей за 3-4 ч до операции или инфузия раствора глюкозы.
7. Использование регионарной анестезии и короткодействующих аналгетиков.

8. Контроль и рестрикция инфузии коллоидных и кристаллоидных растворов до и во время операции.

9. Миниинвазивные оперативные доступы.

10. Предотвращение гипотермии во время и после операции.

11. Назначение высоких концентраций кислорода до операции.

12. Максимальное уменьшение использования опиоидных аналгетиков.

13. Отказ от рутинной установки в брюшную полость дренажей.

14. Раннее удаление мочевого, центрального венозного и эпидурального катетеров, дренажей.

15. Назначение прокинетиков в послеоперационный период.

16. Назначение раннего послеоперационного энтерального питания.

17. Ранняя активизация пациента.

18. Отказ от необоснованных гемотрансфузий.

Идеология FT базируется на необходимости уменьшения стрессовой нагрузки на организм, возникающей в результате хирургической травмы и приводящей к обменным и функциональным нарушениям, пролонгирующим лечение. Стресс - неспецифическая реакция организма на внешние раздражители, необходимая для приспособления к изменившимся условиям внешней среды. У человека при стрессе происходит активация центральной нервной системы: нейроны паравентрикулярного ядра выделяют кортикотропинрилизинг-гормон, активируя систему «гипоталамус-гипофиз-кора надпочечников» и симпатоадреналовую систему. У хирургических пациентов стимуляция гипоталамо-гипофизарной системы проявляется увеличением выброса глюкокортикоидов, а симпатоадреналовой системы - катехоламинов [11]. Вследствие этих изменений возникает стрессорный ответ организма, что проявляется, в первую очередь, изменениями в работе сердечно-сосудистой и дыхательной систем и метаболическими нарушениями, при которых процессы катаболизма преобладают над анаболизмом.

Для снижения выраженности этих изменений FT-хирургия предусматривает изменение подходов на всех этапах лечения и принимает во внимание даже такие детали, как необходимость подробного консультирования пациентки о сути предстоящего вмешательства и его альтернативах, способах подготовки к операции, прогнозах лечения, принципах FT. Важно обсудить особенности течения анестезии, раннего и позднего послеоперационного периода, возможности мультимодального обезболивания. Активная вовлеченность пациента в лечебный процесс, понимание сути выполняемых манипуляций повышают приверженность терапии и способствуют уменьшению психологической напряженности.

В дальнейшем при подготовке к операции рекомендован отказ от рутинного использования механической очистки толстого кишечника с целью профилактики бактериальной транслокации и поддержания нормальной микрофлоры. 
АКТУАЛ ЬНЫЕ ТЕ М Ы

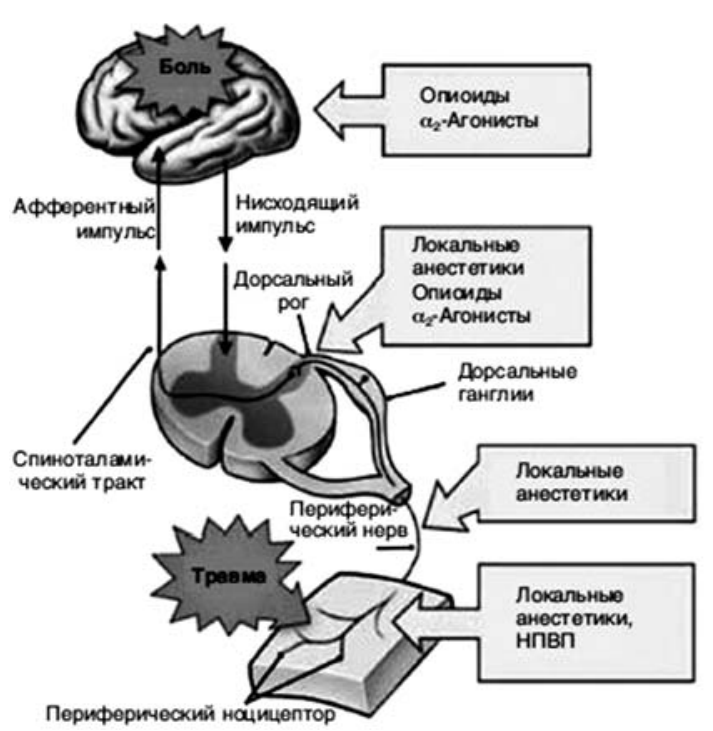

Рис. 1. Механизм действия превентивной аналгезии

Один из обзоров Cochrane свидетельствует о том, что у хирургических пациентов с резекцией кишки несостоятельность анастомозов регистрируется в 4\% случаев при проведении предоперационной подготовки кишечника и в 3\% при ее отсутствии [12]. Авторы рекомендуют назначение клизм только перед операциями, сопровождающимися наложением низких прямокишечных анастомозов, при значительной протяженности поражения или наличии сопутствующих факторов риска несостоятельности швов.

В гинекологии рутинное очищение кишечника при помощи клизмы или перорального назначения Макрогола 4000 (Фортранс, Форлакс) мы применяли исключительно у пациенток с эндометриоидным поражением толстой кишки или с онкологическими заболеваниями.

Среди прочих приемов, рекомендованных на предоперационном этапе, выделяют назначение пробиотиков, отказ от предоперационного голодания, назначение углеводных смесей за 3-4 ч до операции или инфузию раствора глюкозы. В своей практике с целью профилактики гипогликемии и обезвоживания употребление прозрачных жидкостей мы ограничивали за 5-6 ч до операции, а по показаниям инфузионно вводилось 200 мл 5\% раствора глюкозы.

Одним из наиболее важных элементов FT является уменышение частоты использования опиоидных препаратов, как с целью премедикации, так и с целью аналгезии, в связи с тем, что длительное назначение опиатов приводит к увеличению продолжительности послеоперационного пареза кишечника и может вызвать послеоперационную динамическую кишечную непроходимость, негативно влияет на работу сердечно-сосудистой системы и ограничивает возможности ранней мобилизации больной [13].

Отказавшись от практики проведения премедикации, мы активно используем методику упреждающей аналгезии. В ее основе - проведение обезболивания до возникновения болевого стимула и активации периферических нервных окончаний. Это предупреждает выработку нейротрансмиттеров и блокирует передачу нервных импульсов в центральную нервную систему (рис. 1). Упреждающее обезболивание повышает эффективность терапии боли в ранний и отдаленный послеоперационный период [14-19]. Для проведения локального обезболивания разрезов и точек введения троакаров использовался раствор местных анестетиков длительного действия, например бупивакаина. При лапароскопических операциях также может выполняться орошение анестетиком поддиафрагмального пространства. В дальнейшем та- кая аналгезия дополнялась интраоперационным введением 1000 мг парацетамола внутривенно. Это уменьшает не только послеоперационную боль, но и жалобы на интенсивность френикус-симптома после лапароскопии.

Альтернативой опиоидной аналгезии является мультимодальное обезболивание, при котором купирование боли достигается назначением 2-3 лекарственных средств, потенцирующих действие друг друга и позволяющих использовать меньшие курсовые дозы препаратов. К рекомендуемым средствам для мультимодальной аналгезии относятся: нестероидные противовоспалительные препараты (НПВП) и ингибиторы циклооксигеназы-2 (ЦОГ-2), парацетамол, $\alpha_{2}$-адреномиметики, кетамин и глюкокортикоиды (в минимальных дозах), декстрометорфан, габапентин и прегабалин, превентивная локальная аналгезия и раневая постоперационная инфильтрационная аналгезия [20].

Отдельный интерес представляет применение прегабалина, используемого традиционно для купирования хронической боли. На сегодня мы заканчиваем исследование его эффективности у пациенток с наружным генитальным эндометриозом. Эти данные будут опубликованы отдельно, но уже сейчас можно говорить об обнадеживающих результатах, полученных у этой группы пациенток.

Недостаточное обезболивание пациентов может быть причиной развития паралитического илеуса. Связь между болевой импульсацией и кишечной перистальтикой впервые была установлена в эксперименте на животных [21]. Стимуляция афферентных чувствительных нервных волокон вызывает угнетение кишечной моторики. Кишечник получает симпатическую иннервацию от волокон симпатического ствола (T5-L2), а парасимпатическую - от волокон крестцового сплетения (S2-S4) и блуждающего нерва. Кожа передней брюшной стенки получает чувствительную иннервацию от 5-12-й пары межреберных нервов, чувствительные ядра которых находятся в сегментах спинного мозга и некоторые - на уровне Т5-T12. При чрезмерной и длительной болевой афферентной импульсации возможна иррадиация нервных импульсов в соответствующие ядра симпатического ствола с развитием чрезмерной симпатической стимуляции кишечника. Это приводит к его длительному парезу.

Из этих соображений блокада симпатических волокон с сохранением парасимпатической иннервации позволяет эффективно улучшить моторику кишечника. Альтернативой применения традиционных препаратов для купирования боли является более широкое применение эпидуральной анестезии. В США и некоторых странах Европы также исследуются эффекты антагонистов опиоидных рецепторов (альвимопан и метилналтрексон) в качестве еще одной альтернативы [22, 23]. Данные препараты не проникают через гематоэнцефалический барьер и, таким образом, блокируют депрессивное влияние наркотических аналгетиков на желудочнокишечную моторику без потери аналгетического эффекта. Использование эпидуральной продолженной аналгезии особенно актуально у пациенток после лапаротомных операций. Ряд исследователей полагают, что существует корреляция между направлением разреза на передней брюшной стенке и продолжительностью послеоперационного пареза кишечника и другими осложнениями. Преимущество поперечной лапаротомии перед срединной заключается в том, что при последней болевая импульсация распространяется по большему числу чувствительных нервов, чем при поперечном доступе, поскольку такой разрез проходит в рамках одного дерматома [24]. С этой точки зрения в гинекологии наибольшее преимущество имеют вагинальные или лапароскопические операции. Традиционное надлобковое чревосечение хотя и имеет поперечное направление, остается в списке предпочтений на последнем месте. 


\section{АКТ УАЛ В Н Ы Т Е М Ы}

Адекватная анестезия является одним из залогов снижения уровня послеоперационных осложнений [25]. По данным мета-анализа A.Rodgers и соавторы [26] делают вывод, что применение эпидуральной анестезии в общей хирургии снижает общую летальность, частоту госпитальной пневмонии, частоту тромбозов глубоких вен и тромбоэмболии ветвей легочной артерии.

С целью профилактики тромбозов интраоперационно нами применялись система переменной пневмокомпрессии, позволяющая усилить ток крови в сосудистом русле вен нижних конечностей; низкомолекулярные гепарины и компрессионный трикотаж согласно рекомендованным схемам [27]. С нашей точки зрения, особое внимание в гинекологии стоит уделить применению препаратов, нормализующих функцию венозной стенки и способствующих лимфодренажу. При многих доброкачественных гинекологических заболеваниях может отмечаться нарушение венозного и лимфатического оттока, в том числе при миоме матки, пролапсе тазовых органов, инфильтратативных формах эндометриоза, спаечных процессах, за счет нарушения анатомо-функциональных взаимоотношений органов. С 2013 г. препараты на основе диосмина (Флебодиа 600) были включены нами в программы ускоренной реабилитации пациенток с миомой матки, пролапсом и наружным генитальным эндометриозом, а также при наличии варикозного расширения вен нижних конечностей и синдрома хронической тазовой боли. Первые полученные данные показали, что такой подход положительно сказывается не только на самочувствии пациенток и удовлетворенности их проведенным лечением, но и на показателях допплерометрии сосудов малого таза.

Конечно же, ключевую роль в нормализации работы сердечно-сосудистой системы играет правильный выбор объема инфузионной терапии. Согласно последним данным, уменьшение объема инфузий с 40 до 15 мл/кг позволяет уменьшить количество осложнений со стороны дыхательной и сердечно-сосудистой систем, ускорить послеоперационную реабилитацию и уменьшить длительность госпитализации пациентов [28, 29]. Перспективным считается применение целевой инфузионной терапии, режим которой определяется под контролем фракции выброса с помощью чреспищеводной эхокардиографии.

Интраоперационно, помимо перечисленных приемов, оптимально применять короткодействующие анестетики, избегать установки назогастральных зондов и дренажей, предотвращать развитие гипотермии во время операции. Температурный режим в операционной, использование инфузионных растворов приводят к перегрузке центров терморегуляции. Препараты для общей анестезии дополнительно нарушают работу терморегуляторного центра гипоталамуса. Доказано, что через 2 ч от начала операции температура ядра (базальная температура) снижается на $1-3^{\circ} \mathrm{C}$, тем самым в 2-3 раза увеличивается риск послеоперационных инфекционных осложнений, кровопотери, нарушений сердечного ритма [30]. Чтобы избежать теплопотери, могут использоваться согревающие одеяла или коврики, подогрев инфузионных сред и газа для пневмоперитонеума.

Еще в начале XIX в. британский хирург Lawson Tait сформулировал одно из показаний к дренированию брюшной полости как «Whenindoubt - drain» (Когда сомневаешься - дренируй) [31]. Однако в последние годы концепция профилактического дренирования существенно изменилась в пользу отказа от него. Но все же, несмотря на убедительные данные необоснованности рутинного дренирования брюшной полости, во многих ситуациях большинство хирургов сегодня продолжают выполнять эту ненужную манипуляцию.

В заключение программы ускоренной реабилитации дополняются активной мобилизацией пациентов в ранний пос-

\section{Индивидуальный протокол ведения пациента}

Ф.И.О. Иванова М.И. (ретроцервикальный эндометриоз 4 ст.) Аллергия не выявлена возраст 25 лет палата $\mathrm{Bn}$

\section{ПРЕДОПЕРАЦИОННЫЙ ЭТАП}

$\square$ Консультирование хирургом

Консультирование анестезиологом

$\square$ Прием пищи за 64

П Прием жидкостей (прозрачных) за 24

口 Компрессионный трикотаж I класс/\| класс

૧ Раствор глюкозы 5\% 200 мл в/в за 24 до операции

По показаниями:

口 Премедикация __ В _ 4: _ мин

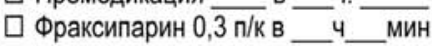

Сонтроль уровня глюкозы в крови

$\square$ Дpyroe

\section{РАННИЙ ПОСЛЕОПЕРАЦИОННЫЙ ПЕРИОД}

$\checkmark$ Пероральный прием жидкостей (максимально быстро после операции)

$\square$ Ранняя активизация пациента

PONV-протокол ${ }^{*}$

Микроинсфузионная помпа

Компрессионный трикотаж

Фраксипарин 0,3/0,6 в 10 ч 00 мин

\section{ИНТРАОПЕРАЦИОННЫЙ ЭТАП}

$\square$ Согревание пациента - Warm Drape

$\checkmark$ Переменная пневмокомпрессия нижних конечностей Kenda

Перфалган $200 \mathrm{Mr}$ в/B

૫ Ингибиторы ЦЦОГ

А Анестетики короткого действия

\section{ПОСЛЕОПЕРАЦИОННЫЙ ПЕРИОД}

П Пероральный прием жидкостей

口 Ранняя активизация пациента

口 PONV-протокол

$\square$ Микроинсузиионная помпа

$\square$ Компрессионный трикотаж

Фраксипарин 0,3/0,6 1 раз в сутки в 10 ч 00 мин

口 Прием твердой пищи

С Сенадексин 1 табл. внутрь

$\square$ Удаление мочевого катетера

Контроль самостоятельного мочеиспускания через 4 ч после удаления катетера

$\square$ Удаление в/в катетера

口 Мелоксикам 7,5/15 мг/сут или

Кетанол 1,0 в/м 3 раза в день

口 Парацетамол до $1000 \mathrm{mr} / \mathrm{cy} т$

Флебодиа 600 по табл.

\section{раз в день}

\section{ВЫПИСКА на __ сутки}

$\square$ Выписка и консультирование по вопросам послеоперационного периода

口 Письменные инструкции по выполнению перевязок, приему медикаментов, ношению компрессионного трикотажа/бандажа, перечню разрешенных продуктов и блюда

$\checkmark$ Информирование о контактных телесонах персонала и клиники для связи в случае срочной необходимости

$\checkmark \underline{\text { Телефонный звонок пациенту на следующий день после }}$ выписки

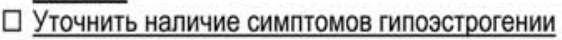

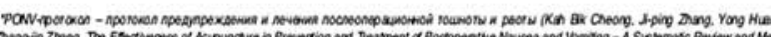

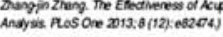

Рис. 2. Пример заполнения протокола FT 


\section{АКТ УАЛ В Н Ы Т Е М Ы}

леоперационный период, ранним удалением катетеров и началом перорального питания, назначением слабительных и противорвотных средств [32], так как известно, что длительная иммобилизация повышает риск тромбоэмболических осложнений и осложнений со стороны дыхательной системы [33], а также может приводить к потере мышечной массы и снижению мышечного тонуса, что негативно влияет на реабилитацию. А раннее начало энтерального питания не оказывает негативного влияния на течение послеоперационного периода.

\section{МАТЕРИАЛЫ И МЕТОДЬ}

С 2012 г. в Швейцарской университетской клинике (Москва, Россия) были внедрены протоколы ускоренной послеоперационной реабилитации гинекологических пациенток Для каждой из них составлялся индивидуальный план, все элементы которого отмечались в специальном листе FT-протокола (рис. 2). Протоколы для пациенток, перенесших пангистерэктомию или овариоэктомию, отличались от прочих тем, что в них был включен пункт о гипоэстрогенных нарушениях после операции, так как своевременное назначение менопаузальной гормональной терапии позволяет эффективно купировать их, тем самым нормализуя качество жизни пациенток.

По программе ускоренной реабилитации за 2012-2014 гг. прошли лечение 975 пациенток с миомой матки, 198 пациенток с эндометриозом и 19 пациенток с раком тела матки: всего 1192 пациентки. Им были выполнены лапароскопическая гистерэктомия ( $\mathrm{n}=44)$, лапароскопическая $(\mathrm{n}=864)$ и лапаротомная $(\mathrm{n}=67)$ миомэктомии, операции по удалению ретроцервикального эндометриоидного инфильтрата $(\mathrm{n}=136)$, в том числе с резекцией толстой кишки $(\mathrm{n}=75)$, лапароскопическая пангистерэктомия без $(\mathrm{n}=4)$ или с лимфаденэктомией $(\mathrm{n}=15)$.

Частота тромбозов, по данным литературы, после гинекологических операций в целом невысока и составляет 1-3\% [25]. Однако существуют данные о тромбозах, регистрируемых после выписки из стационара, особенно среди пациенток группы риска [26-28]. Таким пациенткам мы рекомендовали продолжение профилактических мероприятий на протяжении 7-10 дней после операции [29]. В наших наблюдениях общая частота тромбозов глубоких вен нижних конечностей составила $0,67 \%(\mathrm{n}=8)$.

В рамках анестезиологического пособия преимущественно применялись анестетики, аналгетики и миорелаксанты короткого действия. При проведении инфузионной терапии целью являлось сохранение нормоволемии.

В послеоперационный период активизация пациенток проводилась как можно раньше и в среднем составила $5 \pm 2$ ч (1,5-16 ч). Мочевой катетер удалялся, как только пациентка начинала самостоятельно вставать.

Обезболивание проводилось при помощи НПВП и ингибиторов ЦОГ-2. Использование опиоидных аналгетиков было сведено к минимуму и чаще всего требовалось в первые 12 ч после операции. У пациенток после лапаротомных вмешательств использовалась продленная эпидуральная анестезия.

\section{Fast track: surgical protocols of accelerated rehabilitation in gynecology K.V. Puchkov, V.V. Korennaya, N.M. Podzolkova}

Fast track (FT) surgery - a comprehensive treatment program, including training in the preoperative phase, the use of minimally invasive techniques of surgical intervention and active management of the postoperative period, in order to reduce the timing of hospital treatment, the time rehabilitation and patients as quickly as possible to return to normal life.

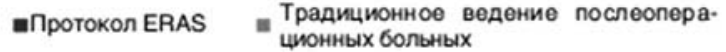

ционных больных

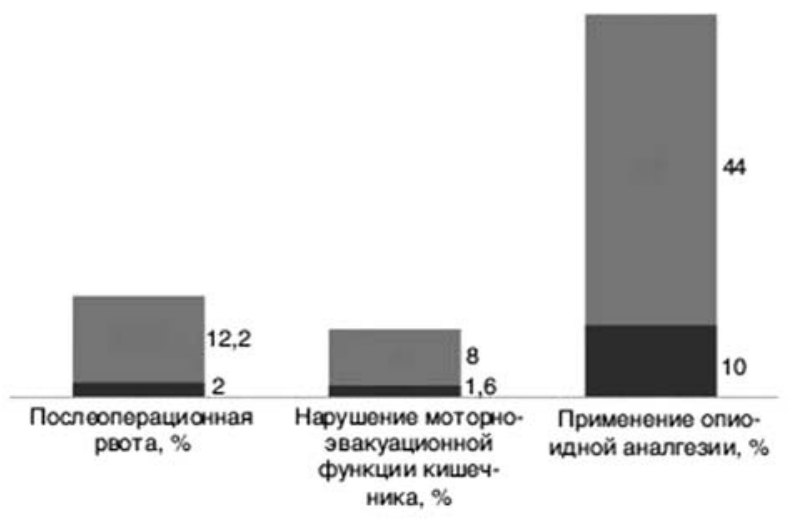

Рис. 3. Особенности течения послеоперационного периода при использовании протоколов ERAS

При сравнении раннего послеоперационного периода после FT было отмечено, что при традиционном ведении пациенток нарушение моторно-эвакуационной функции кишечника развивалось в 5 раз чаще (8\% против 1,6\% прооперированных больных), послеоперационная рвота - в 6 раз чаще $(12,2 \%$ против $2 \%)$, а потребность в обезболивании опиоидными аналгетиками была на $34 \%$ выше (рис. 3). В серии наших наблюдений нами не было отмечено, что дополнительное введение парацетамола в послеоперационный период уменьшает потребность в прочих аналгетиках.

Сроки госпитализации составили в среднем в группе после лапароскопической гистерэктомии 1,1 дня, в группе лапароскопической и лапаротомной миомэктомии $-2,9$ и 4,4 дня соответственно. Пациентки после удаления ретроцервикального эндометриоидного инфильтрата находились в клинике в среднем 4,28 дня, а после лапароскопических пангистерэктомий по поводу рака тела матки - 3,2 дня.

Повторная госпитализация потребовалась 3 пациенткам: 2 с жалобами на вегетативные нарушения, слабость и гипертермию до $38,2-38,4{ }^{\circ} \mathrm{C}$ и 1 пациентке после лимфаденэктомии, у которой отмечалась интенсивная лимфорея. Повторных вхождений в брюшную полость не потребовалось ни у одной из пациенток.

\section{Выводы}

Наш опыт применения протоколов FT-хирургии у гинекологических больных показал, что они позволяют улучшить течение раннего послеоперационного периода, уменьшить постоперационный болевой синдром, риск пареза кишечника и сократить сроки реабилитации. Комплексное применение описанных принципов позволяет добиться хороших результатов у пациенток с разными гинекологическими заболеваниями хирургического профиля.

For the first time the principles of FT programs were formulated in the late twentieth century. Henrik Kehlet and initially introduced in cardiac surgery, coloproctology and oncology, but gradually began to gain recognition in other surgical areas.

Own experience of FT-protocols in gynecologic patients has shown that they can improve during the early postoperative period, no adverse effects on long-term outcomes and readmission rates, can significantly reduce the time of recovery after the operation and increase the satisfaction of patients of the treatment.

Key words: fast track surgery, postoperative care. 


\section{АКТ УАЛ Ь НЫЕ ТЕМ Ы}

\section{СПИСОК ЛИТЕРАТУРЫ}

1. Kehlet H. Multimodal approach to control postoperative pathophysiology and rehabilitation. Br J Anaesth 1997; 78: 606-17.

2. Lassen K, Soop M, Nygren J et al. Consensus review of optimal perioperative care in colorectal surgery: enhanced Recovery after Surgery (ERAS) Group recommendations. Archives of Surgery 2009; 144 (10) 961-9.

3. Varadhan K, Neal K, Dejong CHC et al. The enhanced recovery after surgery (ERAS) pathway for patients undergoing major elective open colorectal surgery: a meta-analysis of randomised controlled trials. Clinical Nutrition 2010; 29 (4): 434-40.

4. Carter J, Philp S, Arora A. Fast track gynaecologic surgery in the overweight and obese patient. Int J Clin Med 2010; 1 (2): 64-9.

5. Carter J, Philp S, Arora V. Poster presentation. Extended experience with an enhanced surgical recovery program. Proceedings of the 13th Biennial Meeting of the International Gynecologic Cancer Society. Czech Republic European Union, Prague 2010.

6. Carter J, Philp S, Arora V. Discharge on postop day 2 after major gynaecological surgery. Is it possible? Ora Presentation 25th Annual Scientific Meeting Australian Society of Gynaecological Oncologists. March 2010; Bunker Bay, Western Australia. 7. Carter J, Szabo R, Sim WW et al. Fast track surgery in gynaecological oncology. A clinical audit. Australian and New Zealand Journal of Obstetrics and Gynaecology 2010; 50 (2) 159-63.

8. Carter J, Philp S. Assessing outcomes after fast track surgical management of corpus cancer. Open Journal of Obstetrics and Gynecology 2011; 1 (3): 139-43.
9. Carter J, Philp S. Development and Extended Experience with a Fast Track Surgery Program. Queenstown, New Zealand: Australian Society of Gynaecological Oncologists Annua Scientifc Meeting Millbrook Resort 2011.

10. Carter J, Philp S, Arora V. Early discharge after major gynaecological surgery: advantages of fast track surgery. Open Journal of Obstetrics and Gynecology 2011; 1 (1): 1-5.

11. Selye H. General adaptation syndrome and the diseases of adaptation. $\mathrm{J}$ Clin Endocrinol 1946; 6: 117-230.

12. Gsenaga KK, Matos D, WilleJurgensen P. Mechanical bowe preparation for elective colorectal surgery. Cochrane Database of Systematic Reviews 2009; 1: CD001544.

13. Delaney CP. Clinical perspective on postoperative ileus and the effect of opiates. Neurogastroenterol Moti 2009; 16: 61-6.

14. Dierking G, Duedahl $\mathrm{TH}$ Rasmussen ML et al. Effects of gabapentin on postoperative morphine consumption and pain after abdomina hysterectomy: a randomized, doubleblind trial. Acta Anaesthesiologica Scandinavica 2004; 48 (3): 322-7.

15. Turan A, Karamanlioplu B, Memis D et al. The analgesic effects of gabapentin after total abdominal hysterectomy. Anesthesia and Analgesia 2004; 98 (5): 1370-3

16. Gilron I, Orr E, Tu D. A placebocontrolled randomized clinical trial of perioperative administration of gabapentin, rofecoxib and their combination for spontaneous and movementevoked pain after abdominal hysterectomy. Pain 2005; 113: 191-200.

17. Fassoulaki A, Stamatakis $E$, Petropoulos $\mathrm{G}$ et al. Gabapentin attenuates late but not acute pain after abdominal hysterectomy. Eur $\mathrm{J}$
Anaesthesiology 2006; 23 (2): 136-41. 18. Sen H, Sizlan A, Yanarates 0 et al. A comparison of gabapentin and ketamine in acute and chronic pain after hysterectomy. Anesthesia and Analgesia 2009; 109 (5): 1645-50. 19. Ajori L, Nazari L, Mazloomfard MM, Amiri Z. Effects of gabapentin on postoperative pain, nausea and vomiting after abdominal hysterectomy: a double blind randomized clinical trial. Archives of Gynecology and Obstetrics 2011: 1-6.

20. Anesthesiology. 2010 Jan; 112 (1): 220-5. Doi:

0.1097/ALN.0b013e3181c6316e.

21. Kalff JC, Schraut WH, Simmons RL et al. Surgical manipulation of the gut elicits an intestinal muscularis inflammatory response resulting in postsurgical ileus. Ann Surg 1998; 228: 652-3. 22. Abraham NS, Byrne CM, Young JM et al. Meta-analysis of non-randomized comparative studies of the short-term outcomes of laparoscopic resection for colorectal cancer. Aust NZ J Surg 2007; 77: 508-16.

23. Cheatham ML, Chapman WC Key SP et al. A meta-analysis of selective versus routine nasogastric decompression after elective laparotomy. Ann Surg 1995; 221: 469-76.

24. Lindgren PG, Nordgren SR, Oresland $\mathrm{T}$ et al. Midline or trasverse abdominal incision for right-sided colon cancer - a randomized trial. Colorectal Dis 2001; 3: 46-50.

25. Moiniche S, Hjorsto N-S, Hansen BL. The effect of balanced analgesia on early convalescence after major orthopedic surgery. ActaAnesthesiologica Scandinavica 2004; 38: 328-35.

26. Rodgers A, Walker N, Schug S et al. Reduction of postoperative mortality and morbidity with epidural or spinal anaesthesia: results from overview of randomised trials. BMJ 2009; 321 : 1-12.

27. Национальный стандарт РФ, протокол ведения больных. Профилактика тромбоэмболии легочной артерии. Утвержден Приказом Федерального агентства по техническому регулированию и метрологии от 18 декабря 2008 г. №570-ст ГОСТ Р 52600.6-2008, с изменениями, внесенными Приказом Ростехрегулирования от 31.12.2008 №4196. / Natsional'nyi standart RF, protokol vedeniia bol'nykh. Profilaktika tromboembolii legochnoi arterii. Utverzhden Prikazom Federal'nogo agentstva po tekhnicheskomu regulirovaniiu i metrologii ot 18 dekabria $2008 \mathrm{~g}$. №570-st GOST R 52600.6-2008, s izmeneniiami, vnesennymi Prikazom Rostekhregulirovaniia ot 31.12 .2008 №4196. [in Russian].

28. Holte $\mathrm{K}$, Klarskov B, Christensen DS et al. Liberal versus restrictive fluid administration to improve recovery after laparoscopic cholecystectomy: a randomized, double-blind study. Ann Surg 2004; 240: 892-9.

29. Nisanevich V, Felsenstein I, Almogy $\mathrm{G}$ et al. Effect of intraoperative fluid management on outcome after intraabdominal surgery. Anesthesiology 2005; 103: 25-32.

30. Sessler DI. Mild perioperative hypothermia. N Engl J Med 1997; 336: 1730-7.

31. Robinson JO. Surgical drainage: a historical perspective. Br J Surg 1986; 73: 422-6.

32. Ramrrez JM, Blasco JA, Roig J et al. Enhanced recovery in colorectal surgery: a multicentre study. BMC Surgery $2011 ; 11$ : p. 9

33. Harper CM, Lyles UM. Physiology and complications after bed rest. J Am Geriatric Society 1998; 36: 1047-54. 


\title{
Ранні предиктори плацентарної дисфункції
}

\author{
Ю.М. Мельник', А.О. Шляхтіна \\ ${ }^{1}$ Київський міський центр репродуктивної та перинатальної медицини \\ ${ }^{2}$ Національна медична академія післядипломної освіти імені П.Л. Шупика, м. Київ
}

\begin{abstract}
У статті представлено предиктори прогнозування плацентарної дисфункції на ранніх термінах вагітності.

Мета дослідження: пошук прогностичних маркерів та критеріїв виникнення плацентарної недостатності на ранніх термінах гестаційного процесу для оптимізації перебігу вагітності та пологів з покращанням перинатальних наслідків. Матеріали та методи. Для вирішення поставленої мети у період з 2013 до 2015 р. було проведено комплексне обстеження 334 вагітних, які залежно від особливостей перебігу вагітності та пологів були розподілені на групи. У контрольну групу увійшли 236 вагітних з неускладненим перебігом гестаційного періоду, без морфологічних ознак плацентарної дисфункції. В основну групу увійшли 98 пацієнток з ускладненим перебігом вагітності, у яких були виявлені порушення плодово-плацентарних взаємовідносин, що підтверджувалося морфологічним дослідженням плацент у післяпологовий період.
\end{abstract}

Результати. Виявлено, що у жінок з плацентарною недостатністю у I триместрі вагітності спостерігався білыш високий

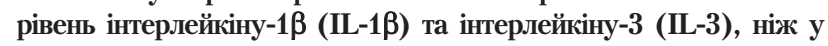
здорових вагітних, а також наявний прямий вірогідний корелящійний зв'язок між IL-1 $\beta$ та пульсаційним індексом (III) у спіральних $(r=0,84)$ і маткових артеріях $(r=0,77)$, зворотний корелящійний зв'язок між вмістом IL-3 та ПI у термінальних гілках артерії пуповини $(\mathrm{r}=-\mathbf{0 , 6 9})$. Установлено наявність зворотного зв'язку між концентрацією ендотеліну-1, вмістом судинного ендотеліального фактора росту $(\mathrm{r}=-0,87)$ та плацентарного фактора росту $(\mathrm{r}=-0,73)$, а також прямого зв'язку між вмістом ендотеліну-1 та ПІ у спіральних артеріях (r=0,89), маткових артеріях $(\mathrm{r}=0,83)$ та термінальних гілках артерії пуповини $(\mathrm{r}=0,79)$.

Заключення. Отже, доведено, що ранніми предикторами плацентарної дисфункції можна вважати вміст ендотеліну-1, судинного ендотеліального фактора росту, плацентарного фактора росту, інтерлейкіну-1, інтерлейкіну-3, а також показники пульсаційного індексу.

Ключові слова: плацентарна дисфункиія, предиктори, ендотелін-1, судинний ендотеліальний фактор росту, плащентарний фактор росту, інтерлейкіни, пульсаиійний індекс.

Частота плацентарної дисфункції коливається від 20,0\% до 50,0\% залежно від факторів, що обтяжують вагітність [3].

Плацентарна недостатність значно впливає на рівень перинатальної смертності та захворюваності новонароджених, посідаючи перше місце з причини антенатальної загибелі плода та збільшуючись за поширеністю з 25,0\% у II триместрі до 46,3\% у III триместрі вагітності. 3 іншого боку, вивчення частоти та структури патології плаценти при материнських втратах свідчить, що плацентарна недостатність спостерігається у 94,4\% випадків $[7,8]$.

До сьогодні пошук нових методів ранньої діагностики та прогнозування плацентарної дисфункції залишається одним із пріоритетних напрямків сучасного акушерства. 3 появою вчення про фактори росту (ФР), які впливають на морфологію плаценти, сформувався новий напрямок у вивченні порушень плодово-плацентарних взаємовідносин [12, 14]. Зокрема, Т.Н. Погорелова та співавтори фіксували дисбаланс ФР (судинного ендотеліального ФР - СЕФР, плацентарного ФР - ПФР) за плацентарної недостатності [1]. Доведено, що патоморфологія матково-плацентарних артерій при плацентарній дисфункції є наслідком патологічної закладки на ранніх термінах вагітності за наявності неадекватної інвазії цитотрофобласта у ділянку плацентарного ложа з подалышою гестаційною перебудовою спіральних артерій, причому рівень ростових факторів має безпосередній вплив на цей процес [9].

Окрім того, на сьогоднішній день одним із важливих механізмів формування дисфункції плодово-плацентарних взаємовідносин є дисбаланс цитокінового статусу [4]. Слід відзначити, що мікроциркуляторні порушення з'являються вже у I триместрі вагітності, ще до появи клінічних ознак плацентарної недостатності. Багаточисленні дослідження дозволили отримати всебічні дані про стан матково-плодово-плацентарного комплексу. Зокрема, результати багатоцентрового проспективного дослідження вагітних засвідчили, що у випадку виявлення ознак двобічного порушення кровотоку у матковій артерії з одночасною верифікацією ангіогенного дисбалансу можливе прогнозування розвитку прееклампсії за 5 тиж до маніфестації ії клінічних проявів. У той самий час, в літературі зустрічаються лише поодинокі дані, присвячені вивченню матково-плодовоплацентарної циркуляції у вагітних з I триместра гестації $[11,16]$.

Мета дослідження: пошук прогностичних маркерів та критеріїв виникнення плацентарної недостаності на ранніх термінах гестаційного процесу для оптимізації перебігу вагітності та пологів з покращанням перинатальних наслідків.

\section{МАТЕРІАЛИ ТА МЕТОДИ}

Для вирішення поставленої мети у період з 2013 до 2015 р. було проведено комплексне обстеження 334 вагітних, які залежно від особливостей перебігу вагітності та пологів були розподілені на групи. У контрольну групу увійшли 236 вагітних з неускладненим перебігом гестаційного періоду, без морфологічних ознак плацентарної дисфункції. В основну групу увійшли 98 пацієнток з ускладненим перебігом вагітності, у яких були виявлені порушення плодово-плацентарних взаємовідносин, що підтверджувалося морфологічним дослідженням плацент у післяпологовий період.

Дослідження рівня ендотеліну-1 та простацикліну проводили імуноферментним методом із застосуванням реагентів «Biomedica» (Австрія) в I триместрі. Уміст ФР, а саме - СЕФР, ПФР та фактора некрозу пухлини (ФНП) у сироватці крові визначали імуноферментним методом тест-системою R\&D Systems (Велика Британія) на 11-12-у тижнях вагітності. Для оцінювання цитокінового статусу визначали концентрацію

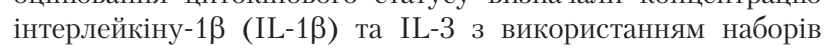
Diaclone (Франція) та подальшим вимірюванням кількісних in vitro-показників реактивами ELISA.

Допплерометричне дослідження проводили з використанням апарату PHILIPS ATL-HDI 4000, PHILIPS HD 11-XE та оцінюванням як внутрішньоплацентарного (у спіральних артеріях та термінальних гілках артерії пуповини), так і позаплацентарного кровотоку (у маткових артеріях). Як прогностичний критерій на ранніх термінах був обраний пульсаційний індекс (ПІ). Дослідження проводили, починаючи 3 10-12-го тижнів вагітності.

Кардіотокографічне дослідження проводили непрямим методом із зовнішнім розташуванням датчиків на передній черевній стінці жінки за критеріями DAWES $\backslash$ REDMAN зі встановленням короткої варіабельності (short-term variation - 


\section{АКТ УАЛ Ь НЫ Т ТЕ М Ы}

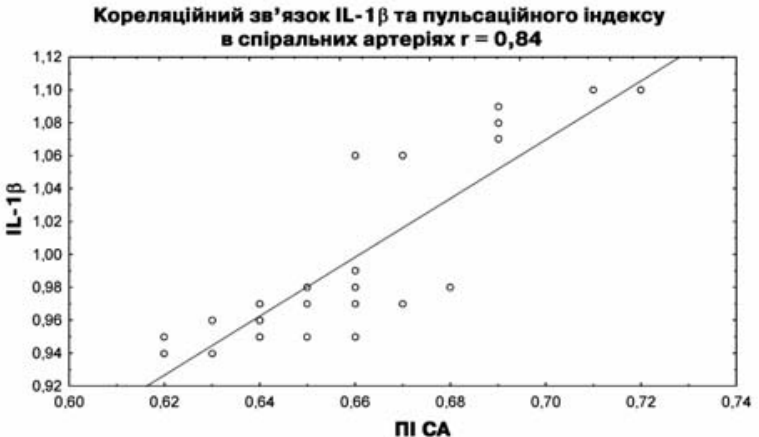

Мал. 1. Діаграма розсіювання залежності вмісту IL-1 $\beta$ від ПІ у спіральних артеріях

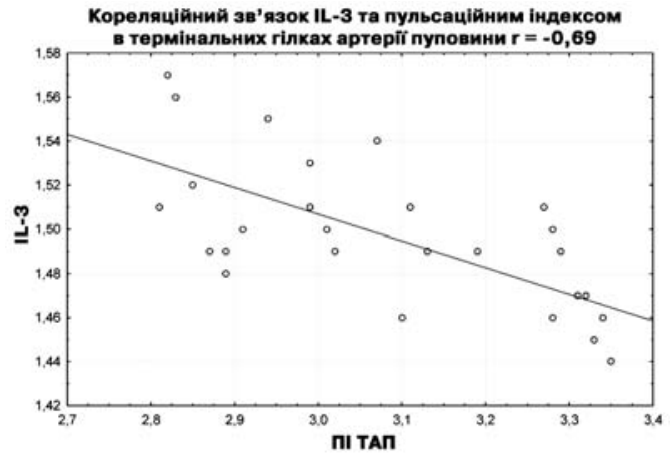

Мал. 3. Діаграма розсіювання залежності вмісту IL-3 від ПI в термінальних артеріях пуповини

STV). Вважали, що значення STV більше 4,0 бала свідчить про відсутність ознак ацидемії плода, 3,5-4,0 бала - про початкові ознаки ацидемії, 3,0-3,5 бала - про ацидоз, 2,5-3,0 бала - про важкий ступінь ацидозу та гіпоксії, менше 2,5 бала - про загрозу антенатальної загибелі плода.

Варіаційно-статистичне оброблення результатів дослідження виконано за допомогою програми «Statistica 6,0» 3 визначенням основних варіаційних показників. Для виявлення кореляційного зв'язку між досліджуваними показниками застосовували коефіцієнт парної кореляції Пірсона (r). При $\mathrm{r}<0,37$ зв'язок вважали слабким, $0,37 \leq \mathrm{r}<0,5$ - помірним, $0,5 \leq r<0,7-$ значним, $0,7 \leq r<0,9-$ міцним.

\section{РЕЗУЛЬТАТИ ДОСЛІДЖЕННЯ ТА ÏХ ОБГОВОРЕННЯ}

3 метою вивчення причинно-наслідкових взаємозв'язків, які впливають на формування плацентарної дисфункції, було проведено вивчення кореляційних взаємовідносин між маркерами ендотеліальної дисфункції, цитокінового профілю, показниками внутрішньоплацентарної та позаплацентарної гемодинаміки, а також показниками реактивності серцевої діяльності плода у жінок 3 клінічно верифікованою плацентарною недостатністю.

У результаті, за наявності плацентарної дисфункції, у I триместрі вагітності встановлений прямий вірогідний кореляційний

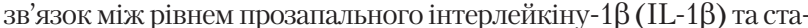
ном кровотоку в системі «мати-плацента-плід» (мал. 1-2).

При цьому вміст IL-1 $\beta$ верифікований на рівні $1,02 \pm 0,08$ пг/мл, ПІ у спіральних артеріях $-0,67 \pm 0,05$, у маткових артеріях - 1,56 $\pm 0,17$, коефіцієнт кореляції визначений як $\mathrm{r}=0,84$ та r=0,77 відповідно.

У той самий час, виявлено зворотний кореляційний зв'язок середньої сили між рівнем протизапального інтерлейкіну-3 (IL3) у жінок з встановленою плацентарною недостатністю, верифікованого як $1,53 \pm 0,09$ пг/мл, та ПІ в термінальних гілках артерії пуповини - 3,08 $\pm 0,27$ (r=-0,69; мал. 3 ).

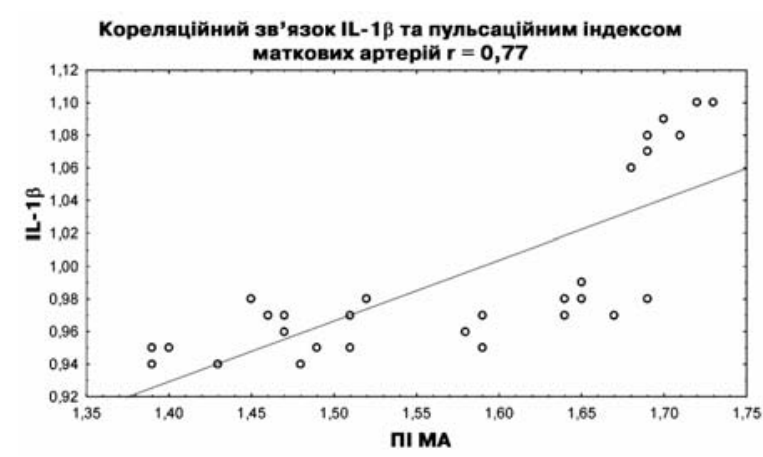

Мал. 2. Діаграма розсіювання залежності вмісту IL-1 $\beta$ від ПI у маткових артеріях

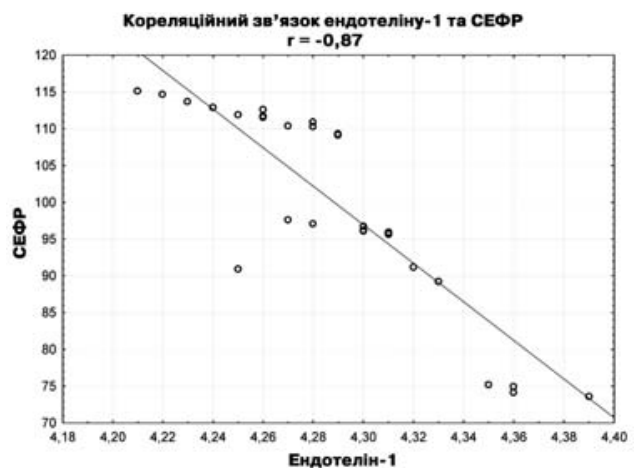

Мал. 4. Діаграма розсіювання залежності вмісту СЕФР від рівня ендотеліну-1

Збільшення контактів ендотелію з імунокомпетентними клітинами призводить до пошкодження ендотеліоцитів за типом імунного запалення та подальшого розвитку дисфункції ендотелію у вигляді дисбалансу ФР, посилення прокоагулянтної активності, тромбоутворення та прогресування гемодинамічних розладів у матково-плодово-плацентарному комплексі [6]. Як наслідок, у жінок з плацентарною недостатністю у даному дослідженні встановлено зниження синтезу СЕФР на тлі вірогідного підвищення вмісту ендотеліну-1. Верифіковано зворотний сильний кореляційний зв'язок між концентрацією ендотеліну- $-4,3 \pm 0,03$ пг/мл та вмістом СЕФР - 94,5 21,4 пг/мл ( $\mathrm{r}=-0,87$; мал. 4). Подібні результати отримані під час аналізу співвідношення рівня ендотеліну-1 та вмісту ПФР $87,2 \pm 24,8$ пг/мл у вагітних з ознаками плацентарної дисфункції (r=-0,73; мал. 5).

На тлі підвищення концентрацій ендотеліну-1 порушується судинорухова функція ендотелію, внаслідок чого у відповідь на звичайні подразнення ендотелій відповідає вазоконстрикцією з порушенням кровотоку в матково-плодовоплацентарному комплексі, що доведено прямими сильними кореляційними зв'язками між вмістом ендотеліну-1 -

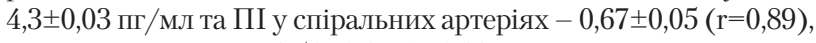
маткових артеріях $-1,56 \pm 0,17$ ( $\mathrm{r}=0,83)$, а також у термінальних гілках артерії пуповини $-3,08 \pm 0,27$ ( $\mathrm{r}=0,79$; мал. 7,8$)$.

За даними низки досліджень, порушення формування внутрішньоплацентарної судинної системи у I триместрі періоду гестації призводить до підвищення периферійної резистентності плодово-плацентарного кровотоку зі змінами реактивності серцевої діяльності плода [5]. У даному дослідженні на користь цього факту свідчить наявність сильного зворотного кореляційного зв'язку (r=-0,71) між ПІ у термінальних гілках артерії пуповини $(1,71 \pm 0,05)$ та показником STV $(3,21 \pm 1,15)$ у жінок з плацентарною дисфункцією (мал. 9).

Отже, за наявності дисфункції ендотелію у вагітних має місце дисбаланс синтезу цитокінів IL-1 $\beta$ та IL-3 з порушенням 
АКТУАЛ ЬНЫЕ ТЕМ Ы

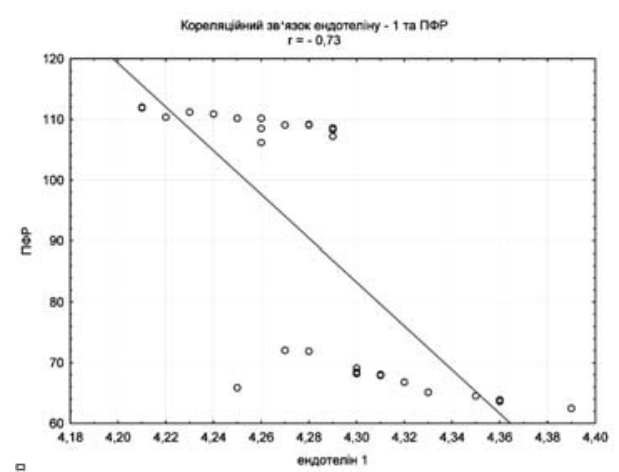

Мал. 5. Діаграма розсіювання залежності вмісту СПФР від рівня ендотеліну-1

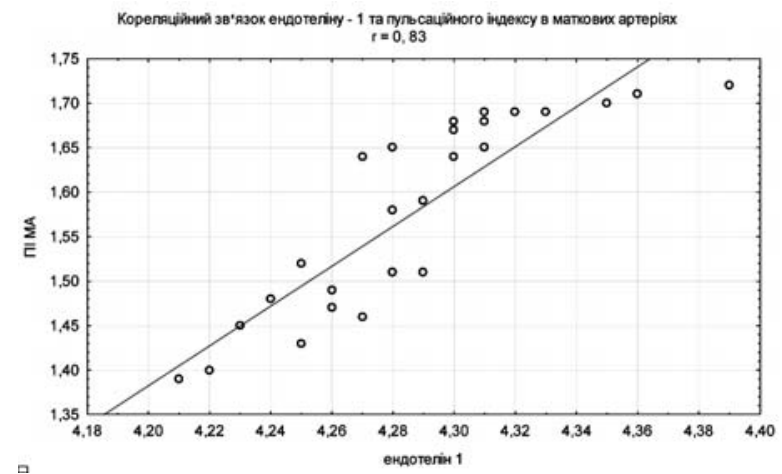

Мал. 7. Діаграма розсіювання залежності вмісту ендотеліну-1 від ПІ в маткових артеріях

внутрішньоплацентарної та позаплацентарної гемодинаміки з I триместра вагітності у результаті порушення процесу інвазії трофобласта, гестаційної перебудови спіральних артерій, зменшення кількості термінальних артерій з підвищенням резистентності у наведених судинах, що є факторами формування плацентарної недостатності. Невідповідність гестаційної перебудови міометральних сегментів спіральних артерій зумовлює вплив на судинний ендотелій, чутливість якого до вазомоторних агентів, а саме - підвищеного рівня ендотеліну-1, перешкоджає нормальному кровотоку у результаті вазоспазму з подальшим зниженням синтезу основних ФР, що спричинює зниження проліферації та міграції ендотеліальних клітин, патологічний ангіогенез та судинну проникність [13]. У результаті відбувається неповноцінна інвазія трофобласта, порушення формування матково-плацентарного комплексу, що призводить до зменшення плацентарного кровопостачання. Зниження швидкості кровотоку у міжворсинчастому просторі, особливо у поєднанні з порушенням синтезу та балансу простаноїдів, зумовлює тромбоутворення, гіперкоагуляцію, підвищення в’язкості крові, відкладення фібрину, що поглиблює порушення мікроциркуляції та ішемію $[2,10]$.

Цитокіновий дисбаланс, ендотеліальна дисфункція з порушенням синтезу ФР та зниженням кровотоку в системі «мати-плацента-плід», маніфестуючи у I триместрі вагітності, прогресують у подалышому. 3 початком II триместра періоду гестації відбувається зниження позаплацентарного кровотоку з приєднанням порушень гемодинаміки плода, які реалізуються у вигляді порушень плодово-плацентарних взаємовідносин $[10,15]$.

\section{висновки}

У статті представлено ранні прогностичні маркери порушень плодово-плацентарних взаємовідносин:

1. За наявності плацентарної дисфункції у I триместрі вагітності встановлено прямий вірогідний кореляційний зв'язок $(\mathrm{p}<0,05)$ між рівнем прозапального інтерлейкіну- $1 \beta$ та

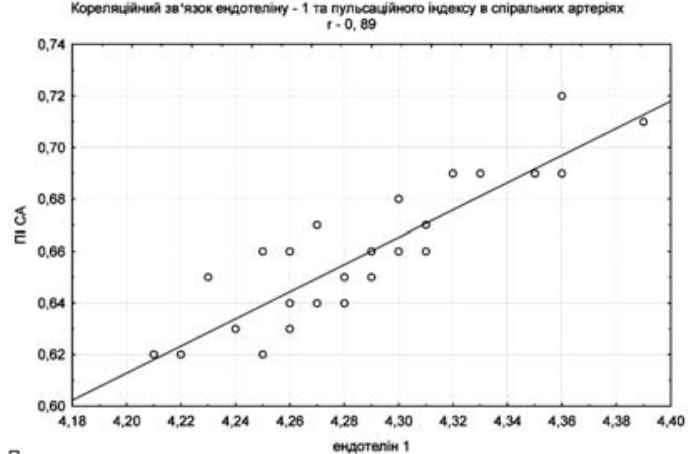

Мал. 6. Діаграма розсіювання залежності вмісту ендотеліну-1 від ПI у спіральних артеріях

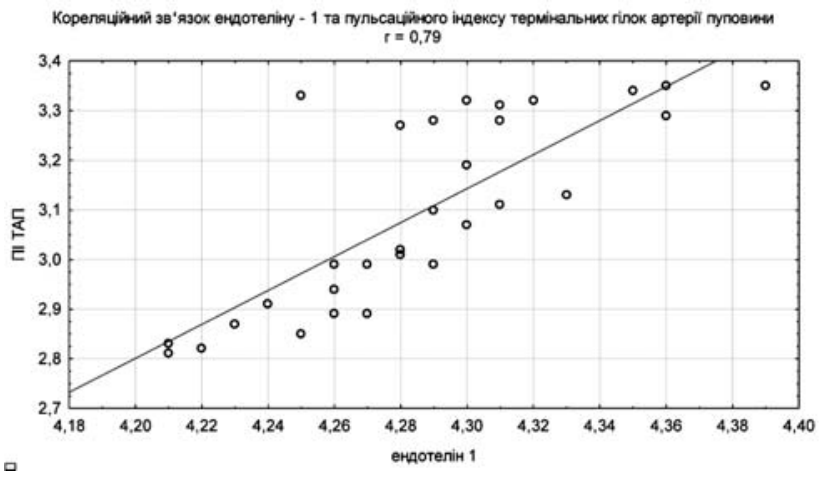

Мал. 8. Діаграма розсіювання залежності вмісту ендотеліну-1 від ПI у термінальних гілках артерії пуповини

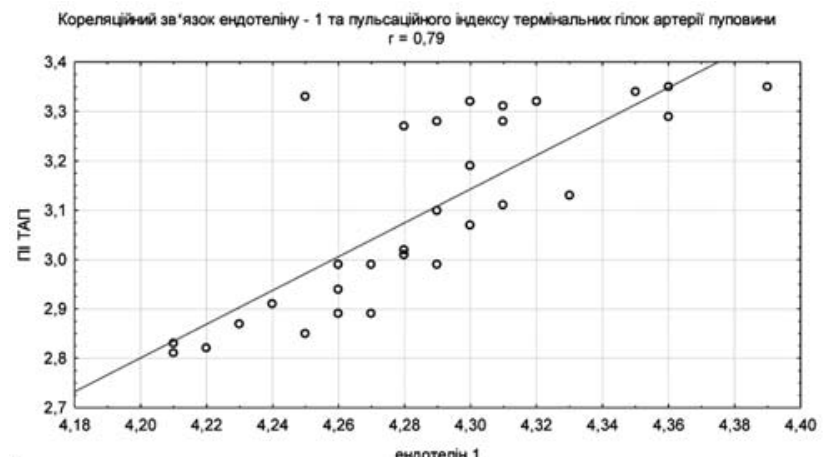

Мал. 9. Кореляційний зв'язок між STV та III артерії пуповини у жінок з плацентарною дисфункцією

пульсаційним індексом (ПІ) у спіральних $(\mathrm{r}=0,84)$ і маткових артеріях $(\mathrm{r}=0,77)$ системи «мати-плацента-плід».

2. Виявлено зворотний кореляційний зв'язок середньої сили між рівнем протизапального інтерлейкіну-3 та ПІ у термінальних гілках артерії пуповини (r=-0,69; $<<0,05)$.

3. Доведено, що у жінок з плацентарною недостатністю існує зворотний зв'язок між концентрацією ендотеліну-1, вмістом судинного ендотеліального фактора росту (СЕФР) (r=-0,87; $\mathrm{p}<0,05)$ та плацентарного фактора росту (ПФР) $(\mathrm{r}=-0,73 ; \mathrm{p}<0,05)$.

4. У вагітних з дисфункцією плаценти встановлено прямий зв'язок між вмістом ендотеліну-1 та ПІ у спіральних артеріях $(\mathrm{r}=0,89 ; \mathrm{p}<0,05)$, маткових артеріях $(\mathrm{r}=0,83 ; \mathrm{p}<0,05)$, а також у термінальних гілках артерії пуповини $(\mathrm{r}=0,79 ; \mathrm{p}<0,05)$.

Отже, ранніми предикторами плацентарної дисфункції можна вважати концентрації ендотеліну-1, СЕФР, ПФР, інтерлейкіну-1 та інтерлейкіну-3, показники ПІ спіральних артерій, термінальних гілок артерії пуповини та маткових артерій. 


\section{АКТ УАЛ Ь Н}

\section{Ранние предикторы плацентарной дисфункции Ю.М. Мельник, А.А. Шляхтина}

В статье представлены предикторы прогнозирования плацентарной дисфункции на ранних сроках беременности

Цель исследования: поиск прогностических маркеров и критериев возникновения плацентарной недостаточности на ранних сроках гестационного процесса для оптимизации течения беременности и родов с улучшением перинатальных исходов.

Maтериалы и методы. Для решения поставленной цели в период с 2013 по 2015 г. было проведено комплексное обследование 334 беременных, которые в зависимости от особенностей течения беременности и родов были разделены на группы. В контрольную группу вошли 236 беременных с неосложненным течением гестационного периода, без морфологических признаков плацентарной дисфункции. В основную группу вошли 98 пациенток с осложненным течением беременности, у которых были выявлены нарушения плодово-плацентарных связей, что подтверждалось морфологическим исследованием плацент в послеродовой период.

Peзультаты. Установлено, что у женщин с плацентарной недостаточностью в I триместре беременности наблюдается более высокий уровень ин-

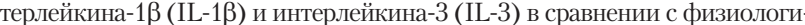
ческой беременностью, а также существует прямая достоверная корреляционная связь между IL-1 $\beta$ и пульсационным индексом (ПИ) в спиральных $(r=0,84)$ и маточных артериях $(r=0,77)$, обратная корреляционная связь между уровнем IL-3 и ПИ в терминальных ветках артерии пуповинь $(\mathrm{r}=-0,69)$. Верифицирована обратная связь между концентрацией эндотелина-1, уровнем сосудистого эндотелиального фактора роста $(\mathrm{r}=-0,87)$ и плацентарного фактора роста ( $\mathrm{r}=-0,73)$, а также прямая связь между содержанием эндотелина-1 и ПИ в спиральных артериях (r=0,89), маточных артериях $(\mathrm{r}=0,83)$ и терминальных ветках артерии пуповины $(\mathrm{r}=0,79)$.

Заключение. Таким образом, доказано, что ранними предикторами плацентарной дисфункции можно считать концентрации эндотелина-1, сосудистого эндотелиального фактора роста, плацентарного фактора роста, интерлейкина-1, интерлейкина-3, а также показатели пульсационного индекса.

Ключевые слова: плачентарная дисфункиия, предикторы, эндоте лин-1, сосудистый эндотелиальный фактор роста, плацентарный фактор роста, интерлейкин, пульсационный индекс.

\section{Early predictors of placental dysfunction J. M. Melnik, A. A. Shlyahtina}

The article presents the predictors of placental dysfunction on the early stage of pregnancy.

The objective: the search for prognostic markers and criteria for the occurrence of placental insufficiency in the early stages of the gestational process to optimize the pregnancy and labor with improved perinatal outcomes.

Patients and methods. To solve this goal in the period from 2013 to 2015 were conducted a comprehensive survey of 334 pregnant women, which depending on the peculiarities of pregnancy and childbirth were divided into groups. The control group consisted of 236 pregnant women with uncomplicated gestational period, no morphological signs of placental dysfunction. The study group included 98 patients with a complicated pregnancy who had revealed violations of the fetal-placental relations, which was confirmed by morphological examination of the placenta in the postpartum period

Results. It was found that pregnant women with placental insufficiency in the first trimester of pregnancy have higher levels of interleukin1B (IL-1v) and interleukin-3 (IL-3) in comparison with physiological pregnancy, as well as there is a direct significant correlation between IL- $1 \mathrm{v}$ and pulsative index (PI) in the spiral $(\mathrm{r}=0.84)$ and uterine artery $(r=0,77)$, and the inverse correlation between the level of IL-3 and PI in the terminal branches of the umbilical artery $(\mathrm{r}=-0,69)$. Verified an inverse relationship between the concentration of endothelin-1, the level of vascular endothelial growth factor $(\mathrm{r}=-0,87)$ and placental growth factor $(\mathrm{r}=-0,73)$, and also a direct link between the content of endothelin-1 and PI in spiral arteries $(r=0,89)$, uterine artery $(\mathrm{r}=0,83)$ and the terminal branches of the umbilical artery $(\mathrm{r}=0.79)$. Conclusion. Thus, it is proven that early predictors of placental dysfunction can be considered the concentration of endothelin-1, vascular endothelial growth factor, placental growth factor, interleukin-1, interleukin-3, and the indices of pulsative index.

Key words: placental dysfunction, predictors, endothelin-1, vascular endothelial growth factor, placental growth factor, interleukin, pulsative index.

\section{Сведения об авторах}

Мельник Юрий Николаевич - Киевский городской центр репродуктивной и перинатальной медицины, 04210, г. Киев, проспект Героев Сталинграда, 16; тел.: (044)-411-91-55. E-mail:yrmelnyk@gmail.com

Шляхтина Анастасия Александровна - Кафедра акушерства, гинекологии и медицины плода Национальной медицинской академии последипломного образования имени П.Л. Шупика, 04074, г. Киев, ул. Мостицкая, 11; тел.: (044) 460-54-45. E-mail: a.shluakhtina@gmail.com

\section{СПИСОК ЛІТЕРАТУРИ}

1. Погорелова Т.Н. Протеомный дисбаланс в плаценте при ее недостаточности / Т.Н. Погорелова, В.О. Гунько, В.А. Линде // Рос. Вест. Акуш. Гинек. - 2014. - T. 14, № 2. - C. 9-13. 2. An EG-VEGF-dependent decrease in homeobox gene NKX3.1 contributes to cytotrophoblast dysfunction: a possible mechanism in human fetal growth restriction / P. Murthi, S. Brouillet, A. Pratt, [et al.] // Mol. Med. - 2015. Vol. 21, № 1. - P. 645-656.

3. Association of first-trimester angiogenic factors with placental histological findings in late-onset preeclampsia / S. Triunfo, F. Crovetto, F. Crispi, [et al.] // Placenta. - 2016. - Vol. 42. - P. 44-50. 4. Bouzid A. Relevance of first trimester serum markers to predict pregnancy complications: A Tunisian preliminary study / A. Bouzid, A. Ayachi, H. Dhaoudi, [et al.] // Gynecol. Obstet. Fertil. 2016. - Vol. 44, N 2. - P. 96-100. 5 . Changes in uterine artery Doppler velocimetry and circulating angiogenic factors in the first half of pregnancies delivering small-for-gestational age neonates / S. Triunfo, F. Crovetto, V. Rodriguez-Sureda, [et al.] // Ultrasound. Obstet. Gynecol. - 2016. http://onlinelibrary.wiley.com/doi/10.10 02/uog.15978/abstract

6. Christians J.K. ADAM12 and PAPP-A Candidate regulators of trophoblast invasion and first trimester markers of healthy trophoblasts / J.K. Christians, A.G. Beristain // Cell. Adh. Migr. 2016 - Vol. 10, N 1-2 - P. 147-153. 7. Competing risks model in screening for preeclampsia by maternal factors and biomarkers at 11-13 weeks gestation N. O'Gorman, D. Wright, A. Syngelaki, [et al.] // Am. J. Obstet. Gynecol. 2016. - Vol. 214, N 1. - P. 103-112. 8. Competing risks model in screening for preeclampsia by maternal factors and biomarkers at 30-34 weeks' gestation / A. Tsiakkas, Y. Saiid, A. Wright [et al.] // Am. J. Obstet. Gynecol. - 2016. - Vol. 215, N 1. - P. 87.
9. First trimester screening with specific algorithms for early and late onset feta growth restriction / F. Crovetto, S. Triunfo, F. Crispi, [et al.] // Ultrasound. Obstet. Gynecol. - 2016. - http: //onlinelibrary wiley.com/doi/10.1002/uog.15879/abst act;jsessionid=1E067EED03F875343580 72E4615D233A.f04t02

10. Komacki J. The use of Doppler in the second half of pregnancy / J. Komacki, J. Skrzypczak // Ginekol. Pol. - 2015. Vol. 86, N 8. - P. 626-630.

11. Kroener L. Predisposing Factors to Abnormal First Trimester Placentation and the Impact on Fetal Outcomes L. Kroener, E.T. Wang, M.D. Pisarska // Semin Reprod Med - 2016 . Vol. 34, N 1. - P. 27-35.

12. Lecarpentier EAngiogenic balance (sFt1/PIGF) and preeclampsia / E. Lecarpentier, V. Tsatsaris // Ann. Endocrinol. - 2016. Vol. 77, N 2. - P. 97-100.

13. Proteomic characterization of macro-, micro- and nano-extracellular vesicles derived from the same first trimester placenta: relevance for fetomaternal communication / M. Tong, T. Kleffmann, S. Pradhan, [et al.] // Hum. Reprod. - 2016. - Vol. 31, N 4. - P. 687-699.

14. Rodriguez A. First-, Second-, and Third-Trimester Screening for Preeclampsia and Intrauterine Growth Restriction / A. Rodriguez, M.G. Tuuli, A.O. Odibo // Clin. Lab. Med. - 2016. Vol. 36, N 2. - P. 331-351.

15. Van den Bosch T. Maximum Peak Systolic Velocity and Management of Highly Vascularized Retained Products of Conception / T. Van den Bosch, D. Van Schoubroeck, D. Timmerman // J Ultrasound. Med. - 2015. - Vol. 34, N 9. - P. 1577-1582.

16. Zhong Y. Serum screening in first trimester to predict pre-eclampsia, small for gestational age and preterm delivery: systematic review and metaanalysis / Y. Zhong, F. Zhu, Y. Ding // BMC Pregnancy Childbirth. - 2015. Vol. 15. - P. 191. 


\title{
Оптимизация терапии диспластических ВПЧ-ассоциированных процессов
}

\author{
В.В. Бобрицкая \\ Харьковская академия последипломного образования
}

Цель исследования: определение степени риска развития клинических форм папилломавирусной инфекции (ПВИ) и возможных путей лечения и профилактики диспластических заболеваний, вызванных вирусом папилломы человека (ВПЧ).

Материаль и методы. Под наблюдением находились 90 пациенток с диагностированным наличием онкогенных штаммов ВПЧ 16-68 (с использованием метода генотипирования). Пациентки были разделены на 3 группы в соответствии с терапией, направленной на патогенетические механизмы развития ПВИ и имеющей целью уменьшение вирусной нагрузки, клинических проявлений, а также возможную элиминацию ВПЧ. Первая (I) группа - 30 человек - получала инъекции $\alpha$-интерферона-2b - по 3 млн ежедневно, 10 инъекций; курсовая доза - 30 млн. Курс повторяли в случае положительных результатов ВПЧ (предварительно выделенных штаммов) по той же схеме либо с интервалом в 1-2 сут; курсовая доза - 30 млн. Вторая (II) группа - 30 человек - получала индол-3-карбинол с эпигаллокатехин-3-галлатом (I3C+EGCG) - препарат Эпигалин ${ }^{\circledR}$ в дозе 400 мг I3C и 90 мг EGCG (2 капсулы в сутки). Курс приема Эпигалина ${ }^{\circledR}$ - до 6 мес. В группу контроля вошли пациентки в количестве 30 человек, не получавшие специфической иммуномодулирующей онкопротекторной терапии. Результаты. В результате проведенной терапии через 3 мес в I группе пациенток, получавших $\alpha$-интерферон-2b, элиминация ВПЧ наблюдалась в 76,2\% случаев, во II группе, получавшей Эпигалин ${ }^{\circledR}$ - в 86,4\% случаев и в группе контроля, не получавшей дополнительной метаболической терапии, - в $24 \%$ случаев. Через 6 мес в I группе элиминация ВПЧ составила 92,6\%, во II группе 95,8\%, что также демонстрирует более высокие результаты эффективности проводимых мероприятий с использованием I3C+EGCG - Эпигалина ${ }^{\circledR}$. Среди пациенток, получавших в период реабилитации после диатермокоагуляции (ДЭК) вагинальные суппозитории Ревитакса (гиалуроновая кислота, чайное дерево, календула, алоэ, центелла), эпителизация происходила на $7-10$ сут ранее, а также без грубой рубцовой деформации.

Заключение. Использование метаболической иммунной «заместительной» терапии папилломавирусной инфекции демонстрирует более высокие результаты, чем изолированное использование электрохирургического (радиоволнового) лечения дисплазий. Препарат Эпигалин ${ }^{\circledast}$ (сочетание 400 мг I3C и 90 мг EGCG) является эффективным онкопротекторным, нормализующим эстрогенный баланс препаратом, способствующим элиминации ВПЧ. Сочетание препарата Эпигалин ${ }^{\circledast}$ с комплексным репаративным и антисептическим действием с натуральными свечами Ревитакса является оптимальным в случаях электрохирургического лечения поражений, вызванных ВПЧ.

Ключевые слова: вирус папилломы человека, элиминация, интерферон, Эпигалин ${ }^{\circledast}$, Ревитакса.

$\Pi$ апилломавирусная инфекция (ПВИ) является одной из наиболее часто изучаемых в настоящее время факторов развития патологии репродуктивной системы [1]. Известна роль вируса папилломы человека (ВПЧ) в развитии диспла- стических процессов различной локализации как женского, так и мужского организма. Однако единственная, оптимальная и наиболее эффективная схема терапии инфекционных поражений, на сегодня не определена [2, 3].

Реализация диспластического, в том числе онкогенного, потенциала ВПЧ зависит от множества различных факторов, а также значительно увеличивается при сочетании нескольких составляющих.

Большое количество данных экспериментальных и клинических исследований подтверждают взаимосвязь ВПЧ различного онкогенного потенциала не только с дисплазией шейки матки, но и с неопластическими процессами пищеварительного тракта, урогенитальной области. И хотя на современном этапе развития научных знаний роль онкогенных штаммов ВПЧ в развитии дисплазий и рака шейки матки является доказанным фактом, многие авторы указывают на возможное наличие ПВИ при отсутствии клинических признаков диспластических процессов [9]. И наоборот, кожные и генитальные дисплазии возникают в случае отсутствия подобной инфекции (либо отрицательных лабораторных результатов).

Различиям в воздействии вирусов высокого и низкого риска можно найти частичное объяснение, основанное на эпидемиологических данных, предположение о взаимодействии ВПЧ и других факторов имеет определенный экспериментальный базис. По мере увеличения объема знаний, особенно при исследовании таких систем, как монослойные культуры клеток коллагена и трансгенные мыши, а также усовершенствования методов определения ВПЧ в клиническом материале весьма вероятно будет подтверждена роль ВПЧ и определены новые механизмы его действия.

В настоящее время полагают, что иммунный статус, повышение уровня провоспалительных цитокинов и клеток воспаления имеют важное, но не единственно определяющее значение [5]. Эффективность иммунного ответа, факторы, влияющие на восприимчивость вирусов, зависимость от штаммов ВПЧ - все эти факторы требуют дальнейшего изучения. Особенность вирусной инфекции - малосимптомное течение с одновременным развитием опасных изменений (рис. 1). Действительно, последние гипотезы, касающиеся цервикального канцерогенеза, предполагают три группы различных событий: выключение контролирующих рост генов, например p53 и Rb-1, приводящее к поражениям низкой степени тяжести; интерференция с генами хозяина, участвующими в контроле транскрипции вирусных генов, что приводит к поражениям высокой степени тяжести; уклонение от иммунной атаки, приводящее к инвазивному заболеванию [1, 2, 7]. ВПЧ-инфекция занимает центральное положение в этой модели и обладает уникальной способностью отмены функции гена хозяина и осуществления трансформирующей и трансактивирующей функций одновременно в нескольких направлениях. Таким образом, ВПЧ способен нанести несколько генетических «ударов» и поэтому при определенных обстоятельствах обусловливает участие нескольких компонентов в неопластическом процессе.

В лечении папилломавирусных поражений, наряду с местным лечением, хирургическим удалением диспластичес- 


\section{В ПОМОЩ В ПРАКТ ИЧЕСКО М В РА У У}

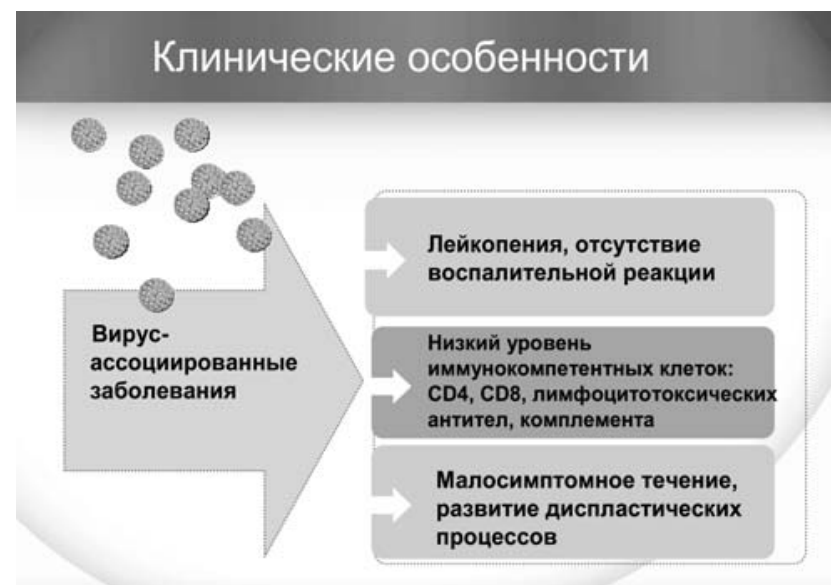

Рис. 1. Клинические особенности вирусассоциированных заболеваний

ких образований широко используют иммуномодулирующие препараты [5, 6, 8]. Интерферон как наиболее доступный препарат «заместительного» иммунного ответа достаточно широко используют в схемах противовирусного лечения [2, 6]. Целесообразным представляется применение инъекционных форм интерферона с учетом более выраженного системного действия препарата. Недостатком интерферонотерапии можно считать гипертермию после инъекции, гриппоподобное состояние, требующее дополнительной симптоматической терапии.

Препаратом онкопротекторного, метаболического действия, нормализующим уровень эстрогенных фракций в организме, является сочетание индол-3-карбинола с эпигаллокатехин-3-галлатом - Эпигалин ${ }^{\circledast}$. Известно, что эпигаллокатехин используют в программах неспецифической профилактики онкологических заболеваний предстательной железы, грудных желез, шейки матки. В программах, направленных на элиминацию ВПЧ, с учетом множества патогенетических механизмов препарат может быть также терапией выбора [1, 4, 9, 10].

Учитывая эффективность различных по своему действию препаратов, представляется целесообразным определение клинических ситуаций, требующих назначения тех или иных схем терапии, потенциальной эффективности комплексных схем лечения.

Цель исследования: определение степени риска развития клинических форм ПВИ и возможных путей лечения и профилактики диспластических заболеваний, вызванных ВПЧ.

\section{МАТЕРИАЛЫ И МЕТОДЫ}

Под наблюдением находились 90 пациенток с диагностированным наличием онкогенных штаммов ВПЧ 16-68 (с использованием метода генотипирования). Генотипирование ВПЧ дает дополнительные возможности определения прогноза течения заболевания, так как выявление нескольких генотипов вируса ассоциировано с менее благоприятным прогнозом течения заболевания и более высоким риском персистенции. Данный контингент пациенток требует более тщательного клинического и лабораторного наблюдения.

Проведение генотипирования позволяет отличить реинфицирование от персистирования инфекции при повторном визите пациента. Получать подобную информацию тем более важно, так как опасность представляет именно хроническая персистентная форма инфекции, а «свежее» инфицирование, наиболее вероятно, спонтанно излечивается.

О реинфицировании свидетельствует изменение спектра генотипов, о персистирующей инфекции - сохранение генотипа вируса через год после первого тестирования; повторное инфицирование тем же генотипом вируса после самостоятельного излечения практически не наблюдается.

С целью определения степени риска реализации онкогенного потенциала диагностированных штаммов ВПЧ мы разработали шкалу, включающую оценку клинических признаков и данных анамнеза, а также сопоставили ее с наличием клинических форм заболевания. Оценку степени риска осуществляли в баллах от 1 до 3 в зависимости от степени выраженности патологии, а также наличия в анамнезе диспластических заболеваний, дисгормональных состояний у пациенток и их ближайших родственников (с учетом генетической природы предрасположенности к развитию онкологических заболеваний).

Учитывали: медицинский анамнез, онкологический анамнез семьи, наличие прочих генитальных инфекций, в том числе в анамнезе, гиперпластические процессы в матке и грудных железах, а также соотношение эстрадиол/прогестерон, фракций эстрогенов - эстрон, эстрадиол. Выполняли цитоморфологическое (метод жидкостной цитологии) и кольпоскопическое исследования.

Следует подчеркнуть, что результат шкалы степени риска развития онкопатологии выше 10 баллов в 76,8\% случаев соответствовал различным степеням дисплазии шейки матки, в $6,8 \%$ случаев - наличию кондилом шейки матки (что, как правило, чаще ассоциируется с ВПЧ низкой степени риска).

Пациентки с результатами по шкале от 10 до 25 баллов были разделены на 3 группы в соответствии с терапией, направленной на патогенетические механизмы развития ПВИ и имеющей целью уменьшение вирусной нагрузки, клинических проявлений, а также возможную элиминацию ВПЧ.

Первая (I) группа - 30 человек - получала инъекции $\alpha-и н-$ терферона- $2 \mathrm{~b}$ - по 3 млн ежедневно, 10 инъекций; курсовая доза - 30 млн. Курс повторяли в случае положительных результатов ВПЧ (предварительно выделенных штаммов) по той же схеме либо с интервалом в 1-2 сут; курсовая доза - 30 млн.

Вторая (II) группа - 30 человек - получала индол-3карбинол с эпигаллокатехин-3-галлатом (I3C+EGCG) препарат Эпигалин ${ }^{\circledast}$ - в дозе 400 мг I3C и 90 мг EGCG (2 капсулы в сутки). Курс приема Эпигалина ${ }^{\circledR}$ - до 6 мес.

В группу контроля вошли пациентки в количестве 30 человек, не получавшие специфической иммуномодулирующей онкопротекторной терапии.

Пациенткам с CIN II, кондиломами урогенитальной области проводили электрохирургическое удаление патологических образований (радиоволновым методом), а также местное лечение комплексным антисептическим и ранозаживляющим препаратом с гиалуроновой кислотой вагинальные свечи Ревитакса. Ревитаксу применяли по 1 суппозиторию в сутки в течение 10 дней с 7-10-го дня после диатермокоагуляции (ДЭК).

У пациенток всех групп наблюдения через 3 мес и 6 мес проводили повторное исследование на наличие ВПЧ-инфекции, а также оценивали степень и сроки эпителизации тканей шейки матки и слизистой оболочки влагалища после ДЭК дисплазий и удаления папилломатозных поражений.

\section{РЕЗУЛЬТАТЫ ИССЛЕДОВАНИЯ И ИХ ОБСУЖДЕНИЕ}

В результате проведенной терапии через 3 мес в I группе пациенток, получавших $\alpha$-интерферон- $2 \mathrm{~b}$, элиминация ВПЧ наблюдалась в 76,2\% случаев, во II группе, получавшей Эпигалин ${ }^{\oplus}$ - в $86,4 \%$ случаев и в группе контроля, не получавшей дополнительной метаболической терапии, - в $24 \%$ случаев (рис. 2 ). 
В ПО МО Щ В ПРАКТ ИЧЕСКО М У В А У

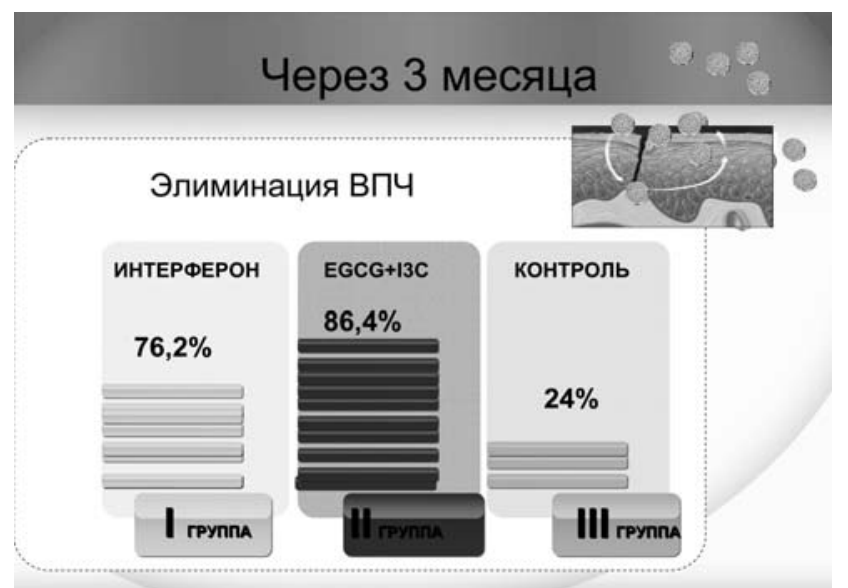

Рис. 2. Элиминация ВПЧ среди пациенток групп наблюдения через 3 мес

В группе пациенток, получавших Эпигалин ${ }^{\circledR}$, также констатирована нормализация соотношения эстрогены/прогестерон, фракций эстрогенов, что не было отмечено у пациенток, получавших интерферонотерапию. Очевидно, данный факт является также способствующим нормализации комплекса защиты от возникновения диспластических процессов, вызванных ВПЧ, и повышает порог восприимчивости эпителиальной ткани к персистенции ПВИ.

Через 6 мес в I группе элиминация ВПЧ составила 92,6\%, во II группе - 95,8\%, что также демонстрирует более высокие результаты эффективности проводимых мероприятий с использованием I3C+EGCG - Эпигалина ${ }^{\circledR}$ (рис. 3). Возможно, определяющую роль играет также оптимальная дозировка составляющих в данном препарате. Известно, что эффекты I3C (не менее 400 мг в сутки), а также EGCG (не менее 90 мг в сутки), являются дозозависимыми, что соответствует составу препарата Эпигалин ${ }^{\oplus}$.

Следует отметить, что среди пациенток, получавших в период реабилитации после ДЭК вагинальные свечи Ревитакса (гиалуроновая кислота, чайное дерево, календула, алоэ, центелла), эпителизация происходила на 7-10 сут ранее, а также без грубой рубцовой деформации. Конечно, следует отметить, что рубцовая деформация шейки матки, слизистой обо-

\section{Оптимізація терапії диспластичних ВПЛ-асоційованих процесів В.В. Бобрицька}

Мета дослідження: визначення ступеня ризику розвитку клінічних форм папіломавірусної інфекції (ПВІ) та можливих шляхів лікування і профілактики диспластичних захворювань, спричинених вірусом папіломи людини (ВПЛ).

Матеріали та методи. Під спостереженням знаходилися 90 пацієнток з діагностованою наявністю онкогенних штамів ВПЛ 16-68 (з використанням методу генотипування). Пацієнтки були розподілені на 3 групи відповідно до терапії, спрямованої на патогенетичні механізми розвитку ПВІ і має на меті зменшення вірусного навантаження, клінічних проявів, а також можливу елімінацію ВПЛ. Перша (I) група - 30 осіб - отримувала ін'єкції $\alpha$-інтерферону- $2 \mathrm{~b}$ - по 3 млн щодня, 10 ін'єкцій; курсова доза 30 млн. Курс повторювали у разі позитивних результатів ВПЛ (попередньо виділених штамів) за тією самою схемою або з інтервалом в 1-2 доби; курсова доза - 30 млн. Друга (II) група - 30 осіб - отримувала індол-3-карбінол з епігаллокатехін-3-галлат (I3C + EGCG) - препарат Епігалін ${ }^{\circledast}$ - у дозі 400 мг I3C і 90 мг EGCG (2 капсули на добу). Курс прийому Епігаліну ${ }^{\circledast}$ - до 6 міс. До групи контролю увійшли пацієнтки у кількості 30 осіб, які не отримували специфічної імуномодулювальної онкопротекторної терапії.

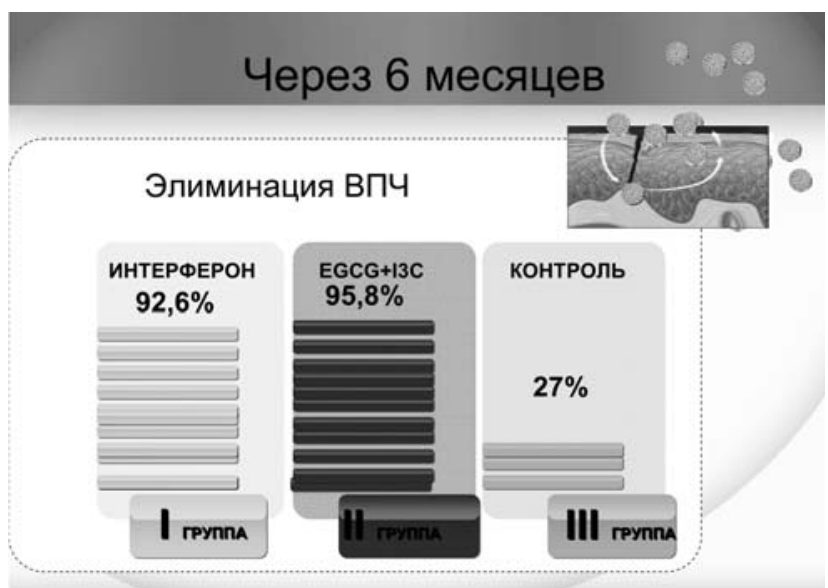

Рис. 3. Элиминация ВПЧ среди пациенток групп наблюдения через 6 мес

лочки влагалища после ДЭК может быть обусловлена превышением экспозиции коагуляции, нарушением режима обработки либо сопутствующими инфекционными факторами, которым не было уделено должного внимания до вмешательства. Однако дополнительное применение натуральных суппозиториев Ревитакса, на наш взгляд, значительно улучшает процессы репарации. Кроме того, растительные компоненты, входящие в состав Ревитаксы (чайное дерево, алоэ, календула), обладают в том числе и противовирусным действием.

\section{выводы}

Использование метаболической иммунной «заместительной» терапии папилломавирусной инфекции демонстрирует более высокие результаты, чем изолированное использование электрохирургического (радиоволнового) лечения дисплазий. Препарат Эпигалин ${ }^{\oplus}$ (сочетание 400 мг І3С и 90 мг EGCG) является эффективным онкопротекторным, нормализующим эстрогенный баланс препаратом, способствующим элиминации ВПЧ. Сочетание препарата Эпигалин ${ }^{\circledast}$ с комплексным репаративным и антисептическим действием с натуральными свечами Ревитакса является оптимальным в случаях электрохирургического лечения поражений, вызванных ВПЧ.

Результати. У результаті проведеної терапії через 3 міс у I групі пацієнток, які отримували $\alpha$-інтерферон-2b, елімінація ВПЛ спостерігалася у 76,2\% випадків, у пацієнток II групи, які отримували Епігалін ${ }^{\circledast}$ - у 86,4\% випадків і в групі контролю, що не одержувала додаткової метаболічної терапії, - у $24 \%$ випадків. Через 6 міс у I групі елімінація ВПЛ склала 92,6\%, у II групі 95,8\%, що також демонструє білыш високі результати ефективності проведених заходів з використанням I3C + EGCG - Епігаліну ${ }^{\circledast}$. Серед пацієнток, які отримували у період реабілітації після діатермокоагуляції (ДЕК) вагінальні супозиторії Ревітакса (гіалуронова кислота, чайне дерево, календула, алое, центелла), епітелізація відбувалася на 7-10 діб раніше, а також без грубої рубцевої деформації.

Заключення. Використання метаболічної імунної «замісної» терапії папіломавірусної інфекції демонструє більш високі результати, ніж ізольоване використання електрохірургічного (радіохвильового) лікування дисплазій. Препарат Епігалін ${ }^{\circledR}$ (поєднання 400 мг I3C і 90 мг EGCG) є ефективним онкопротекторним, нормалізує естрогенний баланс препаратом, що сприяє елімінації ВПЛ. Поєднання препарату Епігалін ${ }^{\oplus}$ з комплексною репаративною та антисептичною дією з природними супозиторіями Ревітакса $є$ оптимальним у випадках електрохірургічного лікування уражень, спричинених ВПЛ.

Ключові слова: вірус папіломи людини, еліміначія, інтерферон, Епігалін $^{\circledast}$, Ревітакса. 


\section{В ПО МО Щ П РАКТ ИЧЕСКО М У В А ЧУ}

\section{Therapy optimization dysplastic HPV-associated processes V.V. Bobrytska}

The objective: to determine the level of risk of developing clinical forms of papilloma virus infection (PVI) and possible ways of treatment and prevention of dysplastic diseases caused by human papilloma virus (HPV)

Patients and methods. The study included 90 patients with diagnosed of oncogenic strains of HPV 16-68 (using the method of genotyping) The patients were divided into 3 groups in accordance with treatment aimed at the pathogenetic mechanisms of development of PVI and with the aim of reducing viral load, clinical manifestations and possible elimination of HPV. The first (I) group - 30 people - were given an injection of $\alpha$-interferon $2 \mathrm{~b} 3 \mathrm{mln}$ per day, 10 injections; course dose - $30 \mathrm{mln}$ The course repeated in case of positive results of HPV (pre-selected strains) according to the same scheme or at intervals of 1-2 days; course dose - $30 \mathrm{mln}$. Second (II) group - 30 people - received indole-3-carbinol with epigallocatechin-3-gallate (I3C+EGCG) - a drug Epigalin ${ }^{\circledR}$ in the dose of $400 \mathrm{mg}$ I3C and $90 \mathrm{mg}$ EGCG ( 2 capsules per day). The course of taking in Epigalin ${ }^{\oplus}$ continued 6 months. The control group included patients in the amount of 30 people who did not receive specific oncoprotective immunomodulatory therapy.
Results. As a result of the therapy after 3 months in group I patients who had received $\alpha$-interferon-2b, elimination of HPV was observed in $76.2 \%$ of cases; in group II, treated with Epigalin ${ }^{\circledast}$ - in $86.4 \%$ of cases and in the control group not receiving additional metabolic therapy in $24 \%$ of cases. After 6 months in group I elimination of HPV was $92.6 \%$, in group II it was $95.8 \%$, which also shows better results of the effectiveness of interventions using I3C+EGCG - Epigalin ${ }^{\oplus}$. Among patients treated in the period of rehabilitation after diathermocoagulation (DEC) drug Revitaxa (hyaluronic acid, tea tree, calendula, aloe vera, centella), epithelialization occurred on 7-10 days earlier, and without rough scar deformation.

Conclusion. The use of metabolic immune replacement therapy of papillomavirus infection shows better results than the isolated use of electrosurgical (radio wave) treatment of dysplasia. The drug Epigalin ${ }^{\circledast}$ (a combination of $400 \mathrm{mg}$ I3C and $90 \mathrm{mg}$ EGCG) is an effective oncoprotective, normalizing the balance of estrogen with the drug, contributing to the elimination of HPV. The combination of the drug Epigalin ${ }^{\oplus}$ with a comprehensive reparative and antiseptic drug Revitaxa (suppositories) is optimal in cases of surgical treatment of lesions caused by HPV.

Key words: human papilloma virus, elimination, interferon, Epigalin ${ }^{\oplus}$, Revitaxa.

\section{Сведения об авторе}

Бобрицкая Виктория Владимировна - Кафедра перинатологии, акушерства и гинекологии Харьковской медицинской академии последипломного образования, 61176, г. Харьков, ул. Корчагинцев, 58. E-mail:bobritska@mail.ru

\section{СПИСОК ЛИТЕРАТУРЫ}

1. Борис О.М. Сучасні підходи до комплексного лікування та профілактики рецидивів папіломавірусної інфекції у жінок репродуктивного віку// Репродуктивна ендокринологія - 2015 № 1 (21).

2. Воробьова Л.І. Папіломавірусна інфекція: актуальна проблема сучасної гінекології // Здоровье женщины. - 2015. - № 3 (99).

3. Волошина Н.Н. и соавт. Профилактика рака репродуктивных органов // Н.Н. Волошина, С.Н. Пащенко, Н.А. Волошин, Н.Ф. Щуров, О.Ю. Петрова// Здоровье женщины. - 2014. № 9 (95).
4. Киселев И.В., Ляшенко А.А. Индинол - регулятор пролиферативных процессов в органах системы. - М.: ЗАО «МираксФарма», 2008. - 48 с. 5. Лазаренко Л.Н., Лигирда Н.Ф., Воро бьева Л.И., Потебня Г.Ф., Демченко О.Н., Спивак Н.Я. Изменение цито кинового профиля организма и показателей клеточного иммунитета у больных дисплазией шейки матки, индуци рованной папилломавирусами //Акушерство и гинекология. - 2011. - № 8. 6. Папилломавирусная инфекция и система интерферона // Лазаренко Л.Н., Спивак Н.Я., Михайленко О.Н. и др. - К.: Украинский фитосоциологический центр, 2008.
7. Сухарева Е.А., Пономарева Л.А. Козлов С.В. Опыт применения индол3-карбинола в лечении доброкачественных дисплазий молочной железы//Лечащий врач. Мед. научнопрактический журнал. - 2012. - № 7. 8. Роговская С.И. Папилломавирусная инфекция у женщин и патология шейки матки: В помощь практикующему врачу. - М., 2008. - 188 с.

9. Татарчук Т.Ф., Калугина Л.В. К вопросу о профилактике и терапии гормонзависимых гиперпролиферативных заболеваний у женщин //Здоровье женщины. - 2013. - № 7 (83). C. 51-57.

10. Sartippour M.R., Pietras R.,
Marquez-garban D.C. et al The combination of green tea and tamoxifen is effective against breast cancer//Carcinogenesis, 2006 Dec;27(12):2424-33.

11. Thangapazham R.L., Singh A.K. Sharma A. et al. Green tea polyphenols and its constituent epigallocatechin gallate inhibits proliferation of human breast cancer cells in vitro and in vivo // CancerLett. - 2007. - Vol. 8. P. 832-841.

12. Spitzer M. Screening and management of women and girls with human papillomavirus infection // Gynecologyc Oncology. - Vol. 107, № 2, syppl 1, nov. 2007. - P. 14-19. 


\section{Місце топічних глюкокортикоїдів у лікуванні дерматитів різної етіології}

\section{Л.Д. Калюжна}

Національна медична академія післядипломної освіти імені П.Л. Шупика, м. Київ УКР. МЕД. ЧАСОПИС, 4 (114) - VII/VIII 2016 on-line. www.umj.com.ua

У статті висвітлюється інформація щодо запальних захворювань шкіри - дерматитів, іхніх видів, симптомів, причин виникнення та лікування.

Ключові слова: атопічний дерматит, місиева терапія, комбіновані топічні глюкокортикоїди, Тримістин ${ }^{\circledR}$-Дарниияя.

\section{Основні характеристики дерматитів}

У практиці лікаря-дерматолога запальні захворювання шкіри (дерматити) займають лідируючу позицію. Провідна причина виникнення захворювання найчастіше залишається невстановленою, проте важливу роль у їхньому розвитку відводять вірусним, бактеріальним і грибкових агентам, не забуваючи про можливу алергійну та токсичну природу захворювання. Згідно з Міжнародною класифікацією хвороб 10-го перегляду до дерматитів зараховують атопічний, себорейний, алергійний контактний, ексфоліативний та інші його види (мал. 1).

Основними факторами патогенного впливу при даному захворюванні є:

- стрес;

• контакт (термічний, хімічний, сонячний, алергійний опік, відмороження);

- проникнення (патоген надходить у кров через травний тракт, дихальну систему, парентерально).

До специфічних симптомів, характерних для більшості дерматитів незалежно від причин їхнього виникнення, належать:

- свербіж (пруриго), інтенсивність якого залежить від сили подразнення нервових закінчень у дермі. Невідповідність інтенсивності пруриго і шкірних проявів (сильне свербіння при незначних висипаннях) ознака алергії при атопічному дерматиті (АД). При контактному дерматиті свербіж у місці приєднання патогену адекватний тяжкості пошкодження;

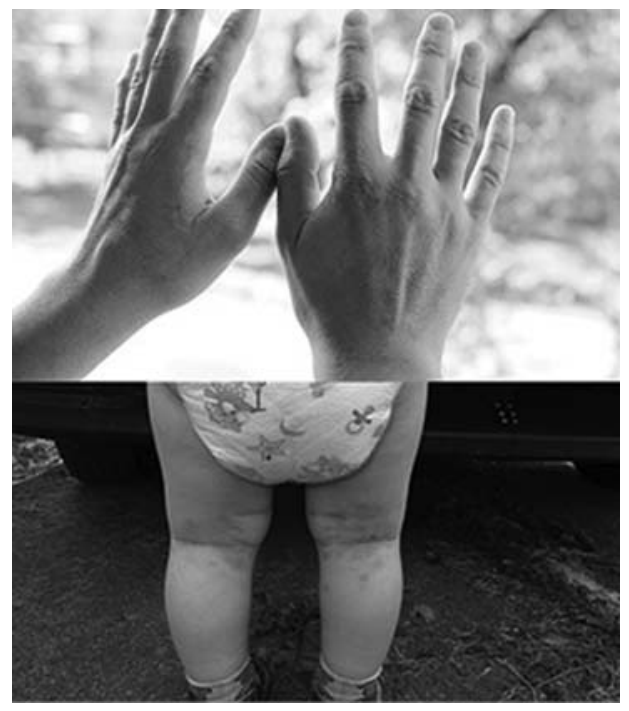

Мал. 1. Запальні захворювання шкіри
- почервоніння (еритема) - обов'язкова при гострій формі захворювання і необов'язкова - при хронічній;

- висипання (екзема), морфологія та локалізація якого типова для конкретного дерматиту;

- ексудація. При гострих формах можливі ексудативні запалення з рясними виділеннями. При хронічних формах - ліхеніфікація (потовщення ділянок шкіри 3 грубим малюнком), тріщини на шкірі та екскоріації;

- лущення шкіри (десквамація), зумовлене підвищеною сухістю при дегідратації, недостатності сальних залоз;

- гіпопігментація та утворення везикул.

Додаткові симптоми мають значення при диференціальній діагностиці конкретних дерматитів, їх виявляють під час опитування, огляду, лабораторних досліджень, функціональних проб.

Перебіг дерматиту можливий у гострій та хронічній формах. Деякі автори зазначають підгострий перебіг, проте чітких рамок, в які можна було б вписати цю форму, немає: лікар визначає іï, грунтуючись на власному клінічному досвіді, а не конкретних діагностичних критеріях.

Початок гострої форми характеризується раптовим виникненням свербежу, незначним підвищенням температури тіла, можливо ринітом (алергійні атопії). У разі розвитку дерматиту, спричиненого вірусними або бактеріальними агентами, відзначають симптоми, характерні для основного захворювання, і висип у вигляді первинних елементів: папули, везикули, рідше - були. Для гострої форми дерматиту характерні загальні симптоми запалення помірної тяжкості (обмежене почервоніння, припухлість, болючість, порушення функції, локальне підвищення температури тіла).

При хронічному перебігу симптоми запалення стерті. На тілі виявляють вторинний висип, за типом якого можна прогнозувати наслідки захворювання:

• виникнення атрофії - несприятливий наслідок;

- струп, тріщини, лусочки, садна, виразки, ерозії сумнівний результат;

- загоєння без сліду, гіперпігментація, дисхромія, депігментація, ліхеніфікація, рубець - сприятливий результат.

\section{Атопічний дерматит}

Найбільш поширеним дерматитом є АД - спадкове захворювання із хронічним перебігом, провідні симптоми якого - екзематозні висипи та ліхеніфікації, аномалії клітинного імунітету в шкірі з порушеною регуляцією Т-клітинної ланки і гіперчутливості до імунних і неімунних агентів $[5,11$. 21]. Поширеність АД серед дітей становить 5-20\%, серед осіб дорослого віку $-2-10 \%$. Найчастіше захворювання виявляють у міських жителів індустріально розвинених країн. Згідно з даними Державного комітету статистики України за 2013 р., поширеність АД серед дітей становила 0,88\%, що, швидше за все, нижче реальних показників [9]. АД розвивається в осіб із генетичною схильністю до атопії під впливом зовнішніх і внутрішніх факторів. 


\section{В ПОМОЩ В ПРАКТ ИЧЕСКО М В РА У У}

Основні фактори, асоційовані з розвитком АД:

- контактні алергени;

- інгаляційні та харчові алергени;

- мікроорганізми;

- статеві гормони;

- стресові фактори;

- потовиділення та кліматичні особливості [6].

Виокремлюють такі ланки патогенезу АД:

- атопічна аномалія конституції;

• особливості функціонування рецепторного апарату клітини;

- особливості морфофункціонального стану шкіри.

Етіологічну основу для розвитку АД створюють наявність у людини функціональних порушень роботи травного тракту, запальні захворювання шлунка і дванадцятипалої кишки, інвазія паразитів, респіраторні захворювання та вогнища хронічної інфекції. Результати досліджень також свідчать про наявність взаємозв'язку між порушеннями роботи нервової системи, судинної регуляції і тяжкістю перебігу АД [3].

\section{Принципи та підходи до лікування при дерматиті}

Широкий спектр дерматитів різного етіопатогенезу, їхня значна поширеність дали поштовх для розроблення безлічі схем лікування із залученням препаратів системної та локальної дії. I хоча на сьогодні універсальної терапевтичної схеми лікування дерматиту не існує, важливою метою кожної з них є зменшення вираження запалення ключового прояву дерматиту. Вибір необхідного лікарського засобу і тривалість терапевтичного курсу визначає лікуючий лікар з урахуванням особливостей перебігу захворювання та індивідуальних якостей самого пацієнта.

Стратегія ведення такого хворого базується на трьох основних принципах:

1. Комплексність діагностичних методів дослідження шкіри пацієнта і його організму з визначенням причин та патогенезу захворювання.

2. Багатофакторність впливу на ланцюги патогенезу, прояви захворювання та фоновий стан організму.

3. Безперервність лікування до повної регенерації шкірних покривів [14].

Ці принципи реалізуються через системний і місцевий терапевтичний вплив на організм пацієнта. Незважаючи на труднощі визначення причини дерматиту, першочерговою рекомендацією щодо його лікування є «ізоляція» потенційного фактора, який спричинив захворювання від пацієнта: при контактному дерматиті - заміна миючого засобу на інший, бажано гіпоалергенний, виключення харчових алергенів із раціону при АД або відміна призначеного лікарського засобу, який є можливою причиною розвитку ексфоліативного дерматиту. Подальші лікувальні заходи спрямовані на патогенез і безпосередньо на симптоматику захворювання, включають застосування антигістамінних десенсибілізувальних препаратів, седативних лікарських засобів і корекцію фонового стану пацієнта.

Ведення пацієнтів із АД будь-якої вікової категорії включає підбір ефективної дієтотерапії, розмежування впливу алергену на організм, застосування гіпосенсибілізувальних, антигістамінних, седативних препаратів, топічних глюкокортикоїдів, фізіотерапевтичні методи лікування, а також корекцію супутніх захворювань і патологічних станів [13-17].

Місцева терапія має забезпечувати зменшення вираженості локального запалення, тим самим нівелюючи основні симптоми гострої та хронічної фаз захворювання, усувати сухість шкіри за її наявності, відновлювати та покращувати бар'єрну функцію шкіри, а також забезпечувати профілактику вторинної інфекції [4]. Це лікування може включати застосування топічних глюкокортикоїдів, топічних інгібіторів кальциневрину, антисептичних засобів. Згідно з протоколом лікування, форми препаратів для зовнішньої терапії необхідно застосовувати диференційовано, залежно від гостроти і динаміки запалення шкіри.

Препарат оптимального вибору повинен мати високу активність і мінімальні системні й місцеві побічні реакції. Сила дії препарату має відповідати вираженості клінічної картини дерматозу; лікарська форма - бути адекватною стадії запального процесу, його морфологічним особливостям; концентрація глюкокортикоїду і частота застосування не повинні спричиняти розвитку побічних ефектів [1].

Принципи топічної терапії АД подібні до таких у лікуванні неалергійних дерматитів: провідною стратегією тут є індивідуальний підхід з урахуванням віку пацієнта, стадії та варіанта захворювання, локалізації та поширеності процесу, наявності інфекції і ефективності попереднього лікування [6]. Як і при дерматиті іншої етіології, важливою частиною лікування при АД є місцева терапія із застосуванням топічних глюкокортикоїдів, ефективність яких при цьому захворюванні доведена у низці клінічних досліджень [18-20, 22-24].

\section{Застосування топічних глюкокортикоїдів у місцевій терапії при дерматиті}

Частіше перебіг дерматиту має стертий характер, запалення ускладнене інфікуючим агентом, визначення якого ускладнене. Одними з найбільш застосовуваних у дерматологічній практиці препаратів локальної дії є топічні глюкокортикоїди через їхнє широке охоплення патогенетичних цілей і хорошу вивченість як позитивних, так і негативних векторів дії.

Відповідно до теорії, яка виникла у 70-х роках XX ст., проникаючи у клітину, глюкокортикоїди зв'язуються з цитозольними рецепторами, створюючи комплекс, який, переміщуючись у ядро, активує експресію генів, що відповідають за синтез білків із протизапальною дією. Однак пізніше вчені встановили, що гормон-рецепторні комплекси зв'язуються з факторами транскрипції, які активуються у результаті впливу медіаторів запалення продуктів вільнорадикального окиснення, токсинів, вірусів, результатом чого є зменшення продукції в клітині рівня протизапальних цитокінів, ферментів, ендотеліну-1, молекул адгезії тощо.

Нещодавно доведена здатність глюкокортикоїдних і мінералокортикоїдних рецепторів взаємодіяти з утворенням гетеродимерів, що зумовлює можливість існування різних варіацій та біологічних ефектів залежно від співвідношення їхньої концентрації у фізіологічних та патологічних умовах $[2,16]$.

Препарати зазначеної групи ефективно усувають алергійні та запальні реакції завдяки:

- судинозвужувальному ефекту, гальмівному впливу на міграцію лімфоцитів і макрофагів, а також на вивільнення цитокінів та інших медіаторів запалення;

- властивості сповільнювати метаболізм арахідонової кислоти - вихідного продукту каскаду різних ферментативних окисно-відновних реакцій;

- ефекту пригнічення активності гіалуронідази, стабілізації лізосомальних мембран клітин епідермісу.

Відповідно до класифікації Miller \& Munro, залежно 


\section{В ПОМОЩ В ПРАКТ ИЧЕСКО М В РА У У}

від активності протизапальної дії препарату, топічні кортикостероїди (глюкокортикоїди + мінералокортикоїди) можна розділити на:

- кортикостероїди з низькою активністю (клас 1 слабкі): гідрокортизону ацетат, преднізолон, а також комбіновані препарати, які містять гідрокортизон і преднізолон;

- кортикостероїди з помірною активністю (клас 2 помірно сильні): тріамцинолону ацетонід, аклометазону дипропіонат, дезоксиметазон, мазипредон, преднікарбат та ін.;

- активні кортикостероїди (клас 3 - сильні): амцинонід, бетаметазону валерат, бетаметазону дипропіонат та ін.;

- високоактивні кортикостероїди (клас 4 - надсильні): галобетазолу пропіонат, гальцинонід, дифлоразону діацетат та ін.

Ефективність лікування хворого з дерматитом залежить від адекватності підібраної лікарської речовини форми препарату з урахуванням активності процесу, його глибини та індивідуальних характеристик пацієнта. Так, при ексудативних процесах рекомендують застосовувати топічні глюкокортикоїди 2-го класу, середньої сили дії. Однак терапію дерматиту варто починати з найбільш слабких, переходячи на більш активні стероїдні препарати через 2-3 тиж за відсутності ефекту. У разі вторинного інфікування варто застосовувати комбіновані протимікробні засоби.

Застосування мазі забезпечує глибоке проникнення лікарського засобу, крему і лосьйону - більш поверхневе. При хронічних процесах рекомендоване застосування мазей, при гострих - крему, лосьйону, емульсії. При надмірній кількості та частоті застосування препарату чи неправильному способі накладання можливий розвиток побічних реакцій. Тому важливо детально пояснити пацієнту спосіб нанесення препарату, зорієнтувавши його, як досягнути оптимального дозування.

Для зручності та стандартизації можна використовувати умовну одиницю «кількості засобу на кінчику пальця» (КЗКП), порадивши користуватися схемою, зображеною на мал. 2 , яка, проте, є орієнтовною та не може бути універсальною: лікар має коригувати дозу залежно від сили препарату [8, 12].

\section{Комбіновані топічні глюкокортикоїди. Тримістин ${ }^{\circledR}$-Дарниця}

Величезний арсенал засобів, що містять топічний глюкокортикоїд як ізольовано, так і в комбінації з іншими групами лікарських засобів, ставить практикуючого лікаря перед складним вибором оптимального препарату. Правильне рішення в таких випадках є запорукою ефективності місцевої терапії. Мазі та креми із глюкокортикоїдами, які застосовують місцево при дерматиті, мають протизапальну, протиалергійну і протисвербіжну дію [15]. При цьому частка мазей, які містять глюкокортикоїди, становить приблизно 15\% усіх зареєстрованих в Україні, з них $60 \%$ - комбіновані препарати [10].

Застосування мазей із топічним глюкокортикоїдом підвищує ризик виникнення поширеного побічного ефекту препаратів цієї групи - приєднання вторинної бактеріальної та грибкової інфекції. При цьому комбінація глюкокортикоїду з антисептиком знижує імовірність розвитку ускладнень. На відміну від комбінації глюкокортикоїду з антибіотиком, поєднання такого препарату з антисептиком має ширший спектр дії.

Відзначено, що застосування традиційних мазей на жировій основі при гострих ексудативних процесах може зу-

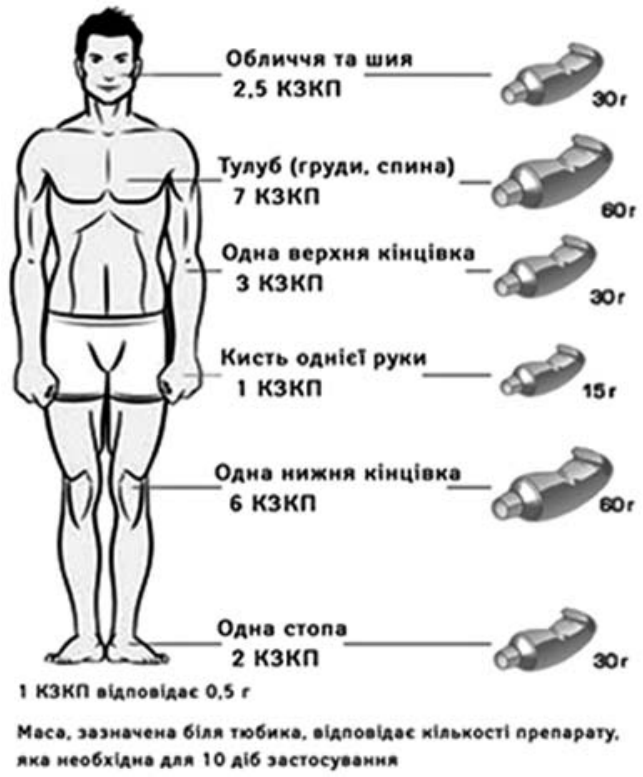

Мал. 2. Дозування м'якої лікарської форми для зовнішнього застосування

мовлювати збільшення вираженості запалення. Гідрофільна ж основа з високою осмолярною активністю не чинить шкідливого впливу на тканини, поглинаючи ексудат і забезпечуючи контроль глибини проникнення глюкокортикоїду, обмежуючи його дію у вогнищі ураження [1].

Серед низки топічних глюкокортикоїдів, які пропонує фармацевтична промисловість, вигідно виділяється оригінальний препарат Тримістин ${ }^{\circledR}$-Дарниця виробництва ПрАТ «Фармацевтична фірма «Дарниця», розроблений у ДУ «Інститут дерматології та венерології НАМН України» під керівництвом професора М.О. Ляпунова. До складу мазі входить 0,25 мг/г фторованого глюкокортикоїду 2-го класу тріамцинолону ацетоніду та 5 мг/г антисептичного засобу мірамістину.

Тріамцинолону ацетонід зумовлює виражену протизапальну, протиалергійну та протиексудативну дію. Він забезпечує регуляцію експресії кортикоїдзалежних генів та впливає на синтез білка. Зменшує утворення, вивільнення та активність медіаторів запалення, пригнічує міграцію клітин до місця запалення. Пригнічує ексудативний компонент запалення за рахунок зменшення вазодилатації та проникності судин у вогнищі запалення. Стабілізує лізосомальні ферменти мембран лейкоцитів; пригнічує синтез антитіл та порушує розпізнавання антигену.

Включення до складу препарату мірамістину допомагає запобігти вторинному інфікуванню, дає можливість уникнути обов'язкової ідентифікації збудника, а також забезпечує антибактеріальний, протигрибковий ефект і захист від найпростіших.

Гідрофільна основа препарату сприяє активації розсмоктування процесу, вибірковому поглинанню ексудату, перешкоджає системному всмоктуванню тріамцинолону ацетоніду, забезпечує активацію неспецифічної захисної реакції в тканинах. Застосування мазі Тримістин ${ }^{\circledR}$-Дарниця забезпечує збереження оптимальних якостей шкіри, не пересушуючи іï.

Препарат можна призначати при запальних захворюваннях шкіри, ускладнених бактеріальною та грибковою інфекцією: екземі, АД, нейродерміті, псоріазі, дискоїдному червоному вовчаку, фотодерматозі, лімфомі шкіри, а також інших захворюваннях, які супроводжуються свербе- 


\section{В ПО МО Щ П РАКТ ИЧЕСКО М У В Р А У}

жем, запаленням, почервонінням, знебарвленням шкіри, а також гіперреакцією на укуси комах [7].

Пацієнтам із захворюваннями шкіри, що не супроводжуються ексудацією, препарат призначають місцево 1-2 рази на добу. За наявності інтенсивної ексудації пацієнту рекомендують провести попереднє оброблення ураженого місця на шкірі і лише після цього нанести мазь. Тривалість курсу визначають індивідуально. Дія мазі частково слабшає при їі нанесенні на поверхню 3 високим вмістом гнійно-некротичних мас. Тому мазь краще наносити на

\section{СПИСОК ЛІТЕРАТУРИ}

1. Белаш Н.Г. (2007) Топические кортикостероиды в практике семейного врача. Мистецтво лікування, 3: 53-54.

2. Деримедведь Л.В., Вереитинова В.П., Тарасенко О.В., Завгородний А.А. (2004) Топические стероиды в практике семейного врача. Провизор, 12 (http://www.provisor.com.ua/ archive/2004/N12/art_31.php).

3. Зайченко Я.О. (2004) Атопічний дерматит: можливі причини, патогенез, клініка. Укр. мед. часопис, 5(43): 21-23.

4. Зубаренко А.В., Портнова О.А. (2009) Атопический дерматит. Концепция эффективной терапии. Здоровье ребенка, 3(18): 103-108.

5. Калюжная Л.Д. (2003) Актуальная проблема дерматовенерологии атопический дерматит. Укр. мед. часопис, 2(34): 87-91 (http://www.umi.com.ua /article/1227).

6. Калюжная Л.Д. (2014) Принципы топической терапии атопического дерматита. Укр. мед. часопис, 5(103): 59-61 (http://www.umj.com.ua/article/80448).

7. Компендиум - лекарственные препараты (2015) Под ред. В.Н. Ковален- ко. МОРИОН, Киев (http://compendium.com.ua/info/29594/trimistin-supsup-darnitsa). ные подходы к применению топических глюкокортикостероидов. Журнал дерматологии и венерологии, 1: 95-99.

9. Кутасевич Я.Ф., Уманец Т.Р. (2014) Эффективность и безопасность при менения топических ингибиторов кальциневрина в педиатрии. Укр. мед. часопис, 3(101): 46-53 (http://www.umj.com.ua/article/74684) 10. Перцев И.М., Деримедведь Л.В., Халеева Е.Л., Чуешов О.В. (2002) Применение кортикостероидных мазей при местном лечении дерматозов. Провизор, 7: 17-20.

11. Суворова К.Н. (1988) Атопический дерматит: иммунопатогенез $v$ стратегия иммунотерапии. РМЖ (Русский медицинский журнал), 6: 363-395.

12. Шупенько Н.М. (2004) Применение топических глюкокортикостероидных гормонов в дерматологической практике. Мистецтво лікування, 6: 44-48.

13. Allen B.R. (2001) Review of atopic
8. Кутасевич Я.Ф. (2000) Современ-

шкіру після їі оброблення теплим мильним розчином або, за необхідності, розчинами антисептиків.

Комбінація топічного глюкокортикоїду з антисептиком на гідрофільній основі забезпечує потрійний ефект препарату для лікування при запальних захворюваннях шкіри, може бути рекомендована як препарат вибору у пацієнтів із дерматитом середньої тяжкості, із приєднаною вторинною інфекцією та порушеною картиною первинного захворювання за умови неефективності або недостатньої ефективності топічних глюкокортикоїдів 1-го класу активності.

dermatitis literature. Atopy Reports: Atopic Dermatitis and Related Disorders, 1(1): 7-9.

14. Ayzdorov.ru (2014) Причины, симптомы, виды дерматита (http://www.ayzdorov.ru/lechenie_dermamit chto.php).

15. Bailey J.M. (1991) New mechanisms for effects of anti-inflammatory glucocorticoids. Biofactors, 3(2): 97-102.

16. Barnes P.J. (2000) New directions in allergic diseases: mechanism-based anti-inflammatory therapies. J. Allergy Clin. Immunol., 106: 5-16.

17. Bieber T., Leung D.Y.M. (2009) Atopic dermatitis. Informa Healthcare, New York, $466 \mathrm{p}$.

18. Broeders J.A., Ahmed Ali U., Fischer G. (2016) Systematic review and meta-analysis of randomized clinical trials (RCTs) comparing topical calcineurin inhibitors with topical corticosteroids for atopic dermatitis: A 15-year experience. J. Am. Acad. Dermatol. May 11 [Epub ahead of print].

19. Brunner P.M., Khattri S., Garcet S et al. (2016) A mild topical steroid leads to progressive anti-inflammatory effects in the skin of patients with moderate-to- severe atopic dermatitis. J. Allergy Clin. Immunol., February 29 [Epub ahead of print].

20. Jensen J.M., Weppner M., Dähnhardt-Pfeiffer S. et al. (2013) Effects of pimecrolimus compared with triamcinolone acetonide cream on skin barrier structure in atopic dermatitis: a randomized, double-blind, right-left arm trial. Acta Derm. Venereol., 93(5): 515-519.

21. Knol E.F., Langeveld E.A., van Reijsen F.C. et al. (1998) Allergic inflammation in atopic dermatitis. Ann. Dermatol. Venerol., 129: 147.

22. Siegfried E.C., Jaworski J.C., Kaiser J.D., Hebert A.A. (2016) Systematic review of published trials: long-term safety of topical corticosteroids and topical calcineurin. BMC Pediatr., 16(1): 75.

23. Silverberg J.I., Nelson D.B., Yosipovitch G. (2016) Addressing treatment challenges in atopic dermatitis with novel topical therapies. J. Dermatolog. Treat., 11: 1-9.

24. Stirling R.G., Chung K.F. (2000) New immunological approaches and cytokine targets in asthma and allergy. Eur. Respir. J., 16(6): 1158-1174. 


\title{
Инновационные подходы к коррекции микронутриентного статуса беременных и кормящих женщин
}

\author{
С.И. Жук, К.К. Бондаренко \\ Национальная медицинская академия последипломного образования имени П.Л. Шупика, г. Киев
}

Большинство исследований последних лет демонстрируют влияние нарушений в обмене фолатов и метиониновом цикле на патогенез дефектов нервной трубки (ДНТ) плода. Метафолин имеет ряд преимуществ, к которым в первую очередь относится непосредственное поступление в организм человека веществ в биологически активной форме и наличие оптимального эффекта, даже в случае, когда у пациентки гомозиготный и/или гетерозиготный генотип $677 \mathrm{C}$ Т полиморфизма МТГФР.

С целью профилактики и лечения различных патологических состояний, связанных с дефицитом фолатов во время беременности, целесообразно применять витаминно-минеральные комплексы, содержащие метафолин - активную форму фолатов с высокой биодоступностью.

Ключевые слова: МТГФР, метафолин, фолиевая кислота, беременность.

$\mathrm{O}_{1}$ ценка роли питания беременных в формировании здоровья ребенка в перинатальный период и младенчестве радикально изменилась в последние несколько десятилетий. Полноценное питание во время беременности имеет колоссальное значение, поскольку не только обеспечивает энергетические потребности организма матери, но и является субстратом для развития новых тканей плода, а также создает энергетический резерв для лактации. Важно помнить, что качество питания зависит от адекватной обеспеченности микронутриентами - витаминами, микроэлементами, полиненасыщенными жирными кислотами, поскольку плод может получить их только от матери. Именно дефицит микронутриентов является одной из причин дефектов развития в антенатальный период: от легкой степени гипотрофии до тяжелых соматических пороков плода. В настоящее время накоплены обширные и убедительные данные, демонстрирующие достоверное снижение частоты врожденных пороков развития нервной трубки, мочевой, сердечно-сосудистой системы у детей, матери которых получали витамины во время беременности в виде витаминно-минеральных комплексов.

Причины дефицита микронутриентов во время беременности хорошо изучены. Основными, безусловно, являются нерациональное несбалансированное питание и низкое содержание микронутриентов в продуктах. Дополнительными факторами являются курение, хронические стрессы, болезни, а также осложнения беременности, прежде всего ранний токсикоз.

Фолиевая кислота - это синтетическая пищевая добавка, которая присутствует в обогащенных пищевых продуктах и витаминных препаратах.

Термин «фолаты» обычно используют как непатентованное название для группы химически родственных соединений на основе структуры фолиевой кислоты.

Пищевые фолаты - это питательные вещества, присутствующие в натуральных пищевых продуктах, таких, как зе- леные листовые овощи, бобовые, яичный желток, печень и цитрусовые.

Значение фолиевой кислоты в организме переоценить невозможно, поскольку основная функция этого жизненно важного витамина - синтез ДНК и клеточная репликация. Фолаты участвуют в синтезе аминокислот, нуклеиновых кислот, эссенциальных фосфолипидов, нейротрансмиттеров (серотонин, мелатонин, дофамин). Именно с недостатком фолиевой кислоты связывают развитие депрессий у немолодых людей, прежде всего женщин в мено- и постменопаузе. Чрезвычайно важна роль фолатов в формировании новых кровеносных сосудов маточно-плацентарного ложа. Дефицит фолиевой кислоты является причиной различных осложнений беременности (помимо дефекта нервной трубки), таких, как самопроизвольный аборт, преждевременные роды, преждевременная отслойка плаценты. Основой этой патологии является приобретенная гипергомоцистеинемия, сопровождающая дефицит витаминов группы В и фолиевой кислоты.

Большинство исследований последних лет демонстрируют влияние нарушений в обмене фолатов и метиониновом цикле на патогенез дефектов нервной трубки (ДНТ) плода.

ДНТ (spinabifida) по-прежнему остаются одним из самых распространенных врожденных пороков развития. Ежегодно в США регистрируют 1 случай ДНТ на 1000 беременностей, при этом 4000 беременностей в год прерываются, включая самопроизвольный выкидыш и искусственный аборт, из-за нарушений развития центральной нервной системы (ЦНС) плода. Ежегодно частота выявления ДНТ в России составляет $0,45 \%$; смертность вследствие ДНТ - 300 новорожденных ( $2 \%$ общей детской смертности).

Ряд исследований установили, что оральные контрацептивы (ОК), содержащие даже менее 50 мкг эстрогенов (все современные препараты содержат их не больше 35 мкг), нарушают кинетику фолатов, и в крови женщин, использующих ОК, повышено содержание витамина А, а также снижены концентрации витамина $\mathrm{B}_{12}$ и фолиевой кислоты. Таким образом, риск развития ДНТ выше у пациенток, которые забеременели сразу после длительного приема ОК, особенно при наличии генетических мутаций ферментов (MTHFR, MTS и пр.), и дополнительно не принимали фолиевую кислоту и витамины группы В.

Особую группу риска по дефициту фолатов и витаминов группы В составляют пациентки, длительное время получавшие гормональную контрацепцию, а также курящие, злоупотребляющие кофе (более 5 чашек в день) и, безусловно, пациентки с генетическими факторами (мутацией метилентетрагидрофолата (MTHFR), цистатионин-b-синтетазы (CBS), транскобаламина), мальабсорбцией, несбалансированным питанием, диагностированной гипергомоцистеинемией (ГГЦ) и ДНТ плода в анамнезе. Следует также учитывать, что до $80 \%$ женщин в возрасте от 18 до 40 лет имеют субоптимальные концентрации фолатов в крови. 


\section{A K Y Ш E P C T B O}

Профилактическое назначение фолатов и витаминов группы В, а также коррекция диеты значительно снижают частоту развития пороков нервной трубки у плода.

По данным крупных исследований, включающих десятки тысяч человек, большинство взрослых людей потребляют меньше фолатов, чем это установлено нормами. В частности, изучение потребления фолатов населением Германии на протяжении 1997-2000 гг. показало, что в среднем потребление фолатов взрослыми составляет 250 мкг/сут вместо установленных для Германии 320 мкг/сут. При этом у 25\% женщин детородного возраста содержание фолатов в эритроцитах и плазме крови снижено.

Наибольшие количества фолиевой кислоты содержат такие продукты, как печень, дрожжи, листовые овощи (шпинат, петрушка, салат латук, перо лука и др.). Необходимый уровень фолатов может обеспечить потребление 800 г свежего салата, 500 г свежей петрушки или 500 г вареной печени в день, что маловероятно в реальной жизни. Таким образом, очевидно, что в большинстве случаев не обойтись без дополнительного приема витаминно-минеральных комплексов.

Так, в Дублине было проведено обогащение круп (фортификация зерновых), являющихся важной составной частью ирландской диеты, витамином $\mathrm{B}_{12}$ в 1981 г. и фолиевой кислотой в 1987 г., что привело к снижению частоты рождения детей с ДНТ с 4,7 до 1,3 на 1000 новорожденных. Профилактика ДНТ приобрела масштабы национальных программ здоровья во многих развитых странах. Например, в США и Канаде ввели в действие программу по обогащению зерновых фолатами, прежде всего для снижения риска рождения детей с ДНТ, на фоне которой число новорожденных с ДНТ уменьшилось на $19 \%$ (Нопет М.А. и соавт., 2001). В ряде стран предпочитают проводить программы, направленные на профилактическое использование фолатсодержащих препаратов женщинами детородного возраста. Так, по данным многоцентрового исследования, проведенного в 33 клинических центрах Англии (обследованы 1817 женщин), более 75 \% случаев ДНТ можно предотвращать с помощью назначения фолиевой кислоты и витамина $\mathrm{B}_{12}$.

Актуальными вопросами оптимальной профилактики ДНТ плода являются длительность применения и дозы фолиевой кислоты. Согласно рекомендациям различных международных организаций (включая Food and Drug Administration, США; Marchof Dimes CDC-Alanta - Spina Bifida Assotiation Public Health Service; Reino Unido Juntade Sanidady Consumode Espana, 2001, и др.), женщины с неотягощенным по ДНТ анамнезом должны получать 400 мкг фолиевой кислоты в сутки в сочетании с витамином $\mathrm{B}_{12}$ в дозе 2 мкг/сут, как минимум, за месяц до зачатия и на протяжении I триместра беременности. В Италии с 2005 г. законодательно утверждена необходимость ежедневного приема 400 мкг фолиевой кислоты женщинами, планирующими беременность.

Беременным и кормящим женщинам рекомендуется употреблять 400-800 мкг/сут, верхний предел физиологической потребности - 1000 мкг (Нормы РФ, 2008). Суточная доза потребления фолиевой кислоты для женщин репродуктивного возраста и беременных с неотягощенным акушерским анамнезом составляют 400-600 кг/сут, для кормящих - 500 мкг/сут.

Профессор Э.И. Цейтель, научный директор Фонда общественного контроля наследственных заболеваний, проводил сравнение эффективности поливитаминных комплексов, содержащих фолиевую кислоту, и монотерапии фолиевой кислотой. Риск дефектов нервной трубки снизился на $92 \%$ при приеме поливитаминов и лишь на $32 \%$ - при приеме монопрепаратов фолиевой кислоты. Установлено сни- жение распространенности пороков развития сердечно-сосудистой системы как после использования поливитаминов, так и после использования высоких доз фолиевой кислоты, однако профилактическая эффективность поливитаминов была выше.

\section{Фолаты, фолиевая кислота L-метилфолат и Метафолин}

Фолат, или витамин $\mathrm{B}_{9}$, считается одним из 13 незаменимых витаминов. Фолаты не синтезируются в организме, их нужно получать либо из пищи, либо посредством дополнительного приема. Ни фолаты, ни фолиевая кислота не являются метаболически активными. Биологической активностью обладают лишь тетрагидрофолат и его производные, а фолиевая кислота сама по себе не является биологически активным соединением.

Чтобы участвовать в клеточном метаболизме, фолиевая кислота и фолаты должны подвергнуться редуцированию. L5-метилтетрагидрофолат (L-метилфолат) является доминирующей формой фолата, которая циркулирует в плазме крови и участвует в биологических процессах

Метафолин - синтетическое производное, созданное на базе 5-метил-тетрагидрофолата (5-МТГФ). Единственное различие между Метафолином и 5-МТГФ - присутствие иона кальция. В организме Метафолин распадается на ионы кальция и 5-МТГФ. Метафолин (кальциевая соль L-5- метилтетрагидрофолиевой кислоты) - молекула, идентичная фолатам, содержащимся в пищевых продуктах и организме человека.

Метафолин имеет ряд преимуществ, к которым в первую очередь относятся непосредственное поступление в организм вещества в биологически активной форме и наличие оптимального эффекта, даже в случае, когда у пациентки гомозиготный и/или гетерозиготный генотип $677 \mathrm{C}$ Т полиморфизма МТГФР.

Метафолин в дозе 200 мкг входит в состав витаминноминерального комплекса Фемибион I Наталкер, который помимо этого компонента содержит витамины $\mathrm{C}, \mathrm{PP}, \mathrm{E}, \mathrm{B}_{1}$, $\mathrm{B}_{2}, \mathrm{~B}_{5}, \mathrm{~B}_{6}, \mathrm{~B}_{12}$, важная метаболическая функция которых во время беременности безусловно доказана.

Возможным заменителем фолиевой кислоты может стать естественная для биологических систем форма - [6S]5-метилтетрагидрофолат (5-МТГФ). Ее использование вместо фолиевой кислоты или в дополнение к ней было бы оправданно при доказательстве равной эффективности с точки зрения предотвращения формирования ДНТ. Поскольку взаимосвязь между уровнем фолатов и риском развития ДНТ уже доказана, то в качестве конечной точки исследования возможно использование такого параметра, как уровень фолатов в эритроцитах.

Целью двойного слепого рандомизированного плацебоконтролируемого исследования Y. Lamersu соавторов было изучение эффективности ежедневного приема 5-МТГФ по сравнению с фолиевой кислотой с точки зрения увеличения уровня фолатов в эритроцитах - общепринятого индикатора содержания фолатов и маркера риска возникновения ДНТ у здоровых женщин репродуктивного возраста.

После проведения скрининга в исследование были включены 144 женщины в возрасте 19-33 лет. Двойное слепое плацебо-контролируемое исследование с параллельным дизайном проводили в течение 24 нед. Участницы были рандомизированы на 4 группы и получали соответственно: 400 мкг фолиевой кислоты, 416 мкг 5-МТГФ, 208 мкг 5МТТФ и плацебо.

Исходно группы не различались по возрасту, индексу массы тела, содержанию фолатов в эритроцитах и плазме, а также по потреблению фолатов с пищей (таблица). Привер- 


\section{A K У Ш E P C T B O}

Исходные характеристики исследуемых групп

\begin{tabular}{|c|c|c|c|c|}
\hline Показатель & $\begin{array}{c}400 \text { мкг фолиевой } \\
\text { кислоты, n=34 }\end{array}$ & $\begin{array}{c}416 \text { мкг 5-МТГФ, } \\
n=35\end{array}$ & $\begin{array}{c}208 \text { мкг 5-МТГФ, } \\
n=33\end{array}$ & $\begin{array}{c}\text { Плацебо, } \\
\mathrm{n}=34\end{array}$ \\
\hline Возраст, годы & $23,6 \pm 3,2^{*}$ & $24,2 \pm 4,0$ & $23,1 \pm 2,7$ & $22,6 \pm 2,4$ \\
\hline Индекс массы тела, кг/м² & $20,7 \pm 2,4$ & $21,6 \pm 3,0$ & $21,0 \pm 2,3$ & $21,3 \pm 1,8$ \\
\hline $\begin{array}{c}\text { Содержание фолатов } \\
\text { в эритроцитах, нмоль/л }\end{array}$ & $668(593,752)^{\star \star}$ & $603(525,692)$ & $656(594,726)$ & $682(612,761)$ \\
\hline $\begin{array}{c}\text { Содержание фолатов в плазме, } \\
\text { нмоль/л }\end{array}$ & $19,3(16,3,22,9)$ & $18,3(15,9,21,1)$ & $19,6(16,8,22,8)$ & $19,7(17,5,22,2)$ \\
\hline $\begin{array}{c}\text { Потребление фолатов с пищей, } \\
\text { мкг/день }\end{array}$ & $244(212,281)$ & $252(215,295)$ & $225(199,254)$ & $232(204,263)$ \\
\hline
\end{tabular}

Примечания: *- арифметическое среднее \pm стандартное отклонение; ** - геометрическое среднее \pm стандартное отклонение.

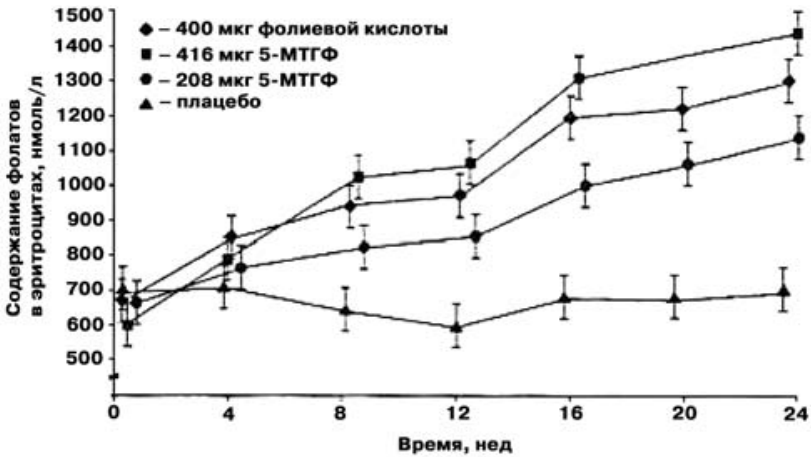

Рис. 1. Динамика средних геометрических значений содержания фолатов в эритроцитах в течение 24 нед приема

женность терапии была высокой, при этом не было достоверных различий между группами $(\mathrm{p}>0,05)$.

На рис. 1 и 2 представлены средние значения концентрации фолатов в эритроцитах и плазме крови во всех трех терапевтических группах и группе плацебо. Статистически достоверные изменения в динамике были выявлены как для концентрации фолатов в эритроцитах, так и для их концентрации в плазме.

Результаты долгосрочного исследования, проведенного в группе здоровых небеременных женщин, продемонстрировали более высокую эффективность биологически активной формы 5-МТГФ по сравнению с эквимолярной дозой фолиевой кислоты в отношении создаваемого уровня фолатов. В качестве индикатора уровня фолатов, непосредственно влияющего на риск развития ДНТ, выбрано содержание фолатов в эритроцитах. Половинная доза 5-МТГФ, равная 208 мкг/сут, не была настолько же эффективной, как доза

\section{Інноваційні підходи до корекції мікронутрієнтного статусу вагітних і жінок, що годують С.І. Жук, К.К. Бондаренко}

Більшість досліджень останніх років демонструють вплив порушень в обміні фолатів і метіоніновому циклі на патогенез дефектів нервової трубки (ДНТ) плода. Метафолін має ряд переваг, до яких в першу чергу відноситься безпосереднє надходження в організм людини речовин в біологічно активній формі і наявність оптимального ефекту, навіть у разі, коли у пацієнтки гомозиготний i/або гетерозеготний генотип 677C Т поліморфізму МТГФР.

3 метою профілактики та лікування різних патологічних станів, пов’язаних з дефіцитом фолатів під час вагітності, доцільно застосовувати вітамінно-мінеральні комплекси, що містять метафолін активну форму фолатів з високою біодоступністю.

Ключові слова: МТГФР, метафолін, фолієва кислота, вагітність.

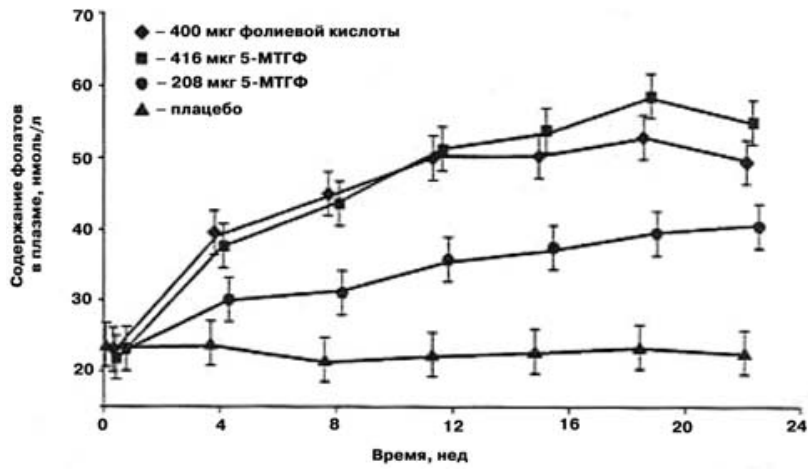

Рис. 2. Динамика средних геометрических значений содержания фолатов в плазме в течение 24 нед приема

416 мкг 5-МТГФ или 400 мкг фолиевой кислоты. Через 24 нед применения всех форм фолатов среднее содержание фолатов в эритроцитах превышало 906 нмоль/л, что принято за пороговое значение, после которого риск развития ДНТ минимален.

Результаты исследования доказали, что применение 5МТГФ более эффективно по сравнению с фолиевой кислотой увеличивает содержание фолатов в эритроцитах у женщин репродуктивного возраста. Дополнительный прием 5МГТФ может стать адекватной альтернативой фолиевой кислоте в поддержании нормального уровня фолатов и, таким образом, в снижении риска развития внутриутробных ДНТ. На основании полученных в исследовании данных рекомендуемый период приема фолиевой кислоты (в течение 4 нед до зачатия) для максимального снижения риска возникновения пороков нервной трубки плода может быть увеличен, как минимум, до 12 нед до зачатия.

\section{Innovative approaches to the correction of chronotrope status of pregnant and lactating women S.I. Zhuk, K.K. Bondarenko}

Most recent studies show the impact of violations in the metabolism of folate and metin period in the pathogenesis of neural tube defects (NTD) of the fetus. Metafolin has a number of advantages, which primarily includes direct intake of substances in biologically active form and the optimum effect, even in the case when the patient homozygote and/or heterozygote genotype $677 \mathrm{C}$ T polymorphism in MTHFR.

With the aim of prevention and treatment of various pathological conditions related to folate deficiency during pregnancy, it is advisable to apply vitamin-mineral complexes, containing metafolin - active form of folate with high bioavailability.

Key words: MTHFR, metafolin, folic acid, pregnancy. 


\section{A K У Ш E P C T B O \\ Сведения об авторах}

Жук Светлана Ивановна - Кафедра акушерства, гинекологии и медицины плода Национальной медицинский академии последипломного образования имени П.Л. Шупика, 04074, г. Киев, ул. Мостицкая,11. E-mail: Zhuksvitlana@ukr.net

Бондаренко Константин Константинович - Кафедра акушерства, гинекологии и медицины плода Национальной медицинский академии последипломного образования имени П.Л. Шупика, 04074, г. Киев, ул. Мостицкая,11; тел: (044) 460-54-45. E-mail: slim40@yandex.ua

\section{СПИСОК ЛИТЕРАТУРЫ}

1. Громова О.А. XIII Всероссийский научный форум «Мать и дитя». Сателлитный симпозиум компании «Д-р Редди'с Лабораторис Лтд.» Фолаты: мифы и реальность. Избыточные дозы фолиевой кислоты. Чего больше вреда или пользы? Гинекология. 2012; 5 .

2. Ших Е.В., Ильенко Л.И. Клиникофармакологические аспекты применения витаминно-минеральных комплексов у женщин в период беременности. - М.: Медпрактика, 2007; 80 Галина Т.В., Симоновская Х.Ю. Метафолин в составе КОК - инвестиция в репродуктивное благополучие. Мировые новости: современная контрацепция как новые возможности предгравидарной подготовки / Под ред. В.Е. Радзинского. - М.:
Редакция журнала StatusPraesens, 2013; 24.

3. Voutilainen S., Rissanen T.H. Virtanen J., Lakka T.A. Salonen J.T. Kuopio Ischemic Heart Disease Risk Factor Study. Low dietary folate intake is as excess incidence of acute coronary events: The Kuopio Ischemic Heart Disease Risk Factor Study. Circulation. 2001; 103 (22): 2674-2680.

4. Shane B. Folic acid, vitamin BI2, and vitamin B6. In: Stipanuk M, ed Biochemical and Physiological aspects of Human Nutrition. Philadelphia, PA6: WB Saunders Co.; 2000; 483-518. 5. Weir D.G., Molloy A.M. Microvascular disease and dementia in the elderly: are they related to hyperhomocysteinemia? Am J Clin Nutr. 2000; 71 (4): 859-860. 6. Morris M.C., Evans D.A., Schneider
J.A., Tangney C.C., Bienias J.L., Aggarwal N.T. Dietary folate and vitamins B-12 and B-6 not associated with incident Alzheimer's disease. J Alzheimers Dis. 2006; 9 (4): 435-443. 7. Wang H.X., Wahlin A., Basun H., Fastbom J., Winblad B., Fratiglioni L. Vitamin $B(12)$ and folate in relation to the development of Alzheimer's disease. Neurology. 2001; 56 (9): 1188-1294.

8. McNulty H., Cuskelly G.J., Ward M. Response of red blood cell folate to intervention: implications for folate recommendations for the prevention of neuronal tube defects. Am J Clin Nutr. 2000; 71: 5 Suppl: 1308S-1311S

9. Shane B. Folic acid, vitamin B-12 and vitamin B-6. In: Stipanuk M, ed. Biochemical and Physiological Aspects of Human Nutrition. Philadelphia, PA: WB Saunders Co.; 2000; 483-518. 10. Centers for Disease Control and Prevention. Spina bifida and anencephaly before and after folic acid mandate-United States, 1995-1996 and 1999-2000. MMWR Morb Mortal Wkly Rep. 2004; 53 (17): 362-365

11. McNulty H., Cuskelly G.J., Ward M. Response of red blood cell folate to intervention: implications for folate recommendations for the prevention of neuronal tube defects. Am J Clin Nutr. 2000; 71: 5 Suppl: 1308S-1311S.

12. Centers for Disease Control and Prevention. Spina bifida and anencephaly before and after folic acid mandate-United States, 1995-1996 and 1999-2000. MMWR Morb Mortal Wkly Rep. 2004; 53 (17): 362-365. 


\title{
Биорегуляционные возможности препаратов Вибуркол и Лимфомиозот в акушерстве и гинекологии
}

\author{
О.И. Остапенко \\ ООО «Институт планирования семьи», г. Киев
}

На современном этапе при лечении акушерско-гинекологических заболеваний (невынашивания беременности, дискоординации родовой деятельности, обезболивании родов, заболеваниях репродуктивной системы у женщин: воспалительных процессах, дисгормональных нарушениях и др.) используется широкий спектр лекарственных средств (ЛС). Среди традиционных ЛС наиболее широко применяются антибиотики, нестероидные противовоспалительные средства (НПВС), анальгетики, спазмолитики, гормональные препараты. Данные ЛС наряду с достижением быстрых и выраженных терапевтических эффектов вызывают различные побочные эффекты и имеют ряд противопоказаний (заболевания желудочно-кишечного тракта, риск тромбообразования, развитие иммунодефицита и др.) [12]. В связи с этим особого внимания и осторожности требует использование ЛС у беременных и кормящих матерей. Также актуальным является повышение эффективности лечения многих гинекологических заболеваний. Все это побуждает искать новые, более эффективные и безопасные подходы лечения и ЛС, в том числе патогенетические [12, 22].

В обзоре представлена краткая характеристика и обзор клинических исследований по применению патогенетического биорегуляционного подхода и комплексных биорегуляционных препаратов (КБП) Вибуркол, Лимфомиозот, Лимфомиозот Н в акушерстве и гинекологии при различных заболеваниях и нарушениях репродуктивной системы у женщин [1-3]. Результаты исследований демонстрируют, что включение одного или нескольких КБП в традиционные схемы лечения способствует сокращению сроков терапии, уменышению количества побочных эффектов, а в ряде случаев - и полному отказу от плохо переносимых пациентами ЛС. К тому же они не отягощают течение сопутствующих заболеваний, хорошо переносятся и обладают благоприятным профилем безопасности, могут применяться во время беременности и кормления грудью [4-22].

Ключевые слова: Вибуркол, Лимфомиозот, Лимфомиозот Н, биорегуляиионньй подход, комплексные биорегуляиионные препараты, акушерство, гинекология, заболевания репродуктивной системы у женщин.

$\mathrm{B}$ ажнейшей задачей современного акушерства и гинекологии является охрана репродуктивного здоровья и снижение перинатальной заболеваемости. Одной из актуальных проблем при решении этой задачи является значительное ограничение применения современных ЛС у женщин репродуктивного возраста и у беременных из-за потенциального или доказанного риска эмбриотоксического, тератогенного воздействии на развивающийся эмбрион/плод [7-10, 12]. В связи с этим актуальна оптимизация схем терапии посредством использования таких патогенетических подходов и препаратов, которые благодаря другим принципам действия на организм в составе комплексного лечения обеспечивают повышение как эффективности, так и безопасности для матери и плода, что является приоритетной задачей.

К одному из таких подходов, который позволяет решать изложенные выше задачи, относится биорегуляционный. Реализу- ется он через использование комплексных биорегуляционных препаратов (КБП). Ранее в литературе использовался термин «антигомотоксические препараты» (АГТП). КБП содержат сверхмалые дозы действующих веществ, которые способствуют активации процессов дренажа и детоксикации, восстановлению процессов саморегуляции в организме. Это, в свою очередь, ведет к активизации процессов самовосстановления/саногенеза. Важное свойство КБП - отсутствие фармакокинетики. Это связано с тем, что сверхмалые дозы действующих веществ не метаболизируются в организме и, следовательно, не требуют дополнительных затрат энергии, а значит, и не оказывают фармакологической нагрузки на организм. По сути, это другая фармакология - «фармакология малых/сверхмалых доз», в отличие от традиционных ЛС - «фармакологии больших доз». Следует отметить, что эти две фармакологии прекрасно сочетаются и дополняют друг друга при условии своевременного и правильного их применения [1-3].

Рассмотрим характеристики и результаты клинических исследований двух КБП, наиболее часто используемых в акушерско-гинекологической практике.

В акушерско-гинекологической практике достойное место занял КБП Вибуркол (ректальные суппозитории). Его широкий спектр действия обусловлен комплексом потенцированных растительных и минеральных компонентов [4-8]:

- Аптечная ромашка - повышает порог болевой чувствительности;

• Белладонна - оказывает выраженный анальгетический эффект и спазмолитическое действие на шейку матки;

• Сладко-горький паслен - обладает транквилизирующим действием;

- Подорожник - оказывает седативный эффект;

- Карбонатом кальция обусловлено анальгетическое действие;

- Ветреница - оказывает регулирующее действие на нейровегетативную систему и является одним из наиболее действенных гомеопатических компонентов для обезболивания родов [4-8].

Благодаря такому спектру действия Вибуркол при оказании акушерско-гинекологической помощи применяется по следующим клиническим показаниям:

- угроза выкидыша в I триместре беременности [8, 9];

- подготовка шейки матки к родам или прерыванию беременности на поздних сроках [9];

- профилактика аномалий родовой деятельности [7, 9];

- обезболивание родов $[9,10]$;

- хронические воспалительные заболевания органов малого таза $[11,12]$.

Эффективность и хорошая переносимость КБП Вибуркол в акушерстве и гинекологии изучена и подтверждена целым рядом научно-клинических исследований [5-12].

В клиническом исследовании «Антигомотоксическая терапия в профилактике дискоординации родовой деятельности» (Крамарский В.А. и соавт., 2008) приняли участие 52 беременные женщины, входящие в группу риска по развитию дискоординации родовой деятельности, которые были раз- 


\section{A K Y Ш E P C T B O}

делены на 2 группы. В 1-ю группу вошли 22 женщины, применявшие в конце беременности и во время родов свечи Вибуркол утром и вечером при появлении предвестников боли. При начавшейся родовой деятельности Вибуркол назначали каждые 3-4 ч. Во 2-й группе (30 женщин) применяли традиционные спазмолитики и $\beta$-миметики [7].

В результате нарушение сократительной деятельности матки (НСДМ) в 1-й группе имело место у $2(9,1 \%)$ женщин, а во 2 -й - у 7 (23,3\%), то есть в 2,5 раза чаще. Оперативное родоразрешение имело место только у женщин из 2-й группы, при этом одной из причин операции было НСДМ - у 4 (13,3\%). Состояние новорожденных при рождении: в 1-й группе оценка по шка-

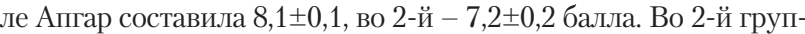
пе 3 новорожденных получали интенсивную терапию в связи с рождением в состоянии гипоксии (оценка по шкале Апгар $5,4 \pm 0,1$ балла).

По результатам исследования были сделаны следующие выводы: у беременных группы риска по развитию дискоординации родовой деятельности применение КБП Вибуркол приводит к достоверному снижению НСДМ, снижению оперативной активности и улучшению состояния новорожденнысх [7].

Интересная работа выполнена на кафедре акушерства и гинекологии лечебного факультета Московского медицинского стоматологического института «Эффективность гомеопати ческих свечей Вибуркол при обезболивании родов» (Тираспольский И.В. и соавт., 1998). В исследование было включено 40 рожениц в возрасте от 18 до 35 лет в сроке беременности от 33-й до 41-й недели. Из них 20 составили основную и 20 контрольную группу. С целью обезболивания роженицы основной группы получали ректальные свечи Вибуркол каждые 2-3 ч в зависимости от интенсивности болевых ощущений на протяжении всего I и в начале II периода родов до появления потуг. Роженицы контрольной группы получали традиционные спазмолитические и обезболивающие ЛС в I период родов. Анальгетический эффект отметили все пациентки основной (100\%) и 11 контрольной (55\%) групп. Седативный эффект наблюдался у 12 пациенток в основной $(60 \%)$ и ни у одной - в контрольной группе (0\%). Объективно отмечалась нормализация беспокойного поведения всех рожениц в основной и 3 - в контрольной группе. Побочные рефлекторные реакции в виде тошноты и рвоты отсутствовали в основной и наблюдались у 2 женщин в контрольной группе [8].

В заключение авторы отметили, что КБП Вибуркол соответствует всем современным требованиям, предъявляемым к анальгетикам в родах: оказывает анальгетическое и транквилизирующее действие, устраняет побочные рефлекторнье реакиии, не обладает отрииательным действием на сократительную деятельность матки и внутриутробное состояние плода. Все это является основанием для внедрения свечей Вибуркол в широкую клиническую практику с целью обезболивания родов [8].

Актуальность и эффективность применения Вибуркола и других КБП в акушерстве и гинекологии, подтвержденная рассмотренными и другими клиническими исследованиями, стала результатом их включения в методические рекомендации, утвержденные МЗ Украины. Например, методические рекомендации под редакцией д-ра мед. наук, проф. С.С. Ле- уш и соавторов «Оптимизачия лечения воспалительных заболеваний половых органов и профилактика спаечного процесса у женщин репродуктивного возраста» (2010) и «Антигомотоксическая терапия гинекологических заболеваний» (2006). В данных публикациях отражена эффективность применения КБП Вибуркол, обеспечивающего комплексный эффект (обезболивающий, спазмолитический, дезинтоксикационный, седативный и противовоспалительный) при лечении воспалительных заболеваний органов малого таза [11, 12].

Целесообразность применения свечей Вибуркол обоснована в методических рекомендациях «Применение гомеопатического метода в акушерстве» под редакцией проф., д-ра мед. наук И.Б. Манухина и соавт. (1998). В данной работе представлены научно обоснованные рекомендации по применению КБП/АГТП, в том числе Вибуркола, при угрозе выкидыша в первом триместре беременности, для подготовки шейки матки к родам, прерыванию беременности на поздних сроках, для профилактики аномалий родовой деятельности и обезболивания родов [9].

В гинекологии в составе комплексной терапии острых и хронических воспалительных прочессов, доброкачественных новообразования $x$ важное патогенетическое место заняли лимфодренажные КБП Лимфомиозот (капли пероральные) и Лимфомиозот $\boldsymbol{H}$ (раствор для инъекций) (таблииа) [5, 11, 12, 15-21]. В их состав входят компоненты в сверхмалых дозах растительного, животного и минерального происхождения, тропные к лимфатической системе, что обеспечивает препаратам разнонаправленное комплексное действие. Во-первых, они активируют лимфоотток из тканей, ускоряют выведение токсинов и избыток жидкости из межклеточного пространства тканей (дренажное, дезинтоксикационное действие). Во-вторых, они усиливают барьерные (защитные) функции лимфоузлов (иммунокорригирующее действие). В-третьих, оказывают противовоспалительное и противоэкссудативное действие [1, 3, 4, 6, 13-15].

Эффект дренирования тканей данными КБП также способствует повышению биодоступности применяемых одновременно традиционных ЛС. Например, антибактериальных средств, что позволяет достигать необходимой терапевтической концентрации обычными дозами антибиотиков, применять их самым коротким курсом, минимизировать их побочные эффекты, повышая в целом эффективность лечения [13-16].

В клиническом исследовании «Лечение хронических воспалительных заболеваний половых органов у женщин фертильного возраста с использованием препаратов Gynacoheel u Lymphomyosot», проведенном на базе Института педиатрии, акушерства и гинекологии АМН Украины (Подольский В.В. и соавт., 2002), участвовали 50 женщин с различными хроническими заболеваниями половых органов, а именно: хронический вагинит, хронический цервицит, хроническая воспалительная болезнь матки, хронический тазовый перитонит. Пациентки были разделены на 2 группы: 25 женщин основной группы получали только КБП/АГТП, в том числе Лимфомиозот; в контрольной группе 25 женщинам назначали традиционную антибактериальную и противовоспалительную терапию. Курс лечения длился две недели. В процессе лечения у больных основной группы гораздо раньше наступало субъективное улучшение состояния (уменьшение/исчезновение болевого синдрома, выделений из половых органов), что было

Рекомендации по применению КБП Лимфомиозот, Лимфомиозот Н

на различных этапах лечения гинекологических заболеваний

\begin{tabular}{|c|c|}
\hline Острый и подострый период, обострение & Завершение курса лечения \\
\hline Лимфомиозот Н (раствор для инъекций) & Лимфомиозот (капли) \\
\hline по 1,1 мл в/м, п/к, в/к & по 10 кап. сублингвально \\
\hline ежедневно №3-5 & 2 p/нед №5-10 \\
\hline
\end{tabular}




\section{A K Y Ш E P C T B O}

подтверждено микробиологическими, вирусологическими исследованиями, а также с помощью ультразвукового исследования органов малого таза. Были сделаны выводы, что антигомотоксическая терапия с успехом может быть использована для лечения хронических воспалительных заболеваний женских половых органов. Лимфомиозот в комбинации с органонаправленным противовоспалительным КБП/АГТП дает хороший терапевтический эффект, особенно в тех случаях, когда необходимы повторные курсы лечения, а традиционная антибактериальная и противовоспалительная терапия не дает ожидаемых результатов [17].

Высокий уровень клинической эффективности КБП в Украине демонстрируют многочисленные диссертационные работы в области акушерства и гинекологии. На базе Национальной медицинской академии последипломного образования имени П.Л. Шупика выполнена диссертационная работа на соискание ученой степени кандидата медицинских наук на тему «Реабилитация репродуктивной функции женщин после перенесенного сальпингоофорита» (автор Пархоменко А.П., научный руководитель - д-р мед. наук, проф. Вдовиченко Ю.П.). В работе предложены схемы терапии с использованием КБП/АГТП, включая Лимфомиозот. Включение в схемы терапии КБП/АГТП позволяет снизить частоту обострений и рецидивов сальпингоофоритов у женщин репродуктивного возраста, улучшить показатели имму ногенеза, улучшить эндокринную функиию яичников [18].

В методических рекомендациях МЗ Украины «Инфекиионно-воспалительные процессы женских половых органов у беременных и их лечение антигомотоксическими препаратами» (Подольский В.В и соавт., 2006) рекомендуется лечение инфекционно-воспалительных процессов женских половых органов у беременных женщин только с использованием Лимфомиозота и еще 2-х КБП/АГТП (противовоспалительного, иммунокорригирующего). Отмечается, что КБП/АГТП Әемонстрируют высокую эффективность и безопасность, в отличие от антибиотиков могут назначаться на ранних сроках беременности. Применение предложенной схемы лечения инфекционно-воспалительных процессов женских половых органов у беременных позволяет предотвратить развитие у пациенток осложнений беременности, в частности невынашивания беременности [19].

Подтверждает эффективность Лимфомиозота и других АГТП клиническое исследование «Оптимизация методов лечения хронических эндоцервикозов у женщин, инфицированных вирусом папилломы человека» (Татарчук Т.Ф., Захаренко Н.Ф., 2005). В исследовании приняли участие 58 больных в возрасте от 21 до 42 лет, разделенных на две группы. На первом этапе всем пациенткам проводили терапию сексуально-трансмиссивных инфекций, элиминацию патогенной микрофлоры и коррекцию гормонального фона. На втором этапе больным контрольной группы $(n=30)$ назначали традиционные иммуномодуляторы и противовоспалительный АГТП местно - в виде мазевых тампонов. Пациенткам основ- ной группы $(\mathrm{n}=28)$ к базовой терапии дополнительно назначали КБП/АГТП, в том числе - Лимфомиозот. Анализ результатов показал тенденцию к ускорению коррекции патологических изменений эпителия шейки матки в сравнении с группой контроля. Через 6 мес после лечения у женщин основной группы наблюдался только один случай рецидива в сравнении с шестью случаями в группе контроля. Авторы пришли к выводу, что использование КБП/АГТП в терапии цервикозов, ассоциированных с вирусом папилломы человека, повышает эффективность традиционной терапии, обеспечивает снижение количества рещидивов заболевания, а также уменьшает риск возможной малигнизации [20].

В рандомизированном клиническом исследовании «Современные особенности лечения полипоза эндометрия» (Татарчук Т.Ф. и соавт., 2005) изучали эффективность КБП/АГТП в составе комплексной терапии полипоза эндометрия. В исследовании приняли участие 70 женщин в возрасте 35-48 лет, которые были поделены на три группы. Все больные получали гестагены и антибиотики. Женщины первой группы $(\mathrm{n}=20)$ также принимали Лимфомиозот и другие КБП/АГТП (энерготропный препарат и регенерирующий слизистую оболочку). Вторую группу составили 20 женщин, которым были назначены традиционные средства и энерготропный КБП/АГТП. Пациентки третьей группы $(n=30)$ получали лишь традиционное лечение [21].

Результаты показали, что наиболее эффективной оказалась терапевтическая схема, которая была применена в первой группе. Сократилась длительность менструального кровотечения, снизилась высеваемость условно-патогенных возбудителей, улучшилась морфологическая характеристика эндометрия. Через месяц после завершения лечения в первой группе не наблюдалось ни одного рецидива полипоза эндометрия, в то время как в третьей группе рецидивы наблюдались у 6,6\% пациенток [21].

Сделан вывод о том, что применение КБП/АГТП в комплексном лечении полипоза эндометрия позволяет значительно повысить эффективность терапевтических мероприятий [21].

\section{Выводы}

Рассмотренный выше обзор показывает, что использование биорегуляционного подхода и сверхмалых доз КБП проверенный временем способ решения ряда актуальных проблем медикаментозной терапии в акушерстве и гинекологии. КБП Вибуркол, Лимфомиозот и Лимфомиозот Н позволяют расширить возможности фармакотерапии. Они имеют как установленную терапевтическую эффективность, так и благоприятный профиль безопасности, что подтверждается исследованиями, диссертациями и официальными рекомендациями МЗ Украины. Их можно применять как самостоятельно, так и включать в схемы лечения с традиционными ЛС. Это дает акушеру-гинекологу гибкость и более широкие возможности при составлении и проведении более эффективной комплексной терапии [4-21]

Информация предназначена для профессиональной деятельности фармацевтических и медицинских работников.

Полная информация о препаратах указана в инструкциях по медицинскому применению.

Дополнительная информация о препаратах.

Лимфомиозот, капли перорапьные. PC № UA/6673/01/01 от 15.06.12. Состав: Araneus diadematus D6, Calcium phosphoricum D12, Equisetum hiemale D4, Ferrum iodatum D12, Fumaria officinalis D4, Gentiana lutea D5, Geranium robertianum D4, Juglans regia ssp. regia D3, Levothyroxinum D12, Myosotis arvensis D3, Nasturtium officinale D4, Natrium sulfuricum D4, Pinus sylvestris D4, Scrophularia nodosa D3, Smilax D6, Teucrium scorodonia D3, Veronica officinalis D3. Побочные действия: в очень редких случаях возможны реакции гиперчувствительности, включая кожные высыпания, зуд, крапивницу.

Лимфомиозот Н, р-р для инъекций. PC №UA/2054/01/01 от 17.11.14. Состав: Araneus diadematus D6, Calcium phosphoricum D12, Equisetum hiemale D4, Ferrum iodatum D12, Fumaria officinalis D4, Gentiana lutea D5, Geranium robertianum D4, Levothyroxinum D12, Myosotis arvensis D3, Nasturtium officinale D4, Natrium sulfuricum D4, Pinus sylvestris D4, Scrophularia nodosa D3, Smilax D6, Teucrium scorodonia D3, Veronica officinalis D3. Побочные действия: в единичных случаях могут возникать реакции гиперчувствительности (или анафилактические реакции), а также изменения в месте введения, тошнота, головокружение, потеря сознания, потливость, покраснение лица, общая слабость. В очень редких случаях возможны реакции гиперчувствительности, включая зуд, эритему, отек или сухость.

Производитель. «Биологише Хайльмиттель Хеель ГмбХ», (Баден-Баден, Германия) 


\section{A K Y Ш E P C T B O}

\section{Біорегуляційні можливості препаратів Вібуркол і Лімфоміозот в акушерстві та гінекології О.І. Остапенко}

На сучасному етапі при лікуванні акушерсько-гінекологічних захворювань (невиношування вагітності, дискоординація родової діяльності, знеболювання пологів, захворювання репродуктивної системи у жінок: запальні процеси, дисгормональні порушення та ін.) використовується широкий спектр лікарських засобів (ЛЗ). Серед традиційних ЛЗ найбілыш широко застосовуються антибіотики, нестероїдні протизапальні засоби, анальгетики, спазмолітики, гормональні препарати. Дані Л3 разом зі швидким вираженим терапевтичним ефектом спричинюють різні побічні ефекти і мають низку протипоказань (захворювання печінки, підшлункової залози, ризик тромбоутворення, розвиток імунодефіциту та ін.) [12]. У зв'язку з цим особливої уваги та обережності вимагає використання ЛЗ у вагітних і матерів-годувальниць. Також актуальним є і підвищення ефективності лікування багатьох гінекологічних захворювань. Усе це спонукає шукати нові, більш ефективні та безпечні підходи лікування і Л3, у тому числі патогенетичні [12, 22].

В огляді представлена коротка характеристика і клінічні досліджен ня щодо застосування біорегуляційного підходу і комплексних біорегуляційних препаратів (КБП) Вібуркол, Лімфоміозот, Лімфоміозот Н в акушерстві та при різних захворюваннях і порушеннях репродуктивної системи у жінок [1-3]. Результати досліджень демонструють, що включення одного або декількох КБП у традиційні схеми лікування сприяє скороченню термінів терапії, зменшенню кількості побічних ефектів, а в ряді випадків повної відмови від ЛЗ, що погано переносяться пацієнтами. До того ж вони не обтяжують перебіг супутніх захворювань, добре переносяться і мають сприятливий профіль безпеки, можуть застосовуватися під час вагітності та годування груддю [4-22].

Ключові слова: Вібуркол, Лімфоміозот, Лімфоміозот Н, біорегуляиійний підхід, комплексні біорегуляиійні препарати, акушерство, гінекологія, захворювання репродуктивної системи у жінок.

\section{Bioregulatory opportunities of Viburkol and Limphomiozot medicines in obstetries and gynecology O. Ostapenko}

Modern obstetrics and gynecology use a wide range of medicines (drugs) when accompanied by pregnancy and childbirth (miscarriage, discoordination labor, labor pain relief), diseases of the female reproductive system (inflammation, dishormonal disorders, etc..). Among the traditional drugs most widely used antibiotics, NSAIDs, analgesics, antispasmodics, hormones. These drugs, along with the achievement of rapid and pronounced therapeutic effects cause different side effects, and have a number of contra-indications (diseases of the liver, the pancreas, the risk of thrombosis, the development of immunodeficiency, etc.) [12]. In this regard, special attention and care requires the use of drugs in pregnant women and nursing mothers. Also relevant is the increase of efficiency of treatment of many gynecological diseases. All these and many other factors encourage to search for new - more effective and safer treatment approaches and drugs, including pathogenesis [12, 22].

The review presents brief characteristics and clinical researches on the use and integrated bioregulatory approach through the use of complex combination bioregulatory medicines (CBM) Viburkol, Limphomiozot, Limphomiozot $\mathrm{N}$ in obstetrics and in various diseases and disorders of the female reproductive system [1-3]. The research results show that the inclusion of one or more of the CBM in the traditional treatment help reduce the duration of therapy, a decrease in some side effects, and in some cases rejection of it. In addition, they do not burden for opportunistic diseases, tolerated well and have a favorable safety profile, can be used during pregnancy and lactation [4-22]

Key words: Viburkol, Limphomiozot, Limphomiozot $N$, bioregulatory approach, combination bioregulatory medicines, obstetrics, gynecology, diseases of the female reproductive system.

\section{Сведения об авторе}

Остапенко Ольга Ивановна - ООО «Институт планирования семьи», 04050, г. Киев, ул. Платона Майбороды, 8. E-mail: ostapenko@ipf.kiev.ua

\section{СПИСОК ЛИТЕРАТУРЫ}

1. Хайне Хартмут. Значение антигомотоксической терапии в регуляторной медицине // Биологическая медицина. - 2004. - № 2. - С. 4-9.

2. Клименко В.Г. Основные положения патогенетического биорегуляционного подхода в общей терапевти ческой практике // Биологическая терапия. - 2013. - № 1. - С. 8-11.

3. Ван Брандт Б., Хайне Х. Регуляторная блокада: определение, значение и терапия//Биологическая медицина - 2006. - С. 4-5.

4. Реквег Г.-Г. Гомеопатическая антигомотоксикология // Гомеопатическая медицина. - Смоленск, 1997. $591 \mathrm{c.}$.

5. Шамугия Б.К., Тимошков М.В. Биорегуляционный подход к лечению боли // Therapia. - 2013. № 2 (77). - С. 75-78.

6. Возможности применения препарата Вибуркол в педиатрической, акушерской и гинекологической практике // Новости медицины и фармации. - 2013. - № 5 (449). C. 10-11

7. Крамарский В.А., Дудакова В.Н. Антигомотоксическая терапия в профилактике дискоординации родовой деятельности // Биологическая медицина. - 2008. - № 2. - С. 23-24. 8. Тираспольский И.В., Каширина Т.Н., Бусоргина О.В., Кузьмин В.Н., Совдагарова Ю.Э. Эффективность гомеопатических свечей Вибуркол при обезболивании родов // Биологическая медицина. - 1998. - № 1. - С. 35-38.

9. Манухин И.Б., Каширина Т.Н., Тираспольский И.В., Бусоргина О.В. Хареба Л.В. Применение гомеопатического метода в акушерстве // Meтодические рекомендации № 137/98 М3 России. - М., 1998. - 18 с.

10. Тираспольский И.В., Каширина Т.Н., Бусоргина О.В., Совдагарова Ю.Э. Методология и опыт проведения терапии угрожающего выкидыша в первом триместре беременности комплексными гомеопатическими препаратами // Биологическая медицина. - 1999. - № 1. C. 40-44.

11. Леуш С.С., Олейник Ю.В., Олейник Е.А. Оптимизация лечения воспалительных заболеваний половых органов и профилактика спаечного процесса у женщин репродуктивного возраста / Методические рекоменда- ции МЗ Украины. - К., 2010. - 32 с 12. Леуш С.С., Олійник Ю.В. Антигомотоксична терапія гінекологічних захворювань / Методичні рекомендації М03 України. - К., 2006. - 30 с. 13. Чурсина Т.Я., Михалев К.А. Аллопатическая и антигомотоксическая терапия острого воспаления: альтернативные или взаимодополняющие пути? // Биологическая терапия. 2006. - № 1. - C. 17-21.

14. Лимфомиозот - эффективный лимфодренажный и противоотечный комплексный биологический препарат // Биологическая терапия. 2013. - № 1. - C. 42-44.

15. Антигомотоксическая терапия в лечении хронического воспаления в гинекологии: эффективность и безопасность // Мистецтво лікування. 2008. - № 3 (49). - C. 58-60.

16. Лахно И.В. Антигомотоксические препараты и репродуктивная функция женщин // Медицинские аспекты здоровья женщины. - 2007. № 3 (6). - С. 31-34.

17. Подольский В.В., Дронова В.Л. Подольский Вл.В. Лечение хронических воспалительных заболеваний половых органов у женщин фертиль- ного возраста с использованием препаратов Gynacoheel и Lymphomyosot // Биологическая терапия. 2002. - № 1. - С. 3-7.

18. Пархоменко А.П. Реабилитация репродуктивной функции женщин после перенесенного сальпингоофорита: Автореф. дисс. ... канд. мед. наук (МЗ Украины). - К., 2003.

19. Подольский В.В., Дронова В.Л., Латышева 3.М., Тетерин В.В., Геревич Г.Й., Теслюк Р.С., Федунов Ю.С. Инфекционно-воспалительные процессы женских половых органов у беременных и их лечение антигомотоксическими препаратами // Методические рекомендации МЗ Украины. - К., 2006. - 26 с.

20. Татарчук Т.Ф., Захаренко Н.Ф. Оптимізація методів лікування хронічних ендоцервікозів у жінок, інфікованих вірусом папіломи людини // Биологическая терапия. - 2005. - № 4. - C. 14-18.

21. Татарчук Т.Ф., Лысяная Т.А., Задорожная Т.Д., Бурлака О.В., Корена К.О. Сучасні особливості лікування поліпозу ендометрія // Биологическая терапия. - 2005. - № 4. C. 34-36. 


\title{
Важность и значение полиморфизма генов при преэклампсии
}

\author{
П.Н. Веропотвелян ${ }^{1}$, И.С. Цехмистренко ${ }^{2}$, Н.П. Веропотвелян ${ }^{1}$, Н.С. Русак ${ }^{1}$, П.С. Горук ${ }^{1}$ \\ ${ }^{1}$ ОКУ «Межобластной центр медицинской генетики и пренатальной диагностики», г. Кривой Рог \\ ${ }^{2}$ Перинатальный центр, г. Киев \\ ${ }^{3}$ КУ «Криворожский городской клинический родильный дом № 1» ДОС»
}

В статье приведен систематический обзор данных о взаимосвязи между полиморфизмами генов системы детоксикации и развитием преэклампсии (ПЭ). Описаны основные гены системы детоксикации (GSTPI,

GSTMI, GSTTI, GPXI, EPHXI, SOD-2, SOD-3, CYPIAL, MTHER, MTR) и их функции. Представляет интерес возможность расчета индивидуального риска развития ПЭ на основании данных о наличии сочетаний разных полиморфизмов в генотипе женщины. Вопрос о ранней диагностике ПЭ остается дискутабельным и до конца не изученным. Необходимо проводить дальнейшее углубленное расширенное исследование данной проблемы.

Ключевые слова: преэклампсия, окислительный стресс, гень системы детоксикации.

$\mathrm{H}$

ачало XXI столетия ознаменовалось динамичным развитием биоинформационных технологий и формированием нового направления - персонифицированной медицины, которая ориентирована на индивидуальный подход к выбору лекарственных препаратов, диагностике, лечению такого осложнения при беременности, как преэклампсия (ПЭ).

ПЭ на сегодня остается одним из наиболее распространенных осложнений беременности, приводящим к серьезным нарушениям в организме матери и плода. Согласно исследованиям N.A. Jameil и соавторов (2014), в структуре материнской и пренатальной заболеваемости и смертности ПЭ занимает третье место, а ее частота от общего числа родов составляет от $11 \%$ до $16 \%$ [7].

Исследования Р. James и соавторов свидетельствуют, что в мире ежегодно регистрируют 8 млн случаев ПЭ, которая является основной причиной материнской и перинатальной смертности, унося жизни 60 тыс. молодых женщин ежегодно [17].

Исследования C. Redman и соавторов иллюстрируют, что развитие ПЭ проходит две стадии [18]. Характерным является то, что в начале возникает нарушение плацентации, включающее неполную инвазию трофобласта в децидуальную оболочку матки и нарушение ремоделирования маточных спиральных артерий, вследствие чего данное нарушение перфузии плаценты приводит к развитию гипоксии и окислительного стресса (рис. 1).

Вторая стадия заболевания проявляется клиническими симптомами в виде артериальной гипертензии, протеинурии, отеков, которые обусловлены повреждением эндотелия и системным воспалением.

По мнению Т. Cronqvist и соавторов (2014), повреждение эндотелия может быть вызвано рядом факторов, выделяемых в том числе синцитиотрофобластом, например микровезикулами [19]. Подобные везикулы могут переносить молекулы ДНК, РНК и белков и обусловливать системные реакции в ответ на местные изменения в плаценте при ПЭ. N. Kan и соавторы отмечают, что все эти изменения в плаценте характерны для дисфункции, проявляющейся окислительным стрессом [11].
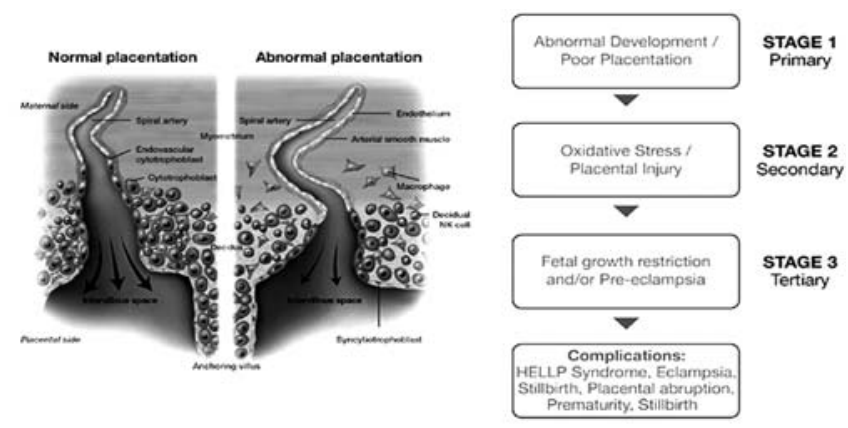

Рис. 1. Развитие преэклампсии [43]

Окислительный стресс - дисбаланс между антиоксидантами и прооксидантами с преобладанием последних. К прооксидантам относят активные формы кислорода и их производные. Они постоянно образуются в живых клетках и необходимы для функционирования клеток иммунной системы. Защита клетки от увеличения содержания активных форм кислорода осуществляется антиоксидантными ферментами (супероксиддисмутаза, каталаза и др.) и неферментными антиоксидантами (глутатион, тиоредоксин, никотинамидадениндинуклеотид (НАД), никотинамидадениндинуклеотидфосфат (НАДФ) [20].

Окислительный стресс при физиологически протекающей беременности играет важную роль в адаптации организма матери к генетически чужеродным тканям плода, так как увеличение окислительного стресса, возможно, связано с ишемией плаценты и повышенной продукцией активных форм кислорода (рис. 2).

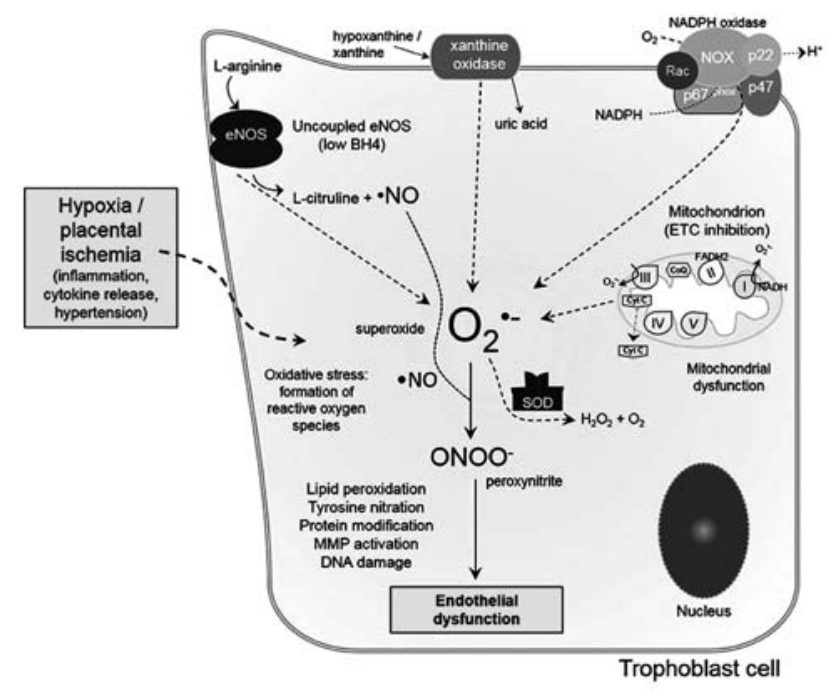

Рис. 2. Механизм развития эндотелиальной дисфункции при ПЗ [44] 


\section{A K Y Ш E P C T B O}

S. Walsh приводит альтернативный механизм увеличения окислительного стресса при ПЭ, где может наблюдаться функциональная недостаточность системы антиоксидантной защиты [21]. Работы других исследователей также иллюстрируют, что уровень окислительного стресса значительно выше в плацентах беременных с ПЭ, чем у здоровых беременных [18].

В публикациях отмечается, что способствующими факторами усиления окислительного стресса в плаценте могут являться однонуклеотидные генетические полиморфизмы генов (ОНП), кодирующие ключевые ферменты системы детоксикации.

В методических документах Европейской ассоциации перинатологов, акушеров-гинекологов хорошо освещается и показано, что глутатион-S-трансферазы (GST) - группа ферментов системы детоксикации (и фазы биотрансформации), катализирующих реакции конъюгации электрофильных ксенобиотиков (лекарственных препаратов, продуктов окислительного стресса, канцерогенов и экзогенных токсинов), с восстановленной формой глутатиона, что приводит к снижению активности этих веществ и дальнейшему выведению их из организма $[22,23]$.

В клетках GST подразделяются на цитозольные, митохондриальные и микросомальные. В свою очередь фермент GSTP1 (глутатион-S-трансфераза пи-1) присутствует во всех органах и тканях организма, за исключением эритроцитов (в них функционирует другой класс GST), и является основным GST в плаценте женщины.

В работах ученых [24] показано, что уровень GSTP1 ниже в плацентах при ПЭ по сравнению со здоровыми беременными, что подтверждает предположение о связи варианта $\mathrm{Val} / \mathrm{Val}$ этого полиморфизма с ПЭ. Аналогично эти результаты подтверждаются и другими исследователями [25]. Но в то же время, другие ученые не рекомендуют делать однозначный вывод о роли ОНП rs 1695 в развитии ПЭ [26, 27].

В проведенных исследованиях Н. Norppa не обнаружено значимо статистических различий, однако отмечено достаточно высокую частоту гомозиготных делеций генов GSTMI и GSTTI [28].

A. Sandoval-Carrillo и соавторы продемонстрировали в своих исследованиях повышенный риск развития ПЭ при нулевых делециях данных генов [29]. В других исследованиях, которые проводились раннее, тоже не было зарегистрировано статистически значимых различий [30, 31]. Однако Y. Kim и соавторы отметили, что при сравнительном анализе плацент пациенток с ПЭ и без нее зарегистрировано увеличение экспрессии GST при ПЭ, но в тоже время авторы не уточнили, какой это класс GST [32].

Представляет интерес ген GPX-1, кодирующий аминокислотную последовательность фермента глутатионпероксидазы-1 (GPX-1).

Данное семейство GPX включает 8 представителей, отличающихся локализацией и субстрактной специфичностью. GPX-1 наиболее широко распространена в организме, встречается в клетках различных органов и тканей. GPX-1 принимает участие в детоксикации перекиси водорода: катализирует реакции конъюгации перекиси водорода с восстановленной формой глутатиона, в результате чего образуется вода и глутатиондисульфид.

Группа ученых проследила связь между активностью GPX в сыворотке крови пациенток с ПЭ и ОНП в генах разных классов GPX, при которой статистически значимых ассоциаций не регистрировали ни с одним из полиморфизмов [33] Сравнение частот разных аллелей ОНП при ПЭ и у здоровых беременных тоже не определило существенных различий. Но, тем не менее, целесообразно подчеркнуть, что такой анализ требует больших выборок и другого дизайна исследования.

Результаты исследований экспрессии генов GPX в плаценте при ПЭ неоднозначны.
Исследования G. Sukhikh и соавторов свидетельствуют о значительном увеличении экспрессии GPX в плацентах пациенток с ПЭ в 36,4\% случаев [34]. Однако другие исследователи обнаружили снижение экспрессии GPX-1, GPX-3 [35].

Также ряд ученых проиллюстрировали, что в плаценте с ПЭ происходит значительное снижение активности фермента GPX-4, и сделали предположение о наличии посттрансляционных модификаций или мутаций, не влияющих на уровень экспрессии гена, но приводящих к снижению активности фермента GPX [35-37]. Авторы указывают на интересный факт - при оценке активности GPX в плацентах пациенток с ранней и поздней ПЭ было установлено, что активность GPX отмечена ниже при ранней, чем при поздней ПЭ, и в обоих вариантах заболевания уровень активности был ниже, чем у здоровых беременных.

J. Yап, Y. Хи [38] сообщают: врач должен помнить, что эти результаты косвенно подтверждают представления о большей тяжести заболевания при ранней по сравнению $c$ поздней ПЭ.

Для дальнейших исследований представляет особый интерес поиск значимых ассоциаций между ОНП в генах GPX и развитием ПЭ с учетом влияния на уровень экспрессии генов и активность кодируемого фермента. Как отмечает N. Kan и соавторы, ген ЕРНХІ кодирует аминокислотную последовательность фермента системы детоксикации эпоксидгидролазы-1, который катализирует реакции фазы биотрансформации эпоксидов, в результате чего может происходить либо активация, либо подавление [11].

Ряд исследователей сообщают, что эпоксиды бывают как экзогенными, образующимися при деградации ароматических соединений (полициклических ароматических углеводородов), так и эндогенными, являющимися сигнальными молекулами, участвующими в регуляции сосудистого тонуса, воспаления, ангиогенеза [22, 39]. Наиболее в кодирующей области гена ЕРНХІ изучены два ОНП: ЕРНХІ c.337 $>$ G $>$ p. Tyr113-His (rs 1051740) и ЕPHXI c.416 A $>$ G- $>$ p. His 139 Arg (rs 2234922).

В исследованиях группы ученых статистически значимых различий между частотами генотипов и аллелей при ПЭ и в группе контроля не отмечены [40]. Но, тем не менее, отмечено, что гаплотип Т и A (Tyr1l3-His139), для которого характерна высокая ферментативная активность, достоверно чаще встречается у пациенток с ПЭ, чем в группе контроля.

Однако, как отмечают другие исследователи, при совместном анализе двух полиморфизмов (rs 1051740, rs 2234922) в одном гаплотипе получили статистически значимые различия [41].

В своей работе некоторые ученые констатируют, что во множественной логистической регрессионной модели, учитывавшей возраст, национальность и паритет, было показано, что в условиях рецессивной модели полиморфизм Tyr1l3 увеличивает риск развития тяжелой ПЭ в 3,5 раза среди всех случаев ПЭ [11]. Характерно то, что значимых различий между частотами аллелей при ПЭ и в группе контроля не регистрировали, как и в выше указанных исследованиях.

По мнению ученых, в условиях повышенной активности фермента ЕРНХІ усиливается инактивация им эпоксиэйкозатриеновых кислот (продукты метаболизма арахидоновой кислоты), способствующих вазодилатации при отсутствии оксида азота, что приводит к повышению тонуса сосудов. Роль такого механизма в патогенезе ПЭ не совсем ясна, поэтому необходимо дальнейшее изучение. Во всех проведенных исследованиях в качестве материала для генотипирования использовали кровь матерей, за исключением только одного исследования, в котором анализ генотипа матери проводили совместно с генотипом младенца [26].

В литературе имеется ряд работ, где показано, что супероксиддисмутаза (SOD) - это фермент, играющий важную 


\section{A K Y Ш E P C T B O}

роль в антиоксидантной защите всех клеток организма от активных форм кислорода. SOD катализирует дисмутацию супероксидазы (побочного продукта окислительного фосфорилирования) до перекиси водорода и молекулярного кислорода. SOD имеет три изоформы: SOD-1, SOD-2, и SOD-3.

После проведенных исследований возник интерес к SOD при ПЭ, где было проиллюстрировано, что активность фермента SOD-1 и уровень экспрессии гена SOD-1 существенно снижены в клетках трофобласта плаценты при ПЭ в сравнении с нормальной беременностью [42]. В других исследованиях было установлено, что полиморфизм rs 4880 T>C Val-9Ala гена SOD-2 связан с усилением окислительного стресса [14].

В работах отдельных исследователей не было подтверждено предположение о связи между SOD и ПЭ. А также, кроме того, не было отмечено активности ферментов SOD-1 и SOD-2 в тканях плаценты у пациенток с ПЭ и группы контроля. Особенностью данного исследования являлось то, что генотипированию подвергались ткани плаценты, - это показывает, что анализировали генотип плода, а не матери.

Но, тем не менее, ряд исследователей обнаружили статистически значимые различия [15]. Генотип rs 4880, приводящий к $\mathrm{Val} / \mathrm{Val}$, существенно чаще регистрировали в группе с ПЭ, чем в группе контроля. По мнению этих ученых, данный полиморфизм затрагивает аминокислотную последовательность SOD-2 в участке, ответственном за транспорт в митохондрии [15].

При выявлении Val вместо Ala изменяется конформация SOD-2 и уменьшается ее содержание в митохондриях, что приводит к снижению защиты против окислительного стресса, который участвует в патогенезе ПЭ. При сочетании Val/Val SOD-2 и Gly/Gly SOD-3 намного увеличивается риск развития ПЭ по сравнению с группой контроля (отношение шансов - 8,51; 95\% CI 2,73-36,25).

K. Rosta и соавторы [16] не обнаружили ассоциации между полиморфизмом Ala40Thr гена SOD-3. Но в то же время продемонстрировано, что у носителей мутантных аллелей значительно повышен риск тяжелой внутриутробной задержки роста плода в сочетании с ПЭ.

Согласно результатам одного исследования, зарегистрировано значительное повышение активности фермента SOD как в плаценте, так и в сыворотке крови пациенток с ПЭ по сравнению с группой контроля [2]. Такие результаты ставят под сомнение изначальные представления о снижении активности SOD в плаценте.

Характеризуя ген NAT-2, можно сказать, что он кодирует аминокислотную последовательность фермента $\mathrm{N}$ - ацетилтрансферазы-2 (II фаза биотрансформации). Данный фермент катализирует реакции переноса ацетильной группы на ксенобиотики (ариламины, гидразины) и канцерогены, что может приводить к их биоактивации или биоинактивации.

P. Zusterzeel и соавторы использовали кофермент в качестве кофактора и оценивали связь между статусом ацетилирования (быстрым, средним, медленным) и ПЭ [3]. В данном исследовании отмечалось, что в группе пациенток с ПЭ было значимо большее число быстрых ацетиляторов, чем в группе контроля. Исследователи также предлагают использовать статус ацетилирования NAT-2 в качестве предиктора развития ПЭ, но при этом учитывать нежелательность применения кофеина и других субстратов NAT-2 в связи с ограниченными возможностями фермента во время беременности.

Ген CYPIAL кодирует аминокислотную последовательность фермента цитохрома P450LAI (I фаза биотрансформации), который относится к суперсемейству ферментов цитохрома Р450. Участники этой огромной группы являются монооксигеназами и катализируют реакции метаболизма ксенобиотиков и, кроме того, принимают участие в синтезе холестерина, стероидов и других липидов.
В одном из исследований проиллюстрировано, что экспрессия CYPIAL не отличается в эндотелиальных клетках маточных артерий беременных и небеременных женщин [4]. Имеющиеся данные в целом не дают возможности сделать заключение о связи между полиморфизмами CYPIAL и ПЭ.

Ген MTHFR кодирует аминокислотную последовательность фермента метилентетрагидрофолатредуктазы. Данный фермент относится к фолатному циклу и катализирует преобразование 5,10-метилентетрагидрофолата в 5-метилтетрагидрофолат, который используется для синтеза метионина из гомоцистеина. Затем метионин превращается в универсальный донор метильной группы S-аденозинметионин, используемый для метилирования ДНК и белков.

A. Laraqui и соавторы [5] рассматривают гомоцистеин цитотоксическим и тромбогенным фактором в кровеносном русле, играющим важную роль на ранних стадиях развития эндотелиальной дисфункции.

На сегодня хорошо известно, что гипергомоцистеинемия увеличивает риск возникновения различных акушерских осложнений, в том числе ПЭ [6].

Снижение активности фермента OHП гена MTHFR может приводить к повышению уровня гомоцистеина в сыворотке крови.

В настоящее время хорошо изучены два полиморфизма гена MTHFR: MTHFR c.665 C >T-> p. Ala $222 \mathrm{Val}$ (rs 1801133) и MTHFR c.1298A>C-> p.Glu 429 Ala (rs 1801133).

Ученые - X. Wu и соавторы - провели мета-анализ, который обобщает результаты 54 исследований MTHFR C677T, включающих участие 7398 беременных с ПЭ и 11230 здоровых [8]. Авторы указывают на наличие повышенного риска развития ПЭ у носительниц полиморфизма MTHFR C677T.

Затем в отношении MTHFR Al 298C изучено путем сравнения 1103 случаев ПЭ и 988 случаев в группе контроля, при котором значимых различий не обнаружено. Представленные результаты согласуются с данными мета-анализа, проведенного другими исследователями [9].

Результаты исследования S. Salimi и соавторов также представляют интерес. Авторы демонстрируют, что риск развития ранней ПЭ у пациенток с аллелью 1298C (АС/CС) регистрировали значительно чаще по сравнению с поздней ПЭ и, кроме того, по сравнению с группой контроля [10].

Несмотря на то что не были обнаружены достоверные различия, как указывают N. Kan и соавторы [11], между частотой развития ПЭ среди носителей аллели 677Т и здоровыми, при учете обоих полиморфизмов (СТ-, ТT/AC-, СС- генотипы) риск развития ПЭ по сравнению с группой контроля существенно увеличивался - в 1,5 раза, а риск развития ранней ПЭ в 2,9 раза. Эти результаты подтверждают данные о различиях в патогенезе ранней и поздней ПЭ, что может быть значимым в выборе тактики ведения пациентки с ПЭ.

Ген MTR кодирует аминокислотный фермент 5-метилтетрагидрофолат-гомоцистеин-метилтрансферазы, известный как кобаламин-зависимая метионинсинтаза. Данный фермент катализирует реакцию биосинтеза метионина из гомоцистеина. Согласно резолюции медицинских документов Европейской ассоциации перинатологов, акушеров-гинекологов - для действия метионинсинтазы необходим метилкобаламин, производное витамина $\mathrm{B}_{12}[22,23]$.

Мутации гена MTR способны приводить к дефектам нервной трубки, недостаточности метилкобаламина типа $\mathrm{CbIG}$, которая проявляется мегалобластной анемией и гомоцистеинемией. Затем указывается, что единственный полиморфизм, который изучали при ПЭ, - MTR c.2756A>G-> p.Asp 919 Gly (rs 1805087). Распространенность более редкого варианта - G b rs1801133 составляет 21,85\% [22].

Как информируют E. Also-Rallo и соавторы и A. PerezSepuveda, в документах резолюции не установлена статистичес- 


\section{A K Y Ш E P C T B O}

ки значимая связь между этим полиморфизмом и ПЭ [1, 12]. Кроме того, в своем исследовании A. Perez-Sepulveda и соавторь также измеряли экспрессию MTR и MTHFR в плаценте [12].

Кроме того Проф. А. Seremak-Mrozikiewicz и соавторы обнаружили значительное повышение экспрессии MTR в плаценте при ПЭ, но, тем не менее, экспрессия MTHFR не отличалась от показателей в группе контроля [13]. Исследователи пришли к заключению, что, возможно, повышение экспрессии MTR является компенсаторным механизмом, связанным с метаболизмом гомоцистеина и его ролью в патогенезе ПЭ.

Таким образом, согласно множеству публикаций, в современной концепции патогенеза ПЭ особая роль отводится разделению ее на раннюю и позднюю.

Целесообразно отметить, что патогенетические события, связанные с окислительным стрессом, происхо-

\section{Важливість і значення поліморфізму генів при прееклампсії \\ П.М. Веропотвелян, І.С. Цехмістренко, М.П. Веропотвелян, Н.С. Русак, М.С. Півнєв}

У статті приведений систематичний огляд даних про взаємозв'язок між поліморфізмами генів системи детоксикації та розвитком прееклампсії (ПЕ). Представлено основні гени системи детоксикації (GSTPI, GSTMI, GSTTI, GPXI, EPHXI, SOD-2, SOD-3, CYPIAI MTHER, MTR) та їхні функції. Становить інтерес можливість розрахунку індивідуального ризику розвитку ПЕ на підставі даних про наявність сполучень різних поліморфізмів у генотипі жінки Питання щодо ранньої діагностики ПЕ залишається дискутабельним і до кінця не вивченим. Необхідно проводити подальше поглиблене розширене дослідження даної проблеми.

Ключові слова: прееклампсія, окиснювальний стрес, гени системи детоксикаиї. дят в плаценте. Возможно, более точные ассоциации лучше было бы получить, проводя генотипирование плода, но это технически сложно и неприменимо в качестве скрининга.

На наш взгляд, в некоторых сложных ситуациях в качестве материала для генотипирования целесообразно проводить забор крови не только у матери, но и у плода.

Результаты многочисленных публикаций свидетельствуют, что связи полиморфизмов генов системы детоксикации с ПЭ неоднозначны и для выявления значимых ассоциаций нужно проводить больше исследований и суммировать результаты с помощью мета-анализов.

Целесообразно подчеркнуть, что представляет интерес возможность расчета индивидуального риска развития ПЭ на основании результатов о наличии сочетаний разных полиморфизмов в генотипе женщины.

\section{The importance and significance of gene polymorphisms in preeclampsia P.N. Veropotvelyan, I.S. Tsehmistrenko, N.P. Veropotvelyan, N.S. Rusak, M.S. Pivnev}

Was to conduct a systematic review of data on the relationship between polymorphisms genes of detoxification system and development of preeclampsia (PE). Presents the main genes of detoxification system (GSTPI, GSTMI, GSTTI, GPXI, EPHXI, SOD-2, SOD-3, CYPIAL, MTHER, MTR) and their functions. Of interest is the possibility of calculating the individual risk of PE based on the results about the presence of a combination of different polymorphisms in the genotype of the female. Question about early diagnosis of PE remains controversial and not fully understood. It is necessary to conduct further in-depth, extended study of this problem.

Key words: preeclampsia, oxidative stress, genes of the detoxification system.

\section{Сведения об авторах}

Веропотвелян Петр Николаевич - ОКУ «Межобластной центр медицинской генетики и пренатальной диагностики», 50000, г. Кривой Рог, пл. Освобождения, За. E-mail: genetika@ukrpost.ua

Цехмистренко Иван Сергеевич - Перинатальный центр, 03150, г. Киев, ул. Предславинская, 9; тел.: (098) 093-21-22. E-mail: tsehmistrenko.m.d@gmail.com

Веропотвелян Николай Петрович - ОКУ «Межобластной центр медицинской генетики и пренатальной диагностики», 50000, г. Кривой Рог, пл. Освобождения, За. E-mail: genetika@ukrpost.ua

Русак Наталья Сергеевна - ОКУ «Межобластной центр медицинской генетики и пренатальной диагностики», 50000, г. Кривой Рог, пл. Освобождения, За. E-mail: genetika@ukrpost.ua

Горук Павел Степанович - ОКУ «Межобластной центр медицинской генетики и пренатальной диагностики», 50000, г. Кривой Рог, пл. Освобождения, 3а. E-mail: genetika@ukrpost.ua

\section{СПИСОК ЛИТЕРАТУРЫ}

1. Also-Rallo E. Polymorphisms of genes involved in homocysteine metabolism in preeclampsia and in uncomplicated pregnancies /E. LopezQuesada, R. Urreizti, M.A. Vilaseca, J.M. Lailla, S. Balcells, D. Grinberg //Eur. J. Obstet. Gynecol. Reprod. Biol. - 2005. - V. 120 (1). P. 45-52.

2. Das B. Assessment of placental oxidative stress in pre-eclampsia /S. Saha-Roy, A. Das Gupta, T.K. Lahiri, H.N. Das //J. Obstet. Gynaecol. India. 2012. - V. 62 (1). - P. 39-42.

3. Zusterzeel P.L. N-acetyl-transferase phenotype and risk for preeclampsia /R.H. te Morsche, M.T. Raijmakers, E.M. Roes, W.H. Peters, R.P. SteegersTheunissen, E.A. Steegers /Am. J.
Obstet. Gynecol. - 2005. - V. 193(3, Pt 1). - P. 797-802

4. Jobe S.0. Estradiol-17в and its cytochrome P450-and catechol-0 methyltransferase-derived metabolites stimulate proliferation in uterine artery endothelial cells: role of estrogen receptor- $\sigma$ versus estrogen receptor-B /J. Ramadoss, J.M. Koch, Y. Jiang, J. Zheng, R.R. Magness /Hypertension. 2010. - V. 55(4). - P. 1005-11.

5. Laraqui A. Relation between plasma homocysteine, gene polymorphisms of homocysteine metabolism-related enzymes, and angiographically proven coronary artery disease /A. Allami, A Carrie, A. Raisonnier, A.S. Coiffard, F. Benkouka et al. //Eur. J. Intern. Med. 2007. - V. 18(6). - P. 474-83.
6. Murakami S. The relation between plasma homocysteine concentration and methylenetetrahydrofolate reductase gene polymorphism in pregnant women /N. Matsubara, M. Saitoh, S. Miyakaw, M. Shoji, T. Kubo //J. Obstet. Gynaecol. Res. -2001. - V. 27(6). P. 349-52.

7. Al-Jameil N. A brief overview of preeclampsia /F. Aziz Khan, M. Fareed, H. Tabassum //J Clin Med Res. - 2014. - V. 6 (1). - P. 1-7.

8. Wu X. Folate metabolism gene polymorphisms MTHFR C677T and A1298C and risk for preeclampsia: a metaanalysis /K. Yang, X. Tang, Y. Sa, R. Zhou, J.Liu et al //J. Assist. Reprod. Genet. - 2015 - V 32 (5) P. 797-805.
9. Li X. Methylenetetrahydrofolate reductase gene C677T, A1298C polymorphisms and pre-eclampsia risk: a meta-analysis /.L. Luo, Q.H. Zhang, C. Mao, X.W. Wang, S. Liu, Q. Chen //Mol. Biol. Rep. - 2014. - V. 41 (8). P. 5435-48.

10. Salimi S. The early-onset preeclampsia is associated with MTHFR and FVL polymorphisms /M. Saravani, M. Yaghmaei, Z. Fazlali, M. Mokhtari, A. Naghavi, F. Farajian-Mashhadi //Arch. Gynecol. Obstet. - 2015. - V. 291 (6). - P. 1303-12.

11. Kan N.E. The significance of polymorphisms genes of detoxification system in preeclampsia /L.A. Bednyagin, V.L. Tyutyunnik et. al. //Obstetrics and gynecology. -2016. - V. 2. - P. 8-13. 


\section{A K У Ш E P C T B O}

12. Perez-Sepulveda A. Levels of key enzymes of methionine-homocysteine metabolism in preeclampsia /P.P. Espana-Perrot, X.B. Fernandez, V. Ahumada, V. Bustos, J.A. Arraztoa et al. // Biomed. Res. Int. - 2013. V. 2013. - P. 8.

13. Seremak-Mrozikiewicz A. The importance of MTHFR, MTR, MTRR and CSE expression levels in Caucasian women with preeclampsia /A. Bogacz, J. Bartkowiak-Wieczorek, H. Wolski, B Czerny, M. Gorska-Paukszta, K. Drews //Eur. J. Obstet. Gynecol. Reprod. Biol. - 2015. - V. 188 (5). - P. 113-7. 14. Hong Y.C. Genetic susceptibility of term pregnant women to oxidative damage /K.H. Lee, C.H. Yi, E.H. Ha D.C. Christiani //Toxicol. Lett. - 2002 - V. 129 (3). - P. 255-62.

15. Procopciuc L.M. The Ala-9Val (MnSOD) and Arg213Gly (EC-SOD) polymorphisms in the pathogenesis of preeclampsia in Romanian women: association with the severity and outcome of preeclampsia /G. Caracostea, G. Nemeti, C. Drugan, I. Olteanu, F.J. Stamatian //Matern. Fetal Neonatal Med. - 2012. - V. 25 (7). - P. 895-900. 16. Rosta K. Association of extracellular superoxide dismutase (SOD3) Ala40Thr gene polymorphism with pre-eclampsia complicated by severe fetal growth restriction /A. Molvarec, A. Enzsoly, B Nagy, Z. Rynai, A. Fekete et al. //Eur. J. Obstet. Gynecol. Reprod. Biol. - 2009. - V. 142 (2). - P. 134-8.

17. James P.R. Management of hypertension before, during and after pregnancy /C. Nelson-Piercy //Heart. 2004. - V. 90 (12). - P. 1499-504.

18. Redman C.W. Placental stress and pre-eclampsia: a revised view /I.L. Sargent //Placenta. -2009. V. 30(Suppl.A). - P. 38-42.

19. Cronqvist T. Syncytiotrophoblas vesicles show altered micro-RNA and haemoglobin content after ex-vivo perfusion of placentas with haemoglobin to mimic preeclampsia/K. Salje, M. Familari, S. Guller, H. Schneider, C. Gardiner et al. //PLoS One. - 2014. V. 9 (2). - -e90020

20. Hansson S.R. Oxidative stress in preeclampsia and the role of free fetal hemoglobin /A. Naav, L. Erlandsson //Front. Physiol. - 2015. - V. 5. P. 516.

21. Walsh S.W. Maternal-placenta interactions of oxidative stress and antioxidants in preeclampsia //Semin. Reprod. Endocrinol. - 1998. V. 16 (1). - P. 93-104.

22. The National Center for Biotechnology Information Gene Database. http: //www. ncbi. nIm. nih.gov/gene

23. OMIM: An Online Catalog of Human Genes and Genetic Disorders. http://www.omim.org

24. Zusterzeel P.L. Susceptibility to pre-eclampsia is associated with multiple genetic polymorphisms in materna biotransformation enzymes N.H Peters, G.J. Burton, W. Visser, H.M. Roelofs, E.A. Steegers //Gynecol. Obstet. Invest. - 2007. - V. 63 (4). P. 209-13.

25. Canto P. Methylenetetrahydrofolate reductase C677T and glutathione Stransferase P1 A313G are associated with a reduced risk of preeclampsia in Maya-Mestizo women /T. CantoCetina, R. Juarez-Velazquez, H. Rosasvargas, H.H. Rangel-Villalobos, S. Canizales-Quinteros et al. //Hypertens. Res. - 2008. - V. 31 (5). P. 1015-9.

26. Gebhardt G.S. Maternal and feta single nucleotide polymorphisms in the epoxide hydrolase and gluthatione Stransferase P1 genes are not associated with pre-eclampsia in the Coloured population of the Western Cape, South Africa M.H. Peters, R. Hillermann, H.J. Odendaal, K. Carelse-Tofa, M.T. Raijmakers, E.A. Steegers //J. Obstet. Gynaecol. - 2004. - V. 24 (8). P. 866-72.

27. Coral-Vбzquez R.M. Analysis of polymorphisms and haplotypes in genes associated with vascular tone, hypertension and oxidative stress in Mexican-Mestizo women with severe preeclampsia /J.F. Romero Arauz, S. Canizales-Quinteros, A. Coronel, E.Y. Valencia, J. Hernondez Rivera et al. //Clin. Biochem. - 2013. V. $46(7-8) .-$ P. $627-32$.

28. Norppa H. Genetic susceptibility, biomarker respones, and cancer
//Mutat. Res.- 2003. - V. 544 (2-3). P. 339-48.

29. Sandoval-Carrillo A. Polymorphisms in the GSTT1 and GSTM1 genes are associated with increased risk of preeclampsia in the Mexican mestizo population /M. Aguilar-Duran, F. Vozquez-Alaniz, F.X. CastellanosJuбrez, M. Barraza-Salas, E. SierraCampos et al. //Genet. Mol. Res. 2014. - V. 13 (1). - P. 2160-5

30. Zhang J. Placental anti-oxidant gene polymorphisms, enzyme activity, and oxidative stress in preeclampsia M. Masciocchi, D. Lewis, W. Sun, A Liu, Y. Wang //Placenta. - 2008. V. 29 (5). - P. 439-43.

31. Atalay M.A. Polymorphisms in angiotensin-converting enzyme and glutathione s-transferase genes in Turkish population and risk for preeclampsia /K. Ozerkan, M. Karkucak, T. Yakut, Y. Atik, O.H. Develioglu //Clin. Exp. Obstet. Gynecol. - 2012. - V. 39 (4). - P. 466-9.

32. Kim Y.N. Toward a better understanding of preeclampsia: Comparative proteomic analysis of preeclamptic placentas /H.K. Kim, M. Warda, N. Kim, W.S. Park, B. Prince Adel et al. // Proteomics Clin. Appl. - 2007. V. 1 (12). - P. 1625-36

33. Mistry H.D. Association between maternal micronutrient status, oxidative stress, and common genetic variants in antioxidant enzymes at 15 weeks gestation in nulliparous women who subsequently develop preeclampsia /C.A. Gill, L.O. Kurlak, P.T. Seed, J.E. Hesketh, C. Meplan et al. //Free Radic. Biol. Med. 2015. - V.78. - P.147-55

34. Sukhikh G.T. Apoptosis and gene expression of antioxidant enzymes in the placenta in preeclampsia /A.M. Krasny, N.E. Kahn et al. //Obstetrics and gynecology. - 2015. - V. 3. P. 11-5.

35. Mistry H.D. Differential expression and distribution of placental glutathione peroxidases 1, 3 and 4 in normal and preeclamptic pregnancy/L.O. Kurlak, P.J. Williams, M.M. Ramsay, M.E. Symonds, F. Broughton Pipkin //Placenta. - 2010. - V. 31 (5). - P. 401-8.

36. Roland-Zejly L. Altered placental glu- tathione peroxidase mRNA expression in preeclampsia according to the presence or absence of labor $N$. Moisan, I. StPierre, J.F. Bilodeau //Placenta. 2011. - V.32(2). - P. 161-7.

37. Mistry H.D. Reduced selenium concentrations and glutathione peroxidase activity in preeclamptic pregnancies $N$. Wilson, M.M. Ramsay, M.E. Symonds, F. Broughton Pipkin //Hypertension. 2008. - V. 52 (5). - P. 881-8.

38. Yan J. Relationships between concentrations of free fatty acid in serum and oxidative-damage levels in placental mitochondria and preeclampsia $X$. Xu //Zhonghua Fu Chan Ke Za Zhi. 2012. - V. 47 (6). - P. 412-7.

39. Groten T. eNOSI4 and EPHX1 polymorphisms affect maternal susceptibility to preeclampsia: analysis of five polymorphisms predisposing to cardiovascular disease in 279 Caucasian and 241 African women /E. Schleussner, T. Lehmann, F. Reister, B. Holzer, K.A. Danso, R. Zeillinger //Arch. Gynecol. Obstet. - 2014. - V. 289 (3). - P. 581-93.

40. Laasanen J. Two exonic single nucleotide polymorphisms in the microsomal epoxide hydrolase gene are jointly associated with preeclampsia /E.L. Romppanen, M. Hiltunen, S. Helisalmi, A. Mannermaa, K. Punnonen, S. Heinonen //Eur. J. Hum. Genet. 2002. - V. 10 (9). - P. 569-73.

41. Pinarbasi E. Association of microsomal epoxide hydrolase gene polymorphism and pre-eclampsia in Turkish women /F.E. Percin, M. Yilmaz, E. Akgun, M. Cetin, A. Cetin //J. Obstet. Gynaecol. Res. - 2007. V. 33 (1). - P. 32-7.

42. Wang Y. Increased superoxide generation is associated with decreased superoxide dismutase activity and mRNA expression in placental trophoblast cells in pre-eclampsia /S.W. Walsh //Placenta. - 2001. V. 22 (2-3). - P. 206-12.

43. https://www.obs-gyn.ox.ac.uk 44.Lissette C. Sonchez-Aranguren. Endothelial dysfunction and preeclampsia: role of oxidative stress /E. Carlos Prada //Front. Physiol., 10 October 2014 


\title{
Стан психоемоційного та вегетативного статусу у жінок з повторною плацентарною дисфункцісю
}

\author{
Д.О. Говсеєв \\ Міський клінічний пологовий будинок № 5 м. Києва
}

\begin{abstract}
Мета дослідження: вивчення особливостей психоемоційного та вегетативного статусу у жінок з плацентарною дисфункцією при попередній гестації.

Матеріали та методи. Було проведено комплексне клініко-лабораторне обстеження 89 жінок, з яких: контрольна група - 42 акушерськи та соматично здорових повторнороділей, розроджених через природні пологові шляхи; I група - 47 жінок 3 плацентарною дисфункцією при попередній гестації. Проводили кардіоінтервалографію за допомогою одноканального електрокардіографа та використовували шкалу-опитувальник стану вагітної і породіллі. Результати. Установлено, що регуляція серцевого ритму у жінок з плацентарною дисфункцією при попередній гестації відбувається в умовах автономного контуру, який контролює нормальну роботу серця та вегетативної нервової системи. Надалі виникає виражене напруження регуляторних механізмів, що проявляється централізацією керування серцевої діяльності та різким підвищенням активності симпатичної нервової системи. На заключному етапі вплив центрального контуру значно зменшується та знову формується патофункціональна вегетативна рівновага.

Заключення. Отримані результати треба враховувати при розробленні тактики ведення вагітності у цих жінок.

Ключові слова: плачентарна дисфункиія, вегетативний та психологічний статус.
\end{abstract}

$\Pi$ роблема плацентарної дисфункції (ПД) є однією з найбільш актуальних у сучасному акушерстві [1, 2]. Незважаючи на те що багато наукових колективів нашої країни і за кордоном працюють над вирішенням даної проблеми, частота порушень у системі мати-плацента-плід зростає з року в рік і на сьогодні сягає $60-70 \%$ [3, 4]. Серед основних причин такої негативної тенденції виділяють збільшення частоти соматичної захворюваності, зростання числа інфекцій, що передаються статевим шляхом, несприятливий вплив виробничих та екологічних чинників, погіршення матеріально-економічного положення населення і технічного забезпечення родопомічних установ і ін. $[5,6]$.

На сьогоднішній день особливу групу високого ризику складають жінки, які народжують повторно та у яких під час першої гестації мали місце різні акушерські і перинатальні ускладнення. Кількість таких жінок зростає з року в рік, а конкретні лікувально-профілактичні методики для них відсутні або мають узагальнювальний і фрагментарний характер.

Незважаючи на багаточисленні наукові дослідження 3 проблеми ПД, багато питань залишаються до кінця не вирішеними. На нашу думку, у першу чергу це стосується оцінювання стану психоемоційного та вегетативного статусу жінок з ПД при попередній гестації.

Мета дослідження: вивчення особливостей психоемоційного та вегетативного статусу жінок з ПД при попередній гестації.

\section{МАТЕРІАЛИ ТА МЕТОДИ}

Відповідно до мети даного наукового дослідження було проведено комплексне клініко-лабораторне обстеження 89 жінок, з яких:

- у контрольну групу увійшли 42 акушерськи та соматично здорові повторнороділлі, розроджені через природні пологові шляхи;

- у I групу - 47 жінок з ПД при попередній гестації.

3 метою виявлення ступеня залучення вегетативної нервової системи і рівня регуляції серцевої діяльності проводили кардіоінтервалографію за допомогою одноканального електрокардіографа [7].

Для оцінювання психоемоційного статусу використовували шкалу-опитувальник стану вагітної і породіллі [7].

\section{РЕЗУЛЬТАТИ ДОСЛІДЖЕННЯ ТА ÏХ ОБГОВОРЕННЯ}

Під час оцінювання стану психоемоційного статусу у першій половині вагітності виявлено, що у 57,4\% жінок I групи він був не порушений, а у $36,2 \%$ фіксували легкий ступінь порушень.

У порівнянні з цим у другій половині вагітності спостерігалася абсолютно інша картина, основною відмінністю якої був високий рівень порушень психоемоційного статусу середнього $(34,0 \%)$ і високого $(21,2 \%)$ ступеня, лише в кожному десятому випадку $(10,6 \%)$ психоемоційні порушення взагалі були відсутні. Під час детальнішого аналізу було відзначено наступне:

- 48,9\% жінок скаржилися на погіршення пам'яті, кмітливості і уваги;

- 34,0\% - на наявність фізичного і психічного дискомфорту;

- 31,9\% мали психотравмувальні ситуації до і під час даної вагітності;

- 31,9\% непокоїлися за стан свого здоров'я;

- 21,2\% побоювалися за результат пологів, здоров'я майбутньої дитини і труднощів, пов'язаних із доглядом за новонародженим;

- 21,2\% скаржилися на зниження настрою і відчуття пригніченості;

- 21,2\% турбували матеріальний і соціальний стан, а також стосунки з родичами;

- 17,0\% фіксували прояви напруженості;

- 14,9\% опитуваних відзначали різні порушення сну;

- 10,6\% відчували паніку, страх і відчай.

Окрім наведених вище особливостей слід зазначити той факт, що у I групі виявлено 12,8\% жінок з граничними психічними розладами (істеричний невроз, невроз нав'язливих станів, астеноневротичні, іпохондричні і субдепресивні порушення). У повсякденному житті пацієнтки прагнули до щадного режиму, обмеження або уникнення навантажень. У процесі обстеження виявлено, що розвитку неврозу передували психотравмувальні ситуації і стреси (екстрагенітальні захворювання, небажана вагітність, розлучення, перинатальні втрати при попередніх пологах і страх перед май- 
A K У Ш E P C T B O

Показники кардіоінтервалографії у першій половині вагітності

\begin{tabular}{|c|c|c|}
\hline Показник & Контрольна група, n=42 & I група, $\mathrm{n}=47$ \\
\hline Частота серцевих скорочень (ЧСС), за 1 хв & $67,73 \pm 2,21$ & $68,31 \pm 2,42$ \\
\hline Математичне очікування (М) & $0,88 \pm 0,04$ & $0,89 \pm 0,05$ \\
\hline Середньоквадратичне відхилення ( $\delta$ ) & $0,07 \pm 0,01$ & $0,04 \pm 0,01^{*}$ \\
\hline Коефіцієнт варіації (V) & $6,91 \pm 0,58$ & $5,31 \pm 0,31^{*}$ \\
\hline Мода (Мо) & $0,81 \pm 0,02$ & $0,80 \pm 0,01$ \\
\hline Амплітуда моди (Амо) & $40,83 \pm 3,35$ & $51,24 \pm 2,42^{*}$ \\
\hline Варіаційний розмах $(\Delta \mathrm{X})$ & $0,30 \pm 0,03$ & $0,19 \pm 0,01^{\star}$ \\
\hline Індекс вегетативної рівноваги (IBP) & $210,41 \pm 22,43$ & $261,52 \pm 18,93^{\star}$ \\
\hline Показник адекватності процесів регуляції (ПАПР) & $48,52 \pm 3,81$ & $58,72 \pm 2,81^{*}$ \\
\hline Вегетативний показник ритму (ВПР) & $5,38 \pm 0,41$ & $7,32 \pm 0,61^{*}$ \\
\hline Індекс напруження (IH) & $122,83 \pm 10,84$ & $149,73 \pm 11,52^{\star}$ \\
\hline
\end{tabular}

Примітка. * - Достовірність р відносно контрольної групи <0,05.

Показники кардіоінтервалографії у другій половині вагітності

\begin{tabular}{|c|c|c|}
\hline Показник & Контрольна група, n=42 & I група, $n=47$ \\
\hline Частота серцевих скорочень (ЧСС), за 1 хв & $78,24 \pm 3,21$ & $79,21 \pm 3,12$ \\
\hline Математичне очікування (М) & $0,80 \pm 0,03$ & $0,78 \pm 0,02$ \\
\hline Середньоквадратичне відхилення ( $\delta)$ & $0,06 \pm 0,01$ & $0,06 \pm 0,01$ \\
\hline Коефіцієнт варіації (V) & $5,34 \pm 0,42$ & $5,29 \pm 0,41$ \\
\hline Мода (Мо) & $0,76 \pm 0,03$ & $0,75 \pm 0,04$ \\
\hline Амплітуда моди (Амо) & $48,10 \pm 3,41$ & $47,87 \pm 3,38$ \\
\hline Варіаційний розмах $(\Delta \mathrm{X})$ & $0,21 \pm 0,03$ & $0,20 \pm 0,03$ \\
\hline Індекс вегетативної рівноваги (IBP) & $324,33 \pm 39,72$ & $418,78 \pm 18,84^{*}$ \\
\hline Показник адекватності процесів регуляції (ПАПР) & $67,23 \pm 6,44$ & $66,89 \pm 6,21$ \\
\hline Вегетативний показник ритму (ВПР) & $8,36 \pm 1,21$ & $11,38 \pm 1,28^{*}$ \\
\hline Індекс напруження (IH) & $235,42 \pm 21,53$ & $305,81 \pm 18,72^{*}$ \\
\hline
\end{tabular}

Примітка. * - Достовірність р відносно контрольної групи <0,05.

бутніми, психотравмувальна обстановка в сім'ї і на роботі, фінансові і побутові труднощі).

Отже, відзначені психічні порушення у вагітних з ПД при попередній вагітності мають самостійне клінічне значення і вимагають проведення психокоригувальної терапії.

Серед різних функціональних методів досліджень вегетативної нервової системи перевагу віддають кардіоінтервалографії. Дані табл. 1 свідчать, що ще до 20 тиж вагітності у жінок I групи відзначали підвищення тонусу симпатичного відділу вегетативної нервової системи, яке виражалося у достовірному зниженні таких показників, як коефіцієнт варіації (контрольна група - 6,9 $\pm 0,58$ і I група $-5,31 \pm 0,31$; $\mathrm{p}<0,05$ ); середньоквадратичне відхилення (контрольна група $-0,07 \pm 0,01$ і I група $-0,04 \pm 0,01 ; \mathrm{p}<0,05)$ та варіаційний розмах (контрольна група $-0,30 \pm 0,03$ і І група $-0,19 \pm 0,01$ $\mathrm{p}<0,05)$. Крім того, простежується тенденція до домінування симпатичних впливів на синусовий ритм, що проявлялось більш високими рівнями показників активності про-

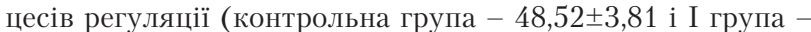
$58,72 \pm 2,81 ; \mathrm{p}<0,05)$; вегетативного показника ритму (конт-

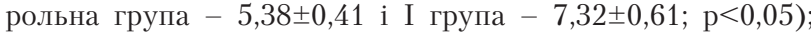
індексу вегетативної рівноваги (контрольна група -

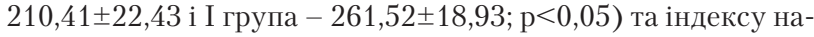

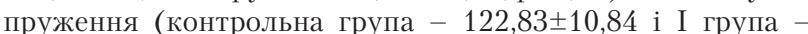
$149,73 \pm 11,52 ; \mathrm{p}<0,05)$
Порівняно з цим після 20 тиж вагітності (табл. 2) встановлені вище розбіжності мали менш виражений характер. Це підтверджується достовірно більш високими значеннями індексу вегетативної рівноваги (контрольна група $324,33 \pm 39,72$ і I група - 418,78 $\pm 18,84$; p $<0,05)$; вегетативного показника ритму (контрольна група - 235,42 21,53 і I група

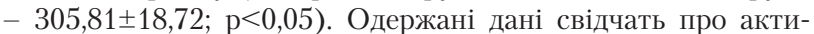
вацію адренергічних механізмів регуляції серцевої діяльності та переважання підвищеного тонусу симпатичної нервової системи. Також тут можна виділити певну спрямованість адаптаційних реакцій, пов'язаних з підвищенням активності центрального контуру регуляції серцевої діяльності.

\section{ВИСНОВКИ}

Отже, регуляція серцевого ритму у жінок з плацентарною дисфункцією при попередній гестації відбувається в умовах автономного контуру, який контролює нормальну роботу серця та вегетативної нервової системи. Надалі виникає виражене напруження регуляторних механізмів, що проявляється централізацією керування серцевої діяльності та різким підвищенням активності симпатичної нервової системи. На заключному етапі вплив центрального контуру значно зменшується та знову формується патофункціональна вегетативна рівновага. Отримані результати треба враховувати при розробленні тактики ведення вагітності у цих жінок. 


\section{A K Y Ш E P C T B O}

\section{Состояние психоэмоционального и вегетативного статуса у женщин с повторной плацентарной дисфункцией \\ Д.А. Говсеев}

Цель исследования: изучение особенностей психоэмоционального и вегетативного статуса у женщин с плацентарной дисфункцией при предыдущей беременности.

Материалы и методы. Было проведено комплексное клиниколабораторное обследование 89 женщин, из которых: контрольная группа - 42 акушерски и соматически здоровых повторнородящих, родоразрешенных через естественные родовые пути; I группа - 47 женщин с плацентарной дисфункцией при предыдущей беременности. Проводили кардиоинтервалографию с помощью одноканального электрокардиографа и использовали шкалу-опросник состояния беременной.

Peзультаты. Установлено, что регуляция сердечного ритма у женщин с плацентарной дисфункцией при предыдущей беременности происходит в условиях автономного контура, который контролирует нормальную работу сердца и вегетативной нервной системы. В дальнейшем возникает выраженное напряжение регуляторных механизмов, что проявляется централизацией управления сердечной деятельности и резким повышением активности симпатической нервной системы. На заключительном этапе влияние центрального контура значительно уменьшается и опять формируется патофункциональное вегетативное равновесие.

Заключение. Полученные результаты необходимо учитывать при разработке тактики ведения беременности у этих женщин.

Ключевые слова: плащентарная дисфункция, вегетативный и психологический статус.

\section{Condition of the psychoemotional and vegetative status at women with a repeated placental dysfuction D.A. Govseev}

The objective: studying of features of the psychoemotional and vegetative status at women with placental dysfunction at the previous pregnancy.

Patients and methods. Complex clinical-laboratory examination of 89 women, from which was conducted: control group - 42 obstetrically and somatically healthy multipara, delivery through natural patrimonial ways; I group - 47 women with placental dysfunction at the previous pregnancy. Carried out a cardiointervalografia by means of a single-channel electrocardiograph and used a scale questionnaire of a condition of the pregnant woman.

Results. It is established that regulation of cardiac rhythm at women at the previous pregnancy happens to placental dysfunction in the conditions of an autonomous contour which controls normal work of heart and vegetative nervous system. Further, there is an expressed strain of regulatory mechanisms that is shown by centralization of management of cardiac activity and sharp rising of activity of sympathetic nervous system. At the final stage influence of the central contour considerably decreases and patofunctionale vegetative equilibrium is again formed. Conclusions. The received results need to be considered when developing tactics of conducting pregnancy at these women.

Key words: placental dysfunction, vegetative and psychological status.

\section{Сведения об авторе}

Говсеев Дмитрий Александрович - Киевский городской родильный дом № 5, 03037, г. Киев, пр. Краснозвездный, 2 ; тел.: (096) 457-03-03

\section{СПИСОК ЛІТЕРАТУРИ}

1. Вдовиченко Ю.П. Прогнозування та корекція фетоплацентарної недостатності у вагітних зі звичним невиношуванням в анамнезі / Ю.П. Вдовиченко, А.В. Ткаченко // Педіатрія, акушерство та гінекологія. - 2009. № 2. - С. 78-85.

2. Венцківський Б.М. Прогнозування невиношування вагітності шляхом комплексної оцінки соматотипологичного та психологічного статусу вагітної / Б.М. Венцківський, А.Л. Костюк, 0.0. Бєлов // Педіатрія, акушерство та гінекологія. - 2011. - № 6. - С. 70-72. 3. Дубосарська 3.М. Сучасні методи діагностики затримки внутрішньоутробного розвитку плода / 3.М. Дубосарська // Тези доповідей науково-практичної конференції акушерів-гінекологів України. - Донецьк, 2012. - С. 69.
4. Запорожан В.М. Акушерство і гінекологія / В.М. Запорожан, М.Р. Цегельский. - К.: Здоров'я, 2006. - 240 с. 5. Коломійцева А.Г. Застосування утрожестану в комплексній терапії звичного невиношування вагітності / А.Г. Коломійцева, С.П. Писарєва Г.Є. Яремко // Педіатрія, акушерство та гінекологія. - 2011. - № 4. C. 144-146.
6. Радзинский В.Е. Плацентарная недостаточность и ее коррекция / В.Е. Радзинский, И.М. Ордиянц // Акушерство и гинекология. - 2010. № 1. - С. 11-16

7. Флейшман А.Н. Методы оценки психоэмоционального и вегетативного статуса у беременных женщин / А.Н. Флейшман. - Новосибирск, 2012. - 222 c. 


\section{$\because$ medinova}

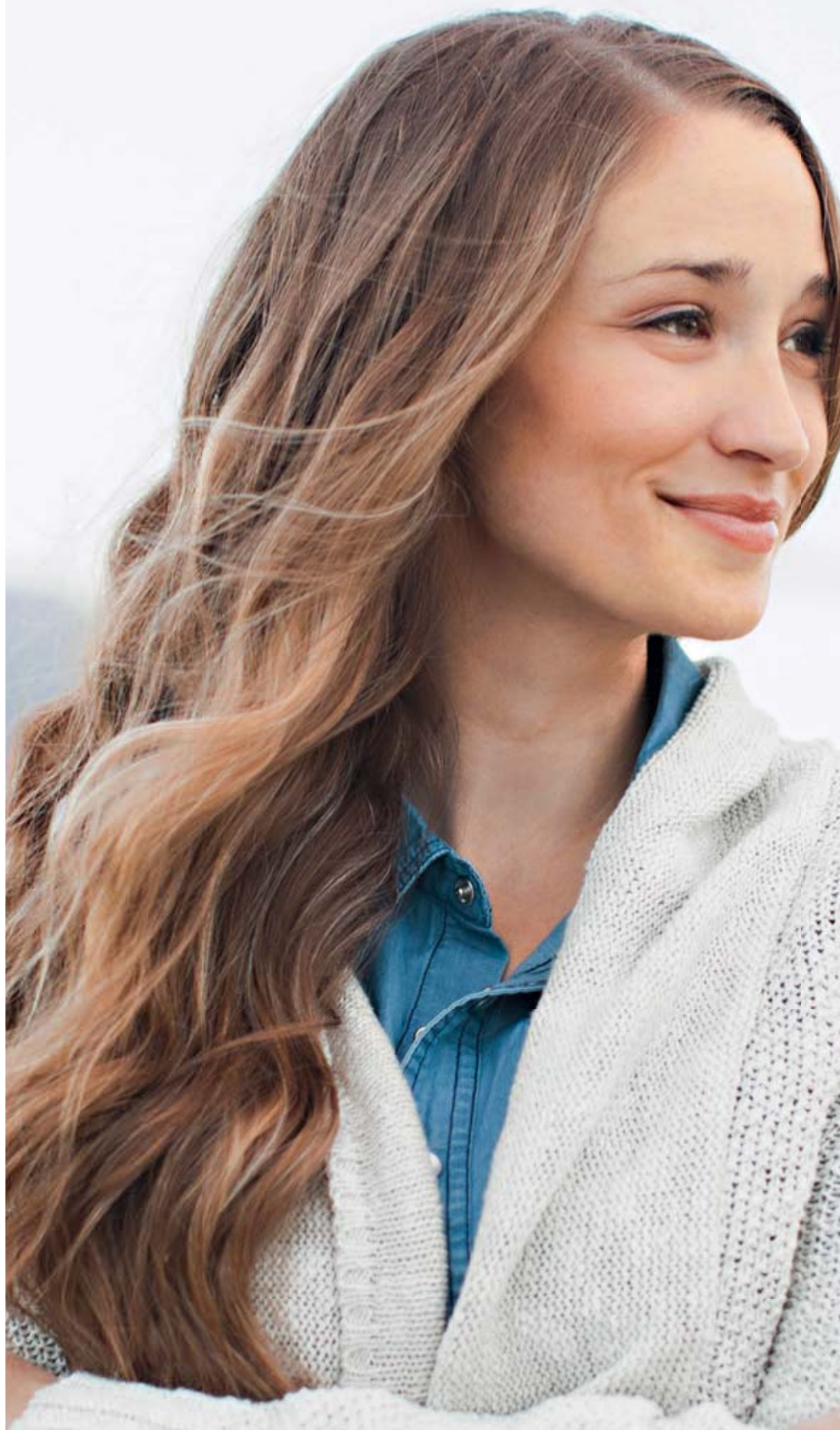

\section{Флуомізин}

деквалінію хлорид 10 мг

- доведена ефективність по відношенню до Atopobium vaginae та інших збудників бактеріального вагінозу

- дозволений до застосування у всіх триместрах вагітності ${ }^{* *}$

\section{Флуомізин}

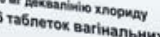

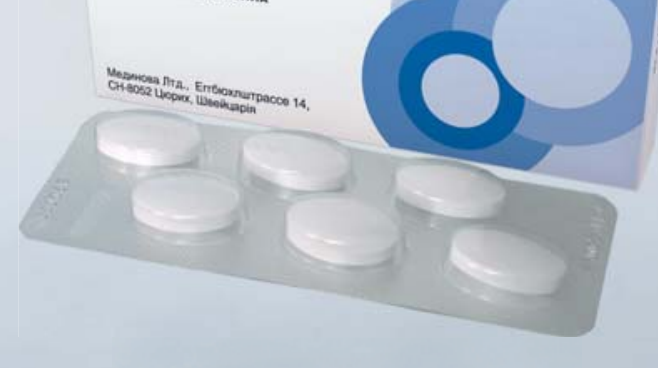




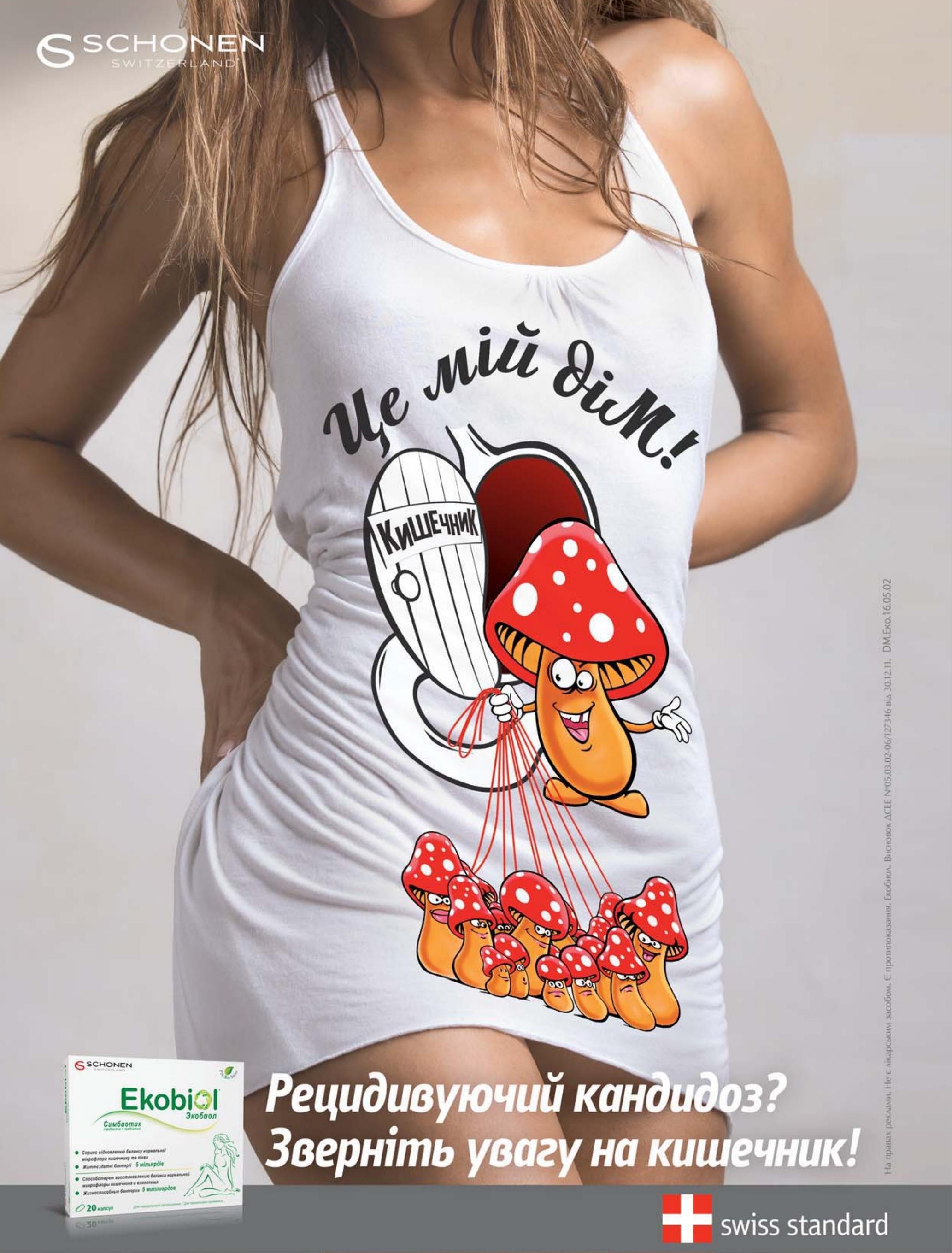




\title{
Морфофункціональні зміни в плаценті у вагітних при затримці росту плода
}

\author{
О.В. Басистий \\ ДУ «Інститут педіатрії, акушерства і гінекології НАМН України», м. Київ
}

\begin{abstract}
Мета дослідження: виявлення морфофункціональних змін в плаценті у вагітних при затримці росту плода різного ступеня тяжкості.

Матеріали та методи. У дослідження були включені 100 вагітних жінок від 23 тиж і до 40 тиж гестації, з яких 80 вагітних із затримкою росту плода різного ступеня тяжкості увійшли в основну групу. До групи контролю увійшли 20 вагітних 3 фізіологічним перебігом вагітності. Залежно від ступеня тяжкості затримки росту плода вагітні основної групи були розподілені на 3 клінічні групи: у I групу увійшли 38 вагітних із затримкою росту плода 1-го ступеня; у ІІ групу - 22 вагітні із затримкою росту плода 2-го ступеня; у III групу - 20 вагітних із затримкою росту плода 3 -го ступеня. Виявлення затримки росту плода у вагітних, форми і ступеня тяжкості, а також порушень матково-плацентарного і плодового кровотоку грунтувалося на результатах ультразвукового і допшлерометричного досліджень. Для діагностики затримки росту плода отримані дані фетометрії порівнювали з нормативними показниками для даного терміну вагітності. Під час забору матеріалу для морфологічного дослідження після відділення посліду вирізали шматочки з центрального, парацентрального і крайового відділів через усю товщу плаценти. 3 крайових відділів шматочки вирізали разом з оболонками. 3 пуповини вирізали два шматочки - на відстані 2 см від місця прикріплення пуповини до плаценти і на протилежній ділянці. Матеріал фіксували у $10 \%$ нейтральному формаліні і заливали у парафін, гістологічні зрізи фарбували гематоксиліном та еозином. Приділяли увагу вираженості компенсаторно-пристосувальним і інволютивно-деструктивним реакціям у плаценті. Оцінювання стану ворсинчастого дерева за ступенем його зрілості проводили з використанням критеріїв, що лежать в основі класифікації порушень розвитку ворсинчастого дерева I.М. Волощук. Статистичне оброблення результатів проводили з використанням стандартних ліцензованих комп'ютерних програм STATISTICA 6.0, Microsoft Excel, ANOVA «Statistica». Статистично достовірними вважали розбіжності при р<0,05.
\end{abstract}

Результати. Морфологія плацент при затримці росту плода характеризується високою частотою порушень материнського кровотоку з переважанням змін, зумовлених недостатнім притоком материнської крові у міжворсинчастий простір. Найбілыш частими морфологічними проявами порушення кровотоку у міжворсинчастому просторі були інфаркти, афункціональні зони, рівномірне звуження і тромбоз міжворсинчастого простору. Частота порушень кровотоку у міжворсинчастому просторі підвищується 3 наростанням ступеня тяжкості затримки росту плода.

Заключення. Плацентарна дисфункція, зумовлена морфологічними і функціональними змінами в плаценті, є основною причиною затримки росту і розвитку плода, його гіпоксіі, що виникає у результаті поєднаної реакції плода і плаценти на різні порушення стану материнського організму. Частота порушень кровотоку у міжворсинчастому просторі підвищується з наростанням ступеня тяжкості затримки росту плода.

Ключові слова: затримка росту плода, вагітні, плащента, плаиентарна дисфункція, морфофункиіональні зміни.
С підкреслюють М. Коvo та співавтори (2015), відставання У розвитку і рості плода є результат його адаптації до порушення основних функцій життєзабезпечення при плацентарній дисфункції [7].

За визначенням W. Mifsud та N.J. Sebire (2014), плацентарна дисфункція - це порушення здатності плаценти забезпечувати адекватну взаємодію материнського організму і плода. При цьому, за наявності різних клініко-патологічних ознак, спочатку, як правило, страждає трофіка, а потім дихання плода [8]. За даними літератури, плацентарна дисфункція може розвиватися під впливом низки ендогенних і екзогенних факторів. До ендогенних факторів належать порушення розвитку плаценти, первинна ферментативна або судинна недостатність у матері, до екзогенних - порушення матково-плацентарного кровотоку, асоційовані з дисфункцією ендотелію, погіршенням реологічних властивостей крові, гіперагрегацією еритроцитів і тромбоцитів, розладами мікроциркуляції, порушенням судинного тонусу, внаслідок несприятливих факторів середовища i різних ускладнень вагітності $[1,4]$.

В основі розвитку плацентарної дисфункції лежить ендотеліальна дисфункція, що формується на тлі неповноцінного ремоделювання спіральних маткових артерій. Як вважають I.P. Crocker та P.I. Sipos (2013), ендотелій є основним об’єктом медіаторів, що виробляються плацентою [6]. Унаслідок дисфункції ендотелію відбувається порушення утворення i вивільнення вазодилатувальних агентів, основним з яких є оксид азоту (NO). При плацентарній дисфункції прогресивно знижується активність нітроксидергічної системи, що призводить до зменшення ендотелійзалежної вазодилатації і свідчить про зниження адаптивних можливостей мікроциркуляції у системі мати-плацента-плід [3].

Формування затримки росту плода пов'язано не з одним чинником, а з їхньою сукупністю, що може спричинити певний каскад незворотних змін в екстраембріональних структурах. Найчастіше розвивається мононуклеарна інфільтрація, базофільні некрози базальної пластини, неспецифічні інволютивно-дистрофічні зміни, недостатній розвиток синцитіальних вузлів зі звапнінням, переважання незрілих склерозованих мембран, фіброз ворсин і патологічна незрілість ворсин. Дистрофічні зміни, що виникають і прогресують при цьому, призводять до зниження функціональної активності хоріона, що й зумовлює незворотні зміни у вигляді затримки росту плода [5].

Мета дослідження: виявлення морфофункціональних змін в плаценті у вагітних при затримці росту плода різного ступеня тяжкості.

\section{МАТЕРІАЛИ ТА МЕТОДИ}

У дослідження були включені 100 вагітних жінок від 23 тиж і до 40 тиж гестації, з яких 80 вагітних із затримкою росту плода різного ступеня тяжкості увійшли в основну групу. До групи контролю увійшли 20 вагітних 3 фізіологічним перебігом вагітності. Залежно від ступеня тяжкості затримки росту плода вагітні основної групи були розподілені на 3 клінічні групи: у I групу увійшли 38 вагітних із затримкою росту плода 1-го ступеня; у II групу - 
A K У Ш E P C T B O

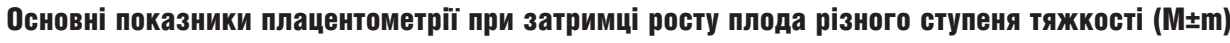

\begin{tabular}{|c|c|c|c|c|c|}
\hline \multirow{2}{*}{ Клінічна група } & \multicolumn{5}{c|}{ Стан ФПК } \\
\cline { 2 - 6 } & $\begin{array}{c}\text { Маса } \\
\text { плаценти, г }\end{array}$ & $\begin{array}{c}\text { Об' см } \\
\text { плаценти, см }\end{array}$ & $\begin{array}{c}\text { Середні } \\
\text { діаметри, см }\end{array}$ & $\begin{array}{c}\text { Плодово-плацентарний } \\
\text { коефіцієнт }\end{array}$ & $\begin{array}{c}\text { Товщина } \\
\text { плаценти, см }\end{array}$ \\
\hline I (затримка росту плода 1-го ст.) & $473,6 \pm 18,6^{*}$ & $465,4 \pm 12,6^{*}$ & $19,48 \times 17,14$ & 0,16 & $2,08 \pm 0,13$ \\
\hline II (затримка росту плода 2-го ст.) & $416,4 \pm 34,2^{*}$ & $408,3 \pm 11,7^{*}$ & $18,27 \times 16,19$ & 0,14 & $1,91 \pm 0,17$ \\
\hline III (затримка росту плода 3-го ст.) & $354,6 \pm 28,4^{*}$ & $342,5 \pm 10,6^{*}$ & $16,53 \times 14,27$ & 0,12 & $1,82 \pm 0,16$ \\
\hline Контрольна & $572,8 \pm 24,6$ & $546,3 \pm 26,4$ & $20,74 \times 19,48$ & 0,16 & $2,23 \pm 0,12$ \\
\hline
\end{tabular}

Примітка. * - достовірність різниці порівняно з контрольною групою $(p<0,05)$.

22 вагітні із затримкою росту плода 2-го ступеня; у III групу - 20 вагітних із затримкою росту плода 3-го ступеня.

Вагітні, які брали участь у дослідженнях, були у віці від 20

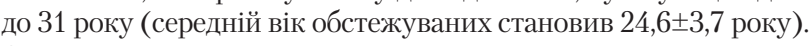
За віком, індексом маси тіла, соматичним та акушерсько-гінекологічним анамнезом пацієнтки обстежуваних груп були зіставні. У всіх групах переважали першороділлі: у I групі $52,64 \%$, у II групі - 54,55\%, у ІІІ групі - 55\% і в групі контролю - 50\%. Медичні аборти (від 1 до 3) мали місце в анамнезі у 15,79\% жінок I групи, у 18,19\% жінок II групи, у 20\% жінок III групи та у $15 \%$ жінок групи контролю. Наявність хронічної урогенітальної інфекції було виявлено у 26,32\% жінок у I групі, у 27,28 \% жінок у II групі, у 30\%жінок у III групі і у $25 \%$ жінок в групі контролю. Мимовільні викидні у пацієнток всіх груп були відсутні. Усі дослідження були виконані з дотриманням біоетичних норм і інформованої згоди жінок перед дослідженнями. Виявлення затримки росту плода у вагітних, форми і ступеня тяжкості, а також порушень матково-плацентарного і плодового кровотоку грунтувалося на результатах ультразвукового і допплерометричного досліджень. Для діагностики затримки росту плода отримані дані фетометрії порівнювали з нормативними показниками для даного терміну вагітності. При цьому були виділені 3 ступеня затримки росту плода: 1-й ступінь відставання фетометричних показників на 2 тиж; 2-й ступінь на 3-4 тиж; 3-й ступінь - на 4 тиж і більше. Залежно від пропорційності відставання різних показників виділяли симетричну і асиметричну форми затримки росту плода. Результатом пологів у контрольній групі вагітних було народження здорових доношених новонароджених, а в основній групі - народження доношених і недоношених новонароджених із затримкою росту плода відповідного ступеня тяжкості. Для морфологічного дослідження було взято 20 плацент після пологів від 20 вагітних з фізіологічним перебігом вагітності, які увійшли в контрольну групу. Відповідно до основної групи було взято 38 плацент від вагітних із затримкою росту плода 1-го ступеня (I група); 22 плаценти від вагітних із затримкою росту плода 2-го ступеня (II група); 20 плацент від вагітних із затримкою росту плода 3-го ступеня (III група). Під час забору матеріалу для морфологічного дослідження після відділення посліду вирізали шматочки з центрального, парацентрального і крайового відділів через усю товщу плаценти. 3 крайових відділів шматочки вирізали разом з оболонками. 3 пуповини вирізали два шматочки - на відстані 2 см від місця прикріплення пуповини до плаценти і на протилежній ділянці. Матеріал фіксували у $10 \%$ нейтральному формаліні і заливали у парафін, гістологічні зрізи фарбували гематоксиліном та еозином. Приділяли увагу вираженості компенсаторно-пристосувальних і інволютивнодеструктивних реакцій у плаценті. Оцінювання стану ворсинчастого дерева за ступенем його зрілості проводили з використанням критеріїв, що лежать в основі класифікації порушень розвитку ворсинчастого дерева I.M. Волощук [2]. Препарати досліджували за допомогою мікроскопа Leica DM 4000 зі стандартним набором оптики. Статистичне оброблення результатів проводили 3 використанням стандартних ліцензованих комп'ютерних програм STATISTICA 6.0, Microsoft Excel, ANOVA «Statistica». Статистично достовірними вважали розбіжності при $\mathrm{p}<0,05$.

\section{РЕЗУЛЬТАТИ ДОСЛІДЖЕННЯ ТА ЇХ ОБГОВОРЕННЯ}

У контрольній групі будова плаценти відповідала гестаційній нормі. Ворсинчасте дерево було зрілим і відповідало гестаційному терміну. Превалювали добре васуляризовані проміжні диференційовані і термінальні ворсини, які містять достатню кількість капілярів, частина 3 них формувала синцитіокапілярні мембрани.

Маса плаценти у контрольній групі становила 572,8 $\pm 24,6$ г, а об'єм плаценти $-546,3 \pm 26,4$ cм $^{3}$, і під час порівняння з групою плацент, узятих від жінок із затримкою росту плода, відбувалось достовірне зниження показників маси та об'єму плацент в основних досліджуваних групах (табл. 1).

При затримці росту плода 1-го ступеня будова плаценти у 63,16\% відповідала гестаційній нормі, а частота морфологічних порушень материнського кровотоку становила $36,84 \%$. При патоморфологічному дослідженні плаценти виявлено, що у групі затримки росту плода 1-го ступеня переважали зміни у міжворсинчастому просторі. Наслідком виявлених порушень став недостатній приток крові у міжворсинчастий простір, а зміни відносно відтоку материнської крові спостерігалися рідко. До морфологічних проявів порушень материнського кровотоку належать всі види патології міжворсинчастого простору (табл. 2): свіжі та застарілі інфаркти - 2,64\% і 7,9\% відповідно, афункціональні зони - 13,16\%, звуження міжворсинчастого простору - 7,9\%, пери- і міжворсинчастий фібриноїд (5,27\% і $5,27 \%$ відповідно), тромбоз міжворсинчастого простору $5,27 \%$, ретроплацентарна гематома $7,9 \%$. При затримці росту плода спостерігалася підвищена кількість синцитіальних вузлів у 26,32\% спостережень. Під час дослідження було виявлено, що у групі із затримкою росту плода 1-го ступеня превалювали плаценти зі зрілим ворсинчастим деревом $-81,58 \%$, де у більшості виявлено термінальні ворсини, які містили нормальну кількість капілярів. Передчасного дозрівання плаценти і варіанта хаотичних склерозованих ворсин не спостерігалось.

При затримці росту плода 2-го ступеня у плацентах відзначено високу частоту морфологічних порушень у міжворсинчастому просторі. Порушення притоку материнської крові у міжворсинчастий простір спостерігалось у 2 рази частіше, ніж порушення ії̈ відтоку. Частота порушень материнського кровотоку при затримці росту плода становила 68,19\%. Морфологічні прояви порушень материнського кровотоку при затримці росту плода 2-го ступеня у плацентах (див. табл. 2): свіжі та застарілі інфаркти - 13,64\% і 18,19\% відповідно, афункціональні зони - 27,28\%, звуження міжворсинчастого простору - 18,19\%, пери- і міжворсинчастий фібриноїд - 9,09\% і 9,09\% відповідно, тромбоз міжворсинчастого простору 18,19\%, ретроплацентарна гематома - 9,09\%. Під час дослідження було виявлено, що у групі із затримкою росту плода 2-го ступеня превалювали плаценти зі зрілим ворсинчастим деревом - 
A K У Ш E P C T B O

Частота і характер морфологічних проявів порушення материнського кровотоку, \%

\begin{tabular}{|c|c|c|c|}
\hline \multirow{2}{*}{$\begin{array}{c}\text { Вид патології } \\
\text { міжворсинчастого простору }\end{array}$} & \multicolumn{2}{|c|}{ Ступінь тяжкості затримки росту плода } \\
\cline { 2 - 4 } & $\mathbf{1 - и ̆ , ~} \mathbf{n} \mathbf{3 8}$ & $\mathbf{2 - и ̆ , ~} \mathbf{n = 2 2}$ & $\mathbf{3 - и ̆ , ~} \mathbf{n = 2 0}$ \\
\hline Застарілі інфаркти & 7,9 & $18,19^{\star}$ & $20^{\star}$ \\
\hline Свіжі інфаркти & 2,64 & $13,64^{\star}$ & $15^{\star}$ \\
\hline Афункційні зони & 13,16 & $27,28^{\star}$ & $30^{\star}$ \\
\hline Звуження міжворсинчастого простору & 7,9 & $18,19^{\star}$ & $20^{\star}$ \\
\hline Периворсинчастий фібриноїд & 5,27 & 9,09 & 15 \\
\hline Міжворсинчастий фібриноїд & 5,27 & 9,09 & 10 \\
\hline Тромбоз міжворсинчастого простору & 5,27 & 18,19 & 20 \\
\hline Ретроплацентарна гематома & 7,9 & 9,09 & 15 \\
\hline
\end{tabular}

Примітка. ${ }^{*}$ - Достовірність різниці порівняно із затримкою росту плода 1-го ступеня ( $\left.<<0,05\right)$.

31,82\%, відзначено незрілість ворсинчастого дерева і превалювання недиференційованих проміжних ворсин у 27,28\% спостережень. Також були виявлені патологічні варіанти ворсинчастого дерева, які не фіксують у нормі при будь-яких термінах гестації, а саме: передчасне дозрівання - 13,64\% і варіант хаотичних склерозованих ворсин - 9,09\%. У цій групі у плацентах під час морфологічного дослідження кількість синцитіальних вузлів у ворсинах було збільшено до 63,64\% спостережень.

При затримці росту плода 3-го ступеня у плацентах відзначено високу частоту порушень материнського кровотоку при затримці росту плода, яка склала 75\%. Морфологічні прояви порушень материнського кровотоку при затримці росту плода 3-го ступеня у плацентах (див. табл. 2): свіжі та застарілі інфаркти 15\% і 20\% відповідно, афункціональні зони - 30\%, звуження міжворсинчастого простору - 20\%, пери- і міжворсинчастий фібриноїд - 15\% і 10\% відповідно, тромбоз міжворсинчастого простору - 20\%, ретроплацентарна гематома - 15\%. 3 високою частотою спостерігалися відхилення у формуванні ворсинчастого дерева - зріле ворсинчасте дерево у 10\% спостережень. Також були виявлені патологічні варіанти ворсинчастого дерева -

\section{Морфофункциональные изменения в плаценте у беременных при задержке роста плода А.В. Басистый}

Цель исследования: выявление морфофункциональных изменений в плаценте у беременных при задержке роста плода разной степени тяжести.

Материаль и методы. В исследование были включены 100 беременных женщин от 23 нед и до 40 нед гестации, из которых 80 беременных с задержкой роста плода разной степени тяжести вошли в основную группу. В группу контроля вошли 20 беременных с физиологическим течением беременности. В зависимости от степени тяжести задержки роста плода беременные основной группы были разделены на 3 клинические группы: в I группу вошли 38 беременных с задержкой роста плода 1-й степени; во II группу - 22 беременные с задержкой роста плода 2-й степени; в III группу - 20 беременных с задержкой роста плода 3-й степени. Выявление задержки роста плода у беременных, формы и степе ни тяжести, а также нарушений маточно-плацентарного и плодового кровотока основывалось на результатах ультразвукового и допплерометрического исследований. Для диагностики задержки роста плода полученные данные фетометрии сравнивали с нормативными показателями для данного срока беременности При заборе материала для морфологического исследования пос ле отделения последа вырезали кусочки из центрального, парацентрального и краевого отделов через всю толщу плаценты. Из краевых отделов кусочки вырезали вместе с оболочками. Из пуповины вырезали два кусочка - на расстоянии 2 см от места прикрепления пуповины к плаценте и на противоположном участке. Материал фиксировали в 10\% нейтральном формалине и заливали в парафин, гистологические срезы окрашивали гематоксили- диференційовані проміжні ворсини - 30\% і варіант хаотичних склерозованих ворсин - 25\%. У цій групі у плацентах під час морфологічного дослідження кількість синцитіальних вузлів у ворсинах було збільшено до 70\% спостережень.

\section{ВИСНОВКИ}

Морфологія плацент при затримці росту плода характеризується високою частотою порушень материнського кровотоку 3 переважанням змін, зумовлених недостатнім притоком материнської крові у міжворсинчастий простір. Найбільш частими морфологічними проявами порушення кровотоку у міжворсинчастому просторі були інфаркти, афункціональні зони, рівномірне звуження і тромбоз міжворсинчастого простору. Частота порушень кровотоку у міжворсинчастому просторі збільшується з наростанням ступеня тяжкості затримки росту плода. Плацентарна дисфункція, зумовлена морфологічними і функціональними змінами у плаценті, є основною причиною затримки росту і розвитку плода, його гіпоксії, що виникає у результаті поєднаної реакції плода і плаценти на різні порушення стану материнського організму

ном и эозином. Уделяли внимание выраженности компенсаторно-приспособительным и инволютивно-деструктивным реакциям в плаценте. Оценку состояния ворсинчатого дерева по степени его зрелости проводили с использованием критериев, лежащих в основе классификации нарушений развития ворсинчатого дерева И.Н. Волощук. Статистическую обработку результатов проводили с использованием стандартных лицензированных компьютерных программ STATISTICA 6.0, Microsoft Excel, ANOVA «Statistica». Статистически достоверными считали расхождения при $\mathrm{p}<0,05$.

Результаты. Морфология плацент при задержке роста плода характеризуется высокой частотой нарушений материнского кровотока с преобладанием изменений, обусловленных недостаточным притоком материнской крови в межворсинчатое пространство. Наиболее частыми морфологическими проявлениями нарушения кровотока в межворсинчатом пространстве явились инфаркты, афункциональные зоны, равномерное сужение и тромбоз межворсинчатого пространства. Частота нарушений кровотока в межворсинчатом пространстве увеличивается с нарастанием степени тяжести задержки роста плода.

Заключение. Плацентарная дисфункция, обусловленная морфологическими и функциональными изменениями в плаценте, является основной причиной задержки роста и развития плода, его гипоксии, возникающей в результате сочетанной реакции плода и плаценты на различные нарушения состояния материнского организма. Частота нарушений кровотока в межворсинчатом пространстве увеличиваеться с нарастанием степени тяжести задержки роста плода.

Ключевые слова: задержка роста плода, беременные, плачента, плацентарная дисфункиия, морфофункииональнье изменения. 


\section{A K Y Ш E P C T B O}

\section{Morphofunctional changes in the placenta of pregnant with Intrauterine growth retardation \\ O.V. Basystyi}

The objective: to reveal morphofunctional changes in the placenta of pregnant with intrauterine growth retardation of different severity. Patients and Methods. The study included 100 pregnant (from 23 to 40 weeks of gestation). The main group consisted of 80 pregnant women with intrauterine growth retardation of different severity. The control group consisted of 20 women with physiological course of pregnancy. The patients of the main group were divided into three clinical groups regarding intrauterine growth retardation staging. Group I included 38 pregnant with stage 1 IUGR, 22 pregnant women with stage II IUGR were in group 2 and 20 pregnant with stage 3 IUGR - in group III. Revealing intrauterine growth retardation in pregnant women, the form and the stage, as well as violations of the uteroplacental and fetal blood flow was based on the results of ultrasound Doppler studies. The comparison of fetometry results and normative indices of the definite duration of gestation was made to diagnose intrauterine growth retardation. For morphological studies fullthickness placenta tissue sections were cut from a central, paracentral and areas after the separation of the placenta. From the marginal areas there were cut tissue sections with membranes. From umbilical cord there were cut two sections at $2 \mathrm{~cm}$ distance from the insertion of the umbilical cord to the placenta and on the opposite side. The tissue samples were fixed with $10 \%$ neutral formalin and embedded in paraf fin; histologic sections were stained by hematoxylin-eosin. We paid attention to the severity of compensatory adaptive and involutory destructive reactions in the placenta. The maturity of villous tree was evaluated using the criteria for Voloshchuk's classification of villous tree maldevelopment. The variational methods were used to make the statistical analysis of outcomes by standard licensed computer programs: STATISTICA 6.0, Microsoft Excel, ANOVA «Statistica». Differences among values were considered statistically significant if $\mathrm{p}<0,05$.

Results. The morphology of the placenta in case of intrauterine growth retardation is characterized by a high incidence of uteroplacental blood flow violations. The changes are mainly caused by insufficient maternal blood in intervillous space. The most common morphological manifestations of the violated blood flow in intervillous space were heart attacks, afunctional areas, successive narrowing and thrombosis of intervillous space. The incidence of blood flow violations in intervillous space is growing with increased severity of fetal growth retardation.

Conclusions. Placental insufficiency due to morphological and functional changes in the placenta is the leading cause of intrauterine growth retardation and fetal hypoxia. It develops as a result of fetal and placenta combined reaction to various disorders in the mother's body. The incidence of blood flow violations in intervillous space is growing with increased severity of fetal growth retardation.

Key words: intrauterine growth retardation, pregnant, placenta, placental insufficiency, morphofunctional changes.

\section{Сведения об авторе}

Басистый Александр Валентинович - ГУ «Институт педиатрии, акушерства и гинекологии НАМН Украины», 04050, г. Киев, ул. Платона Майбороды, 8; тел.: (067) 778-84-61

\section{СПИСОК ЛІТЕРАТУРИ}

1. Ашурова Н.Г. Современный взгляд на проблему задержки внутриутробного развития плода (Обзорная статья) / Н. Г. Ашурова, М.И. Исматова // Наука. Мысль. - 2015. - № 3. - С. 13-18.

2. Волощук И.Н. Морфологические основы и патогенез плацентарной недостаточности: Автореф. дисс. ... дра мед. наук. - М., 2002

3. Жирова Н.В. Особенности течения беременности у женщин в зависимости от функционального состояния сосудистого эндотелия и его роль в формировании хронической плацентарной недостаточности: Клиникоэкспериментальное исследование: Автореф. дисс. ... канд. мед. наук: 14.00.01, 14.00.16 / Жирова Наталья Владимировна; Алт. гос. мед. уни верситет. - Барнаул, 2004. - 24 с. 4. Игнатко И.В. Декомпенсированная плацентарная недостаточность и кри тическое состояние плода / И.В. Иг натко, М.А. Карданова, Ю.И. Толкач,
И.А. Федюнина // Вопросы гинекологии, акушерства и перинатологии. 2015. - № 5. - С. 36-46.

5. Радзинский В.Е. Эктраэмбриональные и околоплодные структуры при нормальной и осложненной беременности / Под ред.: В.Е. Радзинского, А.П. Милованова. - М.: Мед. информ. агентство (МИА), 2004. - 393 с. 6. Crocker I.P. Review: Endothelial progenitor cells in pregnancy and obstetric pathologies / I.P. Crocker, P.I. Sipos //
Placenta. - 2013. - Vol. 34, suppl. P. S62-S67.

7. Kovo M. Pregnancy outcome and placental findings in pregnancies complicated by fetal growth restriction with and without preeclampsia / M. Kovo, L. Schreiber, O. Elyashiv [et al.] // Reprod. Sci. - 2015. - Vol. 22, N 3. - P. 316-321.

8. Mifsud W. Placental pathology in earlyonset and late-onset fetal growth restriction / W. Mifsud, N.J. Sebire // Fetal. Diagn. Ther. - 2014. - Vol. 36, N 2. - P. 117-128. 


\title{
Забезпеченість есенціальними мікроелементами вагітних різного репродуктивного віку, що народжують уперше
}

\author{
В.В. Маркевич \\ Національна медична академія післядипломної освіти імені П.Л. Шупика, м. Київ
}

\begin{abstract}
Мета дослідження: вивчення особливостей забезпечення сироваткового та еритроцитарного пулу есенціальними мікроелементами (МЕ) у ході вагітності жінок різного репродуктивного віку у разі перших пологів.

Матеріали та методи. Визначення МЕ проведено у сироватці крові та еритроцитах у 108 вагітних раннього, середнього та старшого репродуктивного віку, що народжували уперше. Репродуктивний вік вагітних складав відповідно $16,33 \pm 0,21$ року, $24,67 \pm 0,37$ та $36,14 \pm 0,77$ року. Дослідження проведено у III триместрі вагітності на $36,08 \pm 0,59$ тижня гестації. Уміст МЕ (залізо, мідь, цинк, кобальт, магній, марганець)у біосубстратах визначали за допомогою атомно-абсорбційного спектрофотометра $\mathrm{C}$ $115 \mathrm{MI}$, оснащеного комп'ютерною приставкою для автоматичного обчислення вмісту МЕ, виробництва НВО Selmi (Україна).

Результати. Для вагітних раннього репродуктивного віку властиві найнижчі показники забезпеченості сироваткового пулу залізом, кобальтом і цинком та еритроцитарного пулу - залізом і кобальтом. Спостерігається також сироватково-еритроцитарний дисбаланс вмісту цинку. Найнижчий рівень сироваткового та еритроцитарного вмісту міді і марганцю та еритроцитарного вмісту магнію властивий для вагітних старшого репродуктивного віку. Незалежно від репродуктивного віку для вагітних властивий сироватковий дефіцит магнію та цинку. Навпаки, еритроцитарне насичення цинком було значно збільшене, що свідчить про сироватково-еритроцитарний дисбаланс його вмісту. Заключення. Усіх вагітних, особливо раннього та старшого репродуктивного віку, слід зараховувати до групи високого ризику виникнення та прогресування мікроелементозів. Тому надзвичайно актуальною є проблема розроблення методів коррекції мікроелементозів у вагітних. Ключові слова: есенціальні мікроелементи, репродуктивний вік, вагітні, що народжують уперше.
\end{abstract}

$\mathrm{M}$ ікроелементний гомеостаз організму є найваж1 ливішою і обов'язковою умовою його нормального функціонування. Відхилення у вмісті мікроелементів (ME) призводять до значних порушень здоров'я [7, 11] Існує взаємозв'язок між дефіцитом елементів у навколишньому середовищі та станом здоров'я людей $[10,13]$.

Репродуктивний вік жінки потребує мобілізації всіх органів, систем організму для повноцінного розвитку плода. Мікроелементний гомеостаз організму є однією із важливих складових преморбідного фону, на якому розвивається вагітність [4].

ME безпосередньо впливають на організм вагітної та плода. Корекція дефіциту МЕ у вагітних жінок є важливою як для здоров'я жінки, так і для плода $[2,3]$.

Вагітність, навіть за її фізіологічного перебігу, супроводжується напруженістю усіх видів обміну, у тому числі і мікроелементного. Дисбаланс ME негативно впливає на систему мати-плацента-плід [5]. Потреба в МЕ у період вагітності і грудного вигодовування суттєво зростає. МЕ, що надходять в організм, використовуються як для організму матері, так і для правильного розвитку плода [9].

Особливо велике значення відіграє стан забезпечення есенціальними елементами. Їхній дисбаланс у період вагітності, пологів, лактації, порушення гомеостазу МЕ у плаценті, в організмі плода і новонароджених є тригерним фактором недоношування, різних видів внутрішньоутробної патології чи вад розвитку, гіпотрофії, анемії, порушень фізичного і психомоторного розвитку дітей, підвищує дитячу смертність [1].

3 огляду на зазначене вище велике значення має дослідження вмісту та балансу есенціальних МЕ у біосередовищах у ході гестаційного процесу. У регуляції перебігу фізіологічних процесів провідне місце посідають наступні есенціальні МE : залізо - Fe, цинк - Zn, мідь - Cu, кобальт - Co, магній - Mg та марганець - Mn. Актуальним є зіставлення особливостей їхнього вмісту та балансу у вагітних залежно від репродуктивного віку - раннього, середнього та старшого у разі перших пологів.

Мета дослідження: вивчення особливостей забезпечення сироваткового та еритроцитарного пулу есенціальними ME у ході вагітності жінок різного репродуктивного віку у разі перших пологів.

\section{МАТЕРІАЛИ ТА МЕТОДИ}

Визначення МЕ проведено у сироватці крові та еритроцитах у 108 вагітних раннього, середнього та старшого репродуктивного віку, що народжували уперше. Середній вік вагітних складав відповідно $16,33 \pm 0,21$ року, $24,67 \pm 0,37$ та $36,14 \pm 0,77$ року. Вагітні різного репродуктивного віку суттєвим чином не відрізнялись за екологічно-географічною зоною проживання, соціально-економічним станом, рівнем освіти, особливостями способу життя, характером харчування та терміном гестації. Вони не зазнавали дії професійних шкідливостей та не мали захворювань, здатних призводити до дефіциту чи дисбалансу ME (захворювання травного тракту, нирок, ендокринних залоз, спадкових захворювань обміну речовин та інфекційної патології). Уміст $\mathrm{ME}$ ( $\mathrm{Fe}, \mathrm{Zn}, \mathrm{Cu}, \mathrm{Mg}, \mathrm{Co}, \mathrm{Mn}$ ) у біосубстратах визначали за допомогою атомно-абсорбційного спектрофотометра С-115 MI, оснащеного комп'ютерною приставкою для автоматичного обчислення вмісту ME, виробництва HBO Selmi (Україна). Отримані результати співставляли з раніше встановленими показниками вмісту МЕ у біосередовищах здорових вагітних [6, 8, 12]. Статистичне оброблення проводили за визначенням достовірності різниці величин із застосуванням критерію Стьюдента. Результати дослідження опрацьовували 3 використанням пакета програм Excel. 
A K Y Ш E P C T B O

\section{РЕЗУЛЬТАТИ ДОСЛІДЖЕННЯ ТА ЇХ ОБГОВОРЕННЯ}

Забезпеченість сироваткового та еритроцитарного пулу $\mathrm{Fe}$ у жінок, що народжували уперше, була низькою. Найнижчі показники були у вагітних раннього репродуктивного віку.

Уміст Fe у сироватці крові жінок середнього репродук-

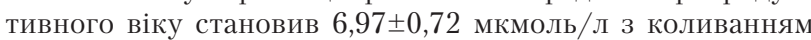
від 0,54 до 23,75 мкмоль/л (таблиця). При цьому лише в $11,1 \%$ вагітних він досягав фізіологічних величин

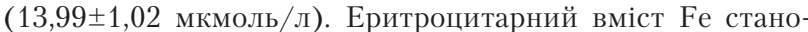
вив 6,192 $\pm 0,405$ мкг/мг, що було значно менше фізіологічного рівня (14,34 $\pm 0,84$ мкг $/$ мг; $\mathrm{p}=0,0001)$. Уміст заліза коливався від 3,12 до 13,87 мкг/мг та лише у 7,7\% вагітних досягав фізіологічного рівня.

У вагітних раннього репродуктивного віку рівень сиро-

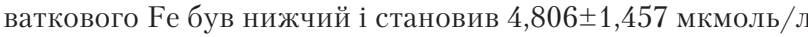
$(\mathrm{p}=0,23)$. Інтервал коливався від 1,23 до 15,56 мкмоль/л. Лише у 16,6\% вагітних сироватковий пул відповідав фізіологічному рівню. Уміст еритроцитарного заліза був менший, ніж у попередній групі, i становив 4,816 $\pm 0,805$ мкг/мг $(\mathrm{p}=0,26)$. Інтервал коливань вмісту становив 3,12-8,68 мкг/мг, та у жодної жінки не досягав фізіологічного рівня.

У жінок старшого та середнього репродуктивного віку показники середнього вмісту Fe у сироватці та еритроцитах не відрізнялися. Діапазон коливань вмісту Fe в еритроцитах становив 1,92-13,56 мкг/мг. У 12,5\% жінок він наближався до фізіологічного рівня.

У міст Zn у сироватці крові жінок середнього репродуктивного віку (див. таблицю) становив 5,957 $\pm 0,973$ мкмоль/л 3 коливанням від 0,87 до 34,36 ммоль/л, що значно менше фізіологічного рівня $(25,88 \pm 4,80$ мкмоль/л; р=0,0001). У $8,9 \%$ вагітних він досягав фізіологічних величин.

У жінок старшого репродуктивного віку середній вміст

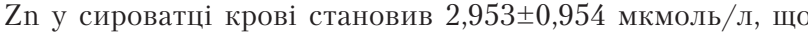
було значно менше $(\mathrm{p}=0,03)$, ніж у вагітних середнього репродуктивного віку. Діапазон коливань його сироваткового вмісту становив 0,05-13,74 ммоль/л, і у жодної жінки він не наближався до фізіологічного рівня [11].

У вагітних раннього репродуктивного віку рівень $\mathrm{Zn}$ у сироватці був набагато нижчий, ніж у жінок обох попередніх груп, і становив $0,986 \pm 0,094$ мкмоль/л $(\mathrm{p}=0,03$ та $\mathrm{p}=0,088$ відповідно). Інтервал коливань сироваткового $\mathrm{Zn}$ становив 0,569-1,431 мкмоль/л і жодного разу не досягав фізіологічного рівня $[11,12]$.

Різниці вмісту еритроцитарного Zn у жінок раннього та середнього репродуктивного віку не відзначено, його рівень становив $1,231 \pm 0,340$ та $1,373 \pm 0,428$ мкг/мг відповідно $(\mathrm{p}=0,9)$. Діапазон коливань Zn у жінок цих груп становив 0,11-23,092 мкг/мг. При цьому у жінок раннього та середнього репродуктивного віку він перевищував фізіологічний рівень $(0,12 \pm 0,0025$ мкг $/$ мг; $\mathrm{p}=0,0001$ та $\mathrm{p}=0,04$ відповідно).

У вагітних старшого репродуктивного віку еритроци-

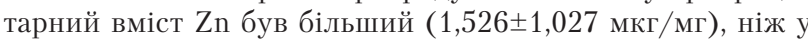
жінок двох попередніх груп ( $\mathrm{p}=0,83$ та $\mathrm{p}=0,89$ відповідно). Інтервал коливань його вмісту був дещо менший $(0,14-13,77$ мкг мг ).

Отже, для вагітних властивий сироватковий дефіцит Zn. При цьому найбільш значущим він був у групі вагітних віком до 18 років. Навпаки, еритроцитарне насичення Zn було значно збільшеним, що свідчить про сироватковоеритроцитарний дисбаланс вмісту Zn.

Для вагітних характерний низький сироватковий вміст

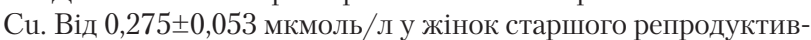

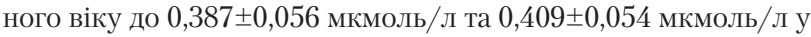

жінок середнього та раннього репродуктивного віку відповідно, що було значно менше фізіологічного рівня $(8,17 \pm 0,75$ ммоль $/ л ; p=0,0001, p=0,0001, p=0,0001$ відповідно за віковими групами вагітних). Коливання сироваткового вмісту Сu становило від 0,033 до 3,545 мкмоль/л.

Еритроцитарний вміст $\mathrm{Cu}$ не відрізнявся суттєво у жінок цих груп, але був найменший у вагітних віком понад 35 років $(0,337 \pm 0,072$ мкг/мг) порівняно з жінками середнього віку $(0,401 \pm 0,042$ мкг $/$ мг на 1 л; $p=0,15)$ та вагітними раннього репродуктвного віку $(0,688 \pm 0,355$ мкг/мг; $\mathrm{p}=0,23)$. Діапазон коливань вмісту $\mathrm{Cu}$ був досить значний - від 0,023 до 1,190 мкг/мг. Фізіологічний рівень Сu в ери-

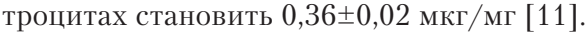

Отже, найнижчий рівень сироваткового та еритроцитарного вмісту Сu властивий для вагітних старшого репродуктивного віку.

Уміст сироваткового $\mathrm{Mg}$ у жінок середнього репродуктивного віку був дещо менший $(0,172 \pm 0,023$ ммоль/л), ніж у вагітних віком до 18 років $(0,259 \pm 0,032$ ммоль/л; $\mathrm{p}=0,08)$ та жінок віком понад 35 років $(0,208 \pm 0,029$ ммоль/л; $\mathrm{p}=0,44)$. Величина коливань сироваткового Mg сягала від 0,004 до 0,552 ммоль/л. У 48,1\% жінок, що народжували уперше, відзначали дуже низький вміст сироваткового $\mathrm{Mg}$ $(<0,120$ ммоль/л).

Еритроцитарний вміст Mg у вагітних середнього репродуктивного віку був більший $(0,419 \pm 0,100$ мкг/мг), ніж у жінок віком менше 18 років $(0,232 \pm 0,037$ мкг мг; $\mathrm{p}=0,49)$, та особливо у вагітних віком понад 35 років $(0,197 \pm 0,025$ мкг мг; $\mathrm{p}=0,04)$. Діапазон коливань вмісту Mg в еритроцитах становив 0,047-5,350 мкг/мг. Разом з тим, у 71,5\% жінок він був у межах 0,119-0,417 мкг/мг.

Отже, у значної частини вагітних, що народжували уперше, відзначали сироватковий дефіцит Mg. Найменший вміст магнію в еритроцитах властивий для жінок старшого репродуктивного віку.

Уміст Со у сироватці крові жінок середнього репродук-

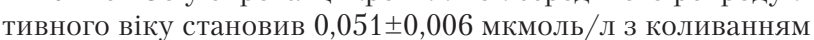
від 0,001 до 0,262 мкмоль/л. При цьому лише у 28,6\% жінок він досягав фізіологічних величин $(0,062 \pm 0,006$ мкмоль/л).

У жінок старшого репродуктивного віку рівень Со був дещо нижчий і становив 0,042 $\pm 0,008$ мкмоль/л $(\mathrm{p}=0,46)$. Він був також значно нижчим, ніж фізіологічний рівень $(\mathrm{p}=0,05)$. Діапазон коливань вмісту Со становив від 0,0052 до 0,131 мкмоль/л. Тільки у 30\% жінок він відповідав фізіологічному рівню.

Найменший вміст сироваткового Со відзначено у жінок

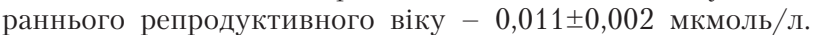
Він був значно менший $(\mathrm{p}=0,002)$, ніж у жінок середнього та старшого репродуктивного віку $(\mathrm{p}=0,002)$. У жодної жінки цієї групи сироватковий вміст Со не досягав фізіологічного рівня.

Еритроцитарний вміст Со суттєво не відрізнявся і становив у вагітних раннього, середнього та старшого репродук-

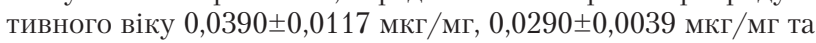
0,0309 $\pm 0,0057$ мкг/мг відповідно. Рівень Со в еритроцитах,

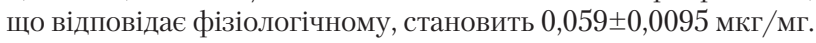
Показники достовірності різниці фізіологічного вмісту за групами вагітних становили відповідно $\mathrm{p}=0,31, \mathrm{p}=0,001$ та $\mathrm{p}=0,05$.

Отже, у значної частини жінок різного віку, що народжують уперше, спостерігається сироватковий та еритроцитарний дефіцит Со. Найбільш значущим за показником сироваткового вмісту він був у вагітних віком менше 18 років.

Уміст Mn у сироватці вагітних середнього репродуктивного віку був у два рази менший, ніж у жінок віком до 18 років, і становив відповідно 0,078 $\pm 0,007$ мкмоль/л та 0,198 $\pm 0,060$ мкмоль/л $(\mathrm{p}=0,0003)$. У вагітних віком понад 
A K Y Ш E P C T B O

Уміст МЕ у сироватці крові (мкмоль/л) та еритроцитах (мкг/мг золи ) вагітних різного репродуктивного віку

\begin{tabular}{|c|c|c|c|c|c|c|c|}
\hline \multirow{3}{*}{ ME } & \multirow{3}{*}{ Показник } & \multicolumn{6}{|c|}{ Репродуктивний вік вагітних } \\
\hline & & \multicolumn{2}{|c|}{ Середній } & \multicolumn{2}{|c|}{ Ранній } & \multicolumn{2}{|c|}{ Старший } \\
\hline & & Сироватка & Еритроцити & Сироватка & Еритроцити & Сироватка & Еритроцити \\
\hline $\mathrm{Fe}$ & $\begin{array}{l}\mathrm{M} \\
\mathrm{m} \\
\mathrm{n}\end{array}$ & $\begin{array}{c}6,97 \\
0,72 \\
54 \\
p=0,23\end{array}$ & $\begin{array}{c}6,192 \\
0,405 \\
62 \\
p=0,26\end{array}$ & $\begin{array}{c}4,806 \\
1,457 \\
12 \\
\mathrm{p}_{2}=0,25\end{array}$ & $\begin{array}{c}4,816 \\
0,805 \\
7 \\
\mathrm{p}_{2}=0,25\end{array}$ & $\begin{array}{c}7,230 \\
1,412 \\
18 \\
p_{1}=0,87\end{array}$ & $\begin{array}{c}6,462 \\
0,845 \\
16 \\
p_{1}=0,77\end{array}$ \\
\hline $\mathrm{Zn}$ & $\begin{array}{c}\mathrm{M} \\
\mathrm{m} \\
\mathrm{n}\end{array}$ & $\begin{array}{c}5,957 \\
0,973 \\
67 \\
p=0,03^{\star}\end{array}$ & $\begin{array}{c}1,373 \\
0,428 \\
57 \\
p=0,9\end{array}$ & $\begin{array}{c}0,986 \\
0,094 \\
12 \\
\mathrm{p}_{2}=0,088\end{array}$ & $\begin{array}{c}1,231 \\
0,340 \\
8 \\
\mathrm{p}_{2}=0,83\end{array}$ & $\begin{array}{c}2,953 \\
0,954 \\
16 \\
\mathrm{p}_{1}=0,03^{\star}\end{array}$ & $\begin{array}{c}1,526 \\
1,027 \\
13 \\
\mathrm{p}_{1}=0,89\end{array}$ \\
\hline $\mathrm{Cu}$ & $\begin{array}{l}\mathrm{M} \\
\mathrm{m} \\
\mathrm{n}\end{array}$ & $\begin{array}{c}0,387 \\
0,056 \\
71 \\
p=0,86\end{array}$ & $\begin{array}{c}0,401 \\
0,042 \\
59 \\
p=0,09\end{array}$ & $\begin{array}{c}0,409 \\
0,054 \\
16 \\
\mathrm{p}_{2}=0,09\end{array}$ & $\begin{array}{c}0,688 \\
0,355 \\
8 \\
\mathrm{p}_{2}=0,23\end{array}$ & $\begin{array}{c}0,275 \\
0,053 \\
20 \\
p_{1}=0,15\end{array}$ & $\begin{array}{c}0,337 \\
0,072 \\
14 \\
p_{1}=0,45\end{array}$ \\
\hline$M g^{\star *}$ & $\begin{array}{l}\mathrm{M} \\
\mathrm{m} \\
\mathrm{n}\end{array}$ & $\begin{array}{c}0,172 \\
0,023 \\
68 \\
p=0,08\end{array}$ & $\begin{array}{c}0,419 \\
0,100 \\
57 \\
p=0,49\end{array}$ & $\begin{array}{c}0,259 \\
0,032 \\
16 \\
\mathrm{p}_{2}=0,24\end{array}$ & $\begin{array}{c}0,232 \\
0,037 \\
8 \\
\mathrm{p}_{2}=0,43\end{array}$ & $\begin{array}{c}0,208 \\
0,029 \\
19 \\
p_{1}=0,44\end{array}$ & $\begin{array}{c}0,197 \\
0,025 \\
16 \\
\mathrm{p}_{1}=0,04^{\star}\end{array}$ \\
\hline Co & $\begin{array}{l}\mathrm{M} \\
\mathrm{m} \\
\mathrm{n}\end{array}$ & $\begin{array}{c}0,051 \\
0,006 \\
70 \\
\mathrm{p}=0,002^{\star}\end{array}$ & $\begin{array}{c}0,029 \\
0,0039 \\
55 \\
p=0,37\end{array}$ & $\begin{array}{c}0,011 \\
0,002 \\
16 \\
\mathrm{p}_{2}=0,002^{\star}\end{array}$ & $\begin{array}{c}0,039 \\
0,0117 \\
8 \\
\mathrm{p}_{2}=0,49\end{array}$ & $\begin{array}{c}0,042 \\
0,008 \\
20 \\
p_{1}=0,46\end{array}$ & $\begin{array}{c}0,031 \\
0,0057 \\
15 \\
p_{1}=0,82\end{array}$ \\
\hline Mn & $\begin{array}{c}\mathrm{M} \\
\mathrm{m} \\
\mathrm{n}\end{array}$ & $\begin{array}{c}0,078 \\
0,007 \\
71 \\
\mathrm{p}=0,0003^{\star}\end{array}$ & $\begin{array}{c}0,0503 \\
0,010 \\
59 \\
p=0,20\end{array}$ & $\begin{array}{c}0,198 \\
0,060 \\
16 \\
\mathrm{p}_{2}=0,05^{\star}\end{array}$ & $\begin{array}{c}0,095 \\
0,049 \\
8 \\
\mathrm{p}_{2}=0,116\end{array}$ & $\begin{array}{c}0,091 \\
0,012 \\
21 \\
p_{1}=0,36\end{array}$ & $\begin{array}{c}0,036 \\
0,006 \\
15 \\
\mathrm{p}_{1}=0,23\end{array}$ \\
\hline
\end{tabular}

Примітки: $\mathrm{p}$ - достовірність різниці показників у вагітних раннього та середнього репродуктивного віку; $\mathrm{p}_{1}$ - достовірність різниці показників у вагітних середнього та старшого віку; $\mathrm{p}_{2}$ - достовірність різниці показників у вагітних раннього та старшого репродуктивного віку; * - різниця показників достовірна; ** - вміст МЕ у ммоль/л.

35 років сироватковий вміст $\mathrm{Mn}(0,091 \pm 0,012$ мкмоль/л) не відрізнявся від його рівня у групі вагітних середнього репродуктивного віку $(\mathrm{p}=0,36)$ та був значно менший, ніж у жінок віком до 18 років $(\mathrm{p}=0,05)$. Коливання його у сироватці становило від 0,0058 мкмоль/л до 0,168 мкмоль/л. За даними інших дослідників, воно становило 0,1-0,8 мкг/л, що відповідає 0,0018-0,014 мкмоль/л [12,13].

Уміст еритроцитарного Mn був найбільший у жінок віком до 18 років $(0,095 \pm 0,049$ мкг/мг), дещо менший $(\mathrm{p}=0,20)-$ у вагітних середнього репродуктивного віку $(0,0503 \pm 0,010$ мкг/мг) та ще менший - у жінок вікової групи більше 35 років $(0,036 \pm 0,006$ мкг $/ м г ; ~ p=0,116, p=0,23)$ порівняно $з$ двома попередніми групами жінок. Коливання вмісту еритроцитарного $\mathrm{Mn}$ сягали 0,005 мкг/мг 0,330 мкг/мг.

Отже, сироватковий та еритроцитарний вміст Mn був найвищий у групі вагітних віком до 18 років та найнижчий у вагітних, вік яких перевищував 35 років.

Для вагітних властивий великий діапазон коливань вмісту есенціальних МЕ, особливо транспортно-сироваткового пулу.

Для жінок незалежно від репродуктивного віку, що народжують уперше, властивий сироватковий дефіцит $\mathrm{Mg}$ та Zn. Навпаки, еритроцитарне насичення Zn було суттєво збільшеним, що є ознакою сироватково-еритроцитарного дисбалансу.

Найбільш несприятливі показники вмісту есенціальних ME отримані у вагітних раннього репродуктивного віку, що народжують уперше. Для них властивий найнижчий рівень сироваткового пулу $\mathrm{Fe}$, Co i Zn та еритроцитарного пулу $\mathrm{Fe}$ i Co, а також спостерігається сироватково- еритроцитарний дисбаланс вмісту Zn. Разом із тим, сироватковий та еритроцитарний вміст $\mathrm{Mg}$ був найвищий саме у цій групі вагітних.

Для вагітних старшого репродуктивного віку властивий дефіцит сироваткового та еритроцитарного вмісту $\mathrm{Cu}$ i Mn та еритроцитарного вмісту Mg.

Це свідчить про те, що перебіг гестаційного процесу супроводжується значним напруженням систем, які забезпечують фізіологічний вміст та баланс МЕ. Тому вагітних, особливо раннього та старшого репродуктивного віку, слід зарахувати до групи високого ризику виникнення мікроелементозів.

\section{ВИСНОВКИ}

1. Вагітних, особливо раннього та старшого репродуктивного віку, слід зарахувати до групи високого ризику виникнення та прогресування мікроелементозів.

2. Для вагітних раннього репродуктивного віку, що народжують уперше, властиві найнижчі показники забезпеченості сироваткового пулу залізом, кобальтом і цинком та еритроцитарного пулу - залізом і кобальтом. У них спостерігається сироватково-еритроцитарний дисбаланс вмісту цинку.

3. Найнижчий рівень сироваткового та еритроцитарного вмісту міді і марганцю та еритроцитарного вмісту магнію властивий для вагітних старшого репродуктивного віку.

4. Для вагітних незалежно від репродуктивного віку, що народжують уперше, властивий сироватковий дефіцит магнію та цинку. Навпаки, еритроцитарне насичення цинком було суттєво збільшеним, що свідчить про сироватково-еритроцитарний дисбаланс його вмісту. 


\section{A K Y Ш E P C T B O}

\section{Обеспечение эссенциальными микроэлементами беременных разного репродуктивного возраста, рожающих впервые \\ B. В. Маркевич}

Цель исследования: изучение особенностей обеспечения сывороточного и эритроцитарного пула эссенциальными микроэлементами (МЭ) в ходе беременности женщин разного репродуктивного возраста в случае первых родов.

Материаль и методы. Определение МЕ проведено в сыворотке крови и эритроцитах у 108 беременных раннего, среднего и старшего репродуктивного возраста, рожавших впервые. Репродук-

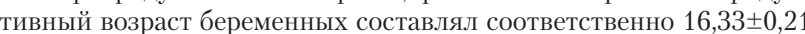

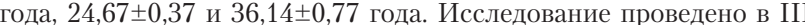
триместре беременности на $36,08 \pm 0,59$ недели гестации. Для определения содержания МЕ (железо, медь, цинк, кобальт, магний, марганец) использовали спектрофотометр C-115M1 производства HBO Selmi (Украина).

Pезультаты. Для беременных раннего репродуктивного возраста свойственны низкие показатели обеспеченности сывороточного пула железом, кобальтом и цинком и эритроцитарного пула - железом и кобальтом. Наблюдается также сывороточно-эритроцитарный дисбаланс содержания цинка. Низкий уровень сывороточного и эритроци тарного содержимого меди и марганца и эритроцитарного содержимого магния свойственен беременным старшего репродуктивного возраста. Независимо от репродуктивного возраста беременным присущ сывороточный дефицит магния и цинка. Напротив, эритроцитарное насыщение цинком было значительно увеличено, что свидетельствует о сывороточно-эритроцитарном дисбалансе его содержания.

Заключение. Всех беременных, особенно раннего и старшего репродуктивного возраста, следует относить к группе высокого риска возникновения и прогрессирования микроэлементозов. Поэтому чрезвичайно актуальна проблема разработки методов их корекции у беременных.

Ключевие слова: эссенциальные микроэлементы, репродуктивный возраст, беременные, рожаюшие впервые.

\section{Provision of essential microelements of pregnant women of all reproductive age give birth first time V.V. Markevich}

The objective: Study features provide serum and erythrocyte pool of essential microelements (iron, copper, zinc, cobalt, magnesium, manganese) in pregnant women of all reproductive age in the case of the first delivery.

Materials and methods. Definition of ME level conducted in serum and red blood cells in 108 pregnant women of early, middle and high reproductive age who gave birth for the first time. Reproductive age of pregnant women was $16,33 \pm 0,21$ years, $24,67 \pm 0,37$ and $36,14 \pm 0,77$ years. The study was conducted in the third trimester in $36,08 \pm 0,59$ weeks of gestation. Content of ME (iron, zinc, copper, magnesium, cobalt, manganese) in the biological substrates was determined by atomic absorption spectrophotometer C-115MI equipped computer console for automatic calculation of ME content production Selmi NGO (Ukraine).

Results. For pregnant women of early reproductive age was typical the lowest indicators of serum level of iron, cobalt and zinc and in erythrocyte pool - iron and cobalt. The lowest level of serum and erythrocyte contents of copper and manganese and magnesium content in erythrocytes inherent in pregnant women of older reproductive age. Regardless of reproductive age, pregnant women had serum deficiency of magnesium and zinc. In contrast, saturation of zinc in erythrocyte was significantly increased, indicating serun - erythrocytic imbalance of its content

Conclusions. All pregnant women, especially young and older reproductive age should be classified at high risk of development and progressing of microelementosis so extremely urgent problem is development of methods of correction of microelementosis in pregnant women.

Key words: essential micrioelements, pregnant women, reproductive age, first birth.

\section{Сведения об авторе}

Маркевич Валентина Владимировна - Кафедра акушерства, гинекологии и перинатологии Национальной медицинской академии последипломного образования имени П.Л. Шупика, 04112, г. Киев, ул. Дорогожицкая, 9; тел.: (066) 886-57-57. E-mail: misto2009Eggmail.com.

\section{СПИСОК ЛІТЕРАТУРИ}

1. Агаджанян Н.А. Экологический портрет человека/ Н.А. Агаджанян, М.В. Велданова, А.В. Скальный. M., 2001. -88 c.

2. Веропотвелян П.М. Мікроелементи та вагітність / П.М. Веропотвелян, М.П. Веропотвелян, О.М. Капаліна, П.С. Горук// Педіатрія, акушерство та гінекологія. - 2012. - № 2. C. $95-100$.

3. Веропотвелян П.Н. Важность микронутриентов при беременности/ П.Н .Веропотвелян, Н.П. Веропотвелян, Ю.С. Погуляй, Н.С. Холодова// Здоровье женщины. - 2014. № 8 (94). - С. 57-64.

4. Гуменюк Е.Г. Физиология беременности / Е.Г. Гуменюк, О.К. Пого- дин, Т.А. Власова. - Петрозаводск: «Инти Тек», 2004. - 120 с.

5. Кравець О.М. Физиологическое значение микроэлементов для женщин репродуктивного возраста / О.М. Кравец, Т.П. Кравец // Здоровье женщи ны. - 2008. - № 2 (34). - С. 37-40. 6. Мікроелементна забезпеченість у системі мати-плацента-плід-новонароджений/ В.Е. Маркевич, І.В. Тарасова, Л.О. Турова, В.В. Маркевич // Вісник СумДУ. Серія «Медицина». 2007. - № 1. - С. 52-58.

7. Роль минеральных веществ в физиологии и патологии ребенка Н.В. Нагорная, А.В. Дубовая, В.В. Алферов [и др.] // Здоровье ребенка. 2008. - № 6 (15). - С. 62-67.
8.Скальный А.В. Биоэлементы в медицине/ А.В. Скальный, И.А. Рудаков. - М.: ОНИКС XXI век. Мир, 2004. $272 \mathrm{c}$

9. Трошина Е.А. Дефицит микроэлементов во время беременности / Е.А. Трошина, А.В. Секинаева Ф.М. Абдулхабирова// Акушерство и гинекология. - 2009. - № 1. С. 7-11.

10. Фролова Т.В. Роль дисбаланса микро- и макроэлементов в формировании хронической патологии детей. / Т.В. Фролова, О.В. Охапкина// Перинатология и педиатрия. - 2013. - № 4 (56). - С. 127-132.

11. Шиц И.В. Особенности элементного статуса беременных женщин с экстрагенитальной патологией в условиях г. Якутска: Автореф. дисс. ... канд. мед. наук: спец. 14.00.16 "Акушерство и гинекология"/ И.В. Шиц. Якутск, 2006. - 22 с.

12. The placenta as a barrier for toxic and essential elements in paired maternal and blood samples of South African delivering women / Cibele V. Rudge, Halina B. Rollin, Claudina M. Nogueira [et all] // Journal of Environmental Monitoring. 2009. - № 7 (11). - P. 1322-1330.

13. Wigle D.T. Environmetal hazards: evidence for effects on child health / D.T. Wigle, T.E. Arbuckle, M. Walker [et al.] // J.Toxicol. Environ. Health B. Crit. Rev. - 2007. - Vol. 10, N 1-2. P. 3-39. 


\title{
Морфологическая классификация повреждений плаценты
}

\author{
Н.П. Веропотвелян ${ }^{1}$, П.Н. Веропотвелян ${ }^{1}$, И.С. Цехмистренко ${ }^{2}$ А.А. Бондаренко ${ }^{1}$, Т.В. Усенко \\ ${ }^{1}$ ОКУ «Межобластной центр медицинской генетики и пренатальной диагностики», г .Кривой Рог \\ ${ }^{2}$ Перинатальный центр, г. Киев \\ ${ }^{3}$ КУ «Днепропетровское областное патологоанатомическое бюро»
}

В статье рассмотрена современная морфологическая классификация, разработанная Амстердамской группой ученых, обеспечивающая принятие консенсуса по определению и характеристикам основных поражений плаценты для выяснения их клинического значения и разработки таргетных воздействий с учетом эхокартины патологии плаценты, выявленной при выполнении пренатального УЗИ.

Проведенные исследования позволяют оптимизировать не только диагностическую, но и лечебную тактику у беременных высокого риска и прогнозировать дальнейшее развитие родов и рождение здорового ребенка.

Ключевые слова: плачента, классификация, осложненная беременность, повреждения.

$\mathrm{M}$

орфологические показатели плаценты зависят от особенностей течения беременности и являются маркером внутриутробного развития [7, 8], при своевременном выявлении которых можно прогнозировать риск неблагоприятных исходов у детей.

В 2013 г. исследователи S. Raisanen и соавторы [9] обнаружили отрицательную связь длины пуповины плаценты с частотой развития некоторых вариантов неврологической патологии у детей. Практически важным можно считать оценку количества крови, секвестрированной в пуповине сразу же после рождения. Это приобретает особую актуальность в контексте отсроченного пережатия пуповины и/или проведения процедуры «wilking» (сдавливание пуповины).

R. Rabe и соавторы [10] в 2011 г. информировали, что осуществление этой манипуляции четыре раза эквивалентно объему крови, поступающему к ребенку в течение 30 с задержки пережатия пуповины. Как известно, сегодня в акушерстве и перинатологии вопросы, связанные с осложнениями гестационного периода, в основе которых лежат нарушения в системе мать-плацента-плод, являются чрезвычайно актуальными.

Как отмечает исследователь R. Redline (2015), нарушение структуры и функции плаценты лежат в основе развития различных осложнений беременности и родов, в том числе мертворождения и смерти матери [13]. Безусловно, регистрирование изменения плаценты при морфологическом исследовании способствуют выяснению причин развития осложнений и, кроме того, выяснению прогноза развития младенца и течения будущих беременностей. Значит, основной целью патоморфологического исследования плаценты является своевременная регистрация патологических изменений, определяющих звенья патогенеза нарушений функционирования системы мать-плацента-плод и ряда заболеваний новорожденных.

В данной работе проведен обзор множества публикаций для определения современной международной морфологической классификации и характеристик основных дефектов (повреждений) плаценты.

Морфологические изменения, выявляемые в тканях плаценты, отражают результат сложной реакции фетоплацентарной системы на патологическое состояние материнского орга- низма [2]. В 2013 г. представлена Международная эмбриологическая терминология, в которой описаны следующие основные термины: хориальная пластинка, котиледон (или долька), ворсины, межворсинчатое пространство, базальная пластинка. Кроме того, в пуповине выделяют амнион, слизистую соединительную ткань, пуповинные артерии и непарную пуповинную вену, в плодных оболочках - амнион, хорион, амниохорион. Необходимо отметить, что отсутствует такой термин, как послед.

В настоящее время исследователи используют в основном классификацию Колледжа американских патологов и Международной федерации ассоциаций по изучению плаценты (International Federation of Placenta Associations) [12].

Как информирует A. Shegolev (2016), в основе объективного и полноценного морфологического изучения плаценты лежит разработка методики исследования и унификации взятия образцов тканей для дальнейшего их гистологического исследования [11]. Автор указывает, что первым этапом является макроскопическое исследование, при котором описывают состояние самой плаценты, пуповины, плодных оболочек с учетом мерных признаков. Так, взвешивание плаценты нужно проводить после отрезания плодных оболочек и пуповины, до взятия образцов ткани и фиксации препарата.

Размеры плаценты представляют в трех измерениях: максимальный диаметр, наибольшая длина линии, перпендикулярной к максимальному диаметру, и толщина (минимальное и максимальное значения). При подтверждении поражений указывают их характер, локализацию и размеры. Места взятия образцов тканей определяют задачами исследования.

\section{Классификация повреждений} (патологических изменений) плаценты

Все изменения плаценты объединены в три группы: сосудистые нарушения, воспалительные и так называемые другие.

I. Сосудистые поражения

1. Материнские стромально-сосудистые поражения.

1.1. Нарушения развития:

- поверхностная имплантация/децидуальная артериопатия;

- увеличение незрелого вневорсинчатого трофобласта.

1.2. Нарушения перфузии:

общие/частичные:

- раннее: гипоплазия дистальных ворсин,

- позднее: ускоренное созревание ворсин;

сегментарные/полные инфаркт(ы) ворсин.

1.3. Нарушение иелостности:

- отслойка плаценты (артериальная);

- краевая отслойка (венозная):

- острая,

- хроническая.

2. Плодные стромально-сосудистые поражения.

2.1. Нарушения развития:

- изменения капилляров ворсин;

- замедленное созревание ворсин (дефект созревания); дисморфизм ворсин. 


\section{A K Y Ш E P C T B O}

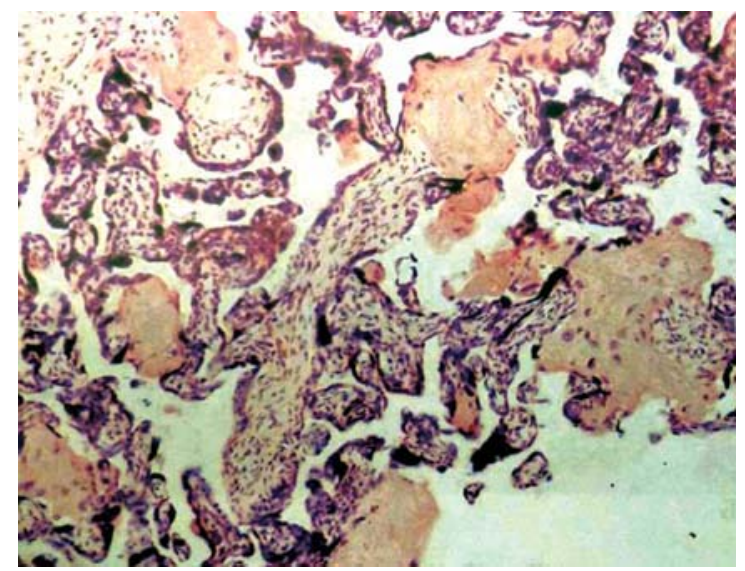

Рис. 1. Фибриноид в плаценте.

Окраска гематоксилином и эозином; ув. 100 [44]

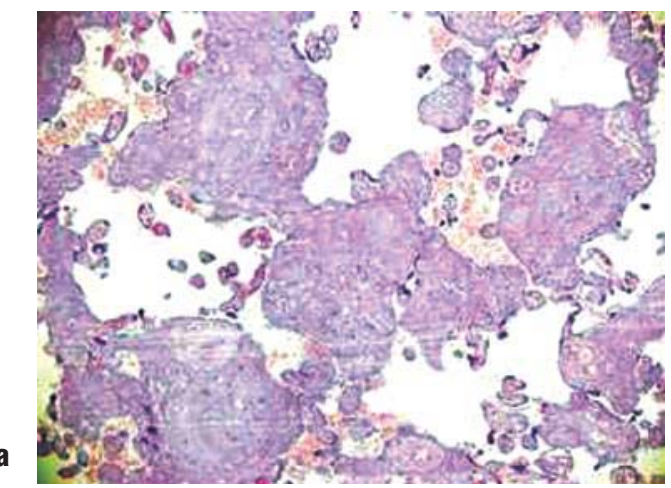

b

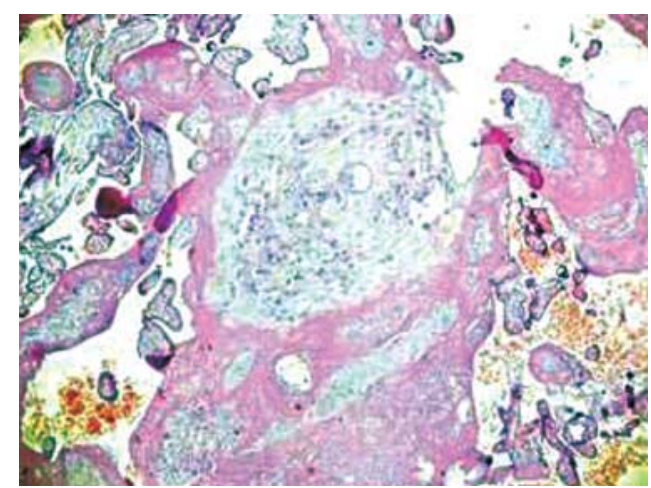

C

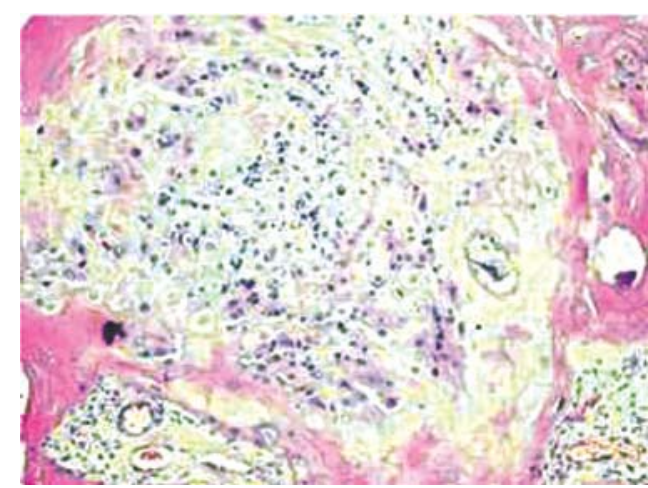

Рис. 2. Клеточные островки в ткани плаценты при поздней преэклампсии: $a$ - увеличение количества островков, $b$ - островок, содержащий вакуолизированные клетки, c- островок с наличием крупных клеток. Окраска гематоксилином и эозином; $а$-ув. 40, b, c-ув. 100 [45]

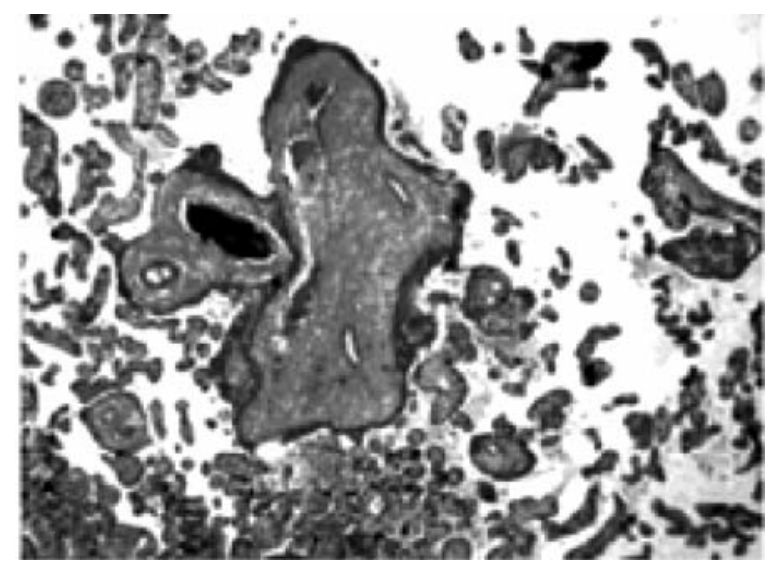

Рис. 3. Полнокровие опорных ворсин, ангиоматоз отдельных ворсин, увеличение числа терминальных ворсинок. Окраска гематоксилином и эозином; ув. 700 [46]

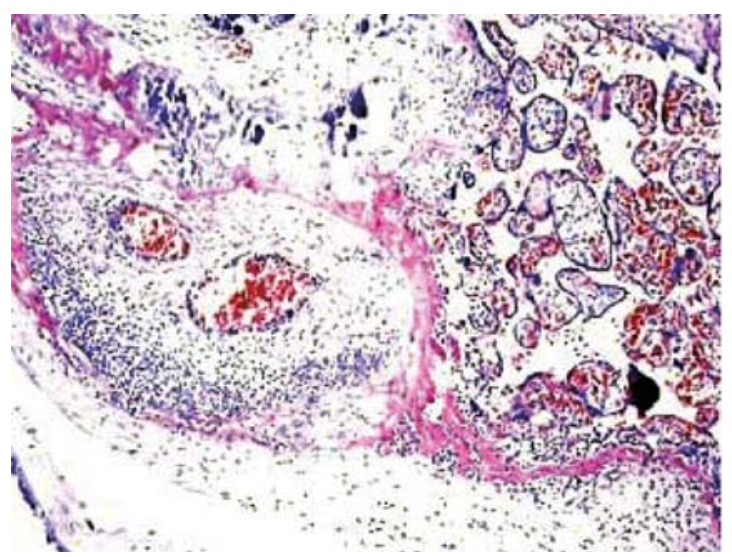

Рис. 4. Гнойные плацентит и хориоамнионит.

Диффузная лейкоцитарная инфильтрация субхориальной части межворсинчатого пространства. Ув. 60 [47]

2.2. Нарушения перфузии:

- общие/частичные:

- обструктивные поражения пуповины,

- свежие отложения фибрина в крупных фетоплацентарных сосудах,

- маленькие участки аваскулярных ворсин;

- сегментарные/полные:

- тромбы в хориальной пластинке или стволовых ворсинах,

- крупные участки аваскулярных ворсин.

2.3. Нарушение иелостности:

- разрыв крупного сосуда;

- разрыв мелкого сосуда (плодно-материнское поражение);

• отек ворсин.

II. Воспалительно-иммунные процессы

1. Инфекиионно-воспалительные поражения:

- острые:

- материнская воспалительная реакция (хориоамнионит, субхорионит),

- плодная воспалительная реакция (васкулит ворсинок/пуповины);

- хронические:

- виллит (цитомегаловирус, другие),

- интервиллузит (малярия, другие).

2. Иммунные/идиопатические воспалительные поражения:

- виллит неясной этиологии и связанные с ним поражения:

- хронический виллит,

- хронический хориоамнионит, 


\section{A K Y Ш E P C T B O}

- лимфоплазмоцитарный децидуит,

- эозинофильный Т-клеточный плодный васкулит;

• хронический гистиоцитарный интервиллузит

\section{III. Другие процессы в плаценте}

1. Массивные отложения периворсинчатого фибрина (-оида) (maternal floor infarction):

• аномалии формы плаценты или прикрепления пуповины.

2. Патологические сращения плаченты:

• изменения, обусловленные меконием;

- увеличение количества циркулирующих ядросодержащих эритроцитов.

Так как основной функцией плаценты является обмен питательными веществами и газами между кровью матери и плода, то соответственно сосудистые нарушения находятся на первом месте по частоте среди всех ее поражений. Достоверным признаком нарушений со стороны матери считается выявление децидуальной артериопатии, характеризующейся фибриноидом (рис. 1). Фибриноид представляет собой сложное вещество, образующееся из элементов дезорганизации соединительной ткани и крови. Повышенное содержание фибриноида объясняется значительной проницаемостью сосудистых стенок, уменьшением антикоагулянтной активности синцития и замедлением кровотока в межворсинчатом пространстве.

При циркуляторных нарушениях, происходящих при преэклампсии, наблюдаются местно также кровоизлияния, отек стромы ворсин, инфаркты, межворсинчатые тромбы. Подобные изменения [2-4] встречаются в основном при преэклампсии и, кроме того, в наблюдениях задержки роста плода (ЗРП).

Количество терминальных ворсин при преэклампсии уменьшается. При средней и тяжелой форме позднего гестоза в строме терминальных ворсин наряду с отеком обнаруживаются процессы очагового фибриноидного некроза. Увеличивается количество склерозированных терминальных волокон (И. Ожиганова, 1994).

Одним из явных признаков гипоксического состояния плаценты является увеличение объема незрелого вневорсинчатого трофобласта, при котором значения чувствительности данного показателя в отношении наличия преэклампсии превышали таковые для децидуальной артериопатии и повышенного количества гигантских клеток в плацентарной площадке

Особенно наглядным проявлением вневорсинчатого трофобласта исследователи считают обнаружение так называемых клеточных островков (рис. 2) [22]. В материнском компартменте нарушения циркуляции обусловлены, прежде всего, полноценным развитием спиральных артерий, поэтому они подразделены на две подгруппы [21]. В первой отмечаются общие или частичные нарушения материнской циркуляции крови, которые приводят к ускоренному созреванию ворсин. Ускоренным созреванием ворсин называют все гистологические изменения ворсинчатого дерева в условиях кровотока с пониженной скоростью, но с большим объемом по сравнению с нормальными показателями.

Такие изменения архитектоники характеризуются наличием участков агглютинированных ворсин с увеличенным количеством синцитиальных узелков и отложений межворсинчатого фибрина на фоне уменьшения разветвленных ворсин. В тех случаях, когда поражения захватывают более $30 \%$ от общего количества дистальных ворсин, то применяется термин дистальная ворсинчатая гипоплазия [11].

Вторая подгруппа характеризуется сегментарными или полными нарушениями циркуляции, объединяющими наличие инфарктов ворсин, расположенных вокруг окклюзированных спиральных артерий.

A. Shegolev информирует (для помощи практическим врачам-морфологам), что в краевых зонах зрелой плаценты практически, как правило, определяются единичные инфаркты не- больших размеров, которые расцениваются как физиологическое явление [11]. Поэтому патологическими инфарктами считают все те, которые выявляют в незрелой плаценте. Затем автор отмечает, что нарушения целостности материнских сосудов представлены также двумя процессами. Первый - это преждевременная отслойка плаценты, которая практически всегда является вторичной по отношению к неполноценному ремоделированию спиральных артерий при тяжелом гестозе и представляет их разрыв в условиях атероза или восстановленного кровотока после ишемии. Но, в то же время, различные травмы и, кроме того, использование ряда вазоактивных веществ также могут осложниться кровотечением.

$\mathrm{y}$ пациенток с высокой гипертензией отслойка плаценты происходит в центральной ее части в условиях кровотока. Практически в большинстве случаев отслойка приводит к прерыванию беременности, но, тем не менее, в отдельных случаях при незначительных кровоизлияниях могут формироваться инфаркты ворсин.

Как сообщает В. Harris, второй разновидностью отслойки плаценты является так называемая краевая, при которой происходит разрыв материнских вен преимущественно по периферии плаценты [23]. Обусловлена такая отслойка в основном преждевременным разрывом плодных оболочек и острым развитием шеечной недостаточности. Кроме того, к факторам риска ее развития относят имплантацию в нижнем сегменте матки, воспаление децидуальных оболочек, гипертензию венозного давления у беременных пациенток. Причиной преждевременных родов практически, как обычно, является острая краевая отслойка плаценты, однако это редко приводит к гипоксии плода. В тех случаях, когда острая краевая отслойка не доходит до развития родов, говорят о хронической краевой отслойке плаценты.

В исследовании R. Redline [24] установлено, что в пользу хронической отслойки плаценты свидетельствуют обнаруженные при морфологическом осмотре свертки крови по краю плаценты с признаками организации, кроме того, отложения гранул гемосидерина. Затем автор в своей следующей работе в 2012 г. сообщает, что сосудистые нарушения со стороны плода по аналогии с материнскими разделены также на три группы [25].

Первую группу составляют нарушения созревания. Созревание ворсин замедленное (задержка), или дистальная ворсинчатая незрелость, характеризуется уменьшенными значениями плодно-плацентарного индекса массы, центральным расположением капилляров в строме и выраженным трофобластом при неполноценных синцитиокапиллярных мембранах в ворсинах.

В проведенных исследованиях M. de Laat и соавторов [26] показано, что подобные изменения характерны у беременных, страдающих сахарным диабетом, ожирением, при ЗРП и, кроме того, при хронической обструкции сосудов пуповины, в том числе вследствие ее гиперизвитости.

T. Stallmach и соавторы сообщают, что так как дистальная незрелость ворсин приводит к гипоксии плода, то в данных наблюдениях в 70 раз выше риск развития внутриутробной гибели плода [27].

Согласно ряду публикаций- изменения капилляров ворсин отражают нарушения их ангиогенеза и включают хорангиоз, хорангиому и многоочаговый хорангиоматоз [25-28]. Исследователи под хорангиозом подразумевают увеличение количества капилляров в терминальных ворсинах плаценты (рис. 3). Авторы указывают, что приведенный выше процесс не относится к опухолевым, а рассматривается в качестве индикатора хронической пренатальной гипоксии, длительность формирования которой составляет несколько недель.

Уточненный диагноз хорангиоза устанавливают в том случае, если при микроскопическом исследовании (увеличение объектива *10) трех и более кусочков, взятых из различных 


\section{A K Y Ш E P C T B O}

участков плаценты вне зон инфарктов и ишемии, в каждом из них регистрируют не менее 10 ворсинок, каждая из которых содержит не менее 10 капилляров. При этом в зависимости от количества сосудов выделяют три степени хорангиоза.

Исследователи акцентируют внимание практического врача на том, что в таких случаях регистрируется высокая корреляция между хорангиозом и перинатальной смертностью [28]. Многие исследователи информируют, что хорангиома является доброкачественной опухолью сосудов плаценты, исходящей из стволовых ворсин, многоочаговым хорингиоматозом обозначают увеличение количества мелких сосудов в периферических участках незрелых промежуточных ворсин [28, 29].

В литературе детально излагаются имеющиеся различия в перечисленных выше процессах, в то же время, все они отражают наличие материнской гипоксемии и/или повышенную экспрессию факторов роста. В практике врача встречаются в ряде случаев, когда такие изменения сочетаются с врожденной патологией, например, с синдромом Биквита-Видемана [31].

R. Redline и соавторы, J. Dicke отмечают, что дисморфизм ворсин имеет относительно обширное их поражение в виде нарушений архитектоники соответствующих тем, которые наблюдаются при анэуплоидных беременностях: нерегулярность контура, включения трофобласта, кистозная дегенерация, разрастание стромы, диспропорция проксимальнодистальной разницы ворсин, аномалии васкуляризации ворсин [32, 33]. Исследователи данной проблемы сообщают, что хорошо выраженные изменения представлены мезенхимальной дисплазией [34, 35]. Авторы указывают, что отдельные случаи дисморфизма ворсин могут считаться проявлением очагового плацентарного мозаицизма.

Вторая группа характеризуется плодно-сосудистыми нарушениями, которые делятся на две подгруппы: сегментарные и полные нарушения. Огромная часть обусловлена нарушениями кровотока в сосудистой системе пуповины, а именно: из-за стриктур, гиперизвитости, аномалий прикрепления. По мнению профессора A. Shegolev, наиболее уязвимым местом пуповины является граница между гиперизвитым и гипоизвитым участками [11]. Автор информирует, что наличие длинной пуповины и обвитие ее вокруг частей плода также сопровождается нарушениями кровотока в ее сосудах. При этом в ткани плаценты обнаруживаются признаки застойного венозного повышенного давления в виде расширения крупных фетоплацентарных вен с пристеночным отложением фибрина и, кроме того, признаки уменьшения кровенаполнения в дистальных отделах ворсинчатого дерева в виде диффузных мелких участков аваскулярных ворсин.

В некоторых исследованиях установлено, что хроническая частичная обструкция сосудов пуповины коррелирует с повреждениями центральной нервной системы (ЦНС) у плода [36]. Сегментарная окклюзия крупного фетоплацентарного сосуда тромбом приводит к повреждениям и некрозу только кровоснабжаемых ворсин. Анализируя наличие хронической частичной обструкции пуповины, автор [36] отмечает, что на начальных стадиях в таких ворсинах регистрируется кариорексис клеток стенки сосудов и стромы, а в итоге происходит «исчезновение» сосуда и формирование аваскулярных ворсин. Подобные нарушения в случае выраженных изменений называют эмбриональной тромботической васкулопатией, которая нередко сочетается с повреждением ЦНС и других органов.

Нарушения целостности плодных сосудов представлены кровотечением и отеком. C. Kaplan, W. Blanc и соавторы в своих работах зафиксировали, что источником кровоизлияния может стать как разрыв относительно крупного сосуда, например, при предлежании сосудов (vasa previa), так и мелких сосудов дистальных ворсин. Последнее может иметь вид межворсинчатого тромба [37].
При водянке плода, и особенно ее прогрессировании, как правило, развивается отек ворсин. В данной ситуации морфологическое исследование плаценты дает возможность в определенной мере провести дифференциальный диагноз между анемией плода (при увеличении количества ядросодержащих эритроцитов) и поражением парвовирусом.

Вторая большая группа поражений плаценты представлена воспалительно-иммунными процессами. Инфекционные заболевания матери оказывают неблагоприятное воздействие на плод как путем непосредственного проникновения к нему возбудителя, так и посредством токсического воздействия на фетоплацентарный комплекс, что нередко приводит к структурным изменениям плаценты с существенными нарушениями ее функции [20].

Как известно, плацента служит своеобразной пропускной преградой, контактирующей с внешней средой (полость матки) и двумя организмами с различными антигенными свойствами (мать и плод). Поэтому в ее функции входит обеспечение своеобразной иммунологической толерантности по отношению к плоду и необходимость защиты от экзогенных микроорганизмов.

Основным проявлением воспаления в плаценте является развитие клеточной реакции без сосудистых изменений. Придерживаясь предложенной классификации, в зависимости от характера течения воспаления развивающиеся изменения подразделяют на острые и хронические. Согласно некоторым данным, острые воспалительно-клеточные реакции развиваются при восходящем бактериальном инфицировании и отражают ответ двух различных иммунных систем [1, 11]. Характеризуя этапы, авторы относят к первому материнский ответ в виде нейтрофильных гранулоцитов, поступающих в хориоамнион из венул децидуальной оболочки в мембраны и в хориальную пластинку из межворсинчатого пространства, - острый хориоамнионит (рис. 4).

И второй - реакция плода в виде нейтрофильных гранулоцитов, проникающих в хориальную пластинку и Вартонов студень через стенки крупных хориальных и пуповинных сосудов, - фетальный и/или пуповинный васкулит.

Эти реакции имеют стереотипный характер. Исследователи в материнском воспалительном ответе выделяют три стадии его развития $[1,11]$ :

- I стадия - начальная реакция, локализующаяся в области субхорионального фибрина и внутренних хориодецидуальных мембран (субхорионит, хорионит);

- II стадия - поражение соединительной ткани между хорионом и амнионом (хориоамнионит);

- III стадия - некроз амниотического эпителия (некротический хориоамнионит).

Для оценки воспалительной реакции согласно Амстердамским критериям необходимо применять только стадии II и III, представляющие собой гистологически развитый хориоамнионит.

Ряд исследователей сообщают, что при фетальном (плодном) воспалительном ответе клеточные реакции первоначально развиваются в хориальных сосудах и пуповинной вене - это является I стадией [38, 39]. После чего в пуповинных артериях развивается II стадия и в заключение поражается в строме пуповины Вартонов студень - III стадия. Авторы указывают, что фетальный ответ в виде хориоамнионита обычно обусловлен высокими концентрациями циркулирующих цитокинов, а не внутриутробной инфекцией, равно как и развитие артериита (стадия плодного ответа), в отличие от флебита, связано с воздействием цитокинов [38, 39].

G. Altshuler, P. Russell в своей работе констатировали, что, как правило, хронические воспалительные клеточные реакции возникают на фоне гематогенной циркуляции вирусов или простейших и локализуются в основном в строме 


\section{A K Y Ш E P C T B O}

ворсин и межворсинчатом пространстве [5]. Ни у кого не вызывает сомнений взаимосвязь внутриутробной инфекции и поражений плаценты. В литературе существует определенное представление о неблагоприятном течении беременности, родов, рождении больных и неполноценных детей при инфицировании последа.

Пренатальные инфекции ( $\mathrm{T}$ - токсоплазмоз; О - другие, в которые входят: микоплазмы, гепатиты, сифилис, стрептококк, кандида и другие вирусные и бактериальные инфекции; R - краснуха, C - цитомегаловирус; Н-герпес) вызывают обычно диффузный виллит (виллузит) с наличием плазматических клеток и, кроме того, развитием отека и фиброза.

Необходимо помнить практическому врачу, что патоморфологическое исследование плаценты является ценным дополнительным методом диагностики врожденного сифилиса.

Структурно-функциональный анализ различных элементов плаценты существенно помогает в понимании развивающихся нарушений, что необходимо для разработки тактики лечения и профилактики пренатально формирующихся нарушений. При сифилистическом процессе в плаценте возникают изменения, характер которых зависит от сроков инфицирования и стадии сифилиса у беременной.

Что касается редкой инфекции, такой, как малярия, она проявляется интервиллузитом, то есть клеточной инфильтрацией межворсинчатого пространства. Но, тем не менее, такая инфекция может вызвать поражение всех трех компонентов плаценты - хориоамнионит, виллит и интервиллузит. В отношении хламидиоза известно, что во время беременности он неблагоприятно воздействует на все звенья фетоплацентарного комплекса. Формируется плацентарная недостаточность и, как следствие, задержка развития плода [10]. Морфологические изменения плаценты при этом могут быть различными. Определение формы инфекционного процесса при беременности и вызванные при них изменения в плаценте позволяют прогнозировать перинатальные осложнения и постнатальный результат.

Частота развития осложнений и летального исхода при гематогенных инфекциях в большей степени коррелировала с выраженностью воспалительного процесса, в отличие от восходящей инфекции, зависящей в основном от уровня цитокинов.

Литературные данные различных исследований, особенно представляет интерес работа R. Redline [6], свидетельствуют, что группы иммунных/идиопатических воспалительных поражений представлены так называемым виллитом неизвестной этиологии и хроническим гистиоцитарным интервиллузитом. Виллит неясной этиологии (ВНЭ) характеризуется поражением дистальных отделов ворсинчатого дерева в виде хронической воспалительной инфильтрации стромы ворсин (непосредственно виллит) и реже - межворсинчатого пространства (интервиллузит и периворсинчатые отложения фибрина) и сосудов стволовых ворсин (облитерирующая фетальная васкулопатия).

Автор [6] считает, что в этот период ВНЭ отражает защитную Т-клеточную реакцию материнского организма на территории плаценты в ответ на антигены плода. ВНЭ высокой степени выраженности характеризуется обширным поражением ворсин плаценты или развитием облитерирующей фетальной васкулопатии и сочетается с ЗРП, поражением ЦНС и внутриутробной гибелью плода.

B исследованиях X. Liao и соавторов сообщается, что при этом ВНЭ выявляют примерно в 5-10\% зрелых плацент и степень его выраженности больше у пациенток, страдающих ожирением [12]. Во время беременности и родов ожирение является фактором риска развития различных осложнений [41]. Нарушение кровотока в плаценте и сосудистый тромбоз являются характерными для беременности, осложненной ожирением, гестационным сахарным диабетом и преэклампсией [42]. До- казано, что плаценты у пациенток с гестационным сахарным диабетом имеют характерную морфологию: плацентарную незрелость и отек, хорангиоз, сосудистые аномалии [43].

Возвращаясь к виллиту - хронический гистиоцитарный интервиллузит, как считают T. Boyd, R. Redine, является своеобразным идиопатическим воспалительным поражением плаценты [15]. Множество публикаций по данной проблеме свидетельствуют, что, согласно названию «своеобразное идиопатическое воспаление плаценты», он характеризуется мономорфной гистиоцитарной инфильтрацией межворсинчатого пространства при отсутствии признаков ВНЭ $[11,12,15]$. В других случаях - сочетается с инфарктами материнского ложа. Такое поражение приводит к развитию спонтанного аборта и ЗРП, преждевременных родов и, кроме того, внутриутробной гибели плода на ранних сроках беременности. Характерно и развитие аналогичных поражений при последующих беременностях.

Проводя анализ морфологической классификации повреждений плаценты, автор одного из исследований характеризует третью основную группу изменений плаценты, состоящую из так называемых других патологических процессов, включающих массивные отложения периворсинчатого фибрина (фибриноида), нарушения имплантации (прикрепления) плаценты, аномалии ее формы и отхождения пуповины, а также увеличение числа циркулирующих ядросодержащих эритроцитов и последствия длительного воздействия мекония [11].

J. Adams-Chapman и соавторы информируют, что массивные отложения периворсинчатого фибрина (фибриноида) являются также инфарктами материнского ложа (maternal floor infarction) и проявляются наличием большого количества фибрина и матриксного фибриноида вокруг дистального отдела ворсинчатого дерева (не менее 30\%) [16]. Аналогичные изменения в плаценте регистрируют на различных сроках беременности, и в большинстве случаев они сочетаются со спонтанными абортами и преждевременными родами и, кроме того, с поражением ЦНС, выраженным задержкой роста и ранней внутриутробной гибелью плода. Патогенез до настоящего времени не установлен, предполагается, что такие изменения отложения фибрина являются универсальной (стереотипной) реакцией повреждения трофобласта при различных воздействиях, в частности, при гестационной гипертензии и материнской тромбофилии.

Тромбофилия - это патологическое состояние, характеризующееся повышением свертывания крови и склонностью к тромбозам и тромбоэмболиям. У 10-12\% женщин диагностируют наследственную тромбофилию, а у пациенток с привычным невынашиванием беременности она достигает 48\% [40]. Нормальная плацента выглядит в виде диска округлой или овальной формы, то есть имеет дискоидальную форму. Нарушения плацентации выражаются в патологическом разрастании плаценты с полным либо частичным отсутствием базальной части отпадающей оболочки (placenta accrete); в плаценте, приращенной к миометрию (или проникшей в миометрий - placenta increta); в плаценте, сращенной с периметрием либо с лежащими рядом с маткой органами (или проникшей в периметрий - placenta percreta).

В зависимости от места прикрепления пуповины выделяют следующие разновидности ее прикрепления: центральное, краевое, маргинальное (ракеткоподобная плацента) и оболочечное (плацента в форме покрывала) [11]. Последние считают патологическими. Исследования R. Naеyе и соавторов показывают, что нормальным является наличие ядросодержащих эритроцитов в кровеносных сосудах плода на сроках беременности менее трех месяцев [17]. Увеличение количества ядросодержащих эритроцитов в периферической крови выявляют в случаях смерти от острой гипоксии. Но, тем не менее, исследователями доказано, что количество яд- 


\section{A K Y Ш E P C T B O}

росодержащих эритроцитов в циркулирующей крови высоко коррелирует с их количеством в капиллярах ворсин на гистологических препаратах [18].

Группа исследователей - C. Bryant и соавторы, M. Cohen и соавторы -установили, что наличие 10 ядросодержащих эритроцитов в 10 полях зрения при большем увеличении микроскопа коррелировало с повышенным их содержанием в пуповинной крови и выраженностью гипоксии у плода [19, 30]. А повышение количества таких эритроцитов в структурах плаценты коррелировало с развитием внутримозговых кровоизлияний у плода.

Наличие мекония в околоплодных водах является достоверным признаком гипоксии плода. В некоторых случаях развивается аспирационный мекониальный синдром, в том числе с развитием аспирационной пневмонии и перинатальных поражений ЦНС. Классические исследования R. Miller и соавторов свидетельствуют - для подтверждения морфологического воздействия мекония на плодные оболочки нужно провести гистохимические реакции для выявления гемосидерина (железа) [14]. Авторы сообщают, что при этом глубина поражения оболочек в определенной мере коррелирует с длительностью поражения.

Таким образом, плацента играет главную роль в нормальном функционировании системы мать-плацента-плод и, безусловно, должна быть исследована в полном объеме.

Анализ результатов работы нашего центра за более чем тридцатилетнюю практику в отделе ультразвуковой и пренатальной диагностики показал, что одним из актуальных вопросов всегда является определение эхографически-морфологических соотношений структурных изменений в плаценте при различных патологических состояниях во время беременности [48]. Оценка плаценты с помощью ультразвукового исследования проводится с целью определения ее локализации, размеров, структуры и выявления патологических отклонений. Проблемы, связанные с плацентой, можно разделить на аномалии локализации, прикрепления и структуры.

\section{Аномалии, связанные с локализацией и прикреплением}

Плацента располагается в области тела матки, обычно в слизистой оболочке ее задней стенки. По разным причинам она может располагаться в различных частях матки, в том числе в области дна и трубных углов, что, вероятнее всего, проявится аномалией родовой деятельности. Окончательное представление о расположении плаценты формируется лишь в III триместре беременности, в котором устанавливается низкое прикрепление плаценты - менее 7 см от внутреннего зева; краевое, если край плаценты доходит до внутреннего зева, или полное предлежание плаценты. При низком расположении плаценты нередки отслойки плаценты, которые на УЗИ распознаются как эхонегативные полости между стенкой матки и плацентой и бывают: ретрохориальные (гипоэхогенная зона, отделяющая ткань плаценты от подлежащего миометрия) субхориальные (ограниченное гипоэхогенное образование между хориальной пластинкой и тканью плаценты, приводящее к изменению плодного контура плаценты) и субамниотические (ограниченное гипоэхогенное пространство, разделяющее хориальную и амниотическую оболочки).

К аномалиям прикрепления плаценты относят приращение плаценты. Выделяют 3 степени в зависимости от глубины прорастания ворсин: pl.accreta, pl.increta, pl. percreta. Плотное прикрепление плаценты отличается меньшей глубиной прорастания ворсин в стенку матки. Эхографический критерий приращения - наличие в толще миометрия участков с лакунарным типом кровотока. Существенную помощь в уточнении диагноза оказывают цветовое допплеровское картирование кровотока и 3D-энергетическая ангиодопплерография.
Плацента, оболочки которой отходит не от краев, а от плодной поверхности, называется экстрахориальной плацентой. Оболочки формируют на поверхности плаценты кольцо в виде валика (pl.circumvallata). Этот вид плаценты часто путают с перегородками в полости матки или амниотическими тяжами. Такие плаценты сопряжены с повышенным риском акушерских осложнений. A. Volkov в журнале «Пренатальная диагностика» за 2005 г. представил описание случаев пренатальной ультразвуковой диагностики экстрахориального типа плацентации, плаценты, «окруженной валиком», - placenta circumvallata [49]. При эхографическом исследовании в 2 наблюдениях в 13 и 14 нед беременности была обнаружена «плацентарная полка». С помощью режима цветового допплеровского картирования проведена дифференциальная диагностика между интраамниальными синехиями, «синдромом амниотических перетяжек» (тяжи Симонарта), placenta circumvallate, внутриматочной перегородкой, амниотической перегородкой при многоплодной беременности. Пренатально верифицирована placenta circumvallata. В первом наблюдении беременность закончилась рождением здорового мальчика с массой тела 3400 г, длинной 52 см. Послеродовой период протекал без осложнений. Во втором наблюдении беременность прекратила развитие в 14 нед. Пренатальные диагнозы подтверждены при изучении последа и абортивного материала.

\section{Аномалии, связанные с изменением эхоструктуры плаценты}

В I триместре беременности детектирование мелкозернистых многочисленных эхонегативных разнокалиберных компонентов в ткани хориона свидетельствует о гидатидомольной структуре и часто встречается при хромосомных аномалиях по типу полиплоидии. Триплоидия - форма полиплоидии, одна из наиболее частых спонтанных аномалий хромосомного набора в процессе эмбриогенеза - заключается в том, что в клетках оказывается по 69 хромосом (не по 2, а по 3 хромосомы из каждой пары). Триплоидию можно разделить на два типа. При I типе дополнительный набор хромосом будет иметь отцовское происхождение, а при II типе дополнительный набор будет иметь материнское происхождение.

Дигиния (триплоидия материнского происхождения) характеризуется излишком материнских хромосом в кариотипе плода, который может образоваться из-за того, что в оплодотворенную яйцеклетку оказывается вовлеченным полярное тельце.

Синдром триплоидии также может развиться, если оплодотворение произошло через короткий промежуток времени после приема противозачаточных средств или длительных менструальных циклов. Играет роль и возрастной фактор: чем старше женщина, тем выше риск возникновения этого заболевания. Для материнской триплоидии характерен маленький размер плаценты, и регресс в данном случае возникает потому, что гипоплазированная плацента не может достаточно обеспечивать растущий плод.

Материнская триплоидия сопровождается характерными аномалиями развития плода. К дефектам лица у плода относятся гипертелоризм, низкая спинка носа, деформированные низко посаженные уши, микрогения, необычная форма черепа, расщелина губы и/или нёба, также имеется синдактилия на руках и ногах, аномалии половых органов, дефекты в брюшной стенке, возможно кистозное изменение почек, гипоплазия надпочечников, врожденные дефекты сердца, пороки развития печени и желчного пузыря. Помимо всего прочего, наблюдается аномальное развитие мозга, обычно дефекты нервной трубки.

Эти аномалии развития плода могут быть заметны при проведении УЗИ уже в 11-14 нед гестации. Для материнской триплоидии также характерна асимметричная задержка развития плода. 


\section{A K Y Ш E P C T B O}

Отцовская триплоидия обусловлена слиянием яйцеклетки с двумя сперматозоидами (диспермией) или оплодотворением диплоидным сперматозоидом (диандрия), поэтому в этих случаях дополнительный набор хромосом будет иметь отцовское происхождение.

На УЗИ при таких отклонениях плацента будет казаться утолщенной, с кистозными образованиями. Плод может быть нормальным или немного меньше нормы, в некоторых случаях можно обнаружить водянку у плода. Отцовская триплоидия связана с повышенным риском развития трофобластической болезни у матери, к которой относятся пузырный занос, хориокарцинома и хорионэпителиома.

Пузырный занос - состояние, сопровождающееся разрастанием трофобласта (наружный слой клеток зародыша), заполняющего полость матки. Вместо развития плода в матке формируются кисты, напоминающие гроздья винограда.

Полный пузырный занос возникает, когда по неизвестным причинам происходит потеря материнских генов и дублирование отцовского генома. Иногда (в 5\% случаев) полный пузырный занос вызван оплодотворением пустой (безъядерной) яйцеклетки двумя сперматозоидами. Первым клиническим признаком этого является несоответствие размеров матки сроку беременности: матка больше, чем должна быть по сроку. Макроскопически визуализируются отечные хориальные ворсинки, пузырьки. Эмбрион погибает на ранних стадиях развития, до установления плацентарного кровообращения.

Неполный (или частичны й) пузырный занос вызван триплоидией, получившейся в результате оплодотворения яйцеклетки двумя сперматозоидами. Эти клетки содержат один набор материнских хромосом и двойной набор отцовских.

До появления клинических симптомов диагноз пузырного заноса устанавливают при УЗИ. Вместо нормальной структуры плодного яйца обнаруживается картина, получившая название «снежной бури». В яичниках определяются билатеральные лютеиновые кисты. При исследовании гормонов отмечается высокий уровень хорионического гонадотропина (ХГЧ), иногда многократно превышающий норму для данного срока беременности [50].

Ключевой задачей УЗИ во II триместре является измерение толщины плаценты, которое проводится на уровне впадения пуповины. Согласно нормативным таблицам толщины плаценты для различных сроков беременности легко определить отклонения от нормы. Увеличение ее толщины гиперплазия - может быть связано с:

- гемолитической болезнью плода, которая возникает вследствие иммунологической несовместимости крови матери

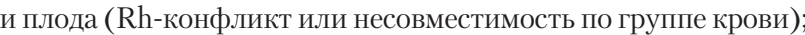

- сахарным диабетом I типа (в том числе гестационным сахарным диабетом, возникающим из-за активизации стероидных гормонов и печеночного фермента инсулиназы);

• осложнением беременности в виде гестоза (преэклампсия или артериальная гипертензия беременных);

- тяжелой анемией беременных;

- TORCH-инфекциями;

- урогенитальными инфекциями матери (хламидиоз, гонорея, сифилис);

• перенесенными во время беременности инфекционными болезнями (грипп, ОРВИ, пиелонефрит);

Это требует динамического допплерометрического исследования плода, а также обязательного комплексного обследования беременной. Иногда увеличение толщины плаценты является ее компенсаторной реакцией вследствие изначально малой занимаемой площади. Уменьшение размеров и толщины плаценты также требует дополнительных методов исследования и не всегда расценивается как патологическое.

Эхоструктура плаценты связана с инволютивно-дистрофическими процессами при увеличении срока беременнос- ти и называется «старение плаценты». Различают четыре степени зрелости плаценты (в основе - характерные изменения в хориальной мембране, паренхиме и базальном слое плаценты: отложение фибриноида и появление множественных кальцификатов). Истинные кальцификаты встречаются главным образом при доношенной беременности. В акушерской практике степень зрелости плаценты определяют по P. Granum и соавт. $(1979,1982)$. Было предложено 4 степени эхографического состояния плаценты [51]. Часто выявляют преждевременное старение плаценты, когда обнаруживают 2-ю степень до 34 нед, а 3-ю степень - до 36 нед. При этом изменяется толщина плаценты, ее структура, что является риском развития плацентарной дисфункции, ЗВРП и требует допплерометрического контроля в артерии пуповины, среднемозговой артерии и динамического УЗконтроля. Таким образом, преждевременное созревание плаценты является патологическим процессом, который вызван патологическими изменениями - тромбозом, оксидативным стрессом и воспалением, склерозом и дистрофией в плаценте. Это - эхосонографический признак патологической незрелости плаценты. Преждевременное созревание плаценты - это возможный эхографический признак плацентарной дисфункции [52].

Инфаркты плаценты проявляются как образования неправильной формы с четкими гиперэхогенными наружными контурами с гипоэхогенным содержимым и располагаются в любом месте плаценты. Инфаркты плаценты имеют изменчивую сонографическую картину. После инфаркта плаценты структура ворсинок сохраняется. Нежизнеспособный участок трофобласта акустически похож на жизнеспособные ворсинки. С увеличением насыщенности клетками инфаркты плаценты становятся гиперэхогенными. Накопление бесклеточного фибрина делает инфаркт плаценты кажущейся гипоэхогенной массой, трудно отличимой от кисты децидуальной перегородки или межворсинчатого тромба. Сонографическая трансформация эхо-картины инфаркта плаценты от гиперэхогенной к гипоэхогенной может развиваться в течение 4 дней.

Локализованные плацентарные инфаркты являются довольно распространенными. Тем не менее инфаркты плаценты детектируются только, если они гиперэхогенные (свежие) или гипоэхогенные (заполненные включениями). Большинство инфарктов плаценты является изоэхогенными и, следовательно, не видны при сонографическом исследовании. Если инфаркты плаценты гипоэхогенные, то они неотличимы от кисты перегородки или межворсинчатого тромбоза [53].

В последние годы появляется все больше публикаций, посвященных мезенхимальной дисплазии плаценты (МДП) - редкой патологии, в основе которой лежат признаки плацентомегалии с большим количеством кист в виде виноградной грозди, что при эхографии и макроскопическом исследовании напоминает картину частичного пузырного заноса. G. Moscoso и соавторы впервые описали МДП в 1991 г. как гиперплазию стволовых ворсин в двух наблюдениях плаценты у беременных с высоким уровнем плазменного $\alpha$-фетопротеина, крупной плацентой и УЗ-признаками частичного пузырного заноса [54]. На плодной поверхности плаценты имелось множество аневризматически расширенных сосудов, а в субхориальной зоне - расширенные стволовые ворсины, заполненные прозрачным студенистым веществом [55] .

Как однокамерные жидкостные образования проявляются кисты плаценты. Субамниотические кисты плаценты определяются в виде анэхогенных однокамерных образований над плодной поверхностью плаценты и чаще всего являются следствием субамниотических гематом.

Среди опухолей плаценты наиболее часто обнаруживается хориоангиома (может сопровождаться повышением уровня АФП) и при УЗИ представляет собой образование с 


\section{A K Y Ш E P C T B O}

четкими контурами сложной эхоструктуры с кистозным и солидным компонентом. При допплерографии в хориоангиоме регистрируют кривые скоростей кровотока, подобные таковым в артерии пуповины. Хориоангиомы больших размеров могут обусловливать формирование артериовенозных шунтов. Это приводит к увеличению венозного возврата к сердцу плода и усилению сердечного выброса. Как следствие этого - тахикардия, гиперволемия, кардиомегалия, а также отеки и антенатальная гибель плода.

К аномалиям изменения дольчатой структуры плаценты относятся двудольчатые и с добавочной долькой. Их диагностика основана на выявлении участков плацентарной ткани, между которыми имеется свободная зона, при допплерографии в этой зоне располагается сосудистая ножка.

При внутриутробном инфицировании, которое происходит в первые 3 мес беременности, возникают истинные пороки развития, формируется первичная фетоплацентарная недостаточность, неразвивающаяся беременность, происходят самопроизвольные выкидыши. При развитии внутриутробной инфекции после 3 мес беременности формируется внутриутробная задержка развития, вторичная фетоплацентарная дисфункция, отмечают признаки инфекционного поражения плода. Наиболее характерными клиническими симптомами внутриутробной инфекции являются: многоводие или маловодие, стойкая тахикардия у плода, задержка развития плода, нарушение его дыхательной и двигательной активности. В настоящее время адекватные статистические данные по внутриутробным инфекциям отсутствуют. Однако существуют отдельные исследования, косвенно свидетельствующие о значительной распространенности внутриутробных инфекций. Так, в среднем у 33\% женщин в репродуктивный период и у 60-80\% пациенток, находящихся в группе высокого риска, в слизи из канала шейки матки обнаруживают цитомегаловирус и вирус простого герпеса. Нормальную влагалищную микрофлору выявляют менее чем у 50\% беременных. По данным УЗИ в

\section{Морфологічна класифікація пошкоджень плаценти \\ П.М. Веропотвелян, М.П. Веропотвелян, І.С. Цехмістренко, А.А. Бондаренко, Т.В. Усенко}

У статті розглянуто сучасну морфологічну класифікацію, розроблену Амстердамською групою вчених, яка забезпечує прийняття консенсусу щодо визначення і характеристик основних уражень плаценти для з'ясування їхнього клінічного значення і розроблення таргетних впливів з урахуванням ехокартини патології плаценти, виявленої під час виконання пренатального УЗД.

Проведені дослідження дозволяють оптимізувати не тільки діагностичну, але і лікувальну тактику у вагітних високого ризику прогнозувати подальший розвиток пологів і народження здорової дитини.

Ключові слова: плачента, класифікачія, ускладнена вагітність, пошкодження. ранние сроки беременности (до 12 нед) к признакам, которые могут свидетельствовать о наличии инфекции, могут быть отнесены: недостаточное развитие хориона, запоздалая редукция желточного мешка, несоответствие размеров эмбриона размерам полости плодного яйца (увеличение, уменьшение), анэмбриония (отсутствие эмбриона), отсутствие редукции хорионической полости, повышение локального тонуса матки, сопровождающееся деформацией плодного яйца, отслойка хориона.

В более поздние сроки к эхографическим признакам инфекции могут быть отнесены: несоответствие размеров плода сроку беременности (задержка развития плода); отек подкожно-жировой основы головы плода; многоводие или маловодие; утолщение или истончение плаценты; кальцификаты в печени, в почках, в селезенке, в головном мозге; поликистоз легких, почек плода; растяжение петель кишечника у плода; взвесь в околоплодных водах, косвенные признаки хориоамнионита в виде «сладж-синдрома». На фоне распространения инфекции у плода могут возникать такие пороки развития, как гидроцефалия и мекониальный перитонит. Однако эти эхографические признаки нельзя считать специфичными только для инфекции. Они могут встречаться и при других осложнениях беременности. Следовательно, диагноз внутриутробной инфекции не может быть подтвержден только данными УЗИ. С этой целью используют также микробиологические, серологические и молекулярно-генетические исследования [56].

Таким образом, ультразвуковая оценка состояния плаценты предоставляет достаточную дородовую информацию, а правильная интерпретация эхографически-морфологических сопоставлений в плаценте лежит в основе правильного пренатального диагноза, который в свою очередь позволяет точно прогнозировать исход беременности, качество жизни и здоровья будущего ребенка, а также заранее планировать тактику ведения беременности, родов и помощь новорожденному в неонатальный период.

\section{Morphological classification of lesions of the placenta \\ N.P. Veropotvelyan, P.N. Veropotvelyan,}

\section{I.S. Tsehmistrenko, A.A. Bondarenko, T.V. Usenko}

The article reviews the current morphological classification developed Amsterdamska a group of scientists that provides the adoption of a consensus on the definition and characteristics of the main lesions of the placenta to determine their clinical significance and the development of targeted effects of egocasting pathology of the placenta, discovered during prenatal ultrasound.

The conducted research allows to optimize not only diagnostic but also therapeutic tactics in pregnant women at high risk and to predict the further development birth and the birth of a healthy child.

Key words: placenta, classification, complications of pregnancy, damage.

Сведения об авторах

Веропотвелян Николай Петрович - ОКУ «Межобластной центр медицинской генетики и пренатальной диагностики», 50000, г. Кривой Рог, пл. Освобождения, За; тел.: (05642) 92-49-30. E-mail: genetika@ukrpost.ua

Веропотвелян Петр Николаевич - ОКУ «Межобластной центр медицинской генетики и пренатальной диагностики», 50000, г. Кривой Рог, пл. Освобождения, За; тел.: (05642) 92-36-09. E-mail: genetika@ukrpost.ua

Цехмистренко Иван Сергеевич - Перинатальный центр, 03150, г. Киев, ул. Предславинская, 9; тел.: (098) 093-21-22. E-mail: tsehmistrenko.m.d@gmail.com

Бондаренко Алла Алексеевна - ОКУ «Межобластной центр медицинской генетики и пренатальной диагностики», 50000, г. Кривой Рог, пл. Освобождения, За; тел.: (05642) 92-38-37. E-mail: genetika@ukrpost.ua;

Усенко Татьяна Викторовна - КУ «Днепропетровское областное патологоанатомическое бюро», 49070, г. Днепр, ул. Космическая, 1; тел.: (098) 258-83-95 


\section{A K У Ш E P C T B O}

\section{СПИСОК ЛИТЕРАТУРЫ}

1. Blanc W. Pathology of the placenta and cord in ascending and hematogenous infections /In: W. Marshall ed. Perinatal infections. CIBA Foundation Symposium 77. London (UK): Excerpta Medica. 1980. - P. 17-38.

2. Gerhard I. Prognostik value of hormone determination in the first trimester of pregnancy /B. Runnebaum //Acta endocrinol. 1983. - Vol. 103, № 256. - P. 158-160. 3. Kaufmann P. Endovascular trophoblast invasion: implications for the pathogenesis of intrauterine growth retardation and preeclampsia /S. Black, B. Huppertz //Biol. Reprod. - 2003. - V. 69 (1). - P. 1-7. 4. Roberts D.J. The placenta in pre-eclampsia and intrauterine growth restriction /M.D. Post //J. Clin. Pathol. - 2008. - V. 61 (12). - P. 1254-60.

5. Altshuler G. The human placental villitides: a review of chronic intrauterine infection /P. Russell //Curr. Top. Pathol. 1975. - V. 60. - P. 63-112.

6. Redline R.W. Villitis of unknown etiology: noninfectious chronic villitis in the placenta //Hum. Pathol. - 2007. - V. 38 (10). P. $1439-46$.

7. Baergen R.N. Morbidity, mortality, and placental pathology in excessively long umbilical cords: retrospective study D. Malicki, C. Behling, K. Benirschke //Pediatr. Dev. Pathol. - 2001. - V. 4 (2). - P. 144-53.

8. Naeye R.L. Umbilical cord length: clinical significance //J. Pediatr. -1985. V. 107 (2). - P. 278-81.

9. Räisänen S. Infertility Treatment and umbilical cord length-novel markers of childhood epilepsy? //A. Sokka, L. Georgiadis, M. Harju, M. Gissler, L. Keski-Nisula et al. //PLoS One. - 2013. - V. 8 (2). - P. 55-94. 10. Rabe H. Milking compared with delayed cord clamping to increase placental transfusion in preterm neonates: a randomized controlled trial //A. Jewison, R.F. Alvarez, D. Crook, D. Stilton, R. Bradley et al. //Obstet. Gynecol. 2011. - V. 117 (2, Pt1). - P. 205-11.

11. Shegolev A.I. Current morphological classificanion of damages to the placenta //Obstetrics and gynecology. - 2016. V. 4. - P. 16-23.

12. Liao X. Maternal obesity exacerbates the extent and severity of chronic villitis in the term placenta /S.M. Leon-Garcia, D.P. Pizzo, M. Parast //Pediatr. Dev. Pathol - 2015. - V. 18. - P. 1-24

13. Redline R.W. The clinical implications of placental diagnoses //Semin. Perinatol. - 2015. - V. 39. - P. 2-8.

14. Miller P.W. Dating the time interval from meconium passage to birth /R.W. Coen, K. Benirschke //Obstet. Gynecol. - 1985. - V. 66 (4). - P. 459-62

15. Boyd T.K. Chronic histiocytic intervillositis: a placental lesion associated with recurrent reproductive loss /R.W. Redline //Hum. Pathol. - 2000. - V. 31 (11). P. 1389-96.
16. Adams-Chapman I. Maternal floor infarction of the placenta: association with central nervous system injury and adverse neurodevelopmental outcome Y.E. Vaucher, R.F. Bejar, K. Benirschke, R.N. Baergen, T.R. Moore //J. Perinatol. 2002. - V. 22 (3). - P. 236-41.

17. Naeye R.L. Sudden death in infants /In E. Gilbert-Barness ed. Potter's pathology of the fetus, infant and child //Philadelphia: Mosby Elsevier. - 2007. -V.1. - P.857-69. 18. Redline R.W. Elevated circulating feta nucleated red blood cells and placenta pathology in term infants who develop cerebral palsy /Hum. Pathol. - 2008. V. 39 (9). - P. $1378-84$

19. Bryant C. Do placental sections accurately reflect umbilical cord nucleated red blood cell differential counts? /M. Beall, L. Mcphaul, W. Forston, M. Ross //J Matern. Fetal Neonatal Med. -2006. -

V. 19 (2). - P. 105-8.

20. Hopker W.W. Placental insufficienty. In histomorfologic diagnosis and classification currents topics in pathology /B. Ohlendor //Berlin - 1979. - Vol. 66. - P. 57-81.

21. Redline R.W. Maternal vascular underperfusion: nosology and reproducibility of placental reaction patterns /T. Boyd, V. Campbell, S. Hyde, C. Kaplan, T.Y. Khong et al. //Pediatr. Dev. Pathol. 2004. - V. 7 (3). - P. 237-49.

22. Stanek J. Chorionic disk extravillous trophoblasts in placental diagnosis //Am. J Clin. Pathol. - 2011. - V. 136 (4). P. 540-54.

23. Harris B.A. Jr. Peripheral placental separation: a review //Obstet. Gynecol. Surv. - 1988. - V. 43 (10). - P. 577-81.

24. Redline R.W. Chronic peripheral separation of placenta: the significance of diffuse chorioamnionic hemosiderosis /D. Wilson-Costello //Am. J. Clin. Pathol. 1999. - V. 111 (6). - P. 804-10

25. Redline R. Distal villous immaturity //Diagn. Histopathol. - 2012. - V. 18 (5) - P. 189-94.

26. de Laat M.W. Hypercoiling of the umbilical cord and placental maturation defect: associated pathology? /van de J.J. Meij, G.H. Visser, A. Franx P.G. Nikkels //Pediatr. Dev. Pathol. 2007. - V. 10 (4). - V. 293-9.

27. Stallmach T. Rescue by birth: defective placental maturation and late fetal mortality /G. Hebisch, K. Meier, J.W. Dudenhausen M. Vogel //Obstet. Gynecol. - 2001. V. 97 (4). - P. 505-9

28. Ogino S. Villous capillary lesions of the placenta: distinctions between chorangioma, chorangiomatosis, and chorangiosis /R.W. Redline //Hum. Pathol. - 2000. V. 31 (8). - P. 945-54.

29. Bagby C. Multifocal chorangiomatosis /R.W. Redline //Pediatr. Dev. Pathol. 2010. - V. 14 (1). - P. 38-44.

30. Cohen M.C. Increased number of feta nucleated red blood cells in the placentas of term or near-term stillborn and neonates correlates with the presence of diffuse intradural hemorrhage in the perinatal period /L.S. Peres, M. Al-Adnani, R. Zapata-Vázquez //Pediatr. Dev. Pathol. - 2014. - V. 17 (1). - P. 1-9.

31. McCowan L.M. Beckwith-Wiedemann syndrome, placental abnormalities, and gestational proteinuric hypertension /D.M. Becroft //Obstet. Gynecol. - 1994 - V. 83 (5, Pt 2). - P. 813-7.

32. Redline R.W. Prevalence of developmental and inflammatory lesions in non-molar first trimester spontaneous abortions M.V. Zaragoza, T. Hassold //Hum. Pathol. 1999. - V. 30 (1). - P. 93-100.

33. Dicke J.M. Umbilical artery Doppler indices in small for gestational age fetuses: correlation with adverse outcomes and placental abnormalities /P. Huettner, S. Yan, A. Odibo, F.T. Kraus //J. Ultrasound Med. - 2009. - V. 28 (12). - P. 1603-10.

34. Pham T. Placental mesenchymal dysplasia is associated with high rates of intrauterine growth restriction and fetal demise: report of 11 new cases and a review of the literature /J. Steele, C. Stayboldt, L. Chan, K. Benirschke //Am. J. Clin. Pathol. - 2006. - V. 126 (1). - P. 67-78.

35. Pavlov K.A. Mesenchymal dysplasia of the placenta /E.A. Dubova, A.I. Shchegolev //Obstetrics and gynecology. - 2010. -V. 5. - P. 15-20.

36. Redline R.W. Correlation of placenta pathology with perinatal brain injury /In: R.N. Baergen ed. //OPlacental pathology. - V. 6. - Philadelphia: Elsevier. - 2013. P. 153-80.

37. Kaplan C. Identification of erythrocytes in intervillous thrombi: a study using immunoperoxidase identification of hemoglobins N.A. Blanc, J. Elias //Hum. Pathol. - 1982. - V.13(6). - P.554-7.

38. Kim C.J. Umbilical arteritis and phlebitis mark different stages of the fetal inflammatory response /B.H. Yoon, R. Romero, J.B. Moon, M. Kim, S.S. Park et al. //Am. J. Obstet. Gynecol. - 2001. V. 185 (2). - P. 496-500.

39. Rogers B.B. Umbilical vein interleukin-6 levels correlate with the severity of placental inflammation and gestational age /J.M. Alexander, J. Head, D. Mclntire, K.J. Leveno //Hum. Pathol. -2002. V. 33 (3). - P. 335-40.

40. Chou A.K. Neonatal and pregnancy outcome in primare antiphospholipid syndrome a 10-year experience in one medical centre /S.C. Hasies, Y.N. Su, S.F. Jeng, C.Y. Chen, P.N. Chou et al. //Pediatr. Neonatol. - 2009. - V. 50 (4). - P. 143-6. 41. Catalano P.M. Management of obesity in pregnancy // Obstet Gynecol. - 2007, Feb. - V. 109 (2 Pt 1). - P. 419-433. Review. PubMed PMID: 17267845.

42. Faber D.R. Role of adipose tissue in haemostasis, coagulation and fibrinolysis D.R. Faber, P.G. de Groot, F.L. Visseren // Obesity Reviews. - 2009. - V. 10. P. 554-563.
43. Frisbee J.C. Vascular adrenergic tone and structural narrowing constrain reactive hyperemia in skeletal muscle of obese Zucker rats. American Journal of Physiology //Heart and Citrulatory Physiology. - 2009. - P. 2066-2074. 44. Kolobov A.V., etc. the human Placenta. Morphological and functional bases: textbook. - Petersburg: ELBI-SPb, 2011. 80 p. II

45. Lyapin V.M. The cell-islets in the placenta in preeclampsia /U.N. Tumanova, A.I. Shchegolev //Modern problems of science and education. - 2016. - V. 3

46. Seidbekova F.0. Morphological changes in the placenta of women who gave birth to newborns with congenital malformations //Medical news. - 2012. V. 5.

47. Zairatyants O.V. et al. Pathological anatomy: Atlas: training. a Handbook for medical students and poslediplomnogo education. - M.: GEOTAR-Media - 2014. $-960 \mathrm{p}$

48. Веропотвелян М.П. Імплантація трофобласта. Еволюція плацентарного кровообігу. Патологія плаценти. Доплерографія в діагностиці патології плаценти //Жіночий лікар. - 2009. - № 3 (23). C. 41-44.

49. Volkov A.E. Placenta, «surrounded by a cushion» (placenta circumvallata): clinical observations and literature review/A.E. Volkov // Prenatal diagnosis, 2005. - № 1. - P. 47-55.

50. Baranov V.S., Kuznetsova T. Cytogenetics of human embryonic development: Scientific and practical aspects / Baranov V.S., Kuznetsova T.V. - St. Petersburg: Publisher N-L, 2006. - 640 p. 51. Milovanov A.P. Pathology of the system mother-placenta-fetus. - M.: Medicine, 1999. - P. 232-236, 238-248.

52. Яремчук Т.П. Преждевременное созревание плаценты: состояние проблемы и рациональная акушерская тактика /Жіночий лікар. - 2008. - № 6. - С. 46. 53. Veropotvelyan N.P., Bondarenko A.A., Gazarova L.V., Usenko T.V. A rare case of placental infarction ultrasound manifestation under decompensated chronic placental dysfunction // Prenatal diagnosis. 2014. - Vol. 13, № 3. - P. 233-238. 54. Moscoso G., Jauniaux E., Hustin J. Placental vascular anomaly with diffuse mesenchymal stem villous hyperplasia: a new elinico-pathological entity? //Pathol. Res. Pract. - 1991. - Vol. 187, № 2-3. -P. 324-328.

55. Веропотвелян П.Н. Редкая патология плаценты - ее мезенхимальная дисплазия /П.Н. Веропотвелян, Н.П. Веропотвелян, И.В. Гужевская, И.С. Цехмистренко, 0.0. Авксентьев // Здоровье женщины. - 2013. - № 7. - С. 106-111. 56. Makarov I.0. Fetoplacental system at high risk of intrauterine infection of the fetus //The Russian Bulletin of Perinatology and Pediatricsю - 2000. - № 2. - P. 5-8. 


\title{
Особливості формування судинного компонента хоріона при невиношуванні вагітності у I триместрі гестації
}

\author{
О.В. Кравченко \\ ВДНЗУ «Буковинський державний медичний університет»
}

У жінок з невиношуванням у ранні терміни вагітності при ультразвуковому дослідженні вивчали об'єм плідного яйця, об'єм порожнини амніону та їхнє співвідношення. 3 використанням спеціальної трьохмірної програми VOCAL проводили підрахунок об' єму хоріона, оцінювання його судинної системи на основі визначення індексу васкуляризації (VI) та індексу кровотоку (FI).

Мета дослідження: вивчення етапів росту та васкуляризації хоріона при загрозі переривання вагітності у I триместрі гестації.

Матеріали та методи. Було обстежено 50 вагітних із загрозою невиношування в ранні терміни гестації: 30 осіб обтяженим акушерським анамнезом (ОАA), які отримували препарат мікронізованого прогестерону по 50 мг 3-4 рази на добу (основна група), і 20 вагітних, анамнез яких не був обтяжений і які знаходились на симптоматичній терапії (контрольна група).

Результати. Аналіз частоти зустрічальності екстрагенітальної патології у групах дослідження засвідчив, що у жінок з невиношуванням та ОАА соматичні захворювання виявляли майже у 2 рази частіше, ніж в контролі (відповідно 60\% і 30\%). Щодо частоти інфекційних ускладнень у I триместрі вагітності у групі жінок із загрозою переривання і ОАА у порівнянні з контрольною групою обстежених, достовірно частіше відзначали порушення піхвового мікробіоценозу у вигляді гарднерельозу (20\% і 10\%), кандидозного кольпіту (30\% і 5,5\%), а також урогенітальних інфекцій - хламідіозу, уреаплазмозу, мікоплазмозу (15\% і 0\%). Усім вагітним проводили санацію вогнища інфекції у I триместрі гестації - місцева терапія, системне лікування - після закінчення процесів плацентації.

Заключення. Проведене дослідження встановило, що використання мікронізованого прогестерону при невиношуванні вагітності у I триместрі гестації сприяє зростанню об'єму хоріона, інтенсивності кровотоку в його паренхімі та повноцінній перебудові спіральних артерій як наслідку адекватного формування плацентарно-маткового кровотоку, що, безумовно, покращує прогноз подалышого перебігу вагітності.

Ключові слова: невиношування вагітності, I триместр гестації, судини хоріона.

$\mathrm{H}$ евиношування вагітності в структурі акушерської патології посідає одне з основних місць. Особливо висока частота переривання вагітності припадає на I триместр гестації. Близько 20\% клінічно підтверджених вагітностей закінчуються спонтанним перериванням, з них 75-80\% - у ранні терміни [3].

Загроза переривання вагітності у I триместрі несе в собі потенціальну небезпеку порушень нормального розвитку екстраембріональних структур і процесів інвазії трофобласта гестаційної перебудови спіральних артерій і формування плодово-плацентарного і матково-плацентарного кровообігу $[1,5]$.
Тому актуальність вивчення особливостей формування та розвитку хоріона у ранні терміни гестації ні у кого не викликає сумнівів.

Мета дослідження: вивчення етапів росту та васкуляризації хоріона при загрозі переривання вагітності у I триместрі гестації.

\section{МАТЕРІАЛИ ТА МЕТОДИ}

Було обстежено 50 вагітних із загрозою невиношування в ранні терміни гестації: 30 осіб - з обтяженим акушерським анамнезом (OAA), які отримували препарат мікронізованого прогестерону по 50 мг 3-4 рази на добу (основна група) і 20 вагітних, анамнез яких не був обтяжений і які знаходились на симптоматичній терапії (контрольна група).

Усі вагітні перебували під диспансерним наглядом. Їх обстежували відповідно до Наказу МОЗ України № 417. Ультразвукові та допплерометричні дослідження проводили за наявності клінічних ознак загрози переривання вагітності та в динаміці лікування. Окрім рутинного обстеження додатково вивчали об'єми плідного яйця, порожнини амніону та їхнє співвідношення. 3 використанням спеціальної трьохмірної програми VOCAL проводили підрахунок об'єму хоріона, оцінювання його судинної системи на основі визначення індексу васкуляризації (VI) та індексу кровотоку (FI) [6-8].

\section{РЕЗУЛЬТАТИ ДОСЛІДЖЕННЯ}

\section{ТА ÏХ ОБГОВОРЕННЯ}

Групи обстежених вагітних були репрезентативні за віком, соціальним статусом та місцем проживання. Першовагітні в основній групі дослідження становили $20 \%$, у контрольній $60 \%$, повторновагітні - відповідно за групами $80 \%$ і $40 \%$.

За даними акушерсько-гінекологічного анамнезу констатовано, що у жінок основної групи в анамнезі відзначали мимовільні викидні у 20\% випадків, викидні, що не відбулися, - у 15\%, тоді як у вагітних контрольної групи репродуктивний анамнез не був обтяжений. Штучне переривання вагітності у жінок, що отримували гормонотерапію, в анамнезі становило 40\%, у контролі - 30\%. Однак достовірної різниці даного показника між групами виявлено не було.

Слід відзначити, що хронічні запальні процеси придатків матки, ерозії шийки матки, доброякісні пухлини матки і придатків до вагітності в обох групах виявляли з однаковою частотою. Лише частота аденоміозу і патології ендометрія у жінок основної групи у порівнянні з контролем була достовірно вищою, відповідно 40\% і 15\%. Імовірно, виражена патологія ендо- і міометрія у жінок основної групи може зумовлювати перешкоджання децидуальної трансформації ендометрія з наступним порушенням нормального формування ворсинчастого хоріона.

Аналіз частоти зустрічальності екстрагенітальної патології у групах дослідження засвідчив, що у жінок з невиношуванням та ОАА соматичні захворювання виявляли майже у 2 рази частіше, ніж в контролі (відповідно 60\% і 30\%). 


\section{A K Y Ш E P C T B O}

На нашу думку, несприятливий екстрагенітальний фон призводить до порушення нормального перебігу вагітності є додатковим фактором ризику виникнення загрози невиношування

Щодо частоти інфекційних ускладнень у I триместрі вагітності у групі жінок із загрозою переривання і OAA у порівнянні з контрольною групою обстежених, достовірно частіше відзначали порушення піхвового мікробіоценозу у вигляді гарднерельозу (20\% і 10\%), кандидозного кольпіту (30\% і 5,5\%), а також урогенітальних інфекцій - хламідіозу, уреаплазмозу, мікоплазмозу (15\% і 0\%).

Усім вагітним проводили санацію вогнища інфекції у I триместрі гестації - місцева терапія, системне лікування після закінчення процесів плацентації.

Результати ультразвукового дослідження у 7-9 тиж гестації засвідчили, що об’єми амніотичної порожнини у жінок досліджуваних груп достовірно не розрізнялися (основна

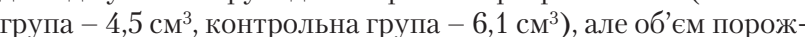
нини плідного яйця був достовірно менший у жінок контрольної групи $\left(14 \mathrm{~cm}^{3}\right)$ у порівнянні з основною $\left(20 \mathrm{~cm}^{3}\right)$. У той самий час, співвідношення об'ємів порожнини хоріона і амніону в основній групі обстежених було достовірно вищим $(6,2)$ у порівнянні з контрольними даними $(2,9)$. Імовірно, зменшення об'єму плідного яйця у жінок контрольної групи зумовлене підвищеним тонусом міометрія, внаслідок чого плідне яйце зазнає підвищеного тиску ззовні [2].

Як видно з мал. 1, динаміка змін об'єму хоріона у жінок, які отримували гормонотерапію, суттєво відрізняється від показників групи вагітних, які знаходились на симптоматичній терапії. Особливо ця різниця виражена у терміні 10-12 тиж гестації [4].

II, a саме - співвідношення судинного компонента і паренхіми, у даному об'ємі тканини в динаміці вагітності зростає поступово, але показники є достовірно вищими у жінок основної групи (мал. 2).

FI протягом I триместра гестації також поступово збільшується, але достовірної різниці у значеннях даного показника у досліджуваних групах у період формування ворсин і в період формування котиледонів не виявлено (мал. 3).

\section{ВИСНОВКИ}

Отже, використання мікронізованого прогестерону при невиношуванні вагітності у I триместрі гестації сприяє зростанню об'єму хоріона, інтенсивності кровотоку в його паренхімі та повноцінній перебудові спіральних артерій як наслідку адекватного формування плацентарно-маткового кровотоку, що, безумовно, покращує прогноз подальшого перебігу вагітності.

\section{Особенности формирования сосудистого компонента хориона при невынашивании беременности в I триместре гестации Е.В. Кравченко}

У женщин с невынашиванием в ранние сроки беременности при ультразвуковом исследовании изучали объем плодного яйца, объем полости амниона и их соотношение. С использованием специальной трехмерной программы VOCAL проводили подсчет объема хориона, оценку его сосудистой системы на основе определения индекса васкуляризации (VI) и индекса кровотока (FI)

Цель исследования: изучение этапов роста и васкуляризации хориона при угрозе прерывания беременности в I триместре гестации.

Материалы и методы. Были обследованы 50 беременных с угрозой невынашивания в ранние сроки гестации: 30 - с отягощенным акушерским анамнезом (ОАА), получавших препарат микронизированного прогестерона по 50 мг 3-4 раза в сутки (основная группа) и 20 беременных, анамнез которых не был обременен и которые находились на симптоматической терапии (контрольная группа). Peзультаты. Анализ частоты встречаемости экстрагенитальной пато-

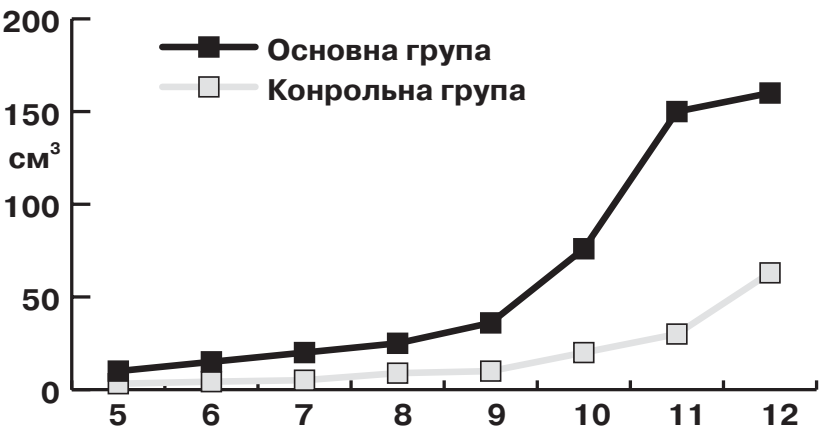

Мал. 1. Динаміка змін об’єму хоріона у I триместрі гестації

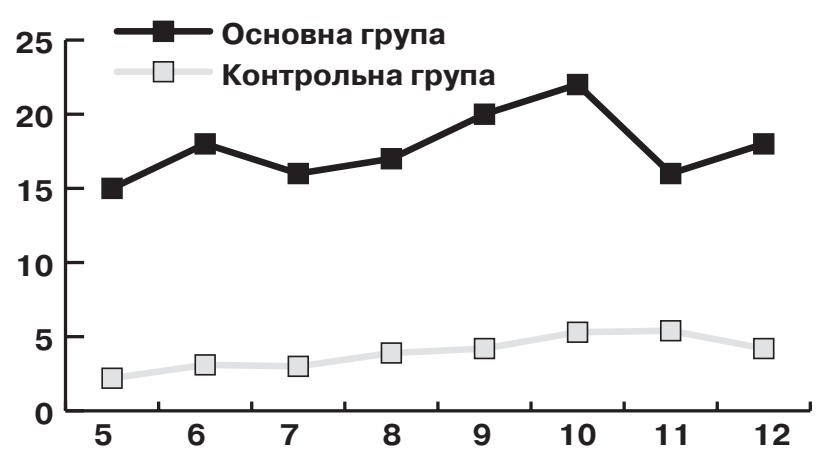

Мал. 2. Динаміка змін VI у I триместрі гестації

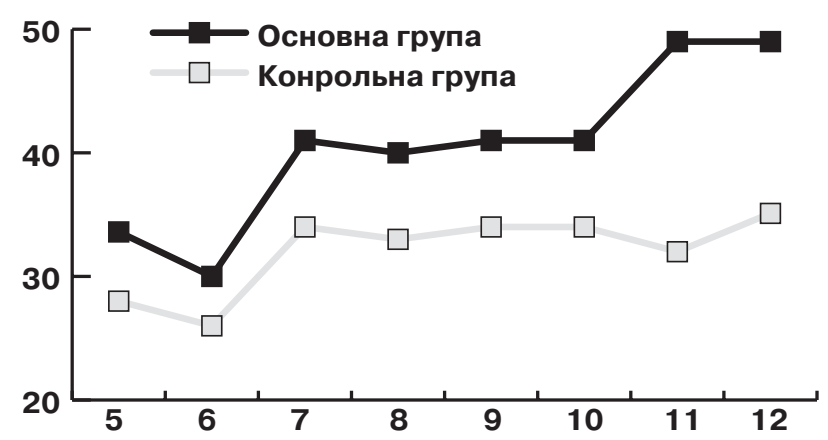

Рис. 3. Динаміка змін FI у I триместрі

логии в группах исследования показал, что у женщин с невынашиванием и ОАА соматические заболевания выявляли почти в 2 раза чаще, чем в группе контроля (соответственно 60\% и 30\%). По частоте инфекционных осложнений в I триместре беременности в группе женщин с угрозой прерывания и ОАА по сравнению с контрольной группой обследованных достоверно чаще отмечали нарушения влагалищного микробиоценоза в виде гарднереллеза (20\% и $10 \%)$, кандидозного кольпита (30\% и 5,5\%), а также урогенитальных инфекций - хламидиоза, уреаплазмоза, микоплазмоза (15\% и 0\%). Всем беременным проводили санацию очага инфекции в I триместре гестации - местная терапия, системное лечение - после окончания процессов плацентации.

Заключение. Проведенное исследование установило, что использование микронизированного прогестерона при невынашивании беременности в I триместре гестации способствует росту объема хориона, интенсивности кровотока в его паренхиме и полноценной перестройке спиральных артерий как следствию адекватного формирования плацентарно-маточного кровотока, что, безусловно, улучшает прогноз дальнейшего течения беременности.

Ключевые слова: невынашивание беременности, I триместр гестации, сосуды хориона. 


\section{A K Y Ш E P C T B O}

\section{Formational features of the vascular component of the chorion in miscarriage in the first trimester of gestation \\ E. V. Kravchenko}

In women with miscarriage in early pregnancy by ultrasound was studied the volume of the ovum, the volume of the cavity of the amnion and their relationship. Using special three-dimensional VOCAL program performed the calculation of the volume of the chorion, the evaluation of his vascular system based on the definition of the vascularization index (VI) and flow index (FI).

The aim of the study: to study the stages of growth and vascularization of the chorion with the threat of miscarriage in the first trimester of gestation.

Materials and methods. There were examined 50 pregnant women with threat of miscarriage at early terms of gestation: 30 - burdened obstetric history $(\mathrm{BOH})$, receiving the drug micronized progesterone $50 \mathrm{mg} 3-4$ times per day (the main group) and 20 pregnant women, the history of which was not encumbered, who were on symptomatic therapy (control group)

Results. Analysis of the frequency of occurrence of extragenital pathology in the study groups showed that in women with recurrent pregnancy loss and $\mathrm{BOH}$ somatic diseases were almost 2 times more often than in the control group (respectively $60 \%$ and $30 \%$ ). The frequency of infectious complications in the first trimester of pregnancy in women with threatened abortion and $\mathrm{BOH}$ compared to the control group of patients, significantly more frequently noted violations of vaginal microbiocenosis, in the form of gardnerellosis ( $20 \%$ and $10 \%$ ), Candida vaginitis ( $30 \%$ and $5.5 \%$ ) and urogenital infections - chlamydia, ureaplasmosis, mycoplasmosis (15\% and $0 \%$ ). All pregnant women was carried out sanitation of the source of infection in the first trimester of gestation - local therapy, systemic treatment after completion of the processes of placentation.

Conclusion. The study found that use of micronized progesterone in miscarriage in the first trimester of gestation contributes to the growth of the volume of the chorion, the intensity of the flow in the parenchyma and a complete restructuring of the spiral arteries resulting in inadequate formation of the placental-uterine blood flow, which certainly improves the prediction of the further course of pregnancy.

Key words: miscarriage, the I trimester of gestation, the vessels of the chorion.

\section{Сведения об авторе}

Кравченко Елена Викторовна - Кафедра акушерства, гинекологии и перинатологии ВГНЗУ «Буковинский государственный медицинский университет», 58002, г. Черновцы, Театральная площадь, 2; тел.: (03722) 4-44-01. E-mail: akusherstvo2@bsmu.edu.ua

\section{СПИСОК ЛІТЕРАТУРИ}

1. Краснопольский В.И. Возможности прогнозирования осложнений беременности при допплерометрии в I триметре гестации / В.И. Краснопольский, В.А. Туманов, Л.И. Титченко // Российский вестник акушера-гинеколога. - 2003. - № 3. - С. 5-9.

2. Милованов А.П. Внутриутробное развитие человека / А.П. Милованов, С.В. Савельев // Руководство для врачей. - М.: МДВ, 2006. - 384 С.

3. Сидельникова В.М. Невынашива- ние беременности - современный взгляд на проблему / В.М. Сидельни кова // Вестник Российской ассоциации акушер. и гинекол. - 2007. № 2. - С. 62-64.

4. Титченко Л.И. Трехмерная реконструкция в I триместре беременности / Л.И. Титченко, М.А. Чечнева, Н.В. Жукова // Российский вестник акушера-гинеколога. - 2003. - № 5. - С. 16-20. 5. Intervillious and uteroplacental circulation in normal early pregnancy and early pregnancy loss assessed by 3 dimensional power Doppler angiography / Merce L.T., Barco M.J. Alcazar J.L. [et. al.] // American Journa of Obstetrics and Gynecology. - 2009

- Mar. 200(3). - P. 315

6. Kurjak A. Three-dimensional and power Doppler in the study of angiogenesis / A. Kurjak, S. Kupesic, T. Zoclan //Ultrasound Obstet Gynecol, 2001 Okt; 18(4).

7. This three-dimensional power Doppler ultrasound useful in the evalua- tion of placental perfusion in normal and growth restricted pregnancy / Guiot C., Gaglioti P., Oberto M. [et. al.] // Ultrasound in Obstet. and Gynecol. 2009. - Sep. 31 (2). - P. 171

8. Uterine artery Doppler at 11-14 weeks of pregnancy to detect hypertensive disorders and related complications inunselected populations / 0 . Gomez, J.M. Martinez, F. Figueras [et. al.] // Ultrasound in Obstetrics and Gynecology. - 2005. - 26 (5). - P. 490-494. 


\title{
Виявлення та характеристика антитіл проти Нsp60 людини у вагітних
}

\author{
М.В. Макаренко ${ }^{1}$, Д.А. Говсєєв, Р.М. Ворона', А.М. Цісаренко ${ }^{2}$ О.Я. Васильчук², \\ О.В. Павлюк', Л.Ф. Яковенкоㄹ, І.В. Крупська², А.П. Погрібна', Л.Л. Сидорик² \\ ${ }^{1}$ Інститут післядипломної освіти Національного медичного університету імені О.О. Богомольця, м. Київ \\ ${ }^{2}$ Інститут молекулярної біології і генетики НАН України, м. Київ
}

Білки теплового шоку (heat shock proteins - HSPs), або молекулярні шаперони, первинно охарактеризовані як учасники клітинної відповіді на різні види стресу (інфекція, дія важких металів, ішемія, гіпоксія, амінокислотне голодування, психоемоційний стрес, гормональний стрес тощо). Нsp60 - один із перших білків, що синтезуються під час ембріогенезу, і є необхідним для розвитку ембріона.

Мета дослідження: виявлення та характеристика антиHsp60-автоантитіл у вагітних для оцінювання можливої перспективи застосування їх як додаткового тесту прогнозування перебігу вагітності.

Матеріали та методи. Обстежено 170 пацієнток, серед них 20 клінічно здорових вагітних (контрольна група) та 150 вагітних з ускладненим анамнезом (основна група). Рівень IgG анти-Hsp60-антитіл у сироватці визначали з використанням імуноферментного аналізу (IФА). Імунореактивність визначали методом вестерн-блотингу (імуноблотинг).

Результати. Методом ІФА анти-Нsp60-позитивну сироватку було виявлено у 7,7\% вагітних контрольної групи та 14,0\% вагітних з ускладненим анамнезом. Не встановлено статистично достовірної різниці між рівнем анти-Нsp60-автоантитіл (за середніми показниками) у вагітних основної групи та вагітних контрольної групи $(0,177 \pm 0,118$ проти $0,134 \pm 0,097$ од. опт. густини; $\mathrm{p}>0,05)$. Частота виявлення патологій у вагітних, сироватка яких була анти-Нsp60-позитивною, вища порівняно з вагітними, сироватка яких була анти-Нsp60-негативною.

Заключення. Одержані результати свідчать, що у дослідженні анти-Нsp60-антитіл як додаткового тесту, зокрема прогнозу перебігу вагітності, поєднане використання ІФА та вестерн-блотингу є більш доцільним.

Ключові слова: вагітність, Нsp60, антитіла проти Нsp60 людини.

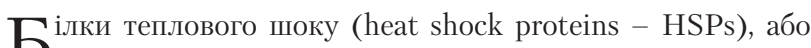
D молекулярні шаперони, первинно охарактеризовані як учасники клітинної відповіді на різні види стресу (інфекція, дія важких металів, ішемія, гіпоксія, амінокислотне голодування, психоемоційний стрес, гормональний стрес тощо). На сьогодні прийнято вважати, що HSPs відіграють важливу роль у вродженому та адаптивному імунітеті [11].

Hsp60 - еволюційно консервативний шаперон/шаперонін мітохондріального походження - забезпечує за допомогою кошаперона Нsp10 правильну укладку клітинних білків у мітохондріях та під час стресу попереджає їхнє неправильне згортання та агрегацію. Нsp60 також виявляють у цитоплазмі клітин, де він виконує антиапоптичну функцію. За стресових умов Нsp60 експонується на поверхні клітин та секретується у міжклітинний простір [6].

Установлено, що шаперонін є антигеном-мішенню при автоімунних захворюваннях (атеросклероз, діабет I типу тощо), а Нsp60-реактивні Т- і В-клітини є частиною імунної відповіді при інфекційних захворюваннях. Нsp60 притаманні імунорегуляторні властивості, він може відігравати як про- так і протизапальну роль залежно від мікрооточення в органімішені, що робить його важливим антигеном гомеостазу [13].

Hsp60 - один із перших білків, що синтезуються під час ембріогенезу, і є необхідним для розвитку ембріона [9]. Експериментально доведений прямий вплив анти-Нsp60-антитіл на розвиток ембріону миші in vitro [10]. Нsp60 у підвищеній кількості виявляють на ранніх стадіях вагітності (7-11 тиж) у материнській плаценті. Він може представляти потенційну мішень у першу чергу для перехресно реагуючих антитіл проти мікробного Hsp60, а також лімфоцитів, сенсибілізованих мікробним Hsp60, що може призводити до імунного відторгнення ембріона. Установлено, що рівень Нsp60 у плаценті не відрізнявся при нормальній вагітності та перерваній на ранніх стадіях. Проте імунні комплекси Нsp60-анти-Нsp60-антитіло виявляли лише у плаценті жінок, які втратили вагітність на ранніх стадіях. Активація такими імунними комплексами, зокрема синтезу прозапальних цитокінів, може негативно впливати на результат вагітності (індукція передчасного народження дитини) [17].

Мета дослідження: виявлення та характеристика антиНsp60-автоантитіл у вагітних для оцінювання можливої перспективи застосування їх як додаткового тесту прогнозування перебігу вагітності.

\section{МАТЕРІАЛИ ТА МЕТОДИ}

Обстежено 170 вагітних, яким було проведено лабораторні та інструментальні дослідження згідно з Наказом МО3 України від 15.07.2011 р. № 417 «Про організацію амбулаторної акушерсько-гінекологічної допомоги в Україні». Серед них 20 клінічно здорових вагітних (контрольна група) та 150 вагітних з ускладненим анамнезом (основна група).

Рівень IgG анти-Нsp60-антитіл у сироватці визначали з використанням імуноферментного аналізу (ІФА) 3 модифікаціями [4]. Як позитивний контроль використовували поліклональні антитіла проти Нsp60 [15], негативний контроль - низькореактивну сироватку клінічно здорових жінок-донорів.

Як антиген використовували рекомбінантний білок Нsp60 людини, одержаний раніше. Одержання та очистку рекомбінантного білка Нsp60 проводили за розробленою методикою [2]. Антитілопозитивною вважали сироватку, оптична густина якої у розведенні 1:100 перевищувала середнє значення оптичної густини сироватки контрольної групи на 2 стандартних відхилення (m+2sd).

Імунореактивність визначали методом вестерн-блотингу (імуноблотинг). Для детектування специфічного зв'язування вторинних антитіл мембрану витримували в ECL-реагенті 5 хв та візуалізували за допомогою трансілюмінатора ChemiDoc XRS+.

Статистичне оброблення результатів досліджень здійснювали за допомогою пакета програм STATISTICA 8.0 (Stat-Soft, 2007, США). Для порівняння вибірок досліджуваних груп використовували U-критерій Манна-Уїтні (Mann-Whitney Utest), частина результатів представлена у вигляді середніх значень з посиланням на середні квадратичні відхилення. 
A K У Ш E P C T B O

Частота виявлення патологій у вагітних з високими рівнями анти-Нsp60-автоантитіл у сироватці, \%

\begin{tabular}{|c|c|c|}
\hline Показник & $\begin{array}{c}\text { Baгітні з високими рівнями } \\
\text { анти-Нsр60-автоантитіл у сироватці }\end{array}$ & $\begin{array}{c}\text { Вагітні з низькими рівнями } \\
\text { анти-Нsр60-автоантитіл у сироватці }\end{array}$ \\
\hline $\begin{array}{c}\text { Мимовільні викидні, завмерла } \\
\text { вагітність в анамнезі }\end{array}$ & 31,8 & 21,7 \\
\hline Тонзилектомія в анамнезі & 14,3 & 2,3 \\
\hline Апендектомія в анамнезі & 23,8 & 53,28 \\
\hline $\begin{array}{c}\text { Запальні захворювання органів } \\
\text { малого таза }\end{array}$ & 66,67 & 25,78 \\
\hline $\begin{array}{c}\text { Перенесені запальні захворювання } \\
\text { травного тракту }\end{array}$ & 33,3 & 17,97 \\
\hline $\begin{array}{c}\text { Перенесені запальні захворювання } \\
\text { сечо-статевої системи }\end{array}$ & 19,0 & 12,5 \\
\hline Хвороби щитоподібної залози & 4,76 & 3,12 \\
\hline Варикозне розширення вен & 4,76 & \\
\hline
\end{tabular}

\section{РЕЗУЛЬТАТИ ДОСЛІДЖЕННЯ}

\section{ТА ÏХ ОБГОВОРЕННЯ}

Було вивчено можливу імунореактивність сироваток вагітних проти шапероніну еукаріот Нsp60 за допомогою IФА та вестерн-блотингу. Таке поєднане використання методів дозволяє визначити як рівень антитіл, так і їхню потенційну здатність з'язатись з антигеном-мішенню. Методом ІФА анти-Нsp60-позитивну сироватку було виявлено у 7,7\% вагітних контрольної групи та 14,0\% вагітних з ускладненим анамнезом. Не встановлено статистично достовірної різниці між рівнем анти-Нsp60-автоантитіл (за середніми показниками) у вагітних основної групи та вагітних контрольної групи (0,177 $\pm 0,118$ проти $0,134 \pm 0,097$ од. опт. густини; $\mathrm{p}>0,05)$ Частота виявлення патологій у вагітних, сироватка яких була анти-Нsp60-позитивною, порівняно з вагітними, сироватка яких була анти-Нsp60-негативною, представлена в таблиці. Установлено, що у вагітних основної групи з високими рівнями антитіл проти Нsp60 людини у сироватці частіше в анамнезі виявляли порушення репродуктивної функції (мимовільні викидні, завмерла вагітність - у 1,5 разу), а також операції (тонзилектомія - у 7 разів та апендектомія - у 1,8 разу), порівняно з вагітними з низькими рівнями досліджуваних антитіл у сироватці.

Результати дослідження імунореактивності сироваток вагітних методом вестерн-блот-аналізу представлено на малюнку. Слід зазначити, що у вагітних контрольної групи лише одна сироватка виявилась високореактивною по відношенню до досліджуваного антигену. У вагітних, у яких в анамнезі були викидні на тлі захворювань з боку органів малого таза, сироватка виявилась високореактивною за результатами вестерн-блотингу. Результати вестерн-блотингу у вагітних не завжди були співставними з результатами ІФА (низькі рівні антитіл за результатами ІФА поєднувались з високою реактивністю досліджуваних антитіл за результатами вестерн-блотингу). Здатність розпізнавати антигенмішень (Нsp60 людини), на нашу думку, є більш важливою характеристикою і може свідчити про потенційну можливість антитіл зв'язуватись з ендогенним Нsp60. Установлено, що анти-Нsp60-антитіла здатні опосередковувати комплементзалежну цитотоксичність, зумовлювати лізис або апоптоз клітин, що експресують на своїй поверхні Hsp60. Антитіла також здатні зв'язувати циркулюючий у плазмі крові ендогенний Нsp60 і утворювати імунні комплекси з патологічним впливом на клітини і тканини [6].

Анти-Нsp60-антитіла різної специфічності виявляють у сироватці здорових осіб, їхній рівень підвищується під час різних захворювань [12]. Вважають, що високі рівні антиНsp60-антитіл слід розглядати як біологічний маркер несприятливого стану організму, наявності хронічних захворювань, аітоімунних процесів, ознаку наявності та важкості перебігу серцево-судинних захворювань, фактор ризику атеросклерозу, маркер канцерогенезу тощо [14, 16].

Раніше нами було встановлено зв'язок між наявністю підвищених рівнів антитіл проти мікробного гомолога Нsp60 людини - шапероніну E.coli (GroEL) та формуванням порушень репродуктивної функції (трубна безплідність, невиношування вагітності) (коефіцієнт взаємного спряження $\mathrm{K}=0,475$; середня сила зв'язку) [3]. За результатами наших попередніх досліджень, рівень анти-GroEL-антитіл знаходився у межах контролю у 92,86\% породіль. У породіль, сироватка яких була анти-GroEL-позитивною, було виявлено зміни клінічних показників (лейкоцитоз, підвищення ШОЕ), фіксували загрозу переривання вагітності, в анамнезі - передчасні пологи, викидні. Проведене нами раніше дослідження рівнів антиGroEL-антитіл у сироватках вагітних з пренатально діагностованою критичною вродженою вадою серця плода не виявило за середніми показниками статистично значущої різниці рівнів досліджуваних антитіл в обстежених вагітних та клінічно здорових жінок (донори крові) [1]. За даними літератури, рівні анти-Нsp60-антитіл у матерів, які народили дітей з анатомічними вадами розвитку, достовірно не відрізнялись від контролю (вагітні з нормальним перебігом вагітності) [7].

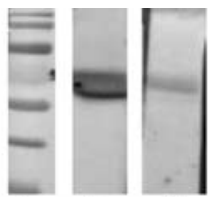

1

2
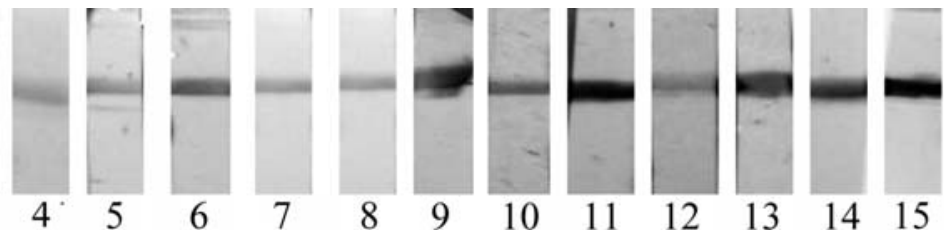

60 кДа

Імунореактивність (розпізнавання антиген-мішені) сироватки клінічно здорових вагітних та вагітних 3 порушеннями репродуктивної функції (в анамнезі - мимовільні викидні/завмерла вагітність) за результатами вестерн-блотингу: 1 - суміш білкових маркерів молекулярної маси; 2 - позитивний контроль (поліклональні анти-Нsp60-антитіла); 3-8 - сироватка клінічно здорових вагітних (розведення 1:100); 9-15 - сироватка вагітних з порушеннями репродуктивної функції (в анамнезі - мимовільні викидні/завмерла вагітність) (розведення 1:100) 


\section{A K Y Ш E P C T B O}

\section{ВИСНОВКИ}

Низькі рівні антитіл проти Нsp60 людини у 92,3\% вагітних контрольної групи та 86\% вагітних з ускладненнями в анамнезі узгоджуються з одержаними нами раніше результатами та даними літератури. Проте висока реактивність за результатами вестерн-блотингу сироватки вагітної є, на нашу думку, несприятливою ознакою. Як вже згадувалось вище, анти-Нsp60-антитіла мають здатність пригнічувати розвиток ембріона, а та-

\section{Идентификация и характеристика антител против Hsp60 человека у беременных М.В. Макаренко, Д.А. Говсеев, Р.М. Ворона, А.М. Цисаренко, О.Я. Васильчук, О.В. Павлюк, Л.Ф. Яковенко, И.В. Крупская, А.П. Погребная,Л.Л. Сидорик}

Белки теплового шока (heat shock proteins - HSPs), или молекулярные шапероны, первоначально охарактеризованы как участники ответа клетки на различные виды стресса (инфекция, влияние тяжельх металлов, ишемия, гипоксия, аминокислотное голодание, психоэмоциональный стресс, гормональный стресс и т.д.). Нsp60 - один из первых белков, которые синтезируются во время эмбриогенеза. Он необходим для развития эмбриона Цель исследования: определение и характеристика анти-Нsp60 аутоантител у беременных для оценки возможной перспективы их использования в качестве дополнительной возможности прогнозирования хода беременности.

Материалы и методы. Обследовано 170 пациенток, среди них 20 клинически здоровых беременных (контрольная группа) и 150 беременных с осложненным анамнезом (основная группа). Уровень IgG анти-Нsp60-антител в сыворотке определяли с использованием иммуноферментного анализа (ИФА). Иммунореактивность определяли методом вестерн-блоттинга (иммунный блоттинг).

Peзультаты. Методом ИФА анти-Нsp60-позитивная сыворотка была обнаружена у 7,7\% беременных контрольной группы и у 14,0\% беременных с усложненным анамнезом. Не установлено статистически достоверной разницы между уровнем анти-Нsp60-аутоантител (по средним показателям) у беременных основной группы и беременных контрольной группы $(0,177 \pm 0,118$ против $0,134 \pm 0,097$ ед. опт плотности; $>>0,05)$. Частота выявления патологий у беременных, сыворотка которых была анти-Нsp60-позитивной, выше по сравнению с беременными, сыворотка которых была анти-Нsp60-негативной. Заключение. Полученные результаты свидетельствуют, что в исследовании анти-Нsp60-антител как дополнительного теста, в частности прогноза хода беременности, совместное использование ИФА и вестерн-блоттинга более целесообразно.

Ключевые слова: беременность, Нsp60, антитела против Нsp60 человека.

\section{Сведения об авторах}

Макаренко Михаил Васильевич - Кафедра акушерства и гинекологии последипломного образования Национального медицинского университета имени А.А. Богомольца, 01601, г. Киев, бульвар Тараса Шевченко, 13/7;тел.: (044) 275-80-77

Говсеев Дмитрий Александрович - Кафедра акушерства и гинекологии последипломного образования Национального медицинского университета имени А.А. Богомольца, 01601, г. Киев, бульвар Тараса Шевченко, 13/7;тел.: (044) 275-80-77. E-mail:nm@proffkom.com

Ворона Роман Николаевич - Кафедра акушерства и гинекологии последипломного образования Национального медицинского университета имени А.А. Богомольца, 01601, г. Киев, бульвар Тараса Шевченко, 13/7;тел.: (044) 275-80-77

Цисаренко Анастасия Николаевна - Лаборатория Института молекулярной биологии и генетики НАН Украины, 03143, г. Киев, ул. Академика Заболотного, 150; тел.: (044) 526-55-89

Васильчук Ольга Яковлевна - Лаборатория Института молекулярной биологии и генетики НАН Украины, 03143, г. Киев, ул. Академика Заболотного, 150; тел.: (044) 526-55-89

Павлюк Ольга Васильевна - Лаборатория Института молекулярной биологии и генетики НАН Украины, 03143, г. Киев, ул. Академика Заболотного, 150; тел.: (044) 526-55-89

Яковенко Людмила Федоровна - Лаборатория Института молекулярной биологии и генетики НАН Украины, 03143, г. Киев, ул. Академика Заболотного, 150; тел.: (044) 526-55-89

Крупская Ирина Владимировна - Лаборатория Института молекулярной биологии и генетики НАН Украины, 03143, г. Киев, ул. Академика Заболотного, 150; тел.: (044) 526-55-89

Погребная Алла Петровна - Лаборатория Института молекулярной биологии и генетики НАН Украины, 03143, г. Киев, ул. Академика Заболотного, 150; тел.: (044) 526-55-89

Сидорик Людмила Леонидовна - Лаборатория Института молекулярной биологии и генетики НАН Украины, 03143 , г. Киев, ул. Академика Заболотного, 150; тел.: (044) 526-55-89 народження дитини) [9, 10]. Тому вагітні, сироватка яких про-

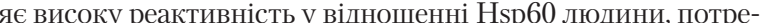

Отже, одержані результати свідчать, що у дослідженні

\section{Identification and characterization of antibodies \\ M. Makarenko, D. Govsieiev, R. Vorona,} (infection, the influence of heavy metals, ischemia, hypoxia, amino acid one of the first proteins that are synthesized during embryogenesis. Hsp60 is necessary for the development of the embryo.

was the identification and charact Patients and methods. Was a group of 170 pregnant women. 20 preg( immunoaswomen from the control group and in $14.0 \%$ of pregnant with complicated anamnesis. A statistically significant differpregnant women of the main group and the control group was not idenConclusions. Our results suggest that in relation to the anti-Hsp60 antibody studies as an additional test, in particular, the forecast of appropriate.

Key words: pregnancy, Hsp60, anti-Hsp60 autoantibodies. перебігу вагітності, поєднане використання ІФА та вестерн- 


\section{A K Y Ш E P C T B O}

\section{СПИСОК ЛІТЕРАТУРИ}

1. Антитіла до Hsp60 у новонароджених, яким під час операції з приводу критичної вродженої вади серця переливали аутологічну пуповинну кров, у ранньому та віддаленому післяопераційному періоді / Г.М. Воробйова, Я.В. Ткаченко, Л.Ф. Яковенко, та ін. // Клінічна хірургія. - 2014. - № 12. C. 33-36.

2. Получение рекомбинантного шаперона GroEL и его иммунологическая кросс-реактивность с Нsp60 / Л.Н. Капустян, Р.Г. Киямова, В. С. Гришкова и др.// Biopolim. Cell. 2006. - V. 22, № 2. - P. 117-12.

3. Антитіла до GroEl E.coli (гомолог Hsp60 людини) у жінок із хронічними запальними захворюваннями органів малого тазу / Л.Ф. Яковенко, О.В. Ромащенко, А.В. Руденко та ін. // ПАГ. 2011. - № 3. - C. 91-96.

4. Avrameas S. Monoclonal IgG and autoantibodies obtained after polyclonal activation, show reactivities similar to those of polyclonal natural autoantibodies / S. Avrameas, T. Termynck // Mol. Immunol. - 1993. - Vol. 30. P. 119-127.

5. Bradford M.A. Rapid and Sensitive Method for the Quantitation of Microgram Quantities of Protein Utilizing the Principle of Protein-Dye Binding / M.A. Bradford // Analytical Biochemistry. - 1976. - Vol. 72. P. 248-254.

6. Chlamydya trachomatis infection and anti-Hsp60 immunity: the two sides of the coin / F. Cappello, E. Macario, V. Di Felice et al. // Plos Pathogens. - 2009. - Vol. 5, N 8. - P. 1-9.

7. Birth defects and anti-heat shock protein 70 antibodies in early pregnancy / D. Child, P. Hudson, C. Hunter-Lavin et al. // Cell Stress and Chaperones. 2006. - Vol. 11, N 1. - P. 101-105. 8. Laemmli U.K. Cleavage of structural proteins during the assembly of bacteriophage T4 / U.K. Laemmli // Nature. -
1970. - Vol. 227, N 5259. P. 680-685.

9. Heat shock protein expression during gametogenesis and embryogenesis [Review] / A. Neuer, S. Spandorfer, P. Giraldo et al. // Infect. Dis. Obstet. Gynecol. - 1999. - Vol. 7. - P. 10-16. 10. The role of heat shock proteins in reproduction / A. Neuer, S. Spandorfer, P. Giraldo et al. // Hum. Reprod. Update. - 2000. - Vol. 6. P. 149-159.

11. Quintana F. The HSP60 immune system network / F. Quintana, I. Cohen // Trends Immunol. - 2011. - Vol. 32, N 2. - P. 89-95.

12. Identification of human heat shock protein 60 (Hsp60) and anti-Hsp60 antibodies in the peripheral circulation of normal individuals / A.G. Pockley, J. Bulmer, B.M. Hanks et al. // Cell Stress Chaperons. - 1999. - Vol. 4. P. 29-35.

13. Rajaiah R. Heat-shock proteins can promote as well as regulate autoimmunity / R. Rajaiah, K. Moudgil // Autoim. Rev. - 2009. - Vol. 8, № 5. P. 388-393

14. Heat shock protein-60 and risk for cardiovascular disease / M. Rizzo, A. Macario, E. de Macario et al. // Curr. Pharm. Des. - 2011. - Vol. 17, N 33. - P. 662-668.

15. Immuno-chemical non-cross-reactivity between eukaryotic and prokaryotic seryl-tRNA synthetases / L. Sidorik, V. Gudzera, V. Dragovoz et al. // FEBS. - 1991. - Vol. 292, N 1. - P. 76-78. 16. Wu T. Antibodies against heat shock proteins in environmental stresses and diseases: frend or foe? / T. Wu, R. Tanguay // Cell Stress Chaper. 2006. - Vol. 11. . - P. 1-12.

17. Heat shock proteins and heat shock protein-antibody complexes in placental tissues / M. Ziegert, S. Witkin, I. Sziller et al. // Infect. Dis. Obstet. Gynecol. 1999. - Vol. 7. - P. 180-185.
Беременным женщинам, как известно, необходимо уделять особенно пристальное внимание организации своего рациона питания.

Коллаборация ученых из университетов Вайоминга и Техаса, возглавленная Джефри Кларком, проводила экспериментальные исследования на бабуинах, у которых, в итоге, была выявлена четкая корреляция между состояни- ем сердечно-сосудистой системы и питанием, получаемым в период внутриутробного развития.

"Неправильное питание в ходе беременности может приводить к таким негативным процессам, как нарушения развития внутренних органов, в частности, сердца. Которое, в итоге, формируется аномальным образом, в результате чего склонно к преждевременному старению", - говорит профессор Джефри Кларк.

Ученые, обнаружившие феномен, заявляют, что последствия от преждевременного старения сердца являются довольно серьезными.

То есть, они могут в значительной степени снизить качество жизни людей, чьи матери не уделяли необходимого внимания своему

med-expert.com.ua 


\title{
Морфологічні особливості стану фетоплацентарного комплексу у жінок з ранніми передчасними пологами після застосування допоміжних репродуктивних технологій
}

\author{
А.С. Мандрикова \\ Національна медична академія післядипломної освіти імені П.Л. Шупика, м. Київ
}

\begin{abstract}
Мета дослідження: вивчення морфофункціональних змін фетоплацентарного комплексу у 28-33 тиж гестації у жінок з ранніми передчасними пологами після застосування допоміжних репродуктивних технологій (ДРТ).

Матеріали та методи. Було проведено обстеження 130 пацієнток, вагітність яких настала після застосування ДРТ. Це жінки, які народили у 28-33 тиж гестації. 3 них 80 жінок мали ранні передчасні пологи на тлі передчасного розриву плодових оболонок (ПРПО) (основна, 1-а, група); 50 - пацієнтки з ранніми передчасними пологами та своєчасним розривом плодового міхура (контрольна, 2-а, група). Основна група включала 4 підгрупи по 20 жінок з урахуванням тривалості безводного проміжку: група 1.1 - безводний проміжок 5-6 год; група 1.2 безводний проміжок 24 год; група 1.3 - безводний проміжок 45-48 годин; група 1.4 - безводний проміжок 5 діб після ПРПО. Результати. Результати проведених досліджень свідчать про те, що основною причиною розвитку ранніх передчасних пологів у жінок після застосування ДРТ є структурні дезорганізаційні зміни колагенових волокон сполучної тканини амніона та хоріону, які призводять до появи мікроскопічних дефектів-розшарувань їхьої поверхні, спричинюючи ПРПО із запуском каскаду локалізованих вогнищевих реакцій гіперчутливості негайного типу і перебудовою епітеліальних клітин плодового міхура. Макрофагальні властивості нейтрофільних гранулоцитів при цьому знижені та запрограмовані на здійснення циклу незавершеного фагоцитозу, що підвищує синтез запальних цитокінів у ділянщі розриву плодового міхура.
\end{abstract}

Заключення. Зниження активності нейтрофільних гранулоцитів посилює ефект порушення цитокінової рівноваги та є предиктором початку спонтанної пологової діяльності у 28-33 тиж гестаціі.

Ключові слова: морфологічні зміни фетоплачентарного комплексу, ранні передчасні пологи, очікувальна тактика ведення пологів.

Проблема ранніх передчасних пологів (РПП) у жінок після 1 застосування допоміжних репродуктивних технологій (ДРТ) залишається однією з найбільш складних та дискутабельних у сучасному акушерстві. Незважаючи на значні успіхи та досягнення у галузях репродуктивної медицини і неонатології, знизити частоту та відсоток РПП не вдається. Їхня питома вага у структурі акушерської патології залишається стабільною, коливаючись від 7,8\% до 11\% усіх бажаних вагітностей. У жінок з відновленою після застосування ДРТ фертильністю цей показник складає близько 17\% за рахунок зростання числа багатоплідних вагітностей, які є додатковим фактором ризику виникнення передчасної пологової діяльності.

Причини невиношування індукованої вагітності різноманітні, проте однією з провідних причин у поліетіологічній структурі початку пологової діяльності в терміні гестації 28-33 тиж у жінок після застосування ДРТ є передчасний розрив плодових оболонок (ПРПО). Ранні передчасні поло- ги призводять до народження недоношених дітей з низькою масою тіла (1000-1500 г) та вираженою морфофункціональною незрілістю. Основна проблема виходжування таких малюків зумовлена незрілістю системи легеневого сурфактанта, що призводить до респіраторного дистрес-синдрому немовлят та інфекційних ускладнень. Ураховуючи ці дані, тактика ведення РПП, причини їхнього виникнення та профілактика перинатальних ускладнень потребує від лікаря різнобічного поглибленого аналізу цієї проблеми та пошуку оптимальних для матері та новонародженого шляхів її вирішення, що і визначає актуальність даного дослідження.

Мета дослідження: вивчення морфофункціональних змін фетоплацентарного комплексу у 28-33 тиж гестації у жінок з РПП після застосування ДРТ.

\section{МАТЕРІАЛИ ТА МЕТОДИ}

Дослідження проводили на кафедрі акушерства, гінекології та перинатології Національної медичної академії післядипломної освіти імені П.Л. Шупика. Клінічна база Київський міський пологовий будинок № 1.

Було проведено обстеження 130 пацієнток, вагітність яких настала після застосування ДРТ. Це жінки, які народили у 28-33 тиж гестації. 3 них 80 жінок мали РПП на тлі ПРПО (основна, 1-а, група); 50 - пацієнтки з РПП та своєчасним розривом плодового міхура (контрольна, 2-а, група). Основна група була розподілена на 4 підгрупи по 20 жінок з урахуванням тривалості безводного проміжку: підгрупа 1.1 - безводний проміжок 5-6 год; 1.2 підгрупа - безводний проміжок 24 год; підгрупа 1.3 - безводний проміжок 45-48 год; підгрупа 1.4 - безводний проміжок 5 діб після ПРПО. У комплекс проведених досліджень були включені загальноприйняті методи обстеження згідно з Наказом МO3 України про надання акушерсько-гінекологічної допомоги при передчасних пологах.

\section{РЕЗУЛЬТАТИ ДОСЛІДЖЕННЯ} TA ÏХ ОБГОВОРЕННЯ

Під час послідовного аналізу розподілу випадків РПП виявлено, що у $62,6 \%$ основною причиною був ПРПО. Під час аналізу 130 історій пологів підтверджено хронологічний ритм виникнення РПП на тлі ПРПО, за яким їхній пік припадав на проміжок від 02.00 ночі до 05.00 ранку. Серед структури акушерських ускладнень РПП на тлі ПРПО перше місце посіла слабкість пологової діяльності (32,4\%), дефект плацентарної тканини (29\%), дистрес плода (28,6\%), передчасне відшарування нормально розташованої плаценти (10\%). У 89,4\% жінок пологи завершилися самостійно, у 9,6\% тактика була вирішена на користь ургентного кесарева розтину. Також увагу привернула доволі висока частота хоріоамніоніту у жінок з РПП на тлі ПРПО - 11,6\% випадків та велуїзиту - 8,8\%. При непорушеному амніоні ці нозологічні форми виникали у $1,3 \%$ жінок $(\mathrm{P} \leq 0,05)$. 


\section{A K Y Ш E P C T B O}

Під час електронно-мікроскопічного дослідження зразків плацент встановлено, що в усіх групах термінальні ворсинки плаценти мали типову будову для даного терміну гестації. Вони були вкриті одношаровими багатоядерними клітинами синцитіотрофобластами, які в різних ділянках мали ультраструктурні особливості будови, що відображали їхній функціональний стан і ступінь зрілості. Багато з них мали клітинні контакти з цитотрофобластами, що демонструє їхню функціональну активність без ознак дегенерації. Це, швидше за все, пов'язано саме з незрілістю досліджуваних послідів. Цитотрофобласт мав велику кількість тонких фібрил, які здатні перетворюватися у компоненти фібриноїда. Досить щільно до синцитіотрофобласта прилягали судини гемомікроциркуляторного русла, що формують гематоплацентарний бар'єр.

Прогресування ультраструктурних змін відбувалося поступово в динаміці пролонгування безводного проміжку і мало зворотний характер. Через 45 год безводного періоду у лакунарних порожнинах крім форменних елементів подекуди спостерігали клітинний детрит частково десквамованого синцитіотрофобласта. У таких клітинах характерним був цитоліз, локальний набряк мітохондрій, розширення канальців ендоплазматичної сітки та фрагменти мієлінової дегенерації. Незначна кількість судин гемомікроциркуляторного русла мала пошкодження, що свідчить про наявність гіпоксичних та ішемічних змін, які розвинулися на тлі компенсаторно-адаптаційних процесів. Водночас, у просвітах мікросудин спостерігався сладж-феномен з утворенням нещільного тромбу.

3 5-ї доби безводного проміжку зростали ознаки запального процесу, а значна частина епітеліальних клітин набувала макрофагальних властивостей. Цей феномен був трактований як компенсаторно-захисна реакція, коли макрофагальні клітини строми амніону не були спроможні повністю забезпечити завершений фагоцитоз, а епітеліальні клітини брали на себе їхню функцію. При порушенні компетентності макрофагальних клітин значно зростала локальна здатність амніону синтезувати запальні цитокіни, що, у свою чергу, посилювало ефект порушення цитокінової рівноваги та виступало додатковим предиктором початку ранньої передчасної пологової діяльності.

Привертає увагу відсутність виражених змін гладенького хоріона. Отже, отримані дані свідчать про дезорганізаційні зміни плодових оболонок помірного ступеня з незначною альтерацією та вираженою тенденцією до локалізації процесу. Результати дослідження стану плодових оболонок та їхніх ультраструктурних і гемодинамічних змін свідчать про розвиток імунного алергійного запалення з морфологічним проявом реакції гіперчутливості негайного типу. Основним патогенетичним наслідком структурно-функціональних порушень фето-

\section{Морфологические особенности состояния фетоплацентарного комплекса у женщин с ранними преждевременными родами после применения вспомогательных репродуктивных технологий А.С. Мандрикова}

Цель исследования: изучение морфофункциональных изменений фетоплацентарного комплекса в 28-33 нед гестации у женщин с ранними преждевременными родами после применения ВРТ. Материалы и методы. Было проведено обследование 130 пациенток, беременность которых наступила после применения ВРТ. Это женщины, которые родили в 28-33 нед гестации. Из них 80 женщин имели ранние преждевременные роды на фоне преждевременного разрыва плодных оболочек (ПРПО) (основная, 1-я, группа); 50 - пациентки с ранними преждевременными родами и своевременным разрывом плодного пузыря (контрольная, 2-я, группа). Основная группа включала 4 подгруппы по 20 женщин с учетом продолжительности безводного промежутка: подгруппа 1.1 - безводный промежуток 5-6 ч; подгруппа 1.2 безводный промежуток 24 ч; подгруппа 1.3 - безводный промежуток 45-48 ч; подгруппа 1.4 - безводный промежуток 5 сут после ПРПО. плацентарного комплексу у жінок з РПП після застосування ДРТ є розлади дозрівання ворсин хоріона та дисциркуляторні зміни кровообігу гіпоксичного характеру.

На основі аналізу клінічних, морфологічних та апаратних методів, залежно від терміну вагітності та тривалості безводного проміжку, з адекватним оцінюванням акушерської ситуації було впроваджено індивідуальну тактику ведення вагітності і пологів у жінок з індукованою вагітністю. Очікувальна тактика без індукції пологової діяльності була обрана у пацієнток із задовільним станом плода за відсутності клініко-лабораторних ознак хоріоамніоніту та ускладнень після передчасного відходження навколоплідних вод. Активну тактику ведення вагітності та пологів високого ризику застосовували у разі розвитку клініки хоріоамніоніту та виникнення ургентних показань до термінового розродження.

Були встановлені вагомі пріоритети використання очікувальної тактики ведення вагітності та РПП у жінок після застосування ДРТ, що дозволили знизити частоту акушерських ускладнень у даного контингенту пацієнток. Завдяки «дозріванню» шийки матки зменшувався відсоток пологового травматизму (3 11\% до 4\%), це привело до зменшення випадків використання утеротонічних засобів за ургентними показаннями. Також відзначено суттєве зниження частоти розвитку респіраторного дистрес-синдрому плода прямо пропорційно пролонгації тривалості безводного проміжку. Негативних впливів збільшення тривалості безводного періоду і пролонгації вагітності на малюкову смертність виявлено не було, також не мав достовірного зростання показник реалізації інфекційних ускладнень з боку матері на тлі тривалого безводного періоду (від 9,26\% до 11,28\%; Р>0,05).

\section{ВИСНОВКИ}

Отже, результати проведених досліджень свідчать про те, що основною причиною розвитку ранніх передчасних пологів у жінок після застосування ДРТ є структурні дезорганізаційні зміни колагенових волокон сполучної тканини амніону та хоріона, які призводять до появи мікроскопічних дефектів-розшарувань їхньої поверхні, спричинюючи передчасний розрив плодових оболонок із запуском каскаду локалізованих вогнищевих реакцій гіперчутливості негайного типу і перебудовою епітеліальних клітин плодового міхура. Макрофагальні властивості нейтрофільних гранулоцитів при цьому знижені та запрограмовані на здійснення циклу незавершеного фагоцитозу, що підвищує синтез запальних цитокінів у ділянці розриву плодового міхура. Зниження активності нейтрофільних гранулоцитів посилює ефект порушення цитокінової рівноваги та є предиктором початку спонтанної пологової діяльності у 28-33 тиж гестації.

Peзультаты. Результаты проведенных исследований свидетельствуют о том, что основной причиной развития ранних преждевременных родов у женщин после применения ВРТ являются структурные дезорганизационные изменения коллагеновых волокон соединительной ткани амниона и хориона, которые приводят к появлению микроскопических дефектов-расслаиваний их поверхности, вызывая ПРПО с запуском каскада локализованных очаговых реакций гиперчувствительности немедленного типа и перестройкой эпителиальных клеток плодного пузыря. Макрофагальные свойства нейтрофильных гранулоцитов при этом снижены и запрограммированы на осуществление цикла незавершенного фагоцитоза, что повышает синтез воспалительных цитокинов в области разрыва плодного пузыря.

Заключение. Снижение активности нейтрофильных гранулоцитов усиливает эффект нарушения цитокинового равновесия и выступает предиктором начала спонтанной родовой деятельности в 28-33 нед гестации.

Ключевые слова: морфологические изменения фетоплачентарного комплекса, ранние преждевременные роды, выжидательная тактика ведения родов. 


\section{A K Y Ш E P C T B O}

\section{Morphological features of the state of fetoplacental complex in women with early preterm birth after assisted reproductive technologies \\ A.S. Mandrykova}

The objective: the study of morphofunctional changes of the fetoplacental complex at 28-33 weeks of gestation in women with early preterm delivery after the application of ART.

Patients and methods. We have examined 130 patients whose pregnancy occurred after the use of ART. This is the woman who gave birth at 28-33 weeks of gestation. Of these, 80 women had early premature births in the background premature rupture of fetal membranes, 50 patients with early preterm delivery and timely rupture of fetal membranes (control group 2). The main group included 4 groups of 20 women with regard to the duration of anhydrous interval: 1.1 - anhydrous interval 5-6 hours (main group 1); 1.2 - anhydrous span 24 hours; 1.3 - anhydrous interval 45-48 hours; 1.4 - anhydrous period 5 days after PRFM.

Results. Thus, the results of the research indicate that the main cause of early preterm birth in women after using ART are structural dezorhanization changes of collagen fibers of the connective tissue amnion and chorionic which lead to the appearance of microscopic defects - delamination its surface, causing premature rupture of fetal membranes the launch stage localized focal immediate type hypersensitivity reactions and restructuring epithelial cell membranes. Neutrophil macrophage properties in this case reduced and programmed to perform a cycle of incomplete phagocytosis, which increases the synthesis of inflammatory cytokines in the area of ??rupture of fetal membranes.

Conclusion. Reduced activity of neutrophils increases the effect of abuse and cytokine balance in favor predictor of early spontaneous labor at 28-33 weeks of gestation.

Key words: morphological changes of the fetoplacental complex, early preterm birth, expectant tactics of childbirth.

\section{Сведения об авторе}

Мандрикова Алиса Сергеевна - Национальная медицинская академия имени П.Л. Шупика, 04112, г. Киев, ул. Дорогожицкая, 9; тел.: (050) 965-72-62. E-mail: alisa-lakky@list.ru

\section{СПИСОК ЛІТЕРАТУРИ}

1. Аржанова О.Н., Шляхтенко Т.Н., Тышкевич О.В. Комплексная терапия плацентарной недостаточности у беременных с наличием в крови антифосфолипидных антител // Акушерство и гинекология. - М., 2011. - № 6. -50 c.
2. Беременность и роды высокого риска / Под ред. Ф. Ариаса, Г. Пескина. - М.: Медицина, 2013. - 654 с 3. Максимович О.Н. Дородовое излитие околоплодных вод: причины диагностика, ведение беременности и родов // Бюл. ВСНЦ СО РАМН. Иркутск, 2011. - № 3 (49). C. 207-212.

4. Преждевременный разрыв плодных оболочек. Информационное письмо / Под ред. В.Е. Радзинского,
И.М. Ордиянц. - М.: Медиабюро Status Preasens, 2011. - $20 \mathrm{c}$.

5. American College of Obstetricians and Gynecologists, authors. Premature rupture of membranes. Washington. 2015. (ACOG Practice Bulletin N1).
Эпидемия ожирения затрагивает большую часть западного мира. И она может привести к катастрофическим последствиям, повлияв на будущее поколение.

Как передает The New Daily, необходимо срочно разворачивать массовую борьбу с ожирением.

Дело в том, что ожирение у родителей повышает риск повреждений мозга, астмы, инсультов и болезней сердца у их подросших детей. И это бесконечная цепочка - тучные родители наделяют детей болезнями и предрасположенностью к ожирению. А те, в свою очередь, передают проблемы своим детям.

Притом, согласно статистике, все больше матерей имеют лишний вес или откровенное ожирение. И ожирение матери повышает риск мертворождения, вы- сокого давления, диабета у нее самой или ребенка, да и грозит осложнениями во время родов. Для ребенка ожирение матери означает набор нейроэндокринных, метаболических, иммунных, воспалительных изменений, которые повлияют на гормональный уровень и подпитку питательными веществами.

med-expert.com.ua 


\section{Оптимізація тактики ведення жінок з рубцем на матці з використанням родинно оріснтованих технологій та партнерських пологів}

\section{І.П. Нецкар}

Національна медична академія післядипломної освіти імені П.Л. Шупика, м. Київ

\begin{abstract}
Мета дослідження: підвищення частоти розродження per vias naturales та зниження частоти перинатальної патології у жінок з рубцем на матці на підставі удосконалення та впровадження методики індивідуальної підготовки подружньої пари під час вагітності та при розродженні.
\end{abstract}

Матеріали та методи. Проведено комплексне обстеження 150 пацієнток з рубцем на матці, яких було розподілено на дві групи: у 1-у групу увійшли 100 жінок з рубцем на матці, яким було виконано повторний кесарів розтин; до 2-ї групи увійшли 50 жінок з рубцем на матці, розроджених через природні пологові шляхи.

Результати. Використання родинно орієнтованих технологій у жінок з рубцем на матці дозволяє поліпшити клінічний перебіг вагітності, знизити частоту порушень функціонального стану фетоплацентарного комплексу, нормалізувати психоемоційний статус і сприяти розродженню через природні пологові шляхи без погіршення показників перинатальної патології і постнатальної адаптації новонароджених.

Заключення. Отримані результати дають право рекомендувати вдосконалений нами алгоритм тактики ведення вагітності для широкого використання у практичній охороні здоров'я.

Ключові слова: рубець на матиі, кесарів розтин, партнерські пологи.

$\Pi$ роблема рубця на матці після операції кесарева розтину $€$ однією $з$ найбільш актуальних у сучасному акушерстві $[5,6]$. Це зумовлено постійним зростанням кількості абдомінальних розроджень, а в структурі показань основне місце посідає наявність рубця на матці [7, 8]. Частота самостійного розродження таких жінок в Україні складає від $1 \%$ до $10 \%$, що є дуже низьким показником у порівнянні 3 іншими країнами $[1,2]$.

Серед нових технологій ведення вагітності та розродження особливе місце посідають родинно орієнтовані технології та партнерські пологи, частота яких підвищується 3 року в рік, а при різних обтяжених ситуаціях такий підхід при розродженні є дієвим резервом зниження частоти акушерської і перинатальної патології [3, 4].

Проведений аналіз даних сучасної літератури свідчить про недостатню вивченість питання ведення вагітності та розродження жінок з рубцем на матці з використанням сучасних технологій, хоча його актуальність не викликає сумнівів, особливо щодо розроблення ефективних лікувально-профілактичних методик.

Мета дослідження: підвищення частоти розродження per vias naturales та зниження частоти перинатальної патології у жінок з рубцем на матці на підставі удосконалення та впровадження методики індивідуальної підготовки подружньої пари під час вагітності та при розродженні.

\section{МАТЕРІАЛИ ТА МЕТОДИ}

Проведено комплексне обстеження 150 пацієнток з рубцем на матці, яких було розподілено на дві групи: у 1-у групу увійшли 100 жінок з рубцем на матці, яким було виконано повторний кесарів розтин; до 2-ї групи увійшли 50 жінок 3 рубцем на матці, розроджених через природні пологові шляхи.

Для аналізу перинатальних результатів у жінок з рубцем на матці проведено комплексне обстеження 150 новонароджених, яких було розподілено на дві групи: 1-а група - 100 дітей, народжених шляхом кесарева розтину; 2-а група - 50 дітей, народжених через природні пологові шляхи. У 1-й групі були виділені дві підгрупи: підгрупа 1.1 - 60 дітей, народжених шляхом планового кесарева розтину до початку пологової діяльності; підгрупа 1.2 - 40 дітей, народжених шляхом кесарева розтину з початком пологової діяльності.

Набір клінічного матеріалу проводили на базі міського пологового будинку № 1 м. Києва, а також на базі жіночих консультацій Печерського та Шевченківського районів м. Києва. Ведення жінок на етапі стаціонару проводилось автором даного дослідження, а на амбулаторному етапі - разом з лікарями жіночих консультацій.

Ведення пацієнток 1-ї групи проводили за загальноприйнятими протоколами МОЗ України [7].

Основним відмінним моментом ведення пацієнток 2-ї групи було використання родинно орієнтованих технологій під час вагітності і розродження.

Критеріями відбору пацієнток у 2-у групу (самостійне розродження жінок з рубцем на матці) були наступними:

- перерва між пологами більше 3 років;

- відсутність важкої екстрагенітальної патології, яка була показанням до попереднього кесарева розтину;

- неускладнений перебіг раннього і віддаленого післяопераційних періодів;

- позитивний психологічний настрій родинної пари на самостійне розродження;

- відсутність важких форм акушерських ускладнень: прееклампсії, плацентарної дисфункції, затримки розвитку плода, важких форм гестаційної анемії.

Методику індивідуальної підготовки до пологів починали з першого звернення родинної пари до акушера-гінеколога, де обговорювались можливості самостійного розродження жінок з рубцем на матці після попереднього кесарева розтину. Контакт лікаря з вагітною є важливим компонентом індивідуальної підготовки до пологів, особливо за наявності рубця на матці.

При первинному зверненні жінки і родинної пари проводили повне обстеження згідно з алгоритмами, затвердженими протоколами МОЗ України.

Індивідуально для кожної жінки з рубцем на матці розробляли програму підготовки, яка включала: комплекс лікувальної фізкультури, фізичні методи дії, тематичні заняття, 


\section{A K Y Ш E P C T B O}

тренінг пологів, за необхідності - консультації фахівців: медичного психолога, неонатолога, анестезіолога тощо.

Підготовка подружніх пар (за наявності у жінки рубця на матці після кесарева розтину) включала:

- обговорення материнських та перинатальних переваг спроби вагінальних пологів;

- підтримка жінки та її партнера у прийнятті рішення;

- проведення УЗД у присутності чоловіка для оцінювання стану рубця на матці з обов'язковим визначенням локалізації плаценти.

Розроблення індивідуального алгоритму проводилось автором разом з лікарем жіночої консультації.

\section{РЕЗУЛЬТАТИ ДОСЛІДЖЕННЯ TA ÏХ ОБГОВОРЕННЯ}

Вік пацієнток досліджуваних груп знаходився у межах від 21 до 42 років. Середній вік пацієнток склав $27,2 \pm 2,6$ року. У 1-й групі переважали жінки віком понад 30 років $52,0 \%$, у 2-й групі таких пацієнток було $34,0 \%$.

Проведений аналіз засвідчив, що у 72,0\% жінок, розроджених повторним кесаревим розтином, показання до попереднього кесарева розтину були скороминущими (аномалії пологової діяльності, прееклампсія важкого ступеня, дистрес плода, передлежання плаценти, кровотеча до пологів або у перший період пологів) і при наступному розродженні дана акушерська ситуація могла не повторитися. У пацієнток, розроджених через природні пологові шляхи, такі показання були у $92,0 \%$ випадків.

Привертає увагу той факт, що у 44,0\% пацієнток 1-ї групи попередній кесарів розтин був виконаний у плановому порядку, тоді як у 2-й досліджуваній групі таких пацієнток було всього 20,0\%, що ще раз підтверджує проведення кесарева розтину у 2-й групі у зв'язку з виниклою акушерською ситуацією, яка вимагає екстреного розродження.

У всіх пацієнток досліджуваних груп перший кесарів розтин був виконаний у нижньому матковому сегменті поперечним розрізом.

Під час аналізу інтра- та післяопераційних ускладнень виявилось, що їхня частота була приблизно однакова в обох групах, проте частота гнійно-септичних ускладнень була дещо вище у 1-й групі, ніж у 2-й (3,0\% і 2,0\% відповідно). Частота субінволюції матки, що створює найменш сприятливі умови для репаративних процесів у матці, в обох групах була майже однаковою (3,0\% і 4,0\% відповідно).

Період після кесарева розтину до наступних пологів склав від 1 року до 12 років. Привертає увагу, що у 19,0\% пацієнток 1-ї групи і в 14,0\% 2-ї групи вагітність настала протягом перших трьох років після попередньої операції. Найчастіше повторну вагітність зберігали через 4-6 років після попереднього кесарева розтину. У 1-й групі це відзначено у 59,0\% жінок, у 2 -й - у 56,0\%. Це дозволяє вважати даний період найбільш сприятливим для настання повторної вагітності.

\section{Оптимизация тактики ведения женщин с рубцом на матке с использованием семейно ориентированных технологий и партнерских родов И.П. Нецкар}

Цель исследования: повышение частоты родоразрешения per vias naturales и снижение перинатальной патологии у женщин с рубцом на матке на основе усовершенствования и внедрения методи ки индивидуальной подготовки супружеской пары во время беременности и при родоразрешении.

Mатериалы $\boldsymbol{u}$ методы. Проведено комплексное обследование 150 пациенток с рубцом на матке, которые были распределены на две группы: в 1-ю группу вошли 100 женщин с рубцом на матке, которым было выполнено повторное кесарево сечение; во 2-ю
Результати проведених досліджень свідчать, що клінічний перебіг вагітності у жінок з рубцем на матці, які планують повторну операцію, характеризується високою частотою різних ускладнень (76,0\%), у структурі яких переважають загроза переривання (53,0\%) та плацентарна дисфункція (26,0\%) із затримкою розвитку плода (20,0\%).

Частота клініко-ехографічних ознак неспроможності рубця на матці складає 33,0\%, однак під час операції це підтверджується тільки у 17,0\%, при цьому інформативність цих ознак становить 50,0\%, що свідчить про наявність резервів підвищення частоти самостійного розродження цих жінок.

Порушення психологічного статусу відіграють значну роль у розвитку ускладнень вагітності при повторній операції та полягають у наявності у жінок з рубцем на матці високої частоти емоційної нестабільності $(57,0 \%)$, зниженого або мінливого настрою (53,0\%) та тривожного стану відносно майбутньої дитини (45,0\%).

Перинатальні результати розродження жінок з рубцем на матці залежать від методу розродження, при цьому самостійні пологи сприяють зменшенню частоти асфіксії середнього та тяжкого ступеня (з 10,0\% до 4,0\%), а також порушень постнатальної адаптації новонароджених (з 28,0\% до 18,0\%).

Використання методики індивідуальної підготовки до партнерських пологів дозволяє нормалізувати психологічний статус жінок з рубцем на матці, що підтверджується зниженням особової (з 82,0\% до 44,0\%) і ситуаційної тривожності (з $66,0 \%$ до $32,0 \%$ ), а також підвищити рівень моральної задоволеності методом розродження (з 36,0\% до 92,0\%), високою самооцінкою (з 48,0\% до 94,0\%) і відсутністю порушень у взаєминах з чоловіком та новонародженим (з 66,0\% до 100,0\%)

Проведення партнерських пологів 3 попередньою індивідуальною підготовкою дозволяє знизити частоту сумарних ускладнень вагітності (з 76,0\% до 52,0\%) за рахунок загрози переривання у різні терміни (з 53,0\% до 38,0\%), плацентарної дисфункції (з 26,0\% до 16,0\%) та затримки розвитку плода (з 20,0\% до 14,0\%). Підвищується частота позитивного ставлення до лактації (з 26,0\% до 88,0\%) на тлі зменшення рівня гіпогалактії (з 69,0\% до 12,0\%) та субінволюції матки (з 17,0\% до 10,0\%).

\section{ВИСНОВКИ}

Отже, результати проведених досліджень свідчать, що використання родинно орієнтованих технологій у жінок 3 рубцем на матці дозволяє поліпшити клінічний перебіг вагітності, знизити частоту порушень функціонального стану фетоплацентарного комплексу, нормалізувати психоемоційний статус і сприяти розродженню через природні пологові шляхи без погіршення показників перинатальної патології і постнатальної адаптації новонароджених. Отримані результати дають право рекомендувати вдосконалений нами алгоритм тактики ведення вагітності для широкого використання у практичній охороні здоров'я. группу вошли 50 женщин с рубцом на матке, родоразрешенных через естественные родовые пути.

Результаты. Использование семейно ориентированных технологий у женщин с рубцом на матке позволяет улучшить клиническое течение беременности, снизить частоту нарушений функционального состояния фетоплацентарного комплекса, нормализовать психоэмоциональный статус и способствовать родоразрешению через естественные родовые пути без ухудшения показателей перинатальной патологии и постнатальной адаптации новорожденных. Заключение. Полученные результаты дают право рекомендовать усовершенствованный нами алгоритм тактики ведения беременности для широкого использования в практическом здравоохранении.

Ключевые слова: рубеи, на матке, кесарево сечение, партнерские роды. 


\section{A K Y Ш E P C T B O}

Optimization of tactics of maintaining women with the cicatrix on a uterus with use family focused technologies and partner labors

\section{I.P. Netskar}

The objective: ising of frequency of a delivery of per vias naturales and depression of perinatal pathology at women with the cicatrix on uterus on the basis of improvement and introduction of a technique of individual preparation of a married couple during pregnancy and at a delivery.

Patients and methods. Complex examination of 150 patients with the cicatrix on a uterus who were distributed on two groups is conducted: 1 group was made by 100 women with the cicatrix on a uterus by which repeated Cesarean section was executed; the 2nd group includ- ed 50 women with the cicatrix on a uterus, delivery through natural patrimonial ways.

Results. Use of the family focused technologies at women with the cicatrix on a uterus allows to improve the clinical course of pregnancy, to reduce the frequency of disturbances of a functional condition of a fetoplacental complex, to normalize the psychoemotional status and to promote a delivery through natural patrimonial ways without deterioration of indicators of perinatal pathology and post-natal adaptation of newborns.

Conclusion. The received results grant to us the right to recommend advanced algorithm of tactics of conducting pregnancy for wide use in practical health care.

Key words: the cicatrix on a uterus, Cesarean section, partner labors.

\section{Сведения об авторе}

Нецкар Ирина Петровна - Национальная медицинская академия последипломного образования имени П.Л. Шупика, 04112, г. Киев, ул. Дорогожицкая, 9. E-mail: prore-first@nтаро.еdu.ua

\section{СПИСОК ЛІТЕРАТУРИ}

1. Гойда Н.Г. Стан репродуктивного здоров'я населення України на межі тисячоліть / Н.Г. Гойда // Журн. практ. лікаря. - 2012. - № 5. C. 2-6.

2. Основы репродуктивной медицины: Практ. руководство / Под ред. В.К. Чайки. - Донецк: Альматео, 2011. - C. 275-321.

3. Наказ МОЗ України від 24.01.2011 p.
«Про затвердження клінічного протоколу з акушерської допомоги «Вагінальні пологи після кесарського розтину». K., 2011. - $39 \mathrm{c}$.

4. Казарян Р.М. Особенности течения беременности и родов у женщин с рубцом на матке после кесарева сечения: Автореф. дис. .канд. мед. наук. - М., 2012. -24 c.

5. Rajakumar C., Agarwal S., Khalil H.
Caesarean scar pregnancy/C. Rajakumar, S. Agarwal, H. Khalil // Journal of Obstetrics and Gynaecology Canada. 2015. - Vol. 37. - P. 199-200.

6. Yela A.A. Conservative management of ectopic pregnancy in cesarean scar: case report / A.A. Yela, N. Marchiani // Revista Brasileira de Ginecologia e Obstetricia. 2013. - Vol. 35. - P. 233-237.

7. Seow K.-M. Cesarean scar pregnan- cy: issues in management / K.-M. Seow, L. Huang, Y.-H. Lin // Ultrasound in Obstetrics and Gynecology. - 2014. Vol. 23. - P. 247-253.

8. Wang J.-H. Methotrexate therapy for cesarean section scar pregnancy with and without suction curettage / J. Wang, K. Xu, J. Lin // Fertility and Sterility. - 2015. - Vol. 92. P. $1208-1213$.

\section{ФИЗИЧЕСКОЙ НАГРУЗКОЙ}

Лечение бесплодия будет более эффективным при сочетании его с физической нагрузкой.

Избавление от лишнего веса и разумный график тренировок позволят быстрее нормализовать работу репродуктивной системы, утверждают исследователи Йельского университета.

По мнению специалистов, наиболее эффективными видами тренировок для женщин, стремящихся зачать ребенка, является ходьба в быстром темпе, танцы, плавание, велоспорт, йога и техники глубокого дыхания.

Bce описанные виды тренировок усиливают кровообращение в малом тазу, нормализуют деятельность сердца, тонизируют, повышают выносливость и снижают уровень холестерина в кро- ви. Правильно построенная программа тренировок всегда воздействует на организм положительно, а регулярные занятия эффективно излечивают от бесплодия. Помочь быстрее нормализовать репродуктивную функцию организма также очень помогает правильное питание.

med-expert.com.ua 


\title{
Клинико-сонологические особенности эндометриоидных образований яичников у женщин в репродуктивный период
}

\author{
О.С. Шаповал \\ гЗ «Запорожская медицинская академия последипломного образования МЗ Украины»
}

\begin{abstract}
Цель исследования: изучение распространенности эндометриоидных кист яичников у женщин в репродуктивный период, особенностей клинической и ультразвуковой картины при эндометриозе.

Материалы и методы. Обследовано 22 пациентки (основная группа) с эндометриоидными образованиями яичников и 50 женщин (контрольная группа) гинекологически и соматически здоровых.

Результаты. Частота выявления эндометриоидных образований яичников в структуре доброкачественных опухолеподобных образований яичников составляет $0,62 \%$. У $72,73 \%$ эндометриоз яичников диагностирован на фоне сопутствующей гинекологической патологии. Клинически в $77,27 \%$ случаев зафиксирован болевой синдром, в $59,09 \%$ - альгодисменорея, в 13,64\% - бесплодие; 18,18\% эндометриоидных кист остаются «немыми» и протекают со стертой клинической картиной. Сонологически у пациенток с эндометриоидными кистами яичников определены аденомиоз, гиперплазия эндометрия, изменения со стороны контралатерального яичника.
\end{abstract}

Заключение. Без проведения дополнительных методов диагностики выявление объемного образования с различными пальпаторными характеристиками возможно от 3 см, что не позволяет четко дифференцировать эндометриоз от функционального воспалительного образования, а также от истинной опухоли яичников. Сонологически патологическое образование диагностируют от 1 см, возможна детализация характера кисты.

Ключевые слова: эндометриоз, репродуктивный период, ретроспективный анализ, УЗИ.

ндометриоидная болезнь на сегодняшний день остается одной из актуальных проблем современной гинекологии. Совершенствование аппаратов ультразвуковой диагностики, развитие и широкое внедрение в практику малоинвазивных хирургических методик не только в лечебных, но и в диагностических целях позволили по-новому взглянуть на проблему генитального эндометриоза [3, 8, 10, 12, 16, 22, 24].

Частота выявления эндометриоза, по данным разных авторов, различна, что обусловлено особенностями диагностики данной патологии. Стабильно высокими остаются показатели аденомиоза (12-40\%) и эндометриоидных кист яичников (10-27\%) как наиболее распространенных форм генитального эндометриоза $[1,2,10,11,13,16,21]$. На сегодняшний день эндометриоидная болезнь может протекать под масками различных заболеваний, имитируя и воспалительный процесс, и нарушения менструального цикла, и онкопатологию $[4,6,14,15,23]$. В клинике бесплодия эндометриоз диагностируют у $6-50 \%$ пациенток [18, 20, 25].

Несмотря на накопленные знания о природе и течении эндометриоза, клиническая диагностика данной патологии представляет определенные трудности, нет единой концеп- ции лечебного процесса, что существенно затягивает время установления диагноза и выбора оптимальных терапевтических стратегий, сопровождаясь снижением репродуктивного потенциала женского населения [5, 17, 19, 24, 25].

Цель исследования: изучение распространенности эндометриоидных кист яичников у женщин в репродуктивный период, особенностей клинической и ультразвуковой картины при эндометриозе.

\section{МАТЕРИАЛЫ И МЕТОДЫ}

Проведен ретроспективный анализ 3555 историй болезни пациенток, находившихся на стационарном лечении в гинекологическом отделении городской больницы № 7 г. Запорожья за период с 2009 по 2014 г. Частота выявления доброкачественных опухолеподобных образований яичников в структуре гинекологической патологии составила 6,44\% (229 человек). При этом функциональные кисты выявляли в 9,4 раза чаще, чем эндометриоидные (у 207 человек - 5,82\% против $22-$ $0,62 \%)$. Для проведения углубленного анализа особенностей течения клинической картины эндометриоидных кист яичников было проанализировано 22 истории болезни. Так, в основную группу вошли 22 пациентки репродуктивного возраста от

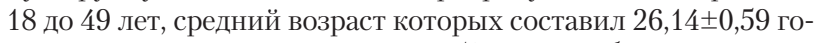
да. В контрольную группу вошли 50 женщин без гинекологической и соматической патологии, обратившихся в лечебное учреждение по вопросу выбора контрацепции. В контрольной группе средний возраст составил $33,3 \pm 0,75$ года. Полученные данные были обработаны с помощью пакета статистических программ STATISTICA (StatSoft Statistica v.6.0).

\section{РЕЗУЛЬТАТЫ ИССЛЕДОВАНИЯ} И ИХ ОБСУЖДЕНИЕ

В возрастном аспекте исследуемые группы были репрезентативны. При госпитализации в стационар ведущее место в структуре жалоб занимал болевой синдром - у 17 пациенток $(77,27 \%)$, при этом боль имела ноющий, тянущий характер различной степени интенсивности. Клинику «острого» живота отмечали у 1 больной (4,55\%). На фоне периодической боли внизу живота нарушения менструального цикла в виде появления мажущих «шоколадных» выделений из половых путей отмечали 2 человека $(9,09 \%)$. Альгодисменорею, которую большинство пациенток считали привычным состоянием, значительно не снижающим качества жизни, отмечали 13 женщин (59,09\%). Обильные менструации, которые также не были отнесены в категорию жалоб при основном заболевании, имели место у 2 человек $(9,09 \%)$. Нарушения репродуктивной функции отмечали 3 пациентки (13,64\%). При этом частота первичного бесплодия наблюдалась в 2 раза чаще по сравнению с вторичным (66,67\% против $33,33 \%)$. При этом в $66,67 \%$ случаев бесплодие протекало на фоне болевого синдрома. У 18,18\% больных наблюдалось асимптомное течение заболевания. 


\section{ГИН Е КО ЛОГИЯ}

Нельзя не отметить, что лишь у 27,27\% госпитализированных в стационар эндометриоидное опухолевидное образование яичников диагностировано в качестве самостоятельной нозологической единицы, в $72,73 \%$ случаев отмечали его сочетание с гинекологической патологией. Структура гинекологической заболеваемости представлена на рис. 1.

Как видно из представленных данных, практически у 70\% пациенток эндометриоидные кисты яичников диагностированы на фоне патологии шейки матки, у 37,5\% имеет место гиперпролиферативная патология эндометрия. Такие заболевания, как миома матки и сопутствующие воспалительные процессы придатков матки, диагностируют реже - в 12,5\% случаев. Полученные данные о высокой частоте пролиферативных процессов эндометрия и диспластических изменений шейки матки могут свидетельствовать об общности некоторых этиопатогенетических звеньев [16] и должны лечь в основу разработки индивидуального алгоритма лечебной тактики с использованием иммуномодулирующей терапии и препаратов, регулирующих процессы пролиферации и апоптоза клеток.

Нельзя не отметить, что $59,1 \%$ госпитализированных имели отягощенный соматический анамнез, структура которого представлена на рис. 2.

Полученные данные свидетельствуют о том, что у 69,23\% женщин с эндометриоидными кистами яичников имеется патология пищеварительного тракта (ПТ) и у 15,38\% дисфункция слизистых оболочек, что может свидетельствовать о сопутствующих нарушениях иммунного статуса организма и необходимости более углубленной диагностики и коррекции выявленных нарушений.

Анализ особенностей менструальной функции показал, что средний возраст начала менархе составлял 13,05 $\pm 0,36$ года с возрастным минимумом 10 лет и максимумом 17 лет. Полученные данные достоверно не отличались в основной и контрольной группах. Все пациентки основной группы имели регулярный менструальный цикл продолжительностью от 21 до 35 дней. При этом средняя продолжительность менструального цикла составляла $28,68 \pm 0,81$ дня. Длительность менструального кровотечения не превышала данных контрольной группы и колебалась от 3 до 9 дней, в среднем - 5,27 $\pm 0,23$ дня

У 13 пациенток (59,09\%) имела место альгодисменорея. По количеству теряемой крови группа женщин с нормальной кровопотерей составила 20 человек (90,91\%). В структуре менструальных нарушений симптом гиперменореи составил $9,09 \%$.

При проведении гинекологического исследования пациенток с эндометриоидными кистами яичников не отмечено увеличения размеров матки, хотя у 2 женщин в анамнезе имела место миома матки. Со стороны пораженного органа образование размерами от 3 до 10 см определяли у всех пациенток. При этом кисты левого яичника определяли несколько чаще, чем правого (10 случаев против 6). У 6 чело-

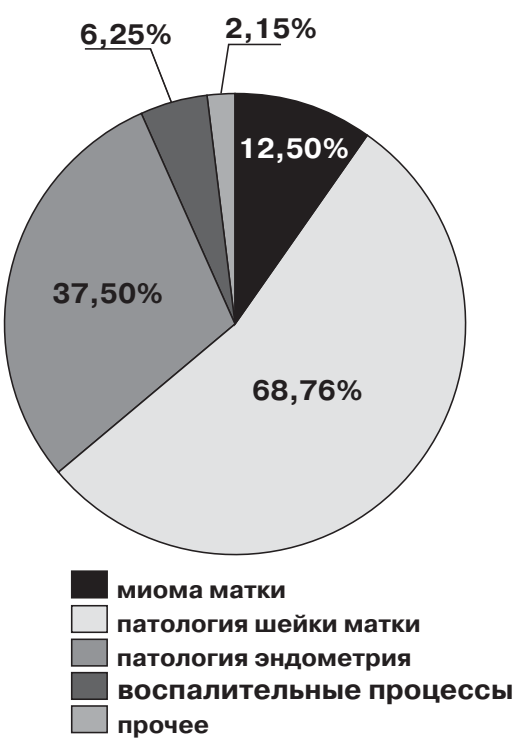

Рис. 1. Структура гинекологической заболеваемости

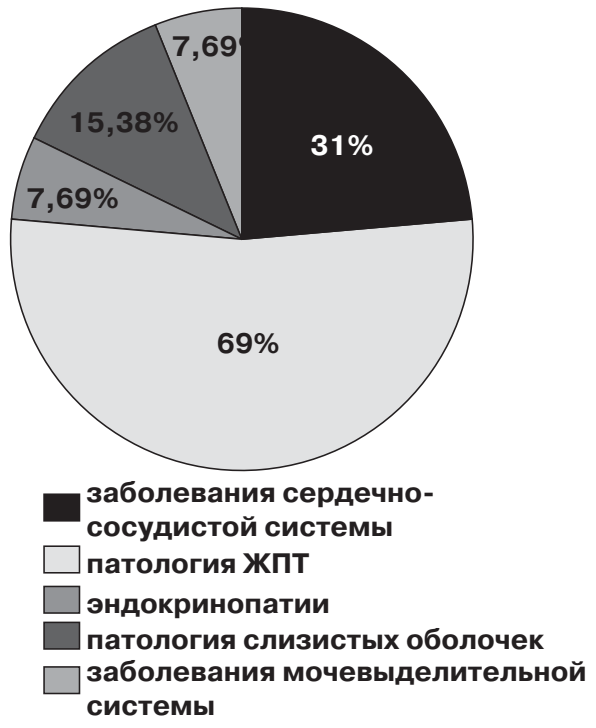

Рис. 2. Структура соматической патологии

Таблица 1

Эхографические параметры матки у пациенток исследуемых групп, мм (Mะm)

\begin{tabular}{|c|c|c|}
\hline Параметры & Основная группа, $\mathrm{n}=22$ & Контрольная группа, n=50 \\
\hline Длина матки & $47 \pm 1,1^{*}$ & $51,58 \pm 0,48^{*}$ \\
\hline Ширина матки & $44,14 \pm 1,47$ & $46,42 \pm 0,62$ \\
\hline Толщина матки & $38,23 \pm 1,36^{\star}$ & $35,08 \pm 0,54^{\star}$ \\
\hline Минимальные размеры матки & 33428425 & 35428446 \\
\hline Максимальные размеры матки & 55457450 & 55444459 \\
\hline Минимальная толщина М-эхо & 4 & 5 \\
\hline Максимальная толщина М-эхо & 16 & 9 \\
\hline Среднее значение М-эхо & $7,37 \pm 0,67$ & $6,12 \pm 0,75$ \\
\hline
\end{tabular}

Примечание. * - Различия статистически значимы при $p<0,05$. 
ГИ н Е К Л Л ги я

Таблица 2

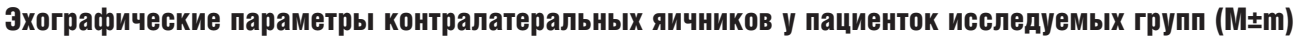

\begin{tabular}{|c|c|c|}
\hline Показатель & Основная группа, $\mathrm{n}=\mathbf{2 2}$ & Контрольная группа, $\mathrm{n}=\mathbf{5 0}$ \\
\hline Длина, мм & $36,5 \pm 2,48^{*}$ & $30,32 \pm 0,17^{\star}$ \\
\hline Ширина, мм & $26,81 \pm 2,13$ & $28,14 \pm 0,13$ \\
\hline Толщина, мм & $26,27 \pm 2,06^{*}$ & $16,72 \pm 0,17^{\star}$ \\
\hline Объем, см $^{3}$ & $17,53 \pm 4,7^{*}$ & $7,44 \pm 0,67^{\star}$ \\
\hline
\end{tabular}

Примечание. * - Различия статистически значимы при р<0,05.

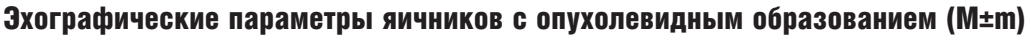

Таблица 3

\begin{tabular}{|c|c|c|}
\hline Показатель & Основная группа, $\mathbf{n = 6}$ & Контрольная группа, $\mathrm{n}=50$ \\
\hline Длина, мм & $48,22 \pm 2,64^{\star}$ & $30,32 \pm 0,17^{\star}$ \\
\hline Ширина, мм & $37,75 \pm 2,39^{*}$ & $28,14 \pm 0,13^{\star}$ \\
\hline Толщина, мм & $30,33 \pm 3,48^{*}$ & $16,72 \pm 0,17^{\star}$ \\
\hline Объем, см $^{3}$ & $29,91 \pm 6,73^{*}$ & $7,44 \pm 0,67^{*}$ \\
\hline
\end{tabular}

Примечание. * - Различия статистически значимы при p<0,05.

век отмечено двухстороннее увеличение яичников. Образование характеризовалось различной степенью напряженности и подвижности, умеренной чувствительностью. Выявленные изменения характерны для многих процессов в придатках матки: и при воспалительных изменениях, и при функциональных кистах, и при истинных опухолях яичников [4, $6,7,9,15,17]$. Поэтому с целью детализации характера образования и выработки лечебной тактики было проведено ультразвуковое исследование (УЗИ) органов малого таза.

При проведении УЗИ оценивали состояние матки и придатков. Полученные результаты обследования пациенток с опухолевидными образованиями яичников были сопоставлены с результатами обследования пациенток контрольной группы. Данные, полученные при сонологическом исследовании матки, представлены в табл. 1.

Анализ результатов сонологического исследования обеих групп выявил в основной группе достоверное увеличение толщины матки - в 1,09 раза $(\mathrm{p}<0,05)$ и уменьшение линейных показателей длины в 1,1 раза $(\mathrm{p}<0,05)$ по сравнению с группой контроля. Несмотря на относительно неизмененные линейные размеры матки признаки аденомиоза в виде неоднородности миоиметрия, наличия включений в миометрии различной эхоплотности были диагностированы у 1/3 пациенток (7 человек). В группе контроля наблюдалась однородная толщина и эхоструктура миометрия.

Сонологические признаки гиперпластических процессов эндометрия были диагностированы у 27,27\% от общего количества больных и у 37,5\% в структуре сопутствующей гинекологической патологии. При установлении диагноза эндометриальной гиперплазии учитывали не только толщину М-эхо, которая у 95,45\% пациенток не превышала допустимые значения и колебалась от 4 до 16 мм, но и такие характеристики, как наличие включений, ровность и четкость контура, наличие деформаций $[2,8]$. Включения различной эхогенности были выявлены у 5 пациенток (22,73\%). Деформаций, неровности контура диагностировано не было.

Полученные данные свидетельствуют о том, что сопутствующая гиперпролиферативная патология эндометрия у женщин с эндометриоидными кистами яичников может быть одним из проявлений нарушений механизмов пролиферации - апоптоза, имеющих место при эндометриоидной болезни. Данное состояние требует проведения комплекса специфических лечебных мероприятий, а не только подбора гормональных препаратов.

Пациенткам обеих групп проводили сонологическое ис-

\begin{tabular}{|c|c|}
\hline Показатель & Основная группа, n=22 \\
\hline Длина & $49,18 \pm 4,16$ \\
\hline Ширина & $39,5 \pm 3,54$ \\
\hline Толщина & $37,82 \pm 3,52$ \\
\hline Максимальные размеры & $88 \times 70 \times 65$ \\
\hline Минимальные размеры, мм & $10 \times 9 \times 5$ \\
\hline
\end{tabular}

следование эхоструктуры яичников. При выявлении опухолевидных образований оценивали их размеры, расположение, форму, толщину капсулы, наличие включений, плотность. В группе контроля достоверных отличий в эхографических параметрах правого и левого яичников выявлено не было. Поэтому сравнение между группами проводили с правым яичником группы контроля как наиболее функционально активным [4, 6].

Проведенный анализ выявил достоверные различия между эхографическими параметрами контралатеральных яичников пациенток обеих групп $(\mathrm{p}<0,05)$ как по длине, так и по толщине. Кроме того, показатели толщины контралатерального, условно здорового, яичника превышали показатели группы сравнения в 1,57 раза. Максимальные показатели размеров яичника в основной группе составили $74 \times 55 \times 50$ мм. Объем контралатерального яичника у пациенток с эндометриодным опухолеподобным образованием достоверно превышал значения в контрольной группе в 2,36 раза (максимальный показатель - 83,25 см³). Полученные результаты свидетельствуют о том, что у пациенток с эндометриоидными кистами яичников отмечается увеличение контралатерального яичника, что может свидетельствовать об адаптивной гиперплазии здорового яичника, либо о двухстороннем гиперпролиферативном процессе (табл. 2).

Провести сонологическую оценку состояния яичника с эндометриоидной кистой оказалось возможным лишь у 6 пациенток $(27,27 \%)$, у которых визуализировалась здоровая ткань яичника. У оставшихся 16 больных (72,73\%) вся ткань яичника была представлена опухолеподобным образованием. Полученные данные приведены в табл. 3.

При УЗИ состояния яичников у пациенток с опухолеподобным образованием по сравнению с группой контроля было выявлено достоверное увеличение всех линейных разме- 


\section{ГИН К КО ЛОГИЯ}

ров пораженного органа: длины - в 1,59 раза ( $<0,05)$, ширины - в 1,34 раза $(\mathrm{p}<0,05)$, толщины - в 1,81 раза $(\mathrm{p}<0,05)$ Максимальные размеры яичника с эндометриоидной кистой составляли 58×47×45 мм. Показатели объема также достоверно превышали аналогичный в группе сравнения в 4,02 paза $(\mathrm{p}<0,05)$, максимальные показатели составили $61,34 \mathrm{~cm}^{3}$.

При УЗИ состояния яичников было выявлено, что диаметр эндометриоидного опухолевидного образования составлял от 10 мм до 88 мм. Образование было однокамерным, округлой или овальной формы, с тонкими стенками содержащее средней и повышенной эхогенности мелкодисперсную взвесь, в ряде случаев - с включениями различной эхогенности $[4,6]$. Образования располагались сбоку либо кзади от матки. Внутренняя поверхность кисты была гладкая, без разрастаний, толщина капсулы образования составляла 1-2 мм.

Сонологические характеристики эндометриоидной кисты представлены в табл. 4.

Таким образом, у пациенток с эндометриоидными опухолеподобными образованиями яичников при проведении УЗИ по сравнению с группой контроля определяется увеличение толщины - в 1,09 раза $(\mathrm{p}<0,05)$, уменьшение линейных показателей длины в 1,1 раза $(\mathrm{p}<0,05)$. У $1 / 3$ пациенток диагностировали явления аденомиоза. При опухолеподобных образованиях яичников отмечали как увеличение линейных показателей длины и толщины, так и увеличение среднего объема яичника на контралатеральной стороне в 2,36 раза. Также отмечали достоверное увеличение всех линейных размеров яичника с эндометриоидной кистой: длины - в 1,59 раза $(\mathrm{p}<0,05)$, ширины - в 1,34 раза $(\mathrm{p}<0,05)$, толщины - в 1,81 раза ( $<<0,05$, объема - в 4,02 раза $(\mathrm{p}<0,05)$. При этом у $72,73 \%$ больных выявляли практически полное отсутствие здоровой ткани яичника. При сопоставлении с данными гинекологического осмотра сонологически удалось диагностировать обра-

\section{Клініко-сонологічні особливості ендометріоїдних утворень яєчників у жінок у репродуктивний період о.С. Шаповал}

мета дослідження: вивчення поширеності ендометріоїдних кіст яєчників у жінок у репродуктивний період, особливостей клінічної та ультразвукової картини при ендометріозі.

Матеріали та методи. Обстежено 22 пацієнтки (основна група) з ендометріоїдними кістами яєчників та 50 жінок (контрольна група) гінекологічно та соматично здорових.

Результати. Частота виявлення ендометріоїдних утворень яєчників у структурі доброякісних пухлиноподібних утворень яєчників становить 0,62\%. У 72,73\% ендометріоз яєчників діагностований на тлі супутньої гінекологічної патології. Клінічно у 77,27\% випадків зафіксовано больовий синдром, у 59,09\% - альгодисменорею, у 13,64\% - безплідність; 18,18\% ендометріоїдних кіст залишаються «німими» і перебігають зі стертою клінічною карти ною. Сонологічно у пацієнток 3 ендометріоїдними кістами яєчників визначені аденоміоз, гіперплазія ендометрія, зміни з боку контралатерального яєчника.

Заключення. Без проведення додаткових методів діагностики виявлення об'ємного утворення з різними пальпаторними характеристиками можливо від 3 см, що не дозволяє чітко диференціювати ендометріоз від функціонального запального утворення, а також істинної пухлини яєчників. Сонологічно патологічне утворення діагностують від 1 см, можлива деталізація характеру кісти.

Ключові слова: ендометріоз, репродуктивний період, ретроспективний аналіз, УЗД. зования уже от 1 см, что позволяет рекомендовать УЗИ в качестве обязательного скринингового метода при эндометриоидной болезни и дифференцированно проводить лечебные мероприятия. Увеличение контралатерального яичника и сопутствующую патологию эндометрия и шейки матки можно рассматривать как единые звенья общего гиперпролиферативного процесса.

\section{Выводы}

1. Частота выявления доброкачественных опухолеподобных образований яичников составляет $6,44 \%$ (функциональные кисты - 5,82\%, эндометриоидные - 0,62\%).

2. У госпитализированных в гинекологическое отделение пациенток диагноз «опухолевидное образование яичника» был установлен у $27,27 \%$ больных, у $72,73 \%$ его диагностировали в сочетании с сопутствующей гинекологической патологией, чаще - с заболеваниями шейки матки и эндометрия.

3. В структуре жалоб в 77,27\% случаев отмечен болевой синдром, в 59,09\% - нарушения менструального цикла в виде альгодисменореи. Бесплодие характерно для 13,64\% пациенток; 18,18\% эндометриоидных кист остаются «немыми» и протекают со стертой клинической картиной.

4. При проведении гинекологического осмотра выявление объемного образования с различными пальпаторными характеристиками возможно от 3 см, что не позволяет четко дифференцировать эндометриоз от функционального воспалительного образования, а также от истинной опухоли яичников.

5. При проведении сонологического исследования отмечено увеличение размеров и объема контралатерального яичника. Выявление объемного образования возможно при размерах 1 см с детализацией характера кисты. У 72,73\% пациенток установлено сонологическое отсутствие здоровой ткани яичника на стороне патологического процесса. У 1/3 пациенток диагностирован аденомиоз.

\section{Clinical and sonological features in endometriomas in women of reproductive age O. Shapoval}

The objective: to study the prevalence of ovarian endometriosis in women of reproductive age, the features of clinical and ultrasound picture of endometriosis

Patients and methods. The study involved 22 patients with endometriomas, the control group - 50 women gynecological and somatically healthy.

Results. The incidence of ovarian endometriomas in the structure of benign tumor-like formations of ovaries is $0,62 \%$. In $72,73 \%$ of ovarian endometriomas occur on a background of concomitant gynecological pathology. Clinically, in $77,27 \%$ of cases there is a pain syndrome, in $59,09 \%$ - algomenorrhea, in $13,64 \%$ - infertility; $18,18 \%$ of cases endometriomas remain «dumb» and proceed with the erased clinical picture. Sonologically in patients with endometriomas adenomyosis, endometrial hyperplasia, changes in the contralateral ovary are determined.

Conclusion. Without additional methods of diagnostic gynecological examination may identify the $3 \mathrm{~cm}$ tumor-like formation of the ovary with different characteristics, which does not allow to differentiate endometrioma from inflammation, functional and ovarian tumors. Ultrasound can diagnose pathological ovarian formation of $1 \mathrm{~cm}$, detailing the nature of the cyst.

Key words: endometriosis, reproductive age, retrospective analysis, ultrasound.

\section{Сведения об авторах}

Шаповал Ольга Сергеевна - ГЗ «Запорожская медицинская академия последипломного образования МЗ Украины», 69096, г. Запорожье, бульвар Винтера, 20._E-mail: shapoval_olga@ukr.net 


\section{ГИН Е КО ЛОГИЯ}

\section{СПИСОК ЛИТЕРАТУРЫ}

1. Адамян Л.В. Эндометриозы/ Л.В. Адамян, В.И. Кулаков, Е.Н. Андреева. - М.: Медицина, Издание 2-е. - 2006. - С. 416.

2. Аничков Н.М. Сочетание аденомиоза и лейомиомы матки / Н.М. Аничков, В.А. Печенникова // Архив патологи. - 2005. - № 3 (67). - С. 31-34.

3. Буланов М.Н. Ультразвуковая диагностика: в 3-х т. / М.Н. Буланов. М., 2010. - Т. 1. - 259 c.

4. Вдовиченко Ю.П. Воспалительные заболевания органов малого таза комплексный подход для эффективной терапии / Ю.П. Вдовиченко, Е.Н. Гопчук // Здоровье женщины. 2012. - № 4 (70). - С. 102-108.

5. Влияние хирургического лечения эндометриомы яичников на овариальный резерв: итоги систематического обзора и мета-анализа // Проблемы женского здоровья. - 2012. № 3. - C. 10-15.

6. Вовк І.Б. Сучасні принципи діагностики та лікування жінок репродуктивного віку 3 пухлиноподібними ураженнями яєчників / І.Б. Вовк, Кондратюк В.К. // Репродуктивное здоровье женщины. - 2006. № 2 (27). - C. 88-93.

7. Вовк І.Б. Пухлиноподібні ураження яєчників: етіологія, патогенез, діагностика та лікування / І.Б. Вовк, Г.В. Чубей, В.К. Кондратюк та інш. // Здоровье женщины. - 2013. - № 2 (78). -

C. 11-15.

8. Гажонова В.Е. Соноэластография в диагностике образований яични ков /В.Е. Гажонова, С.О. Чуркина, Е.Б. Савинова и др. // Кремлевская медицина. - 2009. - № 3. C. 31-37.

9. Герасимова Т.В. Оптимізація диа гностики та лікування функціональних кіст яєчників / Т.В. Герасимова // Медицинские аспекты здоровья женщи ны. - 2014. - № 5 (80). - С. 65-73. 10. Гинекология. Национальное руководство / под ред. В.И. Кулакова Г.М. Савельевой, И.Б. Манухина. М.: ГЭОТАР- Медия, 2009. - 1150 с. 11. Дамиров М.М. Аденомиоз / М.М. Дамирова // Бионом-Пресс. 2004. $-320 \mathrm{c}$.

12. Демидов В.Н. Кисты придатков матки и доброкачественные опухоли яичников / В.Н. Демидов, А.И. Рус Л.В. Адамян // Практическое пособие. - Вып. 2. Эхография органов малого таза у женщин. - М., 2006. C. 5-27.

13. Ищенко А.И. Эндометриоз: диагностика и лечение / А.И. Ищенко,
А.Е. Кудрина. - М.: Гэотар-Мед, 2002. - $104 \mathrm{c}$.

14. Кулаков В.И. Изменения репродуктивной системы и их коррекция у женщин с доброкачественными опухолями и опухолевидными образованиями яичников / В.И. Кулаков, Р.Г. Гатаулина, Г.Т. Сухих. - М.: Триада $X, 2005 .-21 \mathrm{c}$.

15. Онкологическая гинекология / А.Н. Рыбалка, В.А. Заболотнов. Симферополь, 2006. - 616 с

16. Пересада О.А. Эндометриоз диагностические, клинические, онкологические и лечебные аспекты / О.А. Пересада // Медицинские новости. - 2009. - № 14. - С. 14-25.

17. Рыбалка А.Н. Профилактика и ведение осложненных функциональных кист яичников / А.Н. Рыбалка, Я.А. Егорова // Медицинские аспекты здоровья женщины. - 2011. № 1 (40). - С. 11-13.

18. Савицкий Г.А. Перитонеальный эндометриоз и бесплодие (клиникоморфологическое исследование) / Г.А. Савицкий, С.М. Горбушин. СПб: ЭЛБИ-Спб, 2002. - 170 с

19. Сахаутдинова И.В. Современные методы диагностики и лечения эндометриоза яичников / И.В. Сахаутдинова, Г.Т. Мустафина, Е.Н. Хабибул- лина, Е.И. Яркова // Медицинский вестник Башкортостана. - 2015. № 1 (10). - С. 113-115 20. Унанян А.Л. Эндометриоз и репродуктивное здоровье женщин / А.Л. Унанян // Акушерство, гинекология, репродукция. - 2010. - № 3 (4). - C. 6-11.

21. Унанян А.Л. Активный и неактивный аденомиоз: клинико-морфологические варианты развития, дифференцированный подход к терапии / А.Л. Унанян, И.С. Сидорова, Е.А. Коган // Акушерство, гинекология, репродукция. - 2012. - № 2. C. 25-30.

22. Burney R.O. The genetics and biochemistry of endometriosis / R.O. Burney // Curr.Opin. Obstet.Gynecol. - 2013. Vol. 25. - P. 280-286.

23. Diane M. Ultrasound and Assessment of Ovarian Cancer Risk / M. Diane Twickler, E. Moschos // AJR - 2010. February. - 194. - P. 322-329.

24. ESHRE guideline for the diagnosis and treatment of endometriosis. URL: http: //www. guidelines. endometriosis.org/

25. Szamatowicz M. Endometriosis - is the best way of infertility treatment? / M. Szamatowicz // IFFS. - 2007. Abstract Book. - FC 1505. - P. 80
В 2017 году будет отменена бумажная отчетность для врачей первичного звена.

Как сообщили УНИАН в Минздраве, также будет ускорена процедура лицензирования медицинских практик, они будут гармонизированы в соответствии с европейским законодательством. Заместитель министра здравоохранения Павел Ковтонюк отметил, что ключевая функция семейного врача - поддерживать здоровье своих пациентов.

\section{ДЛЯ ВРАЧЕЙ}

"Любая другая работа будет минимизирована. В случае, если семейный врач решит начать частную практику, оплата будет поступать на его счет напрямую, минуя посредников. Это позволит создать простую, прозрачную и понятную для всех систему", - сказал Ковтонюк. По его словам, техническим оператором перечисления бюджетных средств станет прозрачная страховое агентство, которое будет осуществлять документооборот с врачами. Ковтонюк также подчеркнул, что введение новых налогов или страховых взносов не предусматривается.

"Украинцы и так платят налоги. Наша задача - обеспечить их прозрачное и эффективное использование. Каждый гражданин Украины, независимо от места проживания и достатка должен иметь доступ к семейному врачу, а общины не должны отправлять "гонцов" в Киев для вымаливания дополнительных бюджетов. Логика очень простая: вы выбираете врача - мы ему платим", - сказал Ковтонюк. health.unian.net 


\title{
Оцінювання ефективності терапії хронічного тазового болю у жінок з варикозним розширенням вен малого таза
}

\author{
С.О. Остафійчук, Н.І. Геник, Н.В. Дрогомирецька, П.Р. Волосовський \\ Івано-Франківський національний медичний університет
}

\begin{abstract}
Мета дослідження: оцінювання ефективності медикаментозної терапії хронічного тазового болю (ХТБ) у жінок 3 варикозним розширенням вен малого таза (ВРВМТ).

Матеріали та методи. Проведено обстеження 62 жінок репродуктивного віку з ХТБ на тлі ВРВМТ. Пацієнтки отримували діосмінвмісний флеботропний препарат Нормовен (ПАТ «Київський вітамінний завод») по 500 мг 2 рази на день у безперервному режимі per os курсами 14 днів кожного місяця протягом 6 міс. Для попередження рецидиву больового синдрому 30 жінок профілактично вживали препарат Нормовен у наведеній дозі через 3 міс після завершення основного курсу з повтором через 3 міс; 32 пацієнтки знаходилися під динамічним спостереженням без отримання профілактичного лікування. У групу порівняння увійшли 30 здорових жінок.
\end{abstract}

Усім жінкам проводили клініко-лабораторне обстеження, ультразвукове дослідження та допплерометрію для визначення внутрішнього діаметра яєчникових, маткових, аркуатних і внутрішніх клубових вен (см) та пікової систолічної швидкості кровотоку у маткових венах $(\mathrm{cm} / \mathrm{c})$. Больовий синдром оцінювали за шкалами для оцінювання болю (Pain Assessment Scales). Отриманий цифровий матеріал обробляли статистично з використанням програм Microsoft Excel 2000 та Statistica 5.11.

Результати. Установлено, що більшість жінок з ХТБ змушені обмежувати свою повсякденну діяльність, у половини спостерігається порушення сну, майже половина пригнічені, у 79,0\% відзначається емоційна лабільність 3 частою зміною настрою, а третина жінок схильні до депресії. Більшість жінок $(82,2 \%)$ відчували стискаючий, ниючий та м'який характер болю помірної інтенсивності. Після шестимісячного курсу лікування Нормовеном у 67,7\% жінок було досягнуто повну редукцію болю, у більшості жінок відзначено покращення сну, настрою та нормалізації повсякденної діяльності. У третини пацієнток залишався періодичний ниючий біль легкої інтенсивності. Відбулося достовірне зниження інтенсивності болю $(\mathrm{p}<0,05)$, що за

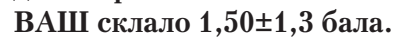

Заключення. Періодичне призначення профілактичних курсів венотоніку дозволили попередити рецидив застійного тазового синдрому та тазового болю у $90,0 \%$ пацієнток. Ключові слова: хронічний тазовий біль, варикозне розширення вен малого таза, Нормовен.

$\mathrm{X}$

ронічний тазовий біль (ХТБ) у жінок є поширеною $\triangle$ медичною та соціальною проблемою. За даними літератури, частота виникнення больового синдрому у жінок репродуктивного віку становить від 14,7\% до 24,0\% [1]. Проте, за даними когортного дослідження на основі проведеного анкетування 5000 жінок, його поширеність зазвичай недооцінюють, позаяк близько 40,0\% жінок не звертаються по медичну допомогу з даною проблемою [4].
Причини, які можуть зумовити тривалий виснажливий дискомфорт у нижніх відділах живота, багаточисленні, i встановлення основного чинника вимагає від пацієнтки роками звертатися до різних спеціалістів. Застій у малому тазі, запальні процеси придатків матки, спайкова хвороба, ендометріоз, кишкові та урологічні проблеми вимагають застосування різних видів терапії. Зазвичай відсутність або короткочасність ефекту від лікування призводить до нервових та психічних порушень, депресії, зниження працездатності, статевих розладів, позначається на відносинах у сім'ї [2].

Одне $з$ провідних місць в етіології ХТБ посідає варикозне розширення вен малого таза (ВРВМТ). Воно є наслідком як вторинних змін при патології жіночої статевої сфери, так і може виникати у результаті первинної патології венозних судин. Клінічна картина за даної венозної проблеми різноманітна та неспецифічна. Основні скарги: «тягнучий», тупий, «пекучий» біль з іррадіацією у нижні кінцівки, що часто виникає після тривалих статичних і динамічних навантажень, з посиленням у другу фазу менструального циклу, прояви диспареунії та дисменореї. Зважаючи на це, відсутність специфічних симптомів робить необхідним обстеження венозної системи малого таза у всіх жінок з больовим синдромом у нижній частині живота. На сучасному етапі у клінічній практиці діагностику ВРВМТ проводять на підставі результатів ультразвукової діагностики. Головним критерієм вираженого венозного застою в органах малого таза є збільшення діаметра основних венозних колекторів: маткових, яєчникових, внутрішніх клубових і аркуатних вен. Допплерографічне дослідження дозволяє виявити зниження пікової систолічної швидкості у судинах малого таза [3].

Призначення терапії, спрямованої на усунення флебостазу, стабілізацію гемодинаміки та зниження ішемії в органах малого таза, на нашу думку, повинно привести до усунення больового синдрому.

Мета дослідження: оцінювання ефективності медикаментозної терапії ХТБ у жінок з ВРВМТ.

\section{МАТЕРІАЛИ ТА МЕТОДИ}

Проведено обстеження 62 жінок репродуктивного віку з ХТБ, що тривав протягом 6 міс та більше, на тлі ВРВМТ. Критерієм виключення з обстеження були наявність у жінок пухлинних процесів будь-яких органів, ендометріозу та гострих запальних захворювань органів малого таза. Усі пацієнтки отримували діосмінвмісний флеботропний препарат Нормовен (ПАТ «Київський вітамінний завод») по 500 мг 2 рази на день у безперервному режимі per os курсами 14 днів щомісячно протягом 6 міс. Після завершення основного курсу для попередження відновлення больового синдрому 30 жінкам (основна група) було запропоновано профілактичне лікування препаратом Нормовен у наведеній дозі через 3 міс з повтором 


\section{ГИН Е КО ЛОГИЯ}

ще через 3 міс; 32 пацієнтки (контрольна група) знаходилися під динамічним спостереженням без отримання профілактичної терапії. У групу порівняння увійшли 30 здорових жінок.

Для верифікації діагнозу всім жінкам проводили комплексне клініко-лабораторне обстеження, ультразвукове дослідження на сканері ALOKA SSD 2000 із застосуванням пульсуючої допплерівської хвилі. Об'єм обстеження передбачав визначення внутрішнього діаметра яєчникових, маткових, аркуатних і внутрішніх клубових вен (см) у комплексі з визначенням пікової систолічної швидкості кровотоку у маткових венах (см/с). Ефективність лікування оцінювали за шкалами для оцінки болю (Pain Assessment Scales), рекомендованими міжнародною асоціацією тазового болю: короткого оцінювання болю, цифрової рейтингової шкали, короткої форми опитувальника болю МакГілла та візуально-аналогової шкали (ВАШ) [5]. Тести проводили у формі анкетування під час включення пацієнток у дослідження та після проведення основної терапії та профілактичного курсу.

Статистичне оброблення результатів виконували за допомогою методів варіаційної статистики на основі стандартних програм статистичного аналізу Microsoft Excel 5.0 .

\section{РЕЗУЛЬТАТИ ДОСЛІДЖЕННЯ ТА ЇХ ОБГОВОРЕННЯ}

На підставі вивчення якісних та кількісних характеристик болю нами встановлено, що в основному жінки висловлювали скарги щодо погіршення загальної активності $(69,4 \%)$, порушення ходи $(43,5 \%)$, негативного впливу симптомів на професійну діяльність (80,6\% випадків). У $44(71,0 \%)$ пацієнток відзначено посилення болю у другу фазу менструального циклу, у більшості - після довготривалого стояння, що, на нашу думку, можна пояснити депонуванням крові у розширених венах, наслідком чого є розвиток венозного повнокров'я органів малого таза. Порушення сну відзначили половина обстежуваних жінок, емоційну лабільність - 49 (79,0\%), а схильність до депресії - третина пацієнток. Зниження якості життя виявлено у 55 (88,7\%) жінок, а прояви диспареунії - у 72,6\% випадків.

Сенсорна характеристика больового синдрому за даними короткого опитувальника болю МакГілла виявила, що у більш ніж половини жінок ХТБ спричинював відчуття виснаженості, у третини - нудоти, в той час як 3 (4,8\%) пацієнтки періодично відзначали жорстокий біль, що призводив до відчаю. За результатами цифрової рейтингової шкали легкий біль відзначено у 17,8\%, помірний - у 82,2\% жінок. Інтенсивність болю за ВАШ становила 4,45 $\pm 1,3$ бала.

Моніторинг клінічної симптоматики у жінок з ХТБ після шестимісячного курсу лікування Нормовеном засвідчив позитивну динаміку. У 67,7\% жінок було досягнуто повну редукцію болю, у більшості жінок відзначено покращення сну, настрою та нормалізацію повсякденної діяльності. У третини пацієнток залишався періодичний ниючий біль легкої інтенсивності. Проте у 2 (3,2\%) жінок залишився пекучий хронічний біль помірної інтенсивності, що, на нашу думку, вимагає продовження призначеної терапії або оперативного лікування. Після лікування відзначено достовірне зниження інтенсивності болю

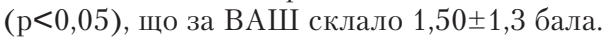

За даними ультразвукового та допплерометричного дослідження венозної системи малого таза у жінок $з$ ВРВМТ під впливом лікування відзначено суттєве покращання ехографічної картини. Так, діаметри маткових вен достовірно зменшилися у 1,5 разу $(\mathrm{p}<0,001)$ і в середньо-

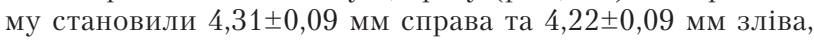
яєчникових вен - у 1,4 разу $(\mathrm{p}<0,001)$ і становили $4,15 \pm 0,37$ мм справа та 4,17 $\pm 0,34$ мм зліва, внутрішніх клубових вен - у 1,3 разу (р<0,001) і становили $10,69 \pm 0,32$ мм справа та 10,75 $\pm 0,27$ мм зліва та достовірно зменшився діаметр аркуатних вен - у 1,5 разу $(\mathrm{p}<0,001)$ - і становив 2,28 0,10 мм. Відбулося вірогідне збільшення пікової систолічної швидкості у маткових венах, яке становило $5,37 \pm 0,15 \mathrm{~cm} /$ с справа та 5,33 $\pm 0,14 \mathrm{~cm} /$ с зліва $(\mathrm{p}<0,05)$.

Отже, запропонований нами лікувальний комплекс є ефективним і патогенетично зумовленим. Унаслідок підвищення тонусу вен, покращання мікроциркуляції та лімфодренажу, зменшення тканинної гіпоксії, хронічного запалення та венозного застою в органах малого таза вдалося усунути хронічний больовий синдром у переважної більшості пацієнток.

Після закінчення основного терапевтичного курсу 30 пацієнткам було запропоновано профілактичне лікування препаратом Нормовен, а 32 жінки знаходилися під динамічним спостереженням без отримання превентивної терапії. Усі жінки обох груп були оглянуті через 6 міс. Опитування обстежених засвідчило, що відновлення больового синдрому у 5,6 разу достовірно частіше турбувало жінок контрольної групи (без отримання профілактичного лікування), ніж основної групі (OR 11,57; 95\% Cl 2,9046,10; р<0,001), - відповідно 18 (56,3\%) та 3 (10,0\%) жінок. Дану проблему 83,3\% пацієнток пов'язують із наявністю стресових факторів, зміною місця роботи, сімейними негараздами. Жінки після профілактичних курсів флеботоніку суб'єктивно оцінювали біль як менш виражений порівняно з контрольною групою. Інтенсивність болю за ВАШ в основній групі склала 1,75 $\pm 1,3$ бала, тоді як у контрольній $-3,50 \pm 1,4$ бала $(\mathrm{p}<0,05)$.

Аналіз ультразвукової картини виявив утримання діаметрів судин малого таза у межах, досягнутих після основного курсу лікування у жінок 3 профілактикою BPBMT (p>0,05). У той самий час, у жінок, яким не застосовували профілактичний курс протягом 6 міс, просвіт вен вірогідно збільшився. Так, діаметри матко-

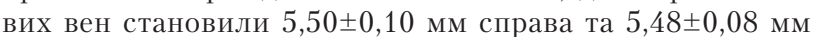

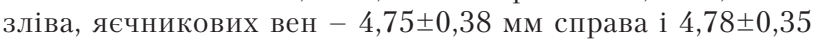
мм зліва, внутрішніх клубових вен $-11,83 \pm 0,35$ мм та $11,90 \pm 0,25$ мм відповідно справа і зліва. Установлено достовірне розширення діаметра аркуатних вен у 1,2 разу $(\mathrm{p}<0,05)$. У пацієнток контрольної групи виявлено зменшення пікової систолічної швидкості у маткових венах

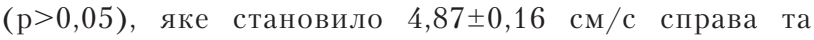
$4,79 \pm 0,13 \mathrm{~cm} /$ с зліва. Наведені дані свідчать про виникнення рецидиву застою в органах малого таза після припинення медикаментозної терапії.

\section{ВИСНОВКИ}

У результаті проведеного дослідження нами встановлено високу ефективність препарату Нормовен для усунення хронічного тазового болю на тлі варикозного розширення вен малого таза. Однак після припинення лікування через 6 міс больовий синдром відновлюється більш ніж у половини випадків. Тому періодичне призначення профілактичних курсів венотоніку дозволяє попередити рецидив застійного тазового синдрому та тазового болю.

Дана проблематика потребує подальшого вивчення у напрямку використання венотонічних препаратів в комбінованій терапії хронічного тазового болю, особливо з точки зору паралельного призначення гормональної терапії. 


\section{ГИН Е КО ЛОГИЯ}

\section{Оценка эффективности терапии хронической тазовой боли у женщин с варикозным расширением вен малого таза \\ С.А. Остафийчук, Н.И. Генык, Н.В. Дрогомирецкая, П.Р. Волосовский}

Цель исследования: оценка эффективности медикаментозной терапии хронической тазовой боли (ХТБ) у женщин с варикозным расширением вен малого таза (ВРВМТ).

Материалы и методы. Проведено обследование 62 женщин репродуктивного возраста с ХТБ на фоне ВРВМТ. Пациентки получали диосминсодержащий флеботропный препарат Нормовен (ОАО «Киевский витаминный завод») по 500 мг 2 раза в день в непрерывном режиме per os курсами 14 дней каждого месяца в течение 6 мес. Для предупреждения рецидива болевого синдрома 30 женщин профилактически принимали препарат Нормовен в указанной дозе через 3 мес после завершения основного курса с повтором через 3 мес 32 пациентки находились под динамическим наблюдением без получения профилактического лечения. В группу сравнения вошли 30 соматически здоровых женщин.

Всем женщинам проводили клинико-лабораторное обследование, ультразвуковое исследование и допплерометрию для определения внутреннего диаметра яичниковых, маточных, аркуатных и внутренних подвздошных вен (см) и пиковой систолической скорости кровотока в маточных венах (cм/c). Болевой синдром оценивали по шкалам для оценки боли (Pain Assessment Scales). Полученный цифровой материал обрабатывали статистически с использованием программ Microsoft Excel 2000 и Statistica 5.11.

Pезультаты. Установлено, что большинство женщин с ХТБ вынуждены ограничивать свою повседневную деятельность, у половины наблюдается нарушение сна, почти половина подавлены, у 79,0\% отмечается эмоциональная лабильность с частой сменой настроения, а треть женщин склонны к депрессии. Большинство женщин (82,2\%) испытывали сжимающий, ноющий и мягкий характер боли умеренной интенсивности. После шестимесячного курса лечения Нормовеном у 67,7\% пациенток была достигнута полная редукция боли, у большинства женщин отмечалось улучшение сна, настроения и нормализация повседневной деятельности. У трети пациенток оставалась периодическая ноющая боль легкой интенсивности Произошло достоверное снижение интенсивности боли $(\mathrm{p}<0,05)$,

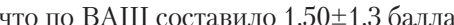

Заключение. Периодическое назначение профилактических курсов венотоника позволили предупредить рецидив застойного тазового синдрома и тазовой боли у $90,0 \%$ пациенток.

Ключевые слова: хроническая тазовая боль, варикозное расширение вен малого таза, Нормовен.

\section{Evaluation of treatment of chronic pelvic pain in women with pelvic varicose veins \\ S.O. Ostafiychuk, N.I. Henyk, N.V. Drohomyretska, P.R. Volosovsky}

The objective: of our study was to evaluate the effectiveness of therapy of chronic pelvic pain (CPP) in women with pelvic varicose veins (PVV).

Patients and methods. The study involved 62 women of reproductive age with CPP and PVV. Patients have received Normoven («Kyiv Vitamin Factory») in a dose $500 \mathrm{mg} 2$ times a day per os courses of 14 days each month for six months. To prevent recurrence of pain 30 women were prescribed the same drug prophylactically during 3 months after the basic course with repetition after 3 months. 32 patients did not receive Normoven as an prevention. The control group consisted of 30 healthy women. All women conducted clinical and laboratory examination, ultrasound and Doppler to determine the internal diameter ovaric, uterine, arcuate and internal iliac veins $(\mathrm{cm})$, and the definition of peak systolic velocity of blood flow in the uterine veins $(\mathrm{cm} / \mathrm{s})$. Pain was assessed by Pain Assessment Scales. The resulting digital material were treated statistically using the program Microsoft Excel 2000 and Statistica 5.11

Results. We found that most of women were limited their daily activities, half have had sleep disorders, almost half was depressed, emotional lability with frequent changes of mood was observed in $79,0 \%$, and a third of women were in depression. Most women feel cramping, aching and tender of pain of moderate intensity $(82,2 \%)$. After 6 months of treatment with Normoven we noticed complete reduction of pain in $67,7 \%$ of women, in most women improved sleep, mood and normalization of daily activities. One-third of patients remained periodic light intensity pain. There was a significant decrease in pain intensity $(\mathrm{p}<0,05)$, which accoding to VAS score was $1,50 \pm 1,3$ points.

Conclusions. Periodic preventive courses of Normoven allowed to prevent recurrence of congestive pelvic syndrome and pelvic pain in $90,0 \%$ of patients

Key words: chronic pelvic pain, varicose veins of the pelvis, Normoven

\section{Сведения об авторах}

Остафийчук Светлана Александровна - Кафедра акушерства и гинекологии имени И.Д. Ланового Ивано-Франковского национального медицинского университета, 76000, г. Ивано-Франковск, ул. Галицкая, 2; тел.: (050) 950-07-70. E-mail:voloshka76@rambler.ru

Генык Наталия Ивановна - Кафедра акушерства и гинекологии имени И.Д. Ланового Ивано-Франковского национального медицинского университета, 76000, г. Ивано-Франковск, ул. Галицкая, 2; тел.: (050) 521-01-96. E-mail: irka-h@i.ua

Дрогомирецкая Наталия Васильевна - Кафедра акушерства и гинекологии имени И.Д. Ланового Ивано-Франковского национального медицинского университета, 76000, г. Ивано-Франковск, ул. Галицкая, 2; тел.: (095) 301-15-31. E-mail: natalya.vl@ukr.net

Волосовский Павел Романович - Кафедра акушерства и гинекологии имени И.Д. Ланового Ивано-Франковского национального медицинского университета, 76000, г. Ивано-Франковск, ул. Галицкая, 2; тел.: (050) 511-54-76. E-mail: volospav@mail.ru

\section{СПИСОК ЛІТЕРАТУРИ}

1. Черкашин М.А. Дифференциальная диагностика хронических тазо вых болей у женщин. Новый взгляд варикозная болезнь вен малого таза / М.А. Черкашин, К.Д. Мурватов // Российский медицинский журнал. 2008. - № 29. - С. 1952 -1955.

2. Пирогова B.I. Синдром хронічного тазового болю: сучасні підходи до розв'язання проблем / В.І. Пирогова С.О. Шурпяк // Здоров'я України. 2012. - № 1. - C. 9-11.

3. Мозес В.Г. Ультразвуковая семиотика варикозного разширения вен малого таза у женщин в основные возрастные биологические периоды жизни / В.Г. Мозес // Ультрозвуковая и функциональная диагностика. - 2005. - № 6. C. 33-38.

4. Zondervan Krina Tynke The epidemiology of chronic pelvic pain in women. Central Oxford Research Ethics Committee Project No 97.079, Oxford, p. 255

5. Hawker Gillian A. Measures of adult pain: Visual Analog Scale for pain (VAS Pain), Numeric Rating Scale for Pain (NRS
Pain), McGill Pain Questionnaire (MPQ), Short-form McGill Pain Questionnaire (SF$M P Q)$, Chronic Pain Grade Scale (CPGS), Short-form-36 Bodily Pain Scale (SF-36 BPS), and Measure of Intermittent and Constant Pain / Gillian A. Hawker, Mian S., Kendzerska T., French M. // Arthritis Care and research. - 2011. - № 11. P. 240-252. 


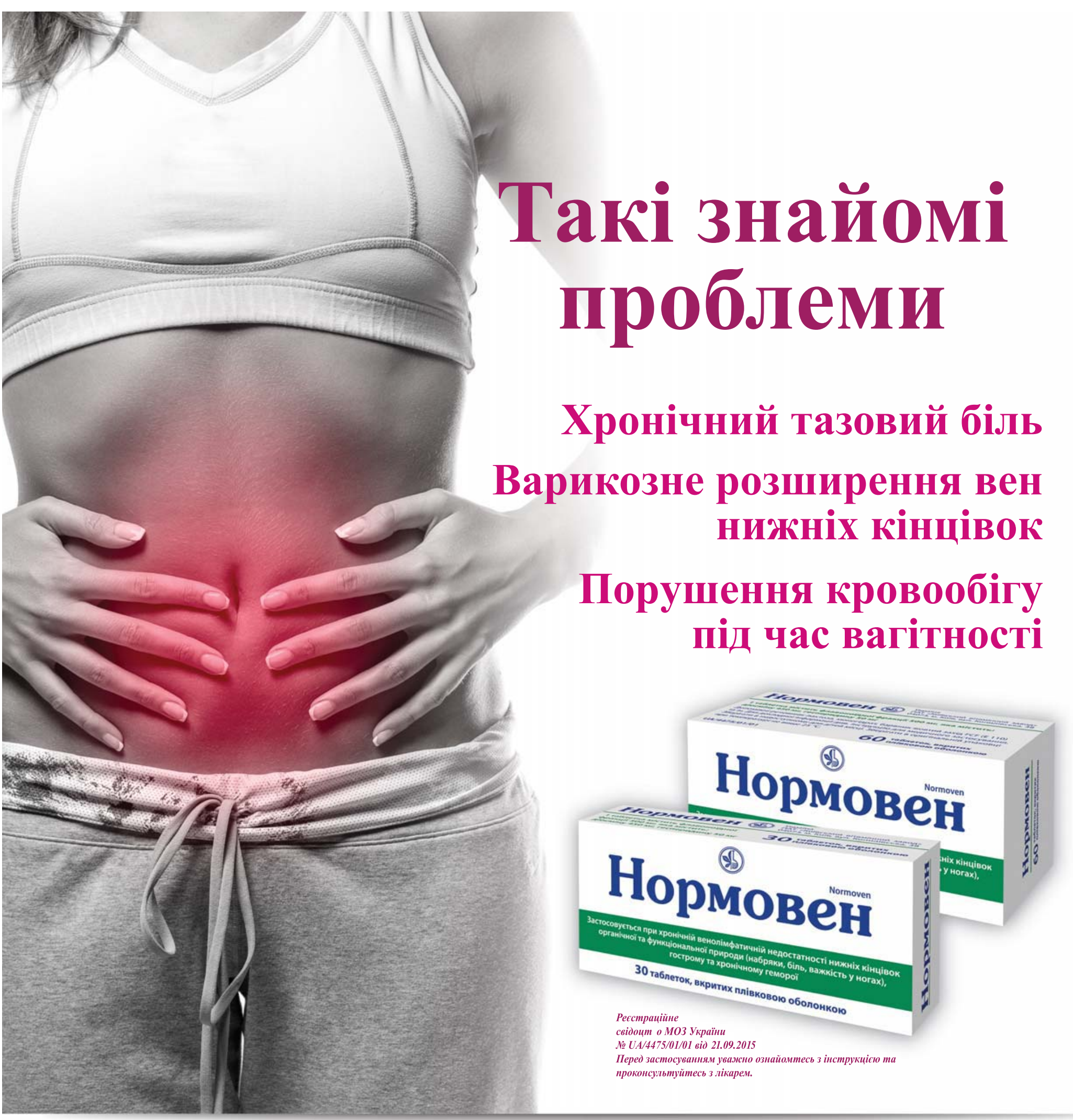

Склад лікарського засобу:

1 таблеткар містить зловонірнӧ̈ракції 500 мг яка містить діосміну

450 мг, гесперидину $50 \mathrm{mr}$

Показання для застосування, Хронічна венолімфатична недостатність нижніх кінщівок органічної та функщіональної природи (набряки, біль, тяжкість у ногах). Гострий та хронічний геморой

Протипоказання. Підвищена чутливість до будь-якого компонента препаратув ванамнезі.

Особливі застереження.

Застосування у період вагітності або годування груддю.

Експериментальні дослідження не виявили тератогенної дії препарату. Дослідження за участю жінок у III триместрі вагітності довели ефективність застосування препарату та не виявили ризику для плода.

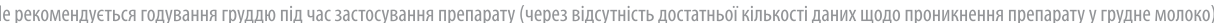

Діти. Даний лікарський засіб не застосовують дітям.

Передозування. На даний час симптоми передозування препарату не описані.

Побічні ефекти. Рідко можливі помірні розлади з боку шлунково-кишкового тракту (діарея, диспепсія, нудота, блювання) або вегетативної нервової системи (головний біль, запаморочення), які не потребують припинення лікування

препаратом.

У осібз підвищеною чутпивістю можпивий розвитокалергічних реакщій до компонентів препарату.

Взаємодія з іншими пікарськими засобами та інші види взаємодій. Не виявлена.

Категорія відпуску. Без рецепта. 


\title{
Порівняльне оцінювання показників якості життя у паціснток після оперативного лікування з приводу міоми матки
}

\author{
О.М. Макарчук, Г.М. Гаврилюк \\ Івано-Франківський національний медичний університет
}

Одним із найбільш поширених доброякісних гіперпроліферативних захворювань жіночих статевих органів є лейоміома матки, частота якої, за даними різноманітних літературних джерел, у жінок репродуктивного віку становить від $20 \%$ до $40 \%$. Вона є основним показанням до хірургічних втручань, у тому числі видалення органа. Віддалені наслідки оперативних втручань з приводу міоми матки стали предметом багаточисленних дебатів. У сучасній літературі не так багато досліджень, що стосуються оцінювання якості життя як при органозберігальній терапії міоми матки, так і після оперативного лікування. Показники якості життя мають, без сумніву, значущу прогностичну цінність та можуть бути використані під час вибору оптимального методу лікування міоми матки, а також при розробленні індивідуального підходу до післяопераційної реабілітації таких пацієнток.

Мета дослідження: вивчення рівня показників якості життя та пошук можливих шляхів його покращання у жінок після оперативного лікування з приводу міоми матки.

Матеріали та методи. Проведено обстеження 80 жінок репродуктивного віку (основна група), у яких була проведена екстирпація матки без придатків. Клініко-лабораторні дослідження проводили у динаміці післяопераційного періоду, а також через 6,12 міс та 3 роки після оперативного лікування. Оцінювання порівняльного аналізу вимагало додаткового формування двох груп порівняння: 20 пацієнток із міомектомією та 20 пацієнток із надпіхвовою ампутацією матки без придатків. У контрольну групу увійшли 20 практично здорових жінок. Оцінювання якості життя проводили шляхом анкетування за допомогою поширеного в клінічних дослідженнях та під час індивідуальному моніторингу опитувальника MOS 36-Item Short-Form Health Survey-MOS SF-36. Статистичне оброблення peзультатів дослідження здійснювали 3 допомогою пакета програм Microsoft Office Excel та Statistica 6.0 for Windows.

Результати. У жінок основної групи показники психоемоційних та вегетосудинних проявів були найбільш вираженими зразу ж після оперативного втручання та зберігалися стійкими через три роки за відсутності вагомих відхилень у групі порівняння. Найбільш часто відзначали швидку втомлюваність $(76,25 \%)$, порушення сну $(88,75 \%)$, дратівливість та зміну настрою $(76,25 \%)$, а також емоційну лабільність, тривожність та депресивні прояви. 3 приведених результатів оцінювання показників якості життя слід відзначити, що в першу чергу порушується рольове функціонування жінок через незадовільній фізичний та емоційний стан, про що свідчать значні відмінності, отримані за шкалою General Health (GH) (загальне оцінювання здоров'я). Через три роки після оперативного лікування у жінок основної групи встановлено стійкий виражений вплив постгістеректомічного стану на показники якості життя. Так, 33,75\% жінок основної групи характеризували якість життя як низьку проти 5,0\% пацієнток контрольної групи та 10,0\% жінок з міомектомією.

Заключення. Найбільший ступінь невдоволеності якістю життя пацієнтки пред'являли щодо здоров'я - 23 (28,75\%) випадки, дещо менший - щодо професійної діяльності $18(22,5 \%)$ випадків, емоційної сфери - 17 (17,5\%) випадків, а також статевої сфери - $11(13,75)$ випадків. Тобто приєднання ускладнень, пов'язаних із симптоматикою постгістеректомічного синдрому, підвищує рівень стресу, а видалення матки як органа створює передумову для психосоматичних порушень. Це забезпечує дію додаткових факторів ризику для розвитку психосоціального дистресу у даній групі пацієнток.

Ключові слова: міома матки, гістеректомія, постхістеректомічний синдром, психосоматичні розлади, якість життя.

$\mathrm{O}_{\mathrm{m}}^{\mathrm{n}}$ дним із найбільш поширених доброякісних гіперпроліферативних захворювань жіночих статевих органів є лейоміома матки, частота якої, за даними різноманітних літературних джерел у жінок репродуктивного віку складає від $20 \%$ до $40 \%$. Під час проведення морфологічних досліджень макропрепаратів після гістеректомій цю нозологію виявляють значно частіше - у $75-85 \%$ випадків, і у $50-70 \%$ вона є основним показанням до хірургічних втручань, у тому числі видалення органа, та відповідно вагомою причиною зниження працездатності та погіршення якості життя сучасної жінки і її фізичного здоров'я $[1,7]$.

Віддалені наслідки оперативних втручань з приводу міоми матки стали предметом багаточисленних дебатів. Існують дані, що жінки після втручань на матці зі збереженими яєчниками висловлюють більше скарг, ніж пацієнтки тієї самої вікової групи, які знаходяться у періоді клімактерію. $€$ дані щодо появи менопаузальної симптоматики через 4-5 років після субтотальної гістеректомії та через 3 роки після тотальної гістеректомії без придатків - оперовані жінки відзначають надмірне збільшення маси тіла у перші $3-5$ років після операції. Незважаючи на збережену функцію яєчників, зростає швидкість втрати кісткової тканини, підвищується ризик розвитку серцево-судинних захворювань, зокрема гіпертонічної хвороби, достовірно зростає відсоток гіперліпідемій $[2,8,9]$.

У сучасній літературі не так багато досліджень, що стосуються оцінки якості життя (ЯЖ) як при органозберігальній терапії міоми матки, так і після оперативного лікування. Так, окремі наукові дослідження стосуються результатів оцінювання якості життя у пацієнток після консервативної міомектомії та емболізації маткових артерій [1]. Низка авторів свідчать про появу домінуючого механізму психологічного захисту жінок із дизадаптивними станами внаслідок гістеректомії, яким є регресія. У цілому адаптація до нового якісного стану життя без матки забезпечується 


\section{ГИ Н Е К О Л Г И Я}

завдяки дії широкого спектра механізмів психологічного захисту та ступеня напруження, тому її можна вважати патогенною, позаяк у випадку гістеректомії вона не тільки не є ефективною, але й провокує виникнення дизадаптивних станів [4-6].

Отже, показники якості життя мають без сумніву значущу прогностичну цінність та можуть бути використані під час вибору оптимального методу лікування міоми матки, а також розроблення індивідуального підходу до післяопераційної реабілітації таких пацієнток.

Мета дослідження: вивчення рівня показників ЯЖ та пошук можливих шляхів його покращання у жінок після оперативного лікування з приводу міоми матки.

\section{МАТЕРІАЛИ ТА МЕТОДИ}

Проведено обстеження 80 жінок репродуктивного віку (основна група), у яких у зв'язку із симптомною фіброміомою матки було проведено оперативне втручання екстирпація матки без придатків. Клініко-лабораторні дослідження проводили у динаміці післяопераційного періоду, а також через 6, 12 міс та 3 роки після оперативного лікування. Оцінювання порівняльного аналізу вимагало додаткового формування двох груп порівняння: 20 пацієнток із міомектомією та 20 жінок із надпіхвовою ампутацією матки без придатків. У контрольну групу увійшли 20 практично здорових пацієнток. Усі групи були зіставні за отриманою освітою, соціальним статусом та сімейним положенням.

Дизайн обстеження включав дослідження гормонального профілю, показників гемостазу, ліпідограми, УЗД статевих органів та грудних залоз, інструментальні методи оцінювання функції яєчників тощо. Оцінювання ЯЖ проводили шляхом анкетування за допомогою поширеного у клінічних дослідженнях та під час індивідуального моніторингу опитувальника MOS 36-Item Short-Form Health Survey-MOS SF36 (Ware J.E. et al., 1992, 1993, 1995). Опитувальник SF-36 може бути використаний для оцінювання ЯЖ у порівнюваних між собою популяційних групах як здорових людей, так і пацієнток з різними гінекологічними захворюваннями. Даний опитувальник дозволяє розділити шкали на два показники: фізичний компонент здоров'я (PF, RF, BP, GH) та психічний компонент здоров'я (VT, SF, RE, MN), що дає можливість аналітично оцінити суб'єктивність задоволення пацієнткою своїм фізичним та психічним станом.

Статистичне оброблення результатів дослідження здійснювали з допомогою пакета програм Microsoft Office Excel та Statistica 6.0 for Windows.

\section{РЕЗУЛЬТАТИ ДОСЛІДЖЕННЯ}

ТА ÏХ ОБГОВОРЕННЯ

У дослідження були включені пацієнтки віком від 20 до 45 років. Результати вивчення сімейного стану дозволили відзначити, що всі пацієнтки контрольної групи та відповідно досліджуваних двох груп на момент обстеження перебували у шлюбі. Рівень освіти був значущим: більше половини жінок мали вищу освіту - 51,25\%. Також привертає увагу факт, що серед жінок контрольної групи питома вага високоосвічених осіб вдвічі нижча, ніж серед пацієнток двох досліджуваних груп ( $<0,01)$. Аналіз зайнятості серед працездатного населення засвідчив, що частка непрацюючих жінок основної групи (28,75\%) майже вдвічі переважає даний показник у контролі - 15,0\% ( $<0,001)$.

Відомо, що навіть у здорових жінок мають місце певні зміни психоемоційного статусу, тому пухлини репродуктивних органів у репродуктивний період є надзвичайно сильним емоційним фактором, який справляє вагомий вплив на всю психосоматичну організацію жінки.

Слід відзначити, що у жінок основної групи показники психоемоційних та вегетосудинних проявів були найбільш вираженими зразу ж після оперативного втручання та зберігалися стійкими через три роки за відсутності вагомих відхилень у групі порівняння. Серед них найбільш часто зафіксовано швидку втомлюваність (76,25\%), порушення сну (88,75\%), дратівливість та зміну настрою (76,25\%), а також емоційну лабільність, тривожність та депресивні прояви. У цієї категорії жінок також відзначено підвищену акцентованість на неприємних соматичних відчуттях (кардіалгія, масталгія, серцебиття), схильність інтерпретувати їх як загрозливі для власного здоров’я, емоційне напруження та неспокій, які були найбільш виражені у перший рік після гістеректомії.

Отже, втрата матки як специфічного органа для організму жінки багатьма пацієнтками переноситься більш емоційно, ніж видалення будь-якого іншого органа, що пов'язано з особливостями їхнього психонейровегетативного статусу, виникненням почуття дефемінізації практично у половини (50, 0\%) жінок.

Що стосується оцінювання показників ЯЖ, слід відзначити, що у цілому ЯЖ пацієнток, оперативно пролікованих з приводу симптомної міоми матки, є значуще нижчою, ніж у контролі. Це погіршення залежить не тільки від болю, але i від емоційного стану, представленого перш за все тривожнодепресивними розладами. Однією з причин збереження болю, незадоволеності своїм станом здоров'я може бути відсутність терапії, що корелює метаболічні розлади, та психотерапії.

Незважаючи на проведене оперативне лікування та усунення симптомів міоми матки жінки основної групи оцінювали своє здоров'я нижче, ніж пацієнтки групи контролю та жінки із консервативною міомектомією ( $<<0,01) .3$ приведених результатів оцінювання показників ЯЖ слід відзначити, що ЯЖ пацієнток обох груп знижується безпосередньо після оперативного втручання власне через біль та психологічні розлади, з ними пов’язані. У першу чергу порушується рольове функціонування жінок через незадовільний фізичний та емоційний стан, про що свідчать значні відмінності, отримані за шкалою General Health (GH) (загальне оцінювання здоров’я), де достовірно частіше пацієнтки з больовим розладом оцінювали своє здоров’я як посереднє ( $<<0,001)$. 3 таким самим ступенем достовірності отримана різниця за наступними шкалами: Role-Physical (RP) (вплив фізичного стану на рольове функціонування), Role-Emotional (RE) (вплив емоційного стану на рольове функціонування), Social Functioning (SF) (соціальне функціонування), Bodily Pain (BP) (інтенсивність болю та його вплив на здатність займатися щоденною діяльністю, включаючи роботу вдома та поза домом).

За шкалами Vitality (VT) (життєздатність) та Mental Health (MH) (самооцінка психічного здоров'я) у жінок 3 міомектомією не було достовірних відмінностей, тоді як пацієнтки з гістеректомією без придатків достовірно частіше нервували, відчували себе пригніченими, змученими, рідше - повними енергії, спокійними та утихомиреними, ніж жінки із надпіхвовою ампутацією матки зі збереженням яєчників $(\mathrm{p}<0,01)$.

Досліджуючи психоемоційну динаміку через три роки після оперативного лікування, виявлено ознаки асенізації, зростання показників депресії з домінуванням соматичних ознак, переважання депресивного настрою, вираженої емоційної лабільності і поступове формування патологічного психоемоційного стану. Ці тенденції максимально виражені зразу ж після операції та стійко домінують через три роки після лікування.

Слід відзначити, що через три роки після оперативного лікування у жінок основної групи встановлено стійкий вира- 


\section{ГИН К КО ЛОГИЯ}

жений вплив постгістеректомічного стану на показники ЯЖ. Так, 33,75\% жінок основної групи характеризували ЯЖ як низьку, тоді як тільки 5,0\% пацієнток контрольної групи та 10,0\% жінок з міомектомією давали подібну характеристику наведеним показникам. Закономірно, що лише 7,5\% жінок основної групи характеризували, якість свого життя як високу проти 40\% у контрольній групі. Найбільший ступінь невдоволеності життям пацієнтки пред’являли щодо здоров'я 23 (28,75\%) випадки, дещо менший - щодо професійної діяльності - 18 (22,5\%) випадків, емоційної сфери 17 (17,5\%), а також статевої сфери - 11 (13,75\%) випадків. Тобто приєднання ускладнень, пов'язаних із симптоматикою постгістеректомічного синдрому, підвищує рівень стресу, а видалення матки створює передумову для психосоматичних порушень. Це забезпечує дію додаткових факторів ризику для розвитку психосоціального дистресу у даній групі пацієнток.

\section{ВИСНОВКИ}

Найбільш значуще у наведеному вище часовому відрізку спостереження страждає емоційна сфера: під час спілкування із цими жінками відзначено знижений емоційний фон, схильність до іпохондрії, підвищена нервозність. Привертає увагу вкрай низьке оцінювання пацієнтками якості статевого життя. Також виявлена пряма залежність показників загальної якості життя (ЯЖ), а також показників здоров’я та емоцій від віку пацієнток. У більш старших пацієнток дані показники були закономірно нижчі, ніж у молодих. Чим більша тривалість захворювання на міому матки, тим нижча ЯЖ у сфері здоров’я, емоцій, статевій сфері, а також загальна ЯЖ $(\mathrm{p}<0,001)$.

Отже, можна зробити висновок, що у цілому ЯЖ пацієнток з оперативним лікуванням міоми матки в перші тижні післяопераційного періоду є значущо нижчою, ніж до

\section{Сравнительная оценка показателей качества жизни у пациенток после оперативного лечения по поводу миомы матки О.М. Макарчук, Г.М. Гаврилюк}

Одним из самых распространенных доброкачественных гиперпролиферативных заболеваний женских половых органов является лейомиома матки, частота которой, по данным различных литературных источников, у женщин репродуктивного возраста составляет от $20 \%$ до 40\%. Она является основным показанием к хирургическим вмешательствам, в том числе удалению органа. Отдален ные последствия оперативных вмешательств по поводу миомь матки стали предметом многочисленных дебатов. В современной литературе не так много исследований, касающихся оценки качества жизни как при органосохраняющей терапии миомы матки, так и после оперативного лечения. Показатели качества жизни имеют, несомненно, значимую прогностическую ценность и могут быть использованы при выборе оптимального метода лечения миомь матки, а также при разработке индивидуального подхода к послеоперационной реабилитации таких пациенток.

Цель исследования: изучение уровня показателей качества жизни и поиск возможных путей его улучшения у женщин после оперативного лечения по поводу миомы матки.

Материаль и методы. Проведено обследование 80 женщин репродуктивного возраста (основная группа), у которых была прове дена экстирпация матки без придатков. Клинико-лабораторные исследования проводили в динамике послеоперационного пери ода, а также через 6, 12 мес и 3 года после оперативного лечения. Оценка сравнительного анализа требовала дополнительно форми рования двух групп сравнения: 20 пациенток с миомэктомией и 20 пациенток с надвлагалищной ампутацией матки без придатков. В контрольную группу вошли 20 практически здоровых женщин. Оценку качества жизни проводили путем анкетирования с помощью распространенного в клинических исследованиях и при индивидуальном мониторинге опросника MOS 36-Item Short-Form операції, незважаючи на симптомний перебіг основного гіперпроліферативного захворювання, що і стало показанням до операції. Це погіршення залежить не тільки від болю, але і від емоційного стану, представленого перш за все тривожно-депресивними розладами, пов'язаними із думками про видалення органа та свою «жіночу повноцінність». Без сумніву, що однією із причин збереження болю, а також незадоволеності своїм станом здоров'я може бути відсутність терапії, що корелює метаболічні розлади, та препаратів психотерапевтичного спрямування.

У жінок з гістеректомією має місце більш вагома психотривожна ситуація, і факт пухлинного утвору та видалення матки є вагомим психоемоційним стресом та чинником низки негативних переживань, прихованої тривоги і напруження, що посилені соматичними фіксаціями. Загалом такі жінки частіше виявляють ознаки депресивної та астенічної поведінки, що є несприятливим психоемоційним фактором і потребує відповідної психокорекції.

Алгоритм ведення пацієнток з міомою матки, яких готують до оперативного лікування, ставить значні вимоги до медичного підходу та індивідуальних психотерапевтичних методів. Таким жінкам необхідно доповнювати спеціалізовану та медичну допомогу заходів з психосоціальної реабілітації у зв'язку 3 їхньою підвищеною лабільністю, низькою стресостійкістю, зниженою упевненістю в собі та своїй жіночій компетенції.

\section{Перспективи подальшого дослідження у даному напрямку}

Отримані дані дозволять у ході подальших досліджень оцінити зміни вираженості симптомів і якості життя, заподіяні різними видами органозберігального консервативного лікування лейоміоми матки у жінок з ожирінням, що забезпечить подальше покращання результатів органозберігального лікування даних захворювань.

Health Survey-MOS SF-36. Статистическую обработку результатов исследования осуществляли с помощью пакета программ Microsoft Office Excel и Statistica 6.0 for Windows.

Peзультаты. У женщин основной группы показатели психоэмоциональных и вегетососудистых проявлений были наиболее выраженными сразу же после оперативного вмешательства и сохранялись устойчивыми через три года при отсутствии весомых отклонений в группе сравнения. Среди них наиболее часто отмечено быструю утомляемость (76,25\%), нарушение сна (88,75\%), раздражительность и смену настроения $(76,25 \%)$, а также эмоциональную лабильность, тревожность и депрессивные проявления. Из приведенных результатов оценки показателей качества жизни следует отметить, что в первую очередь нарушается ролевое функционирование женщин из-за неудовлетворительного физического и эмоционального состояния, о чем свидетельствуют значительные различия, полученные по шкале General Health (GH) (общая оценка здоровья). Через три года после оперативного лечения у женщин основной группы установлено устойчивое выраженное влияние постгистеректомического состояния на показатели качества жизни. Так, 33,75\% женщин основной группы характеризовали качество жизни как низкое по сравнению с 5,0\% пациенток контрольной группы и 10,0\% женщин с миомэктомией.

Заключение. Наибольшую степень неудовлетворенности жизнью пациентки выражали по поводу здоровья - 23 (28,75\%) случая, несколько меньшую - по профессиональной деятельности $18(22,5 \%)$ случаев, эмоциональной - 17 (17,5\%) случаев, а также в половой сфере - 11 (13,75\%) случаев. То есть присоединение осложнений, связанных с симптоматикой постгистеректомического синдрома, повышает уровень стресса, а удаление матки как органа создает предпосылку для психосоматических нарушений. Это обеспечивает действие дополнительных факторов риска для развития психосоциального дистресса в данной группе пациенток.

Ключевые слова: миома матки, гистерэктомия, постгистерєктомический синдром, психосоматические расстройства, качество жизни. 


\section{ГИН Е КО ЛОГИЯ}

\section{Comparison of indicators quality of life in women after operative rehabilitation on uterine fibroids o. Makarchuk, G. Gavrilyuk}

One of the most common benign hyperproliferative diseases of the female reproductive organs are uterine leiomyoma, the frequency of which, according to various literature in women of reproductive age is between $20 \%$ and $40 \%$, and is the main indication for surgery, including removal of the organ. Long-term effects of surgical interventions for uterine fibroids have been the subject of numerous debates. In modern literature is not much research on the assessment of the quality of life both in organ treatment of uterine fibroids, and after surgical recovery. Quality of life have undoubtedly significant prognostic value and can be used in selecting the optimal treatment of uterine fibroids, as well as the development of individual approach to postoperative rehabilitation of patients.

The objective: was the study of quality of life and the search for possible ways to improve in women after surgical healing uterine fibroids. Materials and methods. A survey of 80 women of reproductive age (study group), which was conducted without hysterectomy applications. Clinical and laboratory examination conducted in the dynamics of the postoperative period and at 6,12 months and 3 years after surgical recovery. Assessment of comparative analysis require further formation of two groups comparing 20 patients with myoectomy and 20 women with no uterus amputation supravaginal applications. The control group consisted of 20 healthy patients. Assessment of quality of life survey conducted by using common clinical trials and monitoring at the individual questionnaire MOS 36- Item Short-Form Health
Survey- MOS SF-36. Statistical analysis of the survey results was carried out using the software package Microsoft Office Excel and Statistica 6.0 for Windows.

Results. In women, the main indicators of psycho-emotional and vegetative manifestations were most pronounced immediately after surgery and remained stable in three years with no significant deviations in the comparison group. Among the most frequently observed fatigue $(76,25 \%)$, sleep disorders $(88,75 \%)$, irritability and mood changes $(76,25 \%)$ and emotional lability, anxiety and depressive symptoms. Of The results of evaluation of quality of life should be noted that first disturbed functioning role of women because of poor physical and emotional state, as evidenced by the significant differences obtained on the scale of General Health (GH) (overall health). Three years after the rapid improvement in women's core group established stable condition posthisterektomy pronounced effect on quality of life. Thus, in total $33,75 \%$ of the principal groups characterized as low quality of life, compared with $5,0 \%$ of patients in the control group and $10,0 \%$ of women with myoectomy.

Conclusions. The highest level of dissatisfaction with life studied patients presenting in health $-28,75 \%(23)$ cases, slightly less professional - 22,5\% (18), emotional - 17,5\% (17) and as in the sexual sphere $-13,75 \%$ (11) cases. That associated complications related symptoms posthisterektomy syndrome, increases the level of stress and hysterectomy as the body creates prerequisites for psychosomatic disorders. This action provides additional risk factors for the development of psychosocial distress in this group of patients.

Key words: uterine fibroids, hysterectomy, posthisterektomy syndrome, psychosomatic disorders, quality of life.

\section{Сведения об авторах}

Макарчук Оксана Михайловна - Ивано-Франковский национальный медицинский университет, 76000, г. Ивано-Франковск, ул. Галицкая, 2; тел.: (0342) 55-31-65

Гаврилюк Галина Мирославовна - Ивано-Франковский национальный медицинский университет, 76000, г. ИваноФранковск, ул. Галицкая, 2; тел.: (0342) 55-31-65

\section{СПИСОК ЛІТЕРАТУРИ}

1. Кичигин О.В. Факторы риска развития миомы матки и качество жизни пациенток, оперированных по поводу миомы матки /О.В. Кичигин, И.М. Арестова, Ю.В. Занько // Охрана материнства и детства. - 2013. - № 2 (22). - С. 36-41. 2. Макаров О.В. Синдром постгистерэктомии /О.В. Макаров, В.П. Сметник, Ю.Э. Доброхотова. - М., 2000. C. $10-167$.

3. Павлова Ж.С. Спорные вопросы постгистерэктомического синдрома / ж.С. Павлова, С.С. Лубяна // Ук- раїнський медичний альманах. 2009. - T. 12, № 4. - С. 141-145. 4. Волков А.Е. Психоэмоциональные нюансы посткастрационного синдрома / А.Е. Волков // Актуальные вопросы акушерства и гинекологии. 2002. - № 1 (1). - С. 138-139.

5. Долецкая Д.В. Оценка качества жиз ни у больных миомой матки после различних видов хирургического лечения / Д.В. Долецкая, М.А. Ботвин, Н.М. По бединский // Акушерство и гинекология. -2006 . - № 1. - С. 10-13.
6. Потапов В.А. Качество жизни у женщин с сочетанными гиперпролиферативными процессами женской репродуктивной сферы / В.А. Потапов, В.И. Ивах, Ю.В. Донская Н.В. Симонова, М.В. Медведев // Таврический медико-биологический вестник - 2013 - T. 16, ч. 1 (62) № 2. - C. 188-189.

7. Sabry M. Innovative Oral Treatments of Uterine leiomyoma //Obstetrics Gynecology International. - 2012. P. 1-10.
8. Garry R. Whych hysterectomy? A detailed comprasion of laparoscopic, vaginal and abdominal hysterectomy. Menorrhagia. / R. Garry, S. Shett, C. Sutton // Iss Medical Media Ltd. 1999. - P. 239-252.

9. Hysterectomy, oophorectomy and endogenous sex hormone levels in older women: the Rancho Bernardo Study / G.A. Laughlin, E. Barrett-Connor, D. Kritz-Silverstien, D. von Muhlen / J. Clin. Endjcrinol. Metab. - 2000. Vol. 85. - P. 645. 


\title{
Роль медико-социальных и психологических факторов в отягощенном репродуктивном анамнезе
}

\author{
А.А. Довгань \\ Национальная медицинская академия последипломного образования имени П.Л. Шупика, г. Киев
}

Цель исследования: изучение роли медико-социальных и психологических факторов в отягощенном репродуктивном анамнезе.

Материалы и методы. Для определения медико-социальных и психологических факторов, способствующих потере беременности, проводили анализ материалов анкетирования 228 пациенток, имеющих самопроизвольные аборты, с помощью специально разработанных авторами стандартизированных анкет (1-я группа). Для сравнения на вопросы анкет ответили 132 женщины с нормально протекавшей и закончившейся рождением живого доношенного ребенка беременностью (2-я группа).

Результаты. Установлено наличие особенностей структуры, сроков и механизма прерывания беременности, изменений медико-социального портрета и состояния репродуктивного здоровья пациенток с невынашиванием беременности. В механизме самопроизвольного прерывания беременности преобладает инфекционно-воспалительный генез. Достоверно уменьшилась доля пациенток раннего и позднего репродуктивного возраста, занятых на промышленном производстве и учащихся, увеличилось количество домохозяек, женщин, имеющих сексуальный дебют до 18 лет, хронические воспалительные заболевания половых органов, генитальную микоплазменную и герпетическую инфекцию, опухолевидные образования яичников. Реализации самопроизвольного аборта способствуют следующие факторы: некомфортные жилищные условия; низкий уровень дохода семьи; производственные вредности, преимущественно психоэмоциональное напряжение в процессе повседневной трудовой деятельности; воздействие продуктов промышленного производства; невыполнение рекомендаций врача вследствие финансового неблагополучия и т.д.

Заключение. Полученные результаты необходимо учитывать при разработке алгоритма диагностических и лечебно-профилактических мероприятий.

Ключевые слова: самопроизвольный аборт, медико-сочиальные аспекты.

$\Pi$ роблема невынашивания беременности (НБ) продолжает сохранять свою актуальность и приоритетность в современном акушерстве. Обусловлено это, прежде всего, тем, что НБ является одной из главных составляющих репродуктивных потерь [1-6]. Так, от 15\% до 25\% всех зарегистрированных беременностей прерываются самопроизвольно, при этом 5-20\% приходится на долю привычного НБ, а 80\% беременностей прерываются до 12 нед [3-6].

В последние годы отмечен рост частоты самопроизвольных абортов (CA) [1-6]. Кроме того, каждый эпизод СА усугубляет имеющиеся нарушения репродуктивного здоровья (Р3) женщины [5, 6]. В то же время, сохранение и восстановление Р3 населения - важнейшее направление государственной политики в области улучшения демографической ситуации в стране. При этом первой задачей остается повышение качества и доступности медицинской помощи женщинам и детям.

Проблеме НБ посвящены многие фундаментальные исследования [1-6]. Однако целый ряд вопросов до сих пор остается нерешенным.

Цель исследования: изучение медико-социальных и психологических особенностей РЗ женщин с СА в анамнезе.

\section{МАТЕРИАЛЫ И МЕТОДЫ}

В соответствии с поставленной целью - для изучения медико-социальных факторов пациенток, способствующих реализации СА, использовали социологический метод в форме стандартизированного интервью. С целью определения медико-социальных и психологических факторов, способствующих потере беременности, проводили анализ материалов анкетирования 228 пациенток, имеющих СА, с помощью специально разработанных авторами стандартизированных анкет (1-я группа). Для сравнения на вопросы анкет ответили 132 женщины с нормально протекавшей и закончившейся рождением живого доношенного ребенка беременностью (2-я группа).

Критерии исключения: пациентки с тяжелой экстрагенитальной патологией, являющейся противопоказанием для наступления и пролонгирования беременности; имеющие беременность после применения вспомогательных репродуктивных технологий; не давшие информированного согласия на участие в исследовании.

\section{РЕЗУЛЬТАТЫ ИССЛЕДОВАНИЯ И ИХ ОБСУЖДЕНИЕ}

Клинико-статистический анализ историй болезни женщин с самопроизвольным прерыванием беременности сроком до 22 нед выявил следующие особенности.

Средний возраст пациенток с НБ составляет сегодня $27,9 \pm 2,8$ года, достоверно реже встречаются женщины раннего и позднего репродуктивного возраста. Претерпел изменения и социальный статус пациенток с НБ. Достоверно уменьшилось число женщин, занятых на промышленном производстве и учащихся, достоверно увеличилось количество домохозяек, несущественно возросло число женщин, занятых частной предпринимательской деятельностью. Две трети пациенток имеют хроническую соматическую патологию, нередко сочетанную, структура которой за последние 10 лет не изменилась. Сегодня у 1,4\% исследуемого контингента зарегистрирована ВИЧ-инфекция. Несмотря на некоторое уменьшение среднего возраста менархе, у 9,4\% пациенток менструация начинается позже 16 лет, что достоверно чаще, чем в прошлом десятилетии $(\mathrm{p}=0,050)$.

Если в последнем десятилетии прошлого века каждая третья пациентка с НБ имела сексуальный дебют до 18 лет 


\section{ГИН Е К О ЛОГИЯ}

и вне брака, то сегодня в такой ситуации находится практически каждая вторая. В дальнейшем каждая четвертая пациентка с НБ имеет незарегистрированный брак. Особенности полового поведения приводят к неуклонному росту гинекологических заболеваний. Сегодня $60,3 \%$ женщин, страдающих НБ, указывают на наличие хронических заболеваний в анамнезе, 70,4\% - на перенесенные ИППП. Достоверно увеличилась частота опухолевидных образований яичников, хронических воспалительных заболеваний половых органов, обусловленных инфицированием генитальной микоплазмой, ВПГ-1,-2, ЦМВ

Наметились положительные тенденции в отношении использования средств контрацепции: сегодня их использует каждая вторая пациентка с НБ, в то время как 10 лет назад - только каждая четвертая $(\mathrm{p}=0,000)$. При этом сегодня в 2 раза чаще пациентки отдают предпочтение гормональной контрацепции, достоверно реже применяют внутриматочные контрацептивы, в 4 раза чаще используют барьерные методы предупреждения нежелательной беременности.

На современном этапе несмотря на бесспорное увеличение числа женщин, использующих различные методы контрацепции, как и в предыдущем десятилетии, каждая четвертая пациентка с НБ прерывает первую беременность путем хирургического аборта. В то же время, регистрируют достоверное снижение частоты повторных хирургических абортов. Имеется тенденция к увеличению частоты самопроизвольного прерывания первой беременности, к уменьшению частоты привычного НБ, достоверно реже встречаются пациентки с тремя и более СА. По-видимому, это связано с совершенствованием методов диагностики причин НБ, предгравидарной подготовки и планированием последующей беременности. Частота СА после преодоленного первичного бесплодия достоверно снизилась, очевидно, за счет современных профилактических и лечебных мероприятий при наступлении беременности.

На современном этапе у 51,5\% женщин СА происходит на сроке 5-8 нед, что достоверно чаще по сравнению с предыдущим периодом исследования $(\mathrm{p}=0,000)$. Только у $10,2 \%$ наблюдаются поздние СА (в 2 раза реже, чем в предыдущее десятилетие).

Сегодня мы наблюдаем изменение структуры СА: достоверное увеличение частоты неразвивающейся беременности до $67,3 \%$ (против $25,1 \%$ в предыдущий период исследования; $\mathrm{p}=0,007)$, что, возможно, связано с особенностями полового поведения пациенток.

При патоморфологическом исследовании абортного материала в 98,9\% случаев регистрируют воспалительные изменения хориальной ткани, децидуальной оболочки, эндометрия, что достоверно чаще, чем в предыдущем десятилетии $(\mathrm{p}=0,000)$. Это позволяет заключить, что в механизме самопроизвольного прерывания беременности на современном этапе преобладает инфекционно-воспалительный генез.

Проведенное исследование позволило установить, что реализации СА способствуют следующие факторы: социальные - некомфортные жилищные условия, низкий уровень дохода семьи; производственные - производственные вредности (преимущественно психоэмоциональное напряжение в процессе повседневной трудовой деятельности), воздействие продуктов промышленного производства (загазованность, электромагнитное излучение, вибрация, радиационный фактор); психологические - сильные переживания по поводу рядовых конфликтных ситуаций в семье, снятие стресса путем табакокурения, гигиенические - отсутствие регулярного че- тырехразового питания, пренебрежение горячей пищей домашнего приготовления, низкая физическая активность и табакокурение до наступления данной беременности, безразличное отношение к курению супруга и коллег по работе; медицинские - незапланированная беременность, отсутствие предгравидарной подготовки, невыполнение рекомендаций врача вследствие финансового неблагополучия и т.д.

Анализ материалов анкетирования показал, что женщины, перенесшие СА, имеют психосоциальные особенности. Они достоверно чаще отмечают общую слабость, снижение работоспособности, плохое настроение $(\mathrm{p}=0,000)$, чувство обессиленности $(\mathrm{p}=0,003)$ и измученности $(p=0,000)$, тревогу за свое здоровье $(p=0,045)$, потребность в общении с врачом $(\mathrm{p}=0,006)$, чем пациентки с нормально протекающей беременностью. Женщины с НБ значительно реже чувствуют себя бодрыми и полными сил. Все перечисленное выше резко ограничивает их привычный круг общения $(\mathrm{p}=0,038)$.

При сравнении тех же показателей у женщин с однократно прервавшейся беременностью и с привычным НБ выявлены следующие особенности. Пациенток с несколькими выкидышами в анамнезе в большей степени беспокоят общая слабость, быстрая утомляемость, снижение работоспособности $(\mathrm{p}=0,042)$ и настроения, ослабление памяти $(\mathrm{p}=0,014)$, чувство измученности. У данной категории женщин достоверно чаще возникают ссоры с друзьями и супругом $(\mathrm{p}=0,024)$, они выше оценивают потребность в общении с врачом. Обращает на себя внимание низкий показатель физической активности этих пациенток, выраженные трудности при выполнении привычной работы ( $\mathrm{p}=0,045)$, что значительно их тяготит. Отмечено снижение профессиональных возможностей $(\mathrm{p}=0,050)$, при этом часть опрошенных указывают на необходимость профессионального перепрофилирования

\section{выводы}

Результаты проведенных исследований свидетельствуют о наличии особенностей структуры, сроков и механизма прерывания беременности, изменений медико-социального портрета и состояния репродуктивного здоровья пациенток с невынашиванием беременности (НБ). В структуре самопроизвольных абортов наблюдается достоверное увеличение доли неразвивающейся беременности, выкидышей на сроках 5-8 нед и уменьшение частоты поздних выкидышей. Имеется тенденция к увеличению частоты самопроизвольного прерывания первой беременности, к уменьшению частоты привычного НБ, достоверно реже встречаются пациентки с тремя и более выкидышами, а также с самопроизвольным абортом после преодоления первичного бесплодия. В механизме самопроизвольного прерывания беременности преобладает инфекционно-воспалительный генез. Достоверно уменьшилась доля пациенток раннего и позднего репродуктивного возраста, занятых на промышленном производстве и учащихся, увеличилось количество домохозяек, женщин, имеющих сексуальный дебют до 18 лет, хронические воспалительные заболевания половых органов, генитальную микоплазменную и герпетическую инфекцию, опухолевидные образования яичников. Достоверно чаще пациентки используют контрацепцию, реже прибегают к повторным хирургическим абортам. Реализации самопроизвольного аборта способствуют социальные, производственные, гигиенические и медицинские факторы. Полученные результаты необходимо учитывать при разработке алгоритма диагностических и лечебно-профилактических мероприятий. 


\section{ГИН Е КО ЛОГИЯ}

\section{Роль медико-соціальних та психологічних Факторів в обтяженому репродуктивному анамнезі А.А. Довгань}

Мета дослідження: вивчення ролі медико-соціальних та психологічних факторів в обтяженому репродуктивному анамнезі. Матеріали та методи. Для визначення медико-соціальних та психологічних факторів, що зумовлюють втрату вагітності, проводили аналіз матеріалів анкетування 228 пацієнток, які мали мимовільні аборти, за допомогою спеціально розроблених авторами стандартизованих анкет (1-а група). Для порівняння на запитання анкет відповідали 132 жінки з нормальним перебігом вагітності, яка закінчилася народженням живої доношеної дитини (2-а група) Результати. Установлено наявність особливостей структури термінів і механізму переривання вагітності, змін медико-соціального портрета і стану репродуктивного здоров'я пацієнток 3 невиношуванням вагітності. У механізмі мимовільного переривання вагітності переважає інфекційно-запальний генез. Достовірно зменшилася доля пацієнток раннього і пізнього репродуктивного віку, що зайняті на промисловому виробництві і вчаться, збільшилася кількість домогосподарок, жінок, які мали сексуальний дебют до 18 років, хронічні запальні захворювання статевих органів, генітальну мікоплазменну і герпетичну інфекцію, пухлиноподібн утворення яєчників. Реалізацію мимовільного аборту зумовлюють наступні чинники: некомфортні житлові умови; низький рівень доходу сім'ї; виробничі шкідливості, переважно психоемоційне напруження у процесі повсякденної трудової діяльності; дія продуктів промислового виробництва; невиконання рекомендацій лікаря унаслідок скрутного фінансового становища та ін.

Заключення. Отримані результати необхідно враховувати при розробленні алгоритму діагностичних і лікувально-профілактичних заходів.

Ключові слова: мимовільний аборт, медико-соціальні аспекти.

\section{Role of medical-social and psychological factors in the burdened reproductive anamnesis A.A. Dovgan}

The objective: to show a role of medical-social and psychological factors in the burdened reproductive anamnesis.

Patients and methods. For definition of the medical-social and psychological factorspromoting loss of pregnancy, carried out the analysis of materials of questioning of 228 patients having spontaneous abortions, by means of standardised questionnaires specially developed by authors (1st group). For comparison questions of questionnaires were answered with 132 women with normally proceeding and ended with a birth live the child pregnancy (2nd group).

Results. Results of the spent researches testify to presence of features of structure, terms and the mechanism of interruption of pregnancy, changes of medical-social portrait and a condition of reproductive health of the patients suffering incompetent of pregnancy. In the mechanism of spontaneous interruption of pregnancy prevails infectious-inflammatory genesise. The share of patients of the early and late reproductive age occupied on industrial production and pupils has authentically decreased, the quantity of housewives, the women having a sexual debut till 18 years, chronic inflammatory diseases of genitals, genital micoplasma and virus-herpes infection, tumors formations of ovariums has increased. Realisations of spontaneous abortion promote following factors: social - not comfortable living conditions; low level of the income of a family; Industrial - industrial harm, mainly a psychoemotional pressure in the course of daily labour activity; influence of products of industrial production; default of recommendations of the doctor owing to financial trouble or insufficient competence of these recommendations. Conclusions. The received results are necessary for considering by working out of algorithm of diagnostic and treatment-and-prophylactic actions.

Key words: spontaneous abortion, medical-social aspects.

\section{Сведения об авторе}

Довгань Андрей Анатольевич - Национальная медицинская академия последипломного образования имени П.Л. Шупика, 04112, г. Киев, ул. Дорогожицкая, 9. E-mail: dovgan.a@mail.ru

\section{СПИСОК ЛИТЕРАТУРЫ}

1. Пестрикова Т.Ю. Перинатальные потери. Резервы снижения / Т.Ю. Пестрикова. - М.: Литтерра, 2012. - 208 с. 2. Подзолкова Н.М. Клинические и патогенетические аспекты неразвивающейся беременности / Н.М. Подзолкова, В.Г. Истратов, Т.В. Золотухина и др. // Российский вестник акушера-гинеколога. - 2009. - № 2. - С. 40-44.
3. Радзинский В.Е. Аборт - проблема национальной безопасности страны. Охрана репродуктивного здоровья будущее России / В.Е. Радзинский, М.Б. Хамошина, М.Г. Лебедева И.А. Чакчурина // Мат-лы Всероссийской конференции с международным участием, посвященные 10-летию кафедры акушерства и гинекологии мед. факультета Белгородского гос. университета. - Белгород, 2010. С. 165-167.

4. Радзинский В.Е. Неразвивающаяся беременность / В.Е. Радзинский, В.И. Димитрова, И.Ю. Майскова. М.: «ГЭОТАР-Медиа», 2009. - 196 с. 5. Радзинский В.Е. Прогнозы лечения невынашивания беременности в пер- вом-триместре прогестагенами В.Е. Радзинский, Е.Ю. Запертова, А.В. Миронов // Гинекология. - 2012. - T. 8, № 4. - С. 35-37.

6. Радзинский В.Е. Реабилитация репродуктивного здоровья после хирургического аборта / В.Е. Радзинский, С.М. Семятов // Гинекология. - 2013. - T. 8, № 1. - C. 5-9. 


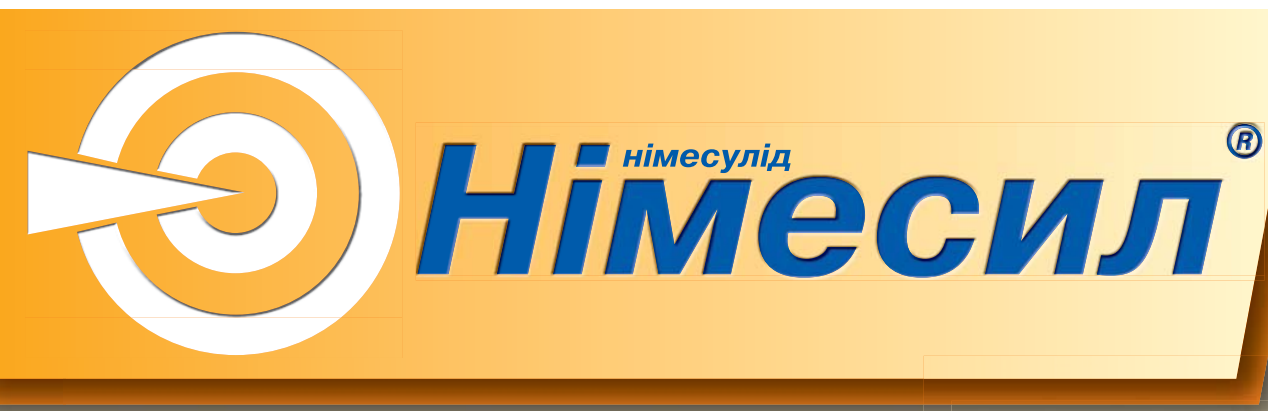

30 пакетиків, гранули для

оральної суспензії

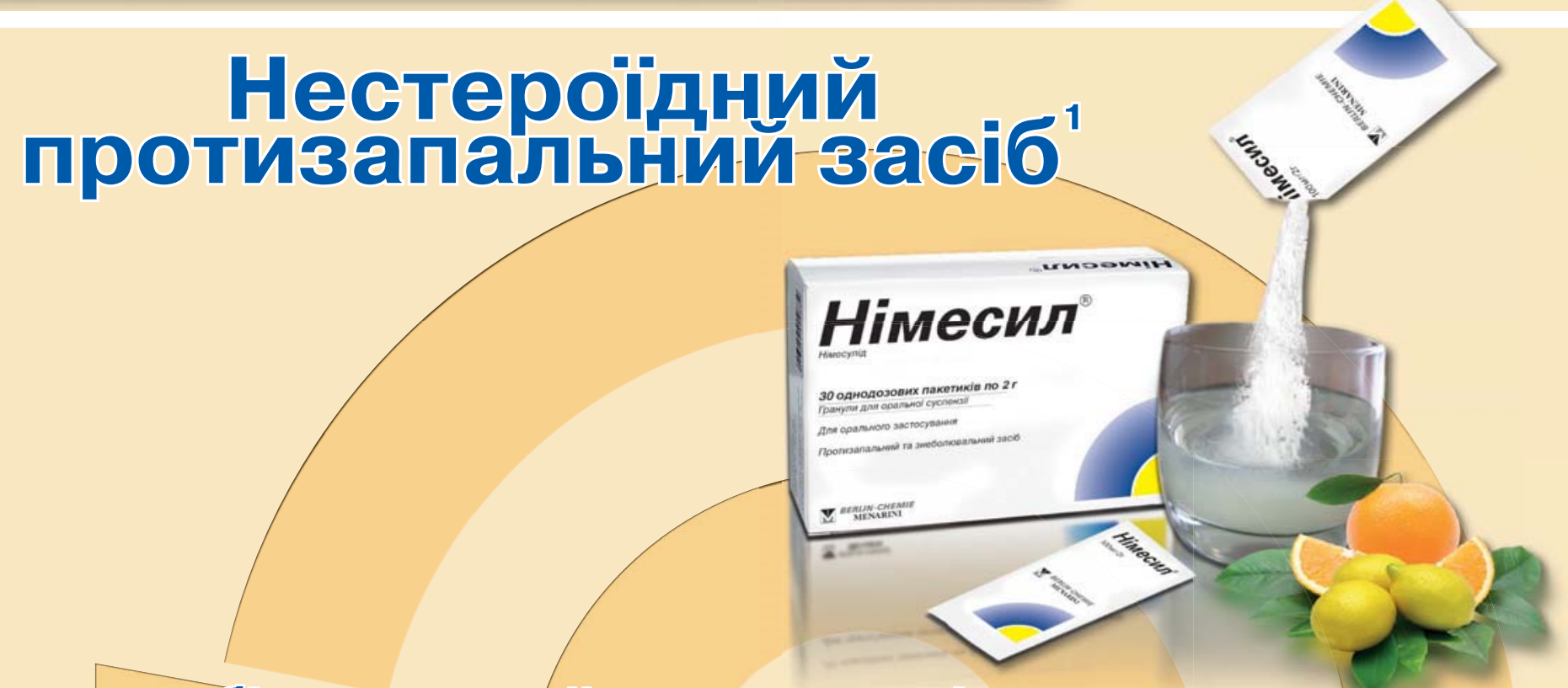

(2) більш-низький ризик гастроінтестинальних геморагічних-ускладнень у порівнянні 3 багатьма іншими НП3П

(2) інгібує колагеназу (до 91,9\%)

(2) інгібує IL-1 $\beta^{5^{*}}$, IL-6 (5,6, IL-8 $^{5^{*}}$ та субстанцію "P"6 (?) додаткове інгібування ФНП- $\alpha$ (до $70 \%)$

(у високих концентраціях)

Інформація про рецептурний лікарський засіб для професійної діяльності спеціалістів в галузі охорони здоров'я. Фармакотерапевтична група: нестероїдні протизапальні засоби. Код АТС М01А X17.

Склад: 1 однодозовий пакет по 2 г гранул містить німесуліду 100 мг.

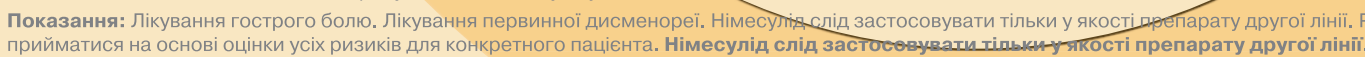

Спосіб застосування та дози. Дорослим та дітям старше 12 років призначають 100 мг німесуліду (1 однодозовий пакет) 2 рази на добу після іди. Максимальна тривалість курсу

лікування Німесилом - 15 діб.

Побічні діі. Анемія, еозинофілія, тромбоцитопенія, панщитопенія, пурпура, підвищена чутливість, анафілаксія, гіперкаліємія, відчуття страхуннНервозність, нічні жахливі сновидіння, запамороченн, головний біль, сонливість, енцефалопатія (синдром Рейє), нечіткий зір, вертиго (запаморочення), тахікардія, гіпертензія, геморагія, лабільність артеріального тиску, приливи, задишка, астма, бронхоспазм, діарея, нудота, блювання, запор, метеоризм, гастрит, кровотечі у травному тракті, виразка та перфорація 12 палої кишки або шлунка, біль у животі, диспепсія, стоматит, випорожнення чорного кольору, збільшення рівня ферментів печінки, гепатит, миттєвий (фульмінантний) гепатит, із летальним кінцем у тому числі,
жовтяниця, холестаз, свербіж, висип, підвищена пітливість, еритема, дерматит, кропив'янка, ангіоневротичинй набряк, набряк обличчя, еритема поліформна, синдром СтівенсаЖжовтниця, холестаз, свербіж, висип, підвищена пітливість, еритема, дерматит, кропив янка, ангіоневротичинй набряк, набряк обличчя, еритема поліформна, синдром Стівенсагіпотермія

Повний перелікпоказань, протипоказань, побічних ефектів, а також докладну інформацію про спосіб та особливості застосування препарату можна знайти в інструкції для медичного застосування препарату Німесил ${ }^{\varpi}$ від 16.04.2015 №222. Перед застосуванням та/або призначенням обов’язково уважно прочитайте цю інструкцію.

Виробник Німесил ${ }^{\bullet}$ Лабораторіос Менаріні С.А. Альфонс XII, 587, 08918 Бадалона, Іспанія. Файн Фудс енд Фармасьютикалз Н.Т.М. С.П.А. Віа дель артіджіанато, $8 / 10$ - 24041, Брембате (БГ), Італія.

1 І Інструкції для медичного застосування препарата Німесил ві від 16.04.2015 №222.

2 Laporte JR, lbanez L, Vidal X Vendrell Land Leone R. Upper Gastrointestinal Bleeding Associated with the Use of NSAIDs. Drug Safety 2004: 27 (6): 411-420.

${ }^{3}$ Castellsague J, Pisa F, Rosolen V. Drigo D, Riera-Guardia N, Giangreco M, Clagnan E, Tosolini F Zanier L Barbone F and Perez-Gutthann S, Risk of upper gastrointestinal complications in a cohort of users of nimesulide and other nonsteroidal anti-inflammatory drugs in Friuli Venezia Giulia, Italy. Pharmacoepidemiology and Drug Dafety 2013 Apr;22(4):365-75. doi: 10.1002/pds.3385. Epub 2012 Dec 11.

${ }^{4}$ Barracchini A, Franceschini N, Amicosante G, Oratore A, Minisola G, Pantaleoni G and Giulio di A. Can Non-steroidal Anti-inflammatory Drugs Act as Metalloproteinase Modulators? An In-vitro Study of Inhibition of Collagenase Activity. J. Pharm. Pharmacol. 1998, 50: 1417-1423, (адаптовано таб.1).

${ }_{5}^{5}$ Kimura T, Iwase M, Kondo G, Watanabe H, Ohashi M, Ito D, Nagumo M. Suppressive effect of selective cyclooxygenase-2 inhibitor on cytokine release in human neutrophils. Int Immunopharmacol. 2003 Oct, $3(10-11), 1519-28$.

${ }^{6}$ Bianchi M, Broggini M, Balzarini P, Franchi S, Sacerdote P. Effects of nimesulide on pain and on synovial fluid concentrations of substance P, interleukin- 6 and interleukin-8 in patients with knee

osteoarthritis: comparison with celecoxib. Int J Clin Pract. 2007 Aug;61(8):1270-7. Epub 2007 Jun 22. 


\section{пинлоберл}

\section{- ЗолотиЙ" Gтандарт}

\section{ПротивапальнОї терапII]}

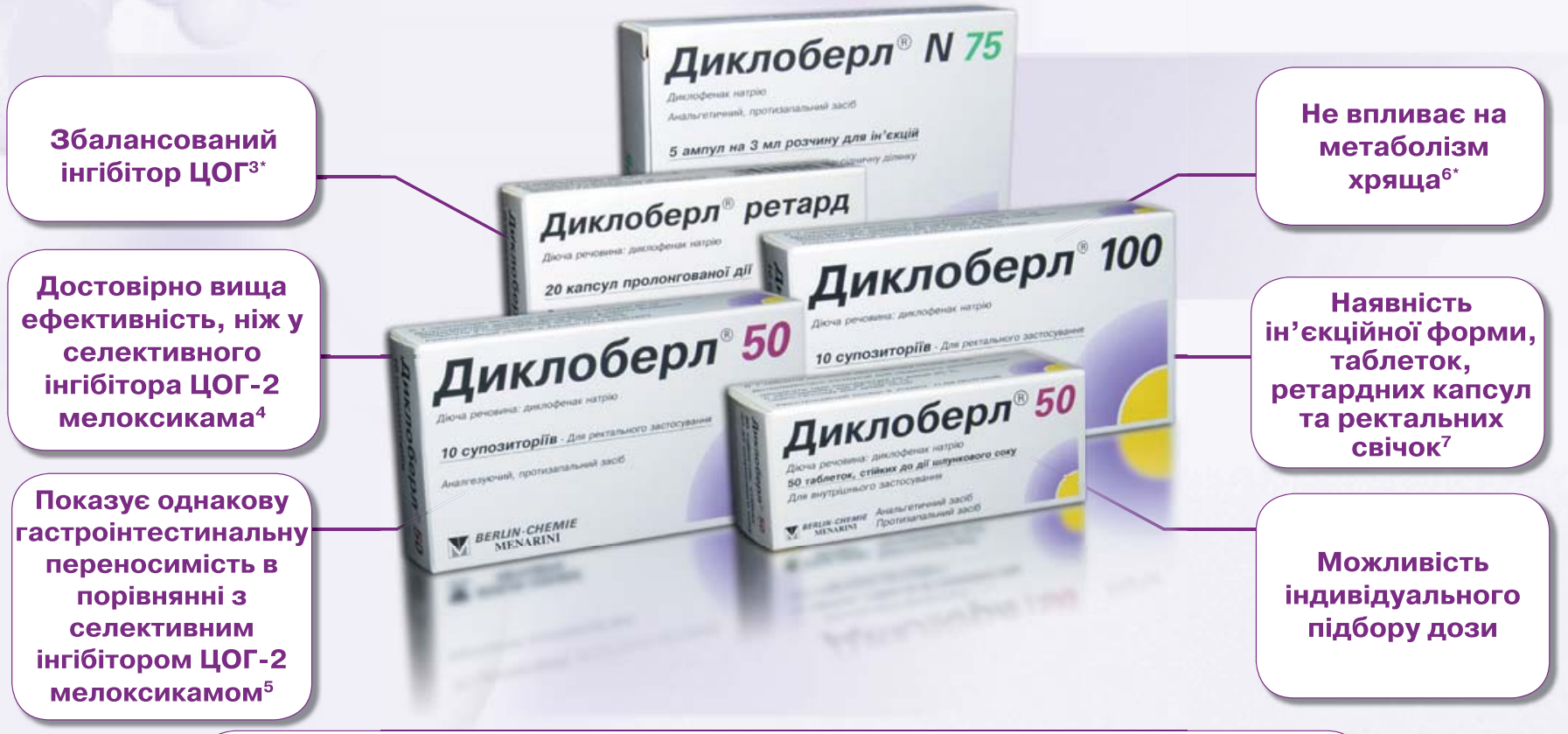

В комбінації з кардіопротекторними дозами АСК диклофенак показує низький ризик гастроінтестинальних ускладнень у порівнянні 3 іншими НПЗП (в тому числі селективними інгібіторами цОГ-2) ${ }^{8}$ 


\title{
Лапароскопическая хирургия в лечении тубоовариальных образований В I триместре беременности
}

\author{
Lucas Minig', Lucas Otaño², Pilar Cruz², María Guadalupe Patrono², Cecilia Botazzí2, Ignacio Zapardieß ${ }^{3}$ \\ ${ }^{1}$ Кафедра гинекологии, институт онкологии Валенсии, Валенсия, Испания, \\ ${ }^{2}$ Отделение акушерства и гинекологии Итальянской больницы, Буэнос-Айрес, Аргентина \\ ${ }^{3}$ Отделение акушерства и гинекологии, Ла-Пас, Университетская больница, Мадрид, Испания \\ Journal of Minimal Access Surgery |January-March 2016 | Volume 12 | Issue 1. Перевод - С.А. Шурпяк
}

\begin{abstract}
Цель исследования: оценить возможность и безопасность лапароскопических операций при тубоовариальных образованиях в I триместре беременности.

Материалы и методы. Обсервационное исследование с проспективным сбором данных, в которое включали всех беременных, оперированных лапароскопическим методом по поводу тубоовариальных образований в I триместре беременности в период с января 1999 года по ноябрь 2012 года в отделении акушерства и гинекологии Итальянской больницы Буэнос-Айреса, Аргентина.

Результаты. В общей сложности в исследование были включены 13 женщин. Средний срок гестации на момент хирургического вмешательства составлял 7 нед (диапазон: 5-12 нед). Основными показаниями к операции были: перекрут кисты в четырех случаях $(30,7 \%)$; разрыв кисты в четырех случаях $(30,7 \%)$. Другие показания включали персистенцию кист яичников у трех пациенток (23\%) и гетеротопическую беременность в двух случаях (15,3\%). В ходе наблюдения не было зафиксировано ни хирургических осложнений, ни прерываний беременности, послеоперационный период протекал без осложнений во всех случаях. Не было зафиксировано ни одного случая задержки внутриутробного роста и врожденных дефектов плода, преждевременных родов или неонатальных осложнений. Заключение. Лечение осложненных тубоовариальных образований лапароскопическим методом в I триместре беременности является безопасным как для матери, так и для плода. Однако необходимы дополнительные исследования с большим числом случаев для поддержки этих выводов.
\end{abstract}

Ключевые слова: тубоовариальные образования, I триместр, лапароскопия, киста яичников, беременность.

Ч астота тубоовариальних образований во время беременности колеблется в диапазоне от 1:81 до 1:8000 [1]. Несмотря на то что подавляющее большинство тубоовариальных образований диагностируют во время ультразвукового исследования в I триместре беременности, частота возникновения осложнений, требующих хирургического лечения, составляет 1-2\% [2]. Наиболее часто во время беременности выявляют дермоидные, функциональные кисты, серозные/муцинозные цистаденомы и эндометриомы [3]. Хотя эти операции традиционно выполняют лапаротомным методом, в последнее время продолжается дискуссия о роли лапароскопической хирургии в менеджменте тубоовариальных образований во время беременности [3]. Несмотря на известные преимущества малоинвазивной хирургии, применение во время беременности лапароскопии позиционируется с осторожностью как для матери, так и плода из-за возможных осложнений, таких, как гибель плода, пороки развития и преждевременные роды [4]. Эти осложнения приписывают эффекту пневмоперитонеума и потенциальному развитию ацидоза у плода, а также возможности повреждения беременной матки иглой Вереша, троакарами или хирургическими инструментами [5]. Тем не менее, нет убедительных опубликованных литературных данных, подтверждающих эти гипотезы.

Цель исследования: оценить целесообразность и безопасность лапароскопических вмешательств в менеджменте тубоовариальных образований в I триместре беременности.

\section{МАТЕРИАЛЫ И МЕТОДЫ}

Это обсервационное исследование с проспективным сбором данных, в которое были включены все беременные, которые подверглись лапароскопическим вмешательствам по поводу тубоовариальных образований в I триместре беременности в период с января 1999 года по ноябрь 2012 года в отделении акушерства и гинекологии Итальянской больницы Буэнос-Айреса, Буэнос-Айрес, Аргентина (The Italian Hospital of Buenos Aires, Buenos Aires, Argentina). Исследование было одобрено Институциональным наблюдательным советом больницы. Все пациентки подписали письменное информированное согласие. Возраст матери, гестационный срок на момент операции, тип хирургической процедуры, продолжительность операции, наличие хирургических осложнений, патогистологическое заключение, срок родов и масса тела плода при рождении получены из медицинской документации.

Оперативное лечение проводили под общим интубационным наркозом по ургентным показаниям в случае болевого синдрома и гемодинамической нестабильности, а также наличия персистирующих и болезненных тубоовариальных образований до 12 нед беременности. Лапароскопический доступ выполняли путем открытой 10-миллиметровой пупочной методики троакаром Hasson с использованием максимум трех дополнительных портов, которые размещали под прямым контролем зрения. Инсуфляцию $\mathrm{CO}_{2}$ в брюшную полость проводили до достижения давления 10-12 мм рт.ст. [3]. Интраоперационную капнографию проводили в течение всей операции [3], перевод в положение Тренделенбурга осуществляли медленно и осторожно до момента адекватной визуализации придатков. Свободную жидкость/кровь аспирировали, использовали монополярную и биполярную энергии, как и у небеременных пациенток. На завершающем этапе операции ткани удаляли с помощью эндо-бага. Ультразвуковое исследование проводили до операции и на этапе выписки из стационара. Для обезболивания в течение послеоперационного периода использовали кетопрофен (первоначально внутривенно, а затем в виде суппозиториев). До 12 нед беременности пациентки получали ежедневно 600 мг вагинального микронизированного прогестерона.

\section{РЕЗУЛЬТАТЫ ИССЛЕДОВАНИЯ И ИХ ОБСУЖДЕНИЕ}

У 13 пациенток были выполнены лапароскопические операции по поводу тубоовариальных новообразований до 12 нед беременности. Средний гестационый срок на момент 
З А Р БЕЖНЫЕ ИССЛЕДОВАНИЯ

Характеристики пациенток, хирургические и неонатальные исходы лапароскопической хирургии при тубоовариальных образованиях в I триместре беременности

\begin{tabular}{|c|c|c|c|c|c|c|c|c|c|}
\hline Случай & 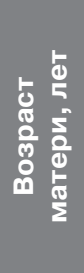 & 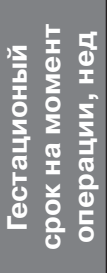 & 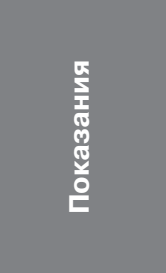 & 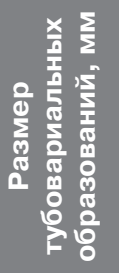 & 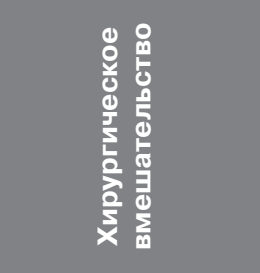 & 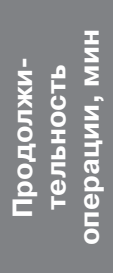 & 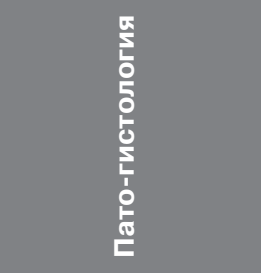 & 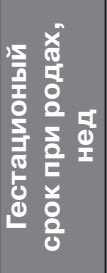 & 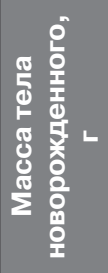 \\
\hline 1 & 29 & 5 & Ургентные & 55 & Цистэктомия & 40 & РГКЖТ & 39 & 3240 \\
\hline 2 & 41 & 5 & Ургентные & 40 & Цистэктомия & 50 & РГКЖТ & 38 & 3350 \\
\hline 3 & 38 & 7 & Ургентные & 35 & Сальпингэктомия & 35 & $\begin{array}{c}\text { Гетеротопическая } \\
\text { беременность }\end{array}$ & 37 & 3300 \\
\hline 4 & 36 & 7 & Ургентные & 60 & Цистэктомия & 40 & РГКЖТ & 39 & 3240 \\
\hline 5 & 30 & 7 & Ургентные & 65 & $\begin{array}{c}\text { Раскручивание + } \\
\text { цистэктомия }\end{array}$ & 60 & Эндометриома & 38 & 3660 \\
\hline 6 & 39 & 7 & Ургентные & 50 & Цистэктомия & 70 & $\begin{array}{c}\text { Серозная } \\
\text { цистаденома }\end{array}$ & 39 & 3350 \\
\hline 7 & 25 & 7 & Ургентные & 60 & $\begin{array}{c}\text { Раскручивание + } \\
\text { цистектомия }\end{array}$ & 25 & $\begin{array}{c}\text { Параовариальная } \\
\text { киста }\end{array}$ & 39 & 3310 \\
\hline 8 & 36 & 8 & Ургентные & 40 & Сальпингэктомия & 60 & $\begin{array}{c}\text { Гетеротопическая } \\
\text { беременность }\end{array}$ & 40 & 3845 \\
\hline 9 & 40 & 11 & Ургентные & 70 & Овариоэктомия & 60 & ГКЖТ & 39 & 3535 \\
\hline 10 & 28 & 12 & Ургентные & 65 & Овариоэктомия & 50 & ГКЖТ & 40 & 3280 \\
\hline 11 & 29 & 12 & $\begin{array}{l}\text { Персисти- } \\
\text { рование }\end{array}$ & 65 & Цистэктомия & 40 & Тератома & 40 & 3420 \\
\hline 12 & 35 & 12 & $\begin{array}{l}\text { Персисти- } \\
\text { рование }\end{array}$ & 50 & Цистэктомия & 50 & ГКЖТ & 40 & 4500 \\
\hline 13 & 31 & 12 & $\begin{array}{l}\text { Персисти- } \\
\text { рование }\end{array}$ & 75 & Цистэктомия & 40 & ГКЖТ & 41 & 3310 \\
\hline
\end{tabular}

Примечание: а - Перекрут придатков; ГКЖТ - геморрагическая киста желтого тела; РГКЖТ - разрыв геморрагической кисти желтого тела.

хирургической процедуры составлял 7 нед (диапазон: 5-12 нед).

Основными показаниями к операции были:

- перекрут кисты - в четырех случаях $(30,7 \%)$;

- разрыв кисты - в четырех случаях (30,7\%).

Другие показания включали персистенцию кист яичников у трех пациенток (23\%) и гетеротопическую беременность в двух случаях (15,3\%). Среднее время операции составило 50 мин (диапазон: 25-70 мин). Детальная информация о хирургических процедурах приведена в табл. 1. Случаи 9-й и 10-й потребовали проведения овариоэктомии в связи с геморрагической кистой желтого тела и возникновением кровотечения во время цистэктомии. Среднее время госпитализации составило 27 ч (диапазон: 15-36 ч). В послеоперационный период как у матери, так и у плода не было зарегистрировано никаких осложнений. Все беременности закончились срочными родами с рождением живых доношенных детей: в восьми случаях - вагинальными родами и в пяти - с помощью кесарева сечения. Не было зарегистрировано ни одного случая задержки внутриутробного развития, врожденных пороков развития или существенных неонатальных осложнений при наблюдении в течение 90 дней после рождения.

В данном исследовании установлено, что лапароскопические вмешательства при тубоовариальных новообразованиях в I триместре беременности безопасны и не имеют явных негативных последствий как для матери, так и для беременности или перинатальных исходов.

Хирургическим процедурам было уделено особое внимание во время исследования, поскольку они считаются потенциально рискованными для матери и плода, что связано с возможным возникновением ацидоза у плода из-за преобра- зования $\mathrm{CO}_{2}$ в угольную кислоту в материнском организме или возможной травмой беременной матки хирургическими инструментами, такими, как игла Вереша, что описывалось в литературе [5]. Тем не менее, исследования показали, что несмотря на абсорбцию $\mathrm{CO}_{2}$ с дальнешей эгодиффузией через плаценту он быстро удаляется вследствие гипердинамического статуса материнского кровотока. На сегодня нет доказательств негативного влияния пневмоперитонеума на мать или плод [6].

В нескольких эпидемиологических исследованиях [7, 8], в которых сравнивались результаты неонатальных и перинатальных исходов у женщин, перенесших лапаротомию и лапароскопию во время беременности, не выявлено никаких существенных различий в послеоперационных осложнениях или исходах беременности между обеими хирургическими методиками.

При отсутствии осложнений беременности II триместр считают самым безопасным временем для выполнения операции [9]. В этот период гестации частота спонтанного аборта ниже, чем в I триместре беременности, частота преждевременных родов ниже, чем в III триместре, в то же время размер матки все еще позволяет манипулировать в области придатков, теоретический риск тератогенеза очень низкий, а функциональные кисты яичников подвергаются спонтанной редукции [9]. Тем не менее, у некоторых пациенток с осложненными тубоовариальными образованиями, такими, как перекрут или разрыв кисты, требуется выполнение ургентных операций в I триместре беременности.

На сегодня в литературе представлены 12 сообщений о 144 клинических случаях лапароскопических вмешательств в I триместре беременности при наличии тубоова- 
З А Р УЕЖНЫЕ ИССЛЕДОВАН ИЯ

Лапароскопическая хирургия в лечении тубоовариальных образований в I триместре беременности

Таблица 2

\begin{tabular}{|c|c|c|c|}
\hline Автор & Год & Количество случаев & Исходы \\
\hline Mashiach и соавт. [10] & 1990 & 9 & Два спонтанных аборта, один ПРПО в 25 нед \\
\hline Busine and Mirullo [11] & 1993 & 3 & Без осложнений \\
\hline Morice и соавт. [12] & 1997 & 6 & Без осложнений \\
\hline Andreoli и соавт. 13] & 1999 & 3 & Без осложнений \\
\hline Soriano и соавт. [14] & 1999 & 39 & Два случая врожденных пороков \\
(1 - мягкая гипоспадия, 1 «заячья губа») \\
\hline Mathevet и соавт. [15] & 2003 & 17 & Без осложнений \\
\hline Purnichescu и соавт. [16] & 2006 & 8 & Без осложнений \\
\hline Ноng [17] & 2006 & 16 & Два спонтанных аборта \\
\hline Lenglet и соавт. 18] & 2006 & 12 & Без осложнений \\
\hline Аzuar и соавт. 19] & 2009 & 11 & Без осложнений \\
\hline Ко и соавт. [20] & 2009 & 11 & Без осложнений \\
\hline Сhang и соавт.[21] & 2011 & 9 & Один спонтанный аборт \\
\hline Данное исследование & 2015 & 157 & Без осложнений \\
\hline Общее число & & 9 & \\
\hline
\end{tabular}

Примечание. ПРПО - преждевременный разрыв плодных оболочек.

риальных образований. Как и в данном исследовании, в публикациях отмечается очень низкая частота интраоперационных и послеоперационных осложнений [10-21]. Soriano и соавторы сообщили о результатах 93 хирургических вмешательств у беременных с тубоовариальными образованиями, 39 из которых были выполнены лапароскопическим методом в I триместре беременности [14]. Среди 39 лапароскопических вмешательств зафиксированы два случая рождения детей с врожденными пороками (мягкая гипоспадия, «заячья губа»), частота которых не отличалась как от наблюдаемых при выполнении лапаротомии в I и II триместрах [14], так и регистрируемых в общей популяции (табл. 2).

Основные рекомендации по выполнению лапароскопических операций при беременности включают в себя следующее [9]:

(A) дорсальное литотомическое положение для операции, выполняемой во время I триместра, и небольшой левый боковой наклон при выполнении операций во II триместре беременности для уменьшения компрессии полой вены;

(Б) следует избегать накладывания инструментов на шейку матки;

(C) пупочная открытая минилапаротомия является предпочтительным методом во избежание ранения матки. В случае увеличенной беременной матки следует выполнять супраумбиликальный срединный разрез без использования иглы Вереша;

(Г) внутрибрюшное давление должно быть менее 12 мм рт.ст., чтобы свести к минимуму продолжительность операции, манипуляции с маткой и потерю крови.

Основным ограничением данного исследования является небольшое число случаев. Однако трудно накопить достаточно данных, чтобы провести более широкомасштабное исследование, так как случаи осложненных тубоовариальных образований при беременности диагностируют редко и ведут по возможности консервативно. Координированная международная онлайн регистрация может быть хорошей стратегией для сбора данных и перспективной для оценки риска, связанного с лапароскопическими вмешательствами во время беременности. Другим ограничением является отсутствие надлежащей информации о дальнейшем психофизическом развитии новорожденных.

\section{Выводы}

Хотя данные относительно лапароскопических вмешательств не получены в ходе рандомизированных контролируемых исследований, а основаны на результатах клинической практики и обзоре литературы, использование лапароскопического метода при тубоовариальных образованиях в I триместре беременности представляется безопасной процедурой для матери и плода. Однако важно учитывать возможность погрешностей анализа публикаций, так как случаи, в которых наблюдались осложнения, могли не публиковаться. Для сведения к минимуму возможных осложнений хирургам следует принимать во внимание особенности хирургической техники при операции у беременных.

\section{Лапароскопічна хірургія у лікуванні тубооваріальних утворень у I триместрі вагітності Lucas Minig, Lucas Otaño, Pilar Cruz, María Guadalupe Patrono, Cecilia Botazzi, Ignacio Zapardiel}

Мета дослідження: оцінити можливість і безпеку лапароскопічних операцій у разі тубооваріальних утворень у I триместрі вагітності.

Матеріали та методи. Обсерваційне дослідження з проспективним збиранням даних, в яке включали всіх вагітних, прооперованих лапароскопічним методом з приводу тубооваріальних утворень у I триместрі вагітності у період з кінця січня 1999 року до листопада 2012 року у відділенні акушерства і гінекології Італійської лікарні Буенос-Айреса, Аргентина

Результати. У дослідження були включені 13 жінок. Середній термін гестації на момент хірургічного втручання становив 7 тиж (діапазон: 5-12 тиж). Основними показаннями до операції були: перекрут кісти у чотирьох випадках (30,7\%); розрив кісти у чотирьох випадках (30,7\%). Інші показання включали персистенцію кіст яєчників у трьох пацієнток (23\%) і гетеротопічну вагітність у двох випадках (15,3\%). У ході спостереження не було зафіксовано ні хірургічних ускладнень, ні переривань вагітності, післяопераційний період проходив без ускладнень у всіх випадках. Не було зафіксовано жодного випадку затримки внутрішньоутробного росту і вроджених дефектів плода, передчасних пологів або неонатальних ускладнень.

Заключення. Лікування ускладнених тубооваріальних утворень лапароскопічним методом у I триместрі вагітності є безпечним як для матері, так і для плода. Однак необхідні додаткові дослідження 3 великою кількістю випадків для підтримки цих висновків.

Ключові слова: тубооваріальні утворення, I триместр, лапароскопія, кіста яєчників, вагітність. 


\section{З АРУБЕЖНЫЕ ИССЛЕДОВАНИЯ}

\section{Laparoscopic surgery for treating adnexal masses during the first trimester of pregnancy Lucas Minig, Lucas Otaño, Pilar Cruz, María Guadalupe Patrono, Cecilia Botazzi, Ignacio Zapardiel}

The objective: to evaluate the feasibility and safety of laparoscopic surgery for treating adnexal masses during the first trimester of pregnancy.

Patients and methods. An observational study of a prospective collection of data of all pregnant women who underwent laparoscopic surgery for adnexal masses during the first trimester of pregnancy between January 1999 and November 2012 at the Obstetrics and Gynecology Department of the Italian Hospital of Buenos Aires, Buenos Aires, Argentina was performed.

Results. A total of 13 women were included. The median (range) gestational age at the moment of surgical procedure was 7 weeks (range:

\section{СПИСОК ЛИТЕРАТУРЫ}

1. Leiserowitz G. Managing ovarian masses during pregnancy. Obstet Gynecol Surv 2006;61:463-70.

2. Yuen PM, Chang AM. Laparoscopic management of adnexal mass during pregnancy. Acta Obstet Gynecol Scand 1997;76:173-6.

3. Hoover K, Jenkins TR. Evaluation and management of adnexal mass in pregnancy. Am J Obstet Gynecol 2011;205:97-102.

4. Amos JD, Schorr SJ, Norman PF Poole GV, Thomae KR, Mancino AT, et al. Laparoscopic surgery during pregnancy. Am J Surg 1996;171:435-7. 5. Whiteside J, Keup H. Laparoscopic management of the ovarian mass: A practical approach. Clin Obstet Gynecol 2009:53:327-34.

6. Fatum M, Rojansky N. Laparoscopic surgery during pregnancy. Obstet Gynecol Surv 2001;56:50-9.

7. Reedy MB, Källén B, Kuehl TJ.
Laparoscopy during pregnancy: A study of five fetal outcome parameters with use of the Swedish Health Registry. Am J Obstet Gynecol 1997;177:673-9.

8. Mazze Rl, Källén B. Reproductive outcome after anesthesia and operation during pregnancy: A registry study of 5405 cases. Am J Obstet Gynecol 1989;161:1178-85.

9. Al-Fozan H, Tulandi T. Safety and risks of laparoscopy in pregnancy. Curr Opin Obstet Gynecol 2002;14:375-9.

10. Mashiach S, Bider D, Moran 0 Goldenberg M, Ben-Rafael Z. Adnexa torsion of hyperstimulated ovaries in pregnancies after gonadotropin therapy. Fertil Steril 1990;53:76-80. 11. Busine A, Murillo D. Conservative laparoscopic treatment of adnexal torsion during pregnancy. J Gynecol Obstet Biol Reprod (Paris) 1994; 23: 918-21. 12. Morice $P$, Louis-Sylvestre $C$, Chapron C, Dubuisson JB. Laparoscopy

5-12 weeks). The main indication of surgery was cyst torsion in four cases $(30.7 \%)$ and rupture of ovarian cysts in four cases $(30.7 \%)$. Other indications included persistent ovarian cyst in three patients (23\%) and heterotopic pregnancy in two cases (15.3\%). Neither surgical complications nor spontaneous abortions occurred in any of the cases and the post-operative period was uneventful in all the cases. No cases of intrauterine growth retardation, preterm delivery, congenital defects, or neonatal complications were registered.

Conclusion. The treatment of complicated adnexal masses by laparoscopic surgery during the first trimester of pregnancy appears to be a safe procedure both for the mother and for the foetus. Additional research on a larger number of cases is stil needed to support these conclusions.

Key words: adnexal masses, first trimester, laparoscopy, ovarian cyst, pregnancy.

for adnexal torsion in pregnant women. J Reprod Med 1997;42:435-9.

13. Andreoli M, Servakov M, Meyers $P$, Mann WJ Jr. Laparoscopic surgery during pregnancy. J Am Assoc Gyneco Laparosc 1999;6:229-33.

14. Soriano $D$, Yefet $Y$, Seidman $D$, Goldenberg M, Mashiach S, Oelsner G. Laparoscopy versus laparotomy in the management of adnexal masses during pregnancy. Fertil Steril 1999; 71: 955-60. 15. Mathevet P, Nessah K, Dargent D, Mellier G. Laparoscopic management of adnexal masses in pregnancy: A case series. Eur J Obstet Gynecol Biol 2003; 108:217-22

16. Purnichescu V, Cheret-Benoist A Von Theobald P, Mayaud A Herlicoviez M, Dreyfus M. Laparoscopic management of pelvic mass in pregnancy. J Gynecol Obstet Biol Reprod (Paris) 2006;35:388-95.

17. Hong JY. Adnexal mass surgery and anesthesia during pregnancy: A 10-year retrospective review. Int $\mathrm{J}$ Obstet Anesth 2006;15:212-6.

18. Lenglet $Y$, Roman $\mathrm{H}$, Rabishong $\mathrm{B}$, Bourdel N, Bonnin M, Bolandard F, et al. Laparoscopic management of ovarian cysts during pregnancy. Gynecol Obstet Fertil 2006;34:101-6.

19. Azuar AS, Bouillet-Dejou L, Jardon K, Lenglet $\mathrm{Y}$, Canis $\mathrm{M}$, Bolandard $\mathrm{F}$, et al. Laparoscopy during pregnancy: Experience of the French university hospital of Clermont-Ferrand. Gynecol Obstet Fertil 2009; 37: 598-603.

20. Ko ML, Lai TH, Chen SC. Laparoscopic management of complicated adnexal masses in the first trimester of pregnancy. Fertil Steril 2009;92:283-7.

21. Chang SD, Yen CF, Lo LM, Lee CL, Liang CC. Surgical intervention for maternal ovarian torsion in pregnancy. Taiwan $\mathrm{J}$ Obstet Gynecol 2011; 50: 458-62. 


\title{
Laparoscopic surgery for treating adnexal masses during the first trimester of pregnancy
}

\author{
Lucas Minig1, Lucas Otaño², Pilar Cruz², María Guadalupe Patrono², Cecilia Botazzí2, Ignacio \\ Zapardie/ ${ }^{3}$ \\ ${ }^{1}$ Department of Gynecology, Valencian Institute of Oncology (IVO), Valencia, Spain, \\ ${ }^{2}$ Department of Obstetrics and Gynecology, Hospital Italiano de Buenos Aires, Buenos Aires, Argentina, \\ ${ }^{3}$ Department of Obstetrics and Gynecology, La Paz University Hospital, Madrid, Spain \\ [Downloaded free from http://wrew.journalofmas.com on Friday, October 07, 2016, IP: 176.8.88.109]
}

\begin{abstract}
The objective: to evaluate the feasibility and safety of laparoscopic surgery for treating adnexal masses during the first trimester of pregnancy.

Patients and methods. An observational study of a prospective collection of data of all pregnant women who underwent laparoscopic surgery for adnexal masses during the first trimester of pregnancy between January 1999 and November 2012 at the Obstetrics and Gynecology Department of the Italian Hospital of Buenos Aires, Buenos Aires, Argentina was performed. Results. A total of 13 women were included. The median (range) gestational age at the moment of surgical procedure was 7 weeks (range: 5-12 weeks). The main indication of surgery was cyst torsion in four cases $(\mathbf{3 0 . 7 \% )}$ ) and rupture of ovarian cysts in four cases $\mathbf{( 3 0 . 7 \% )}$ ). Other indications included persistent ovarian cyst in three patients (23\%) and heterotopic pregnancy in two cases (15.3\%). Neither surgical complications nor spontaneous abortions occurred in any of the cases and the post-operative period was uneventful in all the cases. No cases of intrauterine growth retardation, preterm delivery, congenital defects, or neonatal complications were registered. Conclusion. The treatment of complicated adnexal masses by laparoscopic surgery during the first trimester of pregnancy appears to be a safe procedure both for the mother and for the foetus. Additional research on a larger number of cases is stil needed to support these conclusions.
\end{abstract}

Key words: adnexal masses, first trimester, laparoscopy, ovarian cyst, pregnancy.

$\mathrm{T}$ he incidence of adnexal masses during pregnancy can range between 1:81 and 1:8,000 [1]. Despite the fact that a great majority of the adnexal masses are diagnosed at the time of a first trimester ultrasound, it is estimated that over $1-2 \%$ of them will become symptomatic during the first trimester of pregnancy and they will develop complications that will require surgical treatment [2]. The most common causes of ovarian masses during pregnancy include dermoid cyst, functional cysts, serous/mucinous cistoadenoma and endometrioma [3]. Even though surgery has been traditionally performed by laparotomy, recently there has been a great debate about the role of laparoscopy in the management of adnexal masses in pregnancy [3]. Despite the wellknown advantages of minimally invasive surgery, caution with laparoscopic surgery has been suggested for both the mother and the foetus due to complications such as foetal loss, malformation and preterm birth [4]. These negative effects are attributed to the effects of a pneumoperitoneum and the potential foetal acidosis; possible injury to the gravid uterus by a Veress needle, trocar, or surgical instrument; and the possible injection of carbon dioxide $\left(\mathrm{CO}_{2}\right)$ into the uterine cavity [5].

This is an open access article distributed under the terms of the Creative Commons Attribution-NonCommercialShareAlike 3.0 License, which allows others to remix, tweak, and build upon the work non-commercially, as long as the author is credited and the new creations are licensed under the identical terms. Laparoscopy for adnexal mass in pregnancy in the literature confirming these hypotheses.

The objective: of this study was to evaluate the feasibility and safety of laparoscopic surgery for treating adnexal masses during the first trimester of pregnancy.

\section{MATERIALS AND METHODS}

This is an observational study of a prospective collection of data of all pregnant women who underwent laparoscopic surgery for adnexal masses during the first trimester of pregnancy between January 1999 and November 2012 at the Obstetrics and Gynecology Department of the Italian Hospital of Buenos Aires, Buenos Aires, Argentina. The study was approved by the Institutional Review Board of the hospital. All the patients signed a written informed consent form. The maternal age, gestational age at surgery, type of surgical procedure, length of surgery, surgical complications, pathology report, gestational age at birth and birth weight were extracted from the records.

Surgery was indicated under emergency condition in case of uncontrollable pain and haemodynamic instability. Patients were also included in cases of persistent and painful adnexal mass at 12 weeks of gestation. All the patients underwent general anaesthesia with curarisation and endotracheal intubation. An open 10-mm umbilical laparoscopy technique with Hasson's trocar was performed with a maximum of three additional ports that were placed under direct vision. Abdominal insufflation with $\mathrm{CO}_{2}$ between $10 \mathrm{~mm}$ and $12 \mathrm{~mm}$ of mercury was used. Intraoperative capnography was used during the entire procedure [3] and the patient was placed slowly and carefully in Trendelenburg position until the adnexa was visible. Free fluid/blood was initially aspirated and surgery was performed with monopolar and bipolar energy as in the non-pregnant patients. Finally, all the specimens were removed by using a laparoscopic endo-bad. Foetal ultrasound was performed before the procedure and before hospital discharge. Ketoprofen (initially intravenously and subsequently as a suppository) was used as an analgesic during the post-operative period. A volume of $600 \mathrm{mg}$ of vaginal micronized progesterone was administered daily until 12 weeks of gestation. No prophylactic antibiotics and venous thromboembolism prophylaxis were administered [3]. Women and newborns were followed up for 90 days after the delivery. Perioperative data were collected and a descriptive statistical analysis was done with the software SPSS 15.0 (SPSS Inc., Madrid, Community of Madrid, Spain). For the review of the literature, a MEDLINE search of all English language articles published between 1990 and 2014 containing the search terms 'pregnancy', 'first trimester', 'laparoscopy', 'adnexal mass' was performed. 
З А Р БЕЖНЫЕ ИССЛЕДОВАНИЯ

Patients' characteristics and surgical and neonatal outcomes of the laparoscopic surgery for adnexal mass performed during the first trimester of pregnancy

\begin{tabular}{|c|c|c|l|c|c|c|c|c|c|}
\hline Case & $\begin{array}{c}\text { Maternal } \\
\text { age, } \\
\text { (year }\end{array}$ & $\begin{array}{c}\text { GA at } \\
\text { surgery, } \\
\text { week }\end{array}$ & Indication & $\begin{array}{c}\text { Size of } \\
\text { adnexal } \\
\text { mass, } \mathbf{m m}\end{array}$ & $\begin{array}{c}\text { Surgical } \\
\text { treatment }\end{array}$ & $\begin{array}{c}\text { Duration } \\
\text { of sur- } \\
\text { gery, } \text { min }\end{array}$ & Pathology & $\begin{array}{c}\text { GA at } \\
\text { delivery, } \\
\text { week }\end{array}$ & $\begin{array}{c}\text { New bor } \\
\text { weight, } \\
\text { g }\end{array}$ \\
\hline 1 & 29 & 5 & Emergency & 55 & Cystectomy & 40 & RHCLC & 39 & 3240 \\
\hline 2 & 41 & 5 & Emergency & 40 & Cystectomy & 50 & RHCLC & 38 & 3350 \\
\hline 3 & 38 & 7 & Emergency & 35 & Salpingectomy & 35 & $\begin{array}{c}\text { Heterotopic } \\
\text { pregnancy }\end{array}$ & 37 & 3300 \\
\hline 4 & 36 & 7 & Emergency & 60 & Cystectomy & 40 & RHCLC & 39 & 3240 \\
\hline 5 & 30 & 7 & Emergency & 65 & $\begin{array}{c}\text { Detorsion }+ \\
\text { Cystectomy }\end{array}$ & 60 & Endometriosis & 38 & 3660 \\
\hline 6 & 39 & 7 & Emergency & 50 & Cystectomy & 70 & Serous & 39 & 3350 \\
\hline 7 & 25 & 7 & Emergency & 60 & $\begin{array}{c}\text { Detorsion }+ \\
\text { Cystectomy }\end{array}$ & 25 & Paratubal cyst & 39 & 3310 \\
\hline 8 & 36 & 8 & Emergency & 40 & Salpingectomy & 60 & $\begin{array}{c}\text { Heterotopic } \\
\text { pregnancy }\end{array}$ & 40 & 3845 \\
\hline 9 & 40 & 11 & Emergency & 70 & Oophorectomy & 60 & HCLC & 39 & 3535 \\
\hline 10 & 28 & 12 & Emergency & 65 & Oophorectomy & 50 & HCLC & 40 & 3280 \\
\hline 11 & 29 & 12 & Persistent & 65 & Cystectomy & 40 & Teratoma & 40 & 3420 \\
\hline 12 & 35 & 12 & Persistent & 50 & Cystectomy & 50 & HCLC & 40 & 4500 \\
\hline 13 & 31 & 12 & Persistent & 75 & Cystectomy & 40 & HCLC & 41 & 3310 \\
\hline
\end{tabular}

${ }^{a}$ Adnexal torsion, GA: Gestational age, RHCLC: Ruptured haemorrhagic corpus luteum cyst, HCLC: Haemorrhagic corpus luteum cyst.

\section{RESULTS AND DISCUSSION}

A total of 13 pregnant patients underwent laparoscopic surgery for complicated adnexal mass before 12 weeks of gestation (Table 1). The median (range) gestational age at the moment of surgical procedure was 7 weeks (range: 5 -12 weeks). The main indication of surgery was cyst torsion in four cases $(30.7 \%)$ and rupture of ovarian cysts in four cases (30.7\%). Other indications included persistent ovarian cyst in three patients (23\%) and heterotopic pregnancy in two cases (15.3\%). The median (range) surgical time was $50 \mathrm{~min}$.

The details of the surgical procedures performed are depicted in Table 1. Cases 9 and 10 required oophorectomy due to haemorrhagic corpus luteum cyst by uncontrollable ovarian bleeding at the time of cystectomy. The median (range) hospitalization time was $27 \mathrm{~h}$ (range: 15-36 h). No significant problems were registered for patients under post-surgery prenatal care. All the mothers delivered a full-term, healthy newborns by vaginal delivery in eight cases and by caesarean section in the remaining five cases. No cases of intrauterine growth retardation, congenital defects, or significant neonatal complications were registered at 90 days after birth.

The present study shows that laparoscopic surgery for complicated adnexal masses performed during the first trimester of pregnancy was safe and feasible with no apparent adverse effect on the mother, and the pregnancy or perinatal outcomes were also normal.

Surgical procedures in pregnant women have devoted special attention as they are assumed to be potentially risky for the mother and the foetus. Thus, concerns regarding laparoscopy associated with foetal acidosis because of maternal conversion of $\mathrm{CO}_{2}$ to carbonic acid or possible injury to the gravid uterus by surgical instrument such as a Veress needle were initially described [5]. However, studies have shown that even though there is maternal absorption of $\mathrm{CO}_{2}$ with diffusion across the placenta, it is rapidly removed by the hyperdynamic maternal circulation status. To date, there is no evidence to support any negative effect of $\mathrm{CO}_{2}$ pneumoperitoneum on neither the foetus nor the mother [6].

Several epidemiological studies [7,8], compared the results of foetal-neonatal and maternal outcomes in women who underwent laparotomy versus laparoscopy during pregnancy. These studies have found no significant differences in post-operative complications or pregnancy outcomes between both routes of surgery.

In the absence of any acute complications of pregnancy, the second trimester is recommended as the safest time to perform the surgery [9]. During this period, the spontaneous abortion rate is lower than that in the first trimester, the preterm delivery incidence is lower than that during the third trimester, the size of the uterus still allows the manipulation of the adnexa, the theoretical risk of teratogenesis is very low and functional ovarian cysts disappear spontaneously [9]. However, some patients with complicated adnexal masses such as adnexal torsion or ovarian cyst rupture do require emergency surgery during the first trimester of pregnancy. To date, there are 12 case series reporting on a total of 144 pregnant women with adnexal masses treated by laparoscopy during the first trimester of pregnancy [Table 2]. In accordance with our case series, the reported surgical and post-surgical pregnancy complications rates are very low [10-21]. Soriano et al. reported the results of 93 surgical interventions in pregnant women with suspected adnexal masses; 39 of them were performed by laparoscopy during the first trimester of pregnancy [14]. Within the group of laparoscopic procedures, the study reported cases of two newborns with congenital malformations, one with mild hypospadias and one with cleft lip. The incidence of those conditions was not different from that of procedures performed during the first and second trimester by laparotomy, ${ }^{[14]}$ nor different from the incidence of these conditions in the general population. A detailed summary of the main series reporting the laparoscopic management of adnexal masses during the first trimester of pregnancy is given in Table 2.

Finally, main recommendations proposed for performing laparoscopic surgery include the following [9]:

(a) Dorsal lithotomy position for surgery performed during the first trimester and a slight-left lateral position when performed during the second trimester to decrease compression on the vena cava.

(b) The instrumentation on the cervix for uterine mobilization should be avoided.

(c) Umbilical open mini-laparotomy is the preferred technique to avoid uterine damage. In cases of enlarged gravid uterus, 
З А Р БЕЖНЫЕ ИССЛЕДОВАНИЯ

Laparoscopic surgery for adnexal mass during the first trimester of pregnancy

Table 2

\begin{tabular}{|c|c|c|c|}
\hline Author & Year & Number of cases & Outcome \\
\hline Mashiach et al. [10] & 1990 & 9 & Two spontaneous abortion, One PROM at 25 wk \\
\hline Busine and Mirullo [11] & 1993 & 3 & Uneventful \\
\hline Morice et al. [12] & 1997 & 6 & Uneventful \\
\hline Andreoli et al. [13] & 1999 & 3 & Uneventful \\
\hline Soriano et al. [14] & 1999 & 39 & $\begin{array}{c}\text { Two newborns had congenital malformations } \\
\text { (mild hypospadias and cleft lip) }\end{array}$ \\
\hline Mathevet et al. [15] & 2003 & 17 & Uneventful \\
\hline Purnichescu et al. [16] & 2006 & 8 & Uneventful \\
\hline Hong [17] & 2006 & 16 & Uneventful \\
\hline Lenglet et al. [18] & 2006 & 12 & Uneventful \\
\hline Azuar et al. [19] & 2009 & 11 & Oneventful \\
\hline Ko et al. [20] & 2009 & 9 & Uneventaneous abortion \\
\hline Chang et al. [21] & 2011 & 13 & \\
\hline Current study & 2015 & 157 & \\
\hline Total & & & \\
\hline
\end{tabular}

Minig, et al.: Laparoscopy for adnexal mass in pregnancy

a supraumbilical midline incision without using Veress needle should be performed.

(d) The intra-abdominal pressure should be less than 12 $\mathrm{mmHg}$ to minimize the operative time, uterus manipulation and blood loss.

The main limitation of our study included the facts that the number of cases was small. It is, however, difficult to accumulate enough data to conduct a larger study since complicated cases of adnexal masses are rare in pregnant women and patients with this condition are managed conservatively if possible. A co-ordinated online international registration may be a good strategy for collecting data prospectively to assess the risk associated with laparoscopic surgery during pregnancy. The other limita-

\section{Лапароскопическая хирургия}

\section{в лечении тубоовариальных образований} В I триместре беременности

\section{Lucas Minig, Lucas Otaño, Pilar Cruz, María} Guadalupe Patrono, Cecilia Botazzi, Ignacio Zapardiel

Цель исследования: оценить возможность и безопасность лапароскопических операций при тубоовариальных образованиях в I триместре беременности.

Материалы и методы. Обсервационное исследование с проспективным сбором данных, в которое включали всех беременных, оперированных лапароскопическим методом по поводу тубоовариальных образований в I триместре беременности в период с января 1999 года по ноябрь 2012 года в отделении акушерства и гинекологии Итальянской больницы Буэнос-Айреса, Аргентина.

$\boldsymbol{P}$ езультаты. В общей сложности в исследование были включены 13 женщин. Средний срок гестации на момент хирургического вмешательства составлял 7 нед (диапазон: 5-12 нед). Основными показаниями к операции были: перекрут кисты в четырех случаях (30,7\%); разрыв кисты в четырех случаях (30,7\%). Другие показания включали персистенцию кист яичников у трех пациенток (23\%) и гетеротопическую беременность в двух случаях (15,3\%). В ходе наблюдения не было зафиксировано ни хирургических осложнений, ни прерываний беременности, послеоперационный период протекал без осложнений во всех случаях. Не было зафиксировано ни одного случая задержки внутриутробного роста и врожденных дефектов плода, преждевременных родов или неонатальных осложнений. Заключение. Лечение осложненных тубоовариальных образований лапароскопическим методом в I триместре беременности является безопасным как для матери, так и для плода. Однако необходимы дополнительные исследования с большим числом случаев для поддержки этих выводов. Ключевые слова: тубоовариальные образования, I триместр, лапароскопия, киста яичников, беременность. tion is the lack of proper information regarding the global and neuronal development of the newborns.

\section{CONCLUSION}

Although the evidence on laparoscopy is neither robust nor based on randomised controlled trials, based on our results and the review of the literature, the treatment of complicated adnexal masses by laparoscopic surgery during the first trimester of pregnancy appears to be a safe procedure for the mother as well as for the foetus. It is important to highlight, however, a possible bias of publications since complicated cases might be unpublished. Specific considerations regarding surgical technique should be taken into account by the team in order to minimize complications.

Лапароскопічна хірургія

у лікуванні тубооваріальних утворень

у I триместрі вагітності

Lucas Minig, Lucas Otaño, Pilar Cruz, María

Guadalupe Patrono, Cecilia Botazzi, Ignacio Zapardiel

Мета дослідження: оцінити можливість і безпеку лапароскопічних операцій у разі тубооваріальних утворень у I триместрі вагітності. Матеріали та методи. Обсерваційне дослідження з проспективним збором даних, в яке включали всіх вагітних, прооперованих лапароскопічним методом з приводу тубооваріальних утворень у I триместрі вагітності у період з кінця січня 1999 року до листопада 2012 року у відділенні акушерства і гінекології Італійської лікарні Буенос-Айреса, Аргентина.

Результати. У дослідження були включені 13 жінок. Середній термін гестації на момент хірургічного втручання становив 7 тиж (діапазон: 5-12 тиж). Основними показаннями до операції були: перекрут кісти у чотирьох випадках (30,7\%); розрив кісти у чотирьох випадках $(30,7 \%)$. Інші показання включали персистенцію кіст яєчників у трьох пацієнток (23\%) і гетеротопічну вагітність у двох випадках (15,3\%). У ході спостереження не було зафіксовано ні хірургічних ускладнень, ні переривань вагітності, післяопераційний період перебігав без ускладнень у всіх випадках. Не було зафіксовано жодного випадку затримки внутрішньоутробного росту і вроджених дефектів плода, передчасних пологів або неонатальних ускладнень.

Заключення. Лікування ускладнених тубооваріальних утворень лапароскопічним методом у I триместрі вагітності є безпечним як для матері, так і для плода. Однак необхідні додаткові дослідження з великою кількістю випадків для підтримки цих висновків.

Ключові слова: тубооваріальні утворення, I триместр, лапароскопія, кіста яєчників, вагітність. 


\section{З А Р УБЖЖНЫЕ ИССЛЕДОВАНИЯ}

\section{REFERENCES}

1. Leiserowitz G. Managing ovarian masses during pregnancy. Obstet Gynecol Surv 2006;61:463-70.

2. Yuen PM, Chang AM. Laparoscopic management of adnexal mass during pregnancy. Acta Obstet Gynecol Scand 1997;76:173-6.

3. Hoover K, Jenkins TR. Evaluation and management of adnexal mass in pregnancy. Am J Obstet Gynecol 2011;205:97-102.

4. Amos JD, Schorr SJ, Norman PF, Poole GV, Thomae KR, Mancino AT, et al. Laparoscopic surgery during pregnancy. Am J Surg 1996;171:435-7.

5. Whiteside J, Keup H. Laparoscopic management of the ovarian mass: $A$ practical approach. Clin Obstet Gynecol 2009;53:327-34.

6. Fatum M, Rojansky N. Laparoscopic surgery during pregnancy. Obstet Gynecol Surv 2001;56:50-9.

7. Reedy MB, Källén B, Kuehl TJ.
Laparoscopy during pregnancy: A study of five fetal outcome parameters with use of the Swedish Health Registry. Am J Obstet Gynecol 1997;177:673-9.

8. Mazze RI, Källén B. Reproductive outcome after anesthesia and operation during pregnancy: A registry study of 5405 cases. Am J Obstet Gyneco 1989;161:1178-85.

9. Al-Fozan H, Tulandi T. Safety and risks of laparoscopy in pregnancy. Curr Opin Obstet Gynecol 2002;14:375-9. 10. Mashiach S, Bider D, Moran O, Goldenberg M, Ben-Rafael Z. Adnexal torsion of hyperstimulated ovaries in pregnancies after gonadotropin therapy. Fertil Steril 1990;53:76-80.

11. Busine A, Murillo D. Conservative laparoscopic treatment of adnexal torsion during pregnancy. J Gynecol Obstet Biol Reprod (Paris) 1994;23:918-21. 12. Morice $P$, Louis-Sylvestre $C$, Chapron C, Dubuisson JB. Laparoscopy for adnexal torsion in pregnant women. J Reprod Med 1997;42:435-9.

13. Andreoli M, Servakov M, Meyers $P$, Mann WJ Jr. Laparoscopic surgery during pregnancy. J Am Assoc Gynecol Laparosc 1999;6:229-33.

14. Soriano $D$, Yefet $Y$, Seidman $D$ Goldenberg M, Mashiach S, Oelsner G. Laparoscopy versus laparotomy in the management of adnexal masses during pregnancy. Fertil Steril 1999; 71: 955-60.

15. Mathevet P, Nessah K, Dargent D, Mellier G. Laparoscopic management of adnexal masses in pregnancy: A case series. Eur J Obstet Gynecol Biol 2003;108:217-22.

16. Purnichescu V, Cheret-Benoist A, Von Theobald P, Mayaud A, Herlicoviez M, Dreyfus M. Laparoscopic management of pelvic mass in pregnancy. J Gynecol Obstet Biol Reprod (Paris) 2006;35:388-95.

17. Hong JY. Adnexal mass surgery and anesthesia during pregnancy: A 10-year retrospective review. Int J Obstet Anesth 2006;15:212-6

18. Lenglet $Y$, Roman $H$, Rabishong $B$, Bourdel N, Bonnin M, Bolandard F, et al. Laparoscopic management of ovarian cysts during pregnancy. Gynecol Obstet Fertil 2006;34:101-6.

19. Azuar AS, Bouillet-Dejou L, Jardon $K$ Lenglet $\mathrm{Y}$, Canis $\mathrm{M}$, Bolandard $\mathrm{F}$, et al. Laparoscopy during pregnancy: Experience of the French university hospital of Clermont-Ferrand. Gynecol Obstet Fertil 2009; 37: 598-603.

20. Ko ML, Lai TH, Chen SC. Laparoscopic management of complicated adnexal masses in the first trimester of pregnancy. Fertil Steril 2009;92:283-7.

21. Chang SD, Yen CF, Lo LM, Lee CL, Liang CC. Surgical intervention for maternal ovarian torsion in pregnancy. Taiwan J Obstet Gynecol 2011; 50: 458-62.

\section{Н О В О С Т И МЕД И И Н Ы}

\section{ПЕРИОД МЕЖДУ СКРИНИНГОВЫМИ ОБСЛЕДОВАНИЯМИ ШЕЙКИ МАТКИ МОЖЕТ БЫТЬ УВЕЛИЧЕН ДО 10 ЛЕТ}

Женщины старше 40 лет, получившие отрицательный результат теста на вирус папилломы человека (ВПЧ), могут проходить следующий тест лишь через десять лет.

Инфицирование ВПЧ - один из факторов риска развития рака шейки матки. В настоящее время женщинам предлагают впервые пройти такой скрининг в 25-летнем возрасте, после чего его рекомендуют повторять каждые три года. После 50 лет тест на ВПч проводят реже - раз в пять лет. Чаще такие исследования проводить не стоит - велика вероятность обнаружения дисплазии или других состояний, которые могут исчезнуть самостоятель- но. Их лечение может сопровождаться серьезными побочными эффектами - в результате диагностика принесет больше вреда, чем пользы.

Ученые из Нидерландов проанализировали данные более чем о 43 тысячах женщин в возрасте от 29 лет до 61 года, наблюдение за которыми продолжалось в течение 14 лет. Авторы пришли к выводу, что у женщин старше 40 лет, у которых тест на ВПЧ оказался отрицательным, риск появления аномальных клеток во влагалище и шейке матки был на $72 \%$ ниже, чем у более молодых участниц исследования. Кроме того, было показано, что тест на ВПЧ при оценке риска развития рака шейки матки, был точнее, чем ПАП-тест, также использующийся для этих целей.

Ученые считают, что для женщин после 40, входящих в группу низкого риска, в таком возрасте можно делать скрининг раз в десять лет, а не раз в пять. Однако исследователи отмечают, что женщина должна обращать внимание на свое состояние здоровья, регулярно посещать гинеколога и своевременно сообщать о замеченных изменениях врачу. Одним из симптомов, на который нужно обязательно обратить внимание, является кровотечение между менструациями, во время секса, либо после наступления менопаузы. med-expert.com.ua 


\title{
Роль гиперпролактинемии в генезе преждевременного телархе и ее коррекция у девочек первых пяти лет жизни
}

\author{
О.И. Мальцева \\ Центр планирования семьи КУ «Днепропетровский областной перинатальный центр со стационаром» ДОС
}

Изолированное телархе у девочек 1-5 лет часто обусловлено повышением уровня пролактина (ПРЛ), который играет важную роль как в становлении женской репродуктивной функции (в целом), так и в маммогенезе (в частности). Цель исследования: изучение эффективности воздействия препарата Циклодинон ${ }^{\circledast}$ на девочек с неполной формой преждевременного полового созревания по изосексуальному типу изолированным телархе на фоне повышенного уровня ПРЛ. Материалы и методы. В областном центре планирования семьи на базе КУ «Днепропетровский областной перинатальный центр со стационаром» ДОС было проведено обследование 30 девочек в возрасте от 1 до 5 лет с преждевременным изолированным телархе (ПИТ).

Девочкам с изолированным телархе и повышенным содержанием ПРЛ назначали препарат Циклодинон ${ }^{\circledast}$ в зависимости от возраста и уровня ПРЛ в сыворотке крови в дозе от 1/8 таблетки до 1 таблетки (от 5 капель до 40 капель) утром натощак 1 раз в день (методические рекомендации Института охраны здоровья детей и подростков НАМН Украины).

Результаты. В ходе исследования отмечено стабильное повышение уровня ПРЛ (до 680 мМЕ/л при значениях нормы 110-400 мМЕ/л) при относительно нормальном уровне гонадотропинов и эстрадиола. При применении препарата специального экстракта Vitex Agnus Castus Циклодинона отмечено постепенное, в течение 3 мес снижение уровня пролактина до нормальных значений с 680 до 396 мМЕ/л. Уменьшение уровня ПРЛ коррелировало с регрессом клинических признаков телархе. Побочных или нежелательных явлений при применении Циклодинона на протяжении 3 мес не отмечено.

Заключение. Применение стандартизированного лекарственного растительного препарата Циклодинон ${ }^{\circledast}$ с допаминэргическим эффектом, способствующим нормализации уровня ПРЛ для лечения девочек с неполной формой преждевременного полового созревания по изосексуальному типу - изолированным телархе на фоне повышенного уровня ПРЛ, является эффективным и патогенетически обоснованным. Это подтверждается результатами клинического и гормонального исследований.

Ключевые слова: изолированное телархе, пролактин, Циклодинон ${ }^{\circledast}$.

С охранение репродуктивного потенциала девочек относится к числу самых важных медико-социальных проблем общества в целом и приоритетных задач акушерско-гинекологической науки в частности, поскольку в ближайшие годы они вступят в репродуктивный период и от них во многом будет зависеть не только улучшение демографической ситуации в стране, но и состояние здоровья будущих поколений.

Репродуктивный потенциал формируется под воздействием большого количества факторов. Преждевремен- ное половое созревание возникает как результат преждевременной активации гипоталамо-гипофизарно-яичниковой системы, может быть следствием воздействия гормонально-активных опухолей, патологии ЦНС как органического, так и функционального характера, а также ятрогенных факторов.

В связи с урбанизацией, которая продолжается, несовершенством систем экологической защиты населения все большее количество детей попадают под постоянное влияние экотоксинов и ксенобиотиков, подвержены хроническому стрессу со всеми неблагоприятными последствиями этого влияния: нарушением становления функции центральных и периферических звеньев женской репродуктивной системы и формированием прямых и обратных связей между разными уровнями регуляции женской половой системы.

В практической деятельности детского гинеколога из всех видов нарушений полового развития наиболее часто встречаются девочки с неполной формой преждевременного полового созревания по изосексуальному типу - изолированным телархе на фоне повышенного уровня пролактина.

Известно, что на формирование грудной (молочной) железы значительное влияние оказывает пролактин (ПРЛ), начиная еще с внутриутробного периода онтогенеза, когда происходит закладка ее альвеолярного аппарата [1].

Концентрация ПРЛ в сыворотке крови человека в течение жизни существенно меняется. У новорожденных его уровень в крови достаточно высок, но до 3-го месяца жизни он снижается до 100-250 мМЕ/л. Максимальной границей нормы считается уровень до $400 \mathrm{MME} / л[2,3,5]$.

Для выбора адекватной тактики лечения изолированного телархе у детей принципиальным является назначение препарата с доказанной эффективностью, дофаминергическим эффектом, способствующим нормализации уровня ПРЛ и гипоталамо-гипофизарно-яичниковой системы.

На сегодняшний день имеется доказательная база по применению специального экстракта плодов витекса священного BNO 1095, стандартизированного по содержанию циклических дитерпенов (клерододиенол и т.д) при нарушениях женской репродуктивной системы, ассоциированных с повышением уровня ПРЛ. Данный стандартизированный экстракт является активным веществом препарата Циклодинон ${ }^{\circledR}$, чья эффективность в снижении уровня ПРЛ была доказана как в ходе слепых плацебоконтролируемых исследований $[4,6,7]$, так и в ходе сравнительных исследований с бромокриптином, где он показал сопоставимую с синтетическим ингибитором секреции ПРЛ активность при лучшем профиле безопасности [8]. Кроме того, имеется положительный опыт применения Циклодинона при изолированном телархе у детей первых лет жизни [5].

Цель исследования: изучение эффективности воздействия препарата Циклодинон ${ }^{\circledast}$ на девочек с неполной фор- 


\section{ДЕТСКАЯ И ПОДРОСТКОВАЯ ГИНЕКОЛОГИЯ}

мой преждевременного полового созревания по изосексуальному типу - изолированным телархе на фоне повышенного уровня ПРЛ.

\section{Задачи исследования}

1. Определить уровень гонадотропных гормонов (ФСГ, ЛГ), ПРЛ и эстрадиола в сыворотке крови у девочек с неполной формой преждевременного полового созревания по изосексуальному типу - изолированным телархе до начала лечения и на фоне терапии через 1, 2, 3, 6 мес.

2. Провести ультразвуковое исследование внутренних половых органов перед началом лечения, через 3 и 6 мес от начала терапии.

3. Оценить эффективность негормонального метода лечения девочек с неполной формой преждевременного полового созревания по изосексуальному типу - изолированным телархе на фоне повышенного уровня ПРЛ.

\section{МАТЕРИАЛЫ И МЕТОДЫ}

В областном центре планирования семьи на базе КУ «Днепропетровский областной перинатальный центр со стационаром» ДОС было проведено обследование 30 девочек в возрасте от 1 до 5 лет с преждевременным изолированным телархе (ПИТ).

У девочек было проведено клиническое, ультразвуковое и гормональное обследование.

Ультразвуковое исследование проводили на аппарате ULTIMA фирмы «Радмир»; для определения содержания гормонов (ФСГ, ЛГ, ПРЛ и эстрадиола) в сыворотке крови использовали метод радиологического анализа.

Все пациентки были обследованы эндокринологом, неврологом и педиатром.

Из исследования были исключены девочки с органическими заболеваниями ЦНС, гормонопродуцирующими опухолями и с наличием состояний, требующих лечения другими специалистами и препаратами.

Девочкам с изолированным телархе и повышенным содержанием ПРЛ назначали препарат Циклодинон ${ }^{\circledR}$ в зависимости от возраста и уровня ПРЛ в сыворотке крови в дозе от 1/8 таблетки до 1 таблетки (от 5 капель до 40 капель) утром натощак 1 раз в день (методические рекомендации Института охраны здоровья детей и подростков НАМН Украины).

\section{РЕЗУЛЬТАТЫ ИССЛЕДОВАНИЯ И ИХ ОБСУЖДЕНИЕ}

При изучении клинической симптоматики у всех пациенток наблюдалось увеличение грудной железы до Ма 2 по Таннеру. При проведении ультразвукового исследования у всех пациенток наблюдались соответствующие возрасту размеры и структура внутренних половых органов.

При исследовании гормонального статуса исходный уровень ФСГ и ЛГ составил $0,3 \pm 0,02 \mathrm{ME} / л$ и $0,5 \pm 0,03 \mathrm{ME} / л$ соответственно, уровень эстрадиола - менее 5 пг/мл, что соответствует возрастным нормам, уровень ПРЛ был повышен и составил $680 \pm 11,5$ мМЕ/л при возрастной норме 110-400 мМЕ/л.

Оценку результатов проводили через 1, 2, 3, 6 мес лечения Циклодиноном.

Через один месяц терапии средний уровень ПРЛ составил 575 мМЕ/л. При том, что нормализацию уровня ПРЛ отмечали у 3 (10\%) девочек, имеющих изначально незначительно повышенный уровень ПРЛ. У этих же девочек наблюдалось уменьшение грудной железы до Ма 1.

Через 2 мес приема уровень ПРЛ снизился до 492 мМЕ/л. Достижение пределов нормы отмечали еще у 8 (26,6\%) девочек, у 6 (20\%) из них также наблюдался регресс грудной железы. Через 3 мес терапии Циклодиноном

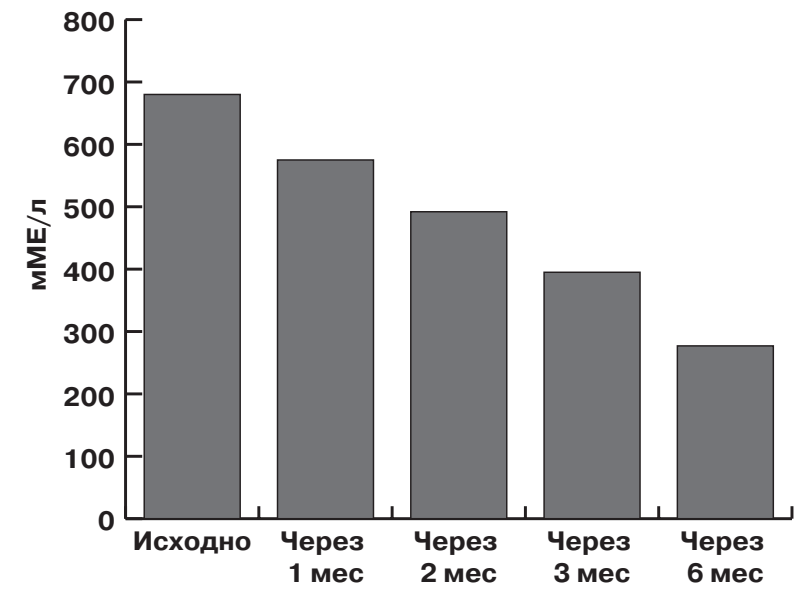

Динамика уровня ПРЛ в процессе лечения, мМЕ/л

уровень ПРЛ в сыворотке крови продолжил снижаться и составил $395 \pm 11,1 \mathrm{мME} / л$.

У этой же когорты пациенток отмечали выраженный регpecc грудных желез и вторичных половых признаков. У 19 (63,3\%) девочек наблюдался полный регресс вторичных половых признаков. У 2 (6,7\%) девочек остались минимальные проявления телархе. У 9 (30\%) девочек через 3 мес лечения отмечали незначительное уменышение грудных желез, снижение

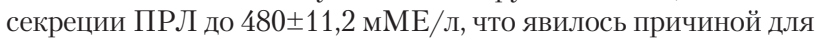
продолжения лечения и дальнейшего наблюдения за детьми.

Через 6 мес от начала терапии Циклодиноном уровень ПРЛ снизился до нормальных возрастных значений у всех

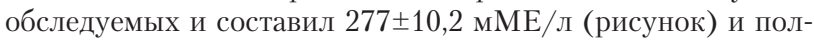
ный регресс вторичных половых признаков.

Уровни ФСГ, ЛГ, эстрадиола колебались в пределах возрастных норм и составили к концу лечения (через 6 мес)

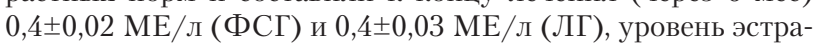
диола - менее 5 пг/мл.

Данные ультразвукового исследования у всех пациенток свидетельствовали о соответствующих возрасту размерах и структуре внутренних половых органов.

На протяжении 6 мес применения препарата Циклодинон ${ }^{\circledR}$ каких-либо побочных реакций или нежелательных явлений не отмечено.

\section{Выводы}

У детей первых пяти лет жизни в генезе изолированного телархе значительную роль играет повышение уровня пролактина (ПРЛ) в сыворотке крови.

Применение стандартизированного лекарственного растительного препарата Циклодинон ${ }^{\circledR}$ с допаминэргическим эффектом способствующим нормализации уровня ПРЛ для лечения девочек с неполной формой преждевременного полового созревания по изосексуальному типу - изолированным телархе на фоне повышенного уровня ПРЛ, является эффективным и патогенетически обоснованным. Это подтверждается результатами клинического и гормонального исследований.

Нормализация уровня ПРЛ кореллировала с нормализацией размеров грудных желез.

Максимальный терапевтический эффект в исследуемой группе наступил через 6 мес

Лечение препаратом Циклодинон ${ }^{\circledR}$ отличается хорошей переносимостью, однако в связи с относительно небольшим количеством пациенток для более детального исследования требуется более длительное наблюдение с включением большего количества пациенток. 


\section{ДЕТСКАЯ И ПОДРОСТКОВАЯ ГИНЕКОЛОГИЯ}

\section{Роль гіперпролактинемії у генезі передчасного телархе та її корекція у дівчаток перших п'яти років життя О.І. Мальцева}

Ізольоване телархе у дівчаток 1-5 років часто зумовлене підвищенням рівня пролактину (ПРЛ), який відіграє важливу роль як у становленні жіночої репродуктивної функції (в цілому), так і мамогенезі (зокрема). мета дослідження: вивчення ефективності впливу препарату Циклодинон ${ }^{\circledR}$ на дівчаток 3 неповною формою передчасного статевого дозрівання за ізосексуальним типом - ізольованим телархе на тлі підвищеного рівня ПРЛ.

Матеріали та методи. В обласному центрі планування сім'ї на базі КУ «Дніпропетровський обласний перинатальний центр зі стаціонаром» ДОС було проведено обстеження 30 дівчаток у віці від 1 до 5 років 3 передчасним ізольованим телархе (ПІТ).

Дівчаткам з ізольованим телархе і підвищеним вмістом ПРЛ призначали препарат Циклодинон ${ }^{\circledast}$ залежно від віку та рівня ПРЛ у сироватці крові в дозі від 1/8 таблетки до 1 таблетки (від 5 крапель до 40 крапель) вранці натщесерце 1 раз на день (методичні рекомендації Інституту охорони здоров'я дітей і підлітків НАМН України).

Результати. У ході дослідження відзначено стабільне підвищення рівня ПРЛ (до 680 мМО/л при значеннях норми 110-400 мМО/л) при відносно нормальному рівні гонадотропінів та естрадіолу. При застосуванні препарату спеціального екстракту Vitex Agnus Castus - Циклодинону відзначено поступове, протягом 3 міс, зниження рівня ПРЛ до рівня нормальних значень - з 680 до 396 мМО/л. Зменшення рівня ПРЛ корелювало з регресом клінічних ознак телархе. Побічних або небажаних явищ під час застосування Циклодинону протягом 3 міс не відзначено.

Заключення. Застосування стандартизованого лікарського рослин ного препарату Циклодинон з допамінергічним ефектом сприяє нормалізації рівня ПРЛ для лікування дівчаток 3 неповною формою передчасного статевого дозрівання за ізосексуальним типом - ізольованим телархе на тлі підвищеного рівня ПРЛ, є ефективним патогенетично обгрунтованим. Це підтверджується результатами клінічного та гормонального досліджень.

Ключові слова: ізольоване телархе, пролактин, Циклодинон ${ }^{\circledR}$.

\section{Role of hyperprolactinemia in the genesis of the premature telarhe and its correction in girls during the first five years of life \\ O. I. Maltseva}

Isolated telarhe in girls of $1-5$ years, often caused by increased levels of prolactin (PL), which plays an important role in the development of the female reproductive function (in general), and in mammohenezis (in particular).

The aim of the study: to study the effectiveness of a drug Cyclodynon ${ }^{\circledR}$ on girls with an incomplete form of precocious puberty by the isosexual type - isolated telarhe on the base of increased levels of PL.

Materials and methods. In the regional center of family planning on the basis of SI «Dnipropetrovsk regional perinatal center with a hospital» DRH survey was conducted in 30 girls aged from 1 to 5 years with premature isolated telarhe (PIT).

Girls with isolated telarhe and a high level of PL were prescribed the drug, Cyclodynon ${ }^{\circledast}$ depending on the age and level of PL in serum at a dose from $1 / 8$ of pill to 1 tablet (from 5 drops to 40 drops) in the morning on an empty stomach 1 time per day (guidelines of the Institute of health protection of children and adolescents of NAMS of Ukraine).

Results. In the study to include 30 girls with isolated telarhe noted a steady increase of PL (up to $680 \mathrm{mIU} / \mathrm{l}$ for normal values 110-560 $\mathrm{mIU} / \mathrm{l}$ ) at relatively normal levels of gonadotropins and estradiol. Use of the drug of special extract of Vitex Agnus Castus Cyclodynon ${ }^{\circledast}$ led to a gradual, within 3 months, reduce of prolactin levels to the normal range of 680 to $396 \mathrm{mIU} / \mathrm{L}$. Reducing of prolactin levels correlated with regression of clinical signs of telarhe. No side effects or undesirable Cyclodynon ${ }^{\circledast}$ application within 3 months is not noted.

Conclusion. A standardized herbal medicinal product Cyclodynon ${ }^{\circledR}$ with dopaminergic effect contributing to the normalization of PL for the treatment of girls with incomplete form of precocious puberty in isosexual type - isolated telarhe on the base of increased level of PL, is an effective and pathogenetically justified. This is confirmed by the results of clinical and hormonal reaserches.

Key words: isolated telarhe, prolactin, Cyclodynon ${ }^{\circledast}$

\section{Сведения об авторе}

Мальцева Ольга Игоревна - Центр планирования семьи КУ «Днепропетровский областной перинатальный центр со стационаром» ДОС, 49000, г. Днепропетровск, ул. Космическая, 17; тел.: (066) 428-92-25. E-mail: cps.rch@gmail.com

\section{СПИСОК ЛИТЕРАТУРЫ}

1. Участие пролактина в формировании фиброзно-кистозной мастопатии // Сергеева и соавт. Акушерство и гинекология. - 2005. - № 5 .

2. Іловайська А.І., Марова Є.І., 2000.

3. Синдром гиперпролактинемии у детей и подростков: причины, диагностика, лечение. / В.В. Смирнов,
Ф.И. Морозкина, М.Д. Утев // Лечащий Врач. - 2014. - № 12.

4. Рівень пролактину та його корекція у дівчат з передчасним телархе. Левинець С.О, Верхошанова О.Г, Перевозчиков В.В. «Здоровье женщинь $3(27) / 2006$

5. Jarry et al. Agnus castus als dopamin- erges Wirkprinzip in Mastodynon® $\mathrm{N}$. Zschr. Phytotherapie 1991, 12, 77-82. 6 . Wuttke W. et al. Behandlung zyklusabhnngiger Brustschmerzen mit einem Agnus castus haltigen Arzneimittel. Geburtshilfe und Frauenheilkunde 1997, 57, 569-574.

7. Wuttke $W$ et al. Chaste tree (Vitex agnus castus) pharmacological and clinical indications. Phytomedicin 2003, 10, 348-357.

8. Kilicdag et. al. Fructus agni casti and bromocriptine for treatment of hyperprolactinemia and mastalgia. Int Journal Gynecol and Obstetrics 85, 2004: 292-293. 


\title{
Субклинический гипертиреоз: диагностические критерии и принципы лечения \\ (Обзор руководства европейской тиреоидной ассоциации 2015 года «Diagnosis and Treatment of endogenous subclinical hyperthyroidism»)
}

\author{
В.В. Галицкая \\ Медицинская лаборатория «Синэво»
}

В статье освещаются рекомендации Европейской тиреоидной ассоциации (European Thyroid Association) по диагностике и лечению субклинического гипертиреоза (2015).

Определение уровня тиреотропного гормона может помочь в диагностике целого ряда патологических состояний: нарушений полового развития, аменореи (первичной или вторичной), ановуляторных циклов, бесплодия, невынашивания беременности, которые требуют специфического лечения при выявлении нарушений гормонального статуса (субклинический, манифестный) с учетом возраста пациента.

Диагностика эндогенного субклинического гипертиреоза основывается исключительно на результатах лабораторных исследований, а не клинических критериях. Эндогенный субклинический гипертиреоз (ЭСГ) определяется при наличии субнормального уровня тиреотропного гормона на фоне нормальных уровней свободного тироксина, общего трийодтиронина и/или свободного трийодтиронина. Выделяют две категории ЭСГ: 1-я степень - уровень тиреотропного гормона 0,1-0,39 мМЕ/л; 2-я степень - уровень тиреотропного гормона $<0,1$ мМЕ/л. Уровни свободного тироксина и свободного трийодтиронина, как правило, находятся в области средневысоких значений при субклиническом уровне тиреотропного гормона и могут помочь дифференцировать ЭСГ от манифестного гипертиреоза.

Рекомендовано исследование уровня тиреотропного гормона как тест первого уровня для диагностики субклинического гипертиреоза. При выявлении низкого уровня тиреотропного гормона необходимо исследовать уровень свободного тироксина, свободного и связанного трийодтиронина.

Больные с первично субнормальным уровнем тиреотропного гормона при концентрации гормонов щитовидной железы в пределах или на верхней границе нормального диапазона должны быть обследованы через 2-3 мес.

Рекомендуется выполнить сцинтиграфию и, по возможности, 24-часовой тест поглощения радиоактивного йода при наличии у пациента со 2-й степенью ЭСГ узлового зоба для определения тактики лечения.

Ультразвуковое исследование с цветным допплером может быть информативным у пациентов с ЭСГ и узловым зобом. Определение уровня антител к рецептору тиреотропного гормона могут подтвердить аутоиммунную этиологию индуцированного гипертиреоза.

Ключевые слова: шитовиднал железа, тиреотропный гормон, тиреотоксикоз, гипертиреоз, болезнь Грейвса, многоузловой токсический зоб.

$\mathrm{B}$ ормальном функционировании репродуктивной системы женщины щитовидная железа (ЩЖ) играет одну из ключевых ролей. Именно поэтому каждый акушер-гинеколог при наличии любых нарушений в этой сфере исключает данную широко распространенную эндокринную патологию, которая может быть причиной целого ряда патологических состояний: наруше- ний полового развития, аменореи (первичной или вторичной), ановуляторных циклов, бесплодия, невынашивания беременности и требует специфического лечения, что будет определяться характером нарушений гормонального статуса: гипотиреоз или тиреотоксикоз. И зачастую только лабораторная диагностика может дать окончательный ответ относительно диагноза, так как клинические проявления не всегда строго специфичны (например, нарушение менструального цикла диагностируют и при гипотиреозе, и при тиреотоксикозе).

Одним из самых распространенных и широко используемых тестов для выявления пациентов с патологией ЩЖ является определение уровня тиреотропного гормона (ТТГ). Этот тест на скрининговом этапе выявления наличия или отсутствия функциональных нарушений ЩЖ признан в мире самым оптимальным и достаточным. Оценка отклонения уровня ТТГ в зависимости от возраста, пола, наличия или отсутствия беременности, триместра беременности позволяет выделить тех пациентов, у которых можно предположить наличие тиреотоксикоза (субклинического или манифестного) или гипотиреоза (центрального) в случае выявления сниженного уровня ТТГ. В случае повышения уровня ТТГ предполагают наличие гипотиреоза (субклинического или манифестного).

Для установления окончательного диагноза и выбора тактики лечения проводят определение уровней периферических гормонов ЩЖ с учетом наличия антител, которые помогают провести дифференциальную диагностику тиреотоксикоза или центрального гипотиреоза, субклинической или манифестной формы заболевания при сниженном уровне ТТГ, а при повышенном уровне ТТГ - установить диагноз субклинического или манифестного гипотиреоза.

На сегодняшний день одной из проблемных тем в эндокринологии остаются варианты дисфункции ЩЖ, которые относятся к категории субклинических форм: субклинический тиреотоксикоз и гипотиреоз. В данных ситуациях перед специалистом всегда возникает целый ряд вопросов, на которые до сегодня нет окончательных ответов: связана ли клиническая картина с патологией ЩЖ и необходимо ли лечить, если да - то как. Ведь уровни периферических гормонов, которые ответственны за развитие клинической картины заболевания, находятся в пределах референтных значений, имеет место только отклонения уровня ТТГ.

В данной статье вниманию акушеров-гинекологов предлагаются рекомендации руководства Европейской Тиреоидной Ассоциации (European Thyroid Association - ETA) по диагностике и лечению пациентов с эндогенным субклиническим гипертиреозом (ЭСГ), опубликованные в 2015 году и ставшие результатом большой работы специальной группы специалистов в данной области. Уровень доказательности каждой рекомендации дан в соответствии с мировыми стандартами: качество (выражено в плюсах: + - низкое, ++- умеренное, +++- высокое) и сила (1 - строгая, 2 - слабая). С полным текстом данного руководства можно ознакомиться на сайте European Thyroid Journal. 


\section{Л АБОРАТОРНЫЕ ИССЛЕДОВАНИЯ}

\section{Эндогенный субклинический гипертиреоз}

ЭСГ может быть результатом болезни Грейвса, автономно функционирующего узла ЩЖ и многоузлового зоба. Диагностика основывается на выявлении постоянно сниженного (субнормального) уровня ТТГ при уровне свободных гормонов ЩЖ, соответствующих референтным пределам.

Большое количество проспективных когортных исследований доказали, что ЭСГ связан с повышенным риском смертности от ишемической болезни сердца, случаев фибрилляции предсердий, сердечной недостаточности, переломов и повышением уровня общей смертности у пациентов с уровнем ТTГ $<0,1 \mathrm{MME}$ /л (2-я степень ЭСГ). Поэтому, несмотря на отсутствие рандомизированных проспективных исследований, есть свидетельства, что лечение ЭСГ показано пациентам старше 65 лет со 2-й степенью ЭСГ, для того чтобы избежать серьезных сердечно-сосудистых последствий, переломов и риска прогрессирования заболевания до манифестного гипертиреоза. Лечение может быть рассмотрено у больных старше 65 лет с уровнем ТТГ 0,1-0,39 мМЕ/л (1-я степень ЭСГ), так как ЭСГ связан с повышенным риском фибрилляции предсердий, а также может быть оправданным у пациентов в возрасте до 65 лет со 2-й степенью ЭСГ из-за риска прогрессирования, особенно при наличии симптомов и/или базовых факторов риска, сопутствующих заболеваний. Нет данных о целесообразности лечения ЭСГ 1-й степени молодых пациентов с бессимптомным течением. Таких больных следует наблюдать без лечения по причине низкого риска прогрессирования до манифестного гипертиреоза и слабых доказательств неблагоприятных последствий для здоровья.

\section{Этиология и распространенность ЭСг}

Наиболее частые причины ЭСГ: болезнь Грейвса, токсическая аденома и токсический многоузловой зоб (таблица). В то время как болезнь Грейвса является наиболее распространенной причиной ЭСГ у более молодых пациентов (<65 лет) в регионе с нормальным йодным обеспечением, токсическая аденома и токсический многоузловой зоб относительно чаще диагностируют в йододефицитных районах у пожилых людей ( $\geq 65$ лет) [8].

Распространенность ЭСГ значительно варьирует - от 0,6\% до $16 \%$ (8-10\%), в зависимости от критериев диагностики, возраста и пола населения, потребления йода. В исследовании National Health and Nutrition Examination Survey (NHANES III) оценено наличие антител ЩЖ, ТТГ и свободного тироксина (Т4св) у пациентов старше 12 лет, которые представляли географически и этнически население США [11]. Распространенность ЭСГ составила $0,7 \%$ при значениях порога отсечения ТТГ $<0,1 \mathrm{мME} /$ л и 1,8\% с точкой отсечения ТТГ $<0,4$ мМЕ/л. ЭСГ является относительно частым состоянием в йододефицитных регионах, и его распространенность составляет $15 \%$ в популяции людей старше 70 лет [12]. Низкие уровни ТТГ также могут быть следствием ятрогенных (экзогенных) причин, связанных с лечением гормонами ЩЖ: высокие дозы тиреоидных гормонов у пациентов с раком ЩЖ, у пациентов при лечении гипотиреоза или по другим причинам (см. таблицу). В данном руководстве рассматриваются только вопросы диагностики и лечения ЭСГ.

\section{Диагностика и определение этиологии Эсг}

Диагностика ЭСГ основывается исключительно на результатах лабораторных исследований, а не клинических критериях. ЭСГ определяется при наличии субнормального уровня ТТГ на фоне нормальных уровней Т4св, общего трийодтиронина (ТЗобщ) и/или свободного трийодтиронина (ТЗсв) [2-7].

Современные возможности лабораторного тестирования могут определять крайне низкие уровни ТТГ 0,01-0,02 мМЕ/л. В соответствии с этим, можно выделить две категории ЭСГ [2-7]:

\footnotetext{
- 1-ю степень ЭСГ: ТТГ 0,1-0,39 мМЕ/л;

- 2-ю степень ЭСГ: ТТГ < 0,1 мМЕ/л.
}

Этиология и дифференциальная диагностика эсг

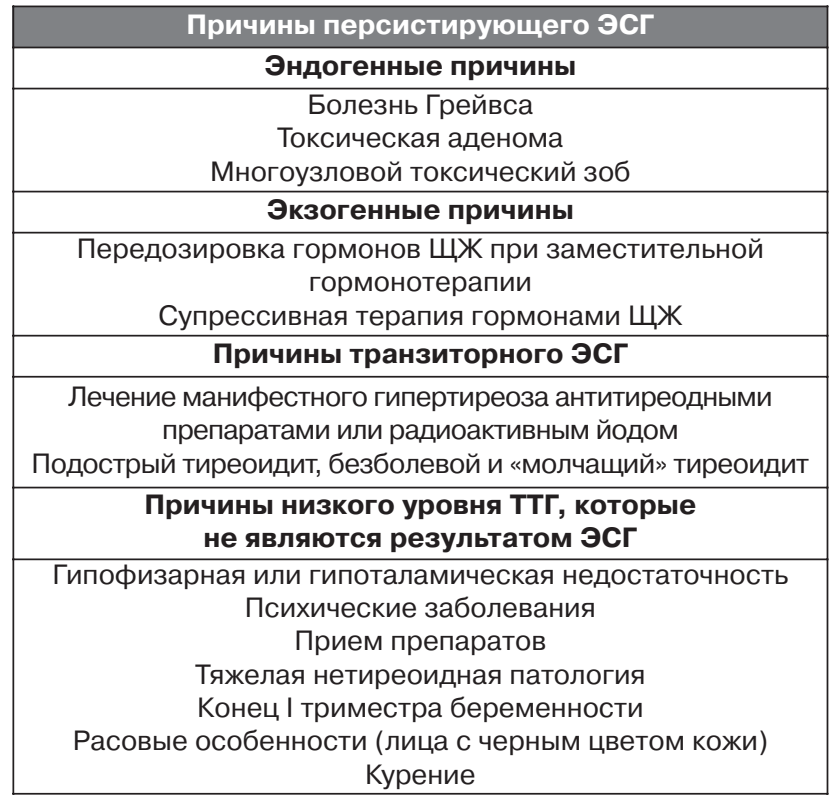

Определение ТТГ в сыворотке крови является наиболее чувствительным тестом диагностики и оценки тяжести ЭСГ [2, $5,13,14]$. Уровни Т4св и ТЗсв, как правило, находятся в области средневысоких значений референсного диапазона при субклиническом ТТГ и могут помочь дифференцировать ЭСГ и манифестный гипертиреоз [3-5]. При гипертиреозе сывороточный уровень Т3 часто более повышен, чем Т4, что вызвано чрезмерным производством ЩЖ ТЗ. Исследование ТЗобщ часто предпочтительнее в клинической практике, потому что анализы, оценивающие ТЗсв, менее точны, чем исследование Т4св [5, 14]. Тем не менее, определение уровня ТЗсв в дополнение к ТТГ помогает в раннем выявлении дисфункции ЩЖ. Его избыток вызван фокальной или мультифокальной автономией ЩЖ у пациентов с зобом, проживающих в районах йодного дефицита [14]. У этих пациентов с неопределяемым уровнем ТТГ и нормальными уровнями Т4св и ТЗобщ определение ТЗсв позволяет провести дифференциальную диагностику между ЭСГ и явным Т3-тиреотоксикозом [15].

Перед установлением диагноза ЭСГ необходимы проведение качественного лабораторного тестирования и адекватная интерпретация уровней гормонов ЩЖ с учетом возможного влияния на их уровни целого ряда факторов, в том числе с учетом физиологических состояний (например беременность), наличия интеркуррентных заболеваний, приема препаратов и возможных артефактов при лабораторном тестировании.

ЭСГ следует дифференцировать от других причин низкого уровня ТТГ центрального генеза, таких, как прием препаратов, подавляющих ТТГ (допамин, высокие дозы глюкокортикоидов, аналоги соматостатина, добутамин, амфетамин, бексаротен, бромокриптин), наличие психических заболеваний, синдрома псевдодисфункции ЩЖ при соматической патологии и гипоталамо-гипофизарных расстройств, которые вызывают дефицит тиреотропин-рилизинг-гормона или тиреотропного гормона. Уровни Т4св и ТЗсв при этом, как правило, находятся на нижней границе нормы [4, 6].

Необходимо обязательное исключение причин, которые временно снижают уровень ТТГ, такие, как подострый, «молчащий» или послеродовой тиреоидит [3-6]. Беременность и пожилой возраст могут затруднить диагностику ЭСГ. Увеличение концентрации хорионического гонадотропина человека может приводить к снижению ТТГ у 18\% беременных на ранних сроках, большинство из которых будут иметь нормальные концентрации Т4св [16]. Кроме того, изменение уровня ТТГ может на- 


\section{Л АБОРАТОРНЫЕ ИССЛЕДОВАНИЯ}

блюдаться у пациентов пожилого возраста в связи со старением и потенциальным изменением в оси гипоталамус-гипофиз-ЩЖ [17, 18].

Потребление йода и/или прием препаратов часто приводят к вторичным изменениям ЩЖ на фоне нетиреоидной патологии у пожилых людей, что еще более осложняет диагностику ЭСГ [4].

Целый ряд исследований установили сдвиг уровня ТТГ в сторону больших концентраций у здоровых лиц преклонного возраста в регионах с нормальным потреблением йода [19]. В противоположность этому, концентрация ТТГ может быть ниже нормального диапазона у некоторых здоровых долгожителей в йододефицитных районах $[20,21]$. Низкий уровень ТТГ снижение в сыворотке Т3 и увеличение в сыворотке крови реверсного Т3 позволяет предположить возрастозависимое снижение активности 5'-дейодиназы или изменения в питании у очень пожилых пациентов с длительно существующим йодный дефицитом [21]. Наконец, субнормальные уровни ТТГ в сыворотке крови часто наблюдаются у людей с темной кожей и здоровых курильщиков [4, 6, 22]

Сцинтиграфия и тест с 24-часовым поглощением радиоактивного йода позволяют дифференцировать пациентов с болезнью Грейвса с нормально диффузным и увеличенным поглощением йода; «теплыми» или «горячими» узлами при токсическом многоузловом зобе и автономно функционирующими узлами ЩЖ; пациентов с тиреоидитом; пациентов, получающих гормоны ЩЖ и йодсодержащие препараты при отсутствии или сниженном поглощении радиоактивного йода [2-6, 13].

Измерение 24-часовой экскреции йода с мочой может помочь подтвердить предполагаемое чрезмерное потребление йода $[4,6]$.

Проведение УЗИ с цветным допплером дает информацию о размерах ЩЖ, ее эхогенности, наличии/отсутствии узлов и васкуляризации, а проведение тонкоигольной аспирационной биопсии поможет выявить рак ЩЖ при многоузловом зобе с гипофункционирующими узлами [4-6, 13].

\section{Рекомендации по диагностике ЭСГ}

Первый чровень исследований: установить стойкий характер изменений уровней гормонов ЩЖ

1. Мы рекомендуем исследование уровня ТТГ как тест первого уровня для диагностики ЭСГ. При выявлении

\section{Субклінічний гіпертиреоїдизм: діагностичні критерії і принципи лікування (Огляд керівництва Європейської тиреоїдної асоціації 2015 року «Diagnosis and Treatment of endogenous subclinical hyperthyroidism») \\ В.В. Галицька}

У статті висвітлюються рекомендації Європейської тиреоїдної асоціації (European Thyroid Association) з діагностики та лікування субклінічного гіпертиреозу (2015). Визначення рівня тиреотропного гормону може допомогти в діагностиці цілої низки патологічних станів: порушень статевого розвитку, аменореї (первинної або вторинної), ановуляторних циклів, безплідності, невиношування вагітності, які потребують спеціального лікування при виявленні порушень гормонального статусу (субклінічний, маніфестний) з урахуванням віку пацієнта.

Діагностика ендогенного субклінічного гіпертиреозу (ЕСГ) грунтується виключно на результатах лабораторних досліджень, а не клінічних умовах. ЕСГ визначається у разі наявності субнормального рівня тиреотропного гормону на тлі нормальних рівнів вільного тироксину, загального трийодтироніну i/або вільного трийодти низкого уровня ТТГ необходимо исследовать гормоны ЩЖ (Т4св и ТЗобщ (или ТЗсв) $[2,5,13,14](1 /+++)$.

2. ТТГ должен быть использован для оценки тяжести ЭСГ и выделения градаций: 1-я степень (ТТГ 0,1-0,39 мМЕ/л), 2-я степень (ТТГ <0,1 мМЕ/л) [2, 5, 13, 14] $(1 /+++)$.

3. Следует исключить причины транзиторного снижения ТТГ, не связанные с ЭСГ, такие, как прием препаратов, недостаточность гипофиза или гипоталамуса, психические болезни и синдром эутиреоидной патологии [4-7] $(1 /+)$

4. При сниженном или погранично низком уровне ТТГ и концентрации гормонов ЩЖ в пределах или на верхней границе нормального диапазона необходимо повторить исследование через 2-3 мес, потому что ЭСГ определяется как стойкое снижение уровня ТТГ [2-6] (1/+). $\ni C \Gamma$

Второй уровень исследований: установить этиологию

5. Рекомендуется выполнить сцинтиграфию и, по возможности, 24-часовой тест захвата радиоактивного йода для определения тактики лечения пациентов с узловым зобом и 2-й степенью ЭСГ [2-6, 13] $(1 /+)$.

6. УЗИ с допплерографией может быть информативным у пациентов с ЭСГ и узловым зобом [13] $(2 /+)$.

7. Определение уровня антител к рецептору ТТГ (АТрТТГ) могут подтвердить аутоиммунную этиологию индуцированного гипертиреоза [23] $(2 /+)$.

Кроме того, АТ-рТТГ помогут выявить аутоиммунную реакцию даже при узловом зобе, потому что приблизительно 17\% пациентов в йододефицитных районах со сцинтиграфическими критериями токсического многоузлового зоба могут быть положительными по АТ-рТТГ [24].

Третий уровень исследования: установить объем необходимого лечения

О необходимом комплексе оценки рисков, ассоциированных с ЭСГ, рекомендациях о принципах лечения читайте в следующем номере.

Тесты, рекомендованные Синэво:

Тиреотропный гормон (ТTT)/1004

Рецепторы ТTГ, антитела IgG (АTрTTГ) / 1106

роніну. Розрізняють дві категорії ЕСГ: 1-й ступінь - рівень тиреотропного гормону $0,1-0,39$ мМО/л; 2 -й ступінь - рівень тиреотропного гормону $<0,1 \mathrm{mMO/л.} \mathrm{Рівні} \mathrm{вільного} \mathrm{тироксину} \mathrm{і} \mathrm{вільного}$ трийодтироніну, як правило, знаходяться в області середньовисоких значень при субклінічному рівні тиреотропного гормону і можуть допомогти диференціювати ЕСГ від маніфестного гіпертиреозу. Рекомендоване дослідження рівня тиреотропного гормону як тест першого рівня для діагностики субклінічного гіпертиреозу. У разі виявлення низького рівня тиреотропного гормону необхідно досліджувати рівень вільного тироксину, вільного і зв'язаного трийодтироніну. Хворі з первинно субнормальним рівнем тиреотропного гормону за концентрації гормонів щитоподібної залози в межах або на верхній межі нормального діапазону повинні бути обстежені через 2-3 міс. Рекомендується виконати сцинтиграфію і, по можливості, 24-годинний тест поглинання радіоактивного йоду за наявності у пацієнта з 2-м ступенем ЕСГ вузлового зоба для визначення тактики лікування. Ультразвукове дослідження з кольоровим допплєром може бути інформативним у пацієнтів з ЕСГ і вузловим зобом.

Визначення рівня антитіл до рецептора тиреотропного гормону можуть підтвердити автоімунну етіологію індукованого гіпертиреозу. Ключові слова: щитоподібна залоза, тиреотропний гормон, тиреотоксикоз, гіпертиреоз, хвороба Грейвса, багатовузловий токсичний зоб.

\section{Все указанные в статье лабораторные исследования выполняются в Медицинской лаборатории Синэво}




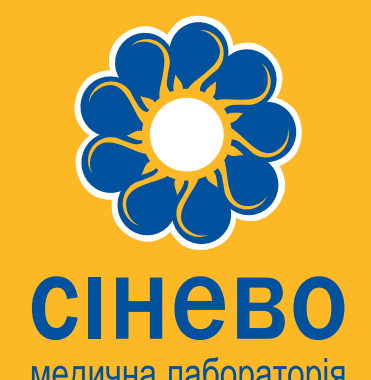

\section{СПІВПРАЦЯ 3 «СІНЕВО»- СУЦІЛЬНИЙ ПЛЮС АЛЯ ЛІКАРЯ}

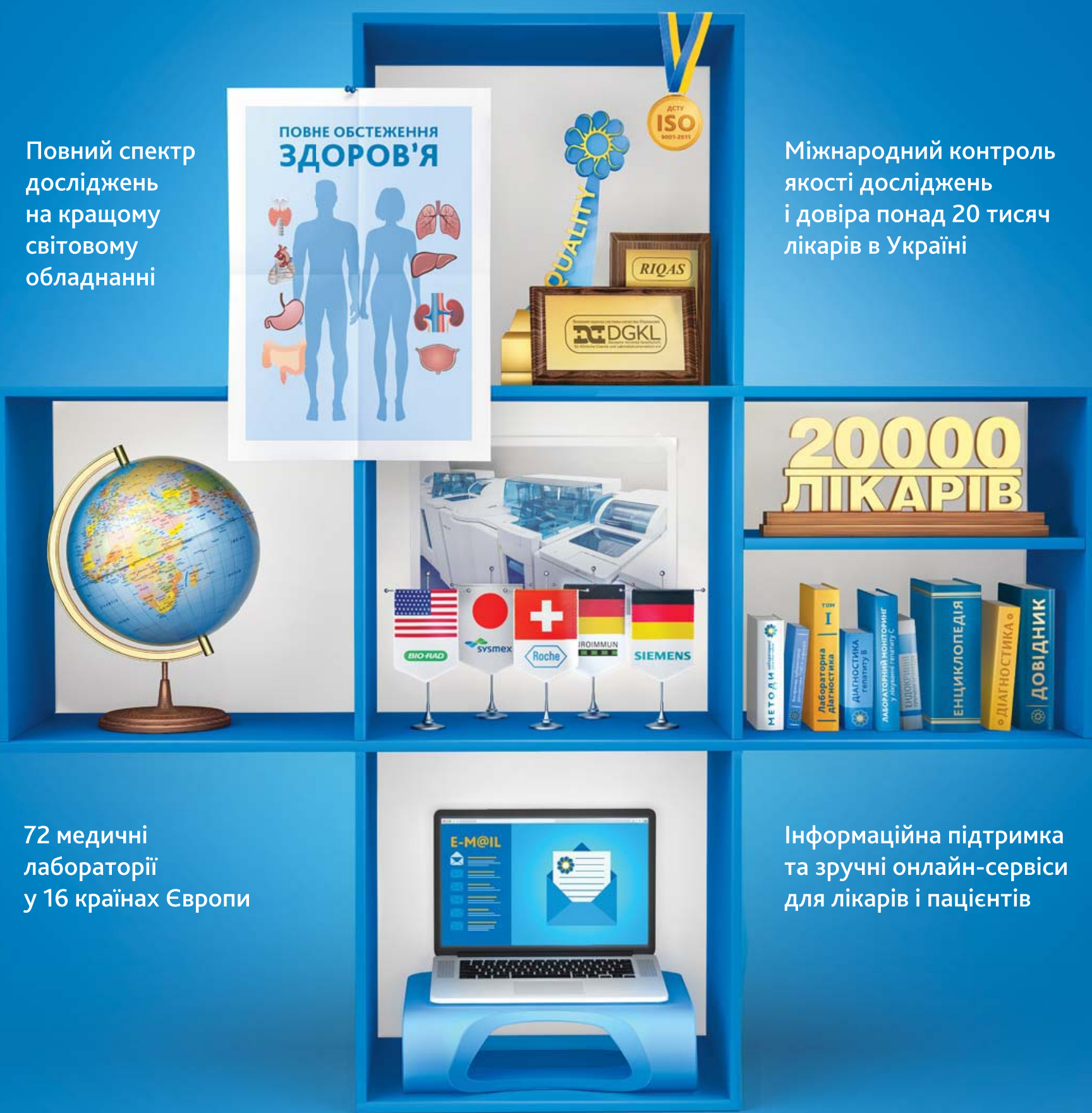




\section{Л АБОРАТОРНЫЕ ИССЛЕДОВАНИЯ}

\section{Subclinical hyperthyroidism: diagnostic criteria and principles of treatment (Review of European Thyroid Association guidelines "Diagnosis and Treatment of endogenous subclini- cal hyperthyroidism", 2015) V.V. Galitskaya}

This article presents the European Thyroid Association guidelines for diagnosis and treatment of subclinical hyperthyroidism, 2015 Determination of thyroid-stimulating hormone levels can help to diagnose a variety of pathological conditions: disorders of sexual development, amenorrhea (primary or secondary), infertility, miscarriage, which require specific treatment after detection of hormonal status disorders (subclinical, overt), taking into account the patient's age. Diagnosis of endogenous subclinical hyperthyroidism is based solely on the results of laboratory tests, not clinical criteria. Endogenous subclinical hyperthyroidism is defined by the presence of sub-normal levels of thyroid-stimulating hormone with normal levels of free thyroxine, total triiodothyronine, and/or free triiodothyronine. There are two categories of endogenous subclinical hyperthyroidism: Class 1 - the level of thyroid-stimulating hormone is $0,1-0,39 \mathrm{mIU} / \mathrm{l}$; class 2 - the level of thy- roid-stimulating hormone is $<0.1 \mathrm{mIU} / \mathrm{l}$. The levels of free thyroxine and free triiodothyronine, as a rule, are medium-high value at a subclinical level of thyroid hormone and can help differentiate between endogenous subclinical hyperthyroidism from overt hyperthyroidism.

Recommended to study the thyroid-stimulating hormone level as the first test for the diagnosis of subclinical hyperthyroidism. In identifying low levels of thyroid-stimulating hormone it is necessary to investigate the level of free thyroxine, free and bound triiodothyronine. Patients with primary sub-normal levels of thyroid-stimulating hormone with concentration of thyroid hormones in the upper limit or in normal range should be evaluated within 2-3 months.

It is recommended to perform scintigraphy and possible 24-hour test the absorption of radioactive iodine if in patient with 2nd degree endogenous subclinical hyperthyroidism there is nodular goiter to determine treatment strategy.

Ultrasonography with color Doppler can be informative in patients with endogenous subclinical hyperthyroidism and nodular goiter.

Determining the level of antibodies to thyroid-stimulating hormone receptors can confirm the etiology of autoimmune-induced hyperthyroidism.

Key words: thyroid, thyroid stimulating hormone, hyperthyroidism, thyrotoxicosis, subclinical hyperthyroidism, Graves' disease, toxic multinodular goiter.

\section{Сведения об авторе}

Галицкая Вита Владимировна - Медицинская лаборатория «Синэво», 03142, Киев, пр-т Палладина, 46/2; тел.: (067) 245-46-23. E-mail: vita.galitskaya@synevo.uq

\section{СПИСОК ЛИТЕРАТУРЫ}

1. Biondi B, Bartalena L, Cooper DS, et al. The 2015 European Thyroid Association Guidelines on Diagnosis and Treatment of Endogenous Subclinical Hyperthyroidism. Eur Thyroid J 2015;4:149-163 DOI: 10.1159/000438750.

2. Surks Ml, Ortiz E, Daniels GH, et al: Subclinical thyroid disease: scientific review and guidelines for diagnosis and management. JAMA 2004; 291 228-238.

3. Biondi B, Palmieri EA, Klain $M$, Schlumberger M, Filetti S, Lombardi G: Subclinical hyperthyroidism: clinica features and treatment options. Eur Endocrinol 2005; 152: 1-9.

4. Biondi B, Cooper DS: The clinica significance of subclinical thyroid dysfunction. Endocr Rev 2008; 29 : 76-131.

5. Bahn RS, Burch HB, Cooper DS, et al: Hyperthyroidism and other causes of thyrotoxicosis: management guidelines of the American Thyroid Association and American Association of Clinical Endocrinologists. Thyroid 2011; 21: 593-646.

6. Cooper DS, Biondi B: Subclinical thyroid disease. Lancet 2012; 379 : 1142-1154.

7. Mitchell AL, Pearce SH: How should we treat patients with low serum thyrotropin concentrations? Clin Endocrinol (Oxf) 2010; 72: 292-296.

8. Bülow Pedersen I, Knudsen N,
Jwrgensen T, Perrild H, Ovesen L, Laurberg P: Large differences in incidences of overt hyper- and hypothyroidism associated with a small difference in iodine intake: a prospective comparative register-based population survey. J Clin Endocrinol Metab 2002; 87: 4462-4469.

9. Marqusee E, Haden ST, Utiger RD: Subclinical thyrotoxicosis. Endocrino Metab Clin North Am 1998; 27: 37-49. 10. Canaris GJ, Manowitz NR, Mayor G, Ridgway EC: The Colorado thyroid disease prevalence study. Arch Intern Med 2000; 160: 526-534.

11. Hollowell JG, Staehling NW, Flanders WD, et al: Serum TSH, T(4), and thyroid antibodies in the United States population (1988-1994): National Health and Nutrition Examination Survey (NHANES III). J Clin Endocrinol Metab 2002; 87: 489-499.

12. Aghini-Lombardi $F$, Antonangeli L, Martino $E$, et al: The spectrum of thyroid disorders in an iodine-deficient community: the Pescopagano survey. Clin Endocrinol Metab 1999; 84: 561-566.

13. Paschke R, Hegedbs L, Alexander E, Valcavi R, Papini E, Gharib H: Thyroid nodule guidelines: agreement, disagreement and need for future research. Nat Rev Endocrinol 2011; 7: 354-361.

14. Baloch Z, Carayon P, Conte-Devolx B, Demers LM, Feldt-Rasmussen U,
Henry JF, LiVosli VA, Niccoli-Sire $P$, John R, Ruf J, Smyth PP, Spencer CA, Stockigt JR; Guidelines Committee, National Academy of Clinical Biochemistry: Laboratory medicine practice guidelines. Laboratory support for the diagnosis and monitoring of thyroid disease. Thyroid 2003; 13: 3-126. 15. Figge J, Leinung $M$, Goodman $A D$, Izquierdo R, Mydosh T, Gates S, Line $B$, Lee DW: The clinical evaluation of patients with subclinical hyperthyroidism and free triiodothyronine (free T 3 ) toxicosis. Am J Med 1994; 96: 229-234.

16. Cooper DS, Laurberg P: Hyperthyroidism in pregnancy. Lancet Diabetes Endocrinol 2013; 1 : 238-249.

17. Harman SM, Wehmann RE, Blackman MR: Pituitary-thyroid hormone economy in healthy aging men: basal indices of thyroid function and thyrotropin responses to constant infusions of thyrotropin releasing hormone. $J$ Clin Endocrinol Metab 1984; 58: 320-326.

18. Mariotti S, Franceschi C, Cossarizza A, Pinchera A: The aging thyroid. Endocr Rev 1995; 16: 686-715.

19. Surks MI, Boucai L: Age- and racebased serum thyrotropin reference limits. J Clin Endocrinol Metab 2010; 95: 496-502.

20. Magri F, Muzzoni B, Cravello L, Fioravanti M, Busconi L, Camozzi D,
Vignati G, Ferrari E: Thyroid function in physiological aging and in centenarians: possible relationships with some nutritional markers. Metabolism 2002; 51: 105-109.

21. Mariotti S, Barbesino G, Caturegli $P$, Bartalena $L$, Sansoni $P$, Fagnoni $F$, Monti D, Fagiolo U, Franceschi C, Pinchera A: Complex alteration of thyroid function in healthy centenarians. J Clin Endocrinol Metab 1993; 77: 1130-1134

22. Belin RM, Astor BC, Powe NR, Ladenson PW: Smoke exposure is associated with a lower prevalence of serum thyroid autoantibodies and thyrotropin concentration elevation and a higher prevalence of mild thyrotropin concentration suppression in the Third National Health and Nutrition Examination Survey (NHANES III). J Clin Endocrinol Metab 2004; 89: 6077-6086.

23. Diana T, Kanitz M, Lehmann M, L Y, Olivo PD, Kahaly GJ: Standardization of a bioassay for thyrotropin receptor stimulating autoantibodies. Thyroid 2015; 25: 169-175

24. Pedersen IB, Knudsen N, Perrild H, Ovesen L, Laurberg P: TSH-receptor antibody measurement for differentiation of hyperthyroidism into Graves' disease and multinodular toxic goitre: a comparison of two competitive binding assays. Clin Endocrinol (Oxf) 2001; 55: $381-390$. 


\title{
Шляхи оптимізації безперервного професійного розвитку лікаря
}

\author{
О.С. Щербінська \\ Національна медична академія післядипломної освіти імені П.Л. Шупика МОЗ України, м. Київ
}

У статті надано інформацію про основні методи активного навчання у межах безперервного професійного розвитку лікарів та шляхи заохочення до них слухачів.

Ключові слова: методи активного навчання, безперервний професійний розвиток, стиль навчання.

Загальні тенденції розвитку медицини та суспільства по-

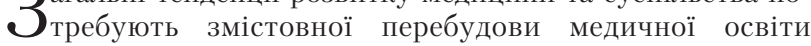
відповідно до світових стандартів. На сучасному етапі розвитку вищої медичної школи першочерговим є необхідність підготовлення висококваліфікованих кадрів, впровадження в галузь нових технологій організації та управління педагогічним процесом [1]. Бурхливий розвиток медицини спонукає змінювати форми і методи підготовки спеціалістів, покращувати рівень освіти як безперервний процес вдосконалення знань лікаря-професіонала [2]. У контексті сучасної освітньої реформи особливу увагу приділяють клінічному навчанню, що спрямоване на досягнення компетентності лікарів та базується на принципах їхньої професійної підготовки $[3,4]$. Грунтуючись на сучасних засадах, викладання дисциплін поступово зміщується у бік безперервного професійного розвитку лікарів та передбачає перехід від пасивних до активних форм навчання $[4,5]$. Загальна освіта, на відміну від клінічного навчання, частіше спрямована на досягнення мети. Вона дає широкий спектр знань та умінь, які необхідні у даній професії, звідки учень зможе у подальшому вибрати те, що буде необхідним у ситуації, яка склалася.

Мета роботи: вивчення методів забезпечення високоякісного медичного обслуговування відповідно до принципів навчання та концепції успішного оволодіння навичками. Завданням клінічних викладачів є забезпечення передачі практичних навичок разом із наданням інформації, яка потрібна слухачам для виконання їхньої повсякденної роботи. Ефективне клінічне навчання робить наголос на використанні теоретичних знань у процесі виконання практичних навичок, накопиченні професійних знань та умінь, які повинні будуватися на системі єдиних державних стандартів.

В умовах України безперервність навчального процесу у післядипломній освіті найбільшою мірою може дати очнозаочна форма навчання, яка складається із заочного (дистанційного) та очного (традиційного) блоків. Мета такого навчання - це оволодіння учнями навичками самостійної роботи, яка охоплює вміння орієнтуватись в інформаційному просторі, знання основної періодичної літератури, навички роботи з нею, підготовка рефератів, доповідей. 3 позиції доказової медицини сучасний лікар має знати основні консенсуси та міжнародні рекомендації [2]. Під час дистанційного навчання лікар одержує завдання із урахуванням фаху та категорії.

При очному навчанні насамперед актуальним має бути клінічне навчання. На нашу думку, для успішного клінічного навчання необхідне вміння викладачів застосовувати різноманітні форми та методики викладання, а також володіння технологіями обробки навичок у контрольованих та змодельованих умовах (рольові ігри, заняття на тренаже- pax), придбання та повторення навички з розвитком іï до рівня компетенції як елементу досягнення досвідченості зі збереженням принципу реалістичної учбової ситуації. Навпаки, дидактична лекція як форма навчання основи дисципліни не придатна для передачі клінічних навичок, вироблення вміння вирішувати різноманітні проблеми. Тому з метою удосконалення підготовки спеціалістів, щоб за відведений термін навчання сформувати у слухачів основи клінічного мислення та удосконалити практичні навички, необхідно у викладацькій роботі використовувати такі методики сучасної активної освіти:

- інтерактивна лекція - ії проведення передбачає запитання у ході лекції з обох боків: і викладача, і слухачів. У такій ситуації викладачу треба володіти матеріалом набагато краще, ніж в дидактичній лекції;

- навчання у малих групах - воно припускає партнерські відносини на практиці між слухачами та викладачем. Слухачі дуже цінують створення таких партнерських відносин. Щоб вони склалися, потрібно створити коло із стільців, між якими буде маленький проміжок. Якщо хтось із слухачів помилився, не треба одразу його виправляти, так само не потрібно й одразу відповідати на запитання слухачів, нехай спробують відшукати вірний шлях самі, щоб він запам'ятався. При цьому головним завдання викладача є створення високого рівня мотивації, підтримання доброзичливої атмосфери, дотримання демократичних принципів викладання. Викладач відіграє роль координатора: планує заняття, ініціює роботу, забезпечує інформаційну підтримку;

- мозковий штурм - дозволяє проводити проблемні заняття, можна обрати із слухачів посередника, який буде направляти заняття у потрібне русло;

- рольові ігри. Викладачі звикли оцінювати тільки медичні знання слухачів у цих іграх. Однак через гру можна дати багатогранну оцінку слухачеві - його знанням, навичкам консультуванню пацієнта та спілкуванню між особистостями, навичкам надання допомоги при невідкладних станах і таке інше. Потрібно часто хвалити учня у ході гри, починати обговорення проведеної слухачами гри із питань, які об'єднують зі слухачами. Спочатку викладач має виділити те, що йому в грі сподобалось, і тільки потім сказати, що він зробив би не так.

Пасивне запам'ятовування і викладення поширене на перших курсах багатьох сучасних медичних вишів, адже студентам необхідно оволодіти 1-2 рівнем знань. У цьому випадку викладач сам вирішує, які знання має вивчити студент. У пасивному навчанні є позитивні сторони, а саме інформація викладається в логічній послідовності, у студента формуються навички з системної роботи, у викладача є можливість навчити більшість студентів, причому чим дидактичніша лекція, тим краще. Недоліки пасивного навчання зумовлюються обмеженням ініціативи студентів, ігноруванням їхньої думки. Отже, студенти не несуть відповідальності за освіту.

Принципова відмінність викладання дисциплін для студентів та дорослих полягає в тому, що у навчанні студентів 


\section{НЕПРЕРЫВНОЕ ПРОФЕССИОНАЛЬНОЕ ОБРАЗОВАНИЕ ВРАЧЕЙ В УКРАИНЕ}

використовується педагогіка. Викладання дисциплін при цьому схоже на постійне повторення із мінімальним контролем з боку учня. Освіта для дорослих - це антрогогіка, освіта тут є актом доброї волі. Вона стимулює різноспрямоване мислення. Наголос робиться на рівні попередньої освіти слухача. Існує шість рис, які відрізняють дорослих від студентів у навчанні:

1) вони перебувають не на початковому рівні знань;

2) критично оцінюють вміння викладача;

3) мають сформований світогляд і власний досвід;

4) мають свої цілі у навчанні;

5) мають уявлення, яким має бути навчання;

6) у них є конфліктні інтереси (позитивні або негативні обставини життя).

Найбільш успішне навчання базується на якомусь рівні, мотивується власною потребою слухача, при цьому застосовуються зворотний зв'язок, самооцінювання. Щоб зорієнтувати, підбурити слухача до участі в активних формах навчання, бажано урахувати його улюблений стиль навчання. Викладач не може дотримуватись пасивної точки зору на процес навчання слухачів, тобто - якщо слухач цікавиться, він вчиться. Типи слухачів можуть бути такими:

- активіст - холерик у навчанні, щиро й швидко віддається набуттю нового досвіду, але ненадовго, швидко байдужіє. Він може блискуче працювати у малій групі, взяти участь у круглому столі, дискусії, встати і виступити. Проте реферати він готувати добре не буде, чи робити огляд літератури, тобто у постійних видах роботи буде халтурити. 3 активістом можна готувати рольові ігри, нехай складні, але короткі;

- рефлектор - багато спостерігає, дуже обережно висловлює свою думку, коли переслухає всіх, і ще думає: так я сказав чи ні. Він підсумує результат залежно від того, чия точка

\section{Оптимизация непрерывного профессионального развития врача O.C. Щербинская}

В статье предоставлена информация об основных методах актив ного обучения в рамках непрерывного профессионального развития врачей и путях привлечения к ним слушателей.

Ключевые слова: методы активного обучения, непрерьвное, про фессиональное развитие, стиль обучения. зору перемогла. Безперспективно просити його вести дискусії - він не зможе сам зробити висновок на аудиторію, не вислухавши їі. Рефлектора вибиває із колії брак часу, він не може переналаштовуватися. Проте добре виконає збір інформації, проаналізує і просинтезує їі, якщо є багато часу. Проведення мозкового штурму з ним - завдання безперспективне;

- теоретик - це людина-план, він не буде робити нічого без плану, сам будує логічні схеми, сам їх перевіряє на практиці. Теоретики захоплюються виконанням планів, це хороші лектори, наукові співробітники, дуже добре вирішують складні ситуації. Їм не притаманні раптові «стрибки», вони не люблять нічого неочікуваного, їм важко у рольових іграх, вони не імпатики;

- прагматик - єдиний критерій цінності будь-якого навчання для нього - це реалізувати знання на практиці. Прагматики навчаються, виходячи із: Ще мені знадобиться у практиці чи ні?». Усі ми, чим досвідченіше стаємо, тим більше фільтруємо інформацію, яка, на його думку, не дасть можливості миттєвої реалізації. Він не сприймає дуже теоретизованої, віддаленої інформації.

Ефективність сучасної підготовки лікарських кадрів є залежним не лише від рівня набутих знань, потрібно ще й позитивні моральні якості, без яких не може відбутися становлення лікаря. Усі види роботи зі слухачами необхідно спрямовувати на установлення гуманізації навчального процесу.

\section{ВИСНОВКИ}

Упровадження сучасних методів активного навчання в очний блок безперервного навчального процесу у післядипломній освіті сприятиме підвищенню ефективності успішного оволодіння навичками. Використання інформації про типи слухачів дозволить оптимізувати рівень засвоєння матеріалу.

\section{Optimisation for physicians continuous professional development O.S. Sherbinska}

This publication contains information about basic methods of active teaching in the frameworks of physicians' continuous professional development and the ways of doctors involving the trainees.

Key word: methods of acting teaching, continuous prof essional development, teachingstile.

\section{Сведения об авторе}

Щербинская Елена Станиславовна - Национальная медицинская академия последипломного образования имени П.Л. Шупика, 04112, г. Киев, ул. Дорогожицкая, 9; тел.: (044) 220-15-41

\section{СПИСОК ЛІТЕРАТУРИ}

1. Дерев'янко Л.І. Вимоги сьогодення до проблеми післядипломної освіти / Л.І. Дерев'янко, Л.А. Васильєва, Н.В. Півньова // Матеріали учбовометодичноі конференції «Актуальні питання післядипломної освіти в Україні». - Харків, 2009. - С. 99-100. 2. Долженко М.Н. Дистанционное обу- чение в системе медицинского после дипломного образования в Украине / М.Н. Долженко, Роберт Бендер // Зб. наук, праць співробітників КМАПО ім. П.Л. Шупика. - К., 2014. - С. 546-550. 3. Ліпкан Г.М. Деякі питання оптимізації навчального процесу / Г.М. Ліпкан, Т.Л. Сакун, І.М. Заїка // Зб. наук. праць співробітників КМАПО ім. П.Л. Шупика - К., 2013. - С. 1069-1072.

4. Мачерет Є.Л. Напрямки оптимізації навчального процесу на клінічній кафедрі / Є.Л. Мачерет, Г.М. Чуприна, 0.0. Коркушко // Зб. наук. праць співробітників КМАПО ім. П.Л. Шупика. - К., 2004. - С. 546-550.
5. Пидаев А.В. Болонский процесс в Европе. Что это такое и нужен ли он Украине? Возможна ли интеграция медицинского образования Украины в Европейское образовательное пространство? / А.В. Пидаев, В.Г. Передерий. - Одесса: Одес. гос. мед. ун-т, 2004. - 192 с. 


\section{Рекомендации международного общества}

\section{по менопаузе в отношении здоровья женщин зрелого возраста и менопаузальной гормональной терапии (2016)}

The IMS Writing Group

Website: www.imsociety.org

Впервые опубликовано в Climacteric 2016;19:109-150. Печатается с сокращениями. Адаптировано - С.А. Шурпяк

\section{Методология}

- Основные данные и информация основываются на международных консенсусных заявлениях, опубликованных IMS, Европейским обществом по менопаузе и андропаузе (EMAS) и Североамериканским обществом по менопаузе (NAMS).

- Это руководство было создано коллективом экспертов и не ограничивается исключительно членами IMS.

- Особое внимание уделялось публикациям, начиная с 2013 года.

• Использована классификация уровней доказательств, которые подробно описаны в Руководстве № 1 Королевского колледжа акушеров и гинекологов.

- Оценка и определение уровней доказательств и рекомендаций для данного руководства изложены далее.

- Там, где это возможно, рекомендации основаны на связи с доказательствами.

- В случае отсутствия достоверных доказательств рекомендации даются на основе обширного опыта експертов и отмечены как рекомендации по улучшению клинической практики. $\square$

\begin{tabular}{|c|c|c|}
\hline \multicolumn{3}{|c|}{$\begin{array}{c}\text { Уровни доказательств и класс рекомендаций (согласно методическим рекомендациям } \\
\text { Королевского колледжа акушерства и гинекологии Великобритании) }\end{array}$} \\
\hline & Классификация уровней доказательств & Класс рекомендаций \\
\hline $1++$ & $\begin{array}{c}\text { Высококачественные мета-анализы, } \\
\text { систематические обзоры рандомизированных } \\
\text { контролируемых исследований или } \\
\text { рандомизированных контролируемых } \\
\text { исследований с очень низким риском } \\
\text { систематической ошибки }\end{array}$ & $\begin{array}{c}\text { [А] По крайней мере, один мета-анализ, систематический } \\
\text { обзор или рандомизированное контролируемое } \\
\text { исследование, которое оценивается как 1++, } \\
\text { и непосредственно применимое к целевой популяции. } \\
\text { Систематический обзор рандомизированных контролируемых } \\
\text { исследований или совокупность доказательств, состоящая } \\
\text { главным образом из исследований, оцениваемых как 1+, } \\
\text { непосредственно применимых к целевой группе населения } \\
\text { и демонстрирующих общую согласованность результатов }\end{array}$ \\
\hline $1+$ & $\begin{array}{c}\text { Хорошо проведенные мета-анализы, } \\
\text { систематические обзоры рандомизированных } \\
\text { контролируемых исследований или } \\
\text { рандомизированные контролируемые исследования } \\
\text { с низким риском систематической ошибки }\end{array}$ & $\begin{array}{c}\text { [В] Совокупность доказательств, в том числе исследования, } \\
\text { оцененные как 2++, непосредственно применимых к целевой } \\
\text { популяции и демонстрирующих однородность результатов; } \\
\text { или экстраполированные данные исследований, } \\
\text { оцененных как 1++ или 1+ }\end{array}$ \\
\hline $1-$ & $\begin{array}{c}\text { Мета-анализы, систематические обзоры } \\
\text { рандомизированных контролируемых } \\
\text { исследований или рандомизированные } \\
\text { контролируемые исследования с высоким риском } \\
\text { систематической ошибки }\end{array}$ & $\begin{array}{c}\text { [C] Совокупность доказательств, в том числе исследований, } \\
\text { оцененных как 2+, непосредственно применимых к целевой } \\
\text { группе населения и демонстрирующих общую } \\
\text { согласованность результатов; или Экстраполированные } \\
\text { данные исследований, оцененных как 2++ }\end{array}$ \\
\hline $2++$ & $\begin{array}{c}\text { Высококачественные систематические обзоры } \\
\text { исследований случай-контроль или когортных } \\
\text { исследований, или исследования случай-контроль } \\
\text { или когортные исследования высокого качества с } \\
\text { очень низким риском ошибочных выводов, } \\
\text { предвзятости или случайности и высокой } \\
\text { вероятностью причинно-следственных отношений }\end{array}$ & $\begin{array}{c}\text { [D] Уровень доказательности } 3 \text { или 4; } \\
\text { или Экстраполированные данные исследований, } \\
\text { оцениваемых как 2+ }\end{array}$ \\
\hline $2+$ & $\begin{array}{c}\text { Правильно проведенные исследования } \\
\text { случай-контроль или когортные исследования } \\
\text { с низким риском ошибочных выводов или } \\
\text { случайности и средней вероятностью причинно- } \\
\text { следственных отношений }\end{array}$ & \\
\hline 2- & $\begin{array}{c}\text { Исследования случай-контроль или когортные } \\
\text { исследования с высоким риском влияния } \\
\text { случайности и значительным риском отсутствия } \\
\text { причинно-следственных отношений }\end{array}$ & \\
\hline 3 & $\begin{array}{l}\text { Неаналитические исследования, например } \\
\text { сообщения о случае, серии случаев }\end{array}$ & \\
\hline 4 & Мнение эксперта & \\
\hline
\end{tabular}




\section{МЕЖДУНАРОДНЫЕ ПРО ТОКОЛЫ}

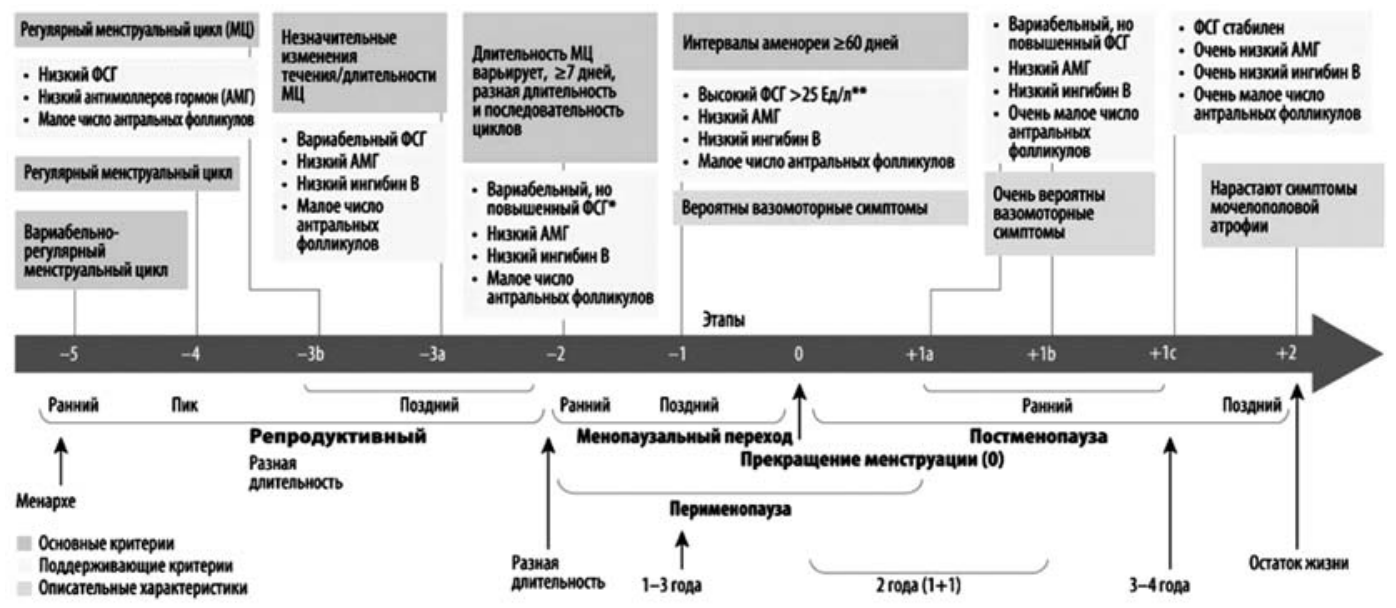

\section{Этапы репродуктивного старения у женщин}

Основные принщипь IMS, касаюшиеся менопаузальной гормональной терапии

- Менопаузальная гормональная терапия (МГТ) остается наиболее эффективным методом терапии вазомоторных симптомов (ВС) и урогенитальных атрофий (УА).

- Другие симптомы, связанные с менопаузой, такие, как перепады настроения, боль в суставах и мышцах, а также нарушения сна, могут уменьшиться при использовании МГТ.

- Назначение индивидуализированной МГТ (в том числе препаратов андрогенов в случае необходимости) может улучшить как сексуальную жизнь, так и общее качество жизни.

- Рассмотрение вопроса о назначении МГТ должно быть частью общей стратегии, включающей также рекомендации в отношении образа жизни, диеты, физических упражнений, отказа от курения и безопасного уровня потребления алкоголя для поддержания здоровья в пери- и постменопаузе.

- МГТ должна быть индивидуализирована с учетом специфики симптомов, необходимости профилактики, личного и семейной анамнеза, результатов исследований, предпочтений и ожиданий женщины.

- Риски и преимущества МГТ отличаются с возрастом и количеством прошедших лет после последней менструации.

- Женщины со спонтанной или ятрогенной менопаузой в возрасте до 45 и особенно в возрасте до 40 лет имеют более высокий риск развития сердечно-сосудистых заболеваний и остеопороза. У этих женщин при отсутствии противопоказаний МГТ рекомендуется, по крайней мере, до достижения среднего популяционого возраста менопаузы.

- Во время консультирования по вопросам МГТ риски и выгоды должны обрисовываться в четких и понятных терминах, в идеале выражаться как значения абсолютного риска в реальных числах.

- МГТ не следует рекомендовать без четких показаний для ее использования.

- Женщины, принимающие МГТ, должны, по крайней мере, один раз в год приходить на медицинское консультирование с проведением объективного осмотра, необходимых лабораторных и инструментальных исследований, уточнения медицинского и семейного анамнеза. В настоящее время нет показаний к расширению скрининга с проведением маммографии или мазков из шейки матки.

- Нет никаких причин для установления обязательного лимита на длительность МГТ.

- Доза и длительность МГТ должны соответствовать целям лечения.

- Решение о прекращении или продолжении терапии должно приниматься хорошо информированной пациенткой совместно с лечащим врачом.

\section{Диагностика менопаузы}

- Менопауза определяется как последняя менструация.

- Менопауза является ретроспективным клиническим диагнозом, поскольку последняя менструация может быть констатирована только через 12 мес аменореи.

- Менопауза является естественным и неизбежным событием, которое происходит в среднем в возрасте 51 года у белой европеоидной расы, с этническими и региональными вариациями.

- Менопауза в возрасте до 40 лет считается преждевременной.

- Точное стадирование репродуктивного старения является важным с клинической и исследовательской точки зрения.

- Критерии, которые считаются «золотым стандартом», для определения репродуктивного возраста были сформулированы Рабочей группой по стадиям старения репродуктивной системы +10 (Stages of Reproductive Aging Workshop + $10-$ STRAW + 10).

- Текущие данные указывают, что критерии STRAW + 10 применимы к большинству, но не ко всем женщинам.

- Критерии не могут быть использованы при СПКЯ или первичной недостаточности яичников, а также после абляции эндометрия или гистерэктомии.

\section{Увеличение массы тела}

Ключевые моменты

- Абсолютное увеличение массы тела в зрелом возрасте не может быть отнесено к менопаузе. [B]

- Гормональные изменения, которые сопровождают менопаузу, связаны с увеличением общего жира в организме и абдоминального жира, даже у стройных женщин. [В]

- Приверженность к здоровому питанию, снижение избытка калорийности в сочетании с физической активностью являются важными компонентами контроля массы тела. [А]

- Менопаузальное накопление абдоминальной жировой массы уменьшается при терапии эстрогенами, кроме того, применение эстрогенов снижает общую массу жировой ткани, улучшает чувствительность к инсулину и ассоциируется с более низким уровнем развития сахарного диабета 2-го типа. [А]

\section{Преждевременная недостаточность яичников}

Ключевые моменть

- Преждевременная недостаточность яичников (ПНЯ) определяется как первичный гипогонадизм у женщин моложе 40 лет с нормальным кариотипом и отсутствием прежде нарушений менструального цикла.

- Диагноз подтверждается при определяемых уровнях ФСГ > $40 \mathrm{ME} / л$ минимум в двух исследованиях с интервалом в 4-6 нед. 


\section{МЕЖДУНАРОДНЫЕ ПРОТОКОЛЫ}

• ПНЯ требует проведения терапии для предотвращения увеличения сердечно-сосудистых заболеваний, остеопороза когнитивных нарушений, деменции и паркинсонизма. [B]

- Диагностика должна включать в себя анализ гормонального статуса, исключение аутоиммунных причин, кариотипирование, исключение синдрома ломкой X-хромосомы и УЗИ органов малого таза. $\square$

- Информацию относительно приливов, сухости влагалища, отсутствия либидо, артралгии, бессонницы и проблем с фертильностью следует выяснять чутко и заботливо.

- Пациенты должны быть обеспечены адекватной информацией и возможностью консультирования.

- Основным методом лечения является ГТ при отсутствии противопоказаний с использованием более высоких доз эстрогенов для женщин старше 40 лет с применением тестостерона у женщин с низким либидо. [C]

- МГТ не может рассматриваться как метод контрацепции.च Лечение должно продолжаться, по крайней мере, до возраста естественной менопаузы.

ЭКО с донацией ооцитов или эмбрионов имеет доказанную высокую эффективность, но неприемлемо для всех женщин с ПНЯ. च

\section{Образ жизни, физические упражнения и диета}

Ключевые моменты

• Регулярные физические упражнения рекомендуется для уменьшения сердечно-сосудистой и общей смертности. [В]

- Оптимальным является, по крайней мере, 150 мин умеренной интенсивности физических упражнений в неделю. [B]

- При подборе интенсивности аэробной нагрузки следует учитывать возраст, гендерную специфику.

- Снижение массы тела на 5-10\% достаточно для улучшения многих отклонений, связанных с синдромом инсулинорезистентности. [B]

- Следует избегать курения. [A]

- Изменения стиля жизни включают социализацию, физическую и умственную активность. $\square$

- Здоровая диета должна включать в себя несколько порций фруктов и овощей в день, волокна из цельного зерна, рыбу два раза в неделю и низкое общее потребление жиров. Соль и потребление алкоголя дожно быть ограничено. 『

\section{Урогинекология}

Ключевые моменть

- Такие симптомы, как сухость влагалища, болезненность, диспареуния, частое мочеиспускание, ноктурия часто наблюдаются у женщин в постменопаузе.

- Существует широкий разброс симптомов и признаков урогенитального старения.

- Урогенитальные симптомы хорошо корригируются терапией эстрогенами. [A]

- Часто требуется длительное лечение в связи с рецидивированием симптомов. При локальном использовании низких доз эстрогенов системные риски не были идентифицированы. [В]

- Системная МГТ не предотвращает развития недержания мочи и не является предпочтительным методом по сравнению с использованием местной терапии эстрогенами при лечении урогенитальных симптомов и инфекций мочевыводящих путей. [В]

- Изменения в образе жизни и тренировка мочевого пузыря рекомендуются в качестве терапии первой линии при симптоматике гиперактивного мочевого пузыря. ■

- Антихолинэргические препараты в сочетании с топической терапией эстрогенами являются первой линией медикаментозной терапии у женщин в постменопаузе с симптомами гиперактивного мочевого пузыря. [А]
- Все женщины с подтвержденным стрессовым недержанием мочи могут значительно облегчить симптомы в первую очередь путем тренировки мышц тазового дна. $\square$

- Дулоксетин может работать синергически с консервативной терапией.

- Некоторые женщины требуют хирургического вмешательства, на сегодня наиболее популярными процедурами являются позадилонная и трансобтураторная фиксация с помощью ленты.

- В настоящее время не признается значимость системной терапии эстрогенами у женщин с чистым стрессовым недержанием мочи. [A]

\section{Постменопаузальный остеопороз}

Ключевые моменты

- Остеопороз представляет собой системное заболевание скелета, характеризующееся уменьшением прочности костей с повышением риска перелома при падении с высоты собственного роста.

- Остеопороз определяется значением $\mathrm{T} \leq-2,5$ балла при ДЭРА или наличием низкотравматичных переломов вследствие хрупкости костей.

- Индивидуальная 10-летняя вероятность перелома может быть оценена при помощи калькуляторов факторов риска, таких, как модель FRAX. [A]

- Пороговые критерии для вмешательств могут быть основаны на 10-летней вероятности перелома, однако будут зависеть от конкретной страны.

- Лечение может проводиться у всех пациентов с остеопоротическими переломами, или со значением Т-критерия $\leq-2,5$ (остеопороз), или со значением Т-критерия $<-1,0>-2,5$ (остеопения) при наличии дополнительных факторов риска. [A]

- Соответствующая оценка предыдущих переломов и вторичных причин остеопороза должна предшествовать любым терапевтическим вмешательствам.

- Изменения образа жизни должны быть частью любой стратегии лечения. [А]

- Выбор фармакотерапии должен основываться на балансе эффективности, риска и затрат.

- МГТ является наиболее подходящей терапией для профилактики переломов в ранней постменопаузе. [A]

\section{Кожа, хрящи и соединительная ткань}

Ключевые моменты

- Эстрогены оказывают влияние на соединительную ткань всего организма. [А]

- Заметное увеличение остеоартрита у женщин после наступления менопаузы предполагает, что женские половые стероиды являются важными для гомеостаза хряща. [В]

- Деградация хрящевой ткани и необходимость хирургической замены суставов уменьшается в когорте, использующей МГТ. [А]

- Менопауза связана с рядом изменений в здоровье кожи, которые могут быть уменьшены при применении МГТ или локальной терапии эстрогенами. [А]

\section{Сердечно-сосудистые заболевания}

\section{Ключевые моменть}

- У женщин в возрасте до 60 лет с недавно наступившей менопаузой без признаков сердечно-сосудистых заболеваний начало монотерапии эстрогенами снижает смертность от ишемической болезни сердца (ИБС) и общую смертность. [А]

- Данные о применении ежедневной непрерывной комбинированной эстроген-прогестагенной терапии являются менее надежными, однако и другие комбинированные режимы терапии, очевидно, оказывают кардиопротективный эффект, как представлено в Датском и Финском исследованиях. [A] 


\section{МЕЖДУНАРОДНЫЕ ПРОТОКОЛЫ}

- Сердечно-сосудистые заболевания являются ведущей причиной смерти среди женщин, но у женщин, которые начали МГТ до 60 лет и/или до 10 лет после наступления менопаузы, в последнем Кокрановском анализе, других метаанализах и 13-летних результатах исследования WHI отмечено стабильное снижение общей смертности. [А]

- Не рекомендуется начало МГТ после 60 лет исключительно для первичной профилактики ишемической болезни сердца. [А]

\section{Венозный тромбоэмболизм}

Ключевые моменть

- Тщательная оценка личного и семейного анамнеза венозного тромбоэмболизма (ВТЭ) имеет важное значение перед назначением МГТ. $\square$

- Пероральные эстрогены противопоказаны женщинам с ВТЭ в анамнезе. [А]

- Трансдермальные эстрогены должны быть препаратами первой линии у женщин с ожирением и эпизодами ВТЭ. [В]

- Риск ВТЭ увеличивается с возрастом и при наличии факторов риска, включая врожденные и приобретенные тромбофилические нарушения. $\square$

- Риск ВТЭ возрастает при использовании пероральной МГТ, но абсолютный риск является низким у женщин в возрасте до 60 лет. $\square$

- Наблюдательные исследования указывают на более низкий риск низкодозированной трансдермальной терапии в сочетании с прогестероном, что подтверждается четким биологическим правдоподобием. $\square$

Биологическое правдоподобие (biological plausibility) критерий, согласно которому наблюдаемая ассочиачия, предположительно причинно-следственная, согласуется с существуюшими биологическими или медицинскими знаниями. Этот способ рассуждения следует применять с осторожностью, поскольку он может мешать развитию новых знаний, которые не согласуются с ранее существующими идеями.

• Некоторые прогестагены, такие, как МПА, производные непрегнанового ряда, и непрерывный комбинированный режим терапии при применении пероральной МГТ связывают с повышением риска ВТЭ. [C]

- Частота ВТЭ ниже у азиатских женщин. [C]

• Популяционный скрининг на тромбофилию не показан перед назначением МГТ. [C]

Ключевые моменть

\section{Когнитивные функции}

- МГТ не следует использовать для улучшения когнитивной функции. [А]

- Здоровые женщины, рассматривающие использование МГТ при вазомоторных симптомах (ВМС) не должны быть обеспокоены тем, что МГТ отрицательно скажется на когнитивной функции. [А]

- Терапия эстрогенами может кратковременно позитивно влиять на когнитивную функцию при хирургической менопаузе при условии инициации в период овариоэктомии. [B]

- Применение здоровыми женщинами в постменопаузе пищевых добавок с фитоэстрогенами (изофлавоноидами сои) в суточной дозе, сравнимой с традиционным азиатским рационом, не оказывает общего влияния на когнитивную функцию. [А]

\section{Болезнь Альцгеймера и деменция}

Ключевые моменть

- Для женщин, страдающих болезнью Альцгеймера, МГТ, инициированная после появления симптомов демен- ции, не влияет на когнитивную функцию или замедление развития болезни. [А]

- МГТ, начатая в течение 10 лет после последнего менструального периода, ассоциируется со снижением риска болезни Альцгеймера и деменции. [B]

- МГТ с использованием эстрогенов и прогестагенов, инициированная в возрасте 65+, увеличивает риск деменции. [А]

\section{Другие неврологические нарушения}

Ключевые моменты

- Невозможно определить, улучшает ли МГТ или не оказывает никакого влияния на депрессивные симптомы в ранней постменопаузе у пациенток без депрессии в анамнезе, поскольку результаты противоречивы. [А]

- Краткосрочная терапия эстрогенами может снижать выраженность симптомов депрессии, возникающих в период менопаузального перехода, и увеличивает вероятность ремиссии. [В]

- МГТ может увеличить частоту приступов у женщин с эпилепсией. [B]

- МГТ не связана с риском развития болезни Паркинсона. [В]

- Влияние МГТ на мигрень и рассеянный склероз в значительной степени неизвестны. [В]

\section{Рак молочной железы}

Ключевые моменты

- Риск развития рака молочной железы, связанный с МГТ у женщин старше 50 лет, является комплексным.

- Повышенный риск связан прежде всего с добавлением синтетического прогестагена к эстрогенной терапии (непрерывный комбинированный режим ККЭ + МПА) и длительностью использования. [В]

- Риск может быть ниже при использовании микронизированного прогестерона или дидрогестерона. [C]

- Относительный риск рака молочной железы при применении МГТ низок и снижается после ее прекращения. [B]

- Недостаточно данных по безопасности для поддержки использования МГТ (монотерапии эстрогенами или эстроген-прогестагенными препаратами) у пациенток, перенесших рак молочной железы

- Риск развития рака молочной железы должен быть оценен до назначения МГT. [D]

- Любой возможный повышенный риск развития рака молочной железы, связанный с МГТ, может быть уменьшен путем отбора женщин с более низким исходным риском, включая низкую плотность молочной железы, а также путем проведения образовательной роботы относительно превентивного изменения образа жизни (снижение массы тела, уменьшение потребления алкоголя, увеличение физической активности). [D]

- У женщин, принимающих МГТ, следует проводить ежегодную маммографию. [D]

\section{Безопасность эндометрия и кровотечение}

Ключевые моменты

- Кровотечение в постменопаузе - это «рак эндометрия, пока не будет доказано обратное», хотя только у $1-14 \%$ таких женщин диагностируется рак эндометрия.

- Слепая биопсия эндометрия приемлема для обследования первой линии, но информативна лишь при большой площади поражения эндометрия (более 50\%). [В]

- Монотерапия эстрогенами в зависимости от дозы и длительности связана с повышенным риском развития гиперплазии и рака эндометрия. [A]

- Для защиты эндометрия требуются адекватная доза и продолжительность использования прогестагена. [А] 


\section{МЕЖДУНАРОДНЫЕ ПРОТОКОЛЫ}

• Если доза эстрадиола составляет 2 мг/50 мкг или меньше, адекватными дозами микронизированного прогестерона как представляется, являются 200 мг в сутки в течение 10-14 дней в месяц при последовательной терапии или 100 мг в сутки при непрерывном комбинированном режиме терапии. [B]

- Более высокие дозы прогестерона могут потребоваться для защиты эндометрия при использовании более высоких доз эстрадиола или у женщин с высоким индексом массы тела. $\square$

\section{Колоректальный рак}

Ключевые моменты

• Большинство наблюдательных исследований показали снижение риска развития колоректального рака (КРР) среди пациенток, использующих пероральную МГТ. [В]

- Три мета-анализа сообщили о снижении риска КРР при использовании МГТ с сохранением протективного эффекта на протяжении 4 лет после ее прекращения. [A]

- Результаты исследования WHI показали, что монотерапия эстрогенами не влияет на риск развития КРР. [А]

- Исследование WHI показало снижение риска развития КРР при использовании терапии Э+П, однако это относилось в основном к локальному процессу. [А]

- Данные о влиянии непероральной МГТ на риск развития КРР на сегодняшний день ограничены.

- Исследование Long-term Intervention on Fractures, LIFT, о влиянии тиболона на частоту переломов показало снижение риска развития КРР у женщин в возрасте 60-79 лет. [А]

- МГТ не должна использоваться исключительно для профилактики КРP. [D]

\section{Другие виды рака}

Ключевые моменть

- В исследовании WHI не было обнаружено увеличения риска развития рака шейки матки при МГТ. [А]

• Долгосрочные когортные исследования не обнаружили увеличения риска развития рака шейки матки при использовании МГТ. [В]

- Недостаточно в настоящее время данных для выводов о взаимосвязи между МГТ и раком яичников.

• Оба клинических исследования WHI (монотерапия эстрогенами или Э + П) не показали значимого увеличения частоты развития рака легких среди принимающих МГТ в сравнении с плацебо. [A]

• В исследовании WHI в группе Э + П риск смерти от рака легких был выше, при этом не отмечено влияния на смертность среди женщин в возрасте 50-59 лет. [А]

- Не установлено четкой связи между использованием МГТ и возникновением гепатоцеллюлярной карциномы. [C]

- Двусторонняя овариоэктомия может быть связана с повышенным риском возникновения гепатоцеллюлярной карциномы. [C]

- Использование МГТ может быть связано со снижением риска развития рака желудка. [C]

- Проведено мало хороших исследований для изучения связи между раком верхних отделов гастроинтестинального тракта, менопаузой и использованием МГТ.

\section{Общее и сексуальное качество жизни}

Ключевые моменть

- При рассмотрении качества жизни и сексуального благополучия следует учитывать возраст, тип и время с момента наступления менопаузы, симптомы менопаузы, общее состояние здоровья, в том числе медикаментозные препараты, которые принимаются по поводу соматической патологии, внутриличностные факторы и межличностные отношения. [А]
- Необходимы диагностика и лечение вульвовагинальной атрофии/урогенитального синдрома менопаузы с целью профилактики формирования порочного круга между болью, связанной с сексуальностью, и другими проявлениями женской сексуальной дисфункции. [В]

- При клинической значимости сексуальных симптомов менопаузы всегда необходимо учитывать биопсихосоциальную модель для разработки эффективного плана лечения. [C]

\section{Андрогенотерапия у женщин}

Ключевые моменть

- Уровень андрогенов снижается с возрастом, однако нет значительных изменений, связанных с естественной менопаузой. [А]

- Существуют убедительные доказательства того, что андрогены влияют на женскую сексуальную функцию и что терапия тестостероном может быть полезна для женщин с утратой возбуждения или либидо. [А]

- Женщины должны быть в полной мере обследованы относительно других причин сексуальной дисфункции, прежде чем может рассматриваться терапия тестостероном. [А]

- Терапию тестостероном следует рассматривать в качестве клинического исследования, которое не должно продолжаться, если женщина не наблюдает позитивных эффектов в течение 6 мес. [A]

\section{Альтернативные методы и биоидентичная} экстемпоральная гормональная терапия (БГТ)

Ключевые моменты

- Альтернативные методы лечения имеют ограниченные доказательства эффективности и безопасности, не контролируются регуляторными органами. [B]

- Когнитивно-поведенческая терапия, управляемое дыхание, иглоукалывание, гипноз и блокада звездчатого ганглия могут быть полезными методами, которые следует учитывать при лечении ВМС. [A]

- Экстемпоральная БГТ не рекомендуется в связи с отсутствием контроля качества этих препаратов наряду с отсутствием доказательств безопасности и эффективности. [В]

- Определение уровней гормонов в сыворотке или слюне для оптимизации МГТ не рекомендуется, поскольку они имеют небольшую ценность для улучшения менеджмента МГТ при выборе начальных доз МГТ или в мониторинге эффективности. [B]

\section{Фармакологические методы терапии} вазомоторных симптомов

Ключевые моменты

- Селективные ингибиторы обратного захвата серотонина (СИОЗС) и селективные ингибиторы обратного захвата серотонина и норадреналина (СИОЗСиН), такие, как венлафаксин, десвенлафаксин, пароксетин, эсциталопрам и циталопрам, эффективно купируют приливы у женщин в постменопаузе. [А]

- Следует избегать применения пароксетина у женщин, получающих тамоксифен. [А]

- Габапентин эффективен в уменьшении проявлений ВMC в более высоких дозах, но имеет больше побочных эффектов, чем СИОЗСиН/СИОЗС. [В]

\section{Вульвовагинальная атрофия}

Ключевые моменты

- Необходимо проводить образовательную роботу с пациентами для полного уточнения симптомов вульвовагинальной атрофии (BВA) и обращения за медицинской помощью в случае необходимости. [A]

- Лечение лучше всего начинать до развития необрати- 


\section{МЕЖДУНАРОДНЫЕ ПРОТОКОЛЫ}

мых атрофических изменений и продолжать для поддержки достигнутых результатов. [В]

- Основным принципом лечения являются восстановление урогенитальной физиологии и в уменьшении проявлений симптомов.

- Когда ВВА является единственным симптомом, локальная терапия эстрогенами является предпочтительным методом. [В]

- Местная терапия эстрогенами характеризуется низким системным уровнем абсорбции эстрадиола, и даже при длительном применении уровни эстрогенов в сыворотке крови не превышают нормального диапазона (<20 пг/мл) для женщин в постменопаузе. [B]

- При применении локально низких доз эстрогенов дополнительное назначение прогестагена не требуется, однако данных о длительном применении недостаточно. [B]

• При наличии противопоказаний или неэффективности применения эстрогенов рекомендуется использование вагинальных лубрикантов и увлажняющих средств и половую жизнь на регулярной основе. [C]

- Местное применение эстрогенов у женщин, получающих тамоксифен или ингибиторы ароматазы, требует тщательного консультирования и обсуждения онкологами. [D]

- Препараты эстриола или тестостерона могут быть вариантом терапии для таких пациенток, но необходимы дополнительные исследования. [C]

- Существуют ограниченные данные о местном использовании эстрогенов у женщин с гормонально зависимыми видами рака, что требует осторожности их применения. [D]

\section{выводы}

Эти рекомендации, основанные на базе фактических данных, созданы для широкого распространения оказания оптимальной помощи всем женщинам среднего и старшего возраста

\section{СПИСОК ЛИТЕРАТУРЫ}

Methodology

1. Royal College of Obstetricians and Gynaecologists. Development of RCOG Greentop Guidelines (Clinical Governance Advice No. 1). http://www.rcog.org. uk/green-top-development

Mid-life body anges

1. Sternfeld B, Wang H, Quesenberry CP $\mathrm{Jr}$, et al. Physical activity and changes in weight and waist circumference in midlife women: ndings from the Study of Women's Health Across the Nation. Am J Epidemiol 2004;160:912-22.

2. Guthrie JR, Dennerstein L, Dudley EC. Weight gain and the menopause: a 5 -year prospective study. Climacteric 1999;2:205-11.

3. Wing RR, Matthews KA, Kuller LH, Meilahn EN, Plantinga PL. Weight gain at the time of menopause. Arch Intern Med 1991:151:97-102.

4. Jacoby E, Goldstein J, Lopez A, Nunez E, Lopez T. Social class, family, and life-style factors associated with overweight and obesity among adults in Peruvian cities. Prevent Med 2003;37:396-405.

5. Hajian-Tilaki KO, Heidari B. Prevalence of obesity, central obesity and the associated factors in urban population aged 20-70 years, in the north of Iran: a population-based study and regression approach. Obes Rev 2007;8:3-10.

6. Fonken LK, Workman JL, Walton JC et al. Light at night increases body mass by shi ing the time of food intake. Proc Natl Acad Sci USA 2010;107:18664-9.

7. Pan $A$, Lucas $M$, Sun $Q$, et al Bidirectional association between depression and type 2 diabetes mellitus in women. Arch Intern Med 2010;170:1884-91.

8. Janssen I, Powell LH, Crawford S Lasley B, Sutton-Tyrrell K. Menopause and the metabolic syndrome: the Study of Women's Health Across the Nation. Arch Intern Med 2008;168:1568-75.

9. Ho SC, Wu S, Chan SG, Sham A Menopausal transition and changes of body composition: a prospective study in Chinese perimenopausal women. Int $J$ Obes (Lond) 2010;34:1265-74.

10. Abdulnour J, Doucet E, Brochu M, et al. E ect of the menopausal transition on body composition and cardiometabolic risk factors: a Montreal-Ottawa New Emerging Team group study. Menopause 2012;19:760-7.

11. Poehlman E, Toth MJ, Gardner A Changes in energy balance and body composition at menopause: a controlled longitudinal study. Ann Intern Med 1995; 123:673-8.

12. Toth MJ, Tchernof A, Sites CK,

Очень важно дальнейшее продолжение исследований среди женщин среднего возраста с целью улучшения качества жизни и обеспечения долгосрочного благополучия в связи с увеличением количества женщин среднего и старшего возраста.

\section{Основные принципь достижения поставленной цели}

- Преимущества и риски МГТ в значительной мере определяются индивидуально.

- Исследования последнего десятилетия показали, что риски могут быть минимизированы, а преимущества - максимально увеличены при выборе оптимального режима в оптимальный период времени.

- Безопасность МГТ зависит преимущественно от возраста и времени, прошедшего после менопаузы.

- Новые данные и повторные анализы предыдущих исследований относительно возраста показывают, что для большинства женщин имеется множество потенциальных преимуществ МГТ, если она применяется по четким показаниям, а риски немногочисленны, если терапия начинается в течение нескольких лет после наступления менопаузы.

- Полученные на сегодня данные позволяют предположить, что с точки зрения любого увеличения риска развития рака молочной железы более значим именно прогестагенный компонент МГТ, а не эстрогенный.

- Современные прогестагены, натуральный прогестерон и СМЭР оптимизируют влияние на метаболизм и молочные железы.

- Получено все больше данных, демонстрирующих преимущества первичной профилактики остеопоротических переломов и ишемической болезни сердца, а также снижение общей смертности среди женщин, у которых МГТ была начата в период, близкий к менопаузе.

Poehlman ET. E ect of menopausal status on body composition and abdomina fat distribution. Int J Obes Relat Metab Disord 2000;24:226-31.

13. Toth MJ, Tchernof A, Sites CK, Poehlman ET. Menopause-related changes in body fat distribution. Ann NY Acad Sci 2000;904:502-6.

14. Wietlisbach V, Marques-Vidal $P$ Kuulasmaa K, Karvanen J, Paccaud F. e relation of body mass index and abdominal adiposity with dyslipidemia in 27 general populations of the WHO MONICA Project. Nutr Metab Cardiovasc Dis 2013:23:432-42

15. Rogers NH, Per eld JW 2nd, Strissel KJ, Obin MS, Greenberg AS. Reduced energy expenditure and increased in ammation are early events in the development of ovariectomy-induced obesity. Endocrinology 2009;150:2161-8.

16. Stubbins RE, Najjar K, Holcomb VB, Hong J, Nunez NP. Oestrogen alters adipocyte biology and protects female mice from adipocyte in ammation and insulin resistance. Diabetes Obes Metab 2012;14:58-66.

17. Davis SR, Castelo-Branco C, Chedraui $\mathrm{P}$, et al. Understanding weight gain at menopause. Climacteric 2012;15:419-29.

18. Raeder MB, Ferno J, Vik-Mo AO Steen VM. SREBP activation by antipsy- chotic- and antidepressant-drugs in cultured human liver cells: relevance for metabolic sidee ects? Mol Cell Biochem 2006;289:167-73.

19. Yuksel H, Odabasi AR, Demircan $S$, et al. E ects of oral continuous 17betaestradiol plus norethisterone acetate replacement therapy on abdominal subcutaneous fat, serum leptin levels and body composition. Gynecol Endocrinol 2006;22:381-7.

20. Davis SR, Walker KZ, Strauss BJ. E ects of estradiol with and without testosterone on body composition and relationships with lipids in postmenopausal women. Menopause 2000;7:395-401. 21. Chen Z, Bassford T, Green SB, et al. Postmenopausal hormone therapy and body composition - a substudy of the estrogen plus progestin trial of the Women's Health Initiative. Am J Clin Nutr 2005;82:651-6.

22. Sorensen $M B$, Rosenfalck $A M$, Hojgaard L, Ottesen B. Obesity and sarcopenia a er menopause are reversed by sex hormone replacement therapy. Obes Res 2001;9:622-6.

23. O'Sullivan AJ, Crampton LJ, Freund $\mathrm{J}, \mathrm{Ho} \mathrm{KK}$. e route of estrogen replacement therapy confers divergent e ects on substrate oxidation and body composition in postmenopausal women. $\mathrm{J}$ Clin Invest 1998:102:1035-40. 


\section{МЕЖДУНАРОДНЫЕ ПРОТОКОЛЫ}

24. dos Reis CM, de Melo NR, Meirelles ES, Vezozzo DP, Halpern A. Body composition, visceral fat distribution and fat oxidation in postmenopausal women using oral or transdermal oestrogen. Maturitas 2003;46:59-68.

\section{Diagnosis of menopause}

1. Harlow SD, Gass M, Hall JE, et al. Executive summary of the Stages of Reproductive Aging Workshop+10: addressing the un nished agenda of staging reproductive aging. Climacteric 2012;15:105-14.

2. Gelbaya TA, Nardo LG, Fitzgerald CT, Horne G, Brison DR, Lieberman BA. Ovarian response to gonadotropins a er laparoscopic salpingectomy or the division of fallopian tubes for hydrosalpinges. Fertil Steril 2006;85:1464-8. 3. Gold EB, Colvin A, Avis N, et al. Longitudinal analysis of the association between vasomotor symptoms and race/ethnicity across the menopausal transition: Study of Women's Health Across the Nation. Am J Pub Health 2006;96:1226-35.

4. Avis NE, Crawford SL, Greendale G, et al. Duration of menopausal vasomotor symptoms over the menopause transition. JAMA Intern Med 2015;175:531-9.

5. Soules MR, Sherman S, Parrott E, et al. Executive summary: Stages of Reproductive Aging Workshop (STRAW). Climacteric 2001:4:267-72. 6. Harlow SD, Crawford S, Dennerstein L, Burger HG, Mitchell ES, Sowers MF. Recommendations from a multi-study evaluation of proposed criteria for staging reproductive aging. Climacteric 2007;10:112-19.

7. Harlow SD, Cain K, Crawford S, et al. Evaluation of four proposed bleeding criteria for the onset of late menopausa transition. J Clin Endocrinol Metab 2006;91:3432-8.

8. Harlow SD, Mitchell ES, Crawford S et al. e ReSTAGE Collaboration: de ning optimal bleeding criteria for onset of early menopausal transition. Fertil Steri 2008;89:129-40.

9. Randolph JF, Jr, Zheng H, Sowers $M R$, et al. Change in folliclestimulating hormone and estradiol across the menopausal transition: e ect of age at the nal menstrual period. J Clin Endocrinol Metab 2011;96:746-54.

10. Freeman EW, Gracia CR, Samme MD, Lin H, Lim LC, Strauss JF, 3rd Association of antimullerian hormone levels with obesity in late reproductiveage women. Fertil Steril 2007;87:101-6. 11. Gracia CR, Freeman EW, Sammel $M D$, Lin $H$, Nelson DB. e relationship between obesity and race on inhibin $B$ during the menopause transition. Menopause 2005;12:559-66.

12. Huddleston HG, Cedars MI, Sohn SH, Giudice LC, Fujimoto W. Racial and ethnic disparities in reproductive endocrinology and infertility. Am J Obstet Gynecol 2010;202:413-19. 13. Randolph JF, Jr, Sowers M, Bondarenko IV, Harlow SD, Luborsky $\mathrm{JL}$, Little RJ. Change in estradiol and folliclestimulating hormone across the early menopausal transition: e ects of ethnicity and age. $\mathrm{J}$ Clin Endocrino Metab 2004;89:1555-61.

14. Randolph JF, Jr, Sowers M, Gold $\mathrm{EB}$, et al. Reproductive hormones in the early menopausal transition: relationship to ethnicity, body size, and menopausal status. J Clin Endocrinol Metab 2003;88:1516-22.

\section{Premature ovarian insu ciency}

1. Coulam CB, Adamson SC, Annegers JF. Incidence of premature ovarian failure. Obstet Gynecol 1986;67:604-6.

2. Ostberg JE, Storry C, Donald AE, et al. A doseresponse study of hormone replacement in young hypogonadal women: e ects on intima media thickness and metabolism. Clin Endocrinol 2007;66:557-64. 3. de Kleijn MJ, van der Schouw YT, Verbeek AL, et al. Endogenous estrogen exposure and cardiovascular mortality risk in postmenopausal women. Am J Epidemiol 2002; 155:339-45

4. Rocca WA, Grossardt BR, Miller VM, et al. Premature menopause or early menopause and risk of ischemic stroke. Menopause 2012;19:272-7.

5. Gallagher JC. E ect of early menopause on bone mineral density and fractures. Menopause 2007;14:567-71. 6. RoccaWA, Bower JH, Maraganore DM et al. Increased risk of cognitive impairment or dementia in women with underwent oophorectomy before menopause. Neurology 2007;69:1074-83.

7. de Almeida DM, Benetti-Pinto CL, Makuch MY. Sexual function of women with premature ovarian failure. Menopause 2011;18:262-6.

8. Vujovic S, Brincat M, Erel $\mathrm{T}$, et al. EMAS position statement: Managing women with premature ovarian failure. Maturitas 2010;67:91-3.

9. Qin Y, Jiao X, Simpson JL, Chen ZJ. Genetics of primary ovarian insu ciency: new developments and opportunities. Hum Reprod Update 2015;21:787-808. 10. Pu D, Xing Y, Gao Y, Gu L, Wu J. Gene variation and premature ovarian failure: a meta analysis. Eur J Obstet Gynecol Reprod Biol 2014;182:226-37. 11. L J, Vujovic S, Dalgleish R, et al. Lack of associations between ESR1 gene polymorphism and premature ovarian failure in Serbian women. Climacteric 2014;17:247-51.

12. Qin Y, Vujovic S, Li G, et al. Ethnic speci city of variants on the ESR1, HK3, BRSK1 genes and the 8q22.3 locus: no association with premature ovarian failure (POF) in Serbian women. Maturitas 2014;77:64-7.
13. La Barbera AR, Miller MM, Ober C, Rebar RW. Autoimmune etiology in premature ovarian failure. Am J Reprod Immunol Microbiol 1988;16:115-22. 14. Nelson LM. Clinical practice. Primary ovarian insu ciency. N Engl J Med 2009;360:606-14.

15. Mishell DR Jr, Nakamura RM, Crosignani PG, et al. Serum gonadotropin and steroid patterns during the normal menstrual cycle. Am J Obstet Gynecol 1971;111:60-5.

16. Hubayter ZR, Popat V, Vanderhoof $\mathrm{VH}$, et al. A prospective evaluation of antral follicle function in women with 46 ,XX spontaneous primary ovarian insu ciency. Fertil Steril 2010;94:1769-74.

17. Tartagni M, Cicinelli E, De Pergola $\mathrm{G}$, et al. $\mathrm{E}$ ects of pretreatment with estrogens on ovarian stimulation with gonadotropins in women with premature ovarian failure: a randomized, placebo controlled trial. Fertil Steril 2007;87:858-61.

18. Lee SJ, Schover LR, Partridge AH, et al. American Society of Clinical Oncology recommendations on fertility preservation in cancer patients. $\mathrm{J}$ Clin Oncol 2006;24:2917-31.

19. Gubbala K, Laios A, Gallos I, et al. Outcomes of ovarian transposition in gynecological cancers; a systematic review and meta-analysis. J Ovarian Res 2014;7:69.

\section{Life yle, diet and exercise}

1. Grindler NM, Santoro NF. Menopause and exercise. Menopause 2015 Sep 21. Epub ahead of print.

2. Dubnov-Raz G, Pines A, Berry EM. Diet and lifestyle in managing postmenopausal obesity. Climacteric 2007;10(Suppl 2):38-41.

\section{Urogynecology}

1. Robinson D, Toozs-Hobson P, Cardozo $L$. e e ect of hormones on the lower urinary tract. Menopause Int 2013;19:155-62.

2. Grady D, Brown JS, Vittingho E, Applegate W, Varner E, Synder T. Postmenopausal hormones and incontinence: the Heart and Estrogen/progestin Replacement Study. Obstet Gynecol 2001;97:116-20.

3. Grodstein F, Li ord K, Resnick NM, Curhan GC. Postmenopausal hormone therapy and risk of developing urinary incontinence. Obstet Gynecol 2004; 103:254-60. 4. Hendrix SL, Cochrane BR, Nygaard $\mathrm{IE}$, et al. $\mathrm{E}$ ects of estrogen with and without progestin on urinary incontinence. JAMA 2005;293:935-48.

5. Cody JD, Richardson K, Moehrer B, Hextall A, Glazener CMA. Oestrogen therapy for urinary incontinence in postmenopausal women. Cochrane Database Syst Rev 2009, Issue 4. Art. No: CD001405. 6. Moore K, Dumoulin C, Bradley C, et al. Adult conservative management. In
Abrams P, Cardozo L, Khoury S, Wein $A$, eds. Incontinence. Paris: Health Publications Ltd, 2013:1101-228.

7. Cardozo L, Lose G, McClish D, Versi E. A systematic review of the e ects of oestrogens for symptoms suggestive of overactive bladder. Acta Obstet Gynaecol Scand 2004;83:892-7.

8. Robinson D, Cardozo L, Milsom I, et al. Oestrogens and overactive bladder. Neurourol Urodyn 2014;33:1086-91. 9. Andersson KE, Chapple CR, Cardozo $\mathrm{L}$, et al. Pharmacological treatment of urinary incontinence. In Abrams $P$, Cardozo L, Khoury S, Wein A, eds. Incontinence. Paris: Health Publications Ltd, 2013:623-728.

10. Dmochowski R, Athanasiou S, Reid F, et al. Surgery for urinary incontinence in women. In Abrams P, Cardozo L, Khoury S, Wein A, eds. Incontinence. Paris: Health Publications Ltd, 2013:1307-76. 11. Sultana CJ, Walters MD. Oestrogen and urinary incontinence in women. Maturitas 1995;20:129-38.

12. Brandberg A, Mellstrom D, Samsioe G. Low dose oral oestriol treatment in elderly women with urogenital infections. Acta Obstet Gynaecol Scand 1987;140:33-8.

13. Cardozo L, Lose G, McClish D, et al. A systematic review of estrogens for recurrent urinary tract infections: ird report of the Hormones and Urogenital erapy Committee. Int Urogynecol J Pelvic Floor Dysfunct 2001;12:15-20. 14. Rees M, Pérez-López FR, Ceasu I, et al.; EMAS. EMAS clinical guide: lowdose vaginal estrogens for postmenopausal vaginal atrophy. Maturitas 2012;73:171-4.

15. Perrota C, Aznar M, Mejia R, AlbertX, $\mathrm{Nq} \mathrm{CW}$. Oestrogens for preventing recurrent urinary tract infection in postmenopausal women. Cochrane Database Syst Rev 2008;16(2):CD005131.

16. Rahn DD, Ward RM, Sanses TV, et al.; Society of Gynecologic Surgeons Systematic Review Group. Vaginal estrogen use in postmenopausal women with pelvic oor disorders: systematic review and practice guidelines. Int Urogynecol J 2015;26:3-13.

17. Cardozo LD, Bachmann G, McClish $D$, Fonda D, Birgerson L. Meta-analysis of estrogen therapy in the management of urogenital atrophy in postmenopausal women: Second report of the Hormones and Urogenital erapy Committee. Obstet Gynecol 1998;92:722-7.

18. Suckling J, Lethaby A, Kennedy R. Local oestrogen for vaginal atrophy in postmenopausal women. Cochrane Database Syst Rev 2003;(4):CD001500.

\section{Po menopausal o eoporosis}

1. de Villiers TJ. Bone health and osteoporosis in postmenopausal women. Best Pract Res Clin Obstet Gynaecol 2009;23:73-85. 


\section{МЕЖДУНАРОДНЫЕ ПРОТОКОЛЫ}

2. Center JR, Nguyen TV, Schneider D, Sambrook PN, Eisman JA. Mortality a er all major types of osteoporotic fracture in men and women: an observational study. Lancet 1999;353:878-82. 3. ISCD Combined 0 cial Position. 2013. www.ISCD.org.

4. Trŭmollieres FA, Pouillns JM, Drewniak N, et al. Fracture risk prediction using BMD and clinical risk factors in early postmenopausal women: sensitivity of the WHO FRAX model. J Bone Min Res 2010;25:1002-9.

5. Rossouw JE, Anderson GL, Prentice $R L$, et al. Risks and bene ts of estrogen plus progestin in healthy postmenopausal women: principal results from the Women's Health Initiative randomized controlled trial. JAMA 2002;288:321-33. 6. Manson JE, Chlebowski RT, Stefanick ML, et al. Menopausal hormone therapy and health outcomes during the intervention and extended poststopping phases of the Women's Health Initiative randomized trials. JAMA 2013;310:1353-68.

7. de Villiers TJ, Gass MLS, Haines CJ, et al. Global Consensus Statement on Menopausal Hormone erapy. Climacteric 2013;16:203-4.

8. de Villiers TJ, Stevenson JC. e WHI: the e ect of hormone replacement therapy on fracture prevention. Climacteric 2012;15:263-6.

9. Bagger YZ, Tanko LB, Alexandersen $\mathrm{P}$, et al. Two to three years of hormone replacement therapy in healthy women have longterm prevention e ects on bone mass and osteoporotic fractures: the PERF study. Bone 2004;34:728-31. 10. Ettinger $B$, Ensrud $\mathrm{KE}$, Wallace $\mathrm{R}$, et al. E ects of ultralow-dose transdermal estradiol on bone mineral density: a randomized clinical trial. Obstet Gynecol 2004;104:443-51.

11. Cummings SR, Ettinger $B$, Delmas $P D$, et al. for the LIFT Trial Investigators. e e ects of tibolone in older postmenopausal women. $\mathrm{N}$ Engl J Med 2008;359:697- 708.

12. Lindsay R, Gallagher JC, Kagan R, Pickar JH, Constantine G. E cacy of tissueselective estrogen complex of bazedoxifene/conjugated estrogens for osteoporosis prevention in atrisk postmenopausal women. Fertil Steril 2009;92:1045-52.

13. Ross AC, Taylor CL, Yaktine AL, Del Valle HB, eds.; Institute of Medicine (US) Committee to Review Dietary Reference Intakes for Vitamin D and Calcium. Reference Intakes for Vitamin D and Calcium. Washington, DC: National Academies Press (US), 2011. 14. Bolland MJ, Avenell A, Baron JA, et al. E ect of calcium supplements on risk of myocardial infarction and cardiovascular events: meta-analysis. BMJ 2010;341:c3691.

15. Dawson-Hughes B, Mithal A, Bonjour
JP, et al. IOF position statement: vitamin D recommendations for older adults. Osteoporos Int 2010;21:1151-4.

16. Bischo-Ferrari HA, DawsonHughes B, Staehelin HB, et al. Fall prevention with supplemental and active forms of vitamin D: a meta-analysis of randomised controlled trials. $\mathrm{Br}$ Med $\mathrm{J}$ 2009;339:b3692.

17. Black DM, Delmas PD, Eastell R, et al. Onceyearly zoledronic acid for treatment of postmenopausal osteoporosis. N Engl J Med 2007;356:1809-22. 18. Black DM, Cummings SR, Karpf $\mathrm{DB}$, et al. Randomized trial of e ect of alendronate on risk of fracture in women with existing vertebral fractures. Lancet 1996;348:1535-41.

19. Shane E, Burr D, Abrahamsen B, et al. Atypical subtrochanteric and diaphyseal femoral fractures: Second Report of a Task Force of the American Society for Bone and Mineral Research. J Bone Miner Res 2014;29:1-23.

20. Khosla S, Burr D, Caulley J, et al. Bisphosphonate-associated osteonecrosis of the jaw: Report of a Task Force of the American Society for Bone and Mineral Research. J Bone Miner Res 2007;22:1479-91.

21. Ettinger B, Black DM, Mitlak BH, et al. Reduction of vertebral fracture risk in postmenopausal women with osteoporosis treated with raloxifene: results from a 3-year randomized clinical trial. Multiple Outcomes of Raloxifene Evaluation (MORE) Investigators. JAMA 1999;282:637-45.

22. Silverman SL, Christiansen $\mathrm{C}$ Genant HK, et al. E cacy of bazedoxifene in reducing new vertebral fracture rate in postmenopausal women with osteoporosis: results of a 3-year randomized, placebo- and active-controlled clinical trial. J Bone Miner Res 2008;12:1923-34.

23. Neer RM, Arnaud CD, Zanchetta JR, et al. E ect of parathyroid hormone (1-34) on fractures and bone mineral density in postmenopausal women with osteoporosis. N Engl J Med 2001;344:1434-41.

24. Meunier PJ, Roux C, Seeman E, et al. e e ects of strontium ranelate on the risk of vertebral fracture in women with postmenopausal osteoporosis. N Engl J Med 2004;350:459-68.

25. Recommendation to restrict the use of Protelos/Osseor (strontium ranelate). European Medicines Agency. EMA/258269/2013.

26. Cummings SR, Martin JS, McClung MR, et al. Denosumab for prevention of fractures in postmenopausal women with osteoporosis. $\mathrm{N}$ Engl $\mathrm{J}$ Med 2009;361:756-65.

Skin, cartilage, conne ive tissues

1. Welton AJ, Vickers MR, Kim J, et al. Health related quality of life a er combined hormone replacement therapy: randomised controlled trial. BMJ 2008;337;550-3.

2. Karsdal MA, Bay-Jensen AC, Henriksen $\mathrm{K}$, Christiansen $\mathrm{C}$. e pathogenesis of osteoarthritis involves bone, cartilage and synovial in ammation: may estrogen be a magic bullet? Menopause Int 2012;18:139-46.

3. Christgau S, Tanko LB, Cloos PA, et al. Suppression of elevated cartilage turnover in postmenopausal women and in ovariectomized rats by estrogen and a selective estrogen-receptor modulator (SERM). Menopause 2004;11:508-18. 4. Cirillo DJ, Wallace RB, Wu L, Yood RA. E ect of hormone therapy on risk of hip and knee joint replacement in the Women's Health Initiative. Arthritis Rheum 2006;54:3194-204.

5. Masuda $\mathrm{Y}$, Hirao T, Mizunuma $\mathrm{H}$. Improvement of skin surface texture by topical estradiol treatment in climacteric women. J Dermatol Treat 2013;24:312-17.

6 . Verdier-Sévrain S. E ect of estrogens on skin aging and the potential role of selective estrogen receptor modulators. Climacteric 2007;10:289-97.

7. Surazynski A, Jarzabek K, Haczynski J, Laudanski P, Palka J, Wolczynski S. Differential e ects of estradiol and raloxifene on collagen biosynthesis in cultured human skin broblasts. Int J Mol Med 2003;12:803-9.

\section{Cardiovascular disease}

1. Maruthur NM, Wang N-Y, Appel LJ. Lifestyle interventions reduce coronary artery disease risk. Results from the PREMIER trial. Circulation 2009; 119:2026-31. 2. Lobo RA, Davis SR, de Villiers TJ, et al. Prevention of diseases a er menopause. Climacteric 2014;17:540-56.

3. Hodis HN, Collins P, Mack WJ, et al. e timing hypothesis for coronary heart disease prevention with hormone therapy: past, present and future in perspective. Climacteric 2012;15:217-28. 4. Hulley S, Grady D, Bush T, et al. Randomized trial of estrogen plus progestin for secondary prevention of coronary heart disease in postmenopausal women. Heart and Estrogen/progestin Replacement Study (HERS) Research Group. JAMA 1998;280:605-13.

5. Manson JE, Chlebowski RT, Stefanick ML, et al. Menopausal hormone therapy and health outcomes during the intervention and extended poststopping phases of the Women's Health Initiative randomized trials. JAMA 2013;310:1353-68.

6. Salpeter SR, Walsh JM, Greyber E, et al. Coronary heart disease events associated with hormone therapy in younger and older women. A meta-analysis. J Gen Intern Med 2006;21:363-6.

7. Salpeter SR, Cheng J, abane L, et al. Bayesian meta-analysis of hormone therapy and mortality in younger women. Ann Intern Med 2009;122:1016-22.

8. Rossouw JE, Prentice RL, Manson $\mathrm{JE}$, et al. Postmenopausal hormone therapy and risk of cardiovascular disease by age and years since menopause. JAMA 2007;297:1465-77. 9. Salpeter SR, Walsh JME, Greyber E, et al. Mortality associated with hormone replacement therapy in younger and older women: A meta-analysis. J Gen Intern Med 2004;19:791-804.

10. Salpeter SR, Buckley NS, Liu H, et al. e coste ectiveness of hormone therapy in younger and older postmenopausal women. Am J Med 2009:122:42-52.

11. Boardman HM, Hartley L, Eisinga A, et al. Hormone therapy for preventing cardiovascular disease in postmenopausal women. Cochrane Database Syst Rev 2015; 3: CD002229. 12. Mikkola TS, Tuomikoski $P$, Lyytinen $\mathrm{H}$, et al. Estradiol-based postmenopausal hormone therapy and risk of cardiovascular and allcause mortality. Menopause 2015;22:976-83.

13. Schierbeck $L$, Rejnmark L, To eng $\mathrm{CL}$, et al. E ect of hormone replacement therapy on cardiovascular events in recently postmenopausal women: randomized trial. BMJ 2012;345:e6409.

14. Harman SM, Black DM, Na olin F, et al. Arterial imaging outcomes and cardiovascular risk factors in recently menopausal women: a randomized trial. Ann Intern Med 2014;161:249-60.

15. Hodis HN. EUTE - Does the trial outcome con rm or refute the timing hypothesis of hormone therapy? Presented at the 14th World Congress on Menopause, May 1-4, 2014, Cancun, Mexico. 16. Berlind IA, Andersen M, Citarella A, et al. Hormone therapy and risk of cardiovascular outcomes and mortality in women treated with statins. Menopause 2015;22:369-76.

\section{Stroke}

1. Henderson WW, Lobo RA. Hormone therapy and the risk of stroke: perspectives 10 years a er the Women's Health Initiative trials. Climacteric 2012;15:229-34.

2. Manson JE, Chlebowski RT, Stefanick ML, et al. Menopausal hormone therapy and health outcomes during the intervention and extended poststopping phases of the Women's Health Initiative randomized trials. JAMA 2013;310:1353-68.

3. Boardman HM, Hartley L, Eisinga A, et al. Hormone therapy for preventing cardiovascular disease in postmenopausal women. Cochrane Database Syst Rev 2015; 3: CD002229. 4. Renoux C, Dell'aniello S, Garbe E, et al. Transdermal and oral hormone replacement therapy and the risk of stroke: a nested case-control study. BMJ 2010;340:c2519. 


\section{МЕЖДУНАРОДНЫЕ ПРОТОКОЛЫ}

5. Lobo RA, Clarkson TB. Di erent mechanisms for bene $t$ and risk of coronary heart disease and stroke in early postmenopausal women: a hypothetical explanation. Menopause 2011;18:237-40.

Coagulation, venous thromboembolism disease and MHT

1. White RH. e epidemiology of venous thromboembolism. Circulation 2003;107(23 Suppl 1):14-8.

2. Archer DF, Oger E. Estrogen and progestogen e ect on venous thromboembolism in menopausal women. Climacteric 2012;15:235-40.

3. Scarabin PY. Hormone therapy and venous thromboembolism among postmenopausal women. Front Horm Res 2014:43:21-32.

4. Roach RE, Lijfering WM, van Hylckama Vlieg A, et al. e risk of venous thrombosis in individuals with a history of super cial vein thrombosis and acquired venous thrombotic risk factors. Blood 2013;122:4264-9.

5. Cushman M, Kuller LH, Prentice R, et al.; Women's Health Initiative Investigators. Estrogen plus progestin and risk of venous thrombosis. JAMA 2004;292:1573-80.

6. Curb JD, Prentice RL, Bray PF, et al Venous thrombosis and conjugated equine estrogen in women without a uterus. Arch Intern Med 2006;166:772-80.

7. Manson JE, Chlebowski RT, Stefanick ML, et al. Menopausal hormone therapy and health outcomes during the intervention and extended poststopping phases of the Women's Health Initiative randomized trials JAMA 2013;310:1353-68.

8. Smith NL, Blondon M, Wiggins KL, et al. Lower risk of cardiovascular events in postmenopausal women taking ora estradiol compared with oral conjugated equine estrogens. JAMA Intern Med 2014;174:25-31.

9. Canonico M, Plu-Bureau G, Lowe GD, Scarabin PY. Hormone replacement ther apy and risk of venous thromboembolism in postmenopausa women: systematic review and metaanalysis. BMJ 2008;336:1227-31.

10. Scarabin PY, Oger E, Plu-Bureau G; EStrogen and THromboEmbolism Risk Study Group. Di erential association of oral and transdermal oestrogenreplacement therapy with venous thromboembolism risk. Lance 2003;362:428-32.

11. Canonico M, Oger E, Plu-Bureau G et al.; Estrogen and romboembolism Risk (ESTHER) Study Group. Hormone therapy and venous thromboembolism among postmenopausal women: impact of the route of estrogen administration and progestogens: the ESTHER study. Circulation 2007;115:840-5.

12. Canonico M, Fournier A, Carcaillon $\mathrm{L}$, et al. Postmenopausal hormone ther- apy and risk of idiopathic venous thromboembolism: results from the E3N cohort study. Arterioscler romb Vasc Biol 2010;30:340-5.

13. Straczek C, Oger E, Yon de Jonage-Canonico MB, et al.; Estrogen and romboembolism Risk (ESTHER) Study Group. Prothrombotic mutations hormone therapy, and venous thromboembolism among postmenopausa women: impact of the route of estrogen administration.

Circulation

2005;112:3495-500.

14. Canonico M, Oger E, Conard J, et al.; EStrogen and THromboEmbolism Risk (ESTHER) Study Group. Obesity and risk of venous thromboembolism among postmenopausal women: di erential impact of hormone therapy by route of estrogen administration. e ESTHER Study. J romb Haemost 2006;4:1259-65

15. Olie V, Plu-Bureau G, Conard J, et al. Hormone therapy and recurrence of venous thromboembolism among postmenopausal women. Menopause 2011;18:488-93.

16. Blondon M, Van Hylckama Vlieg $A$ Wiggins $\mathrm{KL}$, et al. Di erential associations of oral estradiol and conjugated equine estrogen with hemostatic biomarkers. romb Haemost 2014;12:879-86.

17. Scarabin PY, Alhenc-Gelas M, PluBureau $G$, et al. $E$ ects of oral and transdermal estrogen/progesterone regimens on blood coagulation and brinolysis in postmenopausal women. A randomized controlled trial. Arterioscler romb Vasc Biol 1997;17:3071-8.

18. Vehkavaara S, Silveira A, HakalaAla-Pietila $T$, et al. E ects of oral and transdermal estrogen replacement therapy on markers of coagulation, brinolysis, in ammation and serum lipids and lipoproteins in postmenopausal women. romb Haemost 2001;85:619-25.

19. Oger E, Alhenc-Gelas M, Lacut K, et al. Di erential e ects of oral and transdermal estrogen/progesterone regimens on sensitivity to activated protein $\mathrm{C}$ among postmenopausal women: a randomized trial. Arterioscle romb Vasc Biol 2003;23:1671-6.

20. Post MS, Christella M, omassen $L G$, et al. E ect of oral and transdermal estrogen replacement therapy on hemostatic variables associated with venous thrombosis: a randomized placebo controlled study in postmenopausal women. Arterioscler romb Vasc Biol 2003;23:1116-21.

\section{Central nervous sy em}

1. Weber MT, Maki PM, McDermott MP. Cognition and mood in perimenopause: a systematic review and meta-analysis. J Steroid Biochem Mol Biol 2014;142:90-8.

2. Henderson WW. Gonadal hormones and cognitive aging: a midlife perspective. Womens Health 2011;7:81-93. 3. Gleason CE, Dowling NM, Wharton $W$, et al. E ects of hormone therapy on cognition and mood in recently postmenopausal women: ndings from the randomized, controlled KEEPSCognitive and A ective Study. PLoS Med 2015;12:e1001833

4. Espeland MA, Shumaker SA, Leng I, et al. Long-term e ects on cognitive function of postmenopausal hormone therapy prescribed to women aged 50 to 55 years. JAMA Intern Med 2013;173:1429-36.

5. Henderson WW, Sherwin BB. Surgica versus natural menopause: cognitive issues. Menopause 2007;14:572-9.

6. Resnick SM, Maki PM, Rapp SR, et al. E ects of combination estrogen plus progestin hormone treatment on cognition and a ect. J Clin Endocrinol Metab 2006:91:1802-10.

7. Resnick SM, Espeland MA, An Y, et al. $E$ ects of conjugated equine estrogens on cognition and a ect in postmenopausal women with prior hysterectomy. J Clin Endocrinol Metab 2009;94:4152-61.

8. Ya e K, Vittingho $E$, Ensrud $K E$, et al. $E$ ects of ultra-low-dose transdermal estradiol on cognition and health-related quality of life. Arch Neurol 2006;63:945-50.

9. Greenspan SL, Resnick NM, Parker RA. e e ect of hormone replacement on physical performance in communitydwelling elderly women. Am J Med 2005;118:1232-9.

10. Mulnard RA, Cotman CW, Kawas C, et al. Estrogen replacement therapy for treatment of mild to moderate Alzheimer disease: a randomized controlled trial. JAMA 2000;283:1007-15. 11. Henderson WW. Alzheimer's disease: review of hormone therapy trials and implications for treatment and prevention a er menopause. J Steroid Biochem Mol Biol 2014;142:99-106.

12. Hogervorst $E$, Williams J, Budge $M$ Riedel W, Jolles J. e nature of the e ect of female gonadal hormone replacement therapy on cognitive function in postmenopausal women: a meta-analysis. Neuroscience 2000;101:485-512. 13. LeBlanc ES, Janowsky J, Chan BKS, Nelson HD. Hormone replacement therapy and cognition: systematic review and meta-analysis. JAMA 2001;285:1489-99.

14. Shumaker SA, Legault C, Kuller L, et al. Conjugated equine estrogens and incidence of probable dementia and mild cognitive impairment in postmenopausal women: Women's Health Initiative Memory Study. JAMA 2004:291:2947-58.

15. Henderson W. Estrogen-containing hormone therapy and Alzheimer's disease risk: understanding discrepant inferences from observational and experimental research. Neuroscience 2006;138:1031-9.

16. Henderson W, Benke KS, Green RC Cupples LA, Farrer LA. Postmenopausal hormone therapy and Alzheimer's disease risk: interaction with age. J Neurol Neurosurg Psychiatry 2005;76:103-5.

17. Whitmer RA, Quesenberry $\mathrm{CP}$, Zhou J, Ya e K. Timing of hormone therapy and dementia: the critical window theory revisited. Ann Neurol 2011;69:163-9.

18. Shao H, Breitner JCS, Whitmer RA, et al. Hormone therapy and $A D$ dementia: new ndings from the Cache County study. Neurology 2012;79:1846-52.

19. Ya e K, Krueger K, Sarkar S, et al. Cognitive function in postmenopausal women treated with raloxifene. $\mathrm{N}$ Engl J Med 2001;344:1207-13.

20. Ya e K, Krueger K, Cummings SR, et al. E ect of raloxifene on the prevention of dementia and cognitive impairment in older women: the Multiple Outcomes of Raloxifene Evaluation (MORE) randomized trial. Am J Psychiatry 2005;162:683- 90.

21. Henderson WW, Ala T, Sainani KL, et al. Raloxifene for women with Alzheimer disease: A randomized controlled pilot trial. Neurology 2015;85:1937-44.

22. Kreijkamp-Kaspers S, Kok L, et al. $E$ ect of soy protein containing iso avones on cognitive function, bone mineral density, and plasma lipids in postmenopausal women: a randomized controlled trial. JAMA 2004;292:65-74. 23. Henderson WW, St John JA, Hodis $\mathrm{HN}$, et al. Long-term soy iso avone supplementation and cognition in women: A randomized, controlled trial. Neurology 2012;78:1841-8.

24. Bschtemann D, Luppa M, Bramesfeld A, Riedel-Heller S. Incidence of late-life depression: a systematic review. J A ect Disord 2012;142:172-9. 25. Maki PM, Gast MJ, Vieweg A, Burriss SW, Ya e K. Hormone therapy in menopausal women with cognitive complaints: a randomized, double-blind trial. Neurology 2007:69:1322-30.

26. Schmidt PJ, Nieman L, Danace au $M A$, et al. Estrogen replacement in perimenopauserelated depression: a preliminary report. Am J Obstet Gynecol 2000;183:414-20.

27. Soares $C D$, Almeida OP, Jo e $\mathrm{H}$, Cohen LS. E cacy of estradiol for the treatment of depressive disorders in perimenopausal women: a double-blind, randomized, placebo-controlled trial. Arch Gen Psychiatry 2001;58:529-34.

28. Brandes JL. e in uence of estrogen on migraine: a systematic review. JAMA 2006;295:1824-30.

29. Wang SJ, Fuh JL, Lu SR, Juang KD, Wang $\mathrm{PH}$. Migraine prevalence during menopausal transition. Headache 2003;43:470-8. 


\section{МЕЖДУНАРОДНЫЕ ПРОТОКОЛЫ}

30. Christianson MS, Mensah VA, Shen W. Multiple sclerosis at menopause: Potential neuroprotective e ects of estrogen. Maturitas 2015;80:133-9. 31. Wang P, Li J, Qiu S, Wen H, Du J. Hormone replacement therapy and Parkinson's disease risk in women: a meta-analysis of 14 observational studies. Neuropsychiatric Dis Treat 2015;11:59-66.

32. Parkinson Study Group POETRY Investigators. A randomized pilot trial of estrogen replacement therapy in postmenopausal women with Parkinson's disease. Parkinsonism Relat Disord 2011;17:757-60.

33. Harden CL, Herzog AG, Nikolov BG, et al. Hormone replacement therapy in women with epilepsy: a randomized, double-blind, placebo-controlled study. Epilepsia 2006;47:1447-51.

\section{Brea cancer}

1. Chlebowski RT, Hendrix SL, Langer $\mathrm{RD}$, et al.; WHI Investigators. In uence of estrogen plus progestin on breast cancer and mammography in healthy postmenopausal women: the Women's Health Initiative randomized trial. JAMA 2003;289:3243-53.

2. Anderson GL, Chlebowski RT, Rossouw JE, et al. Prior hormone therapy and breast cancer risk in the Women's Health Initiative randomized trial of estrogen plus progestin. Maturitas 2006;55:103-15.

3. Colditz GA, Hankinson SE, Hunter DJ, et al. e use of estrogens and progestins and the risk of breast cancer in postmenopausal women. N Engl J Med 1995;332:1589-93.

4. Bakken K, Fournier A, Lund E, et al. Menopausal hormone therapy and breast cancer risk: impact of di erent treatments. e European Prospective Investigation into Cancer and Nutrition. Int J Cancer 2011;128:144-56.

5. Beral V; Million Women Study Collaborators. Breast cancer and hormonere-placement therapy in the Million Women Study. Lancet 2003;362:419-27. 6. Fournier A, Berrino F, ClavellChapelon F. Unequal risks for breast cancer associated with di erent hormone replacement therapies: results from the E3N cohort study. Breast Cancer Res Treat 2008;107:103-11. 7. Chlebowski RT, Anderson GL, Gass $\mathrm{M}$, et al.; WHI Investigators. Estrogen plus progestin and breast cancer incidence and mortality in postmenopausal women. JAMA 2010;304:1684-92. 8. Anderson GL, Chlebowski RT, Aragaki AK, et al. Conjugated equine oestrogen and breast cancer incidence and mortality in postmenopausal women with hysterectomy: extended followup of the Women's Health Initiative randomised placebo-controlled trial. Lancet Oncol 2012;13:476-86.
9. Chen WY, Manson JE, Hankinson SE, et al. Unopposed estrogen therapy and the risk of invasive breast cancer. Arch Intern Med 2006;166:1027-32. 10. Lundstrum $E$, Christow A, Kersemaekers W, et al. E ects of tibolone and continuous combined hormone replacement therapy on mammographic breast density. Am J Obstet Gynecol 2002;186:717-22.

11. Kenemans $P$, Bundred NJ, Foidart JM, et al.; LIBERATE Study Group. Safety and e cacy of tibolone in breastcancer patients with vasomotor symptoms: a double-blind, randomised non-inferiority trial. Lancet Onco 2009;10:135-46.

12. Cordina-Duverger E, Truong $T$, Anger A, et al. Risk of breast cancer by type of menopausal hormone therapy: a case-control study among postmenopausal women in France. PLoS One 2013;8:e78016.

13. Lyytinen $H$, Pukkala E, Ylikorkala $O$. Breast cancer risk in postmenopausa women using estradiol-progestogen therapy. Obstet Gynecol 2009;113:65-73.

Endometrial safety and bleeding 1. Gupta JK, Chien PF, Voit D, Clark TJ, Khan KS. Ultrasonographic endometria thickness for diagnosing endometria pathology in women with postmenopausal bleeding: a meta-analysis Acta Obstet Gynecol Scand 2002;81:799-816.

2. American College of Obstetricians and Gynecologists. Diagnosis of abnormal uterine bleeding in reproductiveaged women. Practice Bulletin no. 128 Obstet Gynecol 2012;120:197-206.

3. Guido RS, Kanbour-Shakir A, Rulin MC, Christopherson WA. Pipelle endometrial sampling. Sensitivity in the detection of endometrial cancer. J Reprod Med 1995;40:553-5.

4. Woodru JD, Pickar JH. Incidence of endometrial hyperplasia in postmenopausal women taking conjugated estrogens (Premarin) with medroxyprogesterone acetate or conjugated estrogens alone. e Menopause Study Group. Am J Obstet Gynecol 1994;170:1213-23.

5. Weiderpass E, Adami HO, Baron JA, et al. Risk of endometrial cancer following estrogen replacement with and without progestins. J Natl Cancer Inst 1999:91:1131-7.

6. Lethaby A, Suckling J, Barlow D, Farquhar CM, Jepson RG, Roberts $\mathrm{H}$. Hormone replacement therapy in postmenopausal women: endometrial hyperplasia and irregular bleeding. Cochrane Database Syst Rev 2004;CD000402.

7. e Writing Group for the PEPI Trial. E ects of hormone replacement therapy on endometrial histology in postmenopausal women. e Postmenopausa Estrogen/Progestin Interventions (PEPI) Trial. JAMA 1996;275:370-5.
8. Anderson GL, Judd HL, Kaunitz AM, et al. E ects of estrogen plus progestin on gynecologic cancers and associated diagnostic procedures: the Women's Health Initiative randomized trial. JAMA 2003;290:1739-48.

9. Allen N, Tsilidis K, Key $T$, et al. Menopausal hormone therapy and risk of endometrial carcinoma among postmenopausal women in the European Prospective Investigation into Cancer and Nutrition. Am $\mathrm{J}$ Epidemio 2010; 172:1394-403.

10. Somboonporn W, Panna S, Temtanakitpaisan $\mathrm{T}$, Kaewrudee $\mathrm{S}$ Soontrapa S. Effects of the levonorgestrel-releasing intrauterine system plus estrogen therapy in perimenopausal and postmenopausal women: systematic review and metaanalysis. Menopause 2011;18:1060-6. 11. Pickar JH, Yeh IT, Bachmann G, Spero L. Endometrial e ects of a tissue selective estrogen complex containing bazedoxifene/conjugated estrogens as a menopausal therapy. Fertil Steril 2009;92:1018-24.

12. Stovall DW, Utian WH, Gass ML, et al. e e ects of combined raloxifene and oral estrogen on vasomotor symptoms and endometrial safety. Menopause 2007:14:510-17.

13. Bjarnason K, Cerin A, Lindgren R, Weber T. Adverse endometrial e ects during long cycle hormone replacement therapy. Scandinavian Long Cycle Study Group. Maturitas 1999;32:161-70.

14. Erkkola $\mathrm{R}$, Kumento $\mathrm{U}$, Lehmuskoski S, Mattila L, Mustonen M. No increased risk of endometrial hyperplasia with xed longcycle estrogenprogestogen therapy a er ve years. $\mathrm{J} \mathrm{Br}$ Menopause Soc 2004;10:9-13.

15. Allen NE, Tsilidis KK, Key TJ, et al. Menopausal hormone therapy and risk of endometrial carcinoma among postmenopausal women in the European Prospective Investigation Into Cancer and Nutrition. Am J Epidemio 2010;172:1394- 403.

16. Archer DF, Hendrix S, Gallagher $\mathrm{JC}$, et al. Endometrial e ects of tibolone. J Clin Endocrinol Metab 2007;92:911-18.

17. Clarke MJ. Tamoxifen for early breast cancer. Cochrane Database Syst Rev 2008;CD000486.

18. Goldstein SR, Scheele WH, Rajagopalan SK, Wilkie JL, Walsh BW, Parsons AK. A 12-month comparative study of raloxifene, estrogen, and placebo on the postmenopausal endometrium. Obstet Gynecol 2000;95:95-103. 19. Ronkin S, Northington R, Baracat $\mathrm{E}$, et al. Endometrial e ects of bazedoxifene acetate, a novel selective estrogen receptor modulator, in postmenopausal women. Obstet Gyneco 2005; 105:1397-404.

20. Constantine GD, Goldstein SR,
Archer DF. Endometrial safety of ospemifene: results of the phase $2 / 3$ clinical development program. Menopause 2015;22:36-43.

21. Goldstein SR, Bachmann GA, Koninckx PR, Lin VH, Portman DJ, Ylikorkala 0; Ospemifene Study Group. Ospemifene 12-month safety and e cacy in postmenopausal women with vulvar and vaginal atrophy. Climacteric 2014;17:173-82.

22. Goldstein SR, Neven P, Cummings $S$, et al. Postmenopausal evaluation and risk reduction with lasofoxifene (PEARL) trial: 5-year gynecologic outcomes. Menopause 2011;18:17-22.

\section{Ovarian cancer}

1. de Villiers TJ, Pines A, Panay N, et al.; International Menopause Society. Updated 2013 International Menopause Society recommendations on menopausal hormone therapy and preventive strategies for midlife health. Climacteric 2013;16:316-72.

2. Collaborative Group on Epide-miological Studies of Ovarian Cancer. Menopausal hormone use and ovarian cancer risk: individual participant metaanalysis of 52 epidemiological studies. Lancet 2015;385:1835-42.

3. Gompel A, Burger H. A Commentary on a recent update of the ovarian cancer risk attributable to menopausal hormone therapy. Climacteric 2015;18:376-8.

\section{Lung cancer}

1. Torre LA, Bray F, Siegel RL, et al. Global cancer statistics, 2012. CA Cancer J Clin 2015;65:87-108.

2. Weir HK, ompson TD, Soman A, Mwller B, Leadbetter S. e past, present, and future of cancer incidence in the United States: 1975 through 2020. Cancer 2015;121:1827-37.

3. Gallagher LG, Rosenblatt KA, Ray $\mathrm{RM}$, et al. Reproductive factors and risk of lung cancer in female textile workers in Shanghai, China. Cancer Causes Control 2013;24:1305-14.

4. Pesatori AC, Carugno M, Consonni D, et al. Reproductive and hormonal factors and the risk of lung cancer: the EAGLE study. Int J Cancer 2013;132:2630-9.

5. Greiser CM, Greiser EM, Duren M. Menopausal hormone therapy and risk of lung cancer - systematic review and metaanalysis. Maturitas 2010;65:198-204.

6. Clague J, Reynolds P, SullivanHalley $\mathrm{J}$, et al. Menopausal hormone therapy does not in uence lung cancer risk: results from the California Teachers Study. Cancer Epidemiol Biomarkers Prev 2011;20:560-4

7. Chlebowski RT, Anderson GL, Manson JE, et al. Lung cancer among postmenopausal women treated with estrogen alone in the Women's Health Initiative randomized trial. J Natl Cancer Inst 2010;102:1413-21. 


\section{МЕЖДУНАРОДНЫЕ ПРОТОКОЛЫ}

8. Chlebowski RT, Schwartz AG, Wakelee $\mathrm{H}$, et al. Oestrogen plus progestin and lung cancer in postmenopausal women (Women's Health Initiative trial): a posthoc analysis of a randomised controlled trial. Lancet 2009;374:1243-51.

9. Manson JE, Chlebowski RT, Stefanick ML, et al. Menopausal hormone therapy and health outcomes during the intervention and extended poststopping phases of the Women's Health Initiative randomized trials. JAMA 2013;310:1353-68.

10. Schwartz AG, Ray RM, Cote ML, et al. Hormone use, reproductive history and risk of lung cancer: the Women's Health Initiative studies. J orac Oncol 2015;10:1004-13.

Colore al cancer

1. Brenner H, Kloor M, Pox CP. Colorecta cancer. Lancet 2014;383:1490-502.

2. Grodstein F, Martinez ME, Platz EA, et al. Postmenopausal hormone use and risk for colorectal cancer and adenoma. Ann Intern Med 1998;128:705-12. 3. Grodstein F, Newcomb PA, Stampfer MJ. Postmenopausal hormone therapy and the risk of colorectal cancer: a review and meta-analysis. Am J Med 1999;106:574-82.

4. Rossouw JE, Anderson GL, Prentice $\mathrm{RL}$, et al. Risks and bene ts of estrogen plus progestin in healthy postmenopausal women: principal results from the Women's Health Initiative randomized controlled trial. JAMA 2002:288:321-33.

5. Anderson GL, Limacher M, Assaf AR et al. $E$ ects of conjugated equine estrogen in postmenopausal women with hysterectomy: the Women's Health Initiative randomized controlled trial. JAMA 2004;291:1701-12.

6. Prentice RL, Pettinger M, Beresford SA. Colorectal cancer in relation to postmenopausal estrogen and estrogen plus progestin in the Women's Health Initiative clinical trial and observational study. Cancer Epidemio Biomarkers Prev 2009;18:1531-7. 7. Manson JE, Chlebowski RT Stefanick ML, et al. Menopausal hormone therapy and health outcomes during the intervention and extended poststopping phases of the Women's Health Initiative randomized trials. JAMA 2013;310:1353-68.

8. Morois S, Fournier A, ClavelChapelon $F$, et al. Menopausal hormone therapy and risks of colorecta adenomas and cancers in the French E3N prospective cohort: true associations or bias Eur $\mathrm{J}$ Epidemiol 2012;27:439-52.

9. Cummings SR, Ettinger B, Delmas $\mathrm{PD}$, et al. e e ects of tibolone in older postmenopausal women. $\mathrm{N}$ Engl J Med 2008;359:697-708.
Cervical cancer

1. http://uww. cancer-researchuk.org/cancer-info/cancerstats/types/cervix/incidence/uk-cervical-cancer-incidence-statistics (section reviewed 11(06/2014)

2. Marsden J, Sturdee D. Cance issues. Best Pract Res Clin Obstet Gynaecol 2009;23:87-107.

3. Yasmeen S, Romano PS, Pettinge $M$, et al. Incidence of cervical cytological abnormalities with aging in the Women's Health Initiative: a randomized controlled trial. Obstet Gynecol 2006;108:410-19.

4. Sawaya GF, Grady D, Kerlikowske K, et al. e positive predictive value of cervica smears in previously screened postmenopausal women: the Heart and Estrogen/progestin Replacement Study (HERS). Ann Intern Med 2000;133:942-50. 5. Jaakkola S, Pukkala E, Lyytinen HK Ylikorkala O. Postmenopausal estradiol-progestagen therapy and risk fo uterine cervical cancer. Int J Cance 2012;131:E537-43.

\section{Upper ga rointe inal cancers}

1. Fernandez $E$, Gallus $S$, Bosetti $C$ Franceschi S, Negri E, La Vecchia C Hormone replacement therapy and cancer risk: a systematic analysis from a network of case-control studies. Int Cancer 2003;105:408-12.

2. McGlynn KA, Sahasrabuddhe W Campbell PT, et al. Reproductive factors, exogenous hormone use and risk of hepatocellular carcinoma among US women: results from the Liver Cancer Pooling Project. $\mathrm{Br} \mathrm{J}$ Cancer 2015;112(Suppl):1266-72.

3. Freedman ND, Chow WH, Gao YT, et al. Menstrual and reproductive factors and gastric cancer risk in a large prospective study of women. Gut 2007:56:1671-7.

4. Lindblad M, Garcна Rodrhguez LA Chandanos E, Lagergren J. Hormone replacement therapy and risks of oesophageal and gastric adenocarcinomas. Br J Cancer 2006:94:136-41.

5. Camargo MC, Goto Y, Zabaleta J, Morgan DR, Correa P, Rabkin CS. Sex hormones, hormonal interventions, and gastric cancer risk: a meta-analysis Cancer Epidemiol Biomarkers Prev 2012;21:20-38.

6. Wang BJ, Zhang B, Yan SS, et al. Hormonal and reproductive factors and risk of esophageal cancer in women: a meta-analysis. Dis Esophagus 2015 Mar 23. Epub ahead of print 7. Gallus S, Negri E, Chatenoud L, Bosetti C, Franceschi S, La Vecchia C. Postmenopausal hormona therapy and gallbladder cancer risk. Int $J$ Cancer 2002:99:762-3.

General and sexual quality of life in the menopause

1. Lindau ST, Gavrilova N. Sex, health, and years of sexually active life gained due to good health: Evidence from two US population based cross sectional surveys of ageing. BMJ 2010;340:C810. 2. Ayers $B$, Hunter MS. Health-related quality of life of women with menopausal hot ushes and night sweats. Climacteric 2013;16:235-9.

3. Appa AA, Creasman J, Brown JS, et al. e impact of multimorbidity on sexual function in middle-aged and older women: beyond the single disease perspective. J Sex Med 2014;11:2744-55.

4. Avis NE, Brockwell S, Randolph JF $\mathrm{Jr}$, et al. Longitudinal changes in sexual functioning as women transition through menopause: results from the Study of Women's Health Across the Nation. Menopause 2009;16:442-52. 5. Dennerstein L, Dudley E, Burger $\mathrm{H}$. Are changes in sexual functioning during midlife due to aging or menopause? Fertil Steril 2001;76:456-60.

6. Lonnue-Ho mann RA, Dennerstein L Lehert $P$, Szoeke C. Sexual function in the late postmenopause: a decade of follow-up in a population-based cohort of Australian women. J Sex Med 2014;11:2029-38

7. Erekson EA, Martin DK, Ratner ES. Oophorectomy: the debate between ovarian conservation and elective oophorectomy. Menopause 2013;20:110-14.

8. Mann E, Singer D, Pitkin J, Panay N, Hunter MS. Psychosocial adjustment in women with premature menopause: a cross-sectional survey. Climacteric 2012;15:481-9.

9. Panjari M, Bell RJ, Davis SR. Sexual function a er breast cancer. J Sex Med 2011;8:294-302.

10. Bitzer J, Giraldi A, Pfaus J. A standardized diagnostic interview for hypoactive sexual desire disorder in women: standard operating procedure (SOP Part 2). J Sex Med 2013;10:50-7. 11. Wierman ME, Arlt W, Basson R, et al. Androgen therapy in women: a reappraisal: an Endocrine Society clinical practice guideline. J Clin Endocrinol Metab 2014:99:3489-510.

12. Levine K, Williams R, Harmann K. Vulvovaginal atrophy is strongly associated with female sexual dysfunction among sexually active postmenopausal women. Menopause 2008;15:661-6.

13. Nappi RE, Palacios S. Impact of vulvovaginal atrophy on sexual health and quality of life at postmenopause. Climacteric 2014;17:3-9.

14. Portman DJ, Gass ML. Genitourinary syndrome of menopause: new terminology for vulvovaginal atrophy from the International Society for the Study of Women's Sexual Health and e North American Menopause Society. Climacteric 2014; 17:557-63.

15. Nappi RE, Davis SR. e use of hormone therapy for the maintenance of urogynecological and sexual health post WHI. Climacteric 2012;15:267-74.
16. Nappi RE, Domoney C. Pharmacogenomics and sexuality: a vision. Climacteric 2013;16(Suppl 1):25-30.

17. Nappi RE, Cucinella L. Advances in pharmacotherapy for treating female sexual dysfunction. Expert Opin Pharmacother 2015;16:875-87.

18. Pines A, Sturdee DW, MacLennan AH. Quality of life and the role of menopausal hormone therapy. Climacteric 2012;15:213-16.

19. Nastri CO, Lara LA, Ferriani RA, et al. Hormone therapy for sexual function in perimenopausal and postmenopausal women. Cochrane Database Syst Rev 2013, Issue 6. Art. No.: CD009672.

20. Biglia N, Ma ei S, Lello S, Nappi RE. Tibolone in postmenopausal women: a review based on recent randomised controlled clinical trials. Gynecol Endocrinol 2010;26:804-14.

Androgen therapy for perimenopausal and po menopausal women

1. Davison $S L$, Bell $R$, Donath $S$, Montalto JG, Davis SR. Androgen levels in adult females: changes with age, menopause, and oophorectomy. J Clin Endocrinol Metab 2005;90:3847-53.

2. Haring R, Hannemann A, John U, et al. Agespeci c reference ranges for serum testosterone and androstenedione concentrations in women measured by liquid chromatographytandem mass spectrometry. J Clin Endocrinol Metab 2012;97:408-15.

3. Legro RS, Schla WD, Diamond MP, et al. Total testosterone assays in women with polycystic ovary syndrome: precision and correlation with hirsutism. J Clin Endocrinol Metab 2010;95:5305-13

4. Wahlin-Jacobsen S, Pedersen AT, Kristensen E, et al. Is there a correlation between androgens and sexual desire in women? J Sex Med 2015;12:358-73. 5. Randolph JF, Jr, Zheng H, Avis NE, Greendale GA, Harlow SD. Masturbation frequency and sexual function domains are associated with serum reproductive hormone levels across the menopausal transition. J Clin Endocrinol Metab 2015; 100:258-66.

6. American Psychiatric Association. Diagnostic and Statistical Manual of Mental Disorders. Washington DC: American Psychiatric Press, 1994.

7. Wierman ME, Arlt W, Basson R, et al. Androgen therapy in women: a reappraisal: an Endocrine Society clinical practice guideline. J Clin Endocrinol Metab 2014;99:3489-510.

8. Davis SR, Papalia MA, Norman RJ, et al. Safety and e cacy of a testosterone metered-dose transdermal spray for treatment of decreased sexual satisfaction in premenopausal women: a placebo-controlled randomized, dose-ranging study. Ann Intern Med 2008;148:569-77. 


\section{МЕЖДУНАРОДНЫЕ ПРОТОКОЛЫ}

9. Goldstat R, Briganti E, Tran J, Wolfe $\mathrm{R}$, Davis S. Transdermal testosterone improves mood, well being and sexual function in premenopausal women. Menopause 2003;10:390-8.

10. Fooladi $E$, Bell RJ, Jane $F$ Robinson PJ, Kulkarni J, Davis SR Testosterone improves antidepressantemergent loss of libido in women: ndings from a randomized, doubleblind, placebo-controlled trial. J Sex Med 2014;11:831-9.

11. Diagnostic and Statistical Manua of Mental Disorders, Fi $h$ Edition Arlington, VA, USA: American Psychiatric Publishing, 2013.

12. Elraiyah T, Sonbol MB, Wang Z, et al. Clinical review: e bene ts and harms of systemic dehydroepiandrosterone (DHEA) in postmenopausal women with normal adrenal function: a systematic review and meta-analysis. J Clin Endocrinol Metab 2014;99:3536-42. 13. Davis SR, Moreau M, Kroll R, et al. Testosterone for low libido in menopausal women not taking estrogen therapy. $\mathrm{N}$ Engl $\mathrm{J}$ Med 2008;359:2005-17.

14. Berman JR, Almeida FG, Jolin J, et al. Correlation of androgen receptors, aromatase, and 5-alpha reductase in the human vagina with menopausal status. Fertil Steril 2003;79:925-31.

15. Raghunandan C, Agrawal S, Dubey P, Choudhury M, Jain A. A comparative study of the e ects of local estrogen with or without local testosterone on vulvovaginal and sexual dysfunction in postmenopausal women. J Sex Med 2010;7:1284-90.

16. Fernandes T, Costa-Paiva LH, PintoNeto AM. E cacy of vaginally applied estrogen, testosterone, or polyacrylic acid on sexual function in postmenopausa women: a randomized controlled trial. $J$ Sex Med 2014;11:1262-70.

17. Sievers C, Klotsche J, Pieper L, et al. Low testosterone levels predict allcause mortality and cardiovascula events in women: a prospective cohort study in German primary care patients Eur J Endocrinol 2010;163:699-708.

18. Laughlin GA, Goodell V, BarrettConnor $E$. Extremes of endogenous testosterone are associated with increased risk of incident coronary events in older women. J Clin Endocrinol Metab 2010;95:740-7.

19. Ouyang P, Vaidya D, Dobs A, et al. Sex hormone levels and subclinical atherosclerosis in postmenopausal women the Multi-Ethnic Study of Atherosclerosis. Atherosclerosis 2009;204:255-61.

20. Worboys S, Kotsopoulos D, Teede H, McGrath BP, Davis SR. Parental testosterone improves endotheliumdependent and independent vasodilation in postmenopausal women already receiving estrogen. J Clin Endocrinol Metab 2001;86:158-61.
21. Davison S, ipphawong J, Blanchard $\mathrm{J}$, et al. Pharmacokinetics and acute safety of inhaled testosterone in postmenopausal women. $\mathrm{J}$ Clin Pharmacol 2005;45:177-84

22. Lellamo F, Volterrani M, Caminiti G, et al. Testosterone therapy in women with chronic heart failure: a pilot double-blind, randomized, placebo-controlled study. J Am Coll Cardio 2010:56:1310-16.

23. Davis SR, Davison SL, Gavrilescu M et al. E ects of testosterone on visuospatial function and verbal uency in postmenopausal women: results from a functional magnetic resonance imaging pilo study. Menopause 2014;21:410-14.

24. Davison SL, Bell RJ, Gavrilescu M et al. Testosterone improves verbal learning and memory in postmenopausal women: Results from a pilot study. Maturitas 2011;70:307-11. 25. Davis SR, Panjari M, Stanczyk FZ Dehydroepiandrosterone (DHEA) replacement for postmenopausal women. J Clin Endocrinol Metab 2011;96:1642-53.

26. Alkatib $A A$, Cosma M, Elamin MB et al. A systematic review and metaanalysis of randomized placebo-controlled trials of DHEA treatment e ects on quality of life in women with adrenal insu ciency. J Clin Endocrinol Metab 2009:94:3676- 81.

27. Labrie F, Archer D, Bouchard C, et al. $E$ ect of intravaginal dehy droepiandrosterone (Prasterone) on libido and sexual dysfunction in postmenopausal women. Menopause 2009;16:923-31.

28. Bouchard C, Labrie F, Archer DF, et al. Decreased e cacy of twice-weekly intravaginal dehydroepiandrosterone on vulvovaginal atrophy. Climacteric 2015;18:590-607.

\section{Complementary therapies}

1. Lethaby A, Marjoribanks J, Kronenberg

F, Roberts H, Eden J, Brown J. Phytoestrogens for menopausal vasomotor symptoms. Cochrane Menstrual Disorders and Subfertility Group. Cochrane Database Syst Rev 2013;12:CD001395.

2. Shakeri F, Taavoni S, Goushegir A, Haghani $\mathrm{H}$. E ectiveness of red clover in alleviating menopausal symptoms: a 12-week randomized, controlled trial. Climacteric 2015;18:568-73.

3. Taylor-Swanson $L$, omas $A$, Ismail $R$, et al. E ects of traditional Chinese medicine on symptom clusters during the menopausal transition. Climacteric 2015;18:142-56.

4. Lim TY, Considine A, Quaglia A, Shawcross DL. Subacute liver failure secondary to black cohosh leading to liver transplantation. BMJ Case Rep 2013;2013. pii: bcr2013009325.

5. Lu Y-R, Jiang Y-L, Huang R-Q, Yang J-Y, Xiao B-K, Dong J-X. Hypericum per- foratum L. preparations for menopause: a meta-analysis of e cacy and safety. Climacteric 2014;17:325-35

6. Carpenter JS, Burns DS, Wu J, et al. Paced respiration for vasomotor and other menopausal symptoms: a randomized, controlled trial. J Gen Intern Med 2013;28:193-200.

7. Norton S, Chilcot J, Hunter MS Cognitive-behavior therapy for menopausal symptoms (hot ushes and night sweats): moderators and mediators of treatment e ects. Menopause 2014;21:574-8

8. Castelo Branco de Luca A, Maggio da Fonseca A, Carvalho Lopes CM, Bagnoli VR, Soares Jr JM, Baracat EC. Acupuncture-ameliorated menopausal symptoms: single-blind, placebo-controlled, randomized trial. Climacteric 2011;14:140-5

9. Chiu HY, Shyu YK, Chang PC, Tsai PS. $E$ ects of acupuncture on menopause-related symptoms in breast cancer survivors: a meta-analysis of randomized controlled trials. Cancer Nurs 2015 Jun 3. Epub ahead of print.

10. Chiu HY, Pan CH, Shyu YK, Han $B C$, Tsai PS. E ects of acupuncture on menopause-related symptoms and quality of life in women in natural menopause: a meta-analysis of randomized controlled trials. Menopause 2015;22:234-44.

11. Elkins GR, Fisher WI, Johnson AK, Carpenter JS, Keith TZ. Clinical hypnosis in the treatment of postmenopausal hot ashes: a randomized controlled trial. Menopause 2013;20:291-8.

12. Daley AJ, omas A, Roalfe AK, et al. e e ectiveness of exercise as treatment for vasomotor menopausal symptoms: randomised controlled trial. BJOG 2015;122:565-75

13. Walega DR, Rubin LH, Banuvar S, Shulman LP, Maki PM. E ects of stellate ganglion block on vasomotor symptoms: ndings from a randomized controlled clinical trial in postmenopausal women. Menopause 2014;21:807-14.

\section{Bioidentical hormone therapy}

1. Boothby LA, Doering PL, Kipersztok S. Bioidentical hormone therapy: a review. Menopause 2004;11:356-67.

2. MacLennan AH, Sturdee DW. e 'bioidentical/bioequivalent' hormone scam. Climacteric 2006;9:1-3.

3. e Endocrine Society: Position Statement: Bioidentical Hormones, October 2006: http://www.endosociety.org

4. Huntley AL. Compounded or confused? Bioidentical hormones and menopausal health. Menopause Int 2011;17:16-18.

5. Schmidt P. e 2012 Hormone erapy Position Statement of the North American Menopause Society. Menopause 2012;19:257-71.
6. Compounded bioidentical menopausal hormone therapy. Committee Opinion No. 532. American College of Obstetricians and Gynecologists. Obstet Gynecol 2012;120:411-15

7. de Villers TJ, Gass ML, Haines CJ, et al. Global Consensus Statement on Menopausal Hormone erapy. Climacteric 2013;16:203-4.

Vasomotor symptoms: MHT and pharmacologic treatments

1. Loprinzi CL, Sloan J, Stearns V, et al. Newer antidepressants and gabapentin for hot ashes: an individual patient pooled analysis. J Clin Oncol 2009;27:2831-7. 2. Nelson HD, Vesco KK, Haney E, et al. Nonhormonal therapies for menopausal hot ashes: systematic review and meta-analysis. JAMA 2006;295:2057-71.

3. Rada G, Capurro D, Pantoja T, et al. Non-hormonal interventions for hot ushes in women with a history of breast cancer. Cochrane Database Syst Rev 2010;(9):CD004923.

4. Sideras K, Loprinzi CL. Nonhormonal management of hot ashes for women on risk reduction therapy. J Natl Compr Canc Netw 2010;8:1171-9.

5. Loprinzi CL, Kugler JW, Sloan JA, et al. Venlafaxine in management of hot ashes in survivors of breast cancer: a randomised controlled trial. Lancet 2000;356:2059-63.

6. Stearns $V$, Beebe $K L$, lyengar $M$, Dube E. Paroxetine controlled release in the treatment of menopausal hot ashes: a randomized controlled trial. JAMA 2003;289:2827-34.

7. Loprinzi CL, Sloan JA, Perez EA, et al. Phase III evaluation of uoxetine for treatment of hot ashes. $\mathrm{J}$ Clin Oncol 2002;20:1578-83.

8. Evans $M L$, Pritts $E$, Vittingho $E$, McClish K, Morgan KS, Ja e RB. Management of postmenopausal hot ushes with venlafaxine hydrochloride: a randomized, controlled trial. Obstet Gynecol 2005;105:161-6.

9. Stearns V, Slack R, Greep N, et al. Paroxetine is an e ective treatment for hot ashes: results from a prospective randomized clinical trial. J Clin Oncol 2005;23:6919-30.

10. Loprinzi CL, Barton DL, Sloan JA, et al. Mayo Clinic and North Central Cancer Treatment Group hot ash studies: a 20-year experience. Menopause 2008;15:655-60.

11. Barton DL, LaVasseur BI, Sloan JA, et al. Phase III, placebo-controlled trial of three doses of citalopram for the treatment of hot ashes: NCCTG trial N05C9. J Clin Oncol 2010;28:3278-83. 12. Freeman EW, Guthrie KA, Caan B, et al. E cacy of escitalopram for hot ashes in healthy menopausal women: a randomized controlled trial. JAMA 2011;305:267-74. 


\section{МЕЖДУНАРОДНЫЕ ПРОТОКОЛЫ}

13. Guttuso T Jr, Kurlan R, McDermott MP, Kieburtz K. Gabapentin's e ects on hot ashes in postmenopausal women: a randomized controlled trial. Obstet Gynecol 2003;101:337-45.

14. Pandya KJ, Morrow GR, Roscoe JA, et al. Gabapentin for hot ashes in 420 women with breast cancer: a randomised double-blind placebo-controlled trial. Lancet 2005;366:818-24. 15. Sloan JA, Loprinzi CL, Novotny PJ, Barton DL, Lavasseur Bl, Windschitl $\mathrm{H}$ Methodologic lessons learned from hot ash studies. J Clin Oncol 2001;19:4280- 90. 16. Reddy SY, Warner H, Guttuso T Jr, et al. Gabapentin, estrogen, and placebo for treating hot ushes: a randomized controlled trial. Obstet Gynecol 2006;108:41-8.

17. Jo e H, Guthrie KA, LaCroix AZ, et al. Low-dose estradiol and the serotoninnorepinephrine reuptake inhibito venlafaxine for vasomotor symptoms: a randomized clinical trial. JAMA Intern Med 2014:174:1058-66.

18. Bordeleau L, Pritchard KI, Loprinzi $\mathrm{CL}$, et al. Multicenter, randomized, crossover clinical trial of venlafaxine versus gabapentin for the managemen of hot ashes in breast cancer survivors J Clin Oncol 2010;28:5147-52.

19. Suvanto-Luukkonen E, Koivunen R Sundstrum $\mathrm{H}$, et al. Citalopram and uoxetine in the treatment of postmenopausal symptoms: a prospective, randomized, 9-month, placebo-controlled, double-blind study. Menopause 2005; 12:18-26.

20. Kerwin JP, Gordon PR, Senf JH. variable response of women with menopausal hot ashes when treated with sertraline. Menopause 2007:14:841-5. 21. Grady D, Cohen B, Tice J, Kristof M, Olyaie A, Sawaya GF. Ine ectiveness of sertraline for treatment of menopausal hot ushes: a randomized controlled trial. Obstet Gyneco 2007;109:823-30.

22. Bardia A, Novotny $P$, Sloan J, Barton D, Loprinzi C. E cacy of nonestrogenic hot ash therapies among women strati ed by breast cancer history and tamoxifen use: a pooled analysis. Menopause 2009;16:477-83.

23. Jin Y, Desta Z, Stearns V, et al. CYP2D6 genotype, antidepressant use and tamoxifen metabolism during adjuvant breast cancer treatment. $\mathrm{J}$ Nat Cancer Inst 2005;97:30-9.

24. Kelly CM, Juurlink DN, Gomes T, et al. Selective serotonin reuptake inhibitors and breast cancer mortality in women receiving tamoxifen: a population based cohort study. BMJ 2010;340:c693.

25. Noehr-Jensen L, Zwisler ST, Larsen F, Sindrup SH, Damkier P, Brosen K. Escitalopram is a weak inhibitor of the CYP2D6-catalyzed 0-demethylation of (+)-tramadol but does not reduce the hypoalgesic e ect in experimental pain Clin Pharmacol er 2009;86:626-33. 26. Lash TL, Pedersen L, CroninFenton D, et al. Tamoxifen's protection against breast cancer recurrence is no reduced by concurrent use of the SSR citalopram. J Cancer 2008;99:616-21.

Po menopausal vulvovaginal atrophy 1. Portman DJ, Gass ML; Vulvovagina Atrophy Terminology Consensus Conference Panel. Genitourinary syndrome of menopause: new terminology for vulvovaginal atrophy from the International Society for the Study of Women's Sexual Health and the North American Menopause Society. Climacteric 2014;17:557-63.

2. Nappi RE, Kokot-Kierepa M. Vaginal Health: Insights, Views \& Attitudes
(VIVA) - results from an international survey. Climacteric 2012;15:36-44. 3. Nappi RE, Kingsberg S, Maamari R, Simon J. e CLOSER (CLarifying Vaginal Atrophy's Impact On SEx and Relationships) Survey: Implications of vaginal discomfort in postmenopausal women and in male partners. J Sex Med 2013;10:2232-41.

4. Archer DF. E cacy and tolerability of local estrogen therapy for urogenital atrophy. Menopause 2010;17:194-203. 5. Santen RJ. Vaginal administration of estradiol: e ects of dose, preparation and timing on plasma estradiol levels. Climacteric 2015;18:121-34.

6. Simon JA, Maamari RV. Ultra-low-dose vaginal estrogen tablets for the treatment of postmenopausal vaginal atrophy. Climacteric 2013;16(Suppl 1):37-43.

7. Suckling J, Kennedy R, Lethaby A Roberts $H$. Local estrogen therapy for vaginal atrophy in post menopausal women. Cochrane Database Syst Rev 2006 Issue 4 CD 001500.

8. Sturdee DW, Panay N, on behalf of the IMS Writing Group. Recommendations for the management of postmenopausal vaginal atrophy. Climacteric 2010;13:509-22. 9. Constantine G, Graham S, Portman DJ, Rosen RC, Kingsberg SA. Female sexual function improved with ospemifene in postmenopausal women with vulvar and vaginal atrophy: results of a randomized, placebo-controlled trial. Climacteric 2015;18:226-32.

10. Nappi RE, Polatti F. e use of estrogen therapy in women's sexual functioning. J Sex Med 2009;6:603-16.

11. Nappi RE, Panay N, Bruyniks N, Castelo-Branco C, de Villiers TJ, Simon JA e clinical relevance of the e ect of ospemifene on symptoms of vulvar and vaginal atrophy. Climacteric 2015; 18: 233-40.
12. Pinkerton JV, omas S. Use of SERMs for treatment in postmenopausal women. J Steroid Biochem Mol Biol 2014;142:142-54.

13. Portman D, Palacios S, Nappi RE, Mueck AO. Ospemifene, a non-oestrogen selective oestrogen receptor modulator for the treatment of vaginal dryness associated with postmenopausal vulvar and vaginal atrophy: a randomised, placebo-controlled, phase III trial. Maturitas 2014;78:91-8.

14. Sinha A, Ewies AA. Non-hormonal topical treatment of vulvovaginal atrophy: an up-to-date overview. Climacteric 2013;16:305-12.

\section{Novel menopause therapies}

1. Archer DF, Labrie F, Bouchard C, et al.; other participating members of the WA Prasterone Group. Treatment of pain at sexual activity (dyspareunia) with intravaginal dehydroepiandrosterone (prasterone). Menopause 2015;22:950-63.

2. Bouchard C, Labrie F, Archer DF, et al.; WA Prasterone Group. Decreased efcacy of twice-weekly intravaginal dehydroepiandrosterone on vulvovaginal atrophy. Climacteric 2015;18:590-607. 3. Nappi RE, Panay N, Bruyniks N, CasteloBranco C, de Villiers TJ, Simon JA. e clinical relevance of the e ect of ospemifene on symptoms of vulvar and vaginal atrophy. Climacteric 2015;18:233-40.

4. Pinkerton JV, Komm BS, Mirkin S. Tissue selective estrogen complex combinations with bazedoxifene/conjugated estrogens as a model. Climacteric 2013;16:618-28.

5. Smith CL, Santen RJ, Komm B, Mirkin S. Breast-related e ects of selective estrogen receptor modulators and tissue-selective estrogen complexes. Breast Cancer Res 2014;16:212. 


\section{Тактика проведення допоміжних репродуктивних технологій у пацієнток із супутнім ожирінням та метаболічним синдромом}

\section{В.О. Петропавловська}

Національна медична академія післядипломної освіти імені П.Л. Шупика, м. Київ

\begin{abstract}
Мета дослідження: відновлення репродуктивної функції у жінок із супутнім ожирінням та метаболічним синдромом на основі вивчення їхніх клініко-функціональних та ендокринологічних особливостей, а також удосконалення і впровадження алгоритму діагностичних та лікувальнопрофілактичних заходів з використанням допоміжних репродуктивних технологій (ДРТ).

Матеріали та методи. Для вивчення особливостей індукції суперовуляції у пацієнток з надмірною масою тіла і ожирінням був проведений ретроспективний аналіз лікування методами ДРТ 30 пацієнток з IMT $>25$ кг/м² $(38$ циклів стимуляції). Критеріями включення були: вік 18-38 років; безплідність, що є показанням до виконання ЕКЗ/ІКСІ; відсутність протипоказань до індукції суперовуляції і виношування вагітності. У групу порівняння увійшли 30 пацієнток у віці 18-38 років без ендокринних порушень і з нормальною масою тіла (IMT 18,5-24,9 кг/м²), показаннями до використання ДРТ у яких були трубно-перитонеальна безплідність унаслідок непрохідності або відсутності маткових труб або чоловічий чинник безплідності.

Результати. Результати проведених досліджень свідчать про наявність істотних труднощів при проведенні ДРТ у жінок з надмірною масою тіла і супутнім метаболічним синдромом. Отримані результати є важливими з наукової і теоретичної точки зору і дозволяють пояснити недостатню ефективність лікування безплідності у таких пацієнток.

Заключення. Упровадження запропонованого алгоритму поліпшить результати лікування порушень репродуктивної функції у жінок із супутнім ожирінням і метаболічним синдромом, що дозволяє рекомендувати його для практичної охорони здоров'я.
\end{abstract}

Ключові слова: допоміжні репродуктивні технології, надмірна маса тіла, ожиріння.

Чas астота безплідних шлюбів, за даними вітчизняних і за1 рубіжних дослідників, складає від 10\% до 20\% [1, 2]. У структурі жіночої безплідності ендокринні чинники посідають друге місце, причому найчастішою патологією $є$ надмірна маса тіла і наявність метаболічного синдрому, що досягає 20-30\% у жінок репродуктивного віку [3, 4].

Разом з проблемою безплідності останніми роками виявляють неухильне зростання ожиріння. За попередніми даними в Україні не менше $30 \%$ працездатного населення мають надмірну масу тіла, $25 \%$ - ожиріння і до $10 \%$ - метаболічний синдром [5-7]. Ці дані у сукупності з даними інших країн дозволяють визначити існування глобальної «епідемії» ожиріння.

Збільшення кількості жінок з надмірною масою тіла, ожирінням і метаболічним синдромом призводить до того, що все частіше індукцію суперовуляції в рамках програм допоміжних репродуктивних технологій (ДРТ) проводять на тлі наявних метаболічних порушень. У той самий час, ожиріння само по собі дуже часто призводить до порушення менструальної і дітородної функцій жінки. Збільшення маси жирової тканини вище за норму на $20 \%$ і більше зумовлює дисфункцію гіпоталамо-гіпофізарно-яєчникової системи. При ожирінні у 2-5 разів частіше виникають різні форми порушень менструального циклу, такі, як олігоменорея і аменорея, підвищується частота маткових кровотеч і патології ендометрія $[8,9]$. Ожиріння, особливо андроїдного типу, є одним з головних чинників ризику розвитку яєчникової гіперандрогенії, при цьому більш ніж в однієї третини жінок може формуватися синдром полікістозних яєчників (СПКЯ), а частота безплідності у таких жінок досягає 30-40\% [1, 4]. Крім того, у них відзначено недостатню ефективність різних видів терапії, спрямованої на відновлення фертильності, у тому числі і ДРТ.

В останні роки в Україні широко використовують ДРТ, у тому числі і при жіночій безплідності ендокринного генезу, до якого належить надмірна маса тіла і метаболічний синдром $[3,5]$.

У зв'язку з викладеним вище представляє значний інтерес вивчення особливостей проведення ДРТ у пацієнток цієї групи в аспекті підвищення їхньої ефективності.

Мета дослідження: відновлення репродуктивної функції у жінок із супутніми ожирінням та метаболічним синдромом на основі вивчення їхніх клініко-функціональних та ендокринологічних особливостей, а також удосконалення і впровадження алгоритму діагностичних та лікувально-профілактичних заходів з використанням ДРТ.

\section{МАТЕРІАЛИ ТА МЕТОДИ}

Для вивчення особливостей індукції суперовуляції у пацієнток з надмірною масою тіла і ожирінням був проведений ретроспективний аналіз лікування методами ДРТ 30 пацієнток з IMT $>25$ кг/м² (38 циклів стимуляції). Критеріями включення були: вік 18-38 років; безплідність, що є показанням до виконання ЕКЗ/ІКСІ; відсутність протипоказань до індукції суперовуляції і виношування вагітності. У групу порівняння увійшли 30 пацієнток у віці 18-38 років без ендокринних порушень і з нормальною масою тіла (IMT $18,5-24,9$ кг/м²), показаннями до використання ДРТ у яких були трубно-перитонеальна безплідність унаслідок непрохідності або відсутності маткових труб або чоловічий чинник безплідності.

Індукцію суперовуляції у всіх пацієнток здійснювали за стандартним довгим протоколом. Агоністи ГнРГ починали вводити у середині лютеїнової фази циклу, через тиждень після овуляції (як правило, на 21-й день циклу, передування стимуляції). На 2-3-й день циклу починали введення високоочищеного людського менопаузального гонадотропіну. Для завершення процесів дозрівання ооцитів при середньому діаметрі двох домінантних фолікулів $>18$ мм вводили 10000 ОД ХГЛ.

Вплив надмірної маси тіла і ожиріння на індукцію супер- 


\section{БЕСПЛОДИЕ И ПЛАНИРО ВАНИЕ СЕМ ИИ}

овуляції оцінювали за такими показниками, як сумарна доза гонадотропінів, тривалість стимуляції, товщина ендометрія у день перенесення ембріонів, число отриманих ооцитів, частота розвитку синдрому гіперстимуляції яєчників (СГЯ).

Для індукції суперовуляції був вибраний теоретично більш оптимальний протокол стимуляції - короткий протокол з антагоністами ГнРГ. Індукцію суперовуляції проводили за допомогою препарату рФСГ.

Для гальмування передчасного циклу ЛГ використовували антагоніст ГнРГ - ганірелікс. Вибір протоколу був зумовлений результатами досліджень, що засвідчили менший ризик розвитку СГЯ за збереження ефективності, а також зручність, менш болісні ін'єкції і високу точність дозування препарату при використанні шприц-ручки. Фолітропін починали вводити з 2-го дня менструального циклу у стартовій дозі 150-200 МО залежно від оваріального резерву, відповіді яєчників у попередніх стимуляціях. Початкова доза гонадотропінів у перші 5 днів була фіксованою, зміну дозування проводили відповідно до індивідуальних особливостей збільшення фолікулів за даними УЗД. Перед початком стимуляції з кожною пацієнткою була проведена бесіда про планований протокол з демонстрацією і навчанням поводження зі шприц-ручкою. Від кожної пацієнтки було отримано письмову інформовану згоду на використання фолітропіну, що пацієнтки вводять самостійно за допомогою спеціальної шприц-ручки.

Ожиріння і ступінь його вираженості діагностували на підставі величини IMT (ВООЗ, 2008 р.). Діагноз СПКЯ встановлювали на підставі критеріїв Роттердамськой конференції (2013 р.):

1) оліго-/ ановуляція;

2) гіперандрогенія, що має клінічні і біохімічні прояви;

3) ехографічні ознаки полікістозних яєчників.

Метаболічний синдром діагностували згідно з критеріями Міжнародної федерації діабету (2012р.).

У всіх учасників дослідження проводили комплексне обстеження, яке включало наступні етапи:

1. Клініко-анамнестичне дослідження:

- детальне вивчення соматичного і гінекологічного анамнезу;

- об'єктивне дослідження.

2. Лабораторні дослідження.

3. Ультразвукове дослідження органів малого таза до початку лікування і в процесі індукції овуляції (ультразвуковий моніторинг).

4. Анкетування.

5. Статистичні методи оброблення отриманих даних.

\section{РЕЗУЛЬТАТИ ДОСЛІДЖЕННЯ} ТА ЇХ ОБГОВОРЕННЯ

Результати проведених досліджень свідчать, що при порушенні репродуктивної функції у жінок із супутнім ожирінням переважають II та III ступені (73,3\%); частота метаболічного синдрому складає $30,0 \%$; гірсутизму $-30,0 \%$ та артеріальної гіпертензії - 13,3\% відповідно.

Основними причинами безплідності у жінок із супутнім ожирінням є ановуляція (46,7\%); трубно-перитонеальний фактор (33,3\%) та їхнє поєднання (20,0\%). При цьому сумарна частота СПКЯ складає 40,0\%. Первинну безплідність діагностують у $60,0 \%$ випадків та вторинну - у 40,0\% відповідно.

Стан оваріального резерву у пацієнток із супутнім ожирінням залежить від його ступеня, при цьому середне число фолікулів зменшується з 13,2 7 ,2 при I ступені до $6,1 \pm 0,8$ при III ступені ожиріння та наявності метаболічного синдрому.

У пацієнток з безплідністю на тлі супутнього ожиріння спостерігається позитивна кореляційна залежність між IMT i дозою гонадотропінів $(\mathrm{r}=+0,71 ; \mathrm{p}=0,019)$, а також IMT та тривалістю стимуляції ( $\mathrm{r}=+0,66$; $\mathrm{p}=0,039)$.

Для підвищення ефективності ДРТ у жінок із супутнім ожирінням необхідно враховувати ступінь ожиріння, наявність СПКЯ, метаболічного синдрому, а також стан оваріального резерву.

Дози препаратів для індукції суперовуляції у жінок із супутнім ожирінням залежать від ступеня ожиріння, наявності метаболічного синдрому, а також від рівня дисгормональних та дисметаболічних порушень.

Використання удосконаленого нами алгоритму діагностичних та лікувально-профілактичних заходів дозволяє досягнути настання вагітності у жінок із супутнім ожирінням та метаболічним синдромом у $30,0 \%$ випадків; при СПКЯ у $33,3 \%$, а сумарна частота складає $43,3 \%$ на тлі відповідної корекції дисгормональних та дисметаболічних порушень.

\section{ВИСНОВКИ}

Отже, результати даного дослідження свідчать про наявність істотних труднощів при проведенні допоміжних репродуктивних технологій у жінок з надмірною масою тіла і супутнім метаболічним синдромом. Отримані результати є важливими з наукової і теоретичної точки зору і дозволяють пояснити недостатню ефективність лікування безплідності у таких пацієнток. Упровадження запропонованого алгоритму поліпшить результати лікування порушень репродуктивної функції у жінок із супутнім ожирінням і метаболічним синдромом, що дозволяє рекомендувати його для практичної охорони здоров’я.

\section{Тактика проведения вспомогательных репродуктивных технологий у пациенток с сопутствующим ожирением и метаболическим синдромом В.О.Петропавловская}

Цель исследования: восстановление репродуктивной функции у женщин с сопутствующим ожирением и метаболическим синдромом на основе изучения их клинико-функциональных и эндокринологических особенностей, а также усовершенствование и внедрение алгоритма диагностических и лечебно-профилактических мероприятий с использованием вспомогательных репродуктивных технологий (ВРТ).

Материалы $\boldsymbol{u}$ методы. Для изучения особенностей индукции суперовуляции у пациенток с избыточной массой тела и ожирением был проведен ретроспективный анализ лечения методами ВРТ 30 пациенток с ИМТ >25 кг/м² (38 циклов стимуляции). Критериями включения были: возраст 18-38 лет; бесплодие, что было показанием к ЭКО/ИКСИ; отсутствие противопоказаний к индукции суперовуляции и вынашивания беременности. Группу сравнения составили 30 пациенток в возрасте 18-38 лет без эндокринных нарушений и с нормальной массой тела (ИМТ 18,5-24,9 кг $\left./ \mathrm{M}^{2}\right)$, показаниями к применению ВРТ у них было трубно-перитонеальное бесплодие вследствие непроходимости или отсутствия маточних труб или мужской фактор бесплодия.

Peзультаты. Результаты проведенных исследований свидетельствуют о наличии существенных трудностей при выполнении BPT у женщин с избыточной массой тела и сопутствующим метаболическим синдромом. Полученные результаты являются важными с научной и теоретической точки зрения и позволяют объяснить недостаточную эффективность лечения бесплодия таких пациенток.

Заключение. Внедрение предложенного алгоритма улучшит результаты лечения нарушений репродуктивной функции у женщин с сопутствующим ожирением и метаболическим синдромом, что позволяет рекомендовать его для практического здравоохранения.

Ключевые слова: вспомогательные репродуктивные технологии, избыточная масса тела, ожирение. 


\section{БЕСПЛОДИЕ И ПЛАНИРО В АНИЕ СЕМ ИИ}

\section{Tactics of carrying out of auxiliary reproductive technologies at patients with accompanying adiposity and metabolic syndrome V.O. Petropavlovskay}

The objective: restoration of reproductive function at women with accompanying adiposity and metabolic syndrome on the basis of studying at them clinical-functional and endocrinological features, and also improvement and introduction of algorithm of diagnostic and treatment-and-prophylactic actions with use of auxiliary reproductive technologies.

Patients and methods. For studying of features of an induction super ovulation at patients with superfluous weight of body and adiposity the retrospective analysis of treatment by methods of auxiliary reproductive technologies of 30 patients with IMB $>25 \mathrm{~kg} / \mathrm{m} 2$ (38 cycles of stimulation) has been carried out. Criteria of inclusion were age of 18-38 years; barreness that was the indication to ECO/IKSI; absence contra-indications to an induction superovulation and pregnancy. The comparison group was made by 30 patients at the age of $18-38$ years without endocrinological infringements and in normal weight of a body (IMB - 18,5-24,9 kg/m2), indications to application ART for them were tube-peritoneale barreness owing to impassability or absence uterine pipes or the man's factor of barreness.

Results. Results of the spent researches testify about presence of essential difficulties at performance ART at women with superfluous weight of body and an accompanying metabolic syndrome. The results received by us are important from the scientific and theoretical point of view and allow insufficient efficiency of treatment of barreness at these patients.

Conclusions. Results of treatment of infringements of reproductive function at women with accompanying adiposity and a metabolic syndrome that allows to recommend from in practical public health services allow to improve introduction of the received results.

Key words: auxiliary reproductive technologies, superfluous weight bodies, adiposity.

\section{Сведения об авторе}

Петропавловская Виктория Олеговна - Национальная медицинская академия последипломного образования имени П.Л. Шупика, 04112, г. Киев, ул. Дорогожицкая, 9. E-mail: prore-first@nтаро.edu.ua

\section{СПИСОК ЛІТЕРАТУРИ}

1. Прилепская В.Н. Ожирение в практике акушера-гинеколога /В.Н. Прилепская //Акуш. и гин. - 2013. - № 5. - C. 59-61.

2. Світленко А.В. Особливості гормонального статусу у жінок із абдомінально-вісцеральним і глютеофеморальним ожирінням / А.В. Світленко, М.В. Яременко, Н.А. Михайлова // Педіатрія, акушерство та гінекологія. - 2012. - № 3. - C. 16-18.

3. Моисеев С.В. Ожирение / С.В. Мо- исеев //Клинич. фармакол. и терапия. - 2012. - Т. 11, № 5. - С. 64-72.

4. Овсянникова Т.В. Метаболические нарушения у пациенток с хронической ановуляцией и гиперандрогенией / Т.В. Овсянникова И.Ю. Демидов, Н.Д. Фанченко //Пробл. репродукции. - 2009. № 2. - С. 34-37.

5. Геряк С.Н., Швед Н.И. Метаболический синдром и беременность: проблемы и пути решения / С.Н. Ге- ряк, Н.И. Швед // Здоровье женщины. - 2014. - № 4. - С. 35-39.

6. Gluckman P.D. Effect of in utero and earlylife conditions on adult health and disease / P.D. Gluckman, M.A. Hanson, C. Cooper // N Engl J Med. - 2015. Vol. 412 (1). - P. 61-73.

7. Hartil K. Maternal substrate utilization programs the development of the metabolic syndrome in male mice exposed to high fat in utero / K. Hartil, P.M. Vuguin, M. Kruse // Pediatr Res.
- 2015. - Vol. 81 (4). - P. 368-373 8. Anfossi G. Platelet dysfunction in central obesity / G. Anfossi, I. Russo, M. Trovati // Nutrition, Metabolism, and Cardiovascular Diseases. - 2015. Vol. 19. - P. 440-419.

9. Lemieux I. Abdominalbesity and the metabolic syndrome: contribution to global cardiometabolic risk / I. Lemiux, J. Bergeron, P. Pibarot // Arteriosclerosis, Thrombosis, and Vascular Biology. 2014. - Vol. 28. - P. 1039-1049.

\section{ЗА ЭФФЕКТ ПЛАЦЕБО}

Ученые из Медицинской школы Файнберга при Северо-Западном Университете (Northwestern University's Feinberg School of Medicine) сообщили, что обнаружили в головном мозге область, которая отвечает за тот самый эффект плацебо.

Ученые обследовали 56 участников исследования (все они страдали хроническим остеоартритом) с помощью функциональной МРТ, которая помогла выявить, какова активность разных участков мозга в состоянии покоя. После этого авторы провели два эксперимента. В первом приняли участие 17 человек, ко- торым в качестве обезболивающего назначали плацебо - никто их пациентов об этом не знал. 8 человек сообщили об ослаблении болевых ощущений. Исследователи сравнили результаты повторной фМРТ с данными обследования пациентов в покое: они пришли к выводу, что за реакцию на плацебо отвечала область правой средней лобной извилины головного мозга.

Во второй части исследования приняли участие 39 пациентов. Их разделили на две группы: одним давали плацебо, а другим обезболивающий препарат. Авторы изучали активность "плаце- бо области" мозга. Они выяснили, что в одних случаях лекарство ослабляло реакцию организма на плацебо, а в других усиливало ее.

Авторы уверены, что им удалось довольно точно определить, какая область головного мозга отвечает за реакцию на плацебо. Кроме того, они показали, что разные пациенты в разной степени реагируют на плацебо, а также продемонстрировали, что реакцией на плацебо можно управлять. Эти данные, возможно, позволят эффективнее бороться с хроническими болями.

med-expert.com.ua 


\section{Рівні інтерлейкіну-4 та інтерлейкіну-17 (IL-4, IL-17) крові у паціснток зі звичним невиношуванням вагітності, яка настала у циклі екстракорпорального запліднення}

\section{К.П. Головатюк}

Одеський національний медичний університет,

Медичний центр репродуктивного здоров'я «Гамета», м. Одеса

\begin{abstract}
Мета дослідження: вивчення рівнів цитокінів IL-4 і IL-17 у сироватці крові і кондиційних середовищах культур мононуклеарів крові (МНК) і оцінювання асоціативного зв'язку між їньою продукцією та невиношуванням вагітності, яка настала у циклах екстракорпорального запліднення (ЕКЗ). Матеріали та методи. Під спостереженням перебували 240 пацієнток зі звичним невиношуванням вагітності, що настала у циклах ЕКЗ, і 100 умовно здорових фертильних жінок контрольної групи. Визначали концентрації IL-4 та IL-17 у сироватках крові та кондиційних середовищах культур МНК.
\end{abstract}

Результати. Рівні IL-4 у сироватці крові і в кондиційних середовищах при спонтанній і стимульованій мітогеном секреції достовірно не відрізнялися від таких у контрольній групі, тоді як рівні IL-17 перевищували такі у групі контролю у сироватці, у кондиційних середовищах стимульованих і нестимульованих МНК.

Заключення. Дизрегуляція активності циркулюючих мононуклеарів крові у жінок зі звичним невиношуванням вагітності, що настала після проведення ЕКЗ, супроводжується підвищенням секреціi IL-17 i практично незмінною продукцією IL-4 на тлі високих індексів стимуляції продукції цих цитокінів.

Ключові слова: невиношування вагітності, екстракорпоральне запліднення, інтерлейкін-4, інтерлейкін-17, сироватка крові, стимульовані та нестимульовані мононуклеари крові.

Вичне невиношування вагітності (ЗНВ) є серйозним ус$\mathcal{Z}_{\text {кладненням з частотою } 1-5 \% \text { серед пар, які намагають- }}$ ся завагітніти [2]. Більше 50\% вагітних після екстракорпорального запліднення (ЕКЗ) стикаються з проблемою невиношування вагітності, особливо у I триместрі [2].

Імунна система жінки відіграє важливу роль в успішному настанні та перебігу вагітності, контролює запліднення, імплантацію, розвиток плода і підтримує саму вагітність [1, 7-9]. Отже, дослідження імунних клітин, імунних медіаторів/цитокінів у периферійній крові матері і генів відкриває нове у розумінні, принаймні, материнських причин ЗНВ.

Загальновідомо, що Тh2-тип імунітету сприяє нормальній і успішній вагітності, а Th1-тип імунітету пов'язаний $з$ репродуктивною недостатністю і може бути причиною ідіопатичного рецидивного викидня [10].

Інтерлейкін-4 (IL-4) - мультифункціональний плейотропний протизапальний цитокін, який в основному продукується Тh2-клітинами, відіграє важливу роль як медіатор і модулятор імунної та запальної відповіді. Він залучений не тільки в гуморальний і клітинами медійований імунітет, але також є есенціальним регулятором імунної відповіді В- і Т-клітин, макрофагів $[2,4,5]$. У зв'язку з цим сьогодні вважають, що ЗНВ пов'язано з патогенними Th17клітинами, які надлишково секретують інтерлейкін-17 (IL17) і можуть регулюватися за допомогою IL-4. Розвиток Th17-клітин і секреція цитокінів знижуються у пробірці за впливу IFN- $\gamma$ та IL-4, що продукуються Th1- i Th2-клітинами відповідно [3, 11]. Деякі дані дозволяють припустити, що Th2-цитокін IL-4 може становити особливий інтерес для боротьби з Th17-індукованим запаленням. В організмі людини знижена реакція на IL-4, як вважають, зумовлює автоімунне запалення.

Мета дослідження: вивчення рівнів цитокінів IL-4 i IL17 у сироватці крові і кондиційних середовищах культур мононуклеарів крові і оцінювання асоціативного зв'язку між їхньою продукцією та невиношуванням вагітності, яка настала у циклах ЕКЗ.

\section{МАТЕРІАЛИ ТА МЕТОДИ}

Під спостереженням перебували 240 пацієнток групи $\mathrm{H}$ зі ЗНВ, що настала у циклах ЕКЗ, і 100 умовно здорових фертильних жінок контрольної групи (К) 3 наявністю в анамнезі хоча $б$ одних термінових пологів і відсутністю епізодів мимовільного переривання вагітності.

Визначення концентрації IL-4 та IL-17 у периферійній крові виконували цитометричним методом з використанням тест-системи BD Sciences на аналізаторі FACSCalibur, BD Sciences (США). Забір цільної периферійної крові проводили у вакуумні пластикові пробірки типу Vacuette об'ємом 4,0 мл під час отримання клітин з додаванням як антикоагулянта динатрієвої солі етилендіамінтетраацетату (ЕДТА) в кінцевій концентрації 2,0 мг/мл або посилювача згортання при виділенні сироватки.

Для виділення сироватки кров центрифугували 30 хв при 3000 об./хв і зберігали при $-20{ }^{\circ} \mathrm{C}$ до проведення аналізу.

Виділення мононуклеарних клітин (МНК) з цільної крові виконували стандартно, у градієнті щільності фіколурографіну. Клітини культивували у повному культуральному середовищі RPMI 1640, що містить: 10\% ETC, 2 мM L-глутаміну, 80 мкг/мл гентаміцину, 100 мкг/мл ампіциліну і $5 \times 10^{-5} \mathrm{M} \beta$-меркаптоетанолу. Культивування МНК проводили у 24-лункових плоскодонних планшетах, в кожну лунку вміщували 1 мл повного культурального середовища, що містить $1 \times 10^{6}$ клітин. Клітини стимулювали мітогеном конканаваліном А у концентрації 10 мкг/мл. Кондиційні середовища збирали через 24 год після початку інкубації клітин і зберігали при $-20{ }^{\circ} \mathrm{C}$ до проведення аналізу. Уміст цитокінів у сироватках крові та кондиційних 


\section{БЕСПЛОДИЕ И ПЛАНИРО ВАНИЕ СЕМ ИИ}

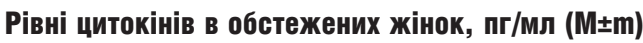

\begin{tabular}{|c|c|c|}
\hline Цитокін & Група Н, n=240 & Група K, n=100 \\
\hline \multicolumn{3}{|c|}{ У сироватці крові обстежених жінок } \\
\hline $\mathrm{IL}-4$ & $7,34 \pm 0,17$ & $7,12 \pm 0,21$ \\
\hline IL-17 & $85,87 \pm 2,16^{\kappa}$ & $65,13 \pm 2,53$ \\
\hline \multicolumn{3}{|c|}{ У кондиційних середовищах нестимульованих МНК } \\
\hline IL-4 & $1,82 \pm 0,32$ & $1,99 \pm 0,15$ \\
\hline IL-17 & $56,82 \pm 0,44^{\kappa}$ & $47,86 \pm 2,14$ \\
\hline \multicolumn{3}{|c|}{ У кондиційних середовищах стимульованих МНК } \\
\hline $\mathrm{IL}-4$ & $12,02 \pm 0,56$ & $12,87 \pm 0,65$ \\
\hline IL-17 & $432,05 \pm 7,22^{\mathrm{k}}$ & $322,37 \pm 9,17$ \\
\hline
\end{tabular}

Примітка. ${ }^{\text {k }}$ - Статистично достовірна різниця 3 показником групи $\mathrm{K}(\mathrm{p}<0,05)$.

середовищах культур МНК визначали за допомогою комерційних наборів компанії BioRad з використанням обладнання і програмного забезпечення Bio-Plex Protein Assay System (Bio-Rad, CША). Для визначення цитокінпродукувальної активності МНК обчислювали індекс стимуляції продукції цитокінів як відношення рівня цитокінів у кондиційних середовищах культур стимульованих МНК до рівня цитокінів у кондиційних середовищах культур нестимульованих МНК.

Статистичне оброблення отриманих даних здійснено за допомогою електронної програми Microsoft Office 2007 for Windows XP Professional, STATISTICA 6.0 (Stat. Soft. Inc., США) з визначенням достовірності відмінностей при значенні $\mathrm{p}<0,05$.

\section{РЕЗУЛЬТАТИ ДОСЛІДЖЕННЯ ТА ÏХ ОБГОВОРЕННЯ}

Досліджувані групи були репрезентативні за віком. Середній вік обстежених жінок групи Н становив $29,80 \pm 0,30$ року, а жінок групи $\mathrm{K}-30,09 \pm 0,30$ року ( $>00,05)$. Переривання вагітності в групі Н у I триместрі мали $51,25 \%$ пацієнток, у II - 34,17\%, у III - 14,58\%.

Під час порівняльного аналізу рівнів цитокінів було встановлено, що у жінок зі ЗНВ, що настала в циклах ЕКЗ, piвні IL-4 у сироватці крові і в кондиційних середовищах при спонтанній і стимульованій мітогеном секреції достовірно не відрізнялися від таких у контрольній групі, тоді як рівні IL-17 перевищували такі в групі контролю у сироватці, у кондиційних середовищах стимульованих і нестимульованих МНК (таблиця).

Індекс стимуляції продукції IL-4 у групі Н був

\section{Уровни итерлейкина-4 и интерлейкина-17 (IL-4, IL-17) крови у пациенток с привычным невынашиванием беременности, которая наступила в цикле экстракорпорального оплодотворения К.П. Головатюк}

Цель исследования: изучение уровней цитокинов IL-4 и IL-17 в сыворотке крови и кондиционных средах культур мононуклеаров крови (МНК) и оценка ассоциативной связи между их продукцией и невынашиванием беременности, которая наступила в циклах экстракорпорального оплодотворения (ЭКО).

Материалы и методы. Под наблюдением находились 240 пациенток с привычным невынашиванием беременности, наступившей в циклах ЭКО, и 100 условно здоровых фертильных женщин контрольной группы. Определяли концентрации IL-4 и IL-17 в сыворотках крови и кондиционных средах культур МНК.

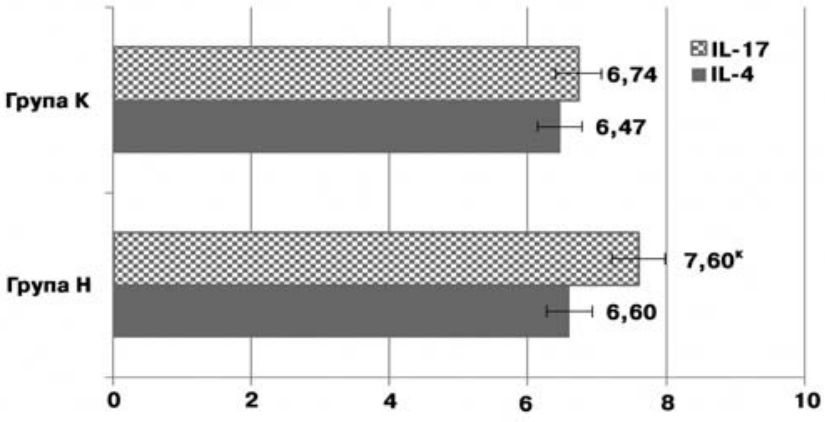

Індекси стимуляції продукції цитокінів IL-4 та IL-17 у жінок зі ЗНВ після ЕК3

$6,60 \pm 0,47(\mathrm{p}>0,05)$, IL-17 $-7,60 \pm 0,85(\mathrm{p}<0,05)$; у групі $\mathrm{K}-$

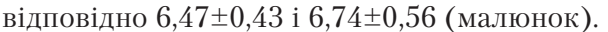

Виявлений дисбаланс продукції цитокінів IL-4 і IL-17 свідчить про те, що сироватковий цитокіновий фон формується не тільки залежно від кількості циркулюючого пулу імунокомпетентних клітин, але і від їхніх функціональних властивостей, можливо, пов'язаних зі зміною генетичної детермінованості.

\section{ВИСНОВКИ}

Дизрегуляція активності циркулюючих мононуклеарів крові у жінок зі звичним невиношуванням вагітності, що настала після проведення ЕКЗ, супроводжується підвищенням секреції IL-17 і практично незмінною продукцією IL-4 на тлі високих індексів стимуляції продукції цих цитокінів.

Pезультаты. Уровни IL-4 в сыворотке крови и в кондиционных средах при спонтанной и стимулированной митогеном секреции достоверно не отличались от таковых в контрольной группе, тогда как уровни IL-17 превышали таковые в группе контроля в сыворотке, в кондиционных средах стимулированных и нестимулированных МНК.

Заключение. Дизрегуляция активности циркулирующих мононуклеаров крови у женщин с привычным невынашиванием беременности, наступившей после проведения ЭКО, сопровождается повышением секреции IL-17 и практически неизменной продукцией IL-4 на фоне высоких индексов стимуляции продукции этих цитокинов.

Ключевые слова: экстракорпоральное оплодотворение, невынашивание беременности, интерлейкин-4, интерлейкин-17, сыворотка крови, стимулированные и нестимулированные мононуклеары крови. 


\section{БЕСПЛОДИЕ И ПЛАНИРО ВАНИЕ С Е ВИ}

\section{Levels interleukine-4 and interleukin-17 (IL-4, IL-17) of blood in patients with habitual recurrent pregnancy loss, which occurred in a loop in vitro fertilization K.P. Golovatyuk}

The objective: was to investigate the levels of cytokines IL-4 and IL 17 in serum and conditioned medium cultures of blood mononuclear cells (MNC) and evaluation association between their products and miscarriage, which occurred in IVF cycles.

Patients and methods. We observed 240 patients with recurrent miscarriage, came in IVF cycles, and 100 apparently healthy fertile women in the control group. The concentrations of IL-4 and IL-17 in serum and conditioned medium of MNC cultures were determined.
Results. The levels of IL-4 in the serum and conditioned medium in spontaneous and stimulated mitogen secretion was not significantly different from those in the control group, whereas IL-17 levels were higher than those in the control group serum, in conditioned media of stimulated and non-stimulated MNCs.

Conclusion. Disregulation of activity of circulating blood mononuclear cells in women with recurrent miscarriage that followed IVF, is accompanied by increased secretion of IL-17 and almost constant production of IL-4 on the back of high stimulation index of production of these cytokines.

Key words: in vitro fertilization, miscarriage, interleukin-4, interleukin17, serum stimulated and non-stimulated mononuclear blood.

\section{Сведения об авторе}

Головатюк Екатерина Петровна - ООО «Медицинский центр репродуктивного здоровья «Гамета», 65039, г. Одесса, ул. Слепнева, 3-А; тел.: (048) 738-68-69. E-mail: info@gameta.od.ua

\section{СПИСОК ЛІТЕРАТУРИ}

1. Cytokines in recurrent pregnancy loss [Текст] / Saini V., Arora S., Yadav A. [et al.] // Clin. Chim. Acta. 2011. - Vol. 412, N 9-10. - P. 702-8. doi: 10.1016/j.cca.2011.01.002.

2. High interleukin-4 expression and interleukin-4 gene polymorphisms are associated with susceptibility to human paracoccidioidomycosis [Текст] / Mendonза M.S., Perazolli T.S., SilvaVergara M.L. [et al.] // Jr. Mem. Inst. Oswaldo Cruz. - 2015. - Vol. 110, N 6. - P. 781-785. doi: 10.1590/007402760150197.

3. IL-6 controls Th17 immunity in vivo by inhibiting the conversion of conventional $\mathrm{T}$ cells into Foxp3+ regulatory $\mathrm{T}$ cells [Текст] / Korn T., Mitsdoerffer M., Croxford A.L. [et al.] // Proc. Natl. Acad.
Sci. - 2008. - Vol. 105, N 47. P. 18460-5. doi: 10. 1073/ pnas. 0809850105.

4. Interleukin-4 gene polymorphism is not involved in the risk of recurrent pregnancy loss [Текст] / Saijo Y., Sata F., Yamada H. [et al.] // Am. J. Reprod. Immunol. - 2004. - Vol. 52, N 2. - P. $143-146$.

5. Lack of Association of the Polymorphisms IL-17A(?197G/A) and IL-17F $(+7488 \mathrm{~A} / \mathrm{G})$ with Multibacillary Leprosy in Mexican Patients [Текст] Escamilla-Tilch M., Estrada-Garcha I., Granados J. [et al.] // Internationa Journal of Genomics. - 2014. Vol. 2014. Article ID 920491, 5 p. http://dx.doi.org/10.1155/2014/92049 1.
6. Rasti Z.The IL-6-634C/G polymorphism: a candidate genetic marker for the prediction of idiopathic recurrentpregnancy loss [Текст] / Rasti Z., Nasiri M., Kohan L. // Int. J. Reprod. Biomed (Yazd). - 2016. - Vol. 14, N 2. - P. 103-8.

7. Regulatory T-cells and immune tolerance in pregnancy: a new target for infertility treatment? [Текст] / Guerin L.R., Prins J.R., Robertson S.A. // Hum. Reprod. Update. - 2009. Vol. 15. - P. 517-535.

8. Robertson S.A. Immune regulation of conception and embryo implantation-all about quality control? [Текст] / S.A. Robertson // J. Reprod. Immunol. - 2010 - Vol. 85 - P. 51-57.

9. The immune system during pregnan- cy [Текст] / Munoz-Suano A., Hamilton A.B., Betz A.G. [et al.] // Immunol. Rev. - 2011. - Vol. 241. P. 20-38.

10. The relationship between cytokine gene polymorphism and unexplained recurrent spontaneous abortion in Saudi females [Текст] / Alkhuriji A.F., Alhimaidi A.R., Babay Z.A. [et al.] // Saudi Medical Journal. - 2013. Vol. 34. - P. 484-489.

11. The role of $\mathrm{T}$ helper 17 (Th17) and regulatory $T$ cells (Treg) in human organ transplantation and autoimmune disease [Текст] / Afzali B., Lombardi G., Lechler R. [et al.] // Clin. Exp. Immunol. - 2007. - P. 148, N 1. - P. 32-46. doi: 10.1111/j.1365-2249. 2007. 03356. $\mathrm{x}$. 


\title{
Анамнестичні фактори, які формують репродуктивне здоров'я жінок із неодноразовими невдалими спробами запліднення in vitro
}

\author{
Н.В. Коцабин, О.М. Макарчук \\ Івано-Франківський національний медичний університет
}

Частка пацієнтів з багаторазовими невдалими спробами лікування методами допоміжних репродуктивних технологій (ДРТ) складає близько $30 \%$ від усіх пацієнтів, які лікуються з використанням ДРТ. Жінки з невдалими спробами ДРТ в анамнезі - це особлива категорія пацієнток, які потребують надзвичайної уваги і більш ретельного обстеження як на етапі підготовки до стимуляції суперовуляції, так і селекції ембріонів, підготовки ендометрія до ембріотрансферу.

Мета дослідження: на основі детального аналізу анамнестичних та клінічних даних безплідних жінок з неодноразовими невдалими спробами запліднення in vitro виокремити групу високого ризику, яка вимагає більш поглибленого вивчення гормональних особливостей, стану оваріального резерву та ендометрія.

Матеріали та методи. Для розуміння глибини проблеми неодноразових невдалих спроб запліднення in vitro i розроблення дієвого алгоритму лікування безплідності у таких подружніх пар було проведено аналіз анамнестичних даних трьох основних груп жінок з безплідністю в анамнезі (105 пацієнток), включених у програму ДРТ. Вони були розподілені за віком: I група - жінки молодше 35 років, II група - віком від 35 до 40 років, III група - віком понад 40 років. Зазначені групи пацієнток порівнювали між собою та із контрольною групою практично здорових жінок (30 осіб).

Результати. Головні стресорні фактори у відсотковому відношенні втричі переважали у групі безплідних жінок і мали прямий зв'язок як із самим фактом процедури запліднення in vitro, так і з хронічним стресовим чинником, зумовленим тривалою безплідністю. Первинну безплідність достовірно частіше відзначали у паціснток молодше 35 років $(\mathrm{p}<0,05)$, вторинну безплідність відзначено у вагомому відсотку у II та III дослідних групах $(\mathrm{p}<0,05)$. Привертає увагу вагомий відсоток поєднання причин безплідності та ідіопатичного фактора у всіх групах, а також переважання трубно-перитонеального фактоpa y II i III дослідних групах та ендокринної дисфункції у I дослідній групі. Причому найчастішою патологією серед даної категорії обстежених був синдром полікістозних яєчників. У пацієнток I та II групи звикле невиношування діагностували вдвічі частіше, ніж у III групі $(p<0,05)$. У досліджуваних групах основне місце належить інфікуванню сечостатевих шляхів, захворюванням респіраторного тракту, патології серцево-судинної системи. Дані стратифікаційного аналізу свідчать про зростання імовірності невдалих спроб екстракорпорального запліднення (ЕКЗ) під впливом постійного хронічного стресу (відношення шансів OR = 2,06; 95\% CI: 0,95-3,17; p<0,05).

Заключення. Серед пацієнток із безплідністю та неодноразовими невдалими спробами використання ДРТ потрібно виділити окрему групу високого ризику невдалих спроб ЕКЗ, причому ця приналежність залежить від тривалості безплідності, віку жінки та комбінації головних факторів. Ключові слова: невдалі спроби запліднення іп vitro, анамнез, безплідність, високий ризик.
Використання допоміжних репродуктивних технологій $\mathbf{B}_{\text {(ДРТ) у лікуванні безплідності оцінюють за частотою дося- }}$ гнення бажаної вагітності по відношенню до кількості пацієнток, пункції фолікулів і перенесення ембріона. Не всі спроби екстракорпорального запліднення (ЕКЗ) закінчуються вагітностями. Частота позитивних результатів після запліднення in vitro за даними всесвітнього реєстру становить близько 20\%, у деяких країнах перевищує 30\%. Причому тільки $70 \%$ вагітностей, що настали у програмі ЕКЗ, завершуються пологами, що частково пояснюється більш старшим віком жінок $[1,3]$.

Як відзначено вище, частка пацієнтів з багаторазовими невдалими спробами лікування методами ДРТ складає близько 30\% від усіх пацієнтів, які лікуються з використанням ДРТ. Жінки з невдалими спробами ДРТ в анамнезі - це особлива категорія пацієнток, які потребують надзвичайної уваги і більш ретельного обстеження як на етапі підготовки до стимуляції суперовуляції, так і селекції ембріонів, підготовки ендометрія до ембріотрансферу [4].

Це зумовлює необхідність пошуку нових підходів до дослідження даної проблеми і є чітким обгрунтуванням актуальності вибраного напрямку.

Мета дослідження: на основі детального аналізу анамнестичних даних безплідних жінок з неодноразовими невдалими спробами запліднення in vitro виокремити групу високого ризику, яка вимагає більш глибокого вивчення гормональних особливостей, стану оваріального резерву та ендометрія.

\section{МАТЕРІАЛИ ТА МЕТОДИ}

Спеціальне клінічне дослідження включало детальне вивчення анамнестичних та клінічних даних.

Для розуміння глибини проблеми неодноразових невдалих спроб запліднення in vitro і розроблення дієвого алгоритму лікування безплідності у таких подружніх пар були проведені ретельне клінічне, лабораторне дослідження та інструментальне обстеження, а також аналітичне порівняння трьох основних груп жінок з безплідністю в анамнезі (105 пацієнток), включених у програму ДРТ. Вони були розподілені за віком: I група - жінки віком молодше 35 років, II група - віком від 35 до 40 років, III група - віком понад 40 років. Зазначені групи пацієнток порівнювали між собою та iз контрольною групою практично здорових жінок (30 осіб).

Статистичне оброблення результатів дослідження здійснювали з допомогою пакета програм Microsoft Office Excel та Statistica 6.0 for Windows.

\section{РЕЗУЛЬТАТИ ДОСЛІДЖЕННЯ TA ÏХ ОБГОВОРЕННЯ}

Середній вік жінок контрольної групи склав $28,0 \pm 0,8$ року, причому основна частина жінок контрольної групи

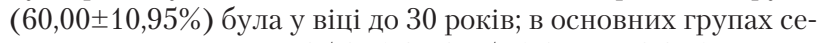
редній вік складав $25,8 \pm 0,9,37,5 \pm 0,8$ та $42,3 \pm 0,4$ року відповідно ( $>0,05)$. 


\section{БЕСПЛОДИЕ И ПЛАНИРО ВАНИЕ СЕМ ИИ}

Аналізуючи фактор професійної зайнятості вагітних, слід зазначити, що переважна більшість жінок займалась нефізичною роботою: розумовою працею були зайняті $20,95 \pm 5,32 \%$ пацієнток основних групі та $20,00 \pm 8,94 \%$ жінок у групі контролю.

Установлено, що у контрольній групі найчастіше виявляли два варіанти соціальної приналежності: студентки

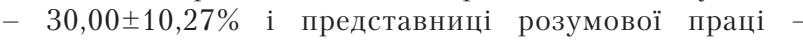
$20,00 \pm 8,94 \%$. У досліджуваних групах відзначено переважання домогосподарок: $22 \quad(21,67 \pm 5,32 \%)$ та $2(20,00 \pm 6,71 \%)$ відповідно, а також службовців - 23 $(21,67 \pm 5,32 \%)$ та $3(15,00 \pm 7,98 \%)$ відповідно $(\mathrm{p}<0,05)$ Інші групи соціального складу виявляли набагато рідше. Привертає увагу факт, що серед жінок контрольної групи питома вага високоосвічених осіб була вдвічі нижча, ніж серед пацієнток досліджуваних груп $(\mathrm{p}<0,01)$. Рівень освіти був значущим: майже третина жінок у досліджуваних групах пацієнток, а саме - $28,57 \pm 5,82 \%$, мали вищу освіту у порівнянні із контролем $-15,00 \pm 7,98 \%(\mathrm{p}<0,01)$. Серед жінок досліджуваних груп частка непрацюючих становила $11,43 \pm 4,14 \%$, тобто у 2,5 разу нижче даного показника у контролі $-25,00 \pm 9,68 \%(\mathrm{p}<0,001)$.

Раннє статеве життя (до 17 років) розпочали 40 жінок $(38,10 \pm 6,28 \%)$ основних досліджуваних груп проти 3 $(15,0 \pm 7,98 \%)$ у контрольній групі $(\mathrm{p}<0,05)$. Аналіз результатів анкетування засвідчив, що $68(64,376 \pm 6,22 \%)$ жінок із безплідністю у досліджуваних групах почали статеве життя до заміжжя $(\mathrm{p}>0,05)$.

Головні стресорні фактори у відсотковому відношенні втричі переважали у групі безплідних жінок і мали прямий зв'язок як із самим фактом процедури запліднення in vitro, так і з хронічним стресовим чинником, зумовленим тривалою безплідністю. Серед них: невпевненість у майбутньому здоров'ї та вірогідність зниження інтелектуального потенціалу майбутньої дитини, необхідність довготривалого перебування в стаціонарі та оперативного розродження, що вимагає додаткової психопрофілактичної роботи з даною категорією вагітних.

Тривалість безплідності на момент обстеження коливалася у межах від 2 до 10 років і більше. У І досліджуваній групі безплідність до 3 років відзначили у $65,71 \pm 10,67 \%$ жінок, також вагомим був відсоток 3 тривалістю

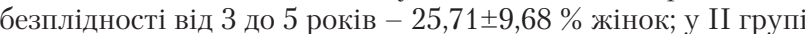
найбільш вагомим був відсоток жінок з безплідністю від 6 до 10 років $-80,0 \pm 8,94 \%$, в той час як у III групі найбільш значущим був показник безплідності більше 10 років $85,71 \pm 7,98 \%$ жінок.

У І досліджуваній групі з первинною безплідністю було $23(65,71 \pm 10,67 \%)$ жінки, у $12(34,29 \pm 10,67 \%)$ жінок в анамнезі виявлено вагітності, тоді як у жінок II і III досліджуваних груп в анамнезі переважала вторинна безплідність, що становило відповідно $65,0 \pm 10,67 \%$ і $71,43 \pm 10,25 \%$ випадків.

Отже, первинну безплідність достовірно частіше відзначали у пацієнток молодше 35 років $(\mathrm{p}<0,05)$, вторинну безплідність відзначено у вагомому відсотку у II та III досліджуваних групах $(\mathrm{p}<0,05)$.

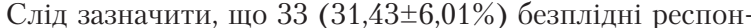
дентки завагітніли 3 першої спроби, у той час як у 37 (35,34 $46,16 \%)$ пацієнток уже була попередня спроба, $19(18,09 \pm 5,00 \%)$ мали три спроби і $15,24 \pm 4,61 \%$ жінок більше трьох спроб.

Привертає увагу вагомий відсоток поєднання причин безплідності та ідіопатичного фактора у всіх групах, а також переважання трубно-перитонеального фактора у II та III

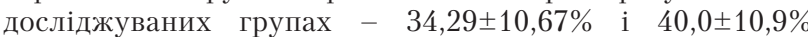
відповідно, та ендокринної дисфункції у I досліджуваній групі. Причому найчастішою патологією серед даної кате- горії обстежених був синдром полікістозних яєчників $74,29 \pm 9,68 \%$ випадків.

У пацієнток контрольної групи вік менархе настав у вікових межах 11-14 років, тоді як у пацієнток досліджуваних груп відзначено пізній вік менархе - після 15 років - у $48,57 \pm 11,2 \%$ жінок I групи, у $45,71 \pm 11,1 \%$ та у $57,14 \pm 11,1 \%$ жінок II та III досліджуваних груп відповідно. Ранній початок менструацій у віці до 11 років спостерігався у кожної п’ятої пацієнтки у II досліджуваній групі.

Аналогічні дані відзначено і щодо характеру менструального циклу. Зафіксовано переважання значного міжменструального інтервалу (>30 днів) у жінок основних досліджуваних груп: у 51,43 $\pm 2,95 \%$ пацієнток I групи та $54,29 \pm 3,70 \%$ пацієнток II і III досліджуваних груп, тоді як у контрольній групі лише у $3,33 \pm 3,36 \%$ пацієнток.

Під час аналізу характеру порушень менструальної функції привертає увагу той факт, що нерегулярний менструальний цикл у жінок III групи виявляли найчастіше - у $51,43 \pm 11,2 \%$ у порівнянні з II групою $-40,0 \pm 10,95 \%$ та I групою $-25,71 \pm 9,68 \%$, а в контрольній групі у 7 разів рідше $3,33 \pm 4,81 \%(\mathrm{p}<0,05)$. Подібну тенденцію відзначено і щодо абортів. Так, від одного до трьох мимовільних абортів мала кожна третя жінка з безплідністю в анамнезі проти $5,0 \pm 4,87 \%$ у контрольній групі $(\mathrm{p}<0,05)$. У пацієнток I та II груп звичне невиношування діагностували вдвічі частіше, ніж у III групі $(\mathrm{p}<0,05)$.

Серед найбільш важливих аспектів клінічної характеристики обстежених жінок особливе значення має фонова генітальна і соматична захворюваність. У групах жінок з безплідністю екстрагенітальну патологію мали більше ніж половина пацієнток (58 $(55,24 \pm 6,42 \%)$ жінок проти $4(20,0 \pm 8,94 \%)$ - у контролі; $p<0,05)$. У досліджуваних групах основне місце належить інфікуванню сечостатевих шляхів - 34,29 $\pm 10,6 \%$; захворюванням респіраторного тракту - 20,0 $2,37 \%$; патології серцево-судинної системи $34,29 \pm 3,60 \%$, яка втричі певажала вісоток у I групі ( $<0,05)$.

Також суттєвою були питома вага ожиріння, яка найбільшою була у жінок III досліджуваної групи $40,0 \pm 10,95 \%$, а найменшою у І групі - 20,0 $\pm 2,37 \%$. Серед обстежених жінок основних груп дисфункцію щитоподібної залози відзначено практично у кожної третьої пацієнтки $31,43 \pm 10,25 \%$ проти $10,0 \pm 2,37 \%$ у контрольній групі. Значущим був відсоток перенесених у дитинстві інфекційних захворювань у порівнянні з пацієнтками групи контролю $(\mathrm{p}<0,05)$.

Патологія органів травного тракту була діагностована у 2,5 разу частіше у жінок II та III досліджуваних груп, ніж у I групі - 25,71 $\pm 9,68 \%$ проти $10,0 \pm 2,37 \%(\mathrm{p}<0,05)$. Крім того, варикозне розширення вен нижніх кінцівок частіше фіксували у пацієнток з безплідністю III групи $(31,43 \pm 10,25 \%)$ проти даних контролю $(\mathrm{p}<0,05)$.

Численні оперативні втручання на придатках створюють передумови для розвитку гормональної дисфункції та зниження оваріального резерву у даної категорії пацієнток. Найбільш поширеним видом виконуваного оперативного втручання в анамнезі в обстежених пацієнток були апендектомія та операції з приводу позаматкової вагітності - найчастіше такі оперативні втручання були в анамнезі жінок III

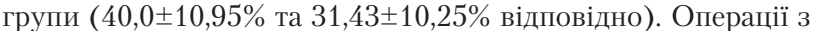
приводу спайкового процесу у малому тазі та на маткових трубах, у тому числі з приводу позаматкової вагітності, втричі частіше відзначено у жінок III досліджуваної групи $(\mathrm{p}<0,05)$. У той час як операції на яєчниках переважали у відсотковому відношенні у I досліджуваній групі $20,0 \pm 8,94 \%$ проти $14,28 \pm 7,98 \%$ у I групі $(\mathrm{p}<0,05)$.

Слід зазначити, що у групі жінок з безплідністю в анамнезі оперативні втручання відзначено удвічі частіше, ніж у 


\section{БЕСПЛОДИЕ И ПЛАНИРО ВАНИЕ СЕМ И}

контрольній групі (р<0,05). Серед гінекологічних захворювань у досліджуваних групах основне місце посідають хронічний ендометрит, аденоміоз та кістозні зміни у придатках практично у кожної третьої жінки з переважанням відсотку жінок у II та III групах $(\mathrm{p}<0,05)$.

Методом стратифікаційного аналізу доведено, що вік жінки понад 35 років майже втричі збільшує шанси невдалих спроб ЕКЗ (OR=2,86; 95\% CI: 1,18-4,53; $<<0,05)$. Крім того, провідним фактором є тривалість безплідності більше 10 років, який у сім разів збільшує ризик невдалих спроб EK3 (OR=7,16; 95\% CI: 1,72-12,6; p<0,002), оперативні втручання на органах малого таза - удвічі, а дисгормональні порушення, у тому числі ожиріння, - у п'ять разів $(\mathrm{OR}=5,12$; 95\% CI: $1,92-8,32, \mathrm{p}<0,002)$.

Дані стратифікаційного аналізу свідчать про зростання імовірності невдалих спроб ЕКЗ під впливом постійного хронічного стресу (відношення шансів $\mathrm{OR}=2,06$; $95 \% \mathrm{CI}$ : $(0,95-3,17 ; \mathrm{p}<0,05)$.

\section{Анамнестические факторы, которые формируют репродуктивное здоровье женщин с неоднократными неудачными попытками оплодотворения in vitro Н.В. Коцабин, О.М. Макарчук}

Часть пациентов с многократными неудачными попытками лечения методами вспомогательных репродуктивных технологий (ВРТ) составляет около 30\% от всех пациентов, которые лечатся с использованием ВРТ Женщины с неудачными попытками ВРТ в анамнезе - это особая категория пациенток, нуждающихся в чрезвычайном внимании и более тщательном обследовании как на этапе подготовки к стимуляции суперовуляции, так и селекции эмбрионов, подготовке эндометрия к эмбриотрансферу.

Цель исследования: на основании тщательного анализа анамнестических и клинических данных бесплодных женщин с неоднократными неудачными попытками оплодотворения in vitro выделить группу высокого риска, которая требует более углубленного изучения гормональных особенностей, состояния овариального резерва и эндометрия. Материалы и методы. Для понимания глубины проблемы неоднократных неудачных попыток оплодотворения in vitro и разработки эффективного алгоритма лечения бесплодия в этих супружеских парах был проведен анализ анамнестических данных трех основных групп женщин с бесплодием (105 пациенток), включенных в программу ВРТ. Они были распределены по возрасту: I группа - женщинь младше 35 лет, II группа - от 35 до 40 лет, III группа - старше 40 лет. Указанные группы пациенток сравнивали между собой и с контрольной группой практически здоровых женщин (30 человек).

Peзультаты. Ведущие стрессорные факторы в процентном отношении втрое преобладали в группе бесплодных женщин и имели прямую связь как с самим фактом процедуры оплодотворения in vitro, так и с хроническим стрессовым фактором, обусловленным длительным бесплодием. Первичное бесплодие достоверно чаще отмечали у пациенток моложе 35 лет $(\mathrm{p}<0,05)$, вторичное бесплодие отмечено в существенном проценте во II и III исследуемых группах ( $<0,05)$. Обращает внимание значительный процент сочетания причин бесплодия и идиопатического фактора во всех группах, а также преобладание трубно-перитонеального фактора во II и III исследуемых группах и эндокринной дисфункции в I исследуемой группе Причем наиболее частой патологией среди данной категории обследованных был синдром поликистозных яичников. У пациенток I и II групп привычное невынашивание диагностировали в два раза чаще, чем в III группе ( $<0,05)$. В исследуемых группах основное место принадлежит инфицированию мочеполовых путей, заболеваниям респираторного тракта, патологии сердечно-сосудистой системы. Данные стратификационного анализа свидетельствуют о росте вероятности неудачных попыток экстракорпорального оплодотворения (ЭКО) под влиянием постоянного хронического стресса (отношение шансов OR=2,06; 95\% CI: 0,95-3,17; $<<0,05$ ).

Заключение. Среди пациенток с бесплодием и неоднократными неудачными попытками использования ВРТ нужно выделить отдельную группу высокого риска неудачных попыток причем данная принадлежность зависит от длительности бесплодия, возраста женщины и комбинации ведущих факторов.

Ключевые слова: неудачные попытки оплодотворения in vitro, анамнез, бесплодие, высокий риск.

\section{висновки}

Отже, як переконливо свідчать результати клінічних досліджень, серед пацієнток із безплідністю з неодноразовими невдалими спробами використання ДРТ слід виділити окрему групу високого ризику невдалих спроб ЕКЗ, причому ця приналежність залежить від тривалості безплідності, віку жінки та комбінації провідних факторів. Ці дані обов’язково необхідно враховувати при розробленні плану лікувально-профілактичних заходів у групі високого ризику.

Перспективи подальшого дослідення в даному напрямку. Установлені клінічні особливості диктують необхідність більш поглибленого вивчення гормональних особливостей, стану оваріального резерву та ендометрія у даної категорії пацієнток для розроблення ефективних лікувальнопрофілактичних і прогностичних методик. Це повинно насторожувати лікарів жіночих консультацій і центрів планування сім'ї вже з ранніх термінів вагітності спостереження таких жінок.

\section{Anamnestic factors that shape reproductive health of women with repeated unsuccessful popygamy in vitro fertilization N.V. Cotsabin, O.M. Makarchuk}

The proportion of patients with multiple unsuccessful attempts of assisted reproductive technology (ART) is about $30 \%$ of all patients treated with the use of ART. Women with history of unsuccessful ART attempts - a special category of patients who require emergency attention and a thorough examination at the stage of preparation for superovulation stimulation,the selection of embryos and endometrium preparation for embryo transfer.

The objective: to distinguish high-risk group of unsuccessful attempts based on a detailed analysis of anamnestic and clinical data of infertile women with repeated unsuccessful ART attempts that requires more indepth study of hormonal features, ovarian reserve and condition of the endometrium.

Materials and methods. For better understanding of the problem of repeated unsuccessful ART attempts and creation of efficient infertility treatment algorithms for these couples we conducted a thorough analysis of anamnestic data of three groups of infertile women (105 patients), which were distributed by age: group I - younger than 35, the II group from 35 to 40, the III group - over 40 years. These groups of patients were compared with each other and with the control group of healthy women (30 persons)

Results. Leading stress factors in the percentage three times prevailed in the group of infertile women and had a direct connection with the fact of procedure «fertilization in vitro» and chronic stressors caused by prolonged infertility. Primary infertility was observed significantly more frequent in patients younger than 35 years $(\mathrm{p}<0,05)$, secondary infertility mostly in the second and third experimental groups $(p<0,05)$. Noteworthy significant percentage of wellknown causes of infertility and idiopathic factor in all groups, and the prevalence of tubal-peritoneal factor in the second and third experimental groups, and endocrine dysfunction in the I experimental group. The most common disorder among this category of woman was polycystic ovary syndrome. Frequency of usual miscarriage among patients of I ana II groups was two times higher than in the third group $(\mathrm{p}<0,05)$. Among the experimental groups the leading place belongs urinary tract infection, respiratory tract diseases, pathologies of the cardiovascular system. Data of the stratified analysis show an increase likelihood of repeated unsuccessful ART attempts under the influence of constant chronic stress (odds ratio $\mathrm{OR}=2,06 ; 95 \% \mathrm{CI}$ : $0,95-3,17 ; \mathrm{p}<0,05)$.

Conclusions. Among infertile patients with repeated unsuccessful ART attempts must be separated a high risk group of failures. The identity depends on the duration of infertility, female age and leading combination of factors.

Key words: repeated unsuccessful ART attempts, anamnesis, infertility, high risk. 


\section{БЕС ПЛОДИЕ И ПЛАНИРО В АН ИЕ С Е В И}

\section{Сведения об авторах}

Макарчук Оксана Михайловна - Ивано-Франковский национальный медицинский университет, 76000, г. Ивано-Франковск, ул. Галицкая, 2; тел.: (0342) 55-31-65

Коцабин Наталия Владимировна - Ивано-Франковский национальный медицинский университет, 76000, г. ИваноФранковск, ул. Галицкая, 2; тел.: (0342) 55-31-65

\section{СПИСОК ЛІТЕРАТУРИ}

1. Аналіз медико-соціального впливу впровадження сучасних медичних технологій на покращення репродуктивного здоров'я жінок 3 невиношуванням вагітності /В.В. Подольський, С.П. Писарєва, В.Л. Дронова [та ін.] //Здоровье женщины. - 2011. - № 9. - С. 100-102. 2. Загребельная И.В. Современные аспекты патогенеза и лечения эндокринного бесплодия /И.В. Загребельная //Международный медицинский журнал. - 2010. -Т. 16, № 1. - С. 55-59.
3. Петренко Н.В. Діагностичні маркери ендокринного безпліддя / Н.В. Петренко // Актуальні питання педіатрії, акушерства та гінекології. - 2015. № 1. - C. 165-167.

4. Савельева Г.М. Способ прогнозирования наступления беременности у паци енток, включенных в программу экстракорпорального оплодотворения, в стандартном длинном протоколе / Г.М. Савельева, П.А. Клименко, Е.Н. Карева // Лечащий врач. - 2013. - № 3. - С. 46-50.
5. Шуршалина А.В. Прегравидарная подготовка эндометрия и вспомогательные репродуктивные технологии / А.В. Шуршалина // Гинекология. 2013. - T. 15, № 2. - C. 12-14.

6. Юзько О.М. Оцінка оваріального резерву у жінок із безпліддям / О.М. Юзько, П.О. Галайко // Здоровье женщины. - 2010. - № 3. C. 10-11.

7. Jaiswar S.P. Prediction of Poor Ovarian response by Biochemical and
Biophysical Markers: A Logistic Regression Model / S.P. Jaiswa, S.M Natu // J Obstet Gynaecol India. 2015. - Vol. 65, № 6. - P. 411-416. 8. Shen M.S. New horizon on successful management for a woman with repeated implantation failure due tounresponsive thin endometrium: use of extended estrogen supplementation / M.S. Shen, C.W. Wang, C.H. Chen // J Obstet Gynaecol Res. - 2013. Vol. 39, № 5. - P. 1092-1094.

СТАТЬИ В ЖУРНАЛЕ «ЗДОРОВЬЕ ЖЕНЩИНЫ» ТЕПЕРЬ ИМЕЮТ ВОЗМОЖНОСТЬ ПОЛУЧАТЬ

\section{УНИВЕРСАЛЬНЫЙ ИДЕНТИФИКАТОР ЦИФРОВОГО ОБЬЕКТА DIGITAL OBJECT IDENTIFIER (DOI) СИСТЕМЫ БИБЛИОГРАФИЧЕСКИХ ССЫЛОК CROSSREF}

CrossRef объединяет издательские организации со всего мира, представляющие 20 тыс. научных изданий и 1500 библиотек, обеспечивая перекрестную связь между публикациями в научных журналах более чем 2800 издательств с помощью цифровой идентификации объектов.

Использование DOI позволит представить отечественные научные достижения мировой науке, улучшит обмен научной информацией между учеными, будет способствовать повышению рейтинга и индекса цитирования ученых Украины за рубежом, позволит вывести отечественные журналы в международное информационное поле.

Внедрение системы DOI в издательскую деятельность повышает публикационную активность изданий, увеличивает доступность научных публикаций за пределами Украины и дает возможность авторам быть представленными в известных наукометрических базах данных. Ценность идентификатора DOI для авторов заключается в том, что его использование в любое время обеспечивает быстрый поиск научной статьи, книги и другой печатной продукции без необходимости проведения поиска на сайтах журналов или поисковых систем.

Идентификатор цифровых объектов DOI является необходимым звеном доступности для анализа научной продукции, который осуществляется информационно-аналитическими системами наукометрических баз данных.

Адрес для переписки: ООО «Группа компаний Мед Эксперт», Украина, 04211, г.Киев-211, а/я 80; Контактный телефон редакции +38 044 498-08-80

Сайт www.med-expert.com.ua

e-mail: pediatr@med-expert.com.ua

Контактное лицо: Шейко Ирина Александровна 


\section{Тактика допоміжних репродуктивних технологій після оперативного лікування жінок з ендометріомами яєчників}

\section{Ю.В. Страховецька}

Національна медична академія післядипломної освіти імені П.Л. Шупика, м. Київ

\begin{abstract}
Мета дослідження: підвищення ефективності відновлення репродуктивної функції у жінок з ендометріоїдними кістами яєчників на основі вивчення у них клініко-функціональних і ендокринологічних особливостей, а також удосконалення і впровадження алгоритму діагностичних і лікувально-профілактичних заходів з використанням ендоскопії та допоміжних репродуктивних технологій (ДРТ).

Матеріали та методи. Обстежено 144 жінки репродуктивного віку, які були прооперовані з приводу безплідності, спричиненої наявністю ендометріӧ̈дних кіст яєчників. Усім пацієнткам було проведено лікування безплідності із застосуванням ДРТ.
\end{abstract}

Результати. За результатами даного дослідження, оптимізація відновлення репродуктивної функції у пацієнток з ендометріоїдними кістами яєчників з використанням оперативного лікування і програм ДРТ дозволяе досягти не лише настання вагітності, але й сприятливого ії перебігу.

Заключення. Отримані результати можуть бути рекомендовані для широкого використання у практичній охороні здоров'я.

Ключові слова: ендометріоми яєчників, допоміжні репродуктивні технології.

Л ікування безплідності у хворих з генітальним ендометріозом є однією з найбільш актуальних проблем акушерства і гінекології. Це зумовлено високою частотою захворювання серед жінок репродуктивного віку, мультифакторіальною природою порушення репродуктивної функції при даному захворюванні, а також необгрунтованими повторними оперативними втручаннями на органах малого таза, відсутністю протирецидивної терапії і несвоєчасним використанням допоміжних репродуктивних технологій (ДРТ) [1, 2].

Найбільш складним науково-практичним завданням вважають подолання безплідності у пацієнток з важкими формами зовнішнього генітального ендометріозу (ЗГЕ), що включають пошкодження яєчників - ендометріоми [3, 4]. За різними оцінками, серед пацієнток із ЗГЕ частота зустрічальності ендометріом становить 15-45\% [5]. Оптимальним методом подолання безплідності у цьому випадку є екстракорпоральне запліднення (ЕКЗ) [6]. Проте частота настання вагітності в протоколах ЕКЗ у таких хворих значно нижче, ніж у разі легких форм ЗГЕ (13,7\% і 28,3\% відповідно) [7,8]. Передбачається, що основними детермінантами невдачі ЕКЗ можуть бути порушення рецептивності ендометрія, фолікулогенезу в яєчниках і зниження якості ембріонів [6].

У низці досліджень було встановлено, що гормональна терапія перед протоколом ЕКЗ підвищує його ефективність [6,7]. У зв'язку з багатолітнім досвідом застосування агоністів гонадотропін-рилізинг-гормону $(\alpha-Г$ нРГ) більшістю європейських професійних асоціацій дана група препаратів рекомендована у якості такої терапії $[1,8]$. При цьому добре відомі особливості $\alpha$-ГнРГ, зумовлені вираженим антигонадотроп- ним ефектом і гіпоестрогенемією, що впливає на прихильність хворих до даного виду лікування перед проведенням повторних циклів ЕКЗ.

Останніми роками з метою медикаментозної терапії ендометріозу стали використовувати похідне норстероїдів дієногест. Опубліковані результати досліджень, що підтверджують його ефективність, порівняну $3 \alpha$-ГнРГ, відносно зниження больового синдрому $[1,7]$. Безперечними перевагами препарату є відсутність вираженої гіпоестрогенемії i пов'язаних з нею побічних ефектів. Проте вітчизняні та іноземні дослідження, присвячені ефективності вживання дієногесту з метою лікування безплідності у хворих із ЗГЕ методом ЕКЗ відсутні. Залишаються суперечливими наукові дані, що стосуються впливу гормональної терапії на характеристики гонадотропної стимуляції яєчників, якість запліднення (ЯЗ) і розвиток ембріонів у протоколах ЕКЗ [6].

У зв'язку з викладеним вище представляє значний інтерес вивчення можливостей ДРТ після оперативного лікування пацієнток даної групи в аспекті підвищення ефективності лікування безплідності.

Мета дослідження: підвищення ефективності відновлення репродуктивної функції у жінок з ендометріоїдними кістами яєчників (ЕКЯ) на основі вивчення у них клінікофункціональних і ендокринологічних особливостей, а також удосконалення і впровадження алгоритму діагностичних i лікувально-профілактичних заходів з використанням ендоскопії та ДРТ.

\section{МАТЕРІАЛИ ТА МЕТОДИ}

Відповідно до поставлених завдань обстежені 144 жінки репродуктивного віку, які були прооперовані з приводу безплідності, спричиненої наявністю ЕКЯ. Усім пацієнткам було проведено лікування безплідності із застосуванням ДРТ: ЕКЗ або ЕКЗ/ICSI.

Критеріями включення пацієнток у дослідження були:

- фолікулостимулювальний гормон (ФСГ) $\leq 12 \mathrm{MO} /$ л;

- антимюллерів гормон (АМГ) $\geq 0,5$ нг/мл;

- операція з приводу ендометріоми яєчника в анамнезі;

- відсутність ЕКЯ на момент вступу до протоколу ЕКЗ;

- стимуляція яєчників у протоколі ЕКЗ з використанням антагоністів ГнРГ (ант-ГнРГ).

Критеріями виключення були:

- IMT $\geq 30$ кг $/ \mathrm{M}^{2}$;

- міома матки діаметром більше 2 см, яка деформує порожнину матки;

- аденоміоз III-IV ступеня;

- загальні протипоказання для протоколу ЕКЗ і настання вагітності.

Залежно від варіанта ад'ювантної гормональної терапії перед вступом до протоколу ЕКЗ (ЕКЗ/ICSI) усіх пацієнток було розподілено на 3 групи. До 1-ї групи увійшли 38 пацієнток, які отримували дієногест протягом 3-6 міс; до 2-ї групи 


\section{БЕСПЛОДИЕ И ПЛАНИРО ВАНИЕ СЕМ И}

увійшли 70 пацієнток, що отримували препарати а-ГнРГ протягом 3-6 міс; до 3-ї групи увійшли 36 жінок, що не отримували гормональної терапії ЗГЕ перед протоколом ЕКЗ.

\section{РЕЗУЛЬТАТИ ДОСЛІДЖЕННЯ ТА ЇХ ОБГОВОРЕННЯ}

Вік пацієнток, включених у дослідження, знаходився у межах від 23 до 42 років; середній вік склав $32 \pm 4,1$ року.

Тривалість безплідності серед обстежених пацієнток становила від 3 до 10 років. Первинну безплідність виявлено у 99 пацієнток із 144 (68,8\%), вторинну - у 45 (31,3\%).

Серед супутньої гінекологічної патології у 28 (19,4\%) обстежених пацієнток на момент вступу до протоколу ЕКЗ виявили наявність міоматозного вузла, який не деформував порожнину матки. Максимальний діаметр міом матки не перевищував 2 см, максимальна кількість вузлів у пацієнтки 2. Аденоміоз діагностували в 11,8\% (у 17 зі 144 пацієнток) випадків. Проста гіперплазія ендометрія без атипії була виявлена в анамнезі у 7 (4,9\%) пацієнток. Хронічний сальпінгоофорит відзначали у 30 зі 144 (20,8\%) обстежених пацієнток, у 14 з яких було виконано видалення маткової труби з приводу сактосальпінксу. Як відзначено у репродуктивному анамнезі, у 6 пацієнток було виконано оперативне втручання з подальшою тубектомією з приводу трубної позаматкової вагітності. Достовірних відмінностей серед обстежених груп щодо наявності супутньої гінекологічної патології не відзначено.

На момент вступу пацієнток до протоколу ЕКЗ хронічні соматичні захворювання були у стадії ремісії або компенсації. Більшість оперативних втручань 3 метою лікування ЗГЕ у жінок досліджуваних груп були виконані з використанням лапароскопічного доступу - 93,7\%; у 6,3\% пацієнток була потреба переходу на лапаротомію зважаючи на спайковий процес 4-го ступеня у черевній порожнини і малому тазі.

У досліджуваних групах основну кількість становлять пацієнтки з одним - 47,9\% або двома $-34,7 \%$ оперативними втручаннями в анамнезі. Відмінностей за кількістю оперативних втручань в анамнезі серед досліджуваних груп не виявлено $\left(\chi^{2}=1,494, \mathrm{df}=2 ; \mathrm{p}=0,474\right)$.

Оцінювання ступеня тяжкості ендометріозу проводили за шкалою американського суспільства репродуктивної медицини (r-AFS). У 63 (44\%) обстежених пацієнток під час останнього оперативного втручання був встановлений III ступінь тяжкості ендометріозу (39,4\%, 47,1\% і 41,7\% для 1-ї, 2-ї і 3-ї груп відповідно; $\left.\chi^{2}=1,673 ; \mathrm{p}=0,714\right)$, у 81 пацієнтки (56,3\%) був встановлений IV ступінь тяжкості ЗГЕ. Двобічне пошкодження яєчників ендометріомами спостерігалося у 44,4 \% випадків, що дещо більше, ніж за даними зарубіжних авторів. За даними низки авторів, двобічне пошкодження яєчників діагностували у $9-28 \%$ випадків виявлення ендометріом. У 1-й групі двобічне пошкодження яєчників спостерігалося у 39\% (15 з 38 пацієнток) випадків,

\section{Тактика вспомогательных репродуктивных технологий после оперативного лечения женщин с эндометриомами яичников Ю.В. Страховецкая}

Цель исследования: повышение эффективности восстановления репродуктивной функции у женщин с эндометриоидными кистами яичников на основе изучения у них клинико-функциональных и эндокринологических особенностей, а также усовершенствование и внедрение алгоритма диагностических и лечебно-профилактических мероприятий с использованием эндоскопии и вспомогательных репродуктивных технологий (ВРТ).

Материаль и методы. Обследованы 144 женщины репродуктивного возраста, которые были прооперированы по поводу бес- у 2-й групі - у 47,1\% і в 44,4\% випадків - у 3-й групі і достовірно не відрізнялося $\left(\chi^{2}=0,586, \mathrm{df}=2 ; \mathrm{p}=0,746\right)$.

Діаметр видалених ендометріом серед обстежених пацієнток варіювався від 1 до 10 см. Частота зустрічальності ендометріоми яєчника більше 3 см у діаметрі у 1-й групі склала 65,8\% (у 25 зі 144 пацієнток), у 2-й групі - 55,7\% (у 39 зі 144 пацієнток), у 3-й групі - 63,9\% (у 23 зі 144 пацієнток), що достовірно не відрізнялося $\left(\chi^{2}=1,287, \mathrm{df}=2 ; \mathrm{p}=0,525\right)$.

Оцінювання оваріального резерву пацієнток проводили на підставі віку, базального рівня ФСГ у сироватці крові, рівня АМГ, числа антральних фолікулів візуалізованого під час УЗД на 2-3-й день менструального циклу. Вік пацієнток, число антральних фолікулів на 2-3-й день циклу при УЗД, базальний рівень ФСГ, рівень АМГ серед досліджуваних груп достовірно не відрізнявся. У 47,2\% обстежених пацієнток був діагностований знижений оваріальний резерв (АМГ $<1,0$ нг/мл). У 1-й групі низький оваріальний резерв виявлений у 47,4\% пацієнток, у 2-й групі - у 41,4\%, у 3 -й групі - у 58,3\%.

Уперше лікування безплідності із застосуванням методів ДРТ проводили у 97 (67,4\%) жінок. Лікування безплідності методом індукції овуляції відзначено в анамнезі у двох пацієнток. Одну і більше спроб ЕКЗ/ICSI в анамнезі мали 47 (32,6\%) жінок. «Бідна відповідь» яєчників на стимуляцію суперовуляції зареєстрована у $24347(51,1 \%)$ пацієнток 3 EKЗ/ICSI, що мали в анаменезі спробу ДРТ.

Отримані результати свідчать, що частота настання вагітності та імплантації у розрахунку на кількість перенесених ембріонів у жінок з ендометріомами залежіть від варіанта ад'ювантної терапії: при використанні дієногесту вона становить $44,8 \%$ та $32,2 \%$; $\alpha$-ГнРГ - $34,3 \%$ та $28,7 \%$; без гормональної терапії - 16,7\% та 17,1\% відповідно.

Під час аналізу ефектівності різних методик ДРТ у жінок 3 ендометріомами відзначено вищу частоту настання вагітності на перенесення ембріона у разі застосування техніки ICSI, ніж ЕКЗ, при використанні дієногесту (58,3\% і $43,5 \%)$. А у жінок, які отримували а-ГнРГ, зафіксовано протилежні результати (35,7\% та 48,3\%). У пацієнток без гормональної терапії дані відрізнялися мало (22,2\% та $28,6 \%)$.

Сумарна частота настання вагітності у жінок після оперативного лікування ендометріом та використання ДРТ складає 32,6\%. При цьому термінові пологи фіксували у $80,9 \%$, передчасні - у $2,1 \%$ та мимовільне переривання вагітності до 20 тіж - у 17,0\% пацієнток.

\section{ВИСНОВКИ}

Отже, результати проведених досліджень свідчать, що оптимізація відновлення репродуктивної функції у пацієнток з ЕКЯ з використанням оперативного лікування і програм ДРТ дозволяє досягти ефективних результатів не лише у настанні вагітності, але й у сприятливому її перебігу. Отримані результати можуть бути рекомендовані для широкого використання у практичній охороні здоров'я.

плодия, вызванного наличием эндометриоидных кист яичников. Всем пациенткам было проведено лечение бесплодия с использованием ВРТ.

Pезультаты. По результатам данного исследования, оптимизация восстановления репродуктивной функции у пациенток с эндометриоидными кистами яичников с использованием оперативного лечения и программ ВРТ позволяет достигнуть не только наступления беременности, но и благоприятного ее течения.

Заключение. Полученные результаты могут быть рекомендованы для широкого использования в практическом здравоохранении.

Ключевые слова: эндометриомы яичников, вспомогательные репродуктивные технологии. 


\section{БЕСПЛОДИЕ И ПЛАНИРО В АНИЕ СЕМ ИИ}

\section{Tactics of auxiliary genesial technologies after expeditious treatment of women with endometriome of ovaries Yu.V. Strakhovetskaya}

The objective: rising of efficiency of restoration of genesial function at women with endometrioidal cysts of ovaries on the basis of studying at them clinical-functional and endocrinologic features, and also improvement and introduction of algorithm of diagnostic and treatment-and-prophylactic actions with use of an endoscopy and auxiliary genesial technologies.

Patients and methods. Were surveyed 144 women of genesial age who were operated concerning the sterility caused by existence the endometrioidal of cysts of ovaries. To all patients sterility treatment with use of auxiliary genesial technologies was carried out.

Results. Optimization of restoration of genesial function at patients with endometrioidal cysts of ovaries with use of expeditious treatment and programs of auxiliary genesial technologies allows to reach effective results not only in respect of pregnancy offensive, but also a favorable current.

Conclusion. The received results can be recommended for wide use in practical health care.

Key words: endometriome of ovaries, auxiliary genesial technologies.

\section{Сведения об авторе}

Страховецкая Юлия Викторовна - Национальная медицинская академия последипломного образования имени П.Л. Шупика, 04112, г. Киев, ул. Дорогожицкая, 9. E-mail: prore-first@nmapo.edu.ua

\section{СПИСОК ЛІТЕРАТУРИ}

1. Адамян Л.В., Бобкова М.В. Современные подходы к лечению эндометриоза // Акушерство и гинекология. 2012. - № 3. - С. 10-14.

2. Адамян Л.В., Кулаков В.И. Эндометриозы. - М.: Медицина, 2013. -317 с. 3. Баскаков В.П. Клиника и лечение эндометриоза. Изд.4. - Л.: Медицина, 2014. -240 c.
4. Давыдов А.И., Пашков В.М. Генитальный эндометриоз / Клинические лекции по акушерству и гинекологии / Под ред. Н. Стрижакова, А.И. Давыдова, Л.Д. Белоцерковцевой. - М.: Медицина, 2010. - С. 241-261. 5. Коханевич Е.В., Дудка С.В., Судома И.О. Современные методы диагностики и лечения генитального эн- дометриоза // 3б. наук. праць асоціації акушерів-гінекологів України. - К.: «Фенікс», 2001. C. $340-342$.

6. Юзько О.М. Сучасні питання допоміжних репродуктивних технологій у жінок $з$ генітальним ендометріозом // Клінічна медицина. - 2015. - № 4. - C. 78-86.
7. Audebert A.J.M. formes occultes et minimes de l'endometriose: strategie therapeutique // Rev. Franc. Gynecol. Obstet. - 2010. - V. 85, № 2. P. 79-84.

8. Barbieri R.L. Etiology and epidemiology of endometriosis // Am. J. Obstet. Gynecol. - 2012. - V. 162, № 2. P. 565-567.

\section{ДО УВАГИ АВТОРІВ! АЛГОРИТМ РЕЕСТРАЦІЇ ОRCID}

\section{Open Researcher and Contributor ID (ORCID) - міжнародний ідентифікатор науковця}

Створення єдиного реєстру науковців та дослідників на міжнародному рівні є найбільш прогресивною та своєчасною ініціативою світового наукового товариства. Ця ініціатива була реалізована через створення в 2012 році проекту Open Researcher and Contributor ID (ORCID). ORCID - це реєстр унікальних ідентифікаторів вчених та дослідників, авторів наукових праць та наукових організацій, який забезпечує ефективний зв'язок між науковцями та результатами їхньої дослідницької діяльності, вирішуючи при цьому проблему отримання повної і достовірної інформації про особу вченого в науковій комунікації.

Для того щоб зареєструватися в ORCID через посилання https://orcid.org/необхідно зайти у розділ «For researchers» i там натиснути на посилання «Register for an ORCID iD».

У реєстраційній формі послідовно заповнюють обов’язкові поля: «First name», «Last name», «E-mail», «Re-enter Email», «Password2 (Пароль), «Confirm password».

У перше поле вводиться ім'я, яке надане при народженні, по-батькові не вводиться. Персональна електронна адреса вводиться двічі для підтвердження. Вона буде використовуватися як Login або ім'я користувача. Якщо раніше вже була використана електронна адреса, яка пропонується для реєстрації, з'явиться попередження червоного кольору. Не можна створювати нового профілю з тією самою електронною адресою. Пароль повинен мати не менше 8 знаків, при цьому містити як цифри, так і літери або символи. Пароль, який визначається словами «Good» або «Strong», приймається системою.

Нижче визначається «Default privacy for new works», тобто налаштування конфіденційності або доступності до персональних даних, серед яких «Public», «Limited», «Private».

Далі визначається частота повідомлень, які надсилає ORCID на персональну електронну адресу, а саме - новини або події, які можуть представляти інтерес, зміни в обліковому записі, тощо: «Daily summery», «Weekly summery», «Quaterly summery», «Never». Необхідно поставити позначку в полі «I'm not a robot» (Я не робот).

Останньою дією процесу реєстрації є узгодження 3 політикою конфіденційності та умовами користування. Для реєстрації необхідно прийняти умови використання, натиснувши на позначку «I consent to the privacy policy and conditions of use, including public access and use of all my data that are marked Public».

Заповнивши поля реєстраційної форми, необхідно натиснути кнопку «Register», після цього відкривається сторінка профілю учасника в ORCID з особистим ідентифікатором ORCID ID. Номер ідентифікатора ORCID знаходиться у лівій панелі під ім'ям учасника ORCID.

Структура ідентифікатора ORCID являє собою номер 3 16 цифр. Ідентифікатор ORCID - це URL, тому запис виглядає як http://orcid.org/xxxx-Xxxx-xxxxxxxx.

Наприклад: http://orcid.org/0000-0001-7855-1679.

Інформацію про ідентифікатор ORCID необхідно додавати при подачі публікацій, документів на гранти і в інших науково-дослідницьких процесах, вносити його в різні пошукові системи, наукометричні бази даних та соціальні мережі.

Подальша робота в ORCID полягає у заповненні персонального профілю згідно із інформацією, яку необхідно надавати. 
ЦИПРОФЛОКСАЦИН 500 Мг + ТИНИДАЗОЛ 600 мг

Комбинация Ципрофлоксацин+Тинидазол оказывает*:

- Двойное действие на бактерии

- Нарушает процесс синтеза ДНК бактерий

- Угнетает действие ДНК-гиразы

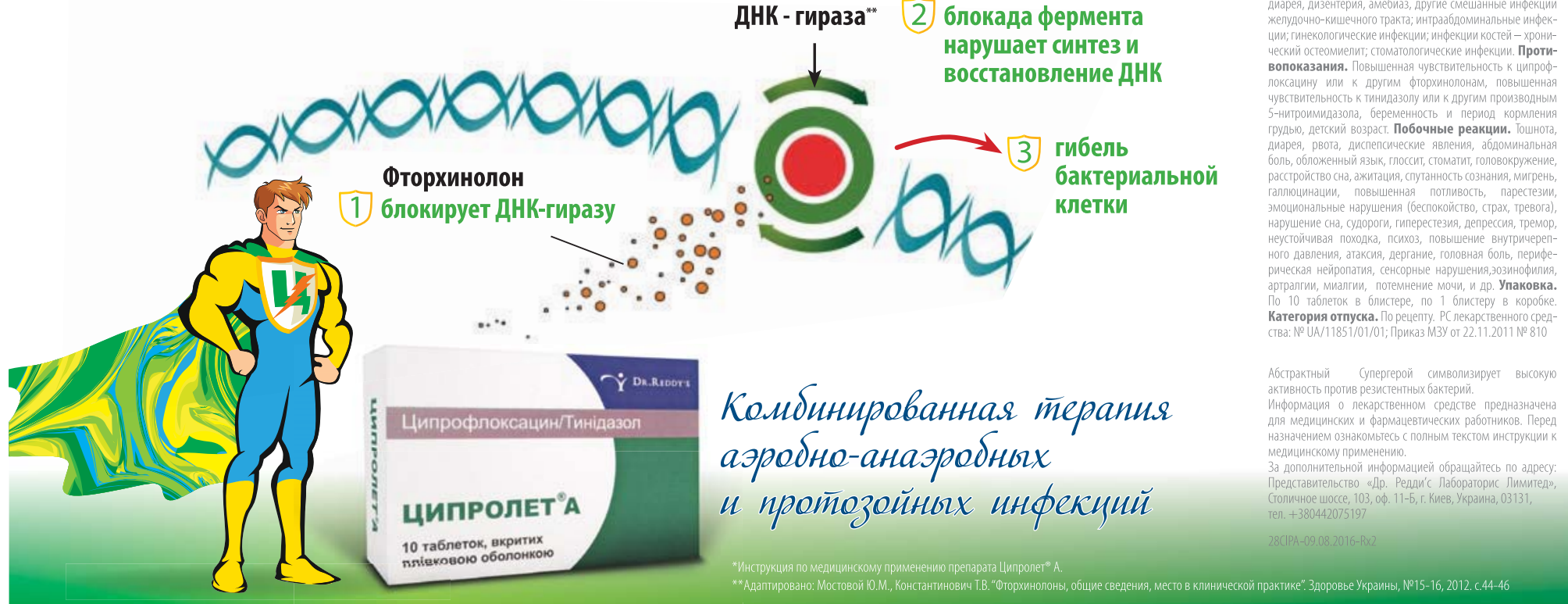

При инфекциях, вызванных чувствительными к препарату микроорганизмами, включая смешанные аэробно-анаэробные инфекции, протозойные инфекции
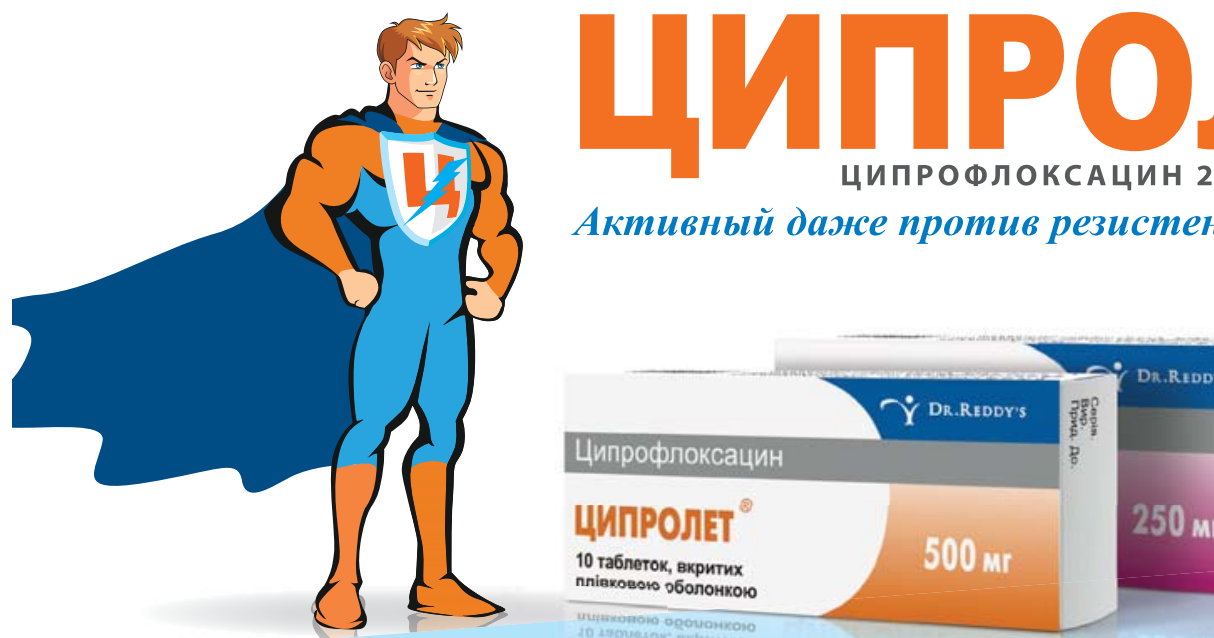

ЦИПРОФЛОКСАЦИН $250 \mathrm{mr} / 500 \mathrm{mr}$ № 10 Активный даже против резистентных бактерий

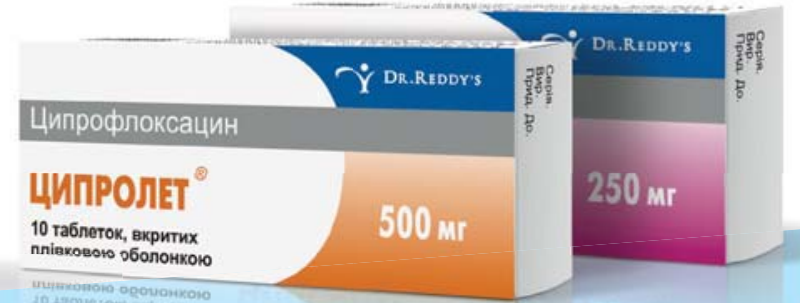

17. Уничтожает бактерии, продуцирующие $\beta$-лактамазы и бактерии, резистентные практически ко всем антибиотикам

岛 Действует как на размножающиеся микроорганизмы, так и на находящиеся в фазе покоя

17. Оказывает бактерицидное действие

Dobepue u upubepsecturocmo, gorazaruture bpenerem*!
(B)

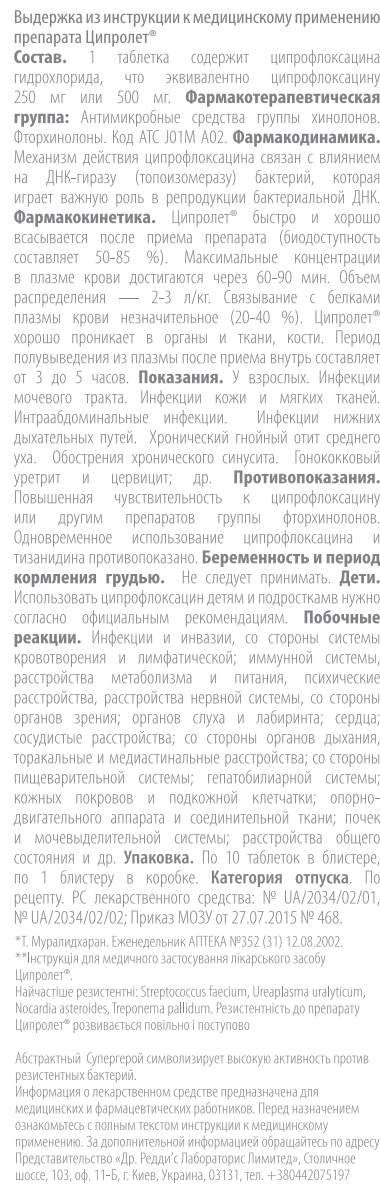

Dr.Reddy's 


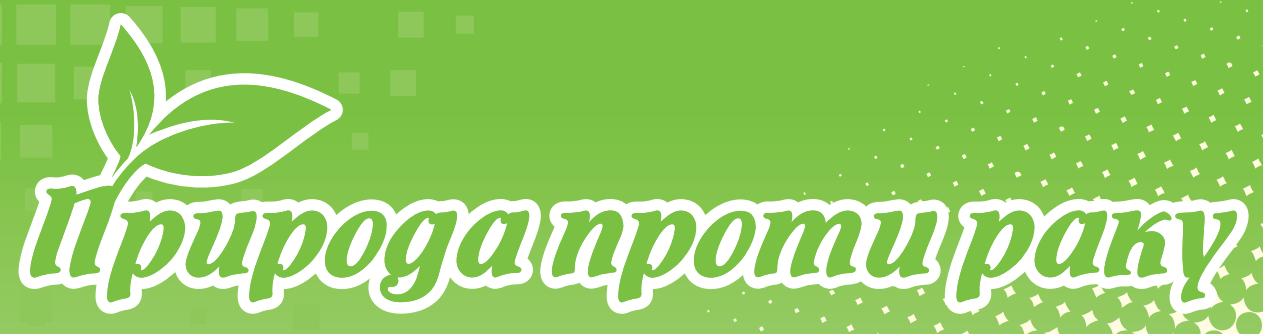

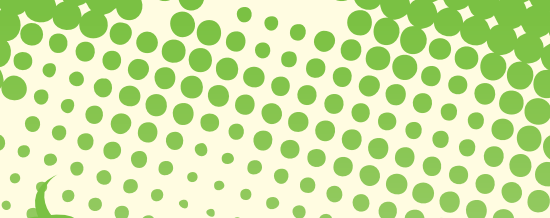

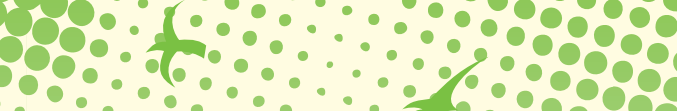

0000000

\section{КОМПЛЕКСНИЙ НІДХІД \\ до лікування \\ та профілактики \\ патології шийки матки}

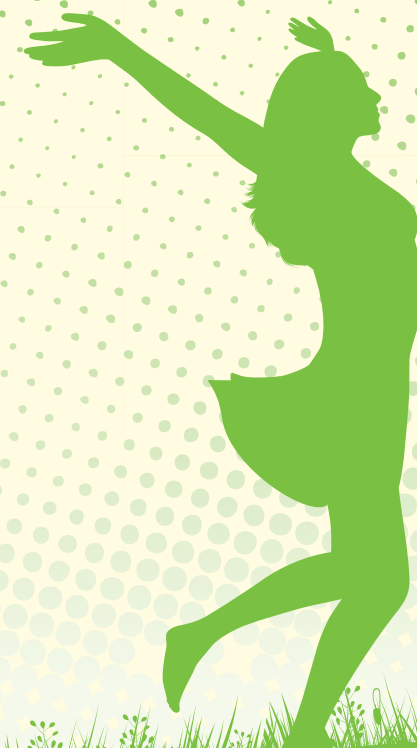

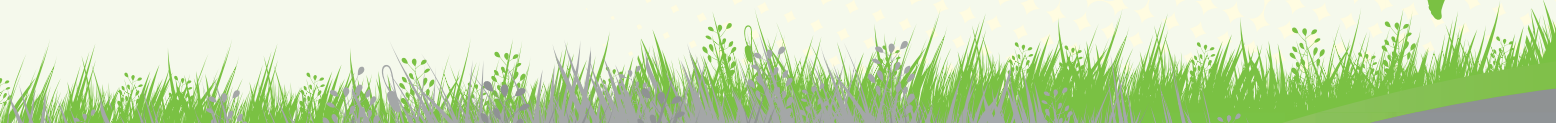

